Silas Silva Santos

\title{
LITISCONSÓRCIO EVENTUAL, ALTERNATIVO E SUCESSIVO NO PROCESSO CIVIL BRASILEIRO
}

Faculdade de Direito da USP

São Paulo

2012 
Silas Silva Santos

\section{LITISCONSÓRCIO EVENTUAL, ALTERNATIVO E SUCESSIVO NO PROCESSO CIVIL BRASILEIRO}

Dissertação apresentada como requisito parcial para obtenção do título de Mestre em Direito Processual, pela Faculdade de Direito da Universidade de São Paulo, sob orientação do Professor Associado RICARDO DE BARROS LEONEL.

São Paulo 
Para minhas queridas Amália e Sarah! 


\section{AGRADECIMENTOS}

Porque Dele, por Ele e para Ele são todas as coisas, sou grato a Deus por até aqui ter me conduzido em paz! Aliás, não convém que nos iludamos, porque o apóstolo Tiago já escrevera que toda boa dádiva e todo dom perfeito descende do Pai das Luzes, em quem não há sombra alguma de variação. Por isso, a Ele seja tributada toda honra e glória, hoje e eternamente.

Mas é evidente que aqui também não se teria chegado não fosse a contribuição particular de notáveis pessoas. Sou grato, em primeira mão, ao meu orientador, professor Ricardo de Barros Leonel, pela fidalguia com que me distinguiu por todos esses três longos anos de trilha acadêmica. Além das gentis conversas ao telefone, incontáveis foram os emails enviados e prontamente respondidos, sem falar nas vezes em que o professor Ricardo interrompeu sua agenda para que nos reuníssemos em São Paulo.

Semelhante expressão de gratidão há de ser estendida aos professores regentes das disciplinas que cursei. Nomino-os para ser enfático na expressão do sentimento: José Rogério Cruz e Tucci, Flávio Luiz Yarshell, Oreste Nestor de Souza Laspro, Paulo Henrique dos Santos Lucon e Gustavo Henrique Righi Ivahy Badaró.

Devo agradecer também aos professores assistentes, que me auxiliaram de perto no cumprimento das inúmeras e gratificantes tarefas enquanto cumpria os créditos exigidos pelo Regimento. São eles os professores José Rubens de Moraes, Heitor Vitor Mendonça Sica e Bruno Freire e Silva.

Aos professores José Rogério Cruz e Tucci e Flávio Luiz Yarshell devo ainda lançar um agradecimento especial, em reconhecimento às gentis e argutas ponderações com que fui presenteado quando do exame de qualificação. Ficaria extremamente feliz se conseguisse trazer para o exame final um trabalho que refletisse o quanto evoluí depois das críticas lançadas naquela honrosa oportunidade.

Não menos importante foi uma conversa que tive com o professor Cândido Rangel Dinamarco. O mestre interrompeu seu trabalho, já num final de tarde, apenas para entender minhas perplexidades. Ouviu atentamente, pensou, fez indagações, sugeriu novos rumos e convidou-me a refletir sobre pontos até então não vislumbrados. Muito obrigado, professor! 
Ainda na esfera acadêmica, sou extremamente grato ao professor Donaldo Armelin, que me recebeu generosamente nos tempos em que fui aluno regular do Mestrado na Pontifícia Universidade Católica de São Paulo. Ali também fui agraciado com a ajuda dos professores Antonio Rigolin e Cassio Scarpinella Bueno, a quem devo externar sinceros agradecimentos.

As companhias agradáveis dos colegas de classe também devem ser registradas. Essencial para mim foi o convívio com Fernando Mil Homens Moreira, Luiz Guilherme Pennacchi Dellore, José Wellington Bezerra da Costa Neto, Tiago Asfor Rocha Lima e César Augusto Luiz Leonardo.

Para desenvolvimento dos estudos contei com a gentileza do meu queridíssimo professor de graduação, Luciano de Souza Pinheiro. A par de sua prazerosa companhia e dos conselhos como que de pai para filho, registro que sua magnífica biblioteca esteve sempre aberta para mim, inclusive em dias e horários fora de expediente. Nesse aspecto também fui agraciado com a inteligência de Paulo Eduardo D’Arce Pinheiro, que me fez refletir sobre pontos que minha imaginação não havia sido capaz de alcançar.

Ainda fui auxiliado pelos amigos Fábio Morong e Caique Thomaz Leite da Silva, que me enviaram da Europa textos valiosíssimos. O querido amigo Fernando Florido Marcondes, além de tudo o mais que nos une, também facilitou demasiadamente o meu acesso à Biblioteca do STF. Postura semelhante foi adotada pelo Desembargador Spencer Almeida Ferreira, no que pertine às obras raras existentes na Biblioteca do TJSP. A eles, pois, também devo agradecer.

Um gesto de gratidão vai ao amigo e incentivador Acir Murad, sempre presente nos momentos mais relevantes de minha vida. Os laços que nos unem vão para muito além desta vivência acadêmica. Aos amigos Osterno Antonio de Souza e Raquel Gasparotto de Souza também devo muito pelo que me fizeram quando precisei de companhia e de um lar em São Paulo.

No ambiente de trabalho, tive a honra de ser auxiliado, inúmeras vezes, pelo eminente juiz Darci Lopes Beraldo. Sem sua companhia penso que o peso deste trabalho teria sido muito maior sobre meus ombros. Obrigado, então, por ter tornado menos íngreme o aclive por que percorri.

Aos servidores da $1^{\mathrm{a}}$ Vara da Comarca de Presidente Venceslau também registro meus agradecimentos, pois o comprometimento e o empenho com que levaram adiante os 
serviços forenses me permitiram a tranquilidade necessária para o desenvolvimento da pesquisa. Ainda nesse campo, agradeço sinceramente o apoio que obtive dos servidores do Setor de Biblioteca do Palácio da Justiça de São Paulo (TJSP).

Também contei com o valoroso incentivo da diretoria e da coordenação das Faculdades Integradas Antonio Eufrásio de Toledo, o que me permitiu desfrutar de um tempo para o indispensável recolhimento. Agradecido sou pela paciência e compreensão que tiveram para comigo.

E, acima de tudo, sou grato aos meus pais e aos meus irmãos, só pelo fato da presença incondicional, mesmo quando estive "ausente" para dar conta deste trabalho. 


\section{RESUMO}

O trabalho versa sobre as modalidades de litisconsórcio chamadas eventual, alternativa e sucessiva. Segundo o texto, há litisconsórcio eventual, passivo ou ativo, quando se formula pedido relacionado a determinado sujeito e, para o caso de não ser possível o acolhimento desse pedido principal, pede-se desde logo o acolhimento do pedido quanto a outro sujeito. De outra parte, ocorre litisconsórcio alternativo, ativo ou passivo, quando para o acolhimento do pedido seja indiferente, do ponto de vista do demandante, o atingimento deste ou daquele colitigante. Por sua vez, o litisconsórcio sucessivo traduz-se na formulação de pedido relacionado a um sujeito e, pressupondo-se a procedência desse pleito, apresenta-se outro pedido relacionado a sujeito diverso. Partindo da constatação de que a legislação brasileira não contempla especificamente essas modalidades litisconsorciais, a investigação principia por delinear as premissas que envolvem o chamado modelo constitucional de processo civil, mediante exposição de valores pertinentes ao acesso à justiça na perspectiva dos direitos fundamentais, com ênfase na ideia de instrumentalidade da ciência processual e de aproximação entre direito e processo. Também são tratadas, a título de premissas, algumas situações que envolvem a "dúvida objetiva" e seus reflexos no processo. Serve igualmente de ponto de partida a construção pertinente à cumulação de pedidos. À luz desse enfoque objetivo de cumulação são extraídos valiosos argumentos tendentes a justificar o tratamento da subsidiariedade, da alternatividade e da prejudicialidade sob o prisma subjetivo. Para demonstrar o nível de influência que a relação substancial pode ensejar na seara do processo, são catalogadas algumas hipóteses extraídas diretamente do direito material e que, conforme se crê, dão suporte à construção do litisconsórcio nas modalidades objeto da investigação. O núcleo do trabalho desenvolve-se mediante argumentação sobre a admissibilidade do litisconsórcio eventual, alternativo e sucessivo no sistema processual brasileiro, com exposição dos requisitos e superação das possíveis objeções. Ao final, tenta-se construir um esquema procedimental que seja reflexo das particularidades do litisconsórcio eventual, alternativo e sucessivo na perspectiva de um processo civil de conhecimento e de caráter individual.

Palavras-chave: litisconsórcio; eventual; alternativo; sucessivo. 


\section{ABSTRACT}

This study deals with the modalities of joinder of parties named fortuitous, alternative and successive. According to the text, there is fortuitous joinder, compulsorily or permissively, when an enquiry is formulated to a specific defendant and, in case it is not possible to accept the main enquiry, it is promptly asked for an enquiry from another defendant. On the other hand, joinder in the alternative modality, compulsorily or permissively, occurs when, for the acceptance of the enquiry, it is indifferent from the plaintiff's perspective the accomplishment of one or another co-litigant. Then, successive joinder conveys in the formulation of an enquiry to a defendant and, assuming the origin of the lawsuit, another enquiry is presented to another defendant. From the findings that the Brazilian legislation does not contemplate these modalities of joinder specifically, the investigation begins outlining the premises that involve the so-called constitutional model of the Civil Procedure, through the exposure of values related to the access to justice regarding the fundamental rights, with an emphasis on the idea of instrumentality of the Civil Procedure principles and the approximation of law and procedure. In addition, this study also deals with some situations including the "objective doubt" and its consequences to the procedure. It also serves as point of departure to the construction connected with the accumulation of enquiries. Under this objective focus of accumulation, valuable arguments are obtained tending to justify the treatment of subsidiarity, prejudiciality and alternative law system under a subjective view. In order to demonstrate the level of influence that the substantial relation is able to cause in a lawsuit, some hypotheses directly extracted from the substantive law are catalogued and, as believed, they support the construction of the joinder of parties in the modalities of this investigation. The core of this study is developed from the argumentation about the admissibility of joinder of parties, fortuitous, alternative or successive, in the Brazilian Civil Procedure, following by the exposure of requirements and the overcoming of possible objections. Finally, there is an attempt to build a procedural scheme which is a consequence of the particularities in a joinder of parties, fortuitous, alternative or successive, from the perspective of a Civil Procedure in an individual understanding and quality.

Keywords: joinder of parties; fortuitous; alternative; succesive. 


\section{SUMÁRIO}

RESUMO viii

ABSTRACT ix

INTRODUÇÃO 6

\section{PARTE I - CONSIDERAÇÕES INICIAIS}

Capítulo Único - SUJEITOS PARCIAIS DO PROCESSO 10

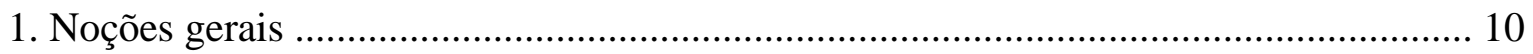

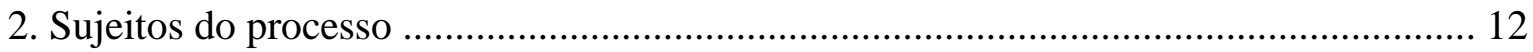

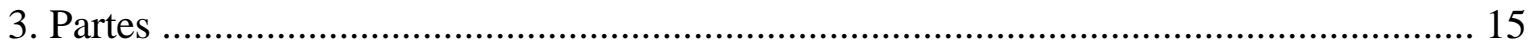

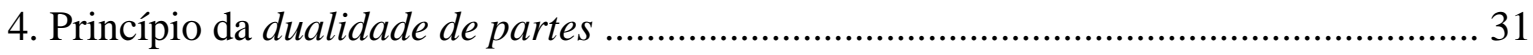

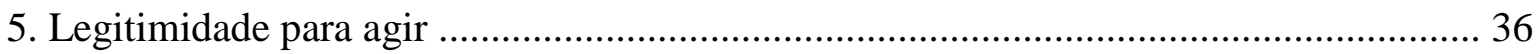

6. Pluralidade de partes: litisconsórcio e intervenção de terceiros .................................... 53

\section{PARTE II - PREMISSAS}

7. Nota prévia

8. Relação entre direito e processo: necessária aproximação 
9. Acesso à justiça 87

10. Razoável duração do processo: compreensão abrangente 96

11. Dúvida e eventualidade: influência na conformação do processo 102

(i) fungibilidade recursal 103

(ii) fungibilidade na tutela de urgência 106

(iii) ainda a fungibilidade 109

(iv) ordem lógica de apreciação de questões afetas às nulidades e ao mérito 110

(v) interposição conjunta de recurso especial e extraordinário 112

(vi) denunciação da lide: especialmente a denunciação pelo autor 113

(vii) princípio da eventualidade e a contestação

(viii) à guisa de conclusão parcial 116

Capítulo II - CUMULAÇÃO DE PEDIDOS

12. Noções gerais e modalidades

13. Requisitos de admissibilidade 130

14. Consequências 138

(i) valor da causa 138

(ii) reflexos da admissibilidade e da inadmissibilidade 139

(iii) fase instrutória 142

(iv) capítulos de sentença 143

(v) apelação 148

(vi) renovação da demanda 155

15. Conclusão do capítulo 158

Capítulo III - NECESSIDADES ADVINDAS DO DIREITO MATERIAL 160

16. Nota prévia 160 
17. Responsabilidade civil do incapaz: Código Civil de 2002 ........................................ 162

18. Responsabilidade dos pais pelos filhos: paternidade socioafetiva

19. Responsabilidade civil subsidiária do Estado pelos atos de suas autarquias e das concessionárias ou permissionárias de serviço público

20. Colisões múltiplas em acidente de trânsito 171

21. Ainda a responsabilidade civil 171

22. Desconsideração da personalidade jurídica 172

23. Contrato de fiança que contemple o benefício de ordem 181

24. Assunção de dívida 183

25. Consignação em pagamento: dúvida sobre a pessoa do credor 186

26. Expurgo inflacionário: instituição financeira em liquidação (caso Bamerindus) 187

27. Pensão alimentícia: aspectos subjetivos 188

28. Ainda o direito de família: investigação de paternidade 189

29. Um caso de direito tributário 192

30. Mandado de injunção: hipótese do art. $8^{\circ}, \S 3^{\circ}$, do ADCT 193

31. Benefício previdenciário originário de união estável 196

32. Fechamento do Capítulo e da Parte II 197

\section{PARTE III - OUTRAS MODALIDADES LITISCONSORCIAIS}

Capítulo I - LITISCONSÓRCIO EVENTUAL 200

33. Noção e terminologia 200

34. Admissibilidade no processo civil brasileiro: fundamentos 208

35. Ainda a admissibilidade: requisitos 213

36. Objeções: tentativa de superação 216 
Capítulo II - LITISCONSÓRCIO ALTERNATIVO .................................................... 223

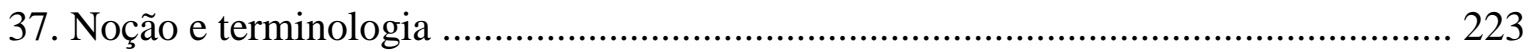

38. Admissibilidade no processo civil brasileiro: fundamentos .................................... 232

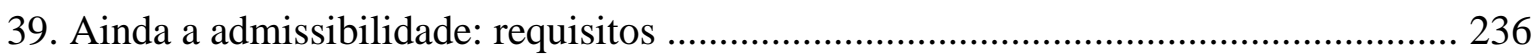

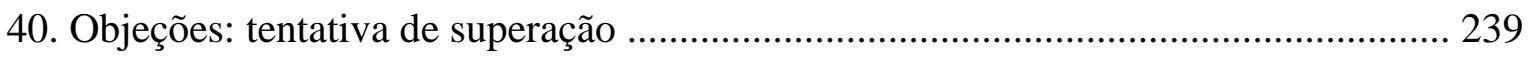

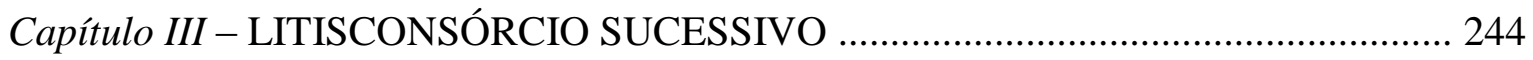

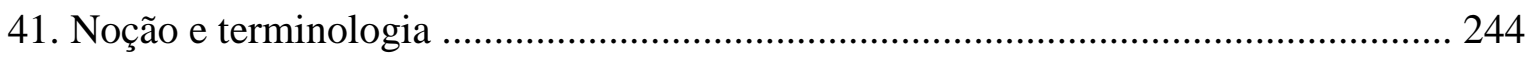

42. Admissibilidade no processo civil brasileiro: fundamentos ..................................... 249

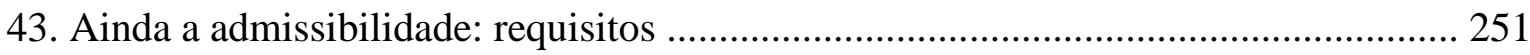

Capítulo IV - DINÂMICA DO LITISCONSÓRCIO EVENTUAL, ALTERNATIVO E

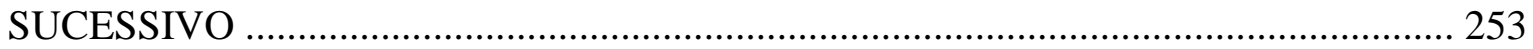

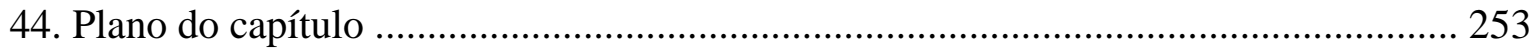

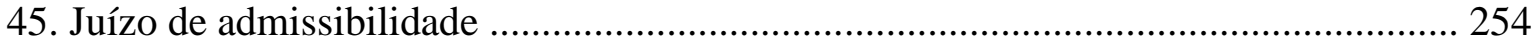

(i) dúvida objetiva e prejudicialidade: como demonstrar? ........................................... 261

(ii) litisconsórcio ulterior e estabilização da demanda ................................................. 268

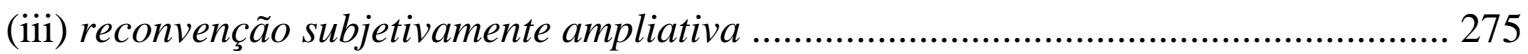

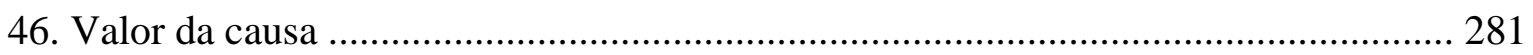

47. Citação: termo inicial do prazo para resposta .......................................................... 284

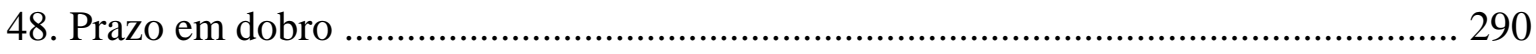

49. Desistência da ação: aquiescência do(s) litisconsorte(s) ......................................... 292

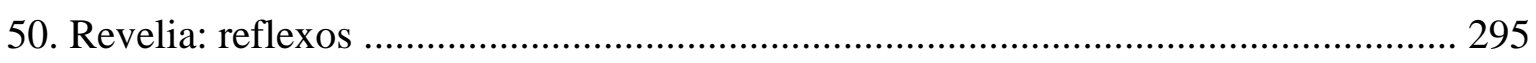

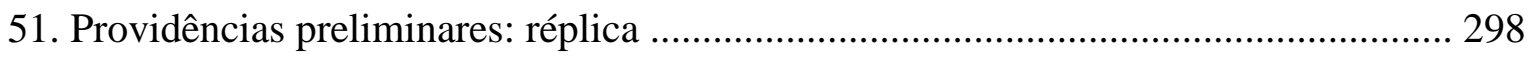

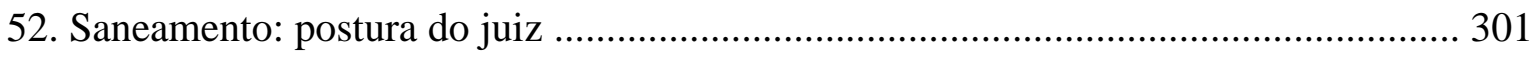

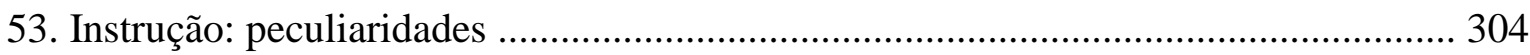


54. Sentença 310

55. Sentença: condenação para o futuro 330

56. Sentença: verbas de sucumbência 335

57. Apelação: generalidades 342

58. Apelação: litisconsórcio eventual e alternativo 346

59. Apelação adesiva: litisconsórcio eventual e alternativo 354

60. Apelação: litisconsórcio sucessivo 363

61. Ação rescisória 372

62. Reclamação constitucional 378

CONCLUSÃO 381

BIBLIOGRAFIA 383 


\section{INTRODUÇÃO}

Em épocas de constantes mutações legislativas, como a que se vive no Brasil, geralmente se sente o desejo, fruto mesmo de uma necessidade prática, de abordar academicamente temas novos e, até por isso, bastante desafiadores. Realmente, a ausência de tratamento doutrinário sobre um assunto inovador do ponto de vista legislativo acaba por exigir manifestações dos intérpretes, com vistas a resolver problemas concretos que pululam no foro e, de certa forma, contribuir para a formação de uma jurisprudência que advenha de uma prévia e profícua reflexão. E nada há de errado nessa postura de enfrentamento de novas questões ou de novos institutos.

Isso, porém, não afasta a utilidade de renovadas incursões em temas clássicos, como é o caso do litisconsórcio. Não se duvida que, nesse tema, a construção acadêmica hoje existente pode ser considerada bem expressiva, circunstância que poderia gerar uma impressão de que nada mais, ou pouca coisa, haveria ainda para se debater. Vale lembrar, apenas de relance, as contribuições monográficas de GUILHERME ESTELLITA ${ }^{1}$, de BARBOSA Moreira $^{2}$, de MATHIAs LAMBAUER ${ }^{3}$ e de CÂNDIDO DinAMARCO ${ }^{4}$. Nesse rol de notáveis contribuições certamente deve ser incluída a tese não publicada de CAMIÑA MOREIRA, que desafiou o tema pelo prisma do processo de execução ${ }^{5}$.

Sabe-se, todavia, que a realidade do foro constitui projeção do que se dá na vida das pessoas, em suas variadas e complexas relações jurídicas. E é exatamente dessa riqueza, ínsita às mutações da própria sociedade, que se podem extrair, de um tema clássico e já muitas vezes visitado, renovadas reflexões.

No estudo que se inicia, tal como se dá em outros setores do tema litisconsorcial, o aporte de problemas advém da configuração da relação de direito material que se quer debater em juízo, circunstância que exige do processualista a apresentação de soluções que

\footnotetext{
${ }^{1}$ Do litisconsórcio no direito brasileiro. Rio de Janeiro: Freitas Bastos, 1955.

${ }^{2}$ Litisconsórcio unitário. Rio de Janeiro: Forense, 1972.

${ }^{3}$ Do litisconsórcio necessário. São Paulo: Saraiva, 1982.

${ }^{4}$ Litisconsórcio. 8. ed. São Paulo: Malheiros, 2009. Cabe lembrar que a primeira edição dessa obra é de 1984.

${ }^{5}$ Litisconsórcio no processo de execução. Tese (Doutorado). São Paulo, PUC-SP, 2001.
} 
sejam coerentes e satisfatórias do ponto de vista teórico e, ao mesmo tempo, razoáveis e funcionais do ponto de vista prático.

Já se disse, com inegável acerto, que as dificuldades de enfrentamento no campo das partes "tendem a proliferar-se na exata medida em que as situações que envolvem os sujeitos de direito no plano do direito material tornem-se mais complexas e mais resistentes ao encarte nas figuras concebidas pelo processo civil tradicional"6.

Então, a partir de uma configuração subjetivamente plural das relações de direito material, analisam-se situações em que se interpõem, entre os sujeitos, vínculos de subsidiariedade, de alternatividade ou de prejudicialidade, dando margem ao que se convencionou chamar de litisconsórcio eventual, alternativo e sucessivo. Tais situações, por paradoxal que seja, existem amiúde no plano prático, conforme se tenta demonstrar no Capítulo III, da Parte II, e a elas se impõe dar um tratamento adequado na perspectiva processual.

Embora se acredite que os tipos litisconsorciais aqui estudados possam ocorrer também no polo ativo, nesta primeira aproximação é suficiente uma amostra do que se que pretende investigar sob o título de litisconsórcio eventual, alternativo e sucessivo, numa exemplificação pertinente ao polo passivo.

Assim, $A$ formula pedido em face de $B$, mas, para o caso de não ser possível acolher-se tal pleito, expõe, desde logo e no mesmo ato de iniciativa processual, pedido subsidiário em face de $C$. Ter-se-ia aqui litisconsórcio eventual.

De modo assemelhado, $D$ move ação em face de $E$ e de $F$, formulando-se pretensão no sentido de que o Estado-juiz acolha o pedido apenas quanto a um dos réus, hipótese que se pode designar litisconsórcio alternativo.

Noutra configuração, $X$ afora ação contra $Y$ e, tendo como pressuposto o acolhimento deste pleito, formula desde logo pedido contra Z. Aqui o caso seria de litisconsórcio sucessivo.

Haja vista que a legislação brasileira não contempla especificamente os institutos aqui versados, sentiu-se a necessidade de buscar nos princípios que regem todo o sistema

\footnotetext{
${ }^{6}$ ARRUDA ALVIM WAMBIER, Teresa; WAMBIER, Luiz Rodrigues. Casos problemáticos: partes ou terceiros? (análise de algumas situações complexas de direito material). In: DIDIER JR., Fredie; ARRUDA ALVIM WAMBIER, Teresa (coord.). Aspectos polêmicos e atuais sobre os terceiros no processo civil e assuntos afins. São Paulo: RT, 2004, p. 1035.
} 
processual, advindos do que se tem chamado de modelo constitucional de processo civil, o aporte teórico indispensável a toda construção. Nessa empreitada de justificação, transpareceu razoável trabalhar também com os influxos que o tema da cumulação de pedidos pode ensejar na tratativa litisconsorcial proposta. Desses dois aspectos ocupam-se os Capítulos I e II, da Parte II.

É evidente que, tratando-se de um tema clássico como é o litisconsórcio, deparou-se com a necessidade, antes de tudo, de situar o instituto dentro de seus aspectos gerais, mediante o enfoque das noções que envolvem o tema das partes no processo civil. Daí a indispensável e prévia abordagem do quanto vem escrito no Capítulo Único da Parte I, onde se tenta deixar bem clara a própria noção de litisconsórcio, apartada da qual nada do que vem adiante se sustentaria.

Como já se adiantou, o Capítulo III da Parte II tende a demonstrar, no plano específico da investigação proposta, que as especificidades do direito material exigem do processualista uma postura interpretativa e talvez até mesmo criativa, que vai muito além dos textos legislativos. Implica dizer que as exigências do direito material vão requerer, em termos concretos, respostas condizentes com o tão decantado caráter instrumental da ciência processual.

Embora haja o costume de trabalhar com um método de investigação dedutivo, típico da argumentação de viés subsuntivo, tenha-se presente que para os casos difíceis, complexos ou não rotineiros $^{7}$ justifica-se uma alteração de método, partindo-se do problema (específico) para se buscar a construção da norma aplicável. Não significa, evidentemente, que o método dedutivo da lógica clássica (pensamento sistemático: parte-se do geral para se chegar ao particular) seja pior que o pensamento problemático, a ponto de ser relegado pela ciência jurídica. Mas parece razoável crer que, num ambiente em que não se tem uma moldura normativa capaz de operar a pura subsunção, torna-se útil o método indutivo, partindo-se, pois, do particular (problema) para se alcançar o geral (norma).

É nisso que se explica a aparente inversão na ordem lógica das tratativas que se contêm no Capítulo III da Parte II (abordagem de direito material), quando em comparação com o que se expõe no ponto central de toda a investigação (Parte III).

\footnotetext{
${ }^{7}$ ARRUDA ALVIM WAMBIER, Teresa. Recurso especial, recurso extraordinário e ação rescisória. 2. ed. São Paulo: RT, 2008, p. 39, texto e nota 54.
} 
Como se percebe, o núcleo do trabalho reside na Parte III, onde se procura delinear, em Capítulos distintos, as noções de litisconsórcio eventual, alternativo e sucessivo, e, mediante aplicação das premissas anteriormente estabelecidas e da visualização dos problemas advindos da conformação do direito material, tenta-se estruturar, em termos processuais, uma gama de justificativas que vão desaguar na admissibilidade dos institutos tratados, a despeito da conformação lacunosa da ordem legislativa em vigor.

O fecho do trabalho traduz-se no exame da dinâmica processual do litisconsórcio eventual, alternativo e sucessivo, numa tentativa de repassar os vários segmentos de um processo cognitivo de recorte individual. Isso não quer dizer, evidentemente, que as modalidades litisconsorciais aqui investigadas estejam enclausuradas no ambiente do processo civil de conhecimento e de espectro individual ${ }^{8}$. Porém, aqui se contenta, declaradamente, com as limitações acima expostas.

Enfim, é sob o estímulo de provocante passagem de CÂNDIDO DINAMARCO ${ }^{9}$, onde se afirma que as noções de litisconsórcio eventual e alternativo são negligenciadas entre nós, que se embrenha no desafiante estudo de um tema clássico numa perspectiva, contudo, ainda pouco divulgada e, talvez por isso mesmo, capaz de gerar inúmeras perplexidades em meio ao declarado entusiasmo com que se ousa desbravar um tema riquíssimo em consequências práticas.

\footnotetext{
${ }^{8}$ CAMIÑA MOREIRA, por exemplo, trabalha com duas hipóteses litisconsórcio eventual no processo de execução (Op. cit., p. 217-218 e 224).

${ }^{9}$ Litisconsórcio, cit., p. 16. Em outro passo da mesma obra lê-se profícua incitação: "Questão elegantíssima, sobre a qual nada se conhece na literatura especializada brasileira, é a que diz respeito à admissibilidade do litisconsórcio alternativo ou eventual em nosso sistema de direito positivo" (Id., nº 182, p. 457).
} 


\section{PARTE I}

\section{CONSIDERAÇÕES INICIAIS}

\section{Capítulo Único}

\section{SUJEITOS PARCIAIS DO PROCESSO}

\section{Noções gerais}

$\mathrm{O}$ instituto denominado processo jurisdicional, analisado sob um determinado prisma, pode ser visto como um conjunto de atos voltados à prestação da atividade jurisdicional do Estado ${ }^{10}$. Esses atos, porque envolvidos na realidade do processo, designam-se atos processuais. Como é intuitivo, os atos processuais não surgem de si mesmos (diferentemente do que se passa com os fatos processuais, v. g., o decurso do tempo), pois que é indispensável a existência de um sujeito que transmita vida ao ato. "Os atos do procedimento não se realizam por acaso ou irracionalmente mas porque as partes têm a faculdade, o ônus, o poder ou o dever de realizá-los, ou porque tem o juiz o poder e o dever de impô-los ou de oferecê-los às partes" $"$.

Quando se estuda o processo pelo ângulo da relação jurídica, também se mostra indispensável a referência aos sujeitos envolvidos nessa mesma relação jurídica (processual); é que esta relação explica-se pelo "sistema de vínculos regidos pelo direito que interligam os sujeitos do processo" ${ }^{\prime 12}$.

Semelhantemente, ao se conceituar o processo como sendo o procedimento desenvolvido em contraditório ${ }^{13}$, nota-se uma inseparável vinculação do conceito à ideia de sujeitos do processo, já que a realidade do contraditório torna-se viva na experiência de atuação dos sujeitos.

\footnotetext{
${ }^{10}$ FREDERICO MARQUES, José. Manual de direito processual civil. São Paulo: Saraiva, 1974. vol. 1, p. 110.

11 DINAMARCO, Cândido Rangel. Instituições de direito processual civil. 6. ed. São Paulo: Malheiros, 2009, vol. II, no 488, p. 200.

${ }^{12} I d ., \mathrm{n}^{\mathrm{o}} 488$, p. 201.

${ }^{13}$ FAZZALARI, Elio. Istituzioni di diritto processuale. 7. Ed. Padova: CEDAM, 1994, p. 82-83.
} 
Não obstante a importância histórica e doutrinária das várias conceituações do que seja processo, tem-se como adequada, para os fins desta pesquisa, a definição que se pode extrair da lição de CÂNDIDO DiNAMARCO, segundo a qual o processo constitui-se no procedimento animado pela relação jurídica processual e desenvolvido em contraditório $^{14}$.

Bem é de ver que nesses três elementos (procedimento, relação jurídica e contraditório) radica, inafastavelmente, a ideia de participação dos sujeitos do processo. Com efeito, o procedimento constitui-se na marcha com que se desenvolvem os atos praticados ou suportados pelos sujeitos do processo; a relação jurídica, de outro lado, só pode existir entre sujeitos e jamais entre objetos; o contraditório, por fim, concretiza-se mediante a bilateralidade de audiência e a cooperação entre os sujeitos processuais.

Daí que a própria compreensão do que seja processo perpassa, necessariamente, o tema dos sujeitos do processo.

Como se decalca dessas asserções, o enfoque acadêmico em torno dos sujeitos do processo configura sempre empreendimento relevante para o aprimoramento da ciência processual e, mais que isso, para a busca - que deve ser constante - de soluções práticas adequadas à realidade circundante e que, de outro lado, apresentem consistente fundamentação teórica. Embora a feição das relações jurídicas materiais seja um dado externo ao processo, este deve estar capacitado a dar respostas condizentes e satisfatórias em termos de proteção jurídica a quem tiver razão no plano material; tais respostas, porém, hão de ser encontradas e justificadas dentro do próprio sistema processual.

${ }^{14}$ Execução civil. 7. ed. São Paulo: Malheiros, 2000, nº 69 e 70, p. 121-125; A instrumentalidade do processo. 14. ed. São Paulo: Malheiros, 2009, no 16, nota 178, p. 149-150. Com o fim precípuo de caracterizar apenas o processo jurisdicional de natureza estatal, pode-se dizer que processo constitui-se no procedimento animado pela relação jurídica e desenvolvido em contraditório perante autoridade judicial, no exercício de sua função jurisdicional, cujo escopo consiste na produção de um resultado jurídico marcado pela imutabilidade. Acredita-se que tal conceito seja suficiente para evitar confusões entre o processo jurisdicional e o chamado processo administrativo, em cujo âmbito visualiza-se a existência de procedimento, de relação jurídica e também de contraditório, podendo, aliás, ser desenvolvido perante autoridade judicial, como nos casos de processo disciplinar presidido por magistrado no exercício de sua atribuição administrativo-correcional. Do conceito de processo que acaba de ser enunciado também resulta a compreensão de que no processo de execução, no cautelar e no de jurisdição voluntária busca-se um resultado jurídico timbrado pela imutabilidade. 


\section{Sujeitos do processo}

Consoante abalizada lição doutrinária, sujeitos processuais são "todas as pessoas que figuram como titulares das situações jurídicas ativas e passivas integrantes da relação jurídica processual"15.

No afã de construir uma classificação dos sujeitos processuais, FREDERICO MARQUES apresenta um critério que parece útil. São sujeitos principais o juiz, o autor e o réu, já que estes encarnam subjetivamente as funções que compõem a estrutura essencial do processo, entendido como actus trium personarum ${ }^{16}$. De fato, as posições subjetivas básicas em que se polarizam os vínculos jurídicos derivados da relação processual dizem respeito àqueles sujeitos: "o autor tem o direito de ação; o réu, o direito de defesa; e o juiz, o poder jurisdicional" ${ }^{\prime 17}$. Em ligeira síntese, poder-se-ia dizer, então, que os sujeitos principais são o juiz ${ }^{18}$ e as partes ${ }^{19}$.

A par desses sujeitos ditos principais existem aqueles caracterizados como secundários. Nessa categoria enquadram-se "todas aquelas pessoas que participam da relação processual sem serem sujeitos principais" ${ }^{20}$. Parece válido acrescentar que não só as pessoas podem ser consideradas sujeitos secundários, porquanto existem entes despersonalizados que, nalguma medida, também podem atuar no processo na condição de

\footnotetext{
${ }^{15}$ DINAMARCO, Cândido Rangel. Instituições de direito processual civil, cit., vol. II, nº 490, p. 203 (grifos do original). Acrescenta-se que não só as pessoas podem ser sujeitos do processo, pois existem alguns entes sem personalidade jurídica capazes de atuar na tela do processo jurisdicional, titularizando situações ativas e passivas da mais alta relevância, como são os casos, v.g., da massa falida, do espólio, do condomínio, do nascituro, de alguns órgãos da recuperação judicial (Comitê e Assembleia Geral) etc.

16 Manual de direito processual civil, cit., vol. 1, p. 172. Fazendo-se um adendo à classificação de FREDERICO MARQUES, pode-se discernir, na categoria dos sujeitos principais, aqueles que são parciais (partes e terceiros intervenientes) e os imparciais (órgãos da jurisdição; juízes e tribunais), conforme sinaliza DINAMARCO (Instituições de direito processual civil, cit., vol. II, nº 490, p. 203).

${ }^{17}$ FREDERICO MARQUES, José. Manual de direito processual civil, cit., p. 115.

${ }^{18}$ Aqui se tem uma metonímia, pois se toma a parte (juiz) pelo todo (juízes e tribunais).

${ }^{19}$ Sobreleva notar que em FREDERICO MARQUES a posição de parte é ocupada não só pelo autor e pelo réu, mas também por aqueles que intervenham, de maneira voluntária ou provocada, em processo pendente, assim como pelo Ministério Público, na condição de parte principal ou na de parte coadjuvante (Manual de direito processual civil, cit., p. 247 e 284).

${ }^{20}$ FREDERICO MARQUES, José. Manual de direito processual civil, cit., p. 173 (grifo não consta do original).
} 
sujeitos secundários, como é o caso já lembrado do Comitê e da Assembleia Geral nos autos da recuperação judicial (Lei $\mathrm{n}^{\circ}$ 11.101/2005).

Dentre os sujeitos secundários divisam-se os auxiliares do juízo e os terceiros ${ }^{21}$. Aqueles "são os que participam da relação processual, completando a atuação dos órgãos jurisdicionais"; existem órgãos auxiliares permanentes (base fixa ou mínima da administração da Justiça) e eventuais (elemento subjetivo variável dentro da relação processual). De sua parte, terceiros "são os que levam ao processo elementos objetivos, tais como provas e bens, imprescindíveis ou úteis para o litígio compor-se, ou para o desenrolar do procedimento" 22 . Não se pode esquecer, dentro do quadro dos terceiros, daqueles sujeitos que, em vez de trazerem algo para o processo, retiram ou extraem dele alguma coisa, tal como ocorre com os arrematantes de bens em hasta pública.

No âmbito dos auxiliares do juízo e dos terceiros existem figuras curiosas e de difícil categorização, tais como o terceiro em poder de quem esteja o documento objeto de incidente de exibição (CPC, arts. 360-362), os licitantes em hastas públicas, os oficiais de cartórios extrajudiciais, os empregadores a quem haja sido determinada a retenção de salários em ações de alimentos; o Comitê na recuperação judicial, a Assembleia-Geral também na recuperação judicial; a autoridade coatora no mandado de segurança, as repartições públicas que estão obrigadas a atender às requisições judiciais em tema probatório (CPC, art. 399) e as instituições financeiras encarregadas de captar os depósitos judiciais ${ }^{23}$.

Ainda segundo o critério proposto por FREDERICO MARQUES, existe a categoria dos sujeitos especiais, na qual se enfeixam os advogados (públicos ${ }^{24}$ ou privados) e o Ministério Público. Tais sujeitos exercem papel relevantíssimo na tela processual, porquanto o advogado é indispensável à administração da justiça (CF, art. 133), tanto assim que a Lei $n^{\circ} 8.906 / 94$ estabelece que os atos privativos de advogado praticados por

\footnotetext{
${ }^{21}$ Importante observar que na lição de FREDERICO MARQUES esses terceiros não são aqueles sujeitos envolvidos na chamada intervenção de terceiros, já que os terceiros intervenientes, ao aviso do aludido autor, adquirem a posição de parte (Manual de direito processual civil, cit., p. 247).

${ }^{22}$ FREDERICO MARQUES, José. Manual de direito processual civil, cit., p. 173.

${ }^{23}$ Com base em lição de NICOLA JAEGER, FREDERICO MARQUES catalogou alguns desses sujeitos como auxiliares eventuais da Justiça, promovendo ainda uma divisão entre os auxiliares por necessidade técnica, os auxiliares por conveniência econômica, os auxiliares por circunstância de fato e os auxiliares resultantes de situações de direito (Manual de direito processual civil, cit., vol. 1, p. 245).

${ }^{24}$ Aqui se inclui a figura da Defensoria Pública.
} 
pessoa não inscrita na $\mathrm{OAB}$ são nulos (art. $4^{\circ}$, caput). $\mathrm{O}$ Ministério Público, semelhantemente, goza da atenção da Constituição Federal, que o coloca como instituição essencial à função jurisdicional do Estado, incumbindo-lhe a defesa da ordem jurídica, do regime democrático e dos interesses sociais e individuais indisponíveis $(\mathrm{CF}$, art. 127, caput).

Cabe destacar, porém, a situação peculiar do Ministério Público e da Defensoria Pública $^{25}$ quando sejam autores de demandas, hipóteses em que serão sujeitos principais e parciais.

Especificamente sobre o Ministério Público, importa ainda considerar que, mesmo não sendo autor de demanda, sua posição processual será a de parte. Com efeito, tamanhos são os poderes processuais enfeixados na órbita de atuação daquele órgão que, mesmo não sendo autor ou réu na demanda, afigura-se coerente considerá-lo como parte ${ }^{26}$.

Ao dizer-se que o Ministério Público ostenta a posição de parte, não se está infirmando o critério classificatório proposto por FREDERICO MARQUES, em cujo âmbito o Parquet é considerado sujeito especial. Realmente, a atuação do Ministério Público mostra-se tão diversificada ${ }^{27}$ no processo civil que não constitui equívoco considerá-lo, para fins classificatórios, como sujeito especial do processo. Apenas no campo da técnica e da dinâmica processual é que se enxerga o Ministério Público, sempre e sempre, como parte $^{28}$.

A despeito da utilidade da classificação aqui anunciada, compreende-se que existe alguma mobilidade dentro dessas categorias de sujeitos processuais. A figura do perito, por exemplo, traduz-se na de um típico auxiliar do juízo (sujeito secundário), mas no incidente

\footnotetext{
${ }^{25}$ A Lei $n^{\circ}$ 11.448/2007 alterou a redação do art. $5^{\circ}$ da Lei de Ação Civil Pública, para conferir legitimidade ativa para a Defensoria Pública manejar ação civil pública.

${ }^{26}$ FREDERICO MARQUES, José. Manual de direito processual civil, cit., p. 291.

${ }^{27}$ Conforme DINAMARCO, o Ministério Público pode ser parte principal, puro fiscal da lei (custos legis) e assistente da parte principal (Instituições de direito processual civil, cit., vol. II, nº 614, p. 435 et seq.).

28 "São diversas as posições assumidas pelos agentes do Ministério Público mas, qualquer que seja a figura processual em cada caso, parte ele sempre será, invariavelmente. Como tal, desfruta de todas as situações ativas e passivas que constituem a trama da relação jurídica processual, estando pois dotado dos poderes e faculdades que toda parte tem e sujeito aos ônus e deveres inerentes à condição de parte; a ele são oferecidas, como a todas as partes, as oportunidades integrantes do trinômio pedir-alegar-provar, inerente à garantia constitucional do contraditório. (...) O custos legis, portanto, é parte" (DINAMARCO, Cândido Rangel. Instituições de direito processual civil, cit., nº 614-615, p. 436-437).
} 
em que se lhe imputa a suspeição ou o impedimento, tal como previsto no art. $138, \S 1^{\circ}$, do CPC, aquele sujeito secundário do processo passa a atuar como sujeito principal. $\mathrm{O}$ mesmo sucede quando o perito interpõe recurso em face da decisão que lhe impõe a multa prevista no art. 424, parágrafo único, do CPC.

O juiz, sujeito principal e imparcial, passa a ser sujeito parcial no âmbito da exceção de suspeição ou de impedimento, na hipótese de não ser reconhecida por ele (juiz) a suspeição ou o impedimento afirmados pelo excipiente (CPC, art. 313, in fine). Aliás, mesmo quando o juiz reconhece o impedimento ou a suspeição (CPC, art. 313), "o seu ato não é de julgamento mas de autêntica submissão à pretensão do excipiente (reconhecimento do pedido)" 29 , de modo que também nesse caso o juiz age como sujeito parcial.

\section{Partes}

A presente pesquisa, conquanto germinada por força de dificuldades extraídas do direito material ${ }^{30}$, tem viés marcadamente processual, razão pela qual importa adotar conceitos puramente processuais - já de há muito debatidos pela doutrina -, os quais servirão de bases para o desenvolvimento de outras premissas e, mais especificamente, de proposições interpretativas em tema de litisconsórcio. Não se quer, com isso, formular novos conceitos; pretende-se, sim, analisar os diversos conceitos hauridos da doutrina mais abalizada, tanto nacional quanto estrangeira, para, com alguma dose de segurança, adotar aquele que pareça mais consentâneo com a dogmática processual e, principalmente, útil para o desenvolvimento do trabalho.

Conquanto a lei não defina o que seja parte, o fato é que tal expressão vem utilizada amiúde pelo legislador, impondo-se, pois, a busca do exato entendimento da noção de $\operatorname{parte}^{31}$. E o afã de se encontrar a precisa noção de parte não se justifica

\footnotetext{
${ }^{29}$ DINAMARCO, Cândido Rangel. Litisconsórcio, cit., nº 2, p. 24.

${ }^{30}$ Cf. Parte II, Cap. III.

${ }^{31}$ MANDRIOLI, Crisanto. Diritto processuale civile. 18. ed. Torino: Giappichelli, 2006. vol. I, p. 305.
} 
simplesmente por uma necessidade acadêmica. Em verdade, a boa compreensão da noção de parte vai render ensejo à solução de "graves problemas práticos"32.

Bem por isso não há como estudar litisconsórcio, em seus variados e possíveis enfoques metodológicos, sem passar, necessariamente, pela compreensão prévia do conceito de parte.

Parte é expressão polissêmica e, em linguagem comum, significa "qualquer porção de um todo" 33 , o fragmento de um determinado objeto. Daí se dizer, por exemplo, que o devedor pagou uma parte do preço; o construtor erigiu uma parte da casa; o aluno respondeu apenas uma parte da prova; concordo contigo em parte. Mas, ainda em linguagem não jurídica, tem-se que o termo parte pode ostentar outras inúmeras conotações: (i) uma "área ou região não especificada" (o pai leva o filho a qualquer parte); (ii) uma "área determinada" (a colisão ocorreu na parte traseira do veículo; o ruído veio $d a$ parte de trás da casa); (iii) um papel ou função a desempenhar ("a parte do governo é cuidar da saúde, educação e segurança"). Além disso, na dependência de expressões que venham acopladas ao termo parte, podem ser visualizados outros significados, alguns, aliás, bem pouco conhecidos: (a) "falou-lhe à parte sobre a promoção", isto é, falou-lhe reservadamente, separadamente sobre a promoção; (b) "a encomenda veio da parte do pai", ou seja, a encomenda veio a mando ou a pedido do pai; (c) o professor tomou parte na reunião; (d) "vítima deu parte do ladrão", isto é, acusou ou denunciou o ladrão; (e) “dar parte de fraco", ou seja, revelar que não tem força ou condições para fazer alguma coisa; (f) "deu parte de doente para fugir ao trabalho", é dizer fingiu-se de doente para fugir ao trabalho; (g) "não saber parte de si" significa estar alheado, arrebatado, extasiado; (h) "pôr ou deixar alguma coisa de parte" quer dizer abstrair-se dela, apartá-la do uso, desprezá-la (v. g., "já pus de parte êste chapéu"); (i) "conservou-se de parte enquanto conversávamos" explicita a ideia de distância, de não interferência; (j) "fulano é cheio de partes", curiosamente, revela que alguém é cheio de manhas, melindres, exigências ${ }^{34}$.

\footnotetext{
${ }^{32}$ CHIOVENDA, Giuseppe. Instituições de direito processual civil. 2. ed. Trad. J. Guimarães Menegale. São Paulo: Saraiva, 1965. vol. II, p. 233.

${ }^{33}$ CALDAS AULETE. Dicionário contemporâneo da língua portuguesa. 2. ed. brasileira. Rio de Janeiro: Delta, 1964. vol. IV, p. 2.989. Cf. também HOUAISS, Antônio (Dicionário Houaiss da língua portuguesa. Rio de Janeiro: Objetiva, 2001, p. 2.138-2.139).

34 Os exemplos e os significados citados foram extraídos do ou influenciados pelo que se contém em CALDAS AULETE (Op. e loc. cit.) e também em HOUAISS (Op. e loc. cit.).
} 
Em linguagem jurídica, igualmente, o termo parte pode expressar realidades juridicamente distintas. Com efeito, no direito contratual é comum a utilização da expressão "partes contratantes", apta a indicar os figurantes de uma dada relação negocial, o que não condiz com o conceito de parte que se tem em direito processual, conforme se verá a seguir. Essa constatação, porém, transparece útil para remarcar que "a noção de parte é comum ao direito material e ao direito processual, enquadrando-se, portanto, na teoria geral do direito" 35 .

Mas, como já anunciado, o que se interpõe como premissa para o estudo aqui desenvolvido diz com o conceito processual de parte, cuja noção - é bom que se diga advém da própria evolução da ciência do processo, porquanto, nos primórdios do sincretismo entre direito material e processo (fase imanentista), a visualização da parte processual derivava da configuração do direito material discutido em juízo. "A velha doutrina procurava, realmente, identificar a posição no processo com a posição do Direito Material, e, a partir daí, construía categorias processuais. Numa palavra, moldava-se o conceito no campo do processo, com os elementos tirados ou transplantados, pura e simplesmente, do Direito Material, sem modificações maiores" ${ }^{\text {36. }}$.

Alcançada a estatura de ramo autônomo da ciência jurídica, o direito processual passou a entender o conceito de parte pelo prisma "quase que exclusivamente",37 processual. Essa expressão de ARRUDA ALVIM (quase que exclusivamente) explica-se pelo fato de o autor considerar útil, talvez em razão do apelo didático, a noção de parte no sentido material ou substancial. São suas as seguintes palavras: "Para determinados efeitos e institutos do processo, pode-se dizer que o conceito material de parte subsiste relevante" ${ }^{, 38}$. Depois de explicar que parte em sentido substancial respeita àquele que afirma, ou de quem se afirma ser o titular do direito material, ARRUDA ALVIM põe em relevo a utilidade, mesmo no campo do processo, da distinção entre parte processual e parte em sentido material:

${ }^{35}$ TUCCI, Rogério Lauria. Parte (verbete), In: Enciclopédia Saraiva do Direito. São Paulo: Saraiva, 1977. vol. 57, p. 157.

${ }^{36}$ ARRUDA ALVIM. Tratado de direito processual civil. 2. ed. São Paulo: RT, 1996. vol. 2, p. 33. Nessa obra o autor traça os marcos da evolução do conceito processual de parte, notadamente à luz de expressiva doutrina alemã. LOPES DA COSTA também delineia a evolução da noção processual de parte (Direito processual civil brasileiro 2. ed. Rio de Janeiro: Forense, 1959. vol. I, p. 348).

${ }^{37}$ ARRUDA ALVIM. Tratado de direito processual civil, cit., p. 33.

${ }^{38} I d .$, p. 39. 
"Esta distinção, entretanto, serve para considerarem-se os efeitos da sentença, quando esses atingem precípua ou diretamente a chamada parte material. A parte material é atingida pelos efeitos primários e substanciais da sentença, que nela encontram o seu destinatário precípuo. Aplica-se, a nosso ver, exclusivamente para informar-nos dos casos em que, como na substituição processual, alguém, que está fora do processo, seja o atingido pelos efeitos da sentença"39.

Conquanto não se negue a utilidade marcadamente didática da distinção entre parte processual e parte em sentido material, para o fim de resolver questões pertinentes ao litisconsórcio, dentre outros institutos processuais, "delineia-se necessária a elaboração de um conceito de parte abstraído de qualquer liame com a situação de direito material" ${ }^{\text {" }}$. É que, sendo uno o conceito de parte, não se pode conceber, no âmbito processual, a existência de parte material e parte formal ${ }^{41}$.

À luz do que se vem de dizer, o conceito de parte expressa uma ideia menos ampla do que a de sujeitos do processo ${ }^{42}$. Com efeito, as partes categorizam-se como sujeitos principais e parciais do processo, não obstante existam outros sujeitos igualmente importantes e com atuação diferenciada em relação àqueles. Em palavras outras, as partes constituem espécie do gênero sujeitos do processo.

\footnotetext{
${ }^{39}$ ARRUDA ALVIM. Tratado de direito processual civil, cit., vol. 2, p. 40 (grifos do original). Em nota de rodapé da mesma página, o autor acrescenta que a parte substancial "é aquela havida como titular da lide. Isto é, aquela a quem - ativa ou passivamente - a lide diz respeito, econômica ou moralmente" (grifos do original).

${ }^{40}$ CRUZ E TUCCI, José Rogério. Limites subjetivos da eficácia da sentença e da coisa julgada civil. São Paulo: RT, 2006, p. 31. Anota-se que o próprio ARRUDA ALVIM, em edição recente de seu Manual, aduz que aquela distinção está "hoje superada” (Manual de direito processual civil. 10. ed. São Paulo: RT, 2006. vol. 2, p. 31).

${ }^{41}$ LOPES DA COSTA, Alfredo de Araújo. Direito processual civil brasileiro, cit., vol. I, p. 349.

${ }^{42}$ ARRUDA ALVIM. Tratado de direito processual civil, cit., vol. 2, p. 18. Daí não se poder concordar com o conceito de sujeitos processuais cunhado por LIEBMAN: "Soggetti del processo e del rapporto processuale sono, oltre al giudice, le parti” (Manuale di diritto processuale civile. 4. ed. Milano: Giuffrè, 1984. vol. I, p. 85). A visão de LIEBMAN parece reduzir, sobremaneira, o espectro dos sujeitos processuais, pois considera como tais apenas o juiz e as partes. Visão reducionista também se vê em CARNELUTTI (Instituciones del nuevo proceso civil italiano. Trad. Jaime Guasp. Barcelona: Bosch, 1942, p. 110).
} 
Mesmo no âmbito estrito do processo, na dependência da perspectiva adotada, a noção de parte admite variantes, em ordem a se concluir pela presença de um conceito polissêmico $^{43}$.

Analisando a legislação italiana, GARBAGNATI propôs uma divisão tripartite da noção de parte, concluindo que o termo pode expressar as seguintes realidades: $(i)$ os sujeitos dos atos do processo; (ii) os sujeitos dos efeitos dos atos do processo; e (iii) os sujeitos da relação litigiosa ${ }^{44}$. COMOGLIO, FERRI e TARUFFO também seguem essa mesma trilha e enxergam, à luz da legislação italiana, a tripartição da noção de parte: $a$ ) sujeitos que, em contraposição ao que sucede com os órgãos jurisdicionais, realizam atos no processo ou são destinatários desses atos; $b$ ) sujeitos que são apenas destinatários dos efeitos dos atos do processo; $c$ ) sujeitos dos efeitos da sentença, isto é, "i soggetti che sono titolari della situazione sostanziale oggetto del processo e della decisione di merito" ${ }^{45}$.

Contudo, não se podem acolher as possíveis significações extraídas da legislação, porquanto os critérios utilizados pela lei nem sempre são científicos. Como facilmente se verifica, a acepção por último vislumbrada por GARBAGNATI (iii) baralha as ideias de parte e de parte legítima ${ }^{46}$ e, ademais, não explica o fenômeno da legitimação extraordinária, hipótese em que o sujeito da relação litigiosa, conquanto vinculado aos "efeitos da sentença”, não está no processo e, de conseguinte, não pode ser considerado parte ${ }^{47}$.

${ }^{43}$ CRUZ E TUCCI, José Rogério. Limites subjetivos da eficácia da sentença e da coisa julgada civil, cit., p. 31. No mesmo sentido, REDENTI: "Parte è termine di significato vario ed oscillante nell'uso, e nemmeno nell'ambito del diritto processuale non può dirsi che esprima un concetto noto e fisso (anzi è fra i più disputati)" (Il giudizio civile con pluralità di parti. Milano: Giuffrè, 1960, nº 58, nota 72, p. 75).

${ }^{44}$ La sostituzione processuale nel nuovo Codice di Procedura Civile. Milano: Giuffrè, 1942, p. 245-248. Sobre o assunto, consulte-se, com proveito, CRUZ E TUCCI (Limites subjetivos da eficácia da sentença e da coisa julgada civil, cit., p. 32).

${ }^{45}$ Lezioni sul processo civile. 4. ed. Bologna: Il Mulino, 2006. vol. I, p. 286.

${ }^{46}$ Nesse sentido, por todos, LIEBMAN (Manuale di diritto processuale civile, cit., vol. I, p. 86).

${ }^{47}$ GIAN ANTONIO MICHELI preconiza que a única maneira de construir a noção de parte, de modo útil para cada tipo de processo, consiste em desvincular tal conceito das ideias de titularidade da situação substancial e também das considerações a respeito dos efeitos do processo. Daí sua conclusão: “Il concetto processuale di parte si esaurisce quindi nella constatazione dei soggetti che partecipano al processo o fin dall'inizio di esso o successivamente" (Corso di diritto processuale civile. Milano: Giuffrè, 1959. vol. I, p. 171-172). O próprio GARBAGNATI explica que, conceitualmente, a noção de parte não guarda vínculo com os sujeitos da relação jurídica litigiosa e que, em verdade, partes são os sujeitos do complexo de direitos, obrigações e ônus surgidos por ocasião do processo (Op. cit., p. 249-250). Em sentido contrário, 
Ao tratar do conceito de parte, CARNELUTTI elabora a distinção entre sujeitos da lide e sujeitos do processo, chamando ambos, porém, de partes. Advém daí a consequente distinção entre partes em sentido material e partes em sentido processual. Para CARNELUTTI, o sujeito da lide converte-se também em sujeito do processo na medida em que é um dos sujeitos "que hacen el proceso" parte direta e indireta, salientando que no primeiro caso existe coincidência entre o sujeito que atua no processo e aquele que é parte em sentido material. O fenômeno da parte indireta ocorre quando uma pessoa distinta do sujeito da lide promove aquela atuação processual, o que se dá, segundo CARNELUTTI, nas hipóteses de representação processual e de substituição processual ${ }^{49}$.

A doutrina alemã também cuidou do assunto. LENT acentuou o caráter puramente processual do conceito de parte e catalogou como tal aquele que pede a seu favor, perante o juiz, a tutela jurídica e aquele contra quem essa tutela é pedida ${ }^{50}$. Em versão mais enxuta, ARRUDA AlVIM retira do texto original em alemão a seguinte tradução para as palavras de LENT: "quem para si pede tutela jurídica e contra quem é a tutela pedida"51.

Tal noção parece pecar, todavia, pela desconsideração de que a parte pode, em certos casos, em nome próprio, pedir a tutela jurídica não para si, mas para outrem, como no caso da substituição processual ${ }^{52}$. Daí parecer mais acertada a definição de SCHÖNKE:

SALVATORE SATTA constrói seu conceito de parte sem promover a cisão entre as noções de parte e de giusta parte (parte legítima), apregoando, com isso, sua discordância com a visão puramente processual do conceito de parte (Diritto processuale civile. 8. ed. Padova: CEDAM, 1973, p. 77-78).

48 Instituciones del nuevo proceso civil italiano, cit., p. 111. Em senso diverso, eis a crítica de SERGIO COSTA: "Tuttavia no si vede perchè i due concetti debbano essere confusi, anche se la legge dà identica denominazione. La parte nel processo è soltanto quella che si determina rispetto alla domanda, e non può confondersi con la parte del rapporto sostanziale" [Parti (verbete), In: Novissimo digesto italiano. Torino: Torinense, 1976. vol. XII, p. 499].

${ }^{49}$ Instituciones del nuevo proceso civil italiano, cit., p. 111.

${ }^{50}$ Diritto processuale civile tedesco. Trad, da 9. ed. alemã por Edoardo F. Ricci. Napoli: Morano, 1962, p. 61-62. Na versão portuguesa de OTHMAR JAUERNIG, parte é “quem procura para si próprio protecção jurídica perante o tribunal e contra quem a proteção jurídica é pedida" (Direito processual civil. 25. ed. Trad. F. Silveira Ramos. Coimbra: Almedina, 2002, p. 98).

${ }^{51}$ Tratado de direito processual civil, cit., vol. 2, p. 30.

52 ARRUDA ALVIM. Tratado de direito processual civil, cit., p. 32. 
"Partes son las personas por las cuales o contra las cuales se pide en nombre propio la tutela jurídica" ${ }^{, 53}$.

Mais acurada ainda é a visão de ROSENBERG, ao considerar que no direito processual só se pode trabalhar com um conceito de parte, em ordem a se rechaçar a divisão entre parte em sentido material e parte em sentido formal. Além disso, o autor demonstra que a noção de parte está desvinculada da titularidade do direito material, pondo em relevo situações em que as partes são "personas distintas de los 'portadores del derecho o de la relación jurídica controvertidos"”. Então, para ROSENBERG, partes "son aquellas personas que solicitan y contra las que se solicita, en nombre propio, la tutela jurídica estatal $", 54$.

Na Espanha, JAIME GUASP, partindo de sua famosa construção acerca do processo como "institución jurídica destinada a la satisfacción de pretensiones" "55, caracteriza as partes por sua imbricação com a ideia de pretensão. A satisfação estaria ligada ao órgão jurisdicional, enquanto a pretensão estaria jungida à posição das partes. Daí o seu conceito: "Parte es quien pretende y frente a quien se pretende, o, más ampliamente, quien reclama y frente a quien se reclama la satisfacción de una pretensión"

Por sua vez, PrIETo-CASTRO y FERRÁNDIZ, sem assumir posição em torno da natureza jurídica do processo, mas pondo em realce o caráter puramente processual do conceito, expõe que partes são as pessoas (físicas ou jurídicas) que se tornam sujeitos de um processo para pretender a outorga de justiça ou tutela jurídica e que, por isso mesmo, "asumen la titularidad de las relaciones que en el mismo se crean, con los derechos, las cargas y las responsabilidades inherentes" $" 57$.

${ }^{53}$ Derecho procesal civil. Trad. da 5. ed. alemã por Prieto Castro e Fairén Guillén. Barcelona: Bosch, 1950, p. 85.

${ }^{54}$ Tratado de derecho procesal civil. Trad. esp. Angela Romera Vera. Buenos Aires: EJEA, 1955. t. I, p. 211 212.

${ }^{55}$ Derecho procesal civil. 3. Ed. Madrid: Instituto de Estudios Politicos, 1968. t. I, p. 170 (grifos do original).

${ }^{56}$ GUASP, Jaime. Derecho procesal civil, cit., t. I, p. 170. O autor também consente com a visão de que a noção de parte é puramente processual. "Por ello, para el proceso, no hay partes materiales y formales, sino sólo la condición de ser o no parte procesal" (Id., p. 170).

${ }^{57}$ Derecho procesal civil. 2. ed. Madrid: Tecnos, 1974 . vol. $1^{\circ}$, p. 56. Ainda em língua espanhola, mas proveniente do México, confira-se, por todos, o conceito de IGNÁCIO MEDINA LIMA [Partes procesales (verbete). In: Enciclopedia jurídica latinoamericana. Santa Fe: Rubinzal Culzoni/Universidad Nacional Autónoma de México, 2007. vol. VIII, p. 171-175]. 
Entre nós foi amplamente aceito e difundido o conceito ministrado por CHIOVENDA: "Parte é aquêle que demanda em seu próprio nome (ou em cujo nome é demandada) a atuação duma vontade da lei, e aquêle em face de quem essa atuação é demandada"58. Ao se referir àquele em cujo nome é demandada, CHIOvENDA fazia alusão à hipótese de o autor comparecer em juízo representado por outrem, dando mostras de que a parte seria o representado e não o representante.

A enunciação chiovendiana foi adjetivada de "excelente" por MOACYR AMARAL SANTOS $^{59}$ e acolhida expressamente por LOPES DA COSTA ${ }^{60}$.

Pelo que se vê em ChiOvendA, a noção de parte por ele engendrada guarda coerência com o seu entendimento acerca de institutos fundamentais do direito processual, como a jurisdição e a ação. Com efeito, sendo a jurisdição uma função do Estado, cujo escopo é a "atuação da vontade concreta da lei por meio da substituição, pela atividade de

58 Instituições de direito processual civil, cit., vol. II, p. 234 (grifos do original). Bem parecida é a noção engendrada por MANDRIOLI, sem alusão, contudo, à "atuação da vontade da lei": "parte è colui che propone la domanda in nome proprio o nel cui nome si propone la domanda; o rispettivamente colui nei cui confronti la domanda è proposta" (Op. cit., vol. I, p. 308). Assim também a descrição de ENRICO REDENTI (Il giudizio civile con pluralità di parti, cit., $\mathrm{n}^{\circ} 58$, nota 72 , p. 75).

${ }^{59}$ Primeiras linhas de direito processual civil. 23. ed. São Paulo: Saraiva, 2004. vol. 1º p. 347. Contudo, o autor conclui seu pensamento com base em SCHÖNKE e ROSENBERG, para assinalar que partes "são as pessoas que pedem ou em face das quais se pede, em nome próprio, a tutela jurisdicional” (Id., p. 347 grifos do original). FREDERICO MARQUES (Manual de direito processual civil, cit., vol. $1^{\circ}$, p. 247) e THEODORO JÚNIOR (Curso de direito processual civil. 21. ed. Rio de Janeiro: Forense, 1997. vol. I, p. 76) também foram abeberar-se na lição de SCHÖNKE. A definição de PONTES DE MIRANDA, igualmente, tem uma carga semântica atrelada à enunciação alemã: "Partes são as pessoas para as quais e contras as quais é pedida a tutela jurídica. (...) Parte é, portanto, quem entra, como sujeito, ativo ou passivo, na relação jurídica processual. Partes são figurantes processuais; há partes que não são os sujeitos da relação jurídica, objeto do litígio" (Comentários ao Código de Processo Civil. 3. ed. atual. por Sergio Bermudes. Rio de Janeiro: Forense, t. I, p. 220-221). No mesmo sentido: EPHRAIM DE CAMPOS JR. (Substituição processual. São Paulo: RT, 1985, p. 12); MARIZ DE OLIVEIRA JR. (Substituição processual. São Paulo: RT, 1971, p. 28); GOMES DA CRUZ (Pluralidade de partes e intervenção de terceiros. São Paulo: RT, 1991, p. 162).

${ }^{60}$ Direito processual civil brasileiro, cit., vol. I, p. 350. Em obra anterior, LOPES DA COSTA já revelava sua predileção pelo enunciado chiovendiano, pois acentuava que serão partes "aquelles em cujo nome ou em face dos quaes se pede uma actuação da lei” (Da intervenção de terceiros no processo. São Paulo: C. Teixeira e Cia., 1930, p. 11). 
órgãos públicos, da atividade de particulares ou de outros órgãos públicos",61, pode-se dizer que partes serão os sujeitos que demandam, em nome próprio (ou em cujo nome é demandado), e em relação a quem se demanda o exercício da função jurisdicional do Estado. Ainda, para bem compreender o conceito chiovendiano, deve-se observar que o direito de ação, para o autor, constitui um direito potestativo, de sorte que tal direito não é dirigido ao Estado, mas sim ao adversário. "O titular do direito de ação tem o direito, que é ao mesmo tempo um poder, de produzir, em seu favor, o efeito de fazer funcionar a atividade jurisdicional do Estado, em relação ao adversário, sem que este possa obstar aquele efeito" ${ }^{\prime 62}$.

Percebe-se, portanto, que na visão de CHIOvEndA a noção de parte está intimamente relacionada com as ideias de demanda pendente e de objeto do processo, sendo criticável, ainda, pela ausência de referibilidade ao contraditório ${ }^{63}$.

Empregando como pano de fundo as lições de LIEBMAN ${ }^{64}$, CÂNDIDO DinAMARCO engendra um conceito bem amplo de partes, adotando como polo metodológico a garantia constitucional do contraditório. Daí dizer que partes são "os sujeitos interessados da relação processual" ${ }^{65}$, isto é, aqueles que titularizam as "situações jurídicas ativas e

${ }^{61}$ Instituições de direito processual civil, cit., vol. II, p. 3 - grifos do original.

${ }^{62}$ AMARAL SANTOS, Moacyr. Primeiras linhas de direito processual civil, cit., vol. $1^{\circ}$, p. 149. Conforme testifica ATHOS GUSMÃO CARNEIRO, a "definição vincula-se evidentemente à teoria chiovendiana da ação como direito potestativo, teoria que ainda mantém a ação como de caráter concreto, embora autônomo. A lei é vontade geral e abstrata; ocorridos os fatos por ela abstratamente previstos, a vontade da lei torna-se, para aquele caso, concreta. Se não for obtida a realização espontânea desta vontade concreta da lei, tal atuação poderá ser pleiteada em juízo. Quem demanda torna-se autor; aquele 'contra quem' (quando houver uma efetiva oposição de interesses) ou 'perante quem' (quando tal oposição não existir) tal atuação é demanda será o réu" (Intervenção de terceiros. 19. ed. São Paulo: Saraiva, 2010, p. 4).

${ }^{63}$ DINAMARCO, Cândido Rangel. Intervenção de terceiros. 5. ed. São Paulo: Malheiros, 2009, n 3, p. 17. Assim também CRUZ E TUCCI (Limites subjetivos da eficácia da sentença e da coisa julgada, cit., p. 31). A crítica de DINAMARCO explica-se porque o autor considera o contraditório como algo inerente ao próprio conceito de processo (Litisconsórcio, cit., $\mathrm{n}^{\circ}$ 1, p. 21).

64 "Sono parti del processo i soggetti del contraddittorio istituito davanti al giudice, i soggetti del processo diversi dal giudice, nei cui confronti quest'ultimo deve pronunciare il suo provvedimento" (Manuale di diritto processuale civile, cit., vol. I, p. 85).

${ }^{65}$ Litisconsórcio, cit., $\mathrm{n}^{\mathrm{o}}$ 2, p. 22 (grifo do original). "Dizem-se interessados porque ali estão sempre em defesa de alguma pretensão própria ou alheia" (DINAMARCO, Cândido Rangel. Instituições de direito processual civil, cit., vol. II, $\mathrm{n}^{\circ}$ 520, p. 252). 
passivas que compõem a relação jurídica processual (faculdades, poderes, deveres, ônus e sujeição)",66 e em “cujas esferas jurídicas atuará o provimento a ser emitido pelo juiz"67.

Consoante a construção de DinAMARCO, o dado decisivo para discernir o que seja parte consiste na titularidade daqueles poderes, deveres, faculdades, ônus e sujeição, desde que atuados, evidentemente, de maneira interessada ${ }^{68}$. Realmente, o juiz, conquanto tenha poderes e deveres, não será, de regra, parte, pois que age de modo desinteressado e também "não está sob sujeição e não é destinatário dos efeitos do provimento jurisdicional"69.

Para o aludido autor, tal concepção seria a "única capaz de explicar sistematicamente a contraposição parte-terceiro, sem as distorções próprias das inconvenientes ligações com fenômenos de direito substancial ou com o objeto do processo"70 . Daí, por conseguinte, o seu conceito puro de terceiro:

\begin{abstract}
“Terceiro, nessa ótica, é toda pessoa que não seja parte no processo, enquanto não o for. A intervenção do terceiro o faz parte desde o momento em que voluntariamente comparecer (intervenção voluntária) ou em que for citado (intervenção provocada: denunciação da lide, chamamento ao processo, sucessores do demandado)" ${ }^{\text {,71. }}$.
\end{abstract}

Como deflui dessa lição, terceiros seriam os sujeitos que não titularizam aquelas situações ativas e passivas acima referidas. Uma vez presente no processo e participando do contraditório, mesmo que seja apenas para coadjuvar uma das partes, o terceiro transforma-se em parte. Bem por isso é que - ainda segundo DINAMARCO - a intervenção de terceiro consiste no "ingresso de um sujeito no processo pendente, tornando-se com isso

\footnotetext{
${ }^{66}$ Litisconsórcio, cit., n ${ }^{\text {o }}$, p. 24.

${ }^{67}$ DINAMARCO, Cândido Rangel. Litisconsórcio, cit., nº 2, p. 22.

68 “São partes os sujeitos interessados do contraditório instaurado perante o juiz, em estado de sujeição ao poder exercido por este” (DINAMARCO, Cândido Rangel. Execução civil, cit., nº 97, p. 164).

${ }^{69} I d ., \mathrm{n}^{\mathrm{o}} 97, \mathrm{p} .164$.

${ }^{70}$ Intervenção de terceiros, cit., $\mathrm{n}^{\mathrm{o}} 3, \mathrm{p} .17$.

${ }^{71}$ Litisconsórcio, cit., $\mathrm{n}^{\circ} 5$, p. 32.
} 
parte e deixando de ser terceiro"72. Sendo assim, o fenômeno da pluralidade de partes abarca a intervenção de terceiros e o litisconsórcio ${ }^{73}$, consoante se verá mais adiante $\left(\mathrm{n}^{\circ} 6\right.$, infra).

Nessa perspectiva, a qualidade de parte adquire-se nas seguintes situações e condições:

"I) pela propositura da demanda inicial adquire-se a qualidade de autor ou executado; II) pela citação adquirem-se as qualidades (a) de réu ou executado, (b) de nomeado à autoria, (c) de litisdenunciado, (d) de chamado ao processo ou (e) de réu em virtude de sucessão universal; III) pela intervenção voluntária tornam-se partes (a) o opoente, (b) a pessoa que formula intervenção litisconsorcial voluntária, (c) o assistente, (d) o terceiro prejudicado que recorre, (e) os sucessores a título universal do autor falecido, (f) o adquirente do bem litigioso, que, mediante concordância do adversário ou por morte do alienante, sucede a este na posição que ocupava; e (g) o adquirente que, sem essa concordância, ingresse como assistente do alienante" ${ }^{, 74}$.

Depois dessa enunciação ampla em torno da noção de parte, o autor citado ainda distingue o que chama de partes na demanda e partes no processo (ou partes na relação

\footnotetext{
${ }^{72}$ Litisconsórcio, $\mathrm{n}^{\circ}$ 8, p. 36. VICENTE GRECO FILHO critica essa orientação e diz que a definição de parte formulada por LIEBMAN, e acolhida por DINAMARCO, não é esclarecedora quando se enfrenta a questão em torno da noção de terceiros, isto porque "basta o ingresso no processo, com a participação no contraditório, para a aquisição da qualidade indiscriminada de parte em sentido processual. Assim, neste sentido, o assistente é parte quanto o são o autor e o réu, ou ainda, por exemplo, é parte o arrematante que vem a manifestar-se na execução se houver alguma impugnação à arrematação. Este último participará de um contraditório limitado, é certo, mas desenvolverá atividade processual e receberá um provimento jurisdicional" (Da intervenção de terceiros. 3. ed. São Paulo: Saraiva, 1991, p. 28).

${ }^{73}$ DINAMARCO, Cândido Rangel. Litisconsórcio, cit., no 6, p. 33. Ver, mais amplamente, ainda neste Capítulo, nº, infra.

${ }^{74}$ DINAMARCO, Cândido Rangel. Instituições de direito processual civil, cit., vol. II, ${ }^{\circ}$ 533, p. 288. Em senso semelhante: LIEBMAN (Manuale... cit., vol. I, p. 86) e GIOVANNI VERDE (Profili del processo civile. Napoli: Jovene, 2002. vol. 1, p. 190). Àquele rol proposto por DINAMARCO deve-se acrescentar a figura do sujeito que "sofre os efeitos da desconsideração incidental da personalidade jurídica" (CRUZ E TUCCI, José Rogério. Limites subjetivos da eficácia da sentença e da coisa julgada, cit., p. 34).
} 
processual). "Partes na demanda são o sujeito que comparece perante o juiz pedindo tutela jurisdicional e aquele em relação ao qual essa tutela é pedida"75. Essa noção, que encampa a definição de parte fornecida por CHIOVENDA, está imbricada com o objeto do processo, entendido como o pedido deduzido em juízo ${ }^{76}$. Dessa forma, a posição de parte na demanda é assumida pelos autores das pretensões cuja satisfação se busca em juízo e pelos réus que figuram como sujeitos passivos daquelas mesmas pretensões deduzidas ${ }^{77}$.

O termo parte no processo exprime noção mais ampla, de sorte que ostentará a condição de parte no processo o sujeito que titularizar aquelas situações ativas e passivas na órbita processual, mesmo que não exercite efetivamente os seus poderes e faculdades ${ }^{78}$.

Logo, a posição de parte no processo adquire-se na forma disposta na transcrição que se fez acima (objeto da nota 74), enquanto que a condição de parte na demanda é assumida por aquele que formula pedido em juízo (autor ou exequente) ou por aquele em face de quem o pedido vem formulado (réu ou executado).

O autor ou exequente, sendo parte na demanda, torna-se parte no processo só pelo fato de deduzir em juízo alguma pretensão. O réu ou executado, por sua vez, conquanto já seja parte na demanda (pois em face dele a pretensão foi deduzida em juízo), só será parte no processo depois da citação ${ }^{79}$, quando então passará a titularizar as situações jurídicas ativas e passivas na tela processual. Disso decorre que é possível ser parte na demanda e não ser parte no processo (réu ou executado antes da citação); também é possível ser parte

\footnotetext{
${ }^{75}$ DINAMARCO, Cândido Rangel. Instituições de direito processual civil, cit., no 437, p. 117.

${ }^{76}$ DINAMARCO, Cândido Rangel. O conceito de mérito em processo civil. In: Fundamentos do processo civil moderno. 5. ed. São Paulo: Malheiros, 2002. t. I, $\mathrm{n}^{\circ} 119$, p. 273-276. Acerca do objeto litigioso no processo civil, confira-se estudo aprofundado de RICARDO LEONEL, com ampla citação bibliográfica (Causa de pedir e pedido: o direito superveniente. São Paulo: Método, 2006, p. 31 et seq.).

${ }^{77}$ DINAMARCO, Cândido Rangel. Litisconsórcio, cit., n 3, p. 26. LUIZ EDUARDO RIBEIRO MOURÃO adota expressamente essa distinção proposta por DINAMARCO (Coisa julgada. Belo Horizonte: Fórum, 2008, p. 235-237).

${ }^{78}$ DINAMARCO, Cândido Rangel. Litisconsórcio, cit., $\mathrm{n}^{\mathrm{o}} 3, \mathrm{p}$. 25. Por isso é que o réu revel, mesmo não exercitando seus poderes e faculdades processuais, considera-se parte no processo e, por ser sujeito passivo da pretensão deduzida em juízo, também é parte na demanda.

${ }^{79}$ Pode ocorrer, outrossim, de o demandado, antes mesmo da citação, comparecer espontaneamente aos autos e, nesse momento, assumir também a posição de parte no processo.
} 
no processo e não ser parte na demanda (o assistente e o Ministério Público atuando como (ustos legis) ${ }^{80}$.

Pelo que se acaba de expor, não há como negar a coerência metodológica existente no pensamento de DinAmARCO, algo que vem desde o seu conceito de processo e passa pela noção processual de parte, pelo conceito puro de terceiro, pela visualização ampla de pluralidade de partes, desembocando na ideia de relatividade da distinção entre intervenção de terceiros e litisconsórcio ${ }^{81}$.

O rigor científico da construção acima aludida vem, de certa forma, sendo colocado à prova, pelo prisma exclusivamente da utilidade, na voz corajosa de SCARPINELLA BUENO. Ao adotar como premissa metodológica a necessária aproximação entre direito e processo, o autor por último citado inclina-se para a orientação clássica, advinda de CHIOVENDA, e aduz que parte será "quem pede e contra quem se pede alguma espécie de tutela jurisdicional" $" 82$, ao passo que terceiro é "todo aquele que não pede ou contra quem nada se pede em juízo" ${ }^{\natural 3}$.

Para o aludido professor, a visualização do fenômeno parte como algo reduzido ao campo exclusivo do processo constitui pensamento que não mais se ajusta ao presente estágio de evolução da ciência processual; isto porque os esforços empreendidos para separar os institutos processuais daqueles de direito material foram necessários na fase em que se buscava consolidar a autonomia do processo frente ao direito substancial. Dessa forma, sem flertar com o sincretismo metodológico (o que seria imperdoável naquela época em que se buscava justificar e demonstrar a autonomia do processo), SCARPINELLA

\footnotetext{
${ }^{80}$ Nesse ponto, equivoca-se MOURÃO ao acentuar, sem ressalvas quanto ao momento anterior à citação, que "todos aqueles que forem parte na demanda, necessariamente, serão partes no processo" (op. cit., p. 237).

81 "Entre as duas categorias fundamentais do fenômeno da pluralidade de partes (litisconsórcio e intervenção de terceiros) inexiste traço divisório intransponível que as distinga inexoravelmente, afastando coincidências ou superposições e evitando toda possível confusão. Em linhas muitos gerais, intervenção é o ingresso de um sujeito no processo pendente, tornando-se com isso parte e deixando de ser terceiro. E litisconsórcio é a situação que existe entre duas ou mais pessoas quando são autores ou réus no mesmo processo. Não raras vezes, do fato da intervenção de um terceiro (coata ou voluntária) resulta uma situação jurídica que perfeitamente se caracteriza como litisconsórcio" (Litisconsórcio, cit., no 8, p. 36). Cfr., neste Capítulo, ${ }^{\circ}$ 6, infra.

${ }^{82}$ SCARPINELla BUENO, Cassio. Partes e terceiros no processo civil brasileiro. 2. ed. São Paulo: Saraiva, 2006, p. 3.

${ }^{83} I d$., p. 3.
} 
BUENO diz que o momento atual é outro, consentâneo, pois, com a afirmação de que a noção de parte imbrica-se, também, com o próprio direito de ação e com o direito material $^{84}$. Eis o critério utilizado pelo autor para distinguir partes de terceiros:

"O que me interessa mais de perto para distinguir os 'terceiros' das 'partes', pois, é o momento imediatamente anterior à sua intervenção. É saber, dada uma relação jurídica processual, dado o exercício de uma determinada demanda que recai sobre determinados bens, a partir de determinados fundamentos, a quem, diretamente, ela diz respeito e a quem, ao menos em tese, podem dizer respeito seus efeitos regulares. Em suma: é importante verificar nesse instante quem é parte e quem é terceiro porque é nesse instante que releva verificar quem pode ou quem deve intervir na qualidade de terceiro juridicamente interessado. E até mais: quem, independentemente de intervir, ficará sujeito ao que for decidido embora pudesse ter sido parte, e simplesmente porque não foi parte é terceiro. É verificar quem pediu e em face de quem se pediu para olhar, em última análise, para as relações de direito material, e constatar em que condições delas afloram eventuais situações legitimantes, vale dizer, situações que autorizarão a intervenção de outros no processo" ${ }^{\Perp 5}$.

\footnotetext{
${ }^{84}$ SCARPINELLA BUENO, Cassio. Partes e terceiros no processo civil brasileiro, cit., p. 5-6.

${ }^{85}$ Id., p. 4 (grifos do original). Essa orientação é encontrada em obra mais recente do mesmo autor (Curso sistematizado de direito processual civil. São Paulo: Saraiva, 2007. vol. 2, t. I, p. 435-436). Cabe lembrar, por relevante, que o doutrinador citado aceita a ideia de que a maioria das formas de intervenção de terceiros catalogadas pelo legislador brasileiro tem a aptidão de guindar o terceiro à qualidade de parte. "Diferentemente de todos, o único que não é e nunca passa a ser parte, porque nunca pede e nunca nada contra ele é pedido diretamente, é o assistente. É ele, e só ele, o único terceiro a intervir no processo pendente e conservar esta qualidade até o final" (Partes e terceiros no processo civil brasileiro, cit., p. 13). Nisso a lição de SCARPINELLA BUENO coincide com a de ARRUDA ALVIM, para quem o assistente simples não é parte, porquanto o que "é relevante e definitivo para determinar quem seja parte, é o fato de alguém pedir no processo, e tendo-se em vista contra quem se pede e que esteja no processo" (Tratado de direito processual civil, cit., vol. 2, p. 30). Assim também no seu Manual de direito processual civil, cit., vol. 2, p. 31 e 120. As alusões de SCARPINELLA BUENO ao "momento" e ao "instante" fazem transparecer a inclinação do autor pelo chamado critério cronológico, muito combatido por GRECO FILHO (Da intervenção de terceiros, cit., p. 22-23).
} 
Sobreleva notar, no afã de retratar fielmente o pensamento do mencionado autor, que ele próprio assume que o critério empregado tenta ser o mais útil possível para o estudo da matéria, de modo que não se pretendeu formular uma construção que seja "válida para todo e qualquer caso ou problema que se apresente para o teórico ou para o prático" $" 86$.

Apesar de se aceitar como adequada a premissa de que os institutos processuais são influenciados pela conformação da relação de direito material discutida, não se tem como livre de críticas a construção de um conceito eminentemente processual com base em elementos retirados do direito material. Se é verdade que a técnica processual deve estar ajustada ao atendimento das necessidades do direito material, não menos correta é a compreensão de que noções conceituais de direito processual devem ser explicadas dentro do espectro fenomenológico do processo.

Daí que, seguindo a orientação que vem desde a clássica doutrina alemã (LENT e ROSENBERG), a noção de parte está imbricada com a teoria do processo e não com a teoria da ação. Muito menos se poderia explicar a noção de parte processual com base em elementos extraídos do direito material. Pensar diferentemente geraria o risco de se criarem confusões desnecessárias entre as noções de parte, de parte legítima, de parte vencedora e de parte da relação de direito material.

Portanto, afigura-se cientificamente adequado e suficientemente útil o critério distintivo apregoado por CÂNDIDO DINAMARCO: partes são os sujeitos do contraditório, isto é, aqueles que titularizam as situações jurídicas ativas e passivas na tela processual; terceiros são os que, por estarem fora do processo concretamente considerado, não titularizam essas posições jurídicas. Contudo, o terceiro, na medida em que intervém, seja qual for a modalidade de intervenção, torna-se parte. Cabe distinguir, ainda dentro do gênero parte, as duas espécies: parte no processo e parte na demanda.

O tema da distinção entre partes e terceiros ganha especial colorido quando se voltam os olhos para o processo coletivo. É que nesse tipo de processo existe um portador ideológico da demanda coletiva, isto é, aquele ente que, em linguagem corrente, representa adequadamente a massa de sujeitos envolvidos com uma dada situação da vida apta a caracterizar um interesse (ou direito) difuso, coletivo ou individual homogêneo. Daí por que MANCUSO considera no mínimo duvidosa a possibilidade de se continuar chamando de

${ }^{86}$ SCARPINELLA BUENO, Cassio. Partes e terceiros no processo civil brasileiro, cit., p. 11. 
terceiros os sujeitos integrantes do conflito coletivo, isso na hipótese de se reconhecer judicialmente a idoneidade da representação do interesse metaindividual pelo autor ideológico $^{87}$.

De sua parte, FREITAS BAZILONI afirma que "tecnicamente não existem terceiros nas ações coletivas, posto que todas as pessoas estarão adequadamente representadas nos respectivos processos. Se terceiro é aquele que não participou da relação processual ou não faz parte da relação de direito material, segue-se que, nas ações coletivas, de uma forma ou outra todos estarão participando" ${ }^{, 88}$.

A despeito dessas ponderáveis argumentações, acredita-se que há, sim, espaço para a distinção entre partes e terceiros. Com efeito, no processo coletivo as partes continuam sendo os sujeitos do contraditório instaurado perante o juiz; é dizer, aqueles que titularizam as posições jurídicas ativas e passivas no âmbito processual. Terceiros são todos aqueles que não são partes.

Mesmo sendo titular da relação de direito material discutida no processo coletivo, o sujeito concernente ao interesse metaindividual, uma vez estando fora do processo, será terceiro em relação àquele processo especificamente considerado. Como já explicitado anteriormente, a vinculação do sujeito ao direito material debatido em juízo é elemento estranho às noções, puramente processuais, de parte e de terceiro. Muito embora a eficácia da sentença e a autoridade da coisa julgada coletiva atinjam a esfera jurídica do sujeito que não está no processo, tal circunstância não o torna parte; será, ainda assim, terceiro.

Concebe-se como válida, portanto, a afirmação da inexistência de distinções, no trato da noção de parte e de terceiro, entre o que se vê no processo de índole singular e no de espectro coletivo ${ }^{89}$.

\footnotetext{
87 Jurisdição coletiva e coisa julgada: teoria geral das ações coletivas. São Paulo: RT, 2006, p. 252. A explicação de tal ideia está em que "na jurisdição coletiva é preciso ter desde logo presente que os sujeitos concernentes ao thema decidendum aí vêm tomados, não singularmente, mas na sua dimensão coletiva, atuando processualmente através de um portador judicial que a norma de regência considera um representante adequado. Nesse particular contexto, compreende-se que a utilidade (ou validade) do discrímen entre parte e terceiro se desvanece, justamente pela impossibilidade material da presença nos autos do universo dos sujeitos concernentes, dada sua expressiva projeção numérica” (id., p. 246).

${ }^{88}$ A coisa julgada nas ações coletivas. São Paulo: Juarez de Oliveira, 2004, p. 83.

${ }^{89}$ CRUZ E TUCCI, José Rogério. Limites subjetivos da eficácia da sentença e da coisa julgada civil, cit., p. 34. A ausência de distinção entre os conceitos de partes e de terceiros aplicáveis aos processos coletivo e
} 


\section{Princípio da dualidade de partes}

Fixadas as noções até aqui desenvolvidas, tem-se por relevante acentuar a existência de certo consenso em torno do chamado princípio da dualidade de partes ${ }^{90}$. Dizse que a própria existência do processo pressupõe a presença de dois sujeitos parciais, com interesses contrapostos ${ }^{91}$. "Il processo civile è costruito in base al sistema delle due parti; ciò significa che due parti sono necessarie e sufficienti ai fini del processo" "92. Tal lição é confirmada em LIEBMAN: "La struttura del processo presuppone almeno due parti in posizione contrapposta (...),93.

Não por outro motivo o legislador brasileiro, atento a essa ideia, define como requisito da petição inicial a indicação de qualificação do autor e do réu (CPC, art. 282,

individual fica ainda mais evidente pelo que se contém na seguinte lição: "A lei especial impôs que, nas ações de corte coletivo, a imutabilidade do decisum, ao invés de ficar restrita às partes formais que participam do processo, conforme o caso, estende-se ultra partes. Assim, por exemplo, na procedência do pedido nas ações civis públicas ou coletivas, a imutabilidade deverá estender-se a todo o grupo, categoria ou classe de lesados, os quais não estão representados nos autos, mas substituídos pelos legitimados extraordinários autorizados por texto legal expresso" (id., p. 318-319). RICARDO LEONEL parece aceitar essa mesma tese, pois, ao tratar da intervenção de terceiros no processo coletivo, menciona que a representatividade adequada faz com que a sentença produza efeitos com relação a todos os interessados, de sorte que, apesar de não serem "partes" no processo, seus interesses foram "adequadamente representados" (Manual do processo coletivo. 2. ed. São Paulo: RT, 2011, p. 241). Ao indicar que os sujeitos "adequadamente representados" no processo coletivo não são partes, o aludido professor do Largo de São Francisco realmente parece acatar a distinção, também para o processo de feição coletiva, entre partes e terceiros. Aliás, não fosse assim, não se justificaria o tratamento, pelo autor, do fenômeno da intervenção de terceiros no campo do processo coletivo.

${ }^{90}$ CÂNDIDO DINAMARCO refere-se ao mesmo fenômeno, mas não lhe dá a designação de princípio; fala em regra da dualidade de partes (Instituições de direito processual civil, cit., vol. II, n ${ }^{\circ}$ 532, p. 282 et seq.).

${ }^{91}$ ARRUDA ALVIM. Tratado de direito processual civil, cit., vol. 2, p. 51.

${ }^{92}$ LENT, Friedrich. Op. cit., p. 66 (grifo do original). Assim também SCHÖNKE: "La relación jurídica procesal requiere para su nacimiento, dos partes. Una parte no puede llevar un proceso contra sí misma; ni tampoco puede una parte intervenir en el proceso como representante de la outra. $\mathrm{Y}$ en caso de que una se convierta en sucesora de la contraria, termina por ello el procedimiento" (op. cit., p. 86 - grifos do original). Nessa mesma obra, SCHÖNKE faz referência, contudo, a autores alemães que negam a existência do princípio da dualidade de partes.

${ }^{93}$ Manuale di diritto processuale civile, cit., vol. I, p. 94-95. 
II). Também por isso se impõe a suspensão do processo no caso de morte de uma das partes (CPC, art. 265, I), sendo necessária a regularização mediante a habilitação dos sucessores da parte falecida (CPC, art. 1.055 e seguintes). Semelhantemente, havendo confusão entre autor e réu, o processo deve ser extinto sem resolução do mérito (CPC, art. $267, \mathrm{X})$, até porque "nessuno può quindi istituire un processo con se stesso"94.

Como se extrai da postura legislativa e também das lições doutrinárias acima aludidas, a ideia de dualidade de partes está intimamente ligada às noções de litígio, de combate, de conflito, de posições contrapostas ${ }^{95}$. Disso advém a dificuldade de conciliar a afirmação de que, para a existência do processo, é necessária a dualidade de partes com a realidade que se tem no campo da chamada jurisdição voluntária.

Sem pretender demonstrar o acerto desta ou daquela postura a respeito de tão intrincado assunto, se aceita como válida a afirmação de que a chamada jurisdição voluntária tem mesmo natureza jurisdicional e o processo que se instaura nesse âmbito conta com a presença de partes $^{96}$; mesmo que aí não haja litígio (pretensões antagônicas), existirá processo e partes.

Também pode não haver pretensões antagônicas na seara do chamado processo necessário. São as situações em que, mesmo diante da concordância de todos os envolvidos na relação de direito material (ausência, pois, de conflito), a via jurisdicional torna-se indispensável para a obtenção daquele determinado resultado jurídico. É o que ocorre nas ações constitutivas necessárias, em relação às quais o próprio legislador, não admitindo alternativa, já promoveu juízo de valor em torno da necessidade da via

\footnotetext{
${ }^{94}$ LENT, Friedrich. Op. cit., p. 66.

95 É o que explica CÂNDIDO DINAMARCO: "Tal é a regra da dualidade das partes, que tem apoio na própria realidade do processo como uma disputa entre dois ou mais sujeitos (combate, duelo) e na premissa de que ele se realiza para a solução de conflitos - e, obviamente, ninguém terá algum conflito consigo mesmo, suscetível de ser dirimido através do processo" (Instituições de direito processual civil, cit., vol. II, $\mathrm{n}^{\mathrm{o}} 532$, p. 282).

96 “Também as demandas destinadas a instaurar processos de jurisdição voluntária indicarão necessariamente as partes" (DINAMARCO, Cândido Rangel. Instituições de direito processual civil, cit., vol. II, n 442, p. 122). No primeiro volume dessa mesma obra, CÂNDIDO DINAMARCO define a jurisdição voluntária como sendo a "atividade jurisdicional destinada a pacificar pessoas mediante a tutela a uma delas ou a ambas, em casos de conflitos postos diante do juiz sem confronto entre possíveis direitos de uma ou de outra" (Instituições de direito processual civil, cit., vol. I, nº 123, p. 328-329 - grifos do original).
} 
jurisdicional para que o direito material seja atuado ${ }^{97}$. Como refere DoNALDO ARMELIN, nessas ações constitutivas negativas "a atuação do Judiciário é indeclinável, já que as partes, através de acordo de vontades, nunca chegariam ao resultado pretendido"98. Mais uma vez pode não haver antagonismo entre partes, mas processo haverá.

Discussão que se põe nessa mesma seara diz respeito ao processo de fiscalização abstrata da constitucionalidade. Não se duvida de que esse tipo de processo gravita na órbita da jurisdição civil. Porém, considerando-se que os institutos fundamentais do processo civil foram criados para solução de conflitos envolvendo partes com interesses contrapostos, a teoria e os conceitos do processo civil clássico devem ser transpostos para o chamado processo objetivo com indispensáveis temperamentos ${ }^{99}$.

Característica que realça bem a coerência dessa assertiva diz respeito, $v . g$., à falta de exigência de demonstração, pelo autor, de interesse jurídico específico para o manejo do processo destinado ao controle abstrato de constitucionalidade ${ }^{100}$.

Uma vez que se cuida de um instrumento político de controle de normas, calcado no interesse público de que a legislação infraconstitucional guarde compatibilidade com as normas advenientes da Constituição da República, e também porque se está diante de um processo sem partes, a doutrina e a jurisprudência alemãs caracterizaram esse instrumento jurídico como sendo um processo objetivo ${ }^{101}$. É que nessa espécie de demanda judicial não

\footnotetext{
${ }^{97}$ BEDAQUE, José Roberto dos Santos. Efetividade do processo e técnica processual. São Paulo: Malheiros, 2006, p. 298.

98 Legitimidade para agir no direito processual civil brasileiro. São Paulo: RT, 1979, p. 60. Pode-se exemplificar com as ações tendentes à anulação de casamento, no âmbito das quais, mesmo que haja concordância de todos os sujeitos envolvidos, a atuação da regra de direito material só se dá pela via judicial. ${ }^{99}$ BARROSO, Luís Roberto. O controle de constitucionalidade no direito brasileiro. São Paulo: Saraiva, 2004, p. 118-119.

100 MARTINS, Ives Gandra da Silva; MENDES, Gilmar Ferreira. Controle concentrado de constitucionalidade: comentários à Lei n ${ }^{\circ}$ 9.868, de 10.11.1999. São Paulo: Saraiva, 2001, p. 85.

101 Id., p. 86-87. Em parecer transcrito no voto do Min. Moreira Alves, quando do julgamento da Representação de Inconstitucionalidade $n^{\circ}$ 1.405/AC, GILMAR F. MENDES assim resumiu a jurisprudência alemã: "Tem-se aqui, pois, o que a jurisprudência dos Tribunais Constitucionais costuma chamar de processo objetivo (objektives Verfahren), isto é, um processo sem sujeitos, destinado, pura e simplesmente, à defesa da Constituição (Verfassungsrechtsbewahrungsverfahren) (Hartmut Söhn, Die abstrakte Normenkontrolle, in Christian Starck, Bundesverfassungsgericht und Grundegesetz, 1976, vol. I, p. 292). Não se cogita, propriamente, da defesa de interesse do requerente (Rechtsschutzbedürfnis), que pressupõe a defesa de situações subjetivas. Nesse sentido, assentou o Bundesverfassungsgericht que, no controle abstrato de
} 
se faz necessária a vinculação do thema decidendum à existência de lesão a direitos próprios ou de terceiros ${ }^{102}$.

Em síntese, pode-se dizer que os atores parciais do processo de controle abstrato de constitucionalidade representam um interesse público, ficando esmaecida, portanto, a ideia, advinda do processo civil clássico, de representação de interesses subjetivos.

Conquanto seja correta a alusão de que o processo objetivo constitui processo sem partes, é preciso aclarar o exato significado dessa afirmação, impondo-se, de partida, a investigação em torno de qual das acepções da expressão partes tem sido utilizada para explicar o fenômeno na tela do processo objetivo.

Levando em conta que neste trabalho o conceito processual de parte diz respeito aos sujeitos que titularizam as posições jurídicas ativas e passivas na tela processual, podese facilmente verificar que o termo partes, tal como utilizado pela doutrina do processo objetivo, não guarda exata sinonímia com a noção processual de parte.

Ao se dizer que o processo objetivo configura um processo sem partes, quer-se expor a ideia de que não existe um interesse subjetivo sendo tutelado, já que o interesse jurídico necessário e suficiente para desencadear o processo de fiscalização abstrata é o interesse público de controle ${ }^{103}$. Em outras palavras, parece correto asseverar que o objeto do processo de controle abstrato de normas não pertine a sujeitos; seria como dizer, num esforço para se chegar à compreensão, que no processo objetivo não há partes em sentido material. Ou ainda, não há sujeitos envolvidos na situação jurídica que se discute como mérito do processo objetivo.

Bem entendidas as coisas, consente-se com a ideia de que também no processo objetivo há partes em senso processual, porquanto a atividade jurisdicional que aí se contém é inerte e só se move mediante a provocação dos sujeitos parciais que, por atuarem no processo, titularizam aquelas posições jurídicas ativas e passivas que estão à base da noção de parte processual.

normas, cuida-se, fundamentalmente, de um processo unilateral, não-contraditório, isto é, de um processo sem partes, no qual existe um requerente, mas inexiste requerido (BVerfGE 1, 14(30); 2, 143(153); 1, 108(226)" (Revista Trimestral de Jurisprudência, vol. 127, fev/89, p. 402-403).

${ }^{102}$ MARTINS, Ives Gandra da Silva; MENDES, Gilmar Ferreira. Op. cit., p. 87-88.

${ }^{103}$ STF, ADI 79, Pleno, Rel. Min. Celso de Mello, j. 13.04.92, DJ 12.09.1989, p. 8426 (RTJ 147-1/3). 
Daí poder-se falar, por exemplo, em legitimidade para o manejo de ação direta de inconstitucionalidade. Que legitimidade é essa? Trata-se, evidentemente, da legitimidade para agir, estando imbricada, pois, com a qualidade jurídica da parte processual.

LUÍs ROBERTO BARROSO chega a dizer que "é corrente o emprego da terminologia 'legitimação ativa e passiva' na ação direta de inconstitucionalidade”, tanto assim que a "praxis do Supremo Tribunal Federal refere-se a requerente e requerido, respectivamente, para designar o autor do pedido e o órgão do qual emanou o ato impugnado" ${ }^{, 104}$.

Como se vê, também no processo objetivo destinado ao controle da constitucionalidade de normas há partes - considerado o sentido puramente processual do termo, conforme noção adotada neste trabalho. De conseguinte, terceiros serão todos aqueles que não forem partes, valendo relembrar que a legislação brasileira não admite a intervenção de terceiros no âmbito do processo de controle abstrato de normas ${ }^{105}$. Porém, a inadmissibilidade da intervenção não importa a conclusão de que simplesmente não existam terceiros. Ao contrário, a vedação da intervenção de terceiros reforça ainda mais a ideia de que também no processo objetivo há espaço para a distinção partes-terceiros.

No que pertine à dualidade de partes, convém observar que, embora não se possa falar em partes com interesses contrapostos - porquanto todos os sujeitos parciais do processo objetivo buscam concretizar o interesse público ao controle da constitucionalidade de normas -, existem partes com posições processuais contrapostas.

O interesse público de controle é uno e por isso não pode ser fracionado entre os sujeitos parciais do processo objetivo. O interesse público que move o autor a propor a demanda tendente, $v . g$, à declaração de inconstitucionalidade de uma norma constitui o mesmo interesse público que legitima o ente emissor da norma a defender a constitucionalidade do ato normativo. Daí a inexistência de partes com interesses contrapostos, haja vista que tais sujeitos parciais atuam sob influência daquele único interesse público de controle.

Considerando-se, entretanto, a existência de inequívoca contraposição na tela do processo, afigura-se adequado asseverar que no processo objetivo também há dualidade de partes. Aliás, tal assertiva ganha reforço, no cenário brasileiro, em razão da participação

\footnotetext{
${ }^{104}$ Op. cit., p. 119.

${ }^{105}$ Arts. $7^{\circ}$ e 18 , da Lei no 9.868/98. Sobre o amicus curiae, confira-se, por todos, SCARPINELLA BUENO (Amicus curiae no processo civil brasileiro: um terceiro enigmático. São Paulo: Saraiva, 2006, passim).
} 
obrigatória do Advogado-Geral da União na defesa do ato normativo impugnado em sede de controle concentrado perante o Supremo Tribunal Federal, ex vi do art. 103, $\S 3^{\circ}$, da Constituição Federal ${ }^{106}$.

É preciso considerar, de outra banda, que a ação direta interventiva, regulada pelos arts. 34 e 36, da Constituição Federal, não dá margem ao surgimento de processo objetivo. Apesar de o Supremo Tribunal Federal, nos casos de intervenção federal, aferir abstratamente acerca da constitucionalidade do ato impugnado, "não se trata de um processo objetivo, sem partes ou sem um caso concreto subjacente. Cuida-se, sim, de um litígio constitucional, de uma relação processual contraditória, contrapondo União e Estado-membro, cujo desfecho pode resultar em intervenção federal"107. Dessa forma, para o caso da ação direta interventiva, não se colocam os questionamentos acerca da incidência do princípio da dualidade de partes.

\section{Legitimidade para agir}

Uma vez delineadas as noções de partes e de terceiros e tecidas algumas considerações acerca do princípio da dualidade de partes, convém avançar na análise do fenômeno jurídico da legitimidade para agir, o que vai desembocar na definição das partes

106 “Quando o Supremo Tribunal Federal apreciar a inconstitucionalidade, em tese, de norma legal ou ato normativo, citará, previamente, o Advogado-Geral da União, que defenderá o ato ou texto impugnado". Observa-se, porém, que a jurisprudência do STF soa no sentido de que essa obrigatoriedade de defesa, pelo Advogado-Geral da União, do ato ou texto impugnado, embora seja a regra geral, deve ser vista com temperamentos, podendo ser afastada, $v . g$., quando sobre a matéria já houver entendimento fixado pelo STF no sentido da inconstitucionalidade do ato normativo. Nesta hipótese o Advogado-Geral da União "não está obrigado a defender tese jurídica se sobre ela esta Corte já fixou entendimento pela sua inconstitucionalidade" (STF, ADI n 1.616/PE, Rel. Min. Maurício Corrêa, j. 24.05.2001, DJ 24.08.2001). No mesmo sentido: STF, ADI no 2.101/MS, Rel. Min. Maurício Corrêa, j. 18.04.2001, DJ 05.10.2001. Em doutrina, confira-se o posicionamento crítico de CLÈMERSON MERLIN CLÈVE (A fiscalização abstrata da constitucionalidade no direito brasileiro. 2. ed. São Paulo: RT, 2000, p. 179-182).

107 BARROSO, Luís Roberto. Op. cit., p. 252. Assim também se manifesta CLÈMERSON MERLIN CLÈVE: “A ação direta interventiva não desencadeia, portanto, um processo objetivo. (...) O objeto do processo não é a declaração da inconstitucionalidade em tese de um ato estatal, mas antes a solução de um conflito entre a União e o Estado-membro que pode desembocar numa intervenção" (Op. cit., p. 128-129). 
legítimas, isto é, daqueles que se enquadram na moldura de giuste parti ou de legittimi contraddittori, como se lê na doutrina italiana ${ }^{108}$.

Os estudiosos já assinalaram, com acerto, que a legitimidade, dado seu amplo espectro de atuação e análise, constitui assunto da teoria geral do direito e que, na esfera processual, constitui um "ponto de conexão entre o direito processual e o direito material"109.

Aceita a premissa, adotada também pela maioria da doutrina brasileira, de que a ação constitui o direito abstrato titularizado pelo sujeito em face do Estado e capaz de fazer atuar a jurisdição para a apreciação do pedido formulado pelo autor, com resultado favorável ou desfavorável ao demandante, pode-se dizer que a legitimidade configura uma das condições para o exercício regular da ação ${ }^{110}$ e define-se como a "qualidade jurídica que se agrega à parte, habilitando-a a ver resolvida no mérito a lide sub judice. Essa qualidade emerge de uma situação jurídica legitimante e dá colorido a uma situação processual oriunda, obviamente, de um processo existente, ou seja, a situação de parte nesse processo" $" 111$.

Essa qualidade jurídica advém de uma indispensável relação entre o sujeito e a causa especificamente considerada. Em palavras outras, a legitimidade provém do vínculo entre os elementos subjetivos da demanda e os seus elementos objetivos (causa de pedir e pedido), analisados à luz das afirmações contidas na petição inicial. "Daí conceituar-se essa condição da ação como relação de legítima adequação entre o sujeito e a causa"112.

\footnotetext{
${ }^{108}$ Por todos, LIEBMAN (Manuale di diritto processuale civile, cit., vol. I, p. 86).

${ }^{109}$ ARMELIN, Donaldo. Legitimidade para agir no direito processual civil brasileiro, cit., p. 9-10.

${ }^{110}$ BARBOSA MOREIRA, José Carlos. O novo processo civil brasileiro. 27. ed. Rio de Janeiro: Forense, 2008, p. 39. Observe-se que para LIEBMAN as condições da ação seriam requisitos de existência da própria ação e sem esta também não haveria exercício de jurisdição (Manuale di diritto processuale civile, cit., vol. I, p. 142). Negando a utilidade das condições da ação, cfr. MARINONI e ARENHART (Manual do processo de conhecimento. São Paulo: RT, 2001, p. 49) e GOMES, Fábio (Carência de ação. São Paulo: RT, 1999, Cap. 7, p. 61 et seq.).

111 ARMELIN, Donaldo. Op. cit., p. 80. DINAMARCO também se refere à legitimidade ad causam como sendo a qualidade que o sujeito ostenta para estar em juízo, na postura de demandante ou de demandado, relativamente a dado conflito levado à apreciação do juiz (Instituições de direito processual civil, cit., vol. II, $\mathrm{n}^{\mathrm{o}} 545$, p. 313).

112 DINAMARCO, Cândido Rangel. Instituições de direito processual civil, cit., n ${ }^{\circ}$ 545, p. 313 (grifos do original).
} 
A situação jurídica legitimante que confere adequado liame entre o sujeito e a causa deflui do modo mais ou menos relevante como o resultado da demanda interferirá na esfera jurídica dos litigantes: "Sempre que a procedência de uma demanda seja apta a melhorar o patrimônio ou a vida do autor, ele será parte legítima; sempre que ela for apta a atuar sobre a vida ou patrimônio do réu, também esse será parte legítima"113.

Essa noção serve de alicerce para a elegante construção segundo a qual a legitimidade para agir constitui um dos aspectos do interesse de agir ${ }^{114}$. É que seria de todo inútil, do ponto de vista da parte e também pelo prisma da administração da Justiça, um provimento jurisdicional respeitante a um sujeito incapaz de extrair algum significado jurídico sob o aspecto do direito material. Ou seja, aquele que não detém legitimidade também não ostenta interesse algum na solução daquele litígio concretamente considerado. A inutilidade da atividade estatal relativamente àquele sujeito (parte ilegítima) torna inviável o desenvolvimento do processo rumo à resolução do mérito ${ }^{115}$.

Afora essa pertinente constatação de índole rigorosamente científica, impõe-se recordar que o direito positivo vigente no Brasil labora com a noção de legitimidade ad causam como sendo instituto diverso do interesse de agir.

Seja como for, releva notar que as três condições da ação previstas no Código de Processo Civil configuram "faixas de estrangulamento entre o direito processual e o substancial, sabido que é sempre da situação da vida lamentada pelo demandante, em associação com o resultado jurídico-substancial pretendido, que resultam a possibilidade jurídica do pedido, o interesse de agir e a legitimidade de parte" ${ }^{116}$. No ponto específico da legitimação para agir, assim se dá porque as situações legitimantes derivam dos esquemas subjetivos abstratos que conformam a relação de direito material agitada no processo.

\footnotetext{
${ }^{113}$ DINAMARCO, Cândido Rangel. Instituições de direito processual civil, cit., $\mathrm{n}^{\circ}$ 545, p. 313. ${ }^{114} I d ., \mathrm{n}^{\circ} 546$, p. $314-316$.

115 FREIRE, Rodrigo da Cunha Lima. Condições da ação: enfoque sobre o interesse de agir. 3. ed. São Paulo: RT, 2005, p. 196-197. Essa imbricação da legitimidade com o interesse de agir vem também acentuada por SUSANA HENRIQUES DA COSTA (Condições da ação. São Paulo: Quartier Latin, 2005, p. $67)$.

${ }^{116}$ DINAMARCO, Cândido Rangel. Instituições de direito processual civil, cit., vol. II, nº 542, p. 307 (grifos do original).
} 
Rememore-se que a legitimidade para agir há de se apresentar tanto no polo ativo quanto passivo da relação processual ${ }^{117}$. Implica dizer que o objeto da demanda deve guardar pertinência com os sujeitos que compõem ambos os polos do processo, sob pena de se configurar a chamada carência de ação.

Num outro enfoque, transparece no sistema processual a cara noção de que a ninguém é dado pleitear, em nome próprio, direito alheio, ressalvadas hipóteses expressamente previstas em lei (CPC, art. $\left.6^{\circ}\right)$. Deflui dessa noção a classificação da legitimidade em ordinária e extraordinária.

Ordinária é a legitimação considerada normal ou comum ${ }^{118}$, caracterizada pela coincidência entre os sujeitos da relação jurídica agitada no processo, tal como retratada na petição inicial, e os ocupantes das posições ativas e passivas na tela processual ${ }^{119}$. De regra, aquele que se afirma titular do interesse subordinante (pretensão) figurará no polo ativo da relação processual; aquele cujo interesse se pretende subordinar será o componente do polo passivo dessa mesma relação ${ }^{120}$. Daí que, segundo abalizada doutrina, o legitimado ordinário tem na sentença a disciplina de sua própria situação ${ }^{121}$.

Em tom de excepcionalidade, a legitimidade extraordinária ou anômala advém de motivos especiais de conveniência, previamente valorados pelo legislador, em ordem a se conferir eficácia legitimante a uma dada situação subjetiva diversa daquela que se submete à apreciação judicial ${ }^{122}$. Por isso é comum dizer-se que, nesse panorama, não há coincidência entre os componentes dos polos da relação processual e os sujeitos figurantes na relação jurídica que se quer debater em juízo ${ }^{123}$. Significa dizer que o legitimado

\footnotetext{
${ }^{117}$ Sob tal aspecto, percebe-se alguma impropriedade na redação do art. $3^{\circ}$, do CPC, segundo o qual para propor ou contestar ação é necessário ter interesse e legitimidade. Evidente que o réu, mesmo sem ter legitimidade ad causam, ostenta interesse e legitimidade para contestar, ainda que seja apenas para arguir essa sua condição peculiar de parte ilegítima.

${ }^{118}$ MARIZ DE OLIVEIRA JR., Waldemar. Op. cit., p. 34.

${ }^{119}$ ARMELIN, Donaldo. Legitimidade para agir no direito processual civil brasileiro, cit., p. 117.

${ }^{120}$ MARIZ DE OLIVEIRA JR., Waldemar. Op. cit., p. 34.

121 BARbOSA MOREIRA, José Carlos. Apontamentos para um estudo sistemático da legitimação extraordinária. In: Direito processual civil: ensaios e pareceres. Rio de Janeiro: Borsoi, 1971, p. 60.

${ }^{122} I d$., p. 59.

${ }^{123}$ DIDIER JR., Fredie. Pressupostos processuais e condições da ação. São Paulo: Saraiva, 2005, p. 232.
} 
extraordinário defende, em nome próprio, direito alheio e, nessas condições, encontrará na sentença a disciplina de situação de outrem ${ }^{124}$.

Em alentado estudo publicado no final da década de 60, BARBOSA MOREIRA propôs uma classificação da legitimidade extraordinária que acabou ganhando foros de cidadania na doutrina brasileira. Tem-se legitimidade extraordinária autônoma quando os sujeitos da relação processual atuam independentemente de algum comportamento do sujeito envolvido no objeto do juízo. Diz-se que nessa hipótese o contraditório constitui-se regularmente com a só presença do legitimado extraordinário ${ }^{125}$.

Em posição menos ampla se enquadra a legitimidade extraordinária subordinada, pois aqui a atuação do legitimado ordinário faz-se necessária para constituição regular do contraditório. Ocorre que, uma vez instaurado o processo, o legitimado extraordinário adquire a possibilidade de intervir, "assumindo posições acessórias, ao lado do autor ou do réu" ${ }^{\prime 26}$.

No campo da legitimidade extraordinária autônoma abre-se espaço para uma subdivisão. Há casos em que a lei confere ao legitimado extraordinário, com exclusividade, a prerrogativa de agir em juízo na defesa de interesse alheio. Implica dizer que o contraditório só se instala regularmente com a presença, no processo, do legitimado extraordinário, excluindo-se a possibilidade de o titular do direito debatido habilitar-se na condição de parte principal. Aliás, a presença deste no processo é destituída de influência e incapaz de deflagrar um contraditório hígido, restando-lhe, contudo, a possibilidade de intervir como parte acessória. Nesses casos, diz-se que a legitimidade extraordinária autônoma configura-se como exclusiva ${ }^{127}$.

124 BARBOSA MOREIRA, José Carlos. Apontamentos para um estudo sistemático da legitimação extraordinária, cit., p. 60.

${ }^{125}$ Id., ibid.

${ }^{126}$ Id., ibid.

${ }^{127} I d$., p. 61. Para THEREZA ALVIM, a legitimidade extraordinária exclusiva não encontra apoio no sistema constitucional (O direito processual de estar em juízo. São Paulo: RT, 1996, p. 92); no mesmo sentido LEONARDO GRECO (A teoria da ação no processo civil. São Paulo: Dialética, 2003, p. 41). Numa crítica mais aprofundada e abrangente acerca da legitimidade extraordinária, confira-se comentário ao art. $3^{\circ}$, da nova Lei do Mandado de Segurança, elaborado por CRUZ E TUCCI [In: MAIA FILHO, Napoleão Nunes; ROCHA, Caio Cesar Vieira; LIMA, Tiago Asfor Rocha (org.). Comentários à nova lei do mandado de segurança. São Paulo: RT, 2010, p. 72-76]. 
De outra parte, situações há em que a eficácia legitimante que habilita um terceiro a litigar sobre direito alheio não exclui e tampouco atenua a possibilidade de agir daquele que seria o legitimado ordinário. O caso será, então, de legitimidade extraordinária autônoma concorrente, porquanto será indiferente, na aferição da regularidade do contraditório, "que no processo figure apenas o legitimado extraordinário, apenas o ordinário, ou ambos"128.

A legitimidade extraordinária autônoma concorrente ainda se pode escandir em primária e subsidiária. Dar-se-á a primeira quando o legitimado extraordinário ostenta a qualidade para desde logo ajuizar a demanda, isto é, sem que tenha de aguardar por algum tempo a iniciativa do legitimado ordinário. Ocorrerá a segunda, diversamente, na hipótese de a legitimidade extraordinária surgir apenas depois de escoado algum prazo e constatada, nesse interregno, a omissão do legitimado ordinário ${ }^{129}$.

No grupo da legitimidade extraordinária autônoma concorrente primária, pode-se encartar a demanda proposta pelo Ministério Público para obter anulação de casamento (art. 1.549, do Código Civil). Na categoria da legitimidade extraordinária autônoma concorrente subsidiária, enfeixa-se a ação de responsabilidade civil proposta por qualquer acionista contra os diretores da sociedade por ações, pelos prejuízos causados ao seu patrimônio, o que se possibilita apenas depois de configurada a omissão da própria sociedade no prazo de três meses, contados da deliberação assemblear respeitante ao tema $\left(\text { art. } 159, \S 3^{\circ} \text {, da Lei n. }{ }^{o} 6.404 / 76\right)^{130}$.

A partir dessas noções, a doutrina esmera-se em discernir que a chamada substituição processual configura apenas uma das variadas formas de exteriorização da legitimidade extraordinária, em ordem a se afirmar a ausência de sinonímia entre os termos $^{131}$.

\footnotetext{
${ }^{128}$ BARBOSA MOREIRA, José Carlos. Apontamentos para um estudo sistemático da legitimação extraordinária, cit., p. 61.

${ }^{129} I d$., p. 62. Sobre as características e consequências da legitimidade extraordinária, cfr. DIDIER JR. (Pressupostos processuais e condições da ação, cit., p. 253-261).

${ }^{130}$ Situação análoga ocorre no mandado de segurança impetrado por legitimado extraordinário (art. $3^{\circ}$, caput, da Lei $n^{\circ}$ 12.016/2009).

${ }^{131}$ Assim explica a doutrina: "Realmente, se considerada a substituição processual como uma efetiva substituição do legitimado ordinário pelo extraordinário, esta só poderá ocorrer nos casos em que tal legitimidade extraordinária seja autônoma e exclusiva, nos termos da classificação retro, ou, ainda,
} 
Bem interessantes, de outra parte, são as disceptações verificadas, no campo do processo coletivo, em torno da natureza da legitimidade para agir. Existem, basicamente, três orientações doutrinárias em torno do tema: (i) para alguns a legitimidade ativa no processo coletivo é ordinária ${ }^{132}$; (ii) para outros a legitimidade caracteriza-se como extraordinária ${ }^{133}$; (iii) para outra parcela da doutrina ainda se deve analisar a natureza do direito debatido (difuso, coletivo ou individual homogêneo): tratando-se de demanda que versa sobre direito difuso ou coletivo, tem-se legitimidade autônoma para a condução do processo; se se cuidar de tutela de direito individual homogêneo, a legitimação é mesmo extraordinária $^{134}$.

Com base em DonALdo ARMElin, seria possível sustentar não haver distinção ontológica entre o que a doutrina alemã chama de direito de conduzir o processo e a legitimidade extraordinária, em ordem a se admitir como despicienda a elaboração doutrinária tedesca, "máxime considerando-se que a problemática suscitada pelos autores excepcionalmente, naquelas hipóteses de legitimidade concorrente, em que o legitimado extraordinário, por omissão do legitimado ordinário, ajuizou ação na qual este não ingressou como litisconsorte" (ARMELIN, Donaldo. Legitimidade para agir no direito processual civil brasileiro, cit., p. 132-133). Em senso parelho manifestou-se EPHRAIM DE CAMPOS JR. (op. cit., p. 24).

132 WATANABE, Kazuo. Tutela jurisdicional dos interesses difusos: a legitimação para agir. In: GRINOVER, Ada Pellegrini (coord.). A tutela dos interesses difusos. São Paulo: Max Limonad, 1984, p. 90 e 94; BARBOSA MOREIRA, José Carlos. Notas sobre o problema da "efetividade" do processo. In: Temas de direito processual, terceira série. São Paulo: Saraiva, 1984, p. 35.

133 DINAMARCO, Pedro. Ação civil pública. São Paulo: Saraiva, 2001, p. 203-205; DINAMARCO, Cândido Rangel. Instituições de direito processual civil, cit., vol. II, nº 548, p. 318-319; DIDIER JR., Fredie. Pressupostos processuais e condições da ação, cit., p. 263-264. TEORI ZAVASCKI também professa que no âmbito do processo coletivo a legitimidade ativa explica-se pelo regime da substituição processual, de modo que o autor da ação coletiva defende, em nome próprio, direito alheio. "Pode-se afirmar, por isso mesmo, que esse regime, de natureza extraordinária no sistema comum do processo civil, é o regime ordinário na ação civil pública" (Processo coletivo: tutela de direitos coletivos e tutela coletiva de direitos. 3. ed. São Paulo: RT, 2008, p. 77).

${ }^{134}$ NERY JUNIOR, Nelson; ANDRADE NERY, Rosa Maria de. Código de Processo Civil comentado e legislação extravagante. 10. ed. São Paulo: RT, 2007, nota 5 ao art. $6^{\circ}$, p. 178; ARRUDA ALVIM. Ação civil pública. Revista de Processo, no 87, p. 156; LEONEL, Ricardo de Barros. Manual do processo coletivo, cit., p. 151-154. Há ainda aqueles que veem uma legitimidade anômala no âmbito das ações coletivas (PAZZAGLINI FILHO, Marino; ELIAS ROSA, Márcio Fernando; FAZZIO JÚNIOR, Waldo. Improbidade administrativa. 4. ed. São Paulo: Atlas, 1999, p. 209) e outros que sustentam a existência de uma legitimação coletiva e, para o caso do Ministério Público, existiria uma legitimação coletiva institucional (THEREZA ALVIM. O direito processual de estar em juízo, cit., p. 119). 
supra-elencados é perfeitamente deslindada através do instituto da substituição processual, que nada mais representa, no plano científico, do que uma forma específica de legitimidade, a chamada legitimidade extraordinária, onde se reconhece a terceiro a possibilidade de atuar em nome próprio na defesa de direito alheio, na esfera processual"135. Em reforço a essa ideia, CÂNDIDO DINAMARCO chega a dizer que "os alemães referem-se à legitimidade extraordinária como poder de conduzir o processo" ${ }^{\text {"136, }}$ em ordem a se poder extrair a conclusão atinente à ausência mesmo de distinção, na essência, entre os institutos aqui considerados.

Daí a nossa inclinação em aceitar a concepção que vê no processo coletivo hipótese de legitimidade ativa extraordinária, sem que isso implique a negação de que o processo de corte coletivo tenha nuances próprias. Tal orientação tem o condão de explicar, de maneira útil para o processo civil brasileiro, a natureza da legitimidade ativa na tela do processo coletivo, notadamente pela ausência de diferenciação ontológica entre a legitimação extraordinária e o que a doutrina alemã chamou de legitimação autônoma para a condução do processo $^{137}$.

A doutrina especializada também vê no processo de fiscalização abstrata de constitucionalidade hipótese de legitimidade extraordinária. Como refere Luís ROBERTO BARROSO, a "propositura da ação direta é um exemplo típico de substituição processual: os órgãos legitimados atuam em nome próprio, mas no interesse da sociedade como um todo" 138

\footnotetext{
${ }^{135}$ Legitimidade para agir no direito processual civil brasileiro, cit., p. 116.

${ }^{136}$ Instituições de direito processual civil, cit., vol. II, no 548, nota 20, p. 320.

${ }^{137}$ Em sentido contrário, ARRUDA ALVIM ensina que as categorias surgidas para explicar institutos do processo individualista, "se forem transpostas para o processo coletivo, resultarão mal aplicadas, justamente porque pertencentes ao processo individualista. Falar-se que os legitimados, nas ações coletivas, são legitimados ordinários, também não se nos afigura correto, porque a legitimação ordinária supõe a coincidência entre o que pede, que é o mesmo para quem se pede, e, mutatis mutandis, isso ocorre com a parte passiva, o réu. A legitimação extraordinária, colocava-se como exceção a essa regra geral, de que as partes sempre perseguiam e defendiam direito próprio. No sistema de ações coletivas, pois, melhor é referirse a uma legitimidade autônoma, ex lege, por definição, sempre havendo descoincidência entre o que postula e os beneficiários dessa postulação, salvo, por exemplo, na hipótese de interesses e direitos individuais homogêneos, em que há o fenômeno da substituição processual (...)" (Ação civil pública, cit., p. 156).

${ }^{138}$ Op. cit., p. 150. Na mesma obra, o autor ainda esclarece que essa particular circunstância - legitimação extraordinária - confere sustentação ao caráter geral da decisão proferida na seara do controle concentrado de constitucionalidade (p. 155). Da opinião segundo a qual a hipótese é mesmo de legitimidade extraordinária
} 
Retomando o fio condutor da pesquisa, importa perquirir sobre a maneira como se afere a presença da legitimidade ad causam numa demanda concretamente considerada. Trata-se de indagação crucial para a compreensão das nuances que envolvem as modalidades litisconsorciais aqui estudadas (eventual, alternativa e sucessiva), além de conferir base teórica para algumas consequências práticas que virão anunciadas a seu tempo.

Transparece preponderante na doutrina a noção segundo a qual as condições da ação são aferidas in status assertionis. Implica dizer que da análise das afirmações do autor, tal como expostas na petição inicial, será possível perquirir acerca da legitimidade das partes. Com efeito, os elementos fático-jurídicos descritos na petição inicial e que servem de razão para o pedido de determinada providência jurisdicional hão de estar relacionados aos sujeitos componentes dos polos da relação processual. Isso será suficiente para desencadear um juízo positivo acerca da legitimidade das partes, mesmo que, ao depois, se verifique a inexistência daqueles suportes fático-jurídicos em que se apoiou a pretensão tal como dantes formulada.

Segundo refere BARBOSA MoreIRA, lícito é dizer "que determinado processo se constitui entre partes legítimas quando as situações jurídicas das partes, sempre consideradas in statu assertionis - isto é, independentemente da sua efetiva ocorrência, que só no curso do próprio processo se apurará -, coincidem com as respectivas situações legitimantes",139.

Em senso análogo, professa DONALDO ARMELIN:

"Evidentemente, tais supedâneos fático-jurídicos do pedido do autor
podem não ter existência real, mas, uma vez retratados na inicial,
adquirem vida própria no processo, e é com base neles que são aferidos
os requisitos indispensáveis ao regular exercício da ação, ensejando,

comungam ADA PELLEGRINI GRINOVER ( $O$ controle difuso da constitucionalidade e a coisa julgada erga omnes das ações coletivas, In: O processo: estudos e pareceres. 2. ed. São Paulo: DPJ, 2009, p. 232) e ABREU FILHO (A suspensão da execução de lei ou ato normativo pelo Senado Federal e a coisa julgada material no controle concentrado da constitucionalidade. Revista de Processo, $\mathrm{n}^{\circ}$ 74, p. 13).

${ }^{139}$ Apontamentos para um estudo sistemático da legitimação extraordinária, cit., p. 59. 
destarte, o pronunciamento judicial sobre aquele pedido, desde que preenchidas outras condições de admissibilidade" ${ }^{\text {"140 }}$.

A partir da dicção do art. 10, I, da Ley de Enjuiciamieto Civil espanhola, e levando em conta especificamente as demandas envolvendo o direito privado, MONTERO AROCA preconiza que a questão da legitimidade ordinária se resolve à luz das afirmações do autor analisadas em duas perspectivas: ativa e passiva. Na primeira perspectiva concentra-se a afirmação de titularidade do direito subjetivo, enquanto que na segunda radica a imputação de titularidade da obrigação. Porém, se o direito subjetivo afirmado existe e se refere àqueles determinados sujeitos frente aos quais se afirmou a titularidade ativa e se imputou a titularidade passiva só se poderá saber ao final do processo ${ }^{141}$.

$\mathrm{Na}$ Itália, onde essa concepção recebe a designação de teoria della prospettazione, diz-se que se consideram legitimados ao processo civil aquele que afirma, in limine litis, uma lesão a um direito subjetivo próprio e aquele a quem se indica a titularidade do dever posto a serviço daquele mesmo direito, porquanto autor da alegada lesão ${ }^{142}$. Evidente que tal proposição - convém esclarecer - pertine à legitimidade ordinária.

Vem de FAZZALARI a lição segundo a qual, no âmbito da teoria geral do direito, a legitimidade ativa consiste num poder ou numa faculdade titularizada por um determinado sujeito, enquanto que a legitimidade passiva indica a posição do sujeito destinatário dos efeitos de um dado comportamento. Esses predicados provêm de uma situação legitimante, consubstanciada numa especial situação em que o sujeito deve achar-se para ser titular de um poder ou destinatário dos efeitos respectivos. Numa perspectiva processual, aludida situação legitimante é "costituita dalla situazione sostanziale asserita dall'attore". Em outras palavras, "è sulla base della situazione sostanziale allegata dall'attore che si stabilisce, in limine litis, il contraddittorio" $" 143$.

\footnotetext{
${ }^{140}$ Legitimidade para agir no direito processual civil brasileiro, cit., p. 34-35. Assim também FLÁVIO YARSHELL (Tutela jurisdicional específica nas obrigações de declaração de vontade. São Paulo: Malheiros, 1993, p. 112-113, nota 94).

${ }^{141}$ De la legitimación en el proceso civil. Barcelona: Bosch, 2007, p. 154. Nessa obra o autor analisa e rechaça as críticas de SATTA e de MONTELEONE (p. 162-166).

${ }^{142}$ FAZZALARI, Elio. Istituzioni di diritto processuale, cit., p. 322-323.

${ }^{143}$ Note in tema di diritto e processo. Milano: Giuffrè, 1957, p. 132-133.
} 
Baseados na experiência jurisprudencial italiana, COMOGLIO-FERRI-TARUFFO aludem a que a legitimidade para agir consiste na titularidade do poder ou do dever de promover ou de suportar um juízo sobre a relação substancial deduzida na causa, "secondo la prospettazione offerta dal'attore, independentemente dall'effettiva titolarità, dal lato attivo ou passivo, del rapporto stesso" 144 .

Entre nós, em voz dissonante levantou-se CÂNDIDO DinAMARCO, mediante o seu conhecido "repúdio à teoria da asserção". Para o citado mestre, não basta que a petição inicial traduza-se numa construção retórica à luz da qual sejam vistas as condições da ação; em verdade, é preciso mais que a singela afirmação. Impõe-se que as condições da ação “existam realmente", sendo irrelevante, para caracterização do instituto, o momento em que ocorre a verificação dessa existência. Daí a conclusão segundo a qual uma "condição da ação da ação é sempre uma condição da ação e por falta dela o processo deve ser extinto sem julgamento do mérito, quer o autor já descreva uma situação em que ela falte, quer dissimule a situação e só mais tarde os fatos revelem ao juiz a realidade" ${ }^{145}$.

LEONARDO GRECO também lembra que a singela afirmação não se mostra suficiente para outorga do direito de ação, sob pena de se autorizar a autolegitimação. "Ou seja, não basta a simples asserção. Se esta for absurda ou vier desacompanhada de qualquer indício da sua verossimilhança, deverá o autor ser julgado carecedor da ação"146.

Essas objeções à teoria assertista não escaparam à percepção e ao enfrentamento a que se propôs ROBERTO BEDAQUE, para quem o critério da profundidade da cognição

${ }^{144}$ Lezioni sul processo civile, cit., vol. I, p. 243. Sem discrepar, TROCKER, Nicolò (L'intervento per ordine del giudice. Milano: Giuffrè, 1984, p. 217, nota 85).

${ }^{145}$ Instituições de direito processual civil, cit., vol. II, n 553 , p. 323 (grifos do original). Posição contrária à teoria da asserção parece ter assumido ARRUDA ALVIM [O art. 268 do CPC, a ilegitimidade e a ocorrência de coisa julgada: critério de interpretação. In: DIDIER JR., Fredie et alli (coord.). O terceiro no processo civil brasileiro e assuntos correlatos: estudos em homenagem ao Professor Athos Gusmão Carneiro. São Paulo: RT, 2010, p. 133-134]. Esclareça-se, porém, que a visão atual de ARRUDA ALVIM entrevê na legitimidade ad causam uma questão de mérito, cuja solução está apta à formação de coisa julgada material (O art. 268 do CPC, a ilegitimidade e a ocorrência de coisa julgada: critério de interpretação, cit., p. 134135). BOTELHO DE MESQUITA também refere que a legitimatio ad causam extrai-se da relação existente entre as partes e a situação substancial em que se funda o pedido, de modo que os elementos que compõem o esquema da legitimidade pertencem à pretensão substancial e não ao processo (Da ação civil. São Paulo: RT, 1975, p. 79).

${ }^{146}$ Op. cit., p. 24. O autor ainda explica que assim deve ser para que o réu não seja exposto ao ilegal constrangimento de ter que se defender sem uma "causalidade adequada" (Id., ibid.). 
auxilia bem o intérprete a evitar confusões entre o plano das condições da ação e o plano do mérito ${ }^{147}$. Significa dizer que, de um modo geral, a presença ou ausência das condições da ação são aferíveis numa análise superficial - no estado das asserções - do segmento fático-jurídico deduzido em juízo.

Até se concebe que a presença, além das afirmações, de algum elemento de prova por mais tênue que seja - capaz de conferir alguma verossimilhança às alegações do autor seja importante para aferição das condições da ação. De modo que as asserções que estiverem evidentemente divorciadas do substrato probatório já presente no limiar do procedimento, desde que analisado em cognição rasa, podem ser desconsideradas para se concluir pela ausência de alguma das condições da ação.

Contudo, não se pode descartar que casos há em que, mesmo não sendo absurdas as asserções do autor, é nenhum o arsenal probatório constante da petição inicial, tudo a depender, por exemplo, da produção de prova testemunhal que se verificará em momento adiantado do iter procedimental.

Figure-se, $v . g$., a hipótese de discussão em torno da existência de contrato verbal cujo valor não supere o quantum para o qual se admita a prova exclusivamente testemunhal $\left(\mathrm{CPC}\right.$, art. 401) ${ }^{148}$. Ou então a demanda em que se busquem os impropriamente chamados alimentos gravídicos, no âmbito da qual a atribuição de legitimidade passiva só pode decorrer da mera afirmação/atribuição de paternidade ao réu, servindo os indícios de paternidade como fundamentos para o exame do próprio mérito da causa (concessão ou não dos alimentos gravídicos) ${ }^{149}$.

Nesse cenário, parecem suficientes as asserções do autor para se aquilatar a presença ou ausência das condições autorizadoras do prosseguimento da demanda rumo à decisão de mérito.

\footnotetext{
${ }^{147}$ Efetividade do processo e técnica processual, cit., p. 252. O autor enfrenta as objeções de CÂNDIDO DINAMARCO nas páginas 253 (nota 56) e 280 (nota 94).

${ }^{148}$ Ainda no campo das hipóteses em que a prova relevante é predominantemente testemunhal, seria bem difícil demonstrar-se a viabilidade de uma demanda (presença das condições da ação), a não ser com base nas afirmações contidas na petição inicial, quando a parte inocente (leia-se, "que se afirma inocente") busque o reconhecimento, nos contratos simulados, da prevalência da vontade real em detrimento da vontade declarada (CPC, art. 404, I).

${ }^{149}$ Cfr. Lei no ${ }^{\circ} 11.804 / 2008$.
} 
É verdade que, sendo bastantes as meras afirmações para desencadear um juízo positivo acerca das condições da ação, poderão surgir situações patológicas em que o autor colocará o réu na contingência de se defender de uma investida abusiva, cuja comprovação dar-se-á somente depois de regular instrução probatória. Mas nem por isso se poderá dizer não ter havido o preenchimento das condições da ação, de sorte que o eventual abuso do autor ao intentar a demanda resolver-se-á pelo ângulo da litigância de má-fé (CPC, art. 18).

Afigura-se, pois, coerente com o sistema processual civil brasileiro - onde existe nítida distinção entre exame do mérito e exame das condições da ação, dando ensejo aos pronunciamentos judiciais de procedência e de carência, com reflexos, por exemplo, no campo da coisa julgada e também no do cabimento de ação rescisória - aceitar a construção da teoria da asserção ${ }^{150}$.

Pondere-se, entretanto, mais uma vez com base na análise percuciente de ROBERTO BEDAQUE, que esse método assertista não se mostra suficiente para solucionar todos os problemas relacionados ao tema ${ }^{151}$, uma vez que no campo do interesse de agir nas ações declaratórias positivas torna-se possível a análise, em cognição aprofundada e mediante exame de provas, do elemento "dúvida objetiva", o qual constitui a mola propulsora da "necessidade" da tutela declaratória. Sem a "dúvida objetiva" em torno da existência duma determinada relação jurídica não há lugar para a demanda de índole declaratória, falecendo, pois, o interesse de agir ${ }^{152}$.

Deflui dessas colocações que a "necessidade" da tutela declaratória, ou o interesse de agir, pode e deve ser examinada não apenas a partir das asserções contidas na petição inicial, mas sim da própria realidade estampada na prova que se produzir a esse respeito, exigindo-se do julgador mais que um exame superficial da matéria ${ }^{153}$.

\footnotetext{
${ }^{150}$ YARSHELL, Flávio Luiz. Tutela jurisdicional específica nas obrigações de declaração de vontade, cit., p. 112-113, nota 94 .

${ }^{151}$ Efetividade do processo e técnica processual, cit., p. 252.

${ }^{152} I d .$, p. 318.

153 "Nas ações declaratórias, como o fato constitutivo do interesse de agir não se confunde com a relação de direito material afirmada, é possível que, havendo controvérsia em relação a ele, seja determina(da) instrução. Conclusão a respeito, se negativa, não se refere ao mérito, pois não se define se a relação de direito material existe, ou não. Reconhece-se apenas que não há incerteza, o que torna desnecessária a tutela declaratória" (BEDAQUE, José Roberto dos Santos. Efetividade do processo e técnica processual, cit., p. 320-321, nota 148). Pondere-se, ainda com BEDAQUE, que semelhante quadro não se verifica quanto às ações declaratórias negativas, uma vez que nestas, caso o réu negue o elemento "dúvida objetiva", o
} 
Seja como for, o que importa para o enfrentamento da nuances em torno do litisconsórcio eventual, alternativo e sucessivo é que, sob a angulação da legitimidade $a d$ causam, a teoria da asserção convém seja aplicada. Daí mostrar-se válida a construção segundo a qual a legitimidade vem "aferida com base no direito substancial afirmado pelo autor, não na sua efetiva existência" ${ }^{\text {154 }}$. As discussões em torno da própria existência do direito afirmado surgirão como questão de mérito. Somente diante dessa perspectiva é que se mostra ainda possível conferir autonomia à legitimidade ad causam, afastando-a do próprio mérito $^{155}$.

Em conclusão: se a teoria da asserção não é suficiente para esclarecer todos os problemas alusivos à verificação da presença das condições da ação (especialmente no que toca ao interesse de agir), ao menos no campo da legitimidade ad causam a questionada teoria encontra plena incidência e aptidão para equacionar os embates verificáveis nessa seara, desde que combinada com a noção de profundidade de cognição ${ }^{156}$.

Visitado o método de análise da legitimidade das partes convém rememorar aspectos relacionados ao momento de verificação dessa condição da ação. É corrente a noção segundo a qual as condições da ação constituem matéria sindicável de ofício ${ }^{157}$ e em

caminho preferível será o da procedência do pedido do autor, declarando-se, assim, inexistente a relação jurídica questionada, mesmo que, a rigor, não estivesse presente o interesse de agir (id., p. 322-324).

${ }^{154}$ BEDAQUE, José Roberto dos Santos. Id., p. 281.

${ }^{155}$ Id., p. 281. Em outra passagem da mesma obra, o autor é enfático: "Parte legítima para propor a ação é quem afirma ser titular do suposto direito material, não quem realmente o seja” (p. 283). Pode-se dizer, em simetria, que parte legítima para figurar no polo passivo será o sujeito a quem se imputa a titularidade passiva daquele suposto direito material, "não quem realmente o seja". No mesmo tom se ouve a doutrina italiana: "La regola è precisamente che legittimato (attivamente o passivamente) è colui che si attribuisca o nei cui confronti si attribuisca la soggettività (attiva o passiva) del rapporto giuridico controverso" [ATTARDI, Aldo. Legittimazione ad agire (verbete). In: Novissimo digesto italiano. Torino: Torinense, 1963. vol. IX, p. 722].

${ }^{156}$ Como já se expôs no texto, as asserções que se colocarem em evidente rota de colisão com elementos seguros de prova, já trazidos à apreciação do juiz na fase postulatória, não servirão, por si só, para desencadear um juízo positivo acerca da legitimidade ad causam. Por exemplo, numa execução em que o exequente se diz credor de $A$ e exibe uma nota promissória emitida por $B$ e não endossada, evidencia-se, a despeito das asserções, a carência de ação, dada a ilegitimidade passiva ad causam.

${ }^{157}$ Existe forte tendência doutrinária em se impor, mesmo nas matérias conhecíveis de ofício, o respeito ao contraditório [RICCI, Edoardo F. Princípio do contraditório e questões que o juiz pode propor de ofício. In: FUX, Luiz; NERY JUNIOR, Nelson; ARRUDA ALVIM WAMBIER, Teresa (coord.). Processo e Constituição: estudos em homenagem ao professor José Carlos Barbosa Moreira. São Paulo: RT, 2006, p. 
qualquer tempo ou grau de jurisdição (CPC, art. 267, § $3^{\circ}$ ). Daí falar-se em matéria não sujeita à preclusão, muito embora a parte que não a alegar logo na primeira oportunidade que tiver possa sujeitar-se a pagar pelas custas de retardamento (CPC, art. 267, § $3^{\circ}$, in fine).

Há que se lembrar, de outra parte, que no âmbito dos recursos de direito estrito (especial e extraordinário) a matéria alusiva às condições da ação não pode surgir pela primeira vez, porquanto indispensável o prequestionamento para que determinada matéria seja apreciada nessa via estreita ${ }^{158}$. Contudo, se admitido o recurso por outro motivo, cabe ao Tribunal (STF ou STJ) aplicar o direito ao caso, abrindo-se, pois, a oportunidade de aferição quanto à legitimidade ad causam, mesmo que tal perquirição não tenha ocorrido nas instâncias ordinárias ${ }^{159}$.

Em geral, as condições da ação devem fazer-se presentes durante todo o arco procedimental, mas nada obsta que, se ausentes no limiar do processo, venham a ser preenchidas no momento da decisão, caso em que o julgador não poderá desprezar tal constatação e, assim, deverá julgar o mérito da causa. Em outras palavras, admite-se o preenchimento superveniente desse requisito de admissibilidade ${ }^{160}$.

Como decorrência dessa noção parece coerente afirmar que as condições da ação, se presentes quando da propositura da demanda e faltantes por ocasião do julgamento, erigir-se-ão em obstáculo à apreciação do mérito ${ }^{161}$.

Então, do ponto de vista da ação e consideradas apenas as particularidades inerentes às partes, releva notar que a legitimidade ad causam configura fator relevante para admitir o exame do mérito da causa.

497; DINAMARCO, Cândido Rangel. O princípio do contraditório e sua dupla destinação. In: Fundamentos do processo civil moderno. 5 ed. São Paulo: Malheiros, 2002. t. I, p. 135].

${ }^{158}$ NERY JUNIOR, Nelson; ANDRADE NERY, Rosa Maria de. Código de processo civil comentado e legislação extravagante, cit., nota 26 ao art. 267, p. 505.

${ }^{159}$ Cfr. Súmula 456/STF e art. 257, do Regimento Interno do STJ. Sobre o assunto, proveitosa é a leitura de artigo de NERY JUNIOR [Questões de ordem pública e o julgamento do mérito dos recursos extraordinário e especial: anotações sobre a aplicação do direito à espécie (STF 456 e RISTJ 257). In: MEDINA, José Miguel Garcia et alli (coord.). Os poderes do juiz e o controle das decisões judiciais: estudos em homenagem à Professora Teresa Arruda Alvim Wambier. São Paulo: RT, 2008, p. 966-975].

${ }^{160}$ DIDIER JR., Fredie. Pressupostos processuais e condições da ação, cit., p. 216.

${ }^{161}$ DINAMARCO, Cândido Rangel. Instituições de direito processual civil, cit., vol. II, nº 554, p. 325. 
Contudo, existem outras condicionantes alusivas às partes que radicadas estão no campo do processo e até precedem logicamente os questionamentos acerca da legitimidade ad causam. Trata-se dos pressupostos processuais relativos às partes, que são a capacidade para ser parte, a capacidade para estar em juízo e a capacidade postulatória. Tais pressupostos hão de se fazer presentes, também, para que se autorize o exame do mérito.

De regra, podem ser partes os sujeitos de direito titulares da capacidade de gozo segundo a legislação civil, abarcando-se as pessoas físicas e jurídicas. Porém, existem alguns entes despersonalizados que, muito embora não sendo pessoas, ostentam a capacidade para atuar na tela processual, como se dá com a figura do espólio, do condomínio, da massa falida, do nascituro e de outros entes dotados da chamada personalidade judiciária ${ }^{162}$.

Para que a atuação desses sujeitos seja válida perante o Estado-juiz imperioso se faz, de outra parte, que sejam também aquinhoados com a capacidade de exercício dos atos que compõem a ordem jurídica. No plano processual, tal requisito chama-se capacidade para estar em juízo, ou simplesmente capacidade processual ou legitimação processual, ou, ainda, legitimatio ad processum ${ }^{163}$. Consiste na "aptidão genérica para praticar atos processuais independentemente de assistência e representação (pais, tutor, curador etc.), pessoalmente, ou por pessoas indicadas pela lei (art. 12 do CPC)"164.

Daí a disciplina legal segundo a qual toda pessoa que se acha no exercício dos seus direitos tem capacidade para estar em juízo (CPC, art. $\left.7^{\circ}\right)$. Tal atributo agrega-se às pessoas físicas, desde que maiores e capazes, e às pessoas jurídicas regularmente constituídas. De conseguinte, para aqueles que, temporária ou definitivamente, não podem exercitar, por si só, os atos da vida civil, cria-se a necessidade de que sejam representados ou assistidos, nos termos da legislação civil, quando pretenderem atuar em juízo. Cogita-se, nessas hipóteses, de integração da capacidade para estar em juízo.

Em certas situações previamente valoradas pelo legislador, impõe-se a integração dessa capacidade mesmo para aqueles que, em situações normais, a teriam por completo. Chama-se a atenção, neste particular, para as hipóteses de nomeação de curador especial em favor do réu preso ou do revel citado por edital ou com hora certa (CPC, art. $9^{\circ}$, II).

\footnotetext{
162 DIDIER JR., Fredie. Pressupostos processuais e condições da ação, cit., p. 111-113.

${ }^{163}$ ALVIM, Arruda. Código de Processo Civil comentado. São Paulo: RT, 1975. vol. II, p. 6.

${ }^{164}$ DIDIER JR., Fredie. Pressupostos processuais e condições da ação, cit., p. 134.
} 
Por fim, a capacidade postulatória insere-se no plano da representação de ordem técnica exigível para a prática de determinados atos processuais, geralmente os postulatórios $^{165}$. Conquanto existam várias exceções previstas em sede legislativa, atribuise capacidade postulacional (ius postulandi) ao técnico da advocacia inscrito perante a Ordem dos Advogados do Brasil ${ }^{166}$, situação que se ajusta à tônica constitucional segundo a qual o advogado é indispensável à administração da justiça (CF/88, art. 133).

Noutra ordem de ideias, porém ainda à vista de tudo quanto se expôs até aqui, pode-se facilmente compreender que as noções de parte e de parte legítima não se confundem com a de parte vencedora, muito embora o êxito no campo do mérito pressuponha que o vencedor seja parte e ostente legitimidade ad causam $^{167}$. Nessa perspectiva, parte vencedora é o sujeito a quem se confere tutela jurisdicional. Em outras palavras, a característica de vencedor se atribui a quem tem razão no campo da relação material debatida no processo $^{168}$; vencedor será o autor quando seu pedido for julgado procedente; semelhantemente, sagrar-se-á vencedor o réu quando o pedido contra si formulado for julgado improcedente ${ }^{169}$.

${ }^{165}$ Sobre a localização sistemática da capacidade postulatória no quadro dos pressupostos processuais, cfr. DIDIER JR. (Pressupostos processuais e condições da ação, cit., p. 141-146).

166 Também detêm capacidade postulacional os membros do Ministério Público, os Defensores Públicos e os Procuradores Federais, Estaduais e Distritais, mesmo que não estejam inscritos na OAB. Fica a ressalva, porém, quanto às fortes discussões em torno da capacidade postulacional dos defensores públicos, já que se debate perante o STF a constitucionalidade do art. $4^{\circ}$, inciso V e $\S 6^{\circ}$, da Lei Complementar $n^{\circ} 80 / 1994$, com a redação que lhe deu a Lei Complementar $n^{\circ}$ 132/2009 (ADI n ${ }^{\circ} 4636 / D F$, proposta pelo Conselho Federal da OAB, Rel. Min. Gilmar Mendes).

${ }^{167}$ ALVIM, Arruda. Código de Processo Civil comentado, cit., vol. II, p. 15.

168 Concebe-se, ao menos em casos particulares, que o mérito de uma demanda seja representado por questões eminentemente processuais, como se dá com a ação rescisória em que se discuta (in)competência absoluta. Aí não se terá uma "relação de direito material"; mas certamente haverá, se julgado o mérito, parte vencedora. Nesse ponto, a noção de parte vencedora atrelada à existência de razão no plano do direito material mostra-se insuficiente. Porém, o que se escreveu no texto serve para elucidar, em linhas gerais e com proveito, a distinção entre parte, parte legítima e parte vencedora.

${ }^{169}$ Sobre tutela jurisdicional em favor do réu, consulte-se, com proveito, HEITOR V. M. SICA ( $O$ direito de defesa no processo civil brasileiro: um estudo sobre a posição do réu. São Paulo: Atlas, 2011, Cap. 10, esp. p. 219 et seq.). 


\section{Pluralidade de partes: litisconsórcio e intervenção de terceiros}

Num estudo cujo cerne consubstancia-se numa particularizada construção acerca do litisconsórcio eventual, alternativo e sucessivo convém que se lancem, previamente, algumas das principais balizas que norteiam o litisconsórcio genericamente considerado e, além disso, que se exponha o seu entrelaçamento com a intervenção de terceiros, assuntos que notoriamente se imbricam. Evidente que, de olhos postos nos objetivos do trabalho, as linhas genéricas a seguir traçadas não guardam a pretensão de esgotamento e nem isso seria necessário para a análise do que se tentará construir em tema de litisconsórcio eventual, alternativo e sucessivo.

Nessa perspectiva, sabe-se que as relações conflitantes levadas à apreciação do Estado-juiz ostentam uma configuração subjetiva mínima que revela a existência de um sujeito figurante do polo ativo e um outro atuando no polo contrário, até mesmo em obséquio ao princípio da dualidade de partes ${ }^{170}$. Em outras palavras, geralmente o que se tem no processo é a presença de um autor litigando contra um réu.

Todavia, nem sempre as relações jurídicas que dão azo à propositura de demanda judicial compõem-se desse coeficiente mínimo. É possível apreciar, cada vez mais, o incremento das hipóteses em que se desvela um complexo de sujeitos envolvidos nas relações jurídicas que vão desaguar em demanda judicial, circunstância que, à evidência, mostra-se apta a alterar também a configuração subjetiva do processo e, conseguintemente, a provocar transformações na dinâmica deste ${ }^{171}$.

Este cenário pode traduzir-se, no campo do processo, na presença de pluralidade de partes. Afigura-se viável, e às vezes até indispensável, que um plexo de sujeitos atue na tela processual ocupando a posição de parte, ou seja, titularizando aquelas posições ativas e passivas referidas alhures.

${ }^{170}$ CALAMANDREI, Piero. Instituciones de derecho procesal civil. Trad. Santiago Sentís Melendo. Buenos Aires: El Foro, 1996. vol. II, § 110, p. 306-307.

171 ASSIS, Araken de. Do litisconsórcio no Código de Processo Civil. In: MARINONI, Luiz Guilherme (coord.). Estudos de direito processual civil: homenagem ao professor Egas Dirceu Moniz de Aragão. São Paulo: RT, 2005, p. 551. 
Seja pelo prisma do conceito de parte no processo como no de parte na demanda, haverá pluralidade de partes sempre que mais de um sujeito ocupar determinada posição parcial na tela do processo.

Designa-se litisconsórcio ${ }^{172}$ a ocorrência de pluralidade de partes na demanda, ou seja, a presença de mais de um sujeito ao menos num dos polos da relação processual ${ }^{173}$. Implica dizer que tal instituto exterioriza-se pela presença, como autor e/ou como réu, de mais de um sujeito: vários autores litigam contra um réu; um autor litiga contra vários réus; ou, ainda, mais de um autor intenta demanda contra mais de um réu. Como refere GUILHERME EstellitA, o litisconsórcio explica-se "como a pluralidade de litigantes, em um ou nos dois lados da causa" ${ }^{, 174}$.

Embora não incidam com a mesma intensidade em todos os casos, as noções de economia processual e de harmonia de julgados atuam, de certa forma, como fundamento para a eclosão da situação litisconsorcial. Na medida em que se intensificam os vínculos justificadores da formação do litisconsórcio desencadeia-se, na mesma proporção, um escalonamento que vai da conveniência embutida na ideia de economia processual à exigência de não contradição entre as decisões. Quanto mais tênue o elo entre os diversos figurantes processuais - como no caso de litisconsórcio fundado na "afinidade de questões por um ponto comum de fato ou de direito" (CPC, art. 46, IV) - mais de perto se vê a incidência da economia processual, sendo pouco influente aquela noção de harmonia de decisões. Se o litisconsórcio, porém, vem lastreado na "comunhão de direitos ou de obrigações relativamente à lide" (CPC, art. 46, I), interpõe-se pujante a coerência que convém exista entre os possíveis julgados, dando-se azo ao litisconsórcio.

Entretanto, há casos em que esses dois vetores não se põem em jogo ou, quando muito, têm importância bem reduzida, dada a inviabilidade de demandas autônomas. É o que sucede quando o próprio legislador valora a situação e impõe a demanda conjunta para os vários litigantes, ou, ainda, quando a relação jurídica deduzida em juízo caracteriza-se

\footnotetext{
${ }^{172}$ Segundo AFFONSO FRAGA, trata-se de vocábulo erudito derivado da junção de duas expressões latinas: litis, genitivo de lis, e consortio, ablativo de consortium. Tal união estaria apta a exprimir uma “comparticipação na lide" (Instituições do processo civil do Brasil. São Paulo: Saraiva \& Cia., t. II, p. 8384).

${ }^{173}$ SCARPINELLA BUENO, Cassio. Partes e terceiros no processo civil brasileiro, cit., p. 75.

${ }^{174}$ Op. cit., p. 22; Em senso parelho, CHIOVENDA (Principii di diritto processuale civile. Napoli: Jovene, 1965, p. 1073).
} 
pela multiplicidade de sujeitos e também pela incindibilidade, situação em que o idêntico tratamento jurídico que se deve conferir aos vários componentes de um dos polos da demanda é que mais de perto fomentará o surgimento do litisconsórcio.

Seja como for, parece exato dizer que no plano do direito material é que se encontra a justificação do litisconsórcio ${ }^{175}$, em razão dos diversos matizes de nexos que enlaçam os contendores em torno das possíveis crises de direito material.

Do quanto se expôs até aqui já se infere as multifárias perspectivas de enfrentamento do tema do litisconsórcio. Esses vários ângulos de percepção conferem bastante utilidade à tradicional classificação do litisconsórcio, tudo a depender, convém frisar, do ponto de vista que se adote.

Por um critério topológico ${ }^{176}$, o litisconsórcio pode ser ativo ou passivo, na dependência de se verificar a pluralidade de litigantes no polo ativo ou passivo da relação processual. Quando a pluralidade concentra-se em ambos os polos, diz-se litisconsórcio misto ou recíproco.

Advirta-se que para CÂNDIDO DINAMARCo não existe o chamado litisconsórcio misto, uma vez que, a rigor, a presença de pluralidade de partes em ambos os polos da relação processual corporifica a existência de dois litisconsórcios e não de um só. Daí ser inadequada uma só designação para entidades jurídicas que podem ser distintas. Com efeito, numa mesma e dada situação o litisconsórcio ativo pode ter vestes de facultatividade enquanto que o litisconsórcio passivo pode ostentar cores de necessariedade. Além disso, um deles pode ser originário e o outro ulterior, dando margem à construção segundo a qual a visualização de dois litisconsórcios (um ativo e outro

\footnotetext{
175 ASSIS, Araken de. Do litisconsórcio no Código de Processo Civil, cit., p. 553. Aceita-se tal ponderação porque assim se dá na generalidade dos casos: as demandas judiciais decorrem de crises verificadas no plano do direito material. Contudo, ações judiciais há em que a mola propulsora reside no plano exclusivo do processo, como se verifica, $v . g$., em mandado de segurança contra ato judicial e também no campo da ação rescisória. FLÁVIO YARSHELL, tratando da ação rescisória, explica que "o interesse juridicamente tutelado, cuja titularidade confere ordinariamente a legitimação, não está na ação rescisória, propriamente, situado no plano material do ordenamento. A situação trazida a julgamento na rescisória é, por assim dizer, 'processual'”' (Ação rescisória. São Paulo: Malheiros, 2005, nº 44, p. 137).

${ }^{176}$ BARBOSA MOREIRA, José Carlos. Litisconsórcio unitário. Rio de Janeiro: Forense, 1972, p. 11.
} 
passivo) consiste no método válido para o exame de cada um quanto ao regime a que se submete. Por isso se cogita de uma "falsa idéia de um litisconsórcio misto",177.

Adotado que seja o prisma da cronologia, distingue-se o litisconsórcio em inicial ou originário e em ulterior ou superveniente ${ }^{178}$. Ocorre o primeiro quando a formação do litisconsórcio advém da própria configuração da petição inicial, isto é, a instauração da relação processual já eclode subjetivamente complexa. De outra parte, ulterior será o litisconsórcio formado já no curso da demanda, seja pela inclusão admitida pela legislação, seja pela inclusão imposta pela legislação ou pelo sistema, conforme se verá adiante.

Importa destacar que o litisconsórcio ulterior pode decompor-se em duas situações distintas, a saber: a inclusão de colegitimado e a intervenção litisconsorcial voluntária.

A primeira figura implica apenas uma ampliação no campo dos elementos subjetivos da demanda, sem que tal redunde no incremento dos seus aspectos objetivos. Significa dizer que a inclusão de um litisconsorte não gera qualquer alteração no campo do pedido e da causa de pedir. Em outras palavras, não se amplia o objeto litigioso do processo só por conta da inclusão do litisconsorte. É o que se dá, v. g., com a inclusão de outros acionistas no polo ativo da demanda em que se busca a anulação de deliberação assemblear; algo semelhante se verifica quando outros cidadãos ingressam no polo ativo de ação popular já em curso, todos eles buscando um único e só resultado.

Já na hipótese de intervenção litisconsorcial voluntária sucede que a ampliação subjetiva ulterior vem acompanhada de uma ampliação objetiva da demanda, mediante o aparecimento de novas partes e em razão da formulação de novo pedido e causa de pedir $^{179}$. "A intervenção litisconsorcial, nessas hipóteses, difere daquela dos colegitimados

\footnotetext{
${ }^{177}$ Litisconsórcio, cit., nº 27, p. 79.

${ }^{178}$ Há aqueles que se valem da expressão litisconsórcio sucessivo para expressar o que no texto se tem como litisconsórcio ulterior (LOPES DA COSTA, Alfredo Araújo. Direito processual civil brasileiro, cit., vol. I, p. 436-437; DINAMARCO, Cândido Rangel. Litisconsórcio, cit., nº 28, p. 80; SILVA, Ovídio A. Baptista da. Comentários ao Código de Processo Civil. São Paulo: RT, 2000, vol. 1, p. 196; LÓPEZ JIMÉNEZ, Raquel. El litisconsórcio. Valencia: Tirant lo Blanch, 2009 p. 33; FAZZALARI, Elio. Istituzioni di diritto processuale, cit., p. 330). Neste trabalho opta-se pelo emprego da expressão litisconsórcio sucessivo, à semelhança da cumulação sucessiva de pedidos, para designar apenas a situação estudada no Cap. III da Parte III, local adequado para o enfrentamento dessa questão terminológica.

${ }^{179}$ SCARPINELLA BUENO, Cassio. Partes e terceiros no processo civil brasileiro, cit., p. 142.
} 
porque através dela se dá uma ampliação do objeto do processo pendente, somando-se novos pedidos ao que já havia sido deduzido pelo autor originário"180.

BARBOSA MOREIRA, escrevendo sobre a intervenção litisconsorcial voluntária ainda ao tempo do $\mathrm{CPC} / 39^{181}$, delineou exemplo que bem elucida o instituto em análise: um contribuinte reclama em juízo contra a cobrança de tributo que reputa indevido; outros contribuintes poderiam voluntariamente achegar-se ao processo pendente e, com base em direito próprio, pedir também o reconhecimento da cobrança indevida do mesmo tributo em relação a si.

O exemplo põe em evidência, de um lado, o fato de os contribuintes incluídos já no curso da demanda pendente não atuarem coadjuvando o autor originário e, de outro, a formulação de pedido calcado em relação de direito material diversa, embora análoga, daquela posta primitivamente na demanda ${ }^{182}$.

Discute-se em doutrina, com eco na posição dos tribunais, até que momento do iter procedimental admite-se a inclusão desses litisconsortes ativos numa dada relação processual pendente. Geralmente se objeta que a inclusão tardia de litisconsortes, principalmente no polo ativo, teria o condão de maltratar o princípio do juiz natural, na medida em que ocorreria a escolha de órgão judicial ${ }^{183}$. Argumenta-se, outrossim, que a intervenção litisconsorcial voluntária atentaria contra o princípio da imutabilidade subjetiva da instância e que, se verificada no polo passivo, ensejaria a imposição de o autor litigar contra quem não deseja.

Os dois últimos argumentos são de fácil superação. Como refere BARBOSA MoREIRA, a noção de imutabilidade subjetiva da instância já vem tantas vezes mitigada pela legislação que fica bem difícil considerá-la como um princípio absoluto. Ainda sob influência da lição do autor citado, tem-se que no chamamento ao processo e na nomeação à autoria o demandante acaba tendo que litigar contra quem não desejava

\footnotetext{
${ }^{180}$ DINAMARCO, Cândido Rangel. Litisconsórcio, cit., nº 18, p. 64 (grifos do original).

${ }^{181}$ Intervenção litisconsorcial voluntária. In: Direito processual civil: ensaios e pareceres. Rio de Janeiro: Borsoi, 1971, p. 28.

${ }^{182}$ Embora a explicação e o exemplo digam respeito à intervenção litisconsorcial voluntária verificável apenas no polo ativo, tem-se por certo que o instituto também se materializa no lado passivo da causa (BARBOSA MOREIRA, José Carlos. Intervenção litisconsorcial voluntária, cit., p. 28).

${ }^{183}$ NERY JUNIOR, Nelson; ANDRADE NERY, Rosa Maria de. Código de Processo Civil comentado e legislação extravagante, cit., nota 4 ao art. 46, p. 255.
} 
originariamente $^{184}$. Pode ser lembrada, a título de reforço, a hipótese prevista no art. 1.698, do Código Civil ${ }^{185}$, segundo a qual se permite o ingresso, na qualidade de parte na demanda, de sujeitos não integrantes da configuração subjetiva originária da relação processual.

Em verdade, mais relevantes do que a vontade dos litigantes originários são as razões de ordem pública que animam a admissibilidade do instituto ${ }^{186}$, mais precisamente a concretização do princípio da economia processual e a obtenção de harmonia dos julgados, tudo em "associação com o desiderato de extrair do processo o máximo proveito útil possível"187.

Sob a angulação do princípio do juiz natural, "deve-se sopesar o princípio da isonomia, que reclama solução idêntica para todos os servidores públicos sujeitos à mesma situação deduzida em juízo, e o da efetividade da jurisdição, a reclamar, dentre outras providências, que o processo possa realizar o direito material no menor tempo e com o menor esforço possível"188.

Daí a coerente conclusão de CÂNDIDO DINAMARCO, consoante a qual apenas à luz do caso concreto é que se poderá verificar alguma violação aos princípios que regem o

\footnotetext{
${ }^{184}$ Intervenção litisconsorcial voluntária, cit., p. 29.

185 "Se o parente, que deve alimentos em primeiro lugar, não estiver em condições de suportar totalmente o encargo, serão chamados a concorrer os de grau imediato (...)”. Para conferir maior rendimento interpretativo a tal dispositivo, imagine-se a hipótese de a constatação, sobre a incapacidade de o parente mais próximo suportar integralmente com o encargo alimentar, advir da prova produzida na fase instrutória, ou seja, em momento posterior ao da estabilização da demanda. Mesmo nesse caso, admite-se como possível a inclusão tardia de litisconsortes.

${ }^{186}$ DINAMARCO, Cândido Rangel. Litisconsórcio, cit., nº 144, p. 397.

${ }^{187} I d ., \mathrm{n}^{\circ} 144$, p. 394.

${ }^{188}$ SCARPINELLA BUENO, Cassio. Partes e terceiros no processo civil brasileiro, cit., p. 145. HEITOR V. M. SICA, a propósito dessa discussão, ainda ressalta outro argumento interessante: "Acrescentamos ser um absurdo contrassenso o sistema autorizar o juiz a dar pela improcedência liminar de processo repetitivo (CPC, art. 285-A) por razões de celeridade e isonomia, mas vedar que demandas idênticas sejam cumuladas no mesmo processo depois que tenha sido aforado. O propósito de uniformizar decisões de $1^{\circ}$ grau, instituído de um lado, é desprestigiado do outro" ( $O$ direito de defesa no processo civil brasileiro, cit., $\mathrm{n}^{\circ} 11.3$, nota 50 , p. 293).
} 
processo, sendo inviável cogitar-se, pois, de veto apriorístico à formação de litisconsórcio superveniente $^{189}$.

Sob outro enfoque e retomando o discurso em torno da classificação, registra-se a distinção entre o litisconsórcio necessário e o facultativo ou voluntário. Aqui o critério relaciona-se com a obrigatoriedade ou não de sua formação, variando a situação conforme a presença dos vários litigantes constitua ou não requisito indispensável para instauração escorreita do contraditório ${ }^{190}$.

Hipóteses há em que a legislação consente que vários sujeitos compareçam em juízo, na qualidade de partes na demanda, em um ou em ambos os polos da relação processual. Fala-se, nesse caso, em litisconsórcio facultativo, muito embora essa facultatividade não fique ao puro alvedrio dos litigantes, porquanto algum liame entre as posições desses litisconsortes há de existir a ponto de se autorizar a demanda em conjunto. Bem por isso, o elenco que se contém no art. 46 do CPC, de onde irradiam as hipóteses de cabimento do litisconsórcio facultativo, consubstancia-se em rol taxativo ${ }^{191}$.

Na generalidade dos casos, nos quais a formação do litisconsórcio vem desde a incoação da demanda, aludida facultatividade gira em torno da posição daquele ou daqueles que ocupa(m) o lado ativo da relação processual. É que na configuração atual da legislação brasileira a vontade dos integrantes do polo passivo torna-se irrelevante quanto à formação ou não do litisconsórcio facultativo. Em outras palavras, não há espaço para recusa pura e simples ao litisconsórcio facultativo, diferentemente do que sucedia ao tempo do $\mathrm{CPC} / 39$. Também não existe ambiente para que o réu ou os réus interponha(m) sua(s) vontade(s) no sentido positivo da formação desse tipo de litisconsórcio, exceção feita ao chamamento ao processo, hipótese em que seria possível cogitar de um litisconsórcio ulterior forjado pela vontade do demandado.

Porém, em obséquio ao princípio da isonomia, do qual emana a noção de que não se concebem tratamentos díspares na tela processual, e à necessidade de rápida solução dos litígios, desvela-se possível alguma limitação à formação do litisconsórcio facultativo. Assim se dá quando num ou em ambos os polos da relação processual se contempla número exagerado de litigantes a ponto de se comprometer a concretização dos valores

${ }^{189}$ DINAMARCO, Cândido Rangel. Litisconsórcio, cit., nº 144, p. 397. Em senso análogo, ARAKEN DE ASSIS (Do litisconsórcio no Código de Processo Civil, cit., p. 560).

${ }^{190}$ BARBOSA MOREIRA, José Carlos. Litisconsórcio unitário, cit., p. 11.

${ }^{191}$ ARRUDA ALVIM. Código de Processo Civil comentado, cit., vol. II, p. 355. 
acima enunciados. Fala-se, então, em limitação ao litisconsórcio multitudinário ${ }^{192}$, a teor do disposto no art. 46, parágrafo único, do $\mathrm{CPC}^{193}$.

Interessante a observação de OvíDIO BAPTISTA, segundo a qual não reside exatamente no número de litigantes o mote do reconhecimento da hipótese de limitação. A diversidade de situações fáticas envolvendo os vários litigantes é que pode, a depender da complexidade do respectivo exame, redundar na limitação do número de litisconsortes, em homenagem ao escopo de se evitar prejuízos para a defesa ou para a própria condução do processo. Assim, quando se estiver diante de questões exclusivamente jurídicas ou quando, mesmo sendo fáticas as discussões, a prova for a mesma para todos os litigantes, a circunstância isolada do grande número de litisconsortes fatalmente não exigirá a limitação preconizada pelo art. 46, p. único, do $\mathrm{CPC}^{194}$.

De sua parte, o litisconsórcio necessário deve ser compreendido a partir de sua nota fundamental: a obrigatoriedade ${ }^{195}$. Ou seja, estar-se-á diante de litisconsórcio necessário sempre que a demanda tiver de ser proposta inexoravelmente contra mais de um sujeito (litisconsórcio passivo), ou que inelutavelmente mais de um sujeito há de ser demandante (litisconsórcio ativo) ${ }^{196}$. Permite-se dizer, na esteira de abalizada doutrina, que será necessário, obrigatório ou indispensável o litisconsórcio quando a lei assim mandar ou quando a natureza da relação jurídica assim o exigir ${ }^{197}$.

São comuns as críticas à redação do art. 47, do CPC, caput, que diz: "Há litisconsórcio necessário, quando, por disposição de lei ou pela natureza da relação jurídica, o juiz tiver de decidir a lide de modo uniforme para todas as partes; caso em que a eficácia da sentença dependerá da citação de todos os litisconsortes no processo".

Alude-se a que o dispositivo baralha a noção de obrigatoriedade de formação com a de uniformidade de sorte no plano do direito material, em ordem a se concluir, 192 DINAMARCO, Cândido Rangel. Litisconsórcio, cit., nº 147, p. 402 e ss. Confira-se, ainda, a obra específica de MICHEL FERRO E SILVA (Litisconsórcio multitudinário. Curitiba: Juruá, 2009, passim).

193 “O juiz poderá limitar o litisconsórcio facultativo quanto ao número de litigantes, quando este comprometer a rápida solução do litígio ou dificultar a defesa. O pedido de limitação interrompe o prazo para resposta, que recomeça da intimação da decisão".

${ }^{194}$ Comentários ao Código de Processo Civil, cit., vol. 1, p. 206.

${ }^{195}$ ESTELLITA, Guilherme. Op. cit., p. 314.

${ }^{196}$ ARRUDA ALVIM. Código de Processo Civil comentado, cit., vol. II, p. 383.

197 ESTELLITA, Guilherme. Op. cit., p. 319. Assim também se lê em DE CRESCI SOBRINHO (Litisconsórcio: doutrina e jurisprudência. Porto Alegre: SAFE, 1990, p. 137-138). 
erroneamente, que o chamado litisconsórcio unitário fosse uma espécie do gênero litisconsórcio necessário.

No afã de mais facilmente compreender tal discussão, releva antecipar outra classificação do litisconsórcio, fundada no critério da uniformidade de sorte no plano do direito material em relação aos colitigantes. Nesse sentido, possível se mostra escandir o litisconsórcio unitário do litisconsórcio comum (ou simples), mediante a verificação sobre se a decisão acerca do mérito da causa deva ou não apresentar-se uniforme no que tange aos litisconsortes componentes de um dos polos da relação processual.

Na ação manejada pelo Ministério Público em face dos cônjuges casados na presença de algum dos vícios descritos no art. 1.548, do Código Civil, afigura-se intuitivo que o resultado do julgamento deva ser uniforme para os litisconsortes passivos (cônjuges), porquanto não se admitiria a invalidade do casamento para um e a concomitante higidez para o outro.

Esse particular caso abrangeria hipótese de litisconsórcio unitário, que se pode definir como "aquele que se constitui, do lado ativo ou do passivo, entre pessoas para as quais há de ser obrigatoriamente uniforme, em seu conteúdo, a decisão de mérito"198 ${ }^{\text {. Essa }}$ uniformidade de tratamento resulta do caráter incindível da relação jurídica deduzida em juízo, corporificada numa unidade monolítica, a despeito da multiplicidade de sujeitos nela imbricados.

Em oposição a esse tipo de aglutinação de partes, irrompe o litisconsórcio comum, também designado de simples por influência alemã, cuja verificação sucede "quando se pode dar tratamento heterogêneo, na decisão de mérito, aos vários co-autores ou coréus" ${ }^{\prime 199}$. Num acidente de trânsito com várias vítimas, o litígio em conjunto desses vários ofendidos (litisconsórcio ativo) pode muito bem não redundar em decisão homogênea, para esses colitigantes, no que pertine ao mérito da causa. A indenização pode variar em fundamento e em extensão entre os vários litisconsortes e não se descarta a viabilidade de procedência para uns e de improcedência para outros; basta que se imagine a ausência de comprovação de prejuízo para um dos colitigantes, situação que redundará na improcedência de sua pretensão indenizatória.

\footnotetext{
${ }^{198}$ BARBOSA MOREIRA, José Carlos. Litisconsórcio unitário, cit., p. 129.

${ }^{199}$ Id., ibid.
} 
Voltando à análise da verba legislativa contida no art. 47, do CPC, crê-se que a autonomia do litisconsórcio unitário, cuja classificação se pauta em critério bem diverso daquele que comanda a noção de obrigatoriedade presente na distinção entre litisconsórcio facultativo e necessário, permite vislumbrar a existência de litisconsórcio facultativo e ao mesmo tempo unitário $^{200}$. Tal circunstância mostra-se suficientemente hábil a afastar a ideia, presente equivocadamente na dicção do dispositivo aludido, de que todo litisconsórcio unitário seja também necessário ${ }^{201}$.

E também não se descarta a possibilidade de verificação de um litisconsórcio necessário e comum (simples ou não unitário); indispensável quanto à formação e passível de encontrar soluções díspares quanto ao mérito, no que tange aos litisconsortes. A par do exemplo clássico da usucapião (CPC, art. 942), em que os litisconsortes obrigatórios podem experimentar soluções diversas no plano do direito material, pode-se sugerir a hipótese contemplada pelo art. 1.376, do Código Civil $^{202}$, donde se extrai que a desapropriação de imóvel onerado com direito de superfície terá como demandados, necessariamente, o proprietário e o superficiário, sem que isso implique, em sede de julgamento, uniformidade de resultado no que concerne ao valor da indenização ${ }^{203}$.

Fincada a noção de que realmente não se confundem o litisconsórcio necessário e o unitário, insta relembrar que a exigência de que vários sujeitos litiguem em conjunto traduz-se numa questão de legitimidade ad causam $^{204}$. O contraditório só se instaura

${ }^{200}$ Lembre-se do clássico exemplo da ação de vários acionistas, litigando em litisconsórcio ativo facultativo, visando à anulação de deliberação assemblear. A decisão que se proferir em termos de mérito será, inelutavelmente, uniforme para os componentes do litisconsórcio ativo. Ter-se-á, portanto, litisconsórcio facultativo, sob o prisma da obrigatoriedade de formação, e unitário sob o aspecto da sorte no plano do direito material. Essa modalidade é chamada, na Espanha, de litisconsórcio quase-necessário (VIDAL PÉREZ, María Fernanda. El litisconsorcio en el proceso civil. Madrid: La Ley, 2007, p. 89-90; MONTERO AROCA, Juan. La intervención adhesiva simple. Barcelona: Editorial Hispano Europea, 1972, p. 19-20).

${ }^{201}$ MATHIAS LAMBAUER, conquanto aceite a distinção entre o litisconsórcio necessário e o unitário, não vê atecnia na redação do art. 47, caput, do CPC (op. cit., p. 168).

202 "No caso de extinção do direito de superfície em consequência de desapropriação, a indenização cabe ao proprietário e ao superficiário, no valor correspondente ao direito real de cada um".

203 SCARPINELLA BUENO, Cassio. Partes e terceiros no processo civil brasileiro, cit., p. 118, nota 85-A. Para aprofundar a análise da distinção entre litisconsórcio unitário e litisconsórcio necessário, cfr. BARBOSA MOREIRA (Litisconsórcio unitário, cit., p. 128-134) e ARRUDA ALVIM (Código de Processo civil comentado, cit., vol. II, p. 384 e ss.), com farta indicação bibliográfica.

${ }^{204}$ DINAMARCO, Cândido Rangel. Litisconsórcio, cit., nº 24, p. 76. 
regularmente na presença de todos quantos devam ser afetados, diretamente, pelo comando sentencial. É nesse sentido que a legislação condiciona a eficácia da sentença à citação de todos os litisconsortes necessários (CPC, art. 47, caput, in fine), abrindo-se espaço para que o juiz aja de ofício no sentido de instar o autor a que promova a integração do contraditório por aqueles que eventualmente estejam ausentes, sob pena de extinção do processo (CPC, art. 47 , p. único) $)^{205}$.

Registre-se, por oportuno, a celeuma que grassa em torno da determinação de integração do contraditório quando se cuide de litisconsórcio necessário ativo. Vozes há no sentido de que o conteúdo do art. 47, p. único, endereça-se exclusivamente ao preenchimento superveniente de litisconsórcio passivo, mediante citação ${ }^{206}$, ao passo que outros entendem ser possível, apesar da redação aparentemente restritiva do citado dispositivo legal, ao juiz ordenar a integração subjetiva da relação processual também pelo prisma do litisconsórcio ativo ${ }^{207}$.

Bem interessante, não só pelo viés teórico, mas também pelas relevantes consequências práticas, emerge a questão posta em torno da natureza da decisão ou mais precisamente do vício que inquina a decisão proferida na ausência de algum colitigante necessário.

Seguindo as pegadas doutrinárias de CHIOVENDA $^{208}$, o legislador pátrio alude à ineficácia da sentença na hipótese de ser preterido algum litisconsorte necessário (CPC, art. 47, caput, in fine). Diz-se comumente que a sentença, nesse caso, considera-se inutiliter datur para todos os litigantes e não só para aquele litisconsorte necessário que

\footnotetext{
${ }^{205}$ Discrepa a doutrina sobre se tal dispositivo estaria a configurar intervenção iussu iudicis. Em sentido positivo, SCARPINELLA BUENO (Partes e terceiros no processo civil brasileiro, cit., p. 139, nota 135). Contrariamente, ARRUDA ALVIM (Código de Processo Civil comentado, cit., vol. II, p. 351) e DINAMARCO (Litisconsórcio, cit., nº 56, p. 132-133), mediante o argumento procedente de que no p. único do art. 47 não existe a discricionariedade que está à base da intervenção iussu iudicis.

${ }^{206}$ BARBI, Celso Agrícola. Comentários ao Código de Processo Civil. 10. ed. Rio de Janeiro: Forense, 1998. vol. I, $\mathrm{n}^{\circ}$ 305, p. 206. CÂNDIDO DINAMARCO encampa a ideia de que a ausência de litisconsorte ativo necessário não pode ser suprida pela determinação judicial de sua inclusão, de sorte que, verificando-se referida ausência, o processo deve ser extinto sem resolução do mérito (Litisconsórcio, cit., no 109, p. 280). Assim também escreveu FLÁVIO YARSHELL (Ação rescisória, cit., nº 45, p. 140-141).

${ }^{207}$ ARRUDA ALVIM. Código de Processo Civil comentado, cit., p. 406; LAMBAUER, Mathias (op. cit., p. 120, com referência à adcitatio).

${ }^{208}$ Principii di diritto processuale civile, cit., § 88, IV, p. 1084-1085.
} 
não participara do contraditório perante o juiz ${ }^{209}$. Encontra-se, além disso, opinião abalizada no sentido de que a preterição de litisconsorte necessário e unitário enseja ineficácia absoluta da sentença, ao passo que semelhante ocorrência no campo do litisconsórcio necessário e comum dá azo à nulidade ${ }^{210}$.

Noutra proposição, alude-se a que o vício da sentença proferida na ausência de litisconsorte necessário situa-se no plano da existência, de sorte que tal pronunciamento seria juridicamente inexistente, dado que a presença das condições da ação configura fator indispensável à própria existência da relação processual e, a fortiori, da sentença que aí se prolate $^{211}$.

Seja como for, dada a gravidade da eiva, parece coerente intuir que a reclamação a esse título pode verificar-se a qualquer tempo no curso do processo ou, até mesmo, em sede de demanda autônoma (ação rescisória e querela nullitatis) ${ }^{212}$. Ajunte-se que as alterações promovidas pela Lei $n^{\circ} 11.232 / 2005$ possibilitam a alegação dessa matéria em sede de impugnação ao cumprimento de sentença (CPC, art. 475-L, I).

Pondere-se, todavia, na companhia de abalizada doutrina, que a análise desse vício há de ser temperada com outros elementos extraídos das noções de instrumentalidade das formas e de prejuízo. Com efeito, mesmo na ausência de algum dos litisconsortes necessários, a ninguém surpreende o fato de a sentença poder trilhar o caminho da improcedência do pedido formulado pelo autor. "Por que não admitir a existência e a

\footnotetext{
${ }^{209}$ BARBI, Celso Agrícola. Comentários ao Código de Processo Civil, cit., vol. I, no 304, p. 205.

${ }^{210}$ DINAMARCO, Cândido Rangel. Litisconsórcio, cit., no 115 et seq., p. 294 et seq. BARBOSA MOREIRA prega que o correto seria considerar, para todos os litigantes, nula a sentença advinda de processo em que se preteriu litisconsorte necessário e unitário, ao passo que, nos casos de litisconsórcio necessário e comum, haveria apenas ineficácia em relação aos litisconsortes preteridos (Litisconsórcio unitário, cit., $\mathrm{n}^{\circ}$ 147, $\mathrm{p}$.
} 232-233).

211 ARRUDA ALVIM WAMBIER, Teresa. Nulidades do processo e da sentença. 5. ed. São Paulo: RT, 2004 , p. 218 e $519-520$.

212 SCARPINELla BUENO, Cassio. Partes e terceiros no processo civil brasileiro, cit., p. 138; DINAMARCO, Cândido Rangel. Litisconsório, cit., no 130 e 131, p. 356 et seq. Para NERY JUNIOR e ANDRADE NERY a ação rescisória é desnecessária, porquanto a sentença ineficaz não produz coisa julgada (Código de Processo Civil comentado e legislação extravagante, cit., nota 21 ao art. 47, p. único, p. 262). Sobre o tema, confira-se também a valiosa lição de ROQUE KOMATSU (Da invalidade no processo civil. São Paulo: RT, 1991, p. 161 et seq.). 
eficácia deste ato, se a falta de citação não causou prejuízo ao réu, a quem o resultado acabou beneficiando?" ${ }^{213}$.

Ainda nesse sentido, ARrUdA Alvim comenta que, se o objeto da demanda consistir num direito disponível e o litisconsorte necessário preterido manifestar anuência quanto ao que foi decidido, não se poderá falar em sentença inutiliter data. "Ora, desde que inocorra prejuízo para o ausente, ipso facto, não tendo sentido cogitar-se de sua proteção, porque ele aceita como bons e jurídicos, os efeitos da sentença, esta valerá para todos os litisconsortes também, que, de per si, nada podem argüir contra a mesma"214.

Noutra ordem de considerações, o regime litisconsorcial experimenta variações na dependência da natureza do litisconsórcio que se forme (necessário ou facultativo; unitário ou comum).

Do ponto de vista do litisconsórcio facultativo, acentua-se a relevância do quanto disposto no art. 46, do CPC, à luz do qual duas ou mais pessoas podem litigar, no mesmo processo, em conjunto, ativa ou passivamente, quando se verificarem as hipóteses de cabimento definidas nos seus quatro incisos ${ }^{215}$. Fácil perceber que esse poder outorgado pelo legislador vem mitigado pela expressão quando, a significar que somente nas hipóteses legais é que a facultatividade de formação do litisconsórcio irrompe apreciável. Repete-se, pois, a noção de taxatividade do elenco de possibilidades de formação do litisconsórcio facultativo, algo que tem inequívoca influência no campo da admissibilidade das modalidades litisconsorciais eventual, alternativa e sucessiva, conforme se tentará demonstrar a seu tempo (infra, Parte III).

213 BEDAQUE, José Roberto dos Santos. Efetividade do processo e técnica processual, cit., p. 461. Em acréscimo, o autor enfatiza: "Se o vício, não obstante gravíssimo, não impediu que o resultado beneficiasse substancialmente aquele que, do ponto de vista técnico-processual, foi prejudicado, não há por que insistir na inexistência do instrumento. Apesar de não observado o contraditório, o réu, privado da ampla defesa, obteve resultado favorável no plano material. A sentença existe e é apta a vincular definitivamente o autor. Já o réu, embora não sujeito à coisa julgada, não tem interesse em impugná-la. Aliás, ele poderá, a qualquer tempo, valer-se do comando nela contido para impedir nova investida do autor contra sua esfera jurídica (...)” (Id., p. 461-462).

${ }^{214}$ Código de Processo Civil comentado, cit., vol. II, p. 351.

${ }^{215}$ Mesmo que o dispositivo citado seja aplicável precipuamente ao litisconsórcio facultativo, tem-se que o litisconsórcio necessário também pode derivar da "comunhão de direitos ou de obrigações relativamente à lide" (inc. I do art. 46), conforme já se registrou em doutrina (SILVA, Ovídio A. Baptista da. Comentários ao Código de Processo Civil, cit., vol. 1, p. 195 e 201). 
Especificamente sobre o rol do art. 46, principia-se com a asserção de que há uma visível escalada de intensidade dos possíveis vínculos aptos a autorizar o litígio em conjunto. Vai-se do vínculo mais intenso (inc. I) até o mais atenuado (inc. IV).

De início, o inciso I verbera que a "comunhão de direitos ou de obrigações relativamente à lide" corporifica hipótese em que vários sujeitos podem atuar em litisconsórcio. A expressão lide aqui vem empregada no sentido de mérito da causa ou de relação jurídica deduzida em juízo, permitindo-se intuir que é a "identidade da relação jurídica de direito material que colegitima ativa e/ou passivamente os seus respectivos titulares"216.

Assim, verificando-se a multiplicidade de sujeitos envolvidos naquela comunhão de direitos ou de obrigações, como sucede nas hipóteses de vários condôminos, de vários herdeiros ou de vários devedores solidários, abrem-se as portas do litígio em conjunto. Mais de um fiador pode, em litisconsórcio facultativo, cobrar do afiançado o valor pago ao credor comum ${ }^{217}$; o alienante também encontra, no inciso I do art. 46, respaldo para litigar contra os adquirentes inadimplentes em relação ao preço $^{218}$.

Permite-se o litisconsórcio, de outro lado, quando "os direitos ou as obrigações derivarem do mesmo fundamento de fato ou de direito" (inciso II do art. 46). A norma predica que a aglutinação de partes irrompe possível quando "a lide fundar-se no mesmo fato ou título jurídico, não em fato ou regra jurídica semelhante" ${ }^{219}$.

Exemplificativamente, o fato da paternidade atribuída a um sujeito redunda, para o filho, no direito à pensão alimentícia e, para a mãe, no direito ao ressarcimento das despesas do parto $^{220}$. As diversas vítimas de um único acidente automobilístico também podem unir-se em litisconsórcio ativo facultativo em face do ofensor comum. De outra parte, baseada num mesmo fundamento de direito seria a demanda de vários servidores

\footnotetext{
${ }^{216}$ CRUZ E TUCCI, José Rogério. A causa petendi no processo civil. 3. ed. São Paulo: RT, 2009, p. 235.

${ }^{217}$ ASSIS, Araken de. Do litisconsórcio no Código de Processo Civil, cit., p. 557.

${ }^{218}$ BARBI, Celso Agrícola. Comentários ao Código de Processo Civil, cit., vol. I, no 290, p. 197.

${ }^{219}$ NERY JR., Nelson; ANDRADE NERY, Rosa Maria de. Código de Processo Civil comentado e legislação extravagante, cit., nota 9 ao art. 46 do CPC, p. 256.

${ }^{220}$ O exemplo é de ARAKEN DE ASSIS (Do litisconsórcio no Código de Processo Civil, cit., p. 557). Remarque-se, uma vez mais, a sutileza de que mesmo fato (idem factum) não é sinônimo de fatos iguais (factum simile), consoante já advertiu CELSO A. BARBI (Comentários ao Código de Processo Civil, cit., $\mathrm{n}^{\circ}$ 291, p. 197).
} 
contra o decreto que os demitira do serviço público por idêntico motivo ${ }^{221}$. Poder-se-ia imaginar a demanda de vários proprietários de imóveis urbanos insurgindo-se contra a municipalidade expedidora de um decreto expropriatório tisnado de vícios aptos a invalidálo.

Paralelamente ao que se diz no inciso II do art. 46 ("mesmo fundamento de fato ou de direito"), a hipótese refletida no inciso III remete à noção de "conexão pelo objeto ou pela causa de pedir", dando margem à ilação de que os incisos II e III versariam, ao menos parcialmente, situações que não se distinguem. É que a "conexão pela causa de pedir" (inc. III) estaria a desvendar realidade idêntica à de direitos e obrigações derivadas do "mesmo fundamento de fato ou de direito" (inc. II) ${ }^{222}$. A única diferença estaria, portanto, na “conexão pelo pedido", prevista no inciso III e não contemplada no inciso II, de modo que este inciso seria dispensável, dada a superposição de hipóteses ${ }^{223}$.

Setores da doutrina, porém, veem a "conexão" prevista no inciso III do art. 46 como um vínculo mais intenso do que a "conexão" definida no art. 103, do CPC, consoante o qual são conexas duas ou mais ações "quando lhes for comum o objeto ou a causa de pedir", tomando-se a expressão objeto como sinônima de pedido mediato (bem da vida almejado) ${ }^{224}$. Além disso, a conexão delineada no inciso III (pelo objeto ou pela causa de pedir) estaria em grau mais acentuado que o vínculo exigido pelo inciso II (mesmo fundamento de fato ou de direito).

Dito de outro modo, a "conexão" prevista como hipótese de admissibilidade do litisconsórcio estaria a exigir a identidade total entre as causas de pedir (o que não se exige para fins da "conexão" prevista no art. 103), ao passo que na previsão do inciso II estariam embutidas duas situações diversas: (i) identidade parcial em razão do mesmo fundamento

${ }^{221}$ SILVA, Ovídio A. Baptista da. Comentários ao Código de Processo Civil, cit., vol. 1, p. 202. Por mesmo fundamento de direito não se deve entender mesmo "fundamento legal" (Id., n 291, p. 197).

222 SCARPINELla BUENO, Cassio. Partes e terceiros no processo civil brasileiro, cit., p. 84. Sobre a origem desse dispositivo ( $\$ 59$, da ZPO alemã, e art. 103, do CPC italiano), consulte-se DAL POZZO, Antonio Araldo Ferraz (Reflexões sobre o litisconsórcio. Justitia, vol. 116, p. 184).

${ }^{223}$ DINAMARCO, Cândido Rangel. Litisconsórcio, cit., nº 43, p. 106. O autor explica que a diversidade de fontes em que se abeberou o legislador brasileiro (italiana e alemã) teria causado essa superposição.

${ }^{224}$ Vale invocar os argumentos de BARBOSA MOREIRA, para quem a presunção de que na lei não existem palavras supérfluas dá margem à noção de que a parte final do inciso III há de ser entendida como sendo representativa de fenômeno distinto daquele conceituado pelo art. 103, do CPC (A conexão de causas como pressuposto da reconvenção. São Paulo: Saraiva, 1979, § 16, nº 71, p. 128-129). 
de fato; (ii) identidade parcial por força do mesmo fundamento de direito ${ }^{225}$. Consectariamente, no que houver de correto nessa postura interpretativa, afigura-se coerente afirmar que a conexidade acolhida no inciso III soa mais intensa do que a definida no inciso $\mathrm{II}^{226}$.

Nesse ponto há de ser lembrada importante lição de BARBOSA MOREIRA, segundo a qual o Código de Processo Civil, “apesar da preocupação definidora manifestada no art. 103, não usa sempre no mesmo sentido a palavra "conexão",227. Daí se cogitar, também com acerto, da existência de graus de conexidade pela causa de pedir ${ }^{228}$, em ordem a se justificar a utilização da expressão conexidade para explicar tanto a hipótese do inciso II quanto a do inciso III do art. 46.

Seja como for, o que há mesmo de relevante nas hipóteses contempladas pelos incisos II e III do art. 46 é a criação de um ambiente em que se privilegia a economia processual e a harmonia de julgados, resultado de uma só instrução capaz de gerar para o julgador "única convicção acerca dos fundamentos comuns"229.

Noutro patamar bem mais tênue de vínculos, admite-se o litisconsórcio quando "ocorrer afinidade de questões por um ponto comum de fato ou de direito" (inc. IV do art. 46). Bem é de ver que a afinidade traduz-se em liame mais arrefecido do que a conexidade, que, por sua vez, expressa vínculo menos apreciável que a comunhão.

A afinidade que se mostra juridicamente relevante, in casu, abate-se sobre questões, cuja compreensão não há de ser aquela rigorosamente técnica, a ponto de se concluir que questão seja aí sinônimo de ponto controvertido, de fato ou de direito. Como já registrou

\footnotetext{
${ }^{225}$ ASSIS, Araken de. Do litisconsórcio no Código de Processo Civil, cit., p. 557. Pregando a distinção entre as hipóteses dos incisos II e III do art. 46, cf. NERY JUNIOR e ANDRADE NERY (Código de Processo Civil comentado e legislação extravagante, cit., nota 10 ao art. 46 do CPC, p. 256).

${ }^{226}$ A ordem dos incisos do art. 46, dessa forma, não estaria exatamente de acordo com uma escala decrescente de intensidade de vínculos justificadores do litisconsórcio (SILVA, Ovídio A. Baptista da. Comentários ao Código de Processo Civil, cit., vol. 1, p. 201-202).

${ }^{227}$ A conexão de causas como pressuposto da reconvenção, cit., § 16, $\mathrm{n}^{\circ}$ 72, p. 130-131.

${ }^{228}$ CRUZ E TUCCI, José Rogério. A causa petendi no processo civil, cit., p. 234. Sem discrepar, DAL POZZO, Antonio Araldo Ferraz (op. cit., p. 175).

${ }^{229}$ DINAMARCO, Cândido Rangel. Litisconsórcio, cit., nº 40, p. 99 (grifos do original).
} 
MACHADO GUIMARÃES, analisando semelhante dispositivo do CPC/39, a expressão questões deve aí ser entendida em sentido amplo ${ }^{230}$.

Aliás, não fosse assim, seria impossível interpretar adequadamente o dispositivo, uma vez que, pela angulação da formação de litisconsórcio facultativo inicial, o autor jamais teria uma questão para justificar a aglutinação de partes, já que os pontos de fato e de direito só se tornam controvertidos, caracterizando verdadeira questão, depois da manifestação impugnativa do réu ${ }^{231}$.

Daí a procedência do entendimento segundo o qual a expressão questões guarda sinonímia com o termo fundamentos ${ }^{232}$. Será, pois, viável a formação de litisconsórcio quando houver afinidade de fundamentos por um ponto comum de fato ou de direito. Vejase que, diversamente do que consta do inciso II, não se exige o mesmo fundamento de fato ou de direito. Basta a afinidade ou semelhança entre os fundamentos, conectados que estejam por ao menos um ponto comum de fato ou de direito. Fala-se, portanto, em "quesito comum" de fato ou de direito ${ }^{233}$.

A título de exemplo, lembre-se da demanda em que várias mulheres pedem indenização do laboratório que pôs à venda anticoncepcional destituído do princípio ativo informado (farinha em vez de remédio). As situações dessas mulheres são distintas, evidentemente, e os prejuízos por elas suportados são de variados matizes. Porém, há em comum a circunstância de terem, conquanto em momentos e em situações diversas (fatos distintos), ingerido o suposto medicamento produzido por aquele específico lote defeituoso.

Quando variados servidores buscam a obtenção de certa vantagem funcional, fundados na mesma verba legislativa, também há espaço para inclusão da hipótese na moldura do inciso IV do art. 46.

De qualquer forma e ainda que se admitam as distinções teóricas entre as hipóteses dos incisos II, III e IV do art. 46, o certo é que o regime jurídico desse tipo de

\footnotetext{
${ }^{230}$ As três figuras do litisconsórcio. Separata do vol. II dos Estudos Jurídicos em Honra de Soriano Neto. Recife: Imprensa Oficial, 1962, p. 179.

${ }^{231}$ DAL POZZO, Antonio Araldo Ferraz. Reflexões sobre o litisconsórcio. Justitia, ano 44, vol. 116, jan./mar. 1982, p. 166-200.

${ }^{232}$ DINAMARCO, Cândido Rangel. Litisconsórcio, cit., nº 41, p. 102.

${ }^{233}$ DAL POZZO, Antonio Araldo Ferraz. Op. cit., p. 181.
} 
litisconsórcio corporifica-se num só ${ }^{234}$. Com efeito, diferentemente do que ocorria sob a égide do Código de Processo Civil de 1939, hoje não mais subsiste a regra segundo a qual o litisconsórcio fundado na afinidade condiciona-se à aquiescência também do réu.

Seguindo a análise do direito positivo, registra-se que o conteúdo linguístico do art. 48, do $\mathrm{CPC}^{235}$, faz transparecer uma absoluta independência (autonomia) entre os colitigantes, a ponto de o comportamento de um em nada projetar-se sobre a esfera do outro.

Todavia, essa suposta autonomia deve ser apreciada com temperamentos, haja vista que no campo do litisconsórcio unitário, por exemplo, a imperiosidade de se conferir decisão uniforme aos litisconsortes pode fazer com que o comportamento de um deles beneficie a posição jurídica dos outros.

Mesmo no campo do litisconsórcio comum, a atitude mais profícua e inteligente de determinado litisconsorte, geralmente observada nas fases postulatória e instrutória, tem condições de acudir, em termos positivos, a situação dos outros. E isso há mesmo de ser assim porque, apesar de se terem relações cindíveis no campo do litisconsórcio comum, não se concebe que o julgador, numa só sentença, "venha a afirmar e ao mesmo tempo negar o mesmo fato, ou venha a adotar duas teses jurídicas antagônicas"236.

Sob o aspecto das ações ou omissões desfavoráveis, adite-se que tanto no litisconsórcio unitário quanto no comum a noção de legitimidade ad actum parece ser a chave da solução dos possíveis questionamentos. Implica dizer que, em relação aos comportamentos capazes de gerar situações prejudiciais, cada litisconsorte só tem legitimidade para a prática do ato que tenha eficácia sobre sua específica situação.

\footnotetext{
${ }^{234}$ SCARPINELla BUENO, Cassio. Partes e terceiros no processo civil brasileiro, cit., p. 86 . O único reparo que se poderia fazer a tal afirmação diz respeito à competência, uma vez que a afinidade a que alude o inciso IV não está apta a impor a modificação da competência relativa, diversamente do que ocorre nos casos de conexão (PONTES DE MIRANDA. Comentários ao Código de Processo Civil, cit., t. II, p. 28-29; ASSIS, Araken de. Cumulação de ações. 4. ed. São Paulo: RT, 2002, § 13, nº 48.3, p. 190-191; DAL POZZO, Antonio Araldo Ferraz. Op. cit., p. 183).

235 "Salvo disposição em contrário, os litisconsortes serão considerados, em suas relações com a parte adversa, como litigantes distintos; os atos e as omissões de um não prejudicarão nem beneficiarão os outros". ${ }^{236}$ DINAMARCO, Cândido Rangel. Litisconsórcio, cit., nº 62, p. 146.
} 
"Inexiste a legitimidade para atos desfavoráveis ou causativos com eficácia além da esfera jurídica do agente" 237 .

Uma vez caracterizado o litisconsórcio em dado processo, fica em aberto a discussão acerca das inúmeras e variadas consequências dessa realidade processual. Nesse contexto, seria adequado ingressar no interessante e relevantíssimo tema da dinâmica do litisconsórcio ou da disciplina processual do litisconsórcio. A tal respeito muito se poderia dizer desde logo, mas os limites e objetivos deste trabalho impõem que, por ora, sejam apenas lembradas algumas das implicações advindas da situação litisconsorcial, na esteira do direito positivo brasileiro.

Entende-se conveniente, pois, que as grandes discussões, geralmente animadas pelas distintas modalidades de litisconsórcio, sejam relegadas a outro momento, quando então a matéria encontrará o devido aprofundamento, nos limites do necessário para o enfrentamento da tentativa de sistematização em torno do aqui chamado litisconsórcio eventual, alternativo e sucessivo (infra, Cap. IV, Parte III).

Diante dessa tomada de consciência, assim colocada em razão de vicissitudes metodológicas e para que se evitem repetições desnecessárias, faz-se menção, primeiramente, a que o litisconsórcio passivo impõe a adoção de regra específica sobre a contagem do prazo para resposta. De fato, quando vários forem os réus, a juntada do último aviso de recebimento ou mandado cumprido deflagrará o termo inicial da contagem do prazo para resposta, ex vi do art. 241, III, do CPC. Relembre-se, ainda em tema de prazo, que os litisconsortes cujos interesses sejam patrocinados por advogados distintos gozam da prerrogativa do prazo em dobro para responder, para recorrer e, de modo geral, para falar nos autos (CPC, art. 191).

Em outro aspecto, põe-se em evidência a regra segundo a qual a presunção de veracidade decorrente da revelia não incide quando, havendo pluralidade de réus, algum deles “contestar a ação" (CPC, art. 320, I). Ainda no aspecto da formação de convencimento acerca de fatos, tem-se que a confissão judicial faz prova contra o confitente, não prejudicando, porém, os litisconsortes (CPC, art. 350, caput).

Interessante questão, pertinente ao campo da prova pericial, é a de saber como os litisconsortes atuarão diante da necessidade de indicação de assistente técnico, visto que a redação do art. $421, \S 1^{\circ}$, I, não parece permitir a indicação de uma pluralidade de

\footnotetext{
${ }^{237}$ DINAMARCO, Cândido Rangel. Litisconsórcio, cit., p. 154 (grifos do original).
} 
assistentes técnicos, muito embora seja bem factível ocorrerem divergências, entre os litisconsortes, quanto à escolha do assistente técnico.

Na seara recursal o problema litisconsorcial também se acentua, porquanto se diz, sem qualquer distinção ou temperamento, que o recurso interposto por um dos litisconsortes a todos aproveita, salvo se distintos ou opostos seus interesses (CPC, art. 509, caput).

No pertinente às verbas de sucumbência, o art. 23, do CPC, assim dispõe: "Concorrendo diversos autores ou diversos réus, os vencidos respondem pelas despesas e honorários em proporção". Sucede que a lei não esclarece sobre qual grandeza há de incidir aludida proporção, se sobre os interesses econômicos ou se sobre o número de litisconsortes. Igualmente, em tema de divisão proporcional dos honorários advocatícios, também não se interpõe como aferidor o grau de relevância da atuação deste ou daquele advogado, deixando-se em aberto, portanto, inúmeras discussões.

A despeito da singeleza como o tema vem tratado em sede legislativa, já se afirmou alhures que a situação litisconsorcial pode derivar de circunstâncias bem diversas, desde a unidade mesma da relação jurídica que envolve vários sujeitos, passando pela similitude entre as diversas relações jurídicas de sujeitos também diversos até se chegar à mera afinidade que se abate entre realidades jurídicas pertinentes a mais de um sujeito. Há, por assim dizer, uma escalada de nexos a envolver a situação de cada um dos vários sujeitos; num extremo figura a unidade e noutro a singela afinidade, ambas entremeadas pela conexidade.

Seja qual for a situação que se verifique, importa registrar que a só presença de vários litigantes, no lado ativo ou passivo da relação processual, dará lugar ao fenômeno litisconsorcial. Do mais intenso ao menos intenso vínculo, os colitigantes serão considerados litisconsortes.

Quando os vínculos são tênues, como se dá na hipótese de mera afinidade, os litigantes bem que poderiam ter ajuizado demandas autônomas, gerando relações processuais distintas que seguiriam, conseguintemente, procedimentos díspares. Todavia, ao se aglutinarem nos moldes da permissão legal e demandarem em conjunto, litisconsórcio haverá. 
Igualmente, quando as causas que tramitam em separado são reunidas e as partes não são totalmente idênticas, pode-se vislumbrar a formação também aí de litisconsórcio num ou em ambos os polos da relação processual ${ }^{238}$.

Se isso for correto, conforme se acredita que seja, afigura-se possível iniciar uma construção segundo a qual a existência de litisconsórcio não pressupõe, invariavelmente, uma comunhão de sortes ou de destinos na tela processual. Colhe-se de CHIOvEndA a interessante passagem no sentido de que o litisconsórcio, apesar dessa designação que acena para uma "certa parità di condizione" entre os colitigantes ${ }^{239}$, não se traduz propriamente num "consorzio" 240 . Outro doutrinador italiano também já registrou que litisconsórcio pode ser tomado como significativo da presença de vários litigantes, mesmo que entre eles não haja "comunanza di sorti", especialmente diante da consideração de que a expressão "consortes" deriva de "sors", designativo de patrimônio e não de sorte ou de $\operatorname{destino}^{241}$.

Sobre tal aspecto, CARNELUTTI referiu-se a uma terminologia segundo a qual o "litisconsórcio simples" ocorre quando os colitigantes estejam em lide apenas em relação à parte contrária, ou seja, na hipótese de não haver lide entre os próprios partícipes do litisconsórcio. De outra parte, ainda segundo CARNELUTTI, o "litisconsórcio recíproco" caracteriza-se por uma maior complicação, pois aí se verifica que todas as partes estão em lide umas com as outras ${ }^{242}$.

${ }^{238}$ DINAMARCO, Cândido Rangel. Litisconsórcio, cit., n ${ }^{\circ}$ 12, p. 49. Não se encara o que se expôs no texto como sendo uma regra absoluta, porquanto haverá situações em que da reunião de causas, mesmo que as partes não sejam idênticas, não se terá formação de verdadeiro litisconsórcio (DAL POZZO, Antonio Araldo Ferraz. Op. cit., p. 177).

${ }^{239}$ Sull litisconsorzio necessario. In: Saggi di diritto processuale civile. Milano: Giuffrè, 1993, vol. sec., p. 427.

${ }^{240}$ Principii di diritto processuale civile, cit., § 88, I, p. 1074.

${ }^{241}$ REDENTI, Enrico. Il giudizio civile con pluralità di parti. Milano: Giuffrè, 1957, nota 2, p. 2. Nesse particular, o sistema brasileiro distingue-se do lusitano, uma vez que lá a expressão litisconsórcio emprega-se tão somente nos casos em que aos litigantes aglutinados impõem-se destinos comuns, restando a expressão "coligação" para expressar a união de litigantes que puderem ser alvo de decisões heterogêneas.

${ }^{242}$ Lezioni di diritto processuale civile, vol. quarto, p. 46. Em seu famoso Sistema del diritto processuale civile, CARNELUTTI voltou a dissertar sobre o assunto, mantendo-se fiel à explanação contida nas Lezioni: "A sua volta il processo litisconsortile o plurilaterale si distingue in semplice o reciproco. Processo litisconsortile semplice vi è quando non tutte le parti sono in lite fra di loro, cioè quando esiste lite fra uno o più parti e tutte le altre, ma non anche fra di queste; (...). Il processo litisconsortile reciproco presenta una 
Portanto, pode-se inferir que o autor citado comungava da ideia de o litisconsórcio não se traduzir, necessariamente, numa comunhão de interesses, uma vez que no chamado "litisconsórcio recíproco" haveria litígio entre os próprios componentes do litisconsórcio $^{243}$.

A essa postura interpretativa somaram-se as vozes autorizadas de CALAMANDREI ${ }^{244}$ e de TARZIA ${ }^{245}$, tudo em oposição ao que propagara GINO ZANI, para quem o litisconsórcio caracterizar-se-ia pelo fato de vários sujeitos ligarem-se por "identità o comunanza di interesse nelle domande" 246 .

Mais recentemente a doutrina italiana voltou ao tema e concluiu por uma construção ampliativa da figura litisconsorcial, a qual existirá quando os colitigantes estiverem em paridade de situação processual e também quando cada um deles se encontrar em lide com todos os demais ${ }^{247}$.

A partir dessas ideias abre-se espaço para avançar e dizer que, em verdade, além de a comunhão de sortes não ser característica do litisconsórcio, situações há em que surge verdadeiro antagonismo entre os colitigantes ${ }^{248}$. Mas isso não compromete a existência mesma do instituto da pluralidade de partes na demanda.

maggiore complicazione, in quanto tutte le parti sono in lite l'una con l'altra" (Sistema del diritto processuale civile. Padova: CEDAM, 1936. vol. 1, p. 926).

${ }^{243}$ Note-se que, posteriormente e sem qualquer explicação, CARNELUTTI passou simplesmente a empregar as expressões "litisconsórcio simples" e "litisconsórcio recíproco" com outra conotação. De fato, na conhecida tradução espanhola de suas Istituzioni del processo civile italiano, o autor explica que o litisconsórcio simples dá-se quando vários autores demandam contra um réu ou quando um autor demanda contra vários réus. Já o litisconsórcio recíproco caracteriza-se pela presença de mais de um autor e mais de um réu (Instituciones del proceso civil, cit., vol. I, p. 394). TARZIA também dá o seu testemunho sobre essa guinada no pensamento de CARNELUTTI (Il litisconsorzio facoltativo nel processo di primo grado. Milano: Giuffrè, 1972, p. 32, nota 54).

${ }^{244}$ Istituzioni di diritto processuale civile. In: Opere giuridiche. Napoli: Morano, 1970. vol. IV, p. 429-430.

${ }^{245}$ Il litisconsorzio facoltativo nel processo di primo grado, cit., $\mathrm{n}^{\circ}$ 6, p. 33.

${ }^{246}$ Litisconsorzio (verbete). In: Nuovo digesto italiano. Torino: UTET, 1938. vol. VII, p. 987. Daí que, para o autor, o litisconsórcio não se confundiria com a mera pluralidade de partes no processo, "consistente nella presenza in genere di più persone nel processo, con autonomia di interessi e di liti” (id., p. 987).

${ }^{247}$ MENCHINI, Sergio. Il processo litisconsortile: struttura e poteri delle parti. Milano: Giuffrè, 1993, p. 6-7. ${ }^{248}$ DINAMARCO, Cândido Rangel. Litisconsórcio, cit., n 11 , p. 47-48. No mesmo sentido: RONCO, Alberto. Studio sul litisconsorzio alternativo. Rivista trimestrale di diritto e procedura civile, anno LVIII, $\mathrm{n}^{\circ}$ 3, p. 924. 
Portanto, não parece adequado pensar que, para haver litisconsórcio, seja indispensável a presença, no mínimo, de uma "afinidade de interesses" entre os sujeitos $\operatorname{aglutinados}^{249}$.

É verdade que a verificação de algum vínculo está à base da configuração litisconsorcial, tanto que, mesmo nos casos de facultatividade de sua formação, os requisitos previstos no art. 46, do CPC, hão de se fazer presentes, lembrando-se, ainda uma vez, que o elenco de incisos ali dispostos traduz-se em rol fechado. Contudo, impõe-se perceber que, mesmo nos casos de vínculos mais tênues, a "afinidade" sugerida não reside na esfera subjetiva dos colitigantes, no sentido de que haja desideratos ou objetivos afins.

A afinidade, com efeito, radica mais precisamente nalgum aspecto dos elementos objetivos da causa, mais precisamente num ou noutro ponto comum de fato ou de direito, sendo irrelevante, ao menos para formação do litisconsórcio, que do ponto de vista dos escopos buscados pelos colitigantes não haja essa afinidade. Em acréscimo, bem é de ver que o sistema legislativo em vigor no Brasil compactua com a existência de litisconsórcio mesmo na presença de interesses distintos ou opostos ${ }^{250}$.

Figure-se o exemplo, para fins de reforço, em que o autor busque em face de dois réus a condenação destes relativamente a certa obrigação solidária. Tal enunciado revela, com nitidez ofuscante, a presença de litisconsortes. Contudo, imagine-se que tais colitigantes passivos, à guisa de defesa própria, imputem um ao outro a responsabilidade isolada (não solidária) pela obrigação cujo adimplemento se busque em juízo. Teria deixado de existir litisconsórcio? O antagonismo entre os litisconsortes passivos afastaria o

\footnotetext{
${ }^{249}$ A posição criticada no texto é adotada por OVÍDIO A. BAPTISTA DA SILVA (Comentários ao Código de Processo Civil, cit., vol. 1, p. 195). MARINONI e MITIDIERO seguem a orientação do mencionado professor gaúcho, nos seguintes termos: "Nem toda pluralidade de partes no mesmo pólo do processo dá ensejo à formação de um litisconsórcio. Litisconsórcio há apenas quando no mesmo pólo do processo existe uma pluralidade de partes ligadas por uma afinidade de interesses" (Código de Processo Civil comentado artigo por artigo. 2. ed. São Paulo: RT, 2010, p. 131).

${ }^{250}$ Assim o diz, claramente, o art. 509, do CPC: "O recurso interposto por um dos litisconsortes a todos aproveita, salvo se distintos ou opostos os seus interesses". A ninguém surpreende a afirmação de que na demanda em que o Ministério Público busca obter a declaração de nulidade de casamento os cônjuges formam litisconsórcio passivo necessário e unitário. Em nada surpreende, outrossim, que tais litisconsortes possam ter interesses diferentes e, segundo MONTERO AROCA, tal diferenciação pode verificar-se tanto no campo da atuação processual como no da posição material frente à nulidade do matrimônio (La intervención adhesiva simple, cit., p. 94).
} 
cúmulo subjetivo? Parece que a resposta só pode ser negativa, como também pareceu a GUILHERME ESTELLITA ${ }^{251}$.

Em outras palavras, a similitude que se abata sobre a situação fática ou sobre o panorama jurídico em que envolvida a posição dos sujeitos, independentemente da diversidade de interesses particulares quanto ao resultado do julgamento, irrompe como necessária e suficiente para autorizar a formação litisconsorcial, tudo a implicar o afastamento da prestigiosa lição de OvíDIO A. BAPTISTA antes lembrada ${ }^{252}$.

Talvez o motivo dessa concepção restritiva, e aqui rejeitada, esteja implicado com a falsa premissa de que o litisconsórcio seja instituto avesso ou diametralmente oposto ao cúmulo objetivo de demandas. Conquanto seja possível abordar o tema do cúmulo de demandas só pela angulação objetiva (causa de pedir e pedido) não convém negar que o cúmulo objetivo possa também se aperfeiçoar numa experiência litisconsorcial.

Tomando como exemplo as pretensões de várias vítimas de um mesmo acidente de trânsito, em que o litisconsórcio é facultativo e comum (não unitário), verifica-se que cada litisconsorte ostenta legitimidade ad causam relativamente àquela específica porção do objeto litigioso do processo que lhe diz respeito, de modo que o pedido de cada um deles há de se imbricar com essa mesma parcela do litígio. Nesse cenário vislumbra-se a ocorrência de um cúmulo de demandas, a um só tempo objetivo e também subjetivo, "na medida em que à pluralidade de sujeitos corresponde uma soma de pedidos, todos eles amalgamados no complexo objeto que esse processo tem"253.

Se é verdade que o cúmulo objetivo pode eclodir entre duas partes apenas - e assim o diz o art. 292, caput, do CPC - não menos correto é entender que o cúmulo subjetivo de

\footnotetext{
251 “Também nos parece mais acertado êsse ponto de vista. Entendido o litisconsórcio não como significando sempre identidade de pretensões ou obrigações, interêsses harmônicos na solução do litígio, mas apenas pluralidade de partes na demanda" (op. cit., p. 224).

252 Diversamente do que assentado no texto, o aludido autor professa que, havendo antagonismo entre os litigantes, não se formaria litisconsórcio, como sucede no caso dos réus em ação de consignação em pagamento onde se discuta a quem se deva pagar (conflito entre os pretensos credores) ou na hipótese das execuções concursais, haja vista que nestas cada credor "está na causa procurando vantagens à custa dos demais" (Comentários ao Código de Processo Civil, cit., vol. 1, p. 204-205). Por tal motivo é que OVÍDIO BAPTISTA não concebe a existência da figura do litisconsórcio eventual, parecendo-lhe mais adequado, na esteira de lição colhida em EMILIO BETTI, falar-se em simples cumulação objetiva de lides (id., p. 205).

${ }^{253}$ DINAMARCO, Cândido Rangel. Litisconsórcio, cit., nº 32, p. 86.
} 
demandas ${ }^{254}$ advém necessariamente de um cúmulo também objetivo. "Todo cúmulo subjetivo tem por substrato um cúmulo objetivo e sem ele não tem como existir",255. A doutrina alemã também já advertiu, em passagem válida para os casos em que no Brasil se designa litisconsórcio comum (não unitário), que toda acumulação subjetiva de demandas representa simultaneamente uma acumulação objetiva, porquanto a pretensão de $A$ contra $X$ apresenta-se inelutavelmente distinta em relação à de $A$ contra $Y$ (hipótese de litisconsórcio passivo) ou a de $B$ contra $X$ (hipótese de litisconsórcio ativo) ${ }^{256}$.

Como refere ARRUdA AlviM, apoiado em doutrina alemã e espanhola, seria possível conceber, na perspectiva que vem de ser anunciada, a existência de uma cumulação exclusivamente objetiva, no âmbito da qual existiriam apenas um autor e um réu. Mas tal constatação não teria o condão de afastar uma cumulação subjetivo-objetiva, “onde, além da pluralidade de pretensões, há mais de duas partes, num dos pólos do processo" $^{, 257}$.

Reputa-se suficientemente demonstrado, portanto, que o litisconsórcio e a cumulação objetiva de demandas não encarnam realidades que se repelem mutuamente. Em verdade, às vezes o litisconsórcio até pressupõe a aglutinação de pedidos ou de causas de pedir, impondo-se a compreensão de que a formação de litisconsórcio, a par do que delineado no art. 46, do CPC, encontra sustentação também e em certa medida nas regras que pertinem à cumulação de pedidos (CPC, art. 292) $)^{258}$.

Noutro campo de indagações, põe-se a dúvida sobre se o litisconsórcio implica pluralidade de relações processuais (vários processos) ou se, diversamente, traduz-se numa unidade de processo.

254 A expressão "cúmulo subjetivo de demandas" não concretiza toda a realidade do instituto do litisconsórcio, uma vez que é possível ocorrer este sem que se verifique aquele, como se dá na hipótese de litisconsórcio unitário. Aqui, embora haja litisconsórcio, não há “cumulação subjetiva de demandas"; trata-se de demanda única e subjetivamente complexa (DINAMARCO, Cândido Rangel. Litisconsórcio, cit., nº 30, p. 82-83). Em conclusão, tem-se que a expressão "cúmulo subjetivo de demandas" fica reservada para os casos de litisconsórcio comum (não unitário), seja necessário ou facultativo (id., no 34, p. 88).

255 DINAMARCO, Cândido Rangel. Id., nº 33, p. 86. JAIME GUASP também já observou que inexiste verdadeira cumulação que deixe de ser objetiva (Derecho procesal civil, cit., t. I, p. 243).

${ }^{256}$ ROSENBERG, Leo. Tratado de derecho procesal civil, cit., t. II, § 94, II, b, p. 99.

${ }^{257}$ Código de Processo Civil comentado, cit., vol. II, p. 362-363.

${ }^{258}$ Eis aí a justificação de se tratar, no Cap. II da Parte II, da cumulação de pedidos como premissa do que se pretende demonstrar em torno das modalidades litisconsorciais eventual, alternativa e sucessiva. 
Para alguns, haverá tantas relações processuais quantos forem os litisconsortes, independentemente do tipo de litisconsórcio que se verifique (facultativo ou necessário; unitário ou comum $)^{259}$. A unidade que se poderia conceber é a de procedimento e não a de $\operatorname{processos}^{260}$.

ENRICO REDENTI, em monografia tantas vezes lembrada, distingue as hipóteses em que há juízo (processo) único com pluralidade de partes daquelas em que há verdadeira cumulação de processos. Para o autor, nos casos em que se verifica o que chamamos de litisconsórcio unitário haveria unidade de processo, apesar da pluralidade de partes. Nos outros casos - conhecidos entre nós por litisconsórcio comum (não unitário) - sucederia o fenômeno da pluralidade de processos, derivada de uma pluralidade de provimentos ${ }^{261}$. À base dessa proposição está a consideração de que o processo (relação processual) configura nada mais que "il processo di formazione del provvedimento giurisdizionale", donde exsurge a conclusão segundo a qual de cada provimento jurisdicional extrai-se um processo. Nessa perspectiva, havendo mais de um provimento dir-se-á existir também mais de um processo $^{262}$.

Numa terceira concepção, tem-se que toda e qualquer modalidade de litisconsórcio congrega-se numa unidade de relação processual $^{263}$. Mesmo nos casos em que, dada a diversidade de relações jurídicas a envolver a situação de cada um dos litigantes, seja possível a dedução das variadas pretensões em processos autônomos, o fato de os vários litigantes comparecerem de uma só vez em juízo, aglutinando suas várias pretensões numa só iniciativa conjunta, haverá processo único, muito embora o objeto desse processo possa ser complexo ${ }^{264}$.

${ }^{259}$ ARRUDA ALVIM. Código de Processo Civil comentado, cit., vol. II, p. 364; SILVA, Ovídio A. Baptista da. Comentários ao Código de Processo Civil, cit., vol. 1, p. 198-199. Em senso análogo, ROSENBERG (Tratado de derecho procesal civil, cit., t. II, § 94, III, 1, p. 100).

${ }^{260}$ ARRUDA ALVIM. Código de Processo Civil comentado, cit., p. 365.

${ }^{261}$ Il giudizio civile con pluralità di parti, cit., $\mathrm{n}^{\mathrm{o}} 7$, p. 10. Relembre-se que na doutrina italiana não se costuma utilizar a expressão litisconsórcio unitário, mas ela foi empregada no texto apenas para facilitar a compreensão do que se extrai da lição de REDENTI.

${ }^{262}$ REDENTI, Enrico. Il giudizio civile con pluralità di parti, cit., nº 14, p. 15.

${ }^{263}$ DINAMARCO, Cândido Rangel. Litisconsórcio, cit., $\mathrm{n}^{\circ}$ 10, p. 40 et seq.; SCARPINELLA BUENO, Cassio. Partes e terceiros no processo civil brasileiro, cit., p. 75.

${ }^{264}$ DINAMARCO, Cândido Rangel. Litisconsórcio, cit., nº 10, p. 40. Assim também se lê em JAIME GUASP e PEDRO ARAGONESES (Derecho procesal civil. 7. ed. Madrid: Thomson-Civitas, 2005. t. I, p. 
“A partir daí, não só a unidade formal do procedimento encerra as pretensões cumuladas (e dirigidas por vários ou a vários sujeitos) mas também a íntima unidade de uma só relação jurídico-processual, onde indisfarçavelmente cada um dos sujeitos de algum modo influi e condiciona as situações jurídicas processuais ativas ou passivas dos demais. (...) A tese da pluralidade de processo repousa sobre a falsa premissa de uma suposta autonomia absoluta entre os colitigantes, no litisconsórcio comum (não-unitário)"265.

Por fim, mas em aspecto diverso daquele até aqui considerado, convém arredar uma falsa percepção que diz respeito à absoluta distinção entre o litisconsórcio e o fenômeno da intervenção de terceiros. Já se disse em doutrina, com acerto, que mesmo no campo da assistência simples verifica-se, pelo fato da intervenção, uma pluralidade de partes ${ }^{266}$. Daí que o fenômeno pluralidade de partes no processo abarca as realidades advindas tanto do litisconsórcio como da intervenção de terceiros ${ }^{267}$.

Essa conclusão vem ainda mais reforçada quando se constata que o fato da intervenção pode muito bem originar uma situação litisconsorcial ${ }^{268}$. Realmente, para ficar apenas com as impressões extraídas da legislação brasileira, a oposição manifestada pelo terceiro cria uma situação litisconsorcial entre as partes originárias. Semelhantemente, o chamamento ao processo tem o efeito de introduzir mais pessoas na composição subjetiva da demanda, dando azo a um litisconsórcio passivo ulterior provocado pelo réu. Não se

250). ARAKEN DE ASSIS enxerga cúmulo de processos apenas nos casos de reunião de demandas autônomas, ex vi do art. 105, do CPC (Cumulação de ações, cit., p. 48), lição que não coincide, inteiramente, com a noção exposta no texto.

${ }^{265}$ DINAMARCO, Cândido Rangel. Litisconsórcio, cit., n 10, p. 41 (grifo do original).

${ }^{266}$ MONTERO AROCA, Juan. La intervención adhesiva simple, cit., p. 95. Relembre-se que "assistência simples", expressão de largo uso entre nós, é sinônimo do que em Espanha se chama "intervenção adesiva simples". Sob a rubrica "pluralidad de partes" outra prestigiosa doutrina espanhola enfoca os institutos do litisconsórcio e da "tercería" (GUASP, Jaime; ARAGONESES, Pedro. Op. cit., p. 246 e ss).

${ }^{267}$ Em sentido oposto ao acolhido no texto, cfr. GOMES DA CRUZ, José Raimundo (Pluralidade de partes e intervenção de terceiros, cit., passim).

${ }^{268}$ DINAMARCO, Cândido Rangel. Litisconsórcio, cit., nº 8, p. 36 et seq. 
descarta, ademais, que na denunciação da lide promovida pelo autor o que se verifica, em verdade, seria algo assimilável ao litisconsórcio eventual (cfr. Parte III, Cap. I, infra).

Aflora dessas observações a acertada pregação de que "há pontos de superposição entre o fato da intervenção e a situação litisconsorcial que a ocorrência desse fato estabelece no processo" 269 . Logo, na esteira do que vem pregando a doutrina, não se mostra fora de propósito tratar conjuntamente os fenômenos do litisconsórcio e da intervenção de terceiros, "que se entrelaçam em um sistema único de "pluralidade de partes' no processo civil" 270 .

Fincadas essas noções iniciais, sente-se um pouco mais à vontade para dar um passo avante, no sentido da construção das premissas do quanto se tentará demonstrar em torno da noção, da viabilidade e da justificação de modalidades litisconsorciais que se podem designar eventual, alternativa e sucessiva.

${ }^{269}$ DINAMARCO, Cândido Rangel. Litisconsórcio, cit., nº 8, p. 38 (grifos do original).

${ }^{270}$ SICA, Heitor Vitor Mendonça. Notas críticas ao sistema de pluralidade de partes no processo civil brasileiro. Texto inédito, cedido gentilmente pelo autor, $\mathrm{n}^{\mathrm{o}}$ 10, p. 47. 


\section{PARTE II}

\section{PREMISSAS}

\section{Nota prévia}

Para o adequado enfrentamento das questões que giram em torno da admissão e da tentativa de sistematização do litisconsórcio eventual, alternativo e sucessivo exige-se que sejam fixadas algumas pilastras indispensáveis. Tem-se consciência de que a investigação que se almeja promover sobre essas específicas modalidades de litisconsórcio implica um exercício de inter-relacionamento de aspectos de direito material e de direito processual, assim como também exige perpassar outros pontos relevantes imbricados com a noção de acesso efetivo à justiça e, como corolário, a de razoável duração do processo.

Observa-se, desde logo, que as linhas traçadas nesta Parte II não têm por escopo desvendar e nem mesmo demonstrar realidades científicas já reconhecidas pela doutrina e, de certa forma, encampadas pelas legislações modernas. $\mathrm{O}$ que se pretende é apenas deixar assentadas algumas constatações, isto é, noções postas, aceitas e bem entendidas pela processualística atual, principiando-se pela a análise do relacionamento que há entre direito material e processo e seguindo-se com a lembrança dos reais significados de acesso à justiça e de razoável duração do processo. Ainda do ponto de vista processual, visualizamse alguns temas em cujos eixos gravitam as noções de dúvida objetiva e de eventualidade. Demais disso, a ponte que se quer construir entre as especificidades da cumulação de pedidos e aquelas modalidades litisconsorciais impõe um lançar d'olhos sobre o panorama atual daquele tipo de cumulação objetiva de demandas.

De outra parte, em razão da significativa influência que algumas noções de direito material irão impor à tratativa da matéria processual, abre-se espaço para o destaque de algumas situações advindas do direito material que, a seu tempo, serão aglutinadas ao estudo do litisconsórcio eventual, alternativo e sucessivo, fomentando-se a construção de novos paradigmas para um instituto já clássico no âmbito da dogmática processual civil. 
Com o objetivo de facilitar a exposição, esta Parte II vem dividida em três Capítulos, sendo os dois primeiros relativos a aspectos processuais e o último pertinente a algumas noções de direito material. 


\section{Capítulo I}

\section{ASPECTOS GERAIS}

\section{Relação entre direito e processo: necessária aproximação}

Depois de superada a fase do sincretismo, no âmbito da qual reinava a confusão entre os planos material e processual, a ciência processual rumou para a conhecida fase autonomista, agora com ênfase em construções conceptuais que propiciaram a separação, quase que em compartimentos estanques, daqueles dois planos. Evidente que a empreitada autonomista teve papel preponderante para o discernimento das realidades do processo, que são efetivamente diversas daquelas que se sentem no âmbito do direito substancial ${ }^{271}$.

Porém, o culto exagerado à autonomia trouxe consigo o germe do excessivo distanciamento entre as noções de direito e processo, de modo a incutir na mentalidade do processualista uma postura de total abstração da realidade do direito material na conformação e no entendimento dos institutos processuais. Preocupados com precisões conceituais e dotadas de cientificidade, os processualistas descuidaram-se dos resultados que se esperavam de sua ciência.

Numa terceira fase dessa evolução, chamada de instrumentalista, voltou-se a atenção para o aspecto teleológico da ciência processual, destinada que é à garantia de fruição das situações de vantagem ditadas pelo direito material, sem que, com isso, se neguem as concepções autonomistas tão bem construídas ao longo do século XIX.

O que importa relevar, no estágio atual da ciência do processo, é que o postulado autonomista "já produziu os resultados científicos desejáveis e não merece ser erguido em pedestal capaz de isolar o processo da realidade" ${ }^{\text {272 }}$. Hoje em dia, portanto, não se pode

\footnotetext{
${ }^{271}$ Sobre o encadeamento e a importância dessas fases de evolução da ciência processual, consulte-se a obra de CÂNDIDO DINAMARCO (A instrumentalidade do processo, cit., $\mathrm{n}^{\circ} 1$, p. 17 et seq.). Os aspectos histórico-evolutivos do relacionamento entre direito e processo também são superiormente tratados por ALVARO DE OLIVEIRA (Teoria e prática da tutela jurisdicional. Rio de Janeiro: Forense, 2008, p. 19-80). ${ }^{272}$ DINAMARCO, Cândido Rangel. Universalizar a tutela jurisdicional. In: Fundamentos do processo civil moderno. 3. ed. São Paulo: Malheiros, 2000, t. II, p. 844-845.
} 
mais investigar as realidades processuais sem a preocupação ou postura metodológica de estudá-las à vista de seus objetivos ${ }^{273}$.

Daí a constatação de que existe uma inevitável e necessária aproximação entre os planos material e processual ${ }^{274}$. E assim deve ser em razão da própria natureza instrumental do direito processual, convocado a atuar sempre que se verifique uma crise, efetiva ou virtual, no plano do direito material. De fato, além de pacificar os contendores, constitui missão do processo realizar o direito material, "de modo a se alcançar a necessária justiça do caso concreto" 275 .

Em conhecida passagem de suas Lezioni, PROTO PISANI expõe que a proibição da autotutela faz com que o direito substancial só se possa dizer existente onde haja normas processuais, disciplinadoras dos meios de tutela jurisdicional, idôneas a garantir, em favor de quem tem razão, a atuação da força do Estado ${ }^{276}$.

Entre nós, ROBERTO BEDAQUE foi quem mais detida e especificamente se debruçou sobre a influência que a configuração do direito material pode induzir quanto ao modo de ser dos institutos processuais ${ }^{277}$. Em passo elucidativo, o mencionado autor registra que

273 “O processualista sensível aos grandes problemas jurídicos sociais e políticos do seu tempo e interessado em obter soluções adequadas sabe que agora os conceitos inerentes à sua ciência já chegaram a níveis mais do que satisfatórios e não se justifica mais a clássica postura metafísica consistente nas investigações conceituais destituídas de endereçamento teleológico" (DINAMARCO, Cândido Rangel. $A$ instrumentalidade do processo, cit., $\mathrm{n}^{\mathrm{o}} 1$ p. 22).

274 “ $\mathrm{O}$ direito processual civil, não obstante tenha identidade, função, finalidade e natureza próprias, serve, atende e volta-se para a aplicação concreta do direito material. $\mathrm{O}$ direito processual civil realiza o direito material, e, por isto mesmo, deixa-se influenciar de forma mais ou menos intensa por ele. Nesta perspectiva, o direito processual civil desempenha a finalidade de instrumento do direito material" (SCARPINELLA BUENO, Cassio. Curso sistematizado de direito processual civil, cit., vol. 1, p. 49-50 - grifos do original).

275 ALVARO DE OLIVEIRA, Carlos Alberto. Teoria e prática da tutela jurisdicional, cit., p. 93.

${ }^{276}$ Lezioni di diritto processuale civile. 5. ed. Napoli: Jovene, 2006, p. 5.

277 Direito e processo: influência do direito material sobre o processo. 5. ed. São Paulo: Malheiros, 2009, passim. Com o advento do Código Civil de 2002, algumas interferências que o direito material pode induzir no panorama processual também mereceram a análise de BARBOSA MOREIRA (O novo Código Civil e o direito processual. In: Temas de direito processual, nona série. São Paulo: Saraiva, 2007, p. 1-20; Solidariedade ativa: efeitos da sentença e coisa julgada na ação de cobrança proposta por um único credor. In: Temas de direito processual, nona série, cit., p. 221-234). Assim também se procedeu na coletânea de artigos coordenada por SCARPINELLA BUENO (Impactos processuais do direito civil. São Paulo: Saraiva, 2008, passim). 
“(...) os aspectos fundamentais do direito processual são concebidos à luz da relação jurídica material"278 ${ }^{, 27}$ de modo que muitas das questões do processo resolvem-se à luz da conformação do direito material debatido na causa. "Quanto mais consciência tiver o processualista desse fenômeno, maiores serão as possibilidades de construção de mecanismos aptos a alcançar os escopos do processo"279.

Exemplificativamente, pode-se afirmar que as discussões em torno dos institutos processuais da ação, da competência, da prova e da coisa julgada refletem, de maneira intensa, aspectos que advêm do direito material, tanto assim que, segundo autorizada doutrina, esses institutos ostentam natureza bifronte: "só no processo aparecem de modo explícito em casos concretos, mas são integrados por um intenso coeficiente de elementos definidos pelo direito material e - o que é mais importante - de algum modo dizem respeito à própria vida dos sujeitos e suas relações entre si e com os bens da vida" 280 .

Outros institutos processuais, embora não enquadrados na categoria dos chamados bifrontes, são "particularmente influenciados pelo direito material", dentre os quais radica o litisconsórcio, cujas condicionantes são ditadas pelo grau, mais ou menos intenso, do relacionamento entre a situação de vários sujeitos e aquilo que se pretende por meio do processo $^{281}$.

Com efeito, para ficar apenas em alguns aspectos que envolvem o tema do litisconsórcio, tem-se que a admissibilidade desse tipo de pluralidade encontra raízes na relação de direito material, de onde promanam as noções de "comunhão de direitos ou de obrigações" (CPC, art. 46, I), de "direitos" ou "obrigações" derivadas do mesmo fundamento de fato ou de direito (CPC, art. 46, II). Ademais, a "conexão" pelo objeto ou pela causa de pedir, a que alude o inciso III do mesmo dispositivo acima citado, guarda nítida vinculação com a relação de direito material afirmada no processo, o que também se pode verificar quando o legislador refere-se à "afinidade de questões por um ponto comum de fato ou de direito" (inciso IV do art. 46).

\footnotetext{
${ }^{278}$ Direito e processo, cit., p. 15. Em outro trecho também digno de nota, o autor enfatizou: "Verifica-se, portanto, que as alterações operadas no plano do direito material não podem ser ignoradas pelo processualista, tendo em vista a necessidade de coordenação destes dois ramos do Direito" (id., p. 65).

${ }^{279}$ BEDAQUE, José Roberto dos Santos. Direito e processo, cit., p. 15.

${ }^{280}$ DINAMARCO, Cândido Rangel. Instituições de direito processual civil, cit., vol. I, nº 6, p. 46.

${ }^{281} I d ., \mathrm{n}^{\circ} 7$, p. $49-50$.
} 
Adite-se que a relação de direito material também comanda, num grau mais ou menos acentuado, se o litisconsórcio pode ou deve ser construído, bem assim se a sentença deve dar aos colitigantes uma resolução uniforme quanto ao mérito ${ }^{282}$.

Logo, o estudo que se vai empreender em torno do litisconsórcio não pode prescindir da análise de algumas situações que envolvem o direito material ${ }^{283}$, conforme se verá no desenrolar da exposição (infra, Cap. III). E assim deve ser porque o caráter autônomo e instrumental do processo civil não implica o reconhecimento de sua neutralidade frente às necessidades do direito substancial ${ }^{284}$.

Essa constatação, contudo, não altera o perfil eminentemente processual da presente investigação, porquanto a devida compreensão de que o direito processual é influenciado pelo direito material não encarna postura de colorido sincrético ${ }^{285}$. Em momento algum, com efeito, revela-se negada a autonomia do processo, sendo suficiente a consciência de que os dois planos (material e processual), posto que imbricados, concernem a "patamares dogmáticos diferentes"286.

Para concluir com BEDAQUE, põe-se em relevo que não "se pretende eliminar o binômio direito-processo, mas apenas aproximar os dois fenômenos",287.

${ }^{282}$ BEDAQUE, José Roberto dos Santos. Direito e processo, cit., p. 117-118. Em sentido parelho: NERY JUNIOR, Nelson; ANDRADE NERY, Rosa Maria de. Código de Processo Civil comentado e legislação extravagante, cit., p. 297, nota 4 ao art. 77.

${ }^{283}$ É que "o direito processual deve adaptar-se às necessidades específicas de seu objeto, apresentando formas de tutela e de procedimento adequadas às situações de vantagem asseguradas pela norma substancial" (BEDAQUE, José Roberto dos Santos. Direito e processo, cit., p. 23).

${ }^{284}$ PROTO PISANI, Andrea. Lezioni di diritto processuale civile, cit., p. 6. No mesmo passo, o autor acrescenta: “(...) il diritto processuale - nei molti procedimenti e nelle varie forme di tutela in cui si articola non è, non può essere, indifferente rispetto alla natura degli interessi in conflitto: non lo è - e per questo non è corretto parlare di neutralità - poichè dalla predisposizione di procedimenti idonei a fornire forme di tutela giurisdizionale adeguate agli specifici bisogni delle singole situazioni di vantaggio dipende l'esistenza o il modo di esistenza dello stesso diritto sostanziale" (id., p. 6).

${ }^{285}$ Depois de afirmar a natureza instrumental do direito processual, PROTO PISANI ainda adverte: "Se ciò è vero, non sarebbe, però, affatto correto ritenere che il diritto processuale sia secondario al diritto sostanziale e che il diritto sostanziale, stante il suo carattere primario (e non strumentale), sia in sè perfetto e quindi possa anche fare a meno del diritto processuale" (Lezioni di diritto processuale civile, cit., p. 4).

${ }^{286}$ CRUZ E TUCCI, José Rogério. A denominada "situação substancial" como objeto do processo na obra de Fazzalari. Revista de Processo, no 68, p. 274.

${ }^{287}$ Direito e processo, cit., p. 27. 


\section{Acesso à justiça}

O embate entre a promessa constitucional de absorção das pretensões de pessoas que clamam por satisfação e as limitações ao exercício do poder de "recebê-las, processálas e acolhê-las" ${ }^{288}$ põe em pauta o real alcance da garantia de acesso à justiça ${ }^{289}$.

Tem-se proclamado, com acerto, que a promessa de acesso à justiça não se resume à ideia de singelo acesso ao Poder Judiciário, como se fosse uma garantia vocacionada a disponibilizar ao jurisdicionado uma resposta qualquer do órgão encarregado da prestação jurisdicional ${ }^{290}$. Em verdade, releva encarecer que a "síntese de todas as garantias

${ }^{288}$ DINAMARCO, Cândido Rangel. Universalizar a tutela jurisdicional, cit., p. 838. Embora se tenha em devida conta o enfoque doutrinal sobre as duas primeiras ondas renovatórias do acesso à justiça (assistência judiciária e representação jurídica para os interesses difusos), o aspecto que mais de perto interessa para a presente investigação gira em torno da terceira onda renovatória, relacionada, mais amplamente, com o aperfeiçoamento técnico do próprio sistema processual (CAPELLETTI, Mauro; GARTH, Bryant. Acesso à justiça. Trad. Ellen Gracie Northfleet. Porto Alegre: SAFE, 2002, p. 67-73), o que, na linguagem elegante de DINAMARCO, configura o anseio de universalização vertical ou qualitativa da tutela jurisdicional.

${ }^{289}$ Registra-se que a expressão "acesso à justiça" não está aqui sendo tratada como "valor de primeira grandeza na constelação axiológica que informa o direito, mas sim de acesso à jurisdição, como atividade estatal, direcionada à declaração lato sensu do direito e à sua realização autoritariamente no mundo empírico" (ARMELIN, Donaldo. Acesso à justiça. Revista da Procuradoria Geral do Estado de São Paulo, no 31, p. 171).

${ }^{290}$ Ao tratar do direito de acesso à justiça, consagrado no inciso XXXV do art. $5^{\circ}$, da CF/88, MARINONI anota: "Uma leitura mais moderna, no entanto, faz surgir a idéia de que essa norma constitucional garanta não só o direito de ação, mas a possibilidade de um acesso efetivo à justiça e, assim, um direito à tutela jurisdicional adequada, efetiva e tempestiva. Não teria cabimento entender, com efeito, que a Constituição da República garante ao cidadão que pode afirmar uma lesão ou uma ameaça a direito apenas e tão-somente uma resposta, independentemente de ser ela efetiva e tempestiva. Ora, se o direito de acesso à justiça é um direito fundamental, porque garantidor de todos os demais, não há como imaginar que a Constituição da República proclama apenas que todos têm o direito a uma mera resposta do juiz. O direito a uma mera resposta do juiz não é suficiente para garantir os demais direitos e, portanto, não pode ser pensado como uma garantia fundamental de justiça" (Garantia da tempestividade da tutela jurisdicional e duplo grau de jurisdição. In: CRUZ E TUCCI, José Rogério (coord.). Garantias constitucionais do processo civil. São Paulo: RT, 1999, p. 218). 
constitucionais e legais do processo, ou mesmo o ideal de perfeição do sistema, é o que costumamos chamar acesso à justiça" ${ }^{291}$.

Calcado em manifestações jurisprudenciais tedescas, NiCOLÒ TROCKER também encontrou ocasião para destacar que o direito de ação não configura uma garantia puramente "formal" de acesso aos tribunais e sim um meio de assegurar ao particular um direito "real" a uma "tutela jurisdicional efetiva e praticamente operante"292.

Como facilmente se percebe, o encaminhamento dessa temática pressupõe, necessariamente, a compreensão de que o processo civil deve trilhar os caminhos tracejados pela Constituição Federal. Implica reconhecer, portanto, que "além de o processo ter de 'ser' conforme o modelo constitucional do processo, ele deve ser interpretado e aplicado com os olhos voltados à realização concreta de valores e situações jurídicas que são a ele exteriores, passando, necessariamente, pelos valores que a própria Constituição exige que, pelo processo, sejam devidamente realizados"293.

Historicamente, o processo penal sempre foi mais bem aquinhoado com garantias constitucionais, mas isso nunca significou que o processo civil fosse "algo de constitucionalmente neutro, insignificante ou indiferente" ${ }^{294}$, tanto assim que, entre nós, FREDERICO MARQUES já alertava para a necessária compreensão de que os institutos do processo civil trazem consigo o "desenvolvimento de um preceito constitucional", situação apta a conferir ao direito processual características políticas e institucionais. Daí a sua conclusão, lastreada em escólio de EDUARDO COUTURE, de que o processo civil "não é 'simples tarefa de rotina forense', e sim, instrumento direto 'de realização da justiça',"295.

\footnotetext{
${ }^{291}$ DINAMARCO, Cândido Rangel. Universalizar a tutela jurisdicional, cit., p. 853.

${ }^{292}$ Processo civile e costituzione: problemi di diritto tedesco e italiano. Milano: Giuffrè, 1974, p. 258 (livre tradução).

${ }^{293}$ SCARPINELLA BUENO, Cassio. Amicus curiae no processo civil brasileiro, cit., p. 45.

${ }^{294}$ MIRANDA, Jorge. Constituição e processo civil. Revista de Processo, nº 98, p. 29. O autor justifica sua assertiva com o argumento de que no processo civil tem-se o "exercício de uma função do Estado e porque o próprio posicionamento recíproco dos indivíduos e dos grupos dentro da sociedade civil não se oferece indiferente às normas constitucionais" (p. 29).

${ }^{295}$ Ensaio sôbre a jurisdição voluntária. 2. ed. São Paulo: Saraiva, 1959, p. 25. Em outra obra também prestigiosa, FREDERICO MARQUES alertou: “O que há de real no processo é o sentido finalístico, a sua teleologia, a sua causa finalis. O processo, como forma de composição de litígios, tem por finalidade propiciar a resolução de conflitos de interêsses dando a cada um o que é seu e garantindo o triunfo da justiça e da liberdade. O scopo del processo é o de "garantir o respeito à pessoa humana e a liberdade do cidadão"”
} 
Consoante proclama autorizado doutrinador uruguaio, "La Constitución es la base, también, del Derecho Procesal, como ciencia y como rama del Derecho Positivo", à vista do que o processo surge como uma garantia universal e fundamental para se alcançar a concreção do direito nas hipóteses em que não se tenha verificado o seu espontâneo e adequado cumprimento ${ }^{296}$.

Já se registrou, com inteiro acerto, que hodiernamente não se concebe o estudo de institutos processuais dentro do círculo fechado do processo, impondo-se, ao revés, uma postura que leve em devida conta o liame entre a Constituição Federal e o direito processual $^{297}$.

Como se decalca dessas ideias, não se pode conceber o processo civil sem a iluminação advinda do foco de irradiação constitucional, de sorte que, em última análise, "a teoria do Estado e o direito constitucional fazem parte da moderna processualística" 298 . Essa postura metodológica, contudo, não implica o esvaziamento do direito processual civil, mas tão somente redunda numa maneira de estudá-lo sob os influxos da Constituição, com o fim de concretizar os valores da ordem jurídica ${ }^{299}$.

(Instituições de direito processual civil. 2. ed. Rio de Janeiro: Forense, 1962. vol. I, p. 34). Mesmo antes disso, JOÃO MENDES DE ALMEIDA JUNIOR, ao estudar o processo criminal brasileiro, já proclamava que o processo tem seus "princípios fundamentalmente consagrados nas constituições políticas" ( $O$ processo criminal brazileiro. 2. ed. Rio de Janeiro: Francisco Alves, 1911, p. 8).

${ }^{296}$ BIDART, Adolfo Gelsi. Incidencia constitucional sobre el proceso. Revista de Processo, no 30, p. $203-$ 204.

${ }^{297}$ GRINOVER, Ada Pellegrini. Os princípios constitucionais e o Código de Processo Civil. São Paulo: Bushatsky, 1975, p. 4.

${ }^{298}$ MARINONI, Luiz Guilherme. Novas linhas do processo civil. São Paulo: RT, 1993, p. 16.

${ }^{299}$ LOPES, João Batista. Efetividade da tutela jurisdicional à luz da constitucionalização do processo civil. Revista de Processo, $\mathrm{n}^{\circ}$ 116, p. 30. Importante outro esclarecimento lançado pelo autor: "A supervalorização dos princípios constitucionais do processo acarreta também o risco de desprezar por completo a legislação processual como se todas as causas pudessem ser resolvidas com aplicação direta da Constituição. A invocação de princípios constitucionais não pode erodir normas técnicas e requisitos necessários ao desenvolvimento do processo (por exemplo, os prazos processuais não podem ser desprezados; as condições da ação (rectius, requisitos de admissibilidade do julgamento do mérito) não podem ser dispensados; a exigência de prova escrita, na ação monitória é inafastável etc.)" (id., p. 32). 
Esse ponto de referência que modela o processo civil às diretivas de índole constitucional traz à tona, como consectário, o enfoque da tutela jurisdicional na perspectiva dos direitos fundamentais ${ }^{300}$.

"De tal sorte, a solução do tormentoso problema das relações entre direito material e processo e dos contornos da tutela jurisdicional só pode ser bem encaminhada se centrarmos o foco numa perspectiva de direito constitucional, visto que aí se situa o núcleo duro do direito fundamental à outorga de jurisdição, desde que o Estado chamou a si o monopólio de prestá-la. (...) Como justamente observa autorizada doutrina, os direitos fundamentais consagrados na Constituição constituem situações subjetivas 'instrumentais', cujo 'reforçamento' constitucional não teria nenhum significado se as correspondentes garantias não permitissem restaurá-las integralmente no caso concreto. $\mathrm{O}$ próprio conceito de inviolabilidade dos direitos fundamentais se exauriria numa estéril abstração se à possibilidade de violação não correspondesse a possibilidade de tutela da situação subjetiva violada (tutela, acrescento, que deve ser efetiva e outorgada em tempo razoável) ${ }^{, 301}$.

Essa concepção - que vê no acesso à justiça a emanação de um direito fundamental - traz ínsita a ideia de que o processo deve ter uma conformação tal que seja capaz de garantir a fruição de todos os demais direitos encampados pelo sistema jurídico ${ }^{302}$. Então,

\footnotetext{
${ }^{300}$ Conforme esclarece BEDAQUE, o “acesso à jurisdição integra, sem dúvida, a categoria dos direitos fundamentais" (Direito e processo, cit., p. 74). Especificamente sobre esse tema, consulte-se texto de ALVARO DE OLIVEIRA (O processo civil na perspectiva dos direitos fundamentais. Revista Forense, $\mathrm{n}^{\circ}$ 372, p. 77-86). Na doutrina constitucionalista, GOMES CANOTILHO igualmente proclama: "o direito de acesso aos tribunais é um direito fundamental formal que carece de densificação através de outros direitos fundamentais materiais" (Direito constitucional e teoria da Constituição. 2. ed. Coimbra: Almedina, 1998, p. 452).

${ }^{301}$ ALVARO DE OLIVEIRA, Carlos Alberto. Teoria e prática da tutela jurisdicional, cit., p. 82.

302 “O titular do direito à tutela jurisdicional efetiva tem perante o Estado um direito a que este leve a cabo uma ação positiva normativa de pré-ordenação de procedimentos adequados" (ZOLLINGER, Marcia Brandão. Proteção processual aos direitos fundamentais. Salvador: JusPodivm, 2006, p. 51). No mesmo sentido, GOMES CANOTILHO averba que "a garantia do acesso aos tribunais pressupõe também dimensões
} 
as leis do processo e a interpretação e aplicação dessas mesmas leis devem movimentar-se de acordo com o ritmo imposto pelos direitos fundamentais.

A postura metodológica de examinar o acesso à justiça pelo prisma dos direitos fundamentais não é destituída de relevância prática, porquanto o viés principiológico daqueles direitos cria ambiente para iluminação interpretativa de regras processuais já existentes e, especialmente, para a formulação de outras regras destinadas a prover sobre situações processuais concretas ${ }^{303}$.

Dentre as linhas de aplicação de normas infraconstitucional segundo o padrão dos direitos fundamentais, a que mais interessa para os rumos desta pesquisa consiste na interpretação mais favorável aos direitos fundamentais, de tal sorte que "havendo dúvida, deve prevalecer a interpretação que, conforme o caso, restrinja menos o direito fundamental, dê-lhe maior proteção, amplie mais o seu âmbito, satisfaça-o em maior grau"304.

de natureza prestacional, na medida em que o Estado deve criar órgãos judiciários e processos adequados (direitos fundamentais dependentes da organização e procedimento)" (op. cit., p. 456). Toda essa construção descende das lições de ROBERT ALEXY, no sentido de que o cidadão titulariza "direitos a ações estatais positivas" (direitos a prestações em sentido amplo), dentre os quais exsurge o "direito a procedimentos como direito à proteção jurídica efetiva", cujos destinatários, a um só tempo, são o legislador e os tribunais: "Direitos a procedimentos podem ser tanto direitos à criação de determinadas normas procedimentais quanto direitos a uma determinada 'interpretação e aplicação concreta' de normas procedimentais" (Teoria dos direitos fundamentais. Trad. Virgílio Afonso da Silva. São Paulo: Malheiros, 2008, p. 474). Em outra passagem da clássica obra, ALEXY complementa: "Direitos a procedimentos judiciais e administrativos são direitos essenciais a uma 'proteção jurídica efetiva'. É condição de uma proteção jurídica efetiva que o resultado do procedimento proteja os direitos materiais dos titulares de direitos fundamentais envolvidos" (id, p. 488).

${ }^{303}$ ALVARO DE OLIVEIRA, Carlos Alberto. O processo civil na perspectiva dos direitos fundamentais, cit., p. 80. O mesmo autor ainda adverte: "Sob o último ângulo visual, o direito fundamental apresenta-se como norma aberta, a estabelecer pura e simplesmente um programa e afirmar uma certa direção finalística para a indispensável concretização jurisdicional, em oposição, assim, àquelas normas que contêm uma ordem positiva ou negativa, capazes de serem apreendidas pelo juiz de forma mais ou menos direta" (id., p. 80).

${ }^{304} I d$., p. 82. Tratando do acesso à jurisdição pelo enfoque dos direitos fundamentais, o autor anuncia o seguinte: "Como fonte específica de normas jurídicas processuais devem ser considerados especialmente dois grupos de direitos fundamentais, pertinentes aos valores da efetividade e da segurança jurídica, valores esses instrumentais em relação ao fim último do processo, que é a realização da Justiça no caso concreto. No primeiro grupo desponta fundamentalmente a garantia de acesso à jurisdição (art. $5^{\circ}, \mathrm{XXXV}$, da Constituição da República). É claro que não basta apenas abrir a porta de entrada do Poder Judiciário, mas prestar 
Sendo assim, o acesso à justiça garantido pelo art. 5, XXXV, da CF/88, a par de constituir um veto ao legislador, no sentido de que este não pode engendrar mecanismos que alijem uma dada situação da vida do crivo da jurisdição, envolve, também, o tema da efetividade do processo, o que, no pensamento de DONALDO ARMELIN, reflete não só uma adequação dos meios aos fins, mas especialmente uma busca de "otimização de seus resultados", algo inseparável da noção instrumental do processo ${ }^{305}$.

Tendo em vista o caráter fluido dessas noções, a doutrina estabelece tópicos que tendem a permitir uma adequada compreensão do significado da expressão acesso à justiça. Nessa perspectiva, ressalta-se que o acesso à justiça ocorre quando: (i) se tem oportunidade de litigar em juízo, como autor ou réu; (ii) o processo se desenvolve nos termos das garantias constitucionais e segundo regras processuais legítimas; (iii) o pedido das partes é julgado; (iv) a decisão judicial apresenta-se justa, segundo a interpretação da hipótese fática e da legislação à luz de valores legítimos; (v) a resposta estatal seja capaz de se concretizar no plano dos fenômenos, mediante a conformação do mundo empírico ao que se decidiu (efetividade) ${ }^{306}$.

Deflui das lições até aqui alinhadas que o direito a uma mera resposta judicial não se mostra capaz de garantir a efetiva fruição dos demais direitos, exsurgindo a nítida conclusão de que esse cenário não concretiza "uma garantia fundamental de justiça"307.

Daí o estreito vínculo entre a noção de acesso à ordem jurídica justa e a visão instrumental do processo ${ }^{308}$, em ordem a exigir uma postura mental de relativização do

jurisdição tanto quanto possível eficiente, efetiva e justa, mediante um processo sem dilações ou formalismos excessivos" (id., p. 84). Em conclusão, ALVARO DE OLIVEIRA faz uma advertência digna de nota: “Observe-se, finalmente, à vista do caráter essencialmente principiológico dos direitos fundamentais, que só se pode determinar o que se entende por processo justo levando-se em conta as circunstâncias peculiares do caso" (id., p. 86).

${ }^{305}$ Acesso à justiça, cit., p. 172.

${ }^{306}$ DINAMARCO, Cândido Rangel. Universalizar a tutela jurisdicional, cit., p. 854. Nem sempre, porém, o processo, por mais adequadas que sejam as formas de tutela e as técnicas processuais, conseguirá atingir a conformação da realidade ao que se dispôs na sentença justa, porquanto existem óbices econômicos que, para ficar apenas num exemplo, impedirão esse resultado almejado quando o executado não tiver patrimônio para responder à obrigação fixada em título judicial. Nesses casos, os entraves exteriores ao processo serão os responsáveis pela não efetivação prática do comando sentencial, sem que isso implique, no caso concreto, amesquinhamento do princípio do acesso à justiça.

307 MARINONI, Luiz Guilherme. Garantia da tempestividade da tutela jurisdicional e duplo grau de jurisdição, cit., p. 218. 
binômio direito e processo, circunstâncias que, conjugadas, desembocam na necessidade de se dotar o sistema processual de efetividade ${ }^{309}$.

Em última análise, para que se garanta a tutela jurisdicional de uma situação de vantagem não é suficiente a predisposição de um procedimento qualquer. Antes, é necessário que o titular da situação de vantagem possa valer-se de um procedimento "strutturato in modo tale da potergli fornire una tutela effettiva e non meramente formale o astratta del suo diritto" 310 .

Para os fins deste trabalho e segundo os limites conscientemente propostos como sendo necessários à compreensão das premissas de índole processual, adota-se o entendimento do que seja efetividade segundo o "programa básico" assim esboçado por BARBOSA MOREIRA:

“a) o processo deve dispor de instrumentos de tutela adequados, na medida do possível, a todos os direitos (e outras posições jurídicas de vantagem) contemplados no ordenamento, quer resultem de expressa previsão normativa, quer se possam inferir do sistema; $b$ ) esses

\footnotetext{
${ }^{308} \mathrm{O}$ caráter instrumental do processo mantém-se presente mesmo na ação rescisória, cujo objeto pode ser integrado por questões exclusivamente processuais ( $v . g$., incompetência absoluta), e também no mandado de segurança contra ato judicial. Isso se dá porque nos casos mencionados "pretende-se, em última análise, tutelar situações no plano material, ainda que indiretamente" (BEDAQUE, José Roberto dos Santos. Direito e processo, cit., p. 14). Semelhantemente, no campo do chamado processo objetivo também ressuma evidente o caráter instrumental da atividade processual: "Também se verifica instrumentalidade nas ações de controle abstrato da constitucionalidade. (...) A evolução da sociedade e do direito passou a exigir, porém, o exercício da jurisdição com o objetivo de tutelar não apenas direitos subjetivos, mas, sim, a própria ordem constitucional, mediante solução de controvérsias a respeito da legitimidade da norma juridicamente abstrata, independentemente de sua incidência em específicos suportes fáticos (...)" (ALVARO DE OLIVEIRA, Carlos Alberto. Teoria e prática da tutela jurisdicional, cit., p. 94). ROBERTO BEDAQUE, porém, mostra-se contrário a essa orientação de ALVARO DE OLIVEIRA (Direito e processo, cit., p. 14). 309 “Al ser el proceso el medio a través del cual se ejerce la potestad jurisdicional, el proceso debe asegurar que la jurisdicción cumpla el cometido constitucional, por ello, el principio central que rige al proceso es el de la tutela jurisdiccional efectiva" (PRIORI POSADA, Giovanni F. El proceso en el Estado Constitucional. In: Constituición y processo: Actas del Seminario Internacional de Derecho Procesal Constituición y processo llevada a cabo en el Campus de la Pontificia Universidad Católica del Perú entre el 22 y el 25 de setiembre de 2009, p. 350).

${ }^{310}$ PROTO PISANI, Andrea. Lezioni di diritto processuale civile, cit., p. 6.
} 
instrumentos devem ser praticamente utilizáveis, ao menos em princípio, sejam quais forem os supostos titulares dos direitos (e das outras posições jurídicas de vantagem) de cuja preservação ou reintegração se cogita, inclusive quando indeterminado ou indeterminável o círculo dos eventuais sujeitos; $c$ ) impende assegurar condições propícias à exata $\mathrm{e}$ completa reconstituição dos fatos relevantes, a fim de que o convencimento do julgador corresponda, tanto quanto puder, à realidade; d) em toda a extensão da possibilidade prática, o resultado do processo há de ser tal que assegure à parte vitoriosa o gozo pleno da específica utilidade a que faz jus segundo o ordenamento; $e$ ) cumpre que se possa atingir semelhante resultado com o mínimo dispêndio de tempo e energias" ${ }^{\prime 11}$.

Como se vê, não se cuida de propor uma efetividade ruim, para tomar de empréstimo a linguagem de ALVARO DE OLIVEIRA, mas sim de uma efetividade virtuosa ${ }^{312}$, centrada na preocupação com os resultados justos que se almejam alcançar por meio do processo.

De fato, a preocupação teleológica, voltada apenas para a performance, não há de ser levada às últimas consequências, a ponto de se obscurecer o entendimento e de se relegar a plano secundário a "dimensão técnica" da ciência processual. O que se busca, com efeito, é dar àquela dimensão "o justo lugar na economia da matéria". Isso porque, encarado como um fim em si mesmo, "o uso da técnica ameaça converter-se em exercício estéril de narcisismo intelectual. Encarado como instrumento de trabalho, vale como

${ }^{311}$ Efetividade do processo e técnica processual. In: Temas de direito processual, sexta série. São Paulo: Saraiva, 1997, p. 17-18. As considerações expostas nas letras "a" e "e" dessa feliz síntese cunhada por BARBOSA MOREIRA serão fundamentais para justificação das ideias expostas mais à frente.

${ }^{312}$ Efetividade e processo de conhecimento. Revista de Processo, no 96, p. 59-69. No texto citado, o autor adverte: "A nosso entender, a efetividade só se revela virtuosa se não colocar no limbo outros valores importantes do processo, a começar pela justiça, mas não só por este. Justiça no processo significa exercício da função jurisdicional de conformidade com os valores e princípios normativos conformadores do processo justo em determinada sociedade (imparcialidade e independência do órgão judicial, contraditório, ampla defesa, igualdade formal e material das partes, juiz natural, motivação, publicidade das audiências, término do processo em prazo razoável, direito à prova)" (p. 60). 
precioso auxiliar do processualista que se esforça por apreender com exatidão a realidade do seu objeto de estudo, na esperança de poder atuar sobre essa mesma realidade",313.

De maneira alguma também se busca reduzir a um plano secundário a dimensão ética do processo ${ }^{314}$. Aliás, não há como conceber a construção de um mecanismo propício à reconstituição dos fatos para que o convencimento do juiz corresponda, tanto quanto possível, à realidade ${ }^{315}$ num ambiente em que se admitam posturas dos sujeitos parciais tendentes a alterar a verdade dos fatos (CPC, art. 14, I, e art. 17, II). Semelhantemente, a meta de atingimento dos resultados do processo com o mínimo de dispêndio de tempo e de energias $^{316}$ só se compreende mediante a assimilação de que as partes não devem formular pretensões, nem alegar defesas, cientes de que são destituídas de fundamento (CPC, art. 14, III) ou opor resistência injustificada ao andamento do processo (CPC, art. 17, IV), só para ficar em algumas recomendações extraídas da legislação.

Em busca de outras premissas e a despeito do inegável entrosamento do ideal de tempestividade da tutela jurisdicional com as noções de acesso à justiça ${ }^{317}$ e de efetividade do processo, os aspectos temporais da tutela jurisdicional serão tratados no tópico seguinte, em razão da relevância que o tema enseja para o estudo do litisconsórcio.

\footnotetext{
${ }^{313}$ BARBOSA MOREIRA, José Carlos. O processo civil, hoje: um Congresso da Associação Internacional de Direito Processual. In: Temas de direito processual civil, quinta série. São Paulo: Saraiva, 1994, p. 238.

314 "Eis por que a doutrina atual considera pobre e insuficiente a indicação do processo como mera técnica instrumentalmente conexa ao direito material. Ele é uma técnica, sim, mas técnica que deve ser informada pelos objetivos e ideologias revelados na ciência processual e levada a efeito com vista à efetivação do valor do justo. Conjuntamente com o próprio direito substancial, o processo é instrumentalmente conexo ao supremo objetivo de pacificar com justiça” (DINAMARCO, Cândido Rangel. Instituições de direito processual civil, cit., vol. I, n 16 p. 63). "Também nessa linha, o Código de Processo Civil brasileiro, que se mostra particularmente empenhado em cultuar a ética no processo, traz normas explícitas quanto aos limites da combatividade permitida e impõe severas sanções à deslealdade. O dever de manter comportamentos condizentes com os mandamentos éticos está sintetizado na fórmula ampla e genérica proceder com lealdade e boa-fé (...)" (DINAMARCO, Cândido Rangel. Instituições de direito processual civil, cit., vol. II, $\mathrm{n}^{\circ}$ 528, p. 265 - grifos do original).

315 Esse é um dos aspectos da efetividade do processo segundo o "programa básico" sumariado por BARBOSA MOREIRA (letra $c$ ).

${ }^{316}$ Letra $e$ do "programa básico" de efetividade exposto por BARBOSA MOREIRA.

${ }^{317}$ NERY JUNIOR, Nelson. Princípios do processo na Constituição Federal. 9. ed. São Paulo: RT, 2009, p. 311. O autor afirma que a exigência de razoável duração do processo constitui desdobramento do princípio do direito de ação, à luz do qual se garante tutela jurisdicional adequada.
} 


\section{Razoável duração do processo: compreensão abrangente}

Consoante apregoa abalizada doutrina, tem-se que a efetividade do processo está intensamente vinculada à rapidez e celeridade com que se deve propiciar a tutela jurisdicional $^{318}$. Essa mesma constatação não escapou à reflexão de NiCOLÒ TROCKER, o qual, embasado na experiência jurisprudencial alemã, pôs em relevo o "stretto rapporto esistente tra effettività e tempestività della tutela giurisdizionale"319.

Embora a duração no tempo constitua uma realidade ínsita ao processo ${ }^{320}$, cumpre assegurar que o tempo gasto para outorga completa do serviço jurisdicional seja o estritamente necessário, evitando-se, destarte, as maléficas dilações indevidas.

As constatações acerca da lentidão dos processos, dos malefícios que semelhante situação provoca na fruição dos direitos e a consequente busca pelo ideal de duração razoável do processo não são fenômenos nacionais e tampouco exclusivos dos nossos dias.

Analisando os possíveis equívocos no encaminhamento das discussões em torno da duração dos processos, BARBOSA MOREIRA indica como primeiro erro a suposição de que a excessiva duração dos processos constitui problema peculiar dos nossos tempos, isto porque desde o século XIV já eram sentidas as queixas alusivas à lentidão do processo canônico, algo que ensejou a edição, pelo Papa Clemente V, da bula Clementina Saepe, a qual introduziu um rito simplificado ${ }^{321}$, dotado, consequentemente, de maior rapidez ${ }^{322}$.

\footnotetext{
${ }^{318}$ ARMELIN, Donaldo. O acesso à justiça, cit., p. 172. Aceitar essa afirmação como correta não implica, todavia, negar os demais fatores, já indicados ao longo do texto, imbricados com a noção de efetividade do processo. CRUZ E TUCCI também delineia a aproximação que existe entre as noções de efetividade e de tempestividade da tutela jurisdicional (Garantias do processo sem dilações indevidas. In: CRUZ E TUCCI, José Rogério (coord.). Garantias constitucionais do processo. São Paulo: RT, 1999, p. 234-237).

${ }^{319}$ Processo civile e costituzione: problemi di diritto tedesco e italiano, cit., p. 259 (grifos do original).

${ }^{320}$ BIDART, Adolfo Gelsi. El tiempo y el proceso. Revista de Processo, no 23, p. 110. Sobre o pormenor, assim dissertou TROCKER: "Il processo - come dice, del resto, la stessa parola procedere - è un rapporto giuridico dinamico e come tale trova nel fattore tempo uno dei suoi elementi caratteristici e naturali” (Processo civile e costituzione, cit., p. 271). Acerca das inúmeras repercussões advindas do fator temporal na vida do processo, consulte-se, por todos, CRUZ E TUCCI (Tempo e processo. São Paulo: RT, 1997, passim). 321 O problema da duração dos processos: premissas para uma discussão séria. In: Temas de direito processual, nona série, p. 369. DONALDO ARMELIN também fez alusão à bula Clementina Saepe para
} 
Ainda segundo BARBOSA MOREIRA, é bem provável que a carga de trabalho dos juízes não cessará de aumentar, ao passo que não é de se esperar que ocorra um incremento de oferta do serviço jurisdicional em proporções equivalentes ao crescimento da demanda. Exasperando ainda mais as preocupações, tem-se que a "pressa em obter resultados e a intolerância com qualquer demora são traços psicológicos bem visíveis no homem de nossos dias"323.

Depois de trabalhar, de maneira crítica, outros pontos da problemática envolvendo a duração dos processos (postura das partes, reformas legislativas e métodos alternativos de solução de conflitos), o autor antes citado conclui que não se pode valorizar tal ou qual aspecto dessa realidade que se mostra bastante complexa, em ordem a se deixar de lado o fascínio por propostas milagrosas, as quais, de regra, deságuam em "amarga decepção"324.

Pondere-se, desde logo, que a noção do que venha a ser razoável duração do processo, e, conseguintemente, quando se configuram os casos de violações a tal garantia, não comporta definição apriorística, impondo-se, sempre, a análise do caso concreto. Não por outro motivo os especialistas, fundados em decisões da Corte Européia dos Direitos do Homem, proclamam os seguintes critérios de apreciação quanto à razoável duração de um dado processo: “a) a natureza do processo e complexidade da causa; b) o comportamento

demonstrar quão vetusto é o embate dos processualistas com relação aos males do tempo $(\mathrm{O}$ acesso à justiça, cit., p. 172-173), movimento que já se verificava, também, desde a legislação medieval espanhola (Fuero Juzgo, II, I, XX; Siete Partidas, III, IV, XI), consoante informou CRUZ E TUCCI na Apresentação do seu Da reconvenção. São Paulo: Saraiva, 1984, p. IX, nota 1.

322 Quanto à importância da bula Clementina Saepe na evolução histórica do processo civil canônico, consulte-se a obra conjunta de CRUZ E TUCCI e AZEVEDO, onde também se lê que a bula Dispendiosam (do ano 1311), editada pelo mesmo Papa Clemente V, veiculava traços de uma forma procedimental acelerada (Lições de processo civil canônico, especialmente Cap. 4, p. 55 et seq.). Especial destaque para a bula Clementina Saepe também se encontra na obra de ALVARO DE OLIVEIRA (Do formalismo no processo civil. São Paulo: Saraiva, 2009, p. 38-41).

${ }^{323}$ O problema da duração dos processos: premissas para uma discussão séria, p. 370. NERY JUNIOR, sobre o ponto, acrescenta: "O tempo no processo assume importância vital nos dias de hoje, porquanto a aceleração das comunicações via web (internet, e-mail), fax, celulares, em conjunto com a globalização social, cultural e econômica, tem feito com que haja maior cobrança dos jurisdicionados e administrados para que haja solução rápida dos processos judiciais e administrativos" (Princípios do processo na Constituição Federal, cit., p. 314-315).

${ }^{324}$ O problema da duração dos processos: premissas para uma discussão séria. In: Temas de direito processual, nona série. São Paulo: Saraiva, 2007, p. 376. 
das partes e de seus procuradores; c) a atividade e o comportamento das autoridades judiciárias e administrativas competentes; d) a fixação legal de prazos para a prática de atos processuais que assegure efetivamente o direito ao contraditório e ampla defesa" ${ }^{\text {}} 25$.

Conquanto não houvesse no Brasil, pelo menos até o final de 2004, texto do qual se pudesse extrair, diretamente, a exigência de razoável duração do processo, a doutrina especializada já anunciava a presença de semelhante postulado no sistema processual pátrio a partir da compreensão ampla do $(i)$ princípio da inafastabilidade da jurisdição $(\mathrm{CF}$, art. $\left.5^{\circ}, \mathrm{XXXV}\right)^{326}$, a indicar a exigência de tutela jurisdicional efetiva, adequada e tempestiva, assim como também do (ii) princípio do devido processo legal ${ }^{327}$.

Além disso, por força da incorporação do Pacto de San José de Costa Rica (Convenção Americana sobre Direitos Humanos) ao ordenamento jurídico brasileiro, entendeu-se que no Brasil também se haveria de cumprir o comando do artigo $8^{\circ}, 1$, do mencionado Pacto: "Toda pessoa tem direito de ser ouvida com as devidas garantias e dentro de um prazo razoável ...”.

E assim se dava por força da norma hospedada no artigo $5^{\circ}, \S 2^{\circ}$, da Constituição da República: "Os direitos e garantias expressos nesta Constituição não excluem outros decorrentes do regime e princípios por ela adotados, ou dos tratados internacionais em que a República Federativa do Brasil seja parte”.

Com base nisso, mesmo antes da chamada Reforma do Poder Judiciário ditada pela Emenda Constitucional $n^{\circ} 45 / 2004$, a doutrina já proclamava que, a despeito dos influxos da garantia do devido processo legal, a exigência de rápida solução do litígio encontraria fundamentação no discurso normativo que se contém no aludido Pacto $^{328}$.

Seja como for, a partir da edição da Emenda Constitucional $\mathrm{n}^{\circ} 45$, de 08 de dezembro de 2004, inseriu-se no direito positivo brasileiro, expressa e definitivamente, a

\footnotetext{
${ }^{325}$ NERY JUNIOR, Nelson. Princípios do processo na Constituição Federal, cit., p. 315. CRUZ E TUCCI alinha apenas os três primeiros critérios como sendo utilizáveis para verificação de uma indevida dilação processual: “ $a$ ) da complexidade do assunto; $b$ ) do comportamento dos litigantes e de seus procuradores ou da acusação e da defesa no processo penal; e $c$ ) da atuação do órgão jurisdicional" (Garantias do processo sem dilações indevidas, p. 239).

${ }^{326}$ NERY JUNIOR, Nelson. Princípios do processo na Constituição Federal, cit., p. 311.

${ }^{327}$ TUCCI, Rogério Lauria; CRUZ E TUCCI, José Rogério. Devido processo legal e tutela jurisdicional. São Paulo: RT, 1993, p. 107.

${ }^{328}$ CRUZ E TUCCI, José Rogério. Tempo e processo, cit., p. 87.
} 
diretriz segundo a qual "a todos, no âmbito judicial e administrativo, são assegurados a razoável duração do processo e os meios que garantam a celeridade de sua tramitação" (CF, art. $5^{\circ}$, LXXVIII).

Fácil intuir que a EC nº 45/2004 explicitou um princípio que já se achava implícito na ordem constitucional brasileira. Na correta percepção de ARAKEN DE ASSIS, a mencionada Emenda simplesmente "declarou" aquilo que já existia no sistema processual pátrio $^{329}$.

Mas, para além da singela afirmação (reconhecimento ou declaração) de uma garantia, prepondera a ideia de que são necessárias posturas concretas na direção do cumprimento desse anseio, ou melhor, dessa promessa constitucional de celeridade.

Tal concretização depende, em certa medida, da disposição de meios humanos e materiais tendentes a aumentar a oferta jurisdicional. Mas não é só isso, porquanto ao legislador também incumbe dotar o sistema de mecanismos impregnados daquele sentido de debelar as dilações indevidas, de maneira que constituem também meios "hábeis para agilizar o processo os mecanismos porventura existentes ou a instituir nas leis processuais" 330 .

À luz dessa necessidade de concretização do ideal da celeridade, exsurge relevante verificar se e em que medida a adoção do litisconsórcio eventual, alternativo e sucessivo coloca-se na rota de implementação daquele princípio constitucional.

Outro aspecto que se mostra relevante, na tratativa desse assunto, diz respeito a uma noção mais abrangente do princípio da razoável duração do processo, isto porque a visualização de que a celeridade há de ser buscada em processos isoladamente considerados pode encerrar uma postura demasiadamente reducionista.

De fato, não se pode negar que a multiplicidade de litígios configura uma das causas de lentidão ${ }^{331}$, de sorte que, a bem da concretização ampla daquele ideal de

\footnotetext{
${ }^{329}$ Duração razoável do processo e reformas da lei processual civil. In: FUX, Luiz; NERY JUNIOR, Nelson; ARRUDA ALVIM WAMBIER, Teresa. Processo e Constituição: estudos em homenagem ao Professor José Carlos Barbosa Moreira. São Paulo: RT, 2006, p. 195.

${ }^{330} I d .$, p. 197.

${ }^{331}$ ARAKEN DE ASSIS. Duração razoável do processo e reformas da lei processual civil, cit., p. 198 et seq.
} 
celeridade, importaria que o sistema fosse dotado de mecanismos aptos a "influir decisivamente na duração dos processos em geral, e não em casos particulares" ${ }^{\text {332 }}$.

Em nada surpreende, pois, a afirmação de que o princípio da razoável duração do processo ostenta um duplo viés. De um lado, importa que cada processo em si considerado não experimente delongas injustificadas; de outro, entende-se necessária a adoção de técnicas que, em seu conjunto, reduzam a carga de trabalho dos órgãos da justiça, circunstância que "viria contribuir para abreviar a duração média do processo" 333 .

É natural conceber-se, portanto, que toda e qualquer contribuição para abreviar a duração média dos processos em geral tenderá à concretização do questionado princípio.

Não se duvida que o autor de uma demanda tenha o poder de tracejar os limites do objeto do processo, levando à apreciação do Estado-juiz a porção do litígio que lhe interessa resolver. Todavia, na medida do interesse da parte, o sistema deve dotar-se de mecanismos aptos a receber a maior porção possível do conflito vivenciado pelo jurisdicionado, algo que contribui para conter a multiplicação de processos e, em última análise, aprimorar o sistema no ponto em que se refere à duração razoável dos processos em geral.

Esse aspecto do problema, porquanto entrosado com a noção de economia processual $^{334}$, revela-se de significativa importância para o encaminhamento das questões que giram em torno da justificação do próprio instituto do litisconsórcio, em ordem a servir de espeque, também, para as modalidades litisconsorciais que se colocam no centro desta pesquisa.

\footnotetext{
332 ARAKEN DE ASSIS. Duração razoável do processo e reformas da lei processual civil, cit., p. 197 (grifou-se).

${ }^{333}$ NERY JUNIOR, Nelson. Princípios do processo na Constituição Federal, cit., p. 314.

334 “A economia processual pode ser entendida como sendo uma relação de proporcionalidade entre meio e fim, uma busca pelo atingimento dos escopos processuais com a máxima eficácia e o menor dispêndio de tempo e de recursos por parte do Estado e das partes" (DUARTE, Ronnie Preuss. Garantia de acesso à justiça: os direitos processuais fundamentais. Coimbra: Almedina, 2007, p. 209). Necessário frisar, seguindo orientação de autorizada doutrina, que a consagração, em nível constitucional, do princípio da razoável duração do processo guindou a regra técnica da economia processual à condição de postulado político (CRUZ E TUCCI, José Rogério. A causa petendi no processo civil, cit., p. 188). A consequência da elevação de princípios processuais ao patamar constitucional também foi referida por GIOVANNI VERDE (op. cit., vol. 1, p. 5).
} 
Realmente, conforme de há muito revelado por autorizada doutrina, a exigência de plenitude da tutela jurisdicional e a notória insuficiência de recursos para se alcançar tal desiderato torna indispensável a aplicação, na tela processual, do princípio del minimo mezzo (ou princípio dell'economia dei giudizi). Todavia, tal aplicação, é bom novamente frisar, não há de se reduzir ao âmbito exclusivo de um processo singular, concebendo-se que a utilização mínima dos meios processuais seja encarada numa perspectiva expandida, apta a abranger uma pluralidade de processos, uma vez que "conviene ottenere il massimo risultato nella attuazione della legge col minimo possibile impiego di attività giurisdizionale" ${ }^{, 335}$.

Não por outro motivo é que COMOGLIO extrai do princípio da economia processual duplo enfoque: o interno e o externo.

“1) in senso endo-processuale (ovvero interno), essa opera sul rapporto tra i singoli atti, tra fasi diverse o gradi successivi di un medesimo processo, mirando ad attuarvi un'equilibrata ed armonica ripartizione delle risorse strumentali; 2) in senso ultra-processuale (od esterno), essa proietta al di là dello stesso giudicato l'esigenza del risparmio di attività o di spesa superflua, preoccupandosi di evitare il futuro promovimento di nuovi processi, con lo sfruttamento adeguato di quello in corso" ${ }^{\text {336. }}$.

De volta ao princípio da razoável duração do processo, convém advertir que o seu manejo deve compatibilizar-se com outros postulados de envergadura também constitucional. Com efeito, não se pode relegar a segundo plano as garantias do contraditório e da ampla defesa, as quais se entrosam na mesma raiz de onde promana o primado da razoável duração do processo, a saber, o princípio do devido processo legal ${ }^{337}$.

Mostra-se indispensável, nessa conformidade, um equilíbrio entre as diretrizes que caminham no sentido da concretização, de um lado, da segurança jurídica, do que resulta o dispêndio de um tempo razoável para a tramitação do processo, e, de outro, da celeridade,

${ }^{335}$ CHIOVENDA, Giuseppe. Principii di diritto processuale civile, cit., p. 133.

${ }^{336}$ Il principio di economia processuale. Padova: CEDAM, 1980. vol. I, p. 71 (grifou-se).

${ }^{337}$ Sobre a razoável duração do processo como emanação do princípio do devido processo legal, consulte-se obra conjunta de ROGÉRIO LAURIA TUCCI e CRUZ E TUCCI (Devido processo legal e tutela jurisdicional, cit., p. 107). 
que reclama a não procrastinação do andamento do feito para além do necessário. “Obtendo-se um equilíbrio desses dois regramentos - segurança/celeridade -, emergirão as melhores condições para garantir a justiça no caso concreto, sem que, assim, haja diminuição no grau de efetividade da tutela jurisdicional" ${ }^{338}$.

Diante desse cenário, a norma hospedada no artigo 5, LXXVIII, da CF/88 (introduzida pela EC 45/2004), terá de necessariamente conviver com aquelas outras garantias também de índole constitucional, tendo-se a percepção de que um "processo informado por preocupações garantísticas necessariamente será menos rápido que um processo que as ponha de lado",339.

Deve-se, pois, preconizar o equilíbrio entre as diversas garantias constitucionais do processo, deixando-se de lado propostas que optem pela celeridade a todo e qualquer custo. Aliás, quando em cotejo com outras garantias constitucionais, parece acertado dizer que as manobras tendentes à obtenção de celeridade é que precisam ceder passo ${ }^{340}$.

Forte nessas premissas, tentar-se-á demonstrar, mais à frente, que a admissão do litisconsórcio eventual, alternativo e sucessivo no âmbito da sistemática processual brasileira pode, numa de suas perspectivas, incrementar o ideal da razoável duração dos processos em geral e, ao mesmo tempo, em nada macular as demais garantias constitucionais do processo civil em vigor.

\section{Dúvida e eventualidade: influência na conformação do processo}

Antes de apreciar o assunto afeto à cumulação de pedidos, a partir do qual se buscará construir grande parte das noções, das justificações teóricas e da sistematização das espécies litisconsorciais aqui investigadas, mostra-se conveniente ter presentes

\footnotetext{
${ }^{338}$ CRUZ E TUCCI, José Rogério. Garantias do processo sem dilações indevidas, cit., p. 237.

${ }^{339}$ BARBOSA MOREIRA, José Carlos. O problema da duração dos processos, cit., p. 377.

340 "Pode-se, assim, afirmar uma tendencial primazia de certos direitos processuais fundamentais sobre o direito à duração razoável do processo. Exemplo é o contraditório ou o acesso à justiça em sentido estrito, o direito à prova, o direito à igualdade no processo e o direito à fundamentação das decisões. Assim é porque, de outra forma, estaria afetada, com grande gravidade, a própria teleologia do processo, qual seja a aptidão para a prolação de uma decisão justa” (DUARTE, Ronnie Preuss. Garantia de acesso à justiça, cit., p. 211).
} 
algumas peculiaridades eminentemente processuais atreladas aos fatores da dúvida e da eventualidade.

Essa tarefa visa a pôr em destaque mais uma constatação: a de que o sistema processual, porque não ignora a existência da dúvida, procura aplacar as dificuldades que dela possam derivar, o que se faz por meio de mecanismos técnicos condizentes com a visão instrumental do processo e com a ideia de que os estados de perplexidade, gerados na própria economia do processo, não podem empecer o acesso à justiça.

Importa considerar, à guisa de explicação prévia, que os institutos a seguir tratados não comungam da mesma natureza, de sorte que não se pretende equiparar, em termos teóricos, os vários fenômenos processuais relacionados com a ideia de eventualidade. $\mathrm{O}$ que se busca delinear é tão somente a presença, na economia interna do processo, de situações diversas, mas que têm em comum o apego à noção ampla de eventualidade.

\section{(i) fungibilidade recursal}

Por mais que se queira outorgar coerência ao sistema recursal e, com isso, obter-se um estado de segurança jurídica significativo, o legislador não alcança um nível de precisão capaz de cobrir todas as hipóteses vivenciadas no foro. Embora a regra, em tema de recurso, seja a da taxatividade e da unicidade, não se pode negar a existência de celeumas doutrinárias, extraídas da legislação e com inevitável repercussão na jurisprudência, respeitante ao cabimento deste ou daquele recurso em certas situações problemáticas.

Tanto é verdade que o Código de Processo Civil de 1939, no seu art. 810, previa: "Salvo a hipótese de má-fé ou erro grosseiro, a parte não será prejudicada pela interposição de um recurso por outro, devendo os autos ser enviados à Câmara, ou Turma, a que competir o julgamento".

Tal regra justificava-se diante dos corriqueiros casos em que, presente a celeuma jurisprudencial sobre o cabimento de recursos diversos para atacar uma mesma decisão, a parte interpunha um recurso e o órgão ad quem, perfilhando orientação diversa quanto à hipótese de cabimento, não dava seguimento ao recurso e, assim, sacrificado permanecia o 
mérito pela preliminar. Aflorou, então, a necessidade de não mais se obstar o trâmite de um recurso "pelo apêgo a sutilezas e a formalismos anódinos" ${ }^{341}$.

Então, na esteira do que se veiculou também no Código de Processo Civil do Estado de Minas Gerais (art. 1.485, p. único) e do Distrito Federal (art. 1.143), o legislador de 1939 encampou o princípio da fungibilidade dos recursos, também designado de teoria do recurso indiferente ou, ainda, de teoria do tanto vale ${ }^{342}$.

Está bem presente na base de conformação desse princípio a noção de "incertezas" e de "embaralhamentos" espraiados pela doutrina e pela jurisprudência em torno do cabimento dos recursos, algo que a doutrina moderna qualifica como dúvida objetiva ${ }^{343}$ ou, em palavras mais exatas, dúvida demonstrável objetivamente ${ }^{344}$.

Mesmo sem previsão expressa no Código em vigor, admite-se que a fungibilidade recursal tenha incidência nos dias de hoje. "Absurdo recusar o benefício ao recorrente em

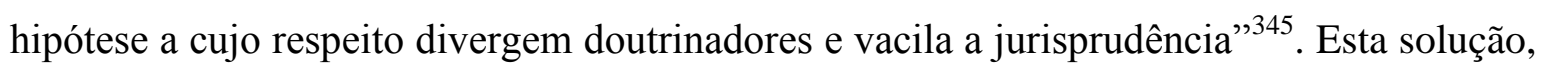
aplicável ao direito atual, não agride o sistema do Código de 1973, “que não leva (nem poderia levar) a preocupação do formalismo ao ponto de prejudicar irremediavelmente o interesse substancial das partes por amor ao tecnicismo"346.

E não se diga que, sob a égide da legislação atual, inexistiria espaço para disceptações doutrinárias e jurisprudenciais acerca do cabimento de certos recursos. Com

${ }^{341}$ MENDONÇA LIMA, Alcides. Recursos cíveis: sistema de normas gerais. Rio de Janeiro/São Paulo: Freitas Bastos, 1963, p. 218. Em outra passagem, o autor relembra as dificuldades existentes na legislação de então quanto ao cabimento de certos recursos: "Entretanto, face ao nosso sistema recursório, é possível e comum a interposição de agravo (sobretudo de petição) quando cabível seria apelação e, o que é pior, interposição de apelação, quando cabível seria agravo. Isso é fruto da ambígua formulação de alguns incisos do art. 842 e, sobretudo, do art. 846 do Código de Processo Civil, ao referir-se êsse último 'a decisões que impliquem a terminação do processo principal, sem lhe resolverem o mérito'. A conceituação de 'mérito' gera dúvidas e perplexidade face a certas decisões, desde que não se pode precisar se entram na classe das meramente terminativas (cabível agravo de petição) ou das definitivas (cabível apelação), como, v.g., em casos de prescrição, de carência de ação, etc" (id., p. 216-217).

${ }^{342} I d .$, p. 218.

${ }^{343}$ PINTO, Nelson Luiz. Manual dos recursos. 3. ed. São Paulo: Malheiros, 2003, p. 89-91.

${ }^{344}$ ARRUDA ALVIM PINTO, Teresa. "Dúvida" objetiva: único pressuposto para a aplicação do princípio da fungibilidade. Revista de Processo, $\mathrm{n}^{\circ}$ 65, p. 62.

345 BARBOSA MOREIRA, José Carlos. Comentários ao Código de Processo Civil. 14. ed. Rio de Janeiro: Forense, 2008, vol. V, nº 141, p. 251.

${ }^{346}$ Id., ibid. 
efeito, a prática forense tem revelado que mesmo no seio de um Código imbuído do propósito de simplificar o sistema recursal - comparativamente ao Código de 1939 - "há muitas dúvidas a respeito da adequação recursal no novo sistema processual"347.

E a Lei n. ${ }^{\circ}$ 11.232/2005, alterando o conceito de sentença residente no art. 162, § $1^{\circ}$, trouxe novas cores para o problema do cabimento dos recursos de apelação e de agravo $^{348}$. É que do conceito de sentença extraem-se inegáveis consequências no tema da recorribilidade, já que o art. 513 continua a dizer que da sentença caberá apelação. Tal discussão, porém, em muito se afasta dos objetivos traçados para esta pesquisa, razão pela qual se deixam de lado maiores aprofundamentos.

O que importa frisar é que o estado de perplexidade, de dubiedade, de vacilação em torno do cabimento de certos recursos, desde que objetivamente caracterizado, ou seja, na medida em que extraível de impropriedades ou imperfeições legislativas ou de celeuma doutrinária ou jurisprudencial ${ }^{349}$, autoriza que se tome um recurso pelo outro.

Note-se que a dúvida objetiva - algo muito distante da singela dúvida subjetiva faz emergir a necessidade de concretização do princípio da instrumentalidade das formas

${ }^{347}$ NERY JUNIOR, Nelson. Princípios fundamentais - teoria geral dos recursos. 5. ed., São Paulo: RT, 2000, p. 113. As variadas hipóteses em que se pode pensar na aplicação do princípio da fungibilidade recursal são catalogadas por NERY JUNIOR (id., p. 119-135) e por NELSON LUIZ PINTO (op. cit., p. 91). ${ }^{348}$ Sobre o ponto, consultem-se: WAMBIER, Luiz Rodrigues; ARRUDA ALVIM WAMBIER, Teresa; MEDINA, José Miguel Garcia. Breves comentários à nova sistemática processual civil: $\mathrm{n}^{\circ} 2$, São Paulo: RT, 2006, p. 37; SCARPINELLA BUENO, Cassio. A nova etapa da reforma do Código de Processo Civil. São Paulo: Saraiva, 2006, vol. 1, p. 20; TEIXEIRA, Guilherme Freire de Barros. Teoria do princípio da fungibilidade. São Paulo: RT, 2008, p. 162-165. À vista das discussões surgidas a partir da Lei $n^{\circ}$ 11.232/2005, há quem sustente a chamada apelação por instrumento (MILMAN, Fabio. O novo conceito legal de sentença e suas repercussões recursais: primeiras experiências com a apelação por instrumento. Revista de Processo, $\mathrm{n}^{\circ}$ 150, p. 160-174).

349 "Essa dúvida pode ser de três ordens: a) o próprio código designa uma decisão interlocutória como sentença ou vice-versa, fazendo-o obscura ou impropriamente; b) a doutrina e/ou jurisprudência divergem quanto à classificação de determinados atos judiciais e, conseqüentemente, quanto à adequação do respectivo recurso para atacá-lo; c) o juiz profere um pronunciamento em lugar de outro" (NERY JUNIOR, Nelson. Princípios fundamentais - teoria geral dos recursos, cit., p. 119). Sem discrepar: VASCONCELOS, Rita de Cássia Corrêa de. Princípio da fungibilidade: hipóteses de incidência no processo civil brasileiro contemporâneo. São Paulo: RT, 2007, p. 87. 
(CPC, art. 250), em ordem a se aceitar, em todos os aspectos, inclusive quanto aos $\operatorname{prazos}^{350}$, a adequação de um recurso em vez de outro.

(ii) fungibilidade na tutela de urgência

Em sua redação originária, o Código de Processo Civil não dispunha, em tom de generalidade, de mecanismo capaz de autorizar a satisfação (fruição), desde o início da demanda (liminarmente) e em caráter provisório, do direito afirmado na petição inicial. Existiam apenas medidas tendentes à conservação da viabilidade de realização futura do direito afirmado, isto é, as cautelares. Mesmo naquela época, para suprir essa lacuna no sistema legislado, a praxe forense valia-se do que se costumava chamar de "cautelar satisfativa".

Porém, com a Lei n. ${ }^{\circ}$ 8.952/94, o art. 273 passou a contar com a seguinte redação: “O juiz poderá, a requerimento da parte, antecipar, total ou parcialmente, os efeitos da tutela pretendida no pedido inicial, desde que, existindo prova inequívoca, se convença da verossimilhança da alegação e: I - haja fundado receio de dano irreparável ou de difícil reparação; II - fique caracterizado o abuso de direito de defesa ou o manifesto propósito protelatório do réu".

Com isso, generalizou-se no sistema processual brasileiro a tutela antecipada, consistente em "oferecer rapidamente a quem veio ao processo pedir determinada solução para a situação que descreve, precisamente aquela solução que ele veio ao processo pedir. Não se trata de obter medida que impeça o perecimento do direito, ou que assegure ao titular a possibilidade de exercê-lo no futuro. A medida antecipatória conceder-lhe-á o exercício do próprio direito afirmado pelo autor" ${ }^{\text {351. }}$.

Esse novo sistema trouxe consigo, por mais paradoxal que seja, inúmeros problemas interpretativos, já que, para se valer da tutela antecipada, a parte não poderia

\footnotetext{
${ }^{350}$ PINTO, Nelson Luiz. Op. cit., p. 91; NERY JUNIOR, Nelson. Princípios fundamentais - teoria geral dos recursos, cit., p. 140-144; BEDAQUE, José Roberto dos Santos. Efetividade do processo e técnica processual, cit., nota 60, p. 116-117; ARRUDA ALVIM PINTO, Teresa. "Dúvida" objetiva: único pressuposto para a aplicação do princípio da fungibilidade, cit., nº 65 , p. 60-61.

${ }^{351}$ DINAMARCO, Cândido Rangel. A reforma do Código de Processo Civil. São Paulo: Malheiros, 1995, n 104, p. 139.
} 
formular pedido com características meramente assecuratórias. E, igualmente, não poderia veicular pedido conservativo (tipicamente cautelar) sob as vestes de tutela antecipada. A partir disso surgiu como inevitável a dificuldade em caracterizar determinada medida como sendo antecipatória dos efeitos da tutela pretendida ou como simplesmente assecuratória da futura realização do direito afirmado.

Para ficar em dois exemplos elucidativos, figurem-se as hipóteses de a parte solicitar a sustação de protesto ou a separação de corpos. Essas medidas seriam cautelares ou antecipatórias?

As dúvidas que surgiram sobre a qualificação jurídica de uma dada providência (se cautelar ou antecipatória) levaram a resultados incompatíveis com a tônica da inovação legislativa. É que o apego à técnica redundou no indeferimento de petições iniciais que, sob as vestes de cautelar antecedente, formulavam pedidos de cunho satisfativo. De outra parte, mesmo na presença dos requisitos exigidos, costumava-se indeferir medidas cautelares só pelo fato de terem sido apresentadas com roupagem de tutela antecipada ${ }^{352}$.

Daí a necessidade de se conferir fungibilidade a tais providências, porquanto a dúvida objetivamente fundada a respeito da qualificação desta ou daquela medida não poderia servir de empeço à efetividade do processo $^{353}$, lembrando-se, por oportuno, que as tutelas de urgências configuram emanação viva da garantia constitucional de acesso à justiça $^{354}$.

\footnotetext{
352 "Muitas são as dúvidas suscitadas na doutrina e na jurisprudência acerca das diferenças ontológicas e funcionais das diversas espécies de tutelas de urgência, em especial acerca do cabimento de cada uma para defesa de determinadas pretensões deduzidas em juízo. (...) Longe de contar com alguma tranquiilidade na doutrina, a sistematização das tutelas de urgência é tema muito controverso, ensejando os mais acalorados debates entre os juristas autorizados da ciência processual, com enormes consequiências práticas no modo de ser do processo. Tudo isso, frise-se, mediante proposições descritivas acerca da mesma legislação processual, tão rica quanto complexa ao estudioso da ciência do direito" (CASTAGNA, Ricardo Alessandro. Tutela de urgência: análise teórica e dogmática. São Paulo: RT, 2008, p. 280-281 - grifos do original).

353 "Nada mais atentatório à efetividade do processo do que a negativa de uma tutela requerida em face da urgência de uma situação de perigo, diante de sua inadequação ao direito processual, havendo dúvida objetiva - até mesmo na doutrina e na jurisprudência - sobre o cabimento de uma em relação à outra" (CASTAGNA, Ricardo Alessandro. Op. cit., p. 283).

${ }^{354}$ Sobre esse aspecto, consulte-se, com proveito, a obra de ROBERTO BEDAQUE (Tutela cautelar e tutela antecipada: tutelas sumárias e de urgência. 4. ed., São Paulo: Malheiros, 2006, Cap. IV, p. 63 et seq.).
} 
Considerando-se esse estado de dúvidas, a Lei n. ${ }^{\circ} 10.444 / 2002$ acrescentou o $\S 7^{\circ}$ ao art. 273 , do $\mathrm{CPC}^{355}$, por intermédio do qual se reconheceu, expressamente, a fungibilidade entre as tutelas de urgência. Então, numa interpretação que confere maior rendimento à regra em análise, pode-se enunciar a seguinte diretriz: (i) a formulação de pedido de tutela antecipada não impede que o juiz, caso entenda tratar-se de verdadeira medida cautelar, defira a providência assecuratória pertinente ao caso, desde que presentes os requisitos para tanto; (ii) a incoação de pedido de tutela cautelar também não obsta a que o juiz, vislumbrando ser caso de tutela antecipada, outorgue a medida satisfativa adequada ao caso, sempre na presença dos respectivos pressupostos ${ }^{356}$.

Apregoa-se em doutrina que a noção de fungibilidade pressupõe e até acentua a distinção entre os institutos à base de cuja confusão se permite tomar um pelo outro: "somente coisas distintas podem ser confundidas" 357 .

Pondera-se, então, que a aplicação da fungibilidade em tema de tutela de urgência requer a existência da dúvida objetiva quanto à caracterização da natureza da medida pleiteada. Como refere MARINONI, "não existindo erro grosseiro do requerente, ou, em outras palavras, havendo dúvida fundada e razoável quanto à natureza da tutela, aplica-se a idéia de fungibilidade, uma vez que o seu objetivo é o de evitar maiores dúvidas quanto ao cabimento da tutela urgente (evidentemente de natureza nebulosa) no processo de conhecimento" 358 .

Nesse cenário, seria razoável excogitar do afastamento da regra da fungibilidade quando se estivesse diante de cautelar típica, prevista claramente na legislação como tal, afastando-se, com isso, possibilidades de dúvidas sobre o seu cabimento ${ }^{359}$.

\footnotetext{
355 "Se o autor, a título de antecipação de tutela, requerer providência de natureza cautelar, poderá o juiz, quando presentes os respectivos pressupostos, deferir a medida cautelar em caráter incidental do processo ajuizado".

356 Quanto ao duplo sentido vetorial da regra da fungibilidade, confira-se, por todos, DINAMARCO, Cândido Rangel. A reforma da reforma. 5. ed. São Paulo: Malheiros, 2003, nº 48, p. 92-94.

${ }^{357}$ MARINONI, Luiz Guilherme. Antecipação de tutela. 9. ed. São Paulo: RT, 2006, p. 161-162.

${ }^{358} I d .$, p. 162.

359 CASTAGNA, Ricardo Alessandro. Op. cit., p. 285. No mesmo sentido: SPADONI, Joaquim Felipe. Fungibilidade das tutelas de urgência. Revista de Processo, $\mathrm{n}^{\circ}$ 110, p. 85-86. Em artigo escrito antes da reforma operada pela Lei $n^{\circ} 10.444 / 2002$, transpareceu no pensamento de ARAKEN DE ASSIS uma propensão a este mesmo raciocínio, segundo o qual a ausência de previsão de uma medida típica é que
} 
Mesmo para aqueles que admitem a incidência da regra da fungibilidade sem apelo ao fator da dúvida objetiva ${ }^{360}$, não há como negar que a confusão - extraída de imprecisão do legislador ou de debates hauridos da doutrina e da jurisprudência - em torno da qualificação de certas medidas urgentes é que alimenta e confere razão de ser à própria noção de fungibilidade.

\section{(iii) ainda a fungibilidade}

Sem a intenção de apresentar um rol exaustivo de hipóteses em que o princípio da fungibilidade atua para aplacar os problemas gerados por dúvidas objetivamente aferíveis, pode-se ainda destacar que as vacilações sobre a medida adequada para obtenção de efeito suspensivo aos recursos que não exibem essa particularidade autorizam a utilização, indistintamente, da ação cautelar e do mandado de segurança ${ }^{361}$.

Raciocínio semelhante pode ser empreendido quando se busca destrancar recurso especial ou extraordinário submetido ao regime de retenção a que alude o art. $542, \S 3^{\circ}$, do CPC. As divergências doutrinárias e a própria oscilação jurisprudencial criam ambiente propício para a incidência da fungibilidade ${ }^{362}$.

De outra parte, à vista dos embates doutrinários acerca da natureza dos embargos ao mandado monitório (se ação ou contestação), mostra-se razoável pensar que o manejo de

poderia desaguar na aplicação da fungibilidade (Fungibilidade das medidas inominadas cautelares e satisfativas. Revista de Processo, $\mathrm{n}^{\circ}$ 100, p. 56).

${ }^{360}$ BEDAQUE, José Roberto dos Santos (Efetividade do processo e técnica processual, cit., nota 61, p. 117118). Relembre-se que na estrutura do pensamento de BEDAQUE a tutela cautelar e a tutela antecipada participam da mesma identidade, sendo realidades "ontologicamente iguais" (Tutela cautelar e tutela antecipada, cit., p. 388, no texto e na nota 205). Também no sentido de que a dúvida objetiva é prescindível para aplicação da fungibilidade na tutela de urgência, TEIXEIRA, Guilherme Freire de Barros (Teoria do princípio da fungibilidade, cit., p. 189-190).

${ }^{361}$ BEDAQUE, José Roberto dos Santos. Efetividade do processo e técnica processual, cit., p. 119.

${ }^{362}$ ARRUDA ALVIM WAMBIER, Teresa. Fungibilidade de "meios": uma outra dimensão do princípio da fungibilidade. In: NERY JR., Nelson; ARRUDA ALVIM WAMBIER, Teresa (coord.). Aspectos polêmicos e atuais dos recursos cíveis e de outras formas de impugnação às decisões judiciais. São Paulo: RT, 2001. vol. 4, p. 1133-1135; VASCONCELOS, Rita de Cássia Corrêa de. Op. cit., p. 235 et seq. 
uma ou outra forma de defesa seja indiferente, mais uma vez apelando-se para a fungibilidade ${ }^{363}$.

No tormentoso campo da distinção entre os planos da validade e da existência pode-se também cogitar de fundadas dúvidas na caracterização de um determinado vício como sendo de nulidade ou de inexistência (jurídica) da sentença, circunstância apta a gerar reflexos na elucidação do mecanismo jurídico apto a confrontar aquele vício. Nessa perspectiva, parcela respeitável da doutrina propugna, em determinadas hipóteses, pela aplicação da fungibilidade entre a ação rescisória e a ação declaratória de inexistência (querela nullitatis) $)^{364}$.

O tema da antecipação de tutela concedida em sentença também rendeu ensejo a disceptações, já que antes da Lei n. ${ }^{\circ} 10.352 / 2001^{365}$ era comum indagar-se, como o fez TERESA ARRUdA ALVIM WAMBIER: qual o recurso cabível? ${ }^{366}$

Para tal questão várias soluções foram engendradas, sem que se percorressem caminhos à margem do sistema então em vigor, tudo a recomendar a incidência mais uma vez - alimentada pela dúvida doutrinária e jurisprudencial - da fungibilidade ${ }^{367}$.

(iv) ordem lógica de apreciação de questões afetas às nulidades e ao mérito

Sabe-se que a ordem lógica de apreciação judicial das questões relacionadas com a solução de um determinado caso consiste na análise, primeiro, de assuntos de índole processual (pressupostos processuais, condições da ação e nulidades processuais) e, depois,

\footnotetext{
${ }^{363}$ BEDAQUE, José Roberto dos Santos. Efetividade do processo e técnica processual, cit., p. 120.

${ }^{364}$ ARRUDA ALVIM WAMBIER, Teresa. Recurso especial, recurso extraordinário e ação rescisória, cit., p. 478-479; VASCONCELOS, Rita de Cássia Corrêa de. Op. cit., p. 174 et seq.

${ }^{365}$ Essa lei acrescentou o inciso VII ao art. 520, do CPC, conferindo-se efeito suspensivo à apelação quando interposta de sentença que "confirmar a antecipação dos efeitos da tutela".

${ }^{366}$ Fungibilidade de "meios": uma outra dimensão do princípio da fungibilidade, cit., p. 1120.

367 O assunto não escapou à perspicácia de ROBERTO BEDAQUE: “Também com relação à tutela antecipada concedida na sentença, alternativa admitida por grande parte da doutrina, instaurou-se divergência com relação ao recurso cabível. Apesar da convicção quanto a ser a apelação o recurso adequado, considerase admissível a incidência da fungibilidade recursal se interposto agravo contra a parte da sentença em que se deu a antecipação, tendo em vista haver manifestação nesse sentido tanto em sede doutrinária quanto jurisprudencial" (Efetividade do processo e técnica processual, cit., p. 121).
} 
de temas atinentes ao mérito da causa. Em outras palavras, o exame do mérito pressupõe estarem vencidas as indagações pertinentes aos requisitos de admissibilidade daquele próprio exame.

Tanto é verdade que o sistema engendra uma etapa preponderantemente saneadora para que, ali, sejam concentradas as atividades tendentes a expungir do processo toda e qualquer irregularidade ou nulidade que possa inviabilizar o exame do mérito $(\mathrm{CPC}$, art. 327 , in fine).

Se do ponto de vista lógico o esquema de apreciação suso referido se justifica, pela angulação do princípio da instrumentalidade das formas hão de se impor alguns temperamentos.

Com a atenção voltada para o campo das nulidades, sejam elas absolutas ou relativas, cominadas ou não, tem-se por certo que o juiz, podendo decidir o mérito em favor da parte a quem aproveita a declaração da nulidade, não a pronunciará e tampouco mandará repetir o ato ou suprir-lhe a falta $\left(\mathrm{CPC} \text {, art. } 249, \S 2^{\circ}\right)^{368}$.

A partir dessa regra mostra-se válida a inversão naquela ordem lógica de apreciação das matérias debatidas na causa. É que, para o evento de o julgamento do mérito ser favorável à parte que se beneficiaria com o reconhecimento da nulidade, o juiz deve, necessariamente, incursionar no exame do próprio mérito antes de se debruçar sobre os aspectos atrelados à arguição da nulidade.

Veja-se que o sistema processual aceita a noção de eventualidade para, em tema de nulidades, ao mesmo tempo conformar-se ao e concretizar o princípio da instrumentalidade das formas.

Esse mesmo tema impõe consequências relevantes na seara recursal. Com efeito, é possível que no momento de se julgar uma apelação ainda penda de apreciação algum recurso de agravo de instrumento. Para tal hipótese o Código de Processo Civil determina que a apelação não será incluída em pauta antes do agravo de instrumento interposto no mesmo processo (art. 559). E o parágrafo único desse artigo acrescenta que, se ambos os recursos houverem de ser julgados na mesma sessão, terá precedência o agravo.

No campo do agravo retido essa regra fica ainda mais saliente, já que a análise desse recurso dá-se preliminarmente ao julgamento da apelação, ex vi do art. 523, caput.

${ }^{368}$ BEDAQUE, José Roberto dos Santos. Efetividade do processo e técnica processual, cit., p. 446. 
Porém, suposta a alegação de nulidade processual no âmbito do agravo (por instrumento ou na forma retida), o órgão colegiado haverá de analisar questões agitadas no bojo da própria apelação para só então, visualizada a possibilidade de julgamento desfavorável à parte que se beneficiaria pelo reconhecimento da nulidade, voltar a atenção para a nulidade afirmada.

Então, para o evento de ser o mérito da apelação julgado favoravelmente ao agravante, impõe-se alteração no procedimento de análise desses recursos. Em vez de se analisar primeiramente o agravo, aprecia-se a apelação, pois que do resultado deste exame dependerá a sorte daquele outro.

(v) interposição conjunta de recurso especial e extraordinário

Nos casos em que o acórdão, proferido segundo a moldura dos arts. 102, III, e 105, III, da Constituição Federal, ostenta capítulos distintos ou, embora sendo único, contenha fundamentação suficiente de nível infraconstitucional federal e também constitucional, mostra-se possível a interposição conjunta - e não necessariamente simultânea - de recurso especial e de recurso extraordinário.

Tal possibilidade exterioriza mais uma faceta do tema da eventualidade, uma vez que, admitidos ambos os recursos, os autos são encaminhados primeiramente ao Superior Tribunal de Justiça, a fim de ser apreciado o recurso especial (CPC, art. 543, caput), cujo conhecimento e provimento a parte recorrente almeja obter.

Porém, para o evento de não ser provido o recurso especial, já estará interposto o recurso extraordinário, o qual terá então seu trâmite destrancado para remessa dos autos ao Supremo Tribunal Federal.

É nesse sentido que o $\S 1^{\circ}$ do art. 543 dispõe: “Concluído o julgamento do recurso especial, serão os autos remetidos ao Supremo Tribunal Federal, para apreciação do recurso extraordinário, se este não estiver prejudicado" (ênfase proposital).

Como se infere do citado dispositivo, a condicional "se" bem exprime a presença da noção de eventualidade. A parte, com a interposição do recurso especial perante o STJ, espera obter êxito em seu reclamo. Porém, existindo também fundamentos de ordem constitucional no acórdão recorrido, não há como negar um estado de hesitação 
relativamente à sorte do recurso especial, de modo que, para o evento de não se afastar o estado de sucumbência por meio do recurso especial, a parte desde logo maneja o extraordinário.

Tenha-se presente que, a rigor, a interposição isolada de um só desses recursos excepcionais encontrará óbice no aspecto do interesse recursal, de vez que a presença de outro fundamento (não atacado) que por si só autoriza a manutenção da decisão faz com que o acórdão transite em julgado ${ }^{369}$.

Como se vê, a noção de eventualidade presente na interposição conjunta de recurso especial e extraordinário não se erige como uma singela possibilidade. Trata-se, em verdade, de uma imposição do sistema recursal brasileiro ${ }^{370}$.

(vi) denunciação da lide: especialmente a denunciação pelo autor

Os estudiosos lecionam que a denunciação da lide "é a ação incidental proposta por uma das partes (da ação principal) via de regra contra terceiro, visando aquela a condenação deste à reparação do prejuízo decorrente de sua eventual derrota na causa, seja pela perda da coisa (evicção), seja pela perda de sua posse direta, seja por lhe assistir direito regressivo previsto em lei ou em contrato (relação jurídica de garantia) ${ }^{\text {} 371}$.

Depreende-se dessa lição que o julgamento da causa principal condiciona, de certo modo, a apreciação da denunciação da lide. Apenas na contingência de haver "derrota" do

\footnotetext{
${ }^{369}$ MANCUSO, Rodolfo de Camargo. Recurso extraordinário e recurso especial. 10. ed. São Paulo: RT, 2007, p. 383-384.

${ }^{370}$ A propósito, confiram-se os verbetes 283 e 126, das Súmulas do STF e do STJ, respectivamente.

${ }^{371}$ SANCHES, Sidney. Denunciação da lide no direito processual civil brasileiro. São Paulo: RT, 1984. p. 31 (grifou-se). Sob a égide do CPC de 1939, prestigiosa doutrina averbou que o antigo chamamento à autoria ostentava natureza de "procedimento incidente" e não de "ação do garantido contra o garante" (ARAÚJO CINTRA, Antonio Carlos. Do chamamento à autoria: denunciação da lide. São Paulo: RT, 1973, p. 111 e 113). Contudo, na vigência do CPC de 1973, o autor por último citado reconheceu que "a denunciação da lide importará, no regime do nôvo Código de Processo Civil, na propositura de uma eventual demanda de regresso, condicionada ao sucumbimento na ação principal" (id, p. 174-175).
} 
denunciante na ação principal é que se passa à análise da chamada lide secundária, que pode, de seu turno, ser julgada procedente ou improcedente ${ }^{372}$.

Para enunciação do que se quer evidenciar, advertindo-se uma vez mais que o objetivo dessas considerações consiste numa singela constatação, suficiente é mostrar que a ação de garantia (denunciação) propõe-se em caráter eventual, isto é, "para o evento de o denunciante sucumbir pelo mérito em relação à causa principal. Se isso não acontecer, ela não será julgada de meritis" ${ }^{373}$.

Convém ater-se, com um pouco mais de detença, na hipótese de denunciação da lide pelo autor, porquanto tal situação pode ser assimilável a de um verdadeiro litisconsórcio eventual ${ }^{374}$, conforme se tentará demonstrar na ocasião própria (Parte III, Cap. I, infra).

Pois bem. Nos termos do art. 71, do CPC, a citação do denunciado será requerida juntamente com a do réu, se o denunciante for o autor. Significa dizer que já na petição inicial o autor veicula pretensões endereçadas a sujeitos distintos (réu e denunciado), com a peculiaridade de que a demanda aforada em face do denunciado ostenta o predicado da subsidiariedade ou da eventualidade, como anteriormente destacado.

O pedido do autor que se vincula ao denunciado vem formulado para o evento de ser improcedente, no todo ou em parte, o pedido manifestado em face do réu (da ação principal).

Convém anotar, a esse respeito, que a denunciação da lide pelo autor confere margem ao raciocínio de que não se cuida de uma verdadeira intervenção de terceiros, isto porque, como refere DinAMARCO, “o litistenunciado já ingressa no processo desde o início, tanto quanto o réu da demanda principal. A rigor, ele não intervém, ou seja, não é integrado na relação processual depois de já inteiramente formada em sua estrutura tríplice",375.

\footnotetext{
${ }^{372}$ CARNEIRO, Athos Gusmão. Intervenção de terceiros, $\mathrm{n}^{\circ}$ 42, p. 108.

${ }^{373}$ DINAMARCO, Cândido Rangel. Intervenção de terceiros, cit., nº 86, p. 168 (grifos do original). Em suas Instituições, DINAMARCO assim se expressou: "O pedido de condenação do litisdenunciado tem sempre o caráter de eventualidade, porque ele só poderá ter o direito alegado, na hipótese (ou seja, no evento) de sairse vencido no litígio relativo ao adversário comum" (vol. II, $\mathrm{n}^{\circ} 600$, p. 409 - grifos do original).

${ }^{374}$ DINAMARCO, Cândido Rangel. Instituições de direito processual civil, cit., vol. II, no 604, p. 415.

${ }^{375}$ Id., ibid.
} 
Compreende-se facilmente, portanto, que nos quadrantes da denunciação da lide evidencia-se sobremaneira a noção de eventualidade e que, de outra parte, a hipótese de denunciação pelo autor imbrica-se nitidamente com a formação de um litisconsórcio eventual entre o réu e o denunciado. Daí a acentuada significação dessas premissas para o desenvolvimento do estudo aqui delineado.

(vii) princípio da eventualidade e a contestação

Conquanto não se desconheçam as várias emanações do princípio da eventualidade, muito bem remarcadas por autorizada doutrina ${ }^{376}$, quer-se laborar, de momento, com apenas um de seus aspectos, mais precisamente o atinente à concentração da defesa do réu na contestação.

A partir da dicção dos arts. 300 e 303, do Código de Processo Civil, pode-se afirmar que o sistema brasileiro adota o princípio da eventualidade no que pertine à resposta do réu por meio de contestação. Com efeito, toda a matéria de defesa que estiver ao alcance do demandado deve ser exposta na contestação, isto porque, em regra, não se admitem alegações outras em momento posterior ao reservado para a contestação.

Interessante que, ao se referir a "toda a matéria de defesa", o legislador acaba por permitir, num mesmo ato processual, a dedução de argumentos defensivos incompatíveis. De fato, “o princípio da eventualidade impõe ao réu o ônus de concentrar, em seu primeiro ato defensivo, todas as alegações de defesa disponíveis, ainda que incompatíveis entre si, para a eventualidade de o juiz rejeitar uma delas, quando passará à análise das demais, sob pena de preclusão"377.

Então, "como medida de previsão", diante do estado de hesitação sobre se determinada alegação será ou não acolhida, o réu tem o ônus de lançar mão de todas as possíveis matérias defensivas - ad eventum -, "para o caso de que a primeira oferecida seja rejeitada"378.

\footnotetext{
${ }^{376}$ TEIXEIRA, Guilherme Freire de Barros. O princípio da eventualidade no processo civil. São Paulo: RT, 2005, passim.

${ }^{377}$ Id., p. 246 (grifou-se).

${ }^{378}$ AMARAL SANTOS, Moacyr. Primeiras linhas de direito processual civil, cit., vol. 2 , p. 213.
} 
Evidente que o assunto da eventualidade em sede de contestação experimenta atenuações relevantes $^{379}$, mas o que importa para o presente estudo é deixar evidenciada (constatada) a regra geral acima exposta.

(viii) à guisa de conclusão parcial

Como facilmente se extrai dos raciocínios acima desenvolvidos, tem-se que o direito processual civil convive com o fator da dúvida e, presente essa realidade inarredável, o próprio sistema processual engendra soluções aptas a conferir harmonia ao desenvolvimento da trama processual, até porque as situações objetivamente duvidosas não poderiam desaguar na impossibilidade de atingimento dos resultados programados para o processo. Semelhantemente, acham-se espraiadas pelas diversas ramificações do direito processual civil as hipóteses em que se trabalha com a noção de eventualidade; lida-se, em situações frequentes, com a ideia de que, para o evento de se dar alguma situação juridicamente apreciável, adota-se esta ou aquela postura processual.

Ora, se para as situações genuinamente processuais conotadas com a dúvida e com a eventualidade são formuladas soluções sistemáticas à luz das quais se supera aquele estado titubeante, com superioridade de razões será necessário encontrar esquemas de solução processual capazes de, sistematicamente, resolver estados de dúvida emergentes da relação de direito material. A essas possíveis necessidades advindas da conformação do direito material ater-se-á no momento próprio (Cap. III, infra).

De seguida, convém analisar certos aspectos da cumulação de pedidos que também servirão de sustentáculo para a elaboração conceitual e também para a construção do regime jurídico do litisconsórcio eventual, alternativo e sucessivo.

${ }^{379}$ Para aprofundamentos nesse tema, sugere-se a obra já referida de GUILHERME F. DE B. TEIXEIRA. 


\section{Capítulo II}

\section{CUMULAÇÃO DE PEDIDOS}

\section{Noções gerais e modalidades}

O direito de provocar a atuação jurisdicional para solução de uma crise jurídica (direito de ação) exercita-se pela propositura da demanda ${ }^{380}$, que é o ato de iniciativa processual por meio do qual a parte deduz uma pretensão perante o órgão jurisdicional ${ }^{381}$.

Ao lado das partes e da causa de pedir, o pedido configura um dos elementos constitutivos (ou identificadores) da demanda ${ }^{382}$, à luz do qual se tem a exata noção da natureza do provimento jurisdicional almejado (pedido imediato) e do concreto bem da vida que se quer conseguir mediante a atuação jurisdicional (pedido mediato) ${ }^{383}$.

$\mathrm{Na}$ generalidade dos casos, a demanda exterioriza-se mediante uma estrutura mínima consubstanciada num único pedido, hipótese que a doutrina qualifica como sendo pedido unitário ${ }^{384}$ fixo $^{385}$ ou simples ${ }^{386}$. É o que ocorre se o autor da demanda postula a restituição de um bem dado em comodato.

\footnotetext{
${ }^{380}$ Sobre o real significado da expressão demanda, confira-se DINAMARCO, Cândido Rangel. Vocabulário do processo civil. São Paulo: Malheiros, 2009, p. 114-118.

${ }^{381}$ DINAMARCO, Cândido Rangel. Instituições de direito processual civil, cit., vol. I, no 113 p. 307. Sendo assim, a petição inicial apresenta-se como "a instrumentalização física da demanda" (Id., vol. III, n 989, p. $362)$.

${ }^{382}$ Id., vol. II, n ${ }^{\circ} 436$, p. 116.

${ }^{383}$ AMARAL SANTOS, Moacyr. Primeiras linhas de direito processual civil, cit., vol. 2, p. 156; LOPES DA COSTA, Alfredo de Araújo. Direito processual civil brasileiro, cit., vol. II, p. 324-325.

${ }^{384}$ CARVAlHO, Milton Paulo de. Do pedido no processo civil. Porto Alegre: Sergio Antonio Fabris Editor/FIEO, 1992, p. 104.

${ }^{385}$ BARBOSA MOREIRA, José Carlos. O novo processo civil brasileiro, cit., p. 13; ALBERTO DOS REIS, José. Comentário ao Código de Processo Civil. Coimbra: Coimbra Editora, 1946, vol. 3, p. 126.

${ }^{386}$ CRUZ E TUCCI, José Rogério. Reflexões sobre a cumulação subsidiária de pedidos. Revista dos Tribunais, vol. 786, p. 58.
} 
Contudo, em homenagem ao princípio da economia processual e valorizando a noção de harmonia de julgados ${ }^{387}$, o sistema processual engendra a faculdade de serem cumuladas, no mesmo processo, várias demandas, donde vem a consequência de que se terá, nesses casos, pedidos múltiplos ${ }^{388}$.

Importa observar que o aspecto do cúmulo de demandas aqui versado diz com a multiplicidade de pretensões. Embora a multiplicidade de partes na demanda (cumulação subjetiva) também possa desencadear, em certos casos, o cúmulo de demandas, não é esse o enfoque de que se ocupa no atual estágio do trabalho ${ }^{389}$.

A cumulação objetiva de demandas, na perspectiva mais reduzida da multiplicidade de pedidos, pode ser inicial ou superveniente: na primeira hipótese o autor, já com a petição inicial, instaura um processo com pretensões múltiplas, enquanto que na segunda situação o cúmulo exterioriza-se em fase intermediária do iter procedimental, como se dá nos casos de ação declaratória incidental, reconvenção, denunciação da lide pelo réu ${ }^{390}$ ou, como sinaliza autorizada doutrina espanhola, pela reunião de processos que tramitam em separado ${ }^{391}$.

${ }^{387}$ Esses dois valores nem sempre se apresentam, para fundamentar a cumulação objetiva de demandas, em simetria de incidência, isto porque na cumulação simples prepondera o valor economia processual, ao passo que na cumulação sucessiva a harmonia de julgamentos é que se tem como ponto saliente na justificação do cúmulo [ARMENTA DEU, Teresa. La acumulación de autos (reunión de procesos conexos). Madrid: Montecorvo, 1983, p. 48 et seq.]. ARRUDA ALVIM ainda refere que a cumulação de pretensões inspira-se no princípio dispositivo, pois ao autor é dada, segundo seu interesse, a liberdade de cumular ou não pedidos (Manual de direito processual civil, cit., vol. 1, p. 414). Há quem divise, ainda nesse campo, a incidência dos princípios da pacificação social, da integridade da ordem jurídica e da efetividade do processo (TJÄDER, Ricardo Luiz da Costa. Cumulação eventual de pedidos: art. 289 do CPC sem segredos. Porto Alegre: Livraria do Advogado, 1998, p. 43-45).

388 TJÄDER, Ricardo Luiz da Costa. Op. cit., p. 33. CÂNDIDO DINAMARCO insere na noção de cúmulo objetivo de demandas as hipóteses em que haja mais de um fundamento deduzido pelo autor para lastrear sua pretensão (Instituições de direito processual civil, cit., vol. II, $\mathrm{n}^{\circ}$ 470, p. 168). Porém, a análise que aqui se empreenderá reduz-se à realidade manifesta no cúmulo de pedidos, compreendendo-se, perfeitamente, que a expressão cúmulo de demandas é bem mais abrangente do que a simples multiplicidade de pedidos.

${ }^{389}$ Sobre o litisconsórcio, cfr. $\mathrm{n}^{\circ}$ 6, supra.

${ }^{390}$ NERY JUNIOR, Nelson; ANDRADE NERY, Rosa Maria de. Código de Processo Civil comentado e legislação extravagante, cit., p. 559, nota 2 ao art. 292.

${ }^{391}$ GUASP, Jaime; ARAGONESES, Pedro. Op. cit., t. I, p. 299. Esses autores distinguem a cumulação sucessiva (ou superveniente) por inserção (como se dá, v. g., na reconvenção) ou por reunião de processos (id., p. 290-291). Anote-se, todavia, que, em monografia específica sobre o tema, ARMENTA DEU esmera- 
Ainda em termos classificatórios, a doutrina distingue a cumulação homogênea da heterogênea. "Homogênea é a cumulação de pedidos feitos pela mesma parte. Heterogênea é a cumulação que ocorre no mesmo processo, mas com ações ajuizadas por partes

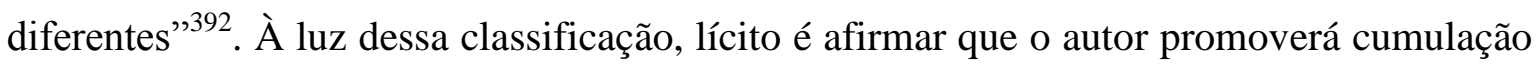
homogênea quando, v. g., deduzir pedido único na petição inicial e, além disso, propuser, no mesmo processo, a chamada ação declaratória incidental. Por outro lado, estar-se-á diante de cumulação heterogênea quando ao pedido do autor somar-se, por exemplo, o pedido incoado pelo réu no âmbito de reconvenção.

A modalidade de cumulação que interessa para o desenvolvimento desta pesquisa é a inicial e homogênea, tal como regrada nos artigos 289 e 292, caput, ambos do Código de Processo Civil ${ }^{393-394}$.

Dada a variedade de situações abarcadas pela cumulação de pedidos, a doutrina concebe a existência de cumulação própria (ou em sentido estrito) e imprópria (ou em sentido amplo) de pedidos ${ }^{395}$. Na primeira espécie tem-se a formulação de mais de um

se em distinguir a acumulación de autos - que pressupõe a conexão - da acumulación de acciones - que exige apenas compatibilidade entre os vários pedidos (op. cit., p. 44-47).

392 NERY JUNIOR, Nelson; ANDRADE NERY, Rosa Maria de. Código de Processo Civil comentado e legislação extravagante, cit., p. 559, nota 3 ao art. 292.

393 Aqui não se fez referência ao art. 288, do CPC, porquanto tal dispositivo não diz respeito propriamente à cumulação alternativa de pedidos, mas sim a "um pedido único, pedido simples, mas formulado alternativamente, por força de ser alternativa a obrigação que lhe serve de fundamento" (CALMON DE PASSOS, J. J. Comentários ao Código de Processo Civil. 8. ed. Rio de Janeiro: Forense, 1998. vol. III, p. 189). Essa também parece ser a orientação externada por ARAKEN DE ASSIS na obra Cumulação de ações, onde o autor tratou do "pedido alternativo" (no singular), ex vi do art. 288, do CPC (n 70.3, p. 245), fora do espaço reservado às "espécies de cumulação de pedidos" (§ 21, no 72 et seq., p. 252 em diante), com menção expressa à lição, acima transcrita, de CALMON DE PASSOS. De sua parte, BARBOSA MOREIRA arremata que o art. 288 abarca as hipóteses de obrigação com prestações alternativas e de obrigação com prestações facultativas, de sorte que, em verdade, "só impropriamente pode ser considerada modalidade de cumulação de pedidos, pois a pluralidade que nela existe não é de pedidos, mas de objetos (mediatos) do pedido" (O novo processo civil brasileiro, cit., p. 13 e 15).

${ }^{394}$ A redação dos dispositivos mencionados é a seguinte: Art. 289: "É lícito formular mais de um pedido em ordem sucessiva, a fim de que o juiz conheça do posterior, em não podendo acolher o anterior”; Art. 292, caput: "É permitida a cumulação, num único processo, contra o mesmo réu, de vários pedidos, ainda que entre eles não haja conexão".

395 ASSIS, Araken de. Cumulação de ações, cit., p. 253, com ampla referência sobre outras classificações adotadas por autores nacionais e estrangeiros. BARBOSA MOREIRA também se vale das expressões 
pedido, com a intenção de que todos eles sejam atendidos, ou seja, acolhidos; aqui se verifica simultaneidade ou multiplicidade de pretensões ${ }^{396}$. Diversamente, na segunda modalidade (cumulação imprópria), deduz-se mais de um pedido, mas desde logo se espera que apenas um ou alguns deles sejam acolhidos pelo julgador; significa dizer que a cumulação imprópria traz embutida a noção de que o acolhimento de um pedido excluirá, inexoravelmente, a apreciação do outro ou outros; nessa hipótese constata-se singularidade de pretensão ${ }^{397}$.

Bem por isso é que a cumulação própria distingue-se pela existência da aditiva " $e$ ", ao passo que a cumulação imprópria caracteriza-se pela disjuntiva "ou” e, em certos casos, pela condicional " $s e$ "398.

A cumulação em sentido estrito (própria) pode ainda desdobrar-se em simples ou sucessiva ${ }^{399}$. Ocorrerá a primeira quando os vários pedidos cumulados apresentarem-se independentes entre si, de sorte que a decisão acerca de um não influirá no julgamento $\operatorname{do}(\mathrm{s})$ outro(s).

Conforme esclarece CALMON DE PASsOS, na cumulação simples "os pedidos nada têm de comum entre si, a não ser os sujeitos", razão pela qual poderiam "ser formulados em processos autônomos, sem qualquer prejuízo, salvo maior dispêndio de tempo e de dinheiro". Daí que - conclui o autor - o julgador "poderá acolher todos, ou rejeitar a todos, como por igual acolher algum e rejeitar outros" $" 400$.

Pode-se sugerir, nesse caso, o exemplo de o autor pedir a condenação do réu a lhe pagar quantia em razão de ilícito extracontratual e, ao mesmo tempo, pedir a restituição de mútuo $^{401}$.

“cumulação em sentido estrito" e "cumulação em sentido amplo" ( $O$ novo processo civil brasileiro, cit., p. 14) para designar o que a maioria dos doutrinadores indica, respectivamente, como cumulação própria e imprópria de pedidos.

${ }^{396}$ ALBERTO DOS REIS, José. Op. cit., $3^{\circ}$ vol, p. 144; CRUZ E TUCCI, José Rogério. Reflexões sobre a cumulação subsidiária de pedidos, cit., p. 59.

397 ALBERTO DOS REIS, José. Op. cit., p. 144; CRUZ E TUCCI, José Rogério. Reflexões sobre a cumulação subsidiária de pedidos, cit., p. 59.

${ }^{398}$ CARVALHO, Milton Paulo de. Op. cit., p. 105-107.

399 ASSIS, Araken de. Cumulação de ações, cit., p. 253.

${ }^{400}$ Comentários ao Código de Processo Civil, cit., vol. III, p. 202.

${ }^{401}$ CARVALHO, Milton Paulo de. Op. cit., p. 106. 
Ter-se-á, de outra parte, cumulação própria sucessiva quando os vários pedidos cumulados mantiverem vínculo de dependência entre si, hipótese em que o acolhimento de um ou mais pedidos condiciona o acolhimento de outro(s). "Concebe-se o autor formular um segundo pedido que, em relação ao primeiro, dependa da sua procedência. Ele pede o acolhimento dos dois pedidos; apenas o último, em virtude do seu caráter de dependência, decorre do êxito do primeiro" 402 .

Conquanto o legislador não explicite essa modalidade de cumulação, nenhuma dúvida paira sobre a admissibilidade desse cúmulo de demandas, podendo-se figurar, para a espécie, o clássico exemplo da investigação de paternidade cumulada com petição de herança $^{403}$.

Como facilmente se depreende dessas ideias, a cumulação sucessiva de pedidos constitui um dos variados aspectos processuais da prejudicialidade, a qual revela, "em sua essência, uma prioridade lògicamente necessária na solução de determinadas questões, em razão do condicionamento que daí resulta para a de outras e que se refletirá especìficamente no sentido em que essas outras hão de ser, por sua vez, resolvidas" ${ }^{404}$. Em

402 ASSIS, Araken de. Cumulação de ações, cit., p. 255-256. Para essa mesma realidade, encontra-se na doutrina espanhola a designação acumulação eventual em sentido impróprio (PRIETO-CASTRO Y FERRÁNDIZ, Leonardo. Derecho procesal civil. 2. ed. Madrid: Tecnos, 1974. vol. $1^{\text {o }}$, p. 101).

${ }^{403}$ BARBOSA MOREIRA, José Carlos. O novo processo civil brasileiro, cit., p. 15.

${ }^{404}$ BARBOSA MOREIRA, José Carlos. Questões prejudiciais e coisa julgada. Rio de Janeiro: Borsoi, 1967, p. 41-42. THEREZA ALVIM refere que prejudicial é "aquela questão que deve, lógica e necessariamente, ser decidida antes de outra, sendo que sua decisão influenciará o próprio teor da questão vinculada" (Questões prévias e os limites objetivos da coisa julgada. São Paulo: RT, 1977, p. 24). Além dos caracteres da antecedência lógica e da necessariedade, SCARANCE FERNANDES acrescenta a nota da autonomia, em ordem a se admitir que a prejudicial, analisada em si mesma, "tem aptidão para ser objeto de processo autônomo" (Prejudicialidade: conceito, natureza jurídica, espécies de prejudiciais. São Paulo: RT, 1988, p. 52). A essa última lição não se pode emprestar adesão, porquanto a autonomia (aptidão da questão prejudicial para ensejar ação autônoma) não configura característica presente em todos os casos de prejudicialidade. Sobre tal nuance, THEREZA ALVIM, com acerto, destaca: “Ainda, vejamos que poderemos estar diante de uma questão que seja prejudicial, em relação a outra, processual, por exemplo, a qual, por sua vez, não pode ser objeto de causa autônoma, e, nem de declaratória incidental, em nosso atual direito positivo. Assim, em tendo o autor usado do procedimento sumaríssimo, poderá o réu objetar quanto ao valor da causa (porque, exemplificativamente, tem interesse em entrar com reconvenção). Essa questão de valor será em relação à questão do tipo de procedimento, prejudicial, enquanto a questão do procedimento será preliminar do julgamento de mérito. E, afirmamos que esse exemplo, como outros que poderiam ser aqui elencados, se 
outras palavras, do vínculo de prejudicialidade resulta que a questão subordinada depende da solução da questão subordinante não no seu ser, "mas no seu modo de ser"

Logo, à semelhança do se dá na cumulação simples, os pedidos aqui são somados e o desejo do autor, ao propô-los cumulativamente, diz com a satisfação de todos, com a peculiaridade da já mencionada sucessividade, "inerente à prejudicialidade" 406 .

Bem é de ver, nessas condições, que o pronunciamento judicial acerca do pedido subordinante ditará, em certa medida, o conteúdo da decisão respeitante ao pedido subordinado. Diz-se "em certa medida" porque o acolhimento do pedido subordinante nem sempre redundará na automática procedência do pedido subordinado. Para se chegar a tal conclusão basta pensar no também clássico exemplo da investigação de paternidade cumulada com alimentos. É evidente que a procedência do pedido relativo à investigação de paternidade influencia o conteúdo da decisão sobre a pensão alimentícia, mas não se pode perder de vista que outras circunstâncias - ditadas pelo direito material - poderão ensejar o desacolhimento do pedido sobre os alimentos: imagine-se que o pai (assim reconhecido na investigação de paternidade) seja inválido para o trabalho ou, por outro motivo, não tenha condições de suportar o encargo financeiro da pensão alimentícia. Nessas condições, ter-se-á a procedência do pedido subordinante (investigação de paternidade) e a improcedência do pedido subordinado (alimentos) ${ }^{407}$.

refere a questão prejudicial, pois influencia o teor da decisão que lhe está subordinada, mas não podem constituir objeto de ação autônoma" (id., p. 21-22).

405 BARBOSA MOREIRA, José Carlos. Questões prejudiciais e questões preliminares. In: Direito processual civil: ensaios e pareceres. Rio de Janeiro: Borsoi, 1971, p. 83.

${ }^{406}$ DINAMARCO, Cândido Rangel. Instituições de direito processual civil, cit., vol. II, no 473, p. 172-173. Cfr. também BARBOSA MOREIRA. Ações cumuladas. Necessidade de julgamento explícito de todas. In: Temas de direito processual, segunda série. São Paulo: Saraiva, 1980, p. 134.

${ }^{407}$ DINAMARCO, Cândido Rangel. Instituições de direito processual civil, cit., vol. II, no 473, p. 173. Daí a utilidade da distinção visualizada por BARBOSA MOREIRA entre a prejudicialidade total ou plena e a prejudicialidade parcial (Questões prejudiciais e coisa julgada, cit., p. 57-58). Versando o tema da conexão por prejudicialidade, OLIVEIRA NETO professa: "Nesse passo, a conexão por prejudicialidade pode ser total ou parcial, conforme a extensão em que a decisão da primeira causa prejudicar a da segunda. Na conexão por prejudicialidade total uma causa afeta a outra completamente, inexistindo qualquer aspecto que reste preservado. (...) Por seu turno, quando a conexão por prejudicialidade é parcial, apenas determinado ato processual ou parte da causa é atingida, restando matéria para conhecimento ou ordenamento sem sofrer influência" (Conexão por prejudicialidade. São Paulo: RT, 1994, p. 87). 
Noutro aspecto, encontra-se em doutrina a preleção segundo a qual a improcedência do pedido prejudicial ou subordinante implicaria a "carência de ação" em relação ao pedido subordinado ou prejudicado ${ }^{408}$.

Não nos parece adequado semelhante entendimento. Crê-se ter ficado assentado que, na cumulação sucessiva, o vínculo que se estabelece entre os pedidos subordinante e subordinado configura prejudicialidade. Disso deriva que não se trata de o primeiro pronunciamento (de rejeição) redundar na exclusão da apreciação do segundo pedido (“carência de ação"). Não! O que se verifica é que a improcedência do pedido subordinante influencia o conteúdo do próprio julgamento do subordinado.

Insiste-se nessa noção: na cumulação sucessiva de pedidos tem-se vínculo de prejudicialidade, de sorte que o equacionamento dessa questão não pode ser pensado como se estivesse em presença de preliminar ao conhecimento do mérito ${ }^{409}$. Por isso é que a análise do pedido subordinante não tem o efeito de impor ou de excluir a análise do pedido subordinado; em verdade, presente a prejudicialidade, o pronunciamento sobre o pedido subordinante influencia o teor (o modo de ser) do julgamento do subordinado.

De outra parte, existe ainda - como já explicitado - a chamada cumulação imprópria de pedidos, que se divide em duas modalidades: (i) cumulação alternativa; (ii) cumulação eventual ou subsidiária.

Na dicção do art. 288, caput, do CPC, o pedido será alternativo quando, pela natureza da obrigação, o devedor puder cumprir a prestação de mais de um modo. Põe-se em causa, pois, o instituto das obrigações alternativas, tal qual regulado pelos arts. $252 \mathrm{e}$ seguintes, do Código Civil.

AlbERTO DOS REIS, em comentário a dispositivo muito semelhante ao acima aludido, enfatizou que o pedido alternativo "pressupõe uma obrigação alternativa"410. Contudo, entre nós, BARBOSA MOREIRA entrevê a possibilidade de aplicação do mesmo art.

\footnotetext{
${ }^{408}$ FREDERICO MARQUES, José. Instituições de direito processual civil, cit., vol. III, p. 51.

409 Como pontua SCARANCE FERNANDES, a "preliminar impede, impossibilita a decisão sobre a subordinada. A prejudicial condiciona o teor da decisão sobre a subordinada” (Op. cit., p. 51).

${ }^{410}$ Comentário ao Código de Processo Civil, cit., vol. 3, p. 127.
} 
288, do CPC, para além das hipóteses de obrigação alternativa, nos casos de obrigações com prestação facultativa ou com faculdade de substituição ${ }^{411}$.

Para tais casos cumpre analisar a quem toca o direito de escolher esta ou aquela prestação. Se ao autor da demanda (sedizente credor) competir a escolha, a petição inicial já pode exteriorizar um pedido fixo, pondo-se em claro, desde logo, a preferência do autor por um determinado modo de cumprimento da obrigação alternativa. Note-se que essa é uma prerrogativa do credor quando a ele compete a escolha, de sorte que não haverá qualquer irregularidade caso o autor, mesmo assim, deduza pedido alternativo, hipótese em que terá havido renúncia ao seu direito de escolher, facultando-se ao réu, portanto, optar por uma ou outra forma de cumprir a obrigação ${ }^{412}$. Essa renúncia, advirta-se, só se terá por aperfeiçoada caso o autor não faça ressalva quanto ao interesse em diferir a indicação para a fase de execução (CPC, art. 571, $\S 2^{\circ}$ ), conforme se tem admitido ${ }^{413}$.

Sendo do réu, conforme presume a lei civil (CC, art. 252), a prerrogativa da escolha, ao autor não se autoriza que formule pedido fixo e, mesmo que assim o faça, o juiz assegurará àquele o direito de cumprir a prestação de um ou de outro modo, nos termos do que prevê o parágrafo único do art. 288 do CPC. Trata-se de hipótese que excepciona o princípio da correlação ou da congruência entre o pedido e a sentença ${ }^{414}$.

\footnotetext{
${ }^{411}$ O novo processo civil brasileiro, cit., p. 13. Obrigação facultativa, no dizer de BARROS MONTEIRO, "é aquela que não tendo por objeto senão uma só prestação, confere ao devedor a faculdade de substituí-la por outra" (Curso de direito civil. 28. ed. São Paulo: Saraiva, 1995, vol. 4, p. 125, onde se vê ampla explicação da matéria, com ênfase na distinção entre as obrigações alternativas e as facultativas). VON TUHR também refere que "en las obligaciones con facultad alternativa sólo una prestación (la prestación principal) es la adeudada, si bien se autoriza al deudor o al acreedor para que en lugar de ella entregue o reclame otra, en concepto supletorio" (Tratado de las obligaciones. Trad. esp. W. Roces. Madrid: REUS, 1999. t. I, p. 56). Entre os processualistas, ARAKEN DE ASSIS fornece exemplo de obrigação com faculdade de substituição (facultas alternativa): "Basta imaginar alguém, em compromisso de compra e venda, depois de pagar o sinal, se obrigando à sub-rogação na dívida hipotecária do proprietário do imóvel. Nada impede, neste caso, que o obrigado pague ao credor hipotecário, liberando o imóvel, e, assim, prestando de modo diverso e irrefutável a obrigação" (Cumulação de ações, cit., p. 245-246).

412 CALMON DE PASSOS, J. J. Comentários ao Código de Processo Civil, cit., vol. III, p. 191; PONTES DE MIRANDA. Comentários ao Código de Processo Civil, cit., t. IV, p. 59.

413 ASSIS, Araken de. Cumulação de ações, cit., p. 246; BARBOSA MOREIRA, José Carlos. O novo processo civil brasileiro, cit., p. 13.

${ }^{414}$ BARBOSA MOREIRA, José Carlos. O novo processo civil brasileiro, cit., p. 13.
} 
Contudo, ainda sob a luz do parágrafo único do art. 288 do CPC, a doutrina adverte que incumbe ao réu, ao oferecer resposta à demanda fixa formulada pelo autor, vindicar a sua prerrogativa de escolher, pois que, se assim não fizer, ao juiz não será dado aplicar, de ofício, a regra acima aludida ${ }^{415}$. Assim se dá porque, tal como o credor pode dispor do seu direito de escolha, o devedor pode comportar-se de semelhante modo, "sem que contra isso possa o juiz insurgir-se" ${ }^{416}$.

Questão mais delicada advém da circunstância de o réu, na hipótese acima figurada, portar-se como revel, isto é, deixar de apresentar contestação. Argumenta-se que a revelia não desnatura a obrigação, que persiste com a nota da alternatividade, de modo que a presunção de veracidade que incide sobre fatos não tem o efeito de alterar a configuração jurídica do instituto em apreço. De conseguinte, o juiz deve, mesmo diante da revelia, deferir ao réu o direito de escolha, mesmo que o autor tenha lançado pedido fixo quando deveria tê-lo feito em forma alternativa ${ }^{417}$.

Pode-se objetar, porém, que a necessidade de se manter coerência com o que se expôs acima, quando se tratou da hipótese em que o réu contesta e não argumenta com a sua prerrogativa de escolha, enseja uma formulação diversa daquela apregoada pela doutrina que se vem de citar.

Com efeito, não existe diferença substancial entre $(a)$ a situação do réu que contesta, mas não alega a sua posição jurídica de poder manifestar a opção entre as várias maneiras de cumprir a obrigação alternativa, e $(b)$ aquela em que o réu simplesmente deixa de contestar. Nas duas hipóteses verifica-se um dado fixo: a ausência de manifestação sobre aquele ponto específico da escolha dentre as alternativas.

\footnotetext{
415 A lição é de ALBERTO DOS REIS (Comentário ao Código de Processo Civil, cit., vol. 3, p. 130), aplicável sem reservas ao direito brasileiro, consoante aplauso manifestado por CALMON DE PASSOS (Comentários ao Código de Processo Civil, cit., p. 192). Eis a ponderação do autor lusitano: “Quando o devedor não faça valer o seu direito de escolha, não pode, a nosso ver, o tribunal substituir-se-lhe. Estamos na esfera de direito disponíveis; não é lícito ao juiz sobrepor-se à vontade das partes e suscitar ex officio uma faculdade de que o respectivo titular não quis fazer uso" (p. 130).

416 CALMON DE PASSOS, J. J. Comentários ao Código de Processo Civil, cit., vol. III, p. 192. Assim também PONTES DE MIRANDA (Comentários ao Código de Processo Civil, cit., t. IV, p. 59).

417 CALMON DE PASSOS, J. J. Comentários ao Código de Processo Civil, cit., p. 192; PONTES DE MIRANDA. Comentários ao Código de Processo Civil, cit., t. IV, p. 54. ARAKEN DE ASSIS, sem explicar o motivo, adere a essa orientação (Cumulação de ações, cit., p. 246).
} 
Tanto numa como noutra, a ausência de manifestação do réu não terá mesmo o efeito de desnaturar a obrigação que, na essência, persiste alternativa. Ocorrerá, pura e simplesmente, uma alteração do sujeito titular da prerrogativa da escolha. Implica dizer que o réu, deixando de oferecer resposta ao pedido fixo formulado pelo autor, na hipótese em que correto teria sido a formulação de pedido alternativo, despoja-se de sua prerrogativa de escolha, devolvendo-a, pois, ao autor da demanda. Diante desse cenário não poderá o juiz, ex officio, aplicar a regra hospedada no parágrafo único do art. 288 do CPC.

Essa interpretação - que se reputa mais adequada - vai ao encontro da diretriz fixada pela legislação no campo da execução das obrigações alternativas, ex vi do art. 571, $\S 1^{\circ}$, do CPC, consoante o qual se devolverá ao credor a opção, se o devedor não a exercitou no prazo marcado.

De outra parte, apregoa-se, a partir de uma análise isolada do art. 288, do CPC, que aí não se verifica propriamente uma pluralidade de pedidos, mas sim de pluralidade de objetos mediatos do pedido ${ }^{418}$. Daí a advertência de CALMON DE PASSOS, para quem o dispositivo citado versa sobre "pedido único, pedido simples, mas formulado alternativamente, por força de ser alternativa a obrigação que lhe serve de fundamento"419. Também PONTES DE MiRANDA reconheceu que na "espécie que é assunto do art. 288, não há acumulatividade de pedidos (art. 292), nem a complexidade da prestação (x mais y mais z), que não permite qualquer alternatividade" ${ }^{\text {,420. }}$.

Contudo, parece válido acrescentar, mediante operação ampliativa, a admissão da cumulação de pedidos alternativos fora do caso especificamente regrado pelo art. 288, porquanto o preenchimento dos requisitos do art. 292, do CPC, constitui fator suficiente também para esse tipo de cumulação. Essa visão ampliativa descende da constatação de que "a faculdade de cumular é também uma projeção da garantia da ação e da ampla liberdade constitucionalmente assegurada aos litigantes" ${ }^{\circ 21}$.

\footnotetext{
${ }^{418}$ BARBOSA MOREIRA, José Carlos. O novo processo civil brasileiro, cit., p. 15.

${ }^{419}$ Comentários ao Código de Processo Civil, cit., vol. III, p. 189. Assim também preleciona ARAKEN DE ASSIS: "Inexiste cúmulo de ações no pedido alternativo. O direito subjetivo se revela único, e se satisfaz, por igual, com apenas uma prestação" (Cumulação de ações, cit., p. 246).

${ }^{420}$ Comentários ao Código de Processo Civil, cit., t. IV, p. 59.

${ }^{421}$ DINAMARCO, Cândido Rangel. Instituições de direito processual civil, cit., vol. II, nº 474, p. 175.
} 
Coerentemente como tal enunciado, admite-se não só a construção de pedido alternativo (no singular), tratado especificamente pelo art. 288, do CPC, como também a de pedidos alternativos (no plural), para o que seria de se invocar a norma hospedada no art. 292, do $\mathrm{CPC}^{422}$.

Assim, por esse viés mais amplo, pode-se dizer que a cumulação alternativa consiste na "reunião de dois ou mais pedidos em uma só iniciativa processual, com a intenção de que apenas um deles seja acolhido, ficando excluído o acolhimento do outro" $" 423$.

Interessante observar que o acolhimento de um dos pedidos alternativos implica o não conhecimento dos demais. Em palavras outras: uma vez acolhido um dos pedidos, o(s) outro(s) fica(m) prejudicado(s), de sorte que o mérito deste(s) sequer é apreciado.

O que se deve pôr em destaque, ademais, nessa específica modalidade de cumulação, é que ao autor apresenta-se indiferente alcançar um resultado jurídico ou outro $^{424}$. Neste caso, o autor não manifesta preferência por este ou por aquele pedido. Daí a consequente liberdade para o julgador acolher qualquer deles, consoante lhe pareça mais consentâneo à justiça do caso concreto, em ordem a se concluir que o acolhimento de um dos pedidos é o quanto basta para que se tenha por julgada procedente a demanda em sua inteireza $^{425}$.

Realidade distinta observa-se na cumulação eventual ou subsidiária de pedidos, uma vez que nessa modalidade, conquanto formulados mais de um pedido, há uma escolha, uma preferência manifestada pelo autor ao construir a petição inicial. Delineia-se a cumulação eventual quando o demandante formula mais de um pedido em sequência, sem almejar que todos sejam acolhidos, a fim de que o julgador, não podendo albergar o pedido primário, aprecie os demais pedidos que se sucederem àquele ${ }^{426}$.

Como reforça CRUZ E TUCCI, patenteia-se o cúmulo subsidiário "toda vez que um pedido tiver de ser tomado em consideração na eventualidade de não proceder um pedido

\footnotetext{
${ }^{422}$ CALMON DE PASSOS, J. J. Comentários ao Código de Processo Civil, cit., vol. III, p. 190.

${ }^{423}$ DINAMARCO, Cândido Rangel. Instituições de direito processual civil, cit., vol. II, no 474, p. 174-175.

${ }^{424} I d ., \mathrm{n}^{\circ} 474$, p. 175.

${ }^{425} I d ., \mathrm{n}^{\circ} 474$, p. $175-176$.

${ }^{426}$ TJÄDER, Ricardo Luiz da Costa. Op. cit., p. 36.
} 
antecedente"427. A expressão "na eventualidade de" desnuda a ideia de que entre os pedidos cumulados interpõe-se a condicional "se" 428 .

Autores há que analisam essa modalidade de cumulação pelo ângulo da alternatividade. Tratar-se-ia, como refere CÂNDIDO DINAMARCO, de uma alternatividade adjetivada de eventual $^{429}$; ou de uma cumulação alternativa por subsidiariedade, como pareceu a CALMON DE PASSOS ${ }^{430}$; para FREDERICO MARQUES, os pedidos subsidiários constituem espécie de pedidos alternativos ${ }^{431}$.

Contudo, em Alberto dos ReIs lê-se que os pedidos subsidiários apenas se apresentam sob a forma ou sob a veste da alternatividade ${ }^{432}$, sem que isso redunde baralhamento das noções de cumulação alternativa e de cumulação subsidiária. O que se tem de comum nessas modalidades de cumulação é que se pede uma coisa ou outra, mas no campo da cumulação subsidiária essa alternatividade revela-se apenas na aparência e não na realidade ${ }^{433}$.

Por isso se tem verberado que a forma mais correta para expressar a cumulação subsidiária dá-se pelo emprego da adversativa "mas"434.

Para o desenvolvimento deste trabalho - até por conta da nomenclatura que se pretende empregar para delimitação das modalidades de litisconsórcio aqui estudadas convém encampar a terminologia tradicional, que procura não agregar à designação da cumulação subsidiária um aspecto (alternatividade) meramente formal ou aparente.

\footnotetext{
${ }^{427}$ Reflexões sobre a cumulação subsidiária de pedidos, cit., p. 59. O mesmo autor sublinha que, de regra, não há qualquer preponderância de natureza substantiva entre os pedidos (primário e subsidiário), porquanto ao demandante abre-se a oportunidade para ordená-los segundo seu alvedrio (id., p. 60). ARAKEN DE ASSIS também propaga a inexistência de regra a estabelecer a ordem dos pedidos, visto que o fator determinante dessa ordem está no interesse do autor (Cumulação de ações, cit., p. 259).

${ }^{428}$ CARVALHO, Milton Paulo de. Op. cit., p. 109.

${ }^{429}$ Instituições de direito processual civil, cit., $\mathrm{n}^{\circ} 475, \mathrm{p} .176-178$.

${ }^{430}$ Comentários ao Código de Processo Civil, cit., vol. III, p. 204.

${ }^{431}$ Instituições de direito processual civil, cit., vol. III, p. 54.

${ }^{432}$ Comentário ao Código de Processo Civil, cit., vol. 3, p. 137.

433 ALBERTO DOS REIS, José. Comentário ao Código de Processo Civil, cit., vol. 3, p. 137.

434 "Pede-se a declaração de nulidade do contrato por simulação, mas, se se entender que o contrato não foi simulado, pede-se que se rescinda por ter sido celebrado em prejuízo do autor, credor dum dos outorgantes; pede-se que se reconheça ao autor o direito de propriedade, mas, se não puder atribuir-se-lhe êsse direito, pede-se, ao menos, que se lhe reconheça o direito de servidão" (Id., p. 138).
} 
Daí a preferência pelas expressões cumulação eventual ou subsidiária de pedidos, seguindo-se a trilha aberta, entre nós, por BARBOSA MOREIRA ${ }^{435}$, ARAKEN DE AsSis ${ }^{436}$ e CRUZ E TUCCI ${ }^{437}$, em conformidade com a tradicional lição de CHIOVEndA ${ }^{438}$.

A par dessa questão terminológica, impende considerar que a cumulação eventual de pedidos assume papel de importante instrumento mitigador dos efeitos rígidos da preclusão, à luz dos quais se proíbe o ingresso de novo pedido no curso do processo ${ }^{439}$, ex vi do art. 264, do $\mathrm{CPC}^{440}$.

Outro ponto assaz importante, ainda no bojo da cumulação eventual de pedidos, diz com o "estado provável de insegurança ou hesitação do demandante perante a argumentação que deverá ser desenvolvida na petição inicial" ${ }^{\prime 41}$. Esse inegável estado de dúvida que se desnuda frente à cumulação eventual de pedidos incentivou a doutrina a vislumbrar o seguinte cenário: o autor formula certa pretensão com base em determinado fundamentos, mas, porque não está seguro de que tal pedido será acolhido, deduz outra pretensão, em caráter subsidiário, "para ser considerada pelo tribunal no caso de não vingar a primeira" ${ }^{442}$.

CALMON DE PASsos também trabalhou com a noção de dúvida para explicar esse tipo de cumulação de pedidos. Registrou que a hesitação do demandante pode radicar na tipificação do suposto ou na consequência jurídica extraível desse suposto. É que, diante

\footnotetext{
${ }^{435}$ O novo processo civil brasileiro, cit., p. 13 e 15.

${ }^{436}$ Cumulação de ações, cit., p. 257.

${ }^{437}$ Reflexões sobre a cumulação subsidiária de pedidos, cit., passim. Em sentido parelho: CARVALHO, Milton Paulo de. Op. cit., p. 108-109; TJÄDER, Ricardo Luiz da Costa. Op. cit., passim; PONTES DE MIRANDA. Comentários ao Código de Processo Civil, cit., t. IV, p. 80.

${ }^{438}$ Instituições de direito processual civil, cit., vol. II, n 179, p. 164.

${ }^{439}$ CRUZ E TUCCI, José Rogério. Reflexões sobre a cumulação subsidiária de pedidos, cit., p. 60.

440 "Feita a citação, é defeso ao autor modificar o pedido ou a causa de pedir, sem o consentimento do réu, mantendo-se as mesmas partes, salvo as substituições permitidas por lei. Parágrafo único. A alteração do pedido ou da causa de pedir em nenhuma hipótese será permitida após o saneamento do processo". Destaquese, por oportuno, a existência de alentados estudos que identificam, embora em tom excepcional, a necessidade de mitigar a rigidez da regra que se acaba de transcrever (LEONEL, Ricardo de Barros. Causa de pedir e pedido: o direito superveniente, cit., especialmente no Cap. 5, p. 223 et seq.; CRUZ E TUCCI, José Rogério. A causa petendi no processo civil, cit., item 4.11, p. 185 et seq.).

${ }^{441}$ CRUZ E TUCCI, José Rogério. Reflexões sobre a cumulação subsidiária de pedidos, cit., p. 61.

${ }^{442}$ ALBERTO DOS REIS, José. Comentário ao Código de Processo Civil, cit., vol. 3, p. 140.
} 
de uma dada realidade fática, não surpreende que possa haver insegurança ao tipificá-la juridicamente: "será a hipótese um usufruto ou um fideicomisso?"443.

Noutros casos, como já sinalizado, a perplexidade reside não no suposto, mas sim na consequência jurídica. O citado autor figurou o exemplo em que, num contrato preliminar de compra e venda, o compromissário comprador adota certo comportamento que, à luz das cláusulas contratuais, pode dar ensejo à própria resolução do negócio, se se entender num certo sentido, ou apenas implicar a imposição de sanções pecuniárias, caso se entenda de outro modo ${ }^{444}$.

Como bem se percebe, o estado de dúvida, de insegurança, de perplexidade confere sustentação ao quanto disposto no art. 289, do CPC, à luz do qual transparece lícito formular mais de um pedido em ordem sucessiva, a fim de que o juiz conheça do posterior, em não podendo acolher o anterior. "O que acontece é a ordem de julgamentos, de modo que, dito 'não' ao pedido $a$, se pode julgar $b$, ou dito 'não' ao pedido $a$ e ao pedido $b$, cabe julgar-se $c$; e assim por diante" ${ }^{, 445}$.

\section{Requisitos de admissibilidade}

Firmadas as noções sobre as diversas modalidades com que se apresenta a cumulação de pedidos, importa identificar, doravante, os requisitos traçados pela legislação como sendo suficientes e necessários para autorizar a aludida cumulação, após o que serão analisadas algumas das variadas consequências processuais do cúmulo de pedidos.

\footnotetext{
${ }^{443}$ Comentários ao Código de Processo Civil, cit., vol. III, p. 205. Eis o exemplo do autor: "Diante da perplexidade, formulamos um pedido, associando-o ao entendimento da espécie como sendo de usufruto, que temos como a mais correta e por isso mesmo formulada prioritariamente; mas assim não parecendo ao magistrado, considerando a hipótese como pertinente a um fideicomisso, outro pedido é formulado em consonância com esse fundamento, para que seja considerado 'posteriormente', isto é, caso não tenha sido possível acolher o anterior" (id., ibid.).

${ }^{444} I d$., p. 205. A conclusão a que chega o autor é esta: "Nada impede formule o autor o pedido de rescisão, com base no entendimento que dá ao fato invocado como fundamento, cumulando a esse pedido o de condenação nas sanções pecuniárias, caso pareça ao magistrado deva prevalecer o segundo entendimento" (Id., ibid.).

${ }^{445}$ PONTES DE MIRANDA. Comentários ao Código de Processo Civil, cit., t. IV, p. 62.
} 
Em linha de princípio, as diversas modalidades de cumulação submetem-se ao crivo do art. 292, § 1' , do CPC: "São requisitos de admissibilidade da cumulação: I - que os pedidos sejam compatíveis entre si; II - que seja competente para conhecer deles o mesmo juízo; III - que seja adequado para todos os pedidos o tipo de procedimento".

Antes da análise dessa tríade de requisitos, convém lembrar que na cabeça do aludido artigo vem permitida a cumulação de pedidos, contra o mesmo réu, ainda que entre eles não haja conexão. Dessa forma, diversamente do que ocorria sob a égide do CPC de $1939^{446}$, a legislação atual dispensa a conexão, em ordem a possibilitar a cumulação mesmo perante diversidade de causa de pedir. Parece evidente que só à causa de pedir é que o artigo faz referência quando alude à conexão, pois que a conexão pelo pedido não seria mesmo de se exigir, porquanto não pode haver, logicamente, cumulação de pedidos se os pedidos forem idênticos.

De outro lado, ao exigir que a cumulação se dê "contra o mesmo réu", a lei prevê o requisito da conexão subjetiva, exsurgindo a constatação de que os pedidos plúrimos, em princípio, hão de se endereçar ao mesmo réu ${ }^{447}$. Entrementes, nada obsta que, em presença de litisconsórcio passivo, o autor deduza vários pedidos em face desses réus. Ou seja, a utilização, pela lei, da expressão no singular (réu) não afasta, em tom absoluto, a cumulação na presença da configuração plural do polo passivo da demanda ${ }^{448}$.

Para além dessa constatação, ARAKEN DE ASSIS ainda preconiza, em situação de litisconsórcio passivo, a admissibilidade de cumulação de pedidos em face de um dos vários réus. Para tanto, formula exemplo elucidativo: "pretendendo a resolução do contrato em que Pedro e Paulo figuram como obrigados, há de se conceder ao autor, também, pedir perdas e danos de Paulo, sob diverso fundamento. Este último pedido se projeta só perante Paulo, enquanto o outro em face de Paulo e Pedro"449.

${ }^{446} \mathrm{O}$ art. 155 do CPC/39 exigia, como requisito para cumulação, que os pedidos fossem conexos e consequentes. Eis o texto do citado dispositivo: "Será permitida a cumulação de pedidos quando forem entre si conexos e conseqüentes, competirem ao mesmo juiz e fồ idêntica a forma dos respectivos processos".

${ }^{447}$ ASSIS, Araken de. Cumulação de ações, cit., p. 260.

${ }^{448}$ AMARAL SANTOS, Moacyr. Primeiras linhas de direito processual civil, cit., vol. 2, p. 161; ASSIS, Araken de. Cumulação de ações, cit., p. 260; PONTES DE MIRANDA. Comentários ao Código de Processo Civil, cit., t. IV, p. 70.

${ }^{449}$ Cumulação de ações, cit., p. 261. 
Como se vê, o requisito legal da existência de "mesmo réu" sofre indispensáveis flexões, tudo no afã de se extrair do instituto o máximo rendimento, sem que isso comprometa a sua essência. Ao revés, essa interpretação flexível é a que se mostra capaz de conferir tuição aos valores que estão à base do instituto da cumulação de pedidos (economia processual e harmonia de julgados).

Volvendo à diretriz do $§ 1^{\circ}$ do art. 292 e seguindo a ordem de requisitos lá disposta, tem-se a compatibilidade entre os pedidos como sendo necessária à admissão da cumulação. Pedidos compatíveis são aqueles que convivem sem conflituosidade, que coexistem sem contradição. Incompatíveis mostrar-se-ão aqueles que se excluírem mutuamente $^{450}$.

Note-se que a compatibilidade exigida ostenta feição jurídica e não puramente lógica $^{451}$. Essa necessidade de convivência harmônica entre os pedidos decorre, sobretudo, do direito material, mas não se descarta, como lembra DinAMARCO, que a incompatibilidade resulte de razões processuais ou éticas ${ }^{452}$.

A partir de uma análise a contrario sensu do que até aqui se expôs chega-se à noção de que os pedidos serão incompatíveis quando inconciliáveis entre si, isto é, quando o julgador não puder acolhê-los simultaneamente, porquanto um apresenta-se excludente do outro.

Exemplificativamente, haverá incompatibilidade entre o pedido de declaração de nulidade de negócio jurídico formulado cumulativamente com outro tendente à obtenção da condenação do réu a cumprir a obrigação derivada daquele mesmo negócio.

Havendo incompatibilidade entre os pedidos, a petição inicial mostra-se, ineludivelmente, inepta, na forma do art. 295, parágrafo único, inciso IV, do CPC. De maneira que a ausência de regularização no prazo de 10 dias importará o indeferimento da petição inicial (CPC, art. 284, p. único), lembrando-se que a abertura de oportunidade para

\footnotetext{
${ }^{450}$ AMARAL SANTOS, Moacyr. Primeiras linhas de direito processual civil, cit., vol. 2, p. 161-162; PONTES DE MIRANDA. Comentários ao Código de Processo Civil, cit., t. IV, p. 76.

${ }^{451}$ CALMON DE PASSOS, J. J. Comentários ao Código de Processo Civil, cit., vol. III, p. 207. A propósito, RICARDO TJÄDER conclui que compatibilidade jurídica pode existir mesmo quando a lógica comum considere como ilógicos os diversos pedidos formulados pelo autor (op. cit., p. 51).

${ }^{452}$ Instituições de direito processual civil, cit., vol. III, nº 996, p. 376.
} 
regularização constitui dever do juiz e direito da parte, já que aqui se está diante de vício sanável $^{453}$.

Diante da necessidade de regularização, caberá ao autor optar pelo pedido que mais lhe interessar, manifestando-se desistência em relação ao(s) outro(s). Não se concebe, portanto, que o juiz realize tal escolha, de modo que, na ausência de manifestação expressa do autor quanto ao pedido de sua preferência, incumbe ao julgador simplesmente indeferir a petição inicial, forte na constatação da inépcia.

Frise-se que a compatibilidade entre os pedidos constitui questão que não se coloca na seara da cumulação alternativa e tampouco na da eventual, uma vez que, nessas hipóteses, o demandante conscientemente formula mais de um pedido para que o julgador acolha apenas um deles. Ainda que entre os diversos pedidos haja incompatibilidade, o que importa registrar é que a solução dada ao litígio externará um conteúdo tal que afastará toda e qualquer possibilidade de contradição ou incompatibilidade. Demais disso, a formulação de pedidos com a interposição da disjuntiva "ou", para o caso de cúmulo alternativo, ou da condicional "se", na hipótese de cúmulo eventual, afasta a ilação de que a petição inicial pudesse ser inepta ${ }^{454}$.

Daí poder o exemplo acima figurado ajustar-se à técnica da cumulação eventual: o autor pede a anulação do contrato e, para o evento de ser improcedente tal pleito, pede, subsidiariamente, a condenação do réu a cumprir a obrigação respectiva. Ou, de outro modo: o autor postula a anulação do casamento e, para o evento de não ser procedente tal pleito, formula desde logo o pedido de divórcio.

Pondere-se, contudo, que essa liberdade de cumulação, desatrelada da noção de compatibilidade entre os diversos pedidos, não se mostra absolutamente irrestrita nem mesmo no campo da cumulação eventual ${ }^{455}$. Tanto que a doutrina orienta que não se aceite uma cumulação tal como a seguir exemplificada: o autor reclama o pagamento do preço

${ }^{453}$ NERY JUNIOR, Nelson; ANDRADE NERY, Rosa Maria de. Código de Processo Civil comentado e legislação extravagante, cit., notas 1 e 2 ao art. 284, p. 553. Em senso parelho: DINAMARCO, Cândido Rangel. Instituições de direito processual civil, cit., vol. III, nº 996, p. 378.

${ }^{454}$ Especificamente sobre a cumulação eventual, RICARDO TJÄDER explica: "Esta possibilidade exsurge da própria natureza do pedido eventual em que não são pedidas duas coisas, dois bens da vida, mas um ou outro, não se justificando, assim, a exigência de compatibilidade entre duas coisas que, automaticamente, se excluem" (op. cit., p. 51).

${ }^{455}$ CRUZ E TUCCI, José Rogério. Reflexões sobre a cumulação subsidiária de pedidos, cit., p. 61. 
pela alienação de um automóvel e, subsidiariamente, reivindica a propriedade de um imóvel ${ }^{456}$.

A par da compatibilidade de pedidos, com as ressalvas suso referidas em torno da cumulação imprópria (alternativa e eventual), a legislação reivindica que "seja competente para conhecer deles o mesmo juízo". Conquanto a lei empregue a expressão "mesmo juízo", impõe-se que todas as espécies de competência sejam observadas para que se tenha por preenchido tal requisito ${ }^{457}$.

A condicionante em foco atuará com maior ou menor intensidade a depender da natureza da regra de competência com que se tiver de trabalhar. Variará o grau de influência se se estiver diante de regra de competência absoluta ou de competência relativa.

Assim, se para cada um dos pedidos cumulados houver a definição de um órgão jurisdicional com competência absoluta para processá-los e julgá-los, será inviável a cumulação, seja esta de que modalidade for (própria: simples e sucessiva; imprópria: alternativa e eventual). Com essa problemática geralmente se depara quando são previstas Justiças distintas para apreciar os vários pedidos que se pretende cumular, hipótese em que não terá trânsito o cúmulo objetivo de demandas ${ }^{458}$.

Exemplo clássico de inadmissão de cumulação diz com a demanda fundada em direito de propriedade sobre imóveis que se situam em foros distintos; o óbice advém da regra de competência absoluta prevista no art. 95, in fine, do CPC.

O caminho que conduz à cumulação de pedidos torna-se um pouco mais tranquilo quando se está, diversamente, em presença de regra de competência relativa. A uma, porque, em havendo conexão entre os diversos pedidos cumulados ${ }^{459}$, tal circunstância acarreta a modificação da competência (CPC, art. 105), de modo que o órgão judicial competente para um dos pedidos torna-se, ipso facto, prevento para a outra porção da

\footnotetext{
${ }^{456}$ CRUZ E TUCCI, José Rogério. Reflexões sobre a cumulação subsidiária de pedidos, cit., p. 61.

${ }^{457}$ DINAMARCO, Cândido Rangel. Instituições de direito processual civil, cit., vol. III, no 996, p. 376.

${ }^{458}$ A propósito, a Súmula 170, do Superior Tribunal de Justiça, preconiza: "Compete ao juízo onde primeiro for intentada a ação envolvendo acumulação de pedidos, trabalhista e estatutário, decidi-la nos limites da sua jurisdição sem prejuízo do ajuizamento de nova causa, com o pedido remanescente, no juízo próprio".

${ }^{459}$ É o que geralmente ocorre com a cumulação sucessiva, porquanto presente o vínculo de prejudicialidade entre os diversos pedidos cumulados. A prejudicialidade põe em evidência a presença da conexão (DINAMARCO, Cândido Rangel. Instituições de direito processual civil, cit., vol. II, no 473, p. 173).
} 
demanda (CPC, art. 106) ${ }^{460}$. A duas, porquanto, mesmo que não haja conexão, a ausência de oposição de exceção de incompetência também deságua na prorrogação da competência $\left(\mathrm{CPC}\right.$, art. 114) ${ }^{461}$, sendo oportuno rememorar, na esteira de sólida orientação jurisprudencial, que a incompetência relativa não pode ser reconhecida de ofício (Súmula 33/STJ).

Como se vê, ressalvadas as hipóteses de conexão, o réu evitará a cumulação de pedidos - em relação aos quais exista previsão distinta de competência - se opuser exceção declinatória de foro e nela obtiver êxito.

Outro requisito que se deve implementar concerne ao procedimento, porquanto o inciso III do $\S 1^{\circ}$ do art. 292 exige que os pedidos cumulados sigam, em sua tramitação, o mesmo encadeamento procedimental. Sendo fiel à letra do Código de Processo Civil, impõe-se como fator de admissibilidade da cumulação que "seja adequado para todos os pedidos o tipo de procedimento".

Contudo, no afã de conferir maior rendimento à cumulação de pedidos e recebendo o estímulo do princípio da instrumentalidade das formas, a legislação consente que, havendo diversidade de procedimento para os vários pedidos formulados, o autor mesmo assim poderá cumulá-los, desde que empregue o procedimento ordinário (CPC, art. 292, § $\left.2^{\circ}\right)^{462}$

É que, sendo o procedimento ordinário o mais amplo em garantias e meios de defesa dentre aqueles previstos na legislação, a adoção desse rito em nada prejudicaria os interesses do réu e tampouco atentaria, de regra, contra o interesse público na correta

\footnotetext{
${ }^{460}$ ASSIS, Araken de. Cumulação de ações, cit., p. 266.

${ }^{461}$ PONTES DE MIRANDA. Comentários ao Código de Processo Civil, cit., t. IV, p. 77.

${ }^{462}$ Apegado à letra da lei, PONTES DE MIRANDA doutrinou que a cumulação, nessas condições, só será viável se o autor fizer, expressamente, a opção pelo procedimento ordinário. "A simples cumulação de pedidos, com ritos diferentes, não faz entender-se que o autor ou autores quiseram o rito ordinário". Daí que, não havendo manifestação expressa do autor, "tem o juiz de indeferir a petição inicial, porque cabia ao autor ou aos autores dizer qual o procedimento" (Comentários ao Código de Processo Civil, cit., t. IV, p. 77). No entanto, as tendências no sentido da adaptabilidade do procedimento às necessidades da causa (BEDAQUE, José Roberto dos Santos. Direito e processo, cit., p. 68-70) e da flexibilidade procedimental (GAJARDONI, Fernando da Fonseca. Flexibilização procedimental: um novo enfoque para o estudo do procedimento em matéria processual, de acordo com as recentes reformas do CPC. São Paulo: Atlas, 2008, p. 201) conduzem à impressão de que o juiz, mesmo de ofício, possa impor a marcha procedimental que se mostrar adequada ao tipo de cumulação formulado pelo autor.
} 
administração da justiça. Nada obsta, pois, que pedidos vinculados ao procedimento ordinário e sumário possam ser cumulados e processados pelo rito ordinário.

Todavia, existem procedimentos dotados de tamanha especificidade que acabam merecendo ser integrados no catálogo dos procedimentos especiais, donde exsurgem certas incongruências procedimentais dificilmente superáveis pela singela opção pelo rito ordinário.

Consoante se lê em doutrina, o problema radical, nesse campo, situa-se na tentativa de acomodação, no âmbito do procedimento ordinário, de pedido atrelado a procedimento especial ( $v . g$., consignação de pagamento) cumulado com outro de procedimento comum; a mesma problemática exterioriza-se quando se quer processar, pela moldura do procedimento ordinário, pedidos que, isoladamente, estariam a reclamar procedimento especial (v. g., prestação de contas e consignação de pagamento) ${ }^{463}$.

A esse respeito, CÂNDIDO DINAMARCo observa que as demandas de rito especial que, após a fase de resposta, se enveredam para o procedimento ordinário ( $v . g$., possessórias; consignação em pagamento; depósito) podem ser cumuladas com outras que reclamem diverso procedimento. Basta que, depois daquela fase inicial, todos os pedidos sigam pelos caminhos do procedimento ordinário ${ }^{464}$.

Constitui sinal eloquente dessa admissibilidade o quanto disposto no art. 921, do CPC, o qual permite a junção, em processo único, de pedido de índole possessória (que

\footnotetext{
${ }^{463}$ ASSIS, Araken de. Cumulação de ações, cit., p. 270-271.

${ }^{464}$ Instituições de direito processual civil, cit., vol. III, n ${ }^{\circ}$ 996, p. 377. Entretanto, ARAKEN DE ASSIS propõe que, em princípio, a regra geral é a da inadmissão de cumulação de pedidos sujeitos a procedimento especial com quaisquer outros, mesmo que reduzidas ao rito ordinário. $\mathrm{O}$ mesmo autor, contudo, admite algumas exceç̃os: consignação de pagamento cumulada com adjudicação compulsória; possessória cumulada com condenatória e demolitória; desconstituição de promessa de compra e venda cumulada com possessória (Cumulação de ações, cit., p. 271-272). Para dar coerência ao seu raciocínio, ARAKEN DE ASSIS expõe que a adaptabilidade dos vários pedidos ao procedimento ordinário impõe-se apenas quando se estiver diante de cumulação simples. De modo que, na presença de cumulação sucessiva ou eventual, aquela perfeita compatibilidade de ritos não se interpõe, já que o procedimento da ação subsequente (prejudicada ou subsidiária) não interfere no encadeamento dos atos relativos à ação principal ou primária, afeiçoando-se o procedimento daquela ao rito desta. Na cumulação simples a equivalência de importância entre os vários pedidos é que impõe a perfeita acomodação dos procedimentos, algo que não se coloca quando se está diante de cumulação sucessiva ou eventual (Cumulação de ações, cit., p. 272-273).
} 
reclama procedimento específico) com pedido de natureza condenatória (processável pelo rito comum: sumário ou ordinário).

De outro lado, não escapou à argúcia de ARAKEN DE ASSIS outra interessante e importantíssima limitação à cumulação de pedidos, não prevista embora na legislação que trata do tema. O citado autor, influenciado pela letra do art. 46, parágrafo único, do CPC que versa sobre a limitação do litisconsórcio facultativo - apregoa, com razão, que a cumulação de pedidos em número excessivo pode comprometer a isonomia entre as partes, a rápida solução do litígio e o direito de defesa do réu. Dessa forma, incumbe ao juiz, de ofício ou a requerimento, "coibir a combinação engenhosa de ações hipotéticas em número tão exagerado, na inicial, que o réu, às voltas com exíguo prazo de defesa, veja seriamente prejudicada a coleta das provas necessárias à instrução da resposta"465.

Afigura-se coerente asseverar que, nessa hipótese de cumulação multitudinária de pedidos, o réu poderá requerer a limitação, tal como ocorre com o litisconsórcio facultativo. Tal requerimento suspenderá o curso do prazo para resposta, cumprindo ao juiz, se o caso exigir, impor o desmembramento do processo ${ }^{466}$. Note-se bem: haverá o desmembramento do processo e não a amputação prematura e descarte dos pedidos que se mostrarem exorbitantes ${ }^{467}$.

${ }^{465}$ Cumulação de ações, cit., p. 274. Em senso oposto, RICARDO TJÄDER rechaça a tese, argumentando que a recusa da cumulação fora dos parâmetros do art. 292, do CPC, implica privilégio ao réu e atentado a todos os princípios justificadores da cumulação de pedidos, razão pela qual não se poderiam alargar as hipóteses de inadmissibilidade da cumulação para além das barreiras construídas a partir da letra do art. 292. Por fim, TJÄDER ainda refere que tal limitação redundaria numa prévia amputação de um dos pedidos do autor, infundindo-lhe, de maneira iníqua, a certeza de que seus interesses não seriam atendidos na integralidade, tendo-se de aguardar por todo o tramitar do processo consciente de que sua pretensão não será satisfeita na totalidade (op. cit., p. 53-55).

466 SCARPINELLA BUENO refere que em todos os casos de inadmissão da cumulação de pedidos a consequência adequada será a adoção da técnica do desmembramento do processo e jamais a sua extinção (Curso sistematizado de direito processual civil, cit., vol. 2, t. I, p. 87). Embora a orientação do citado professor sirva para lastrear a ideia aqui defendida (no sentido do desmembramento do processo quando haja cúmulo de pedidos em número excessivo), não se comunga com a tese inflexível de que sempre e sempre terá de haver o desmembramento, pois - já se viu acima - hipóteses haverá ( $v . g$., nos casos de inadmissão por força das regras de competência) em que, à falta de requerimento do autor no sentido do desmembramento, outro caminho não restará ao juiz que não a exclusão parcial dos pedidos cumulados.

${ }^{467}$ Sendo assim, crê-se adequada a tese de ARAKEN DE ASSIS, não se compactuando com as objeções de RICARDO TJÄDER, porquanto os mesmos princípios que justificam a cumulação subjetiva (litisconsórcio) 


\section{Consequências}

Doravante abre-se convite para o estudo de algumas das variadas consequências da cumulação de pedidos, em suas diversas modalidades. Conscientiza-se, desde logo, que a apreciação dessas consequências (ou da dinâmica da cumulação) não se faz em caráter exaustivo, pois a riqueza e a amplitude do tema desafiam as previsões legislativas e até mesmo a imaginação dos estudiosos. Salienta-se, ademais, que muitas das possíveis consequências já foram anunciadas no curso da exposição até aqui encetada. Então, o anúncio que vem na sequência serve apenas para sinalizar o destino para o qual propende esta investigação, que se constitui no exame da admissibilidade das modalidades litisconsorciais eventual, alternativa e sucessiva e de suas possíveis repercussões no campo do processo civil de corte individual e considerada apenas sua fase cognitiva.

(i) valor da causa

Ao cuidar das regras pertinentes à atribuição de valor à causa, o legislador faz expressa referência à cumulação de pedidos e dispõe que, presente a cumulação, o valor da causa corresponderá à soma dos valores de todos eles (CPC, art. 259, II). Advirta-se, porém, que a modalidade de cumulação veiculada nesse dispositivo é a própria, abrangendo as espécies simples e sucessiva. Implica dizer que, se o autor formula vários pedidos para que todos eles sejam apreciados e acolhidos pelo julgador, sejam eles independentes entre si (cumulação simples), sejam eles imbricados pelo nexo da

estão presentes no seio da cumulação objetiva, sendo evidente que no campo do litisconsórcio facultativo a limitação pode operar-se (CPC, art. 46, p. único). Ademais, o réu não obteria qualquer privilégio com essa limitação, pois que, de uma forma ou de outra, todos os pedidos do autor teriam trânsito perante o Poder Judiciário mediante a técnica do desmembramento de autos. O que se busca, então, é a harmonização das posições jurídicas de autor e réu, longe de se tentar conferir algum privilégio a quaisquer deles. A necessidade de convivência entre os princípios que animam a cumulação e aqueles outros inerentes ao modelo constitucional do processo civil brasileiro, como o do devido processo legal e o da isonomia, desemboca, para a espécie, na prevalência destes e não daqueles. 
prejudicialidade (cumulação sucessiva), o valor da causa corresponderá à expressão econômica de todos eles, numa operação de adição.

Diferentemente, se se estiver diante de cumulação alternativa de pedidos, o valor da causa corresponderá à compostura daquele pedido que se apresentar mais expressivo do ponto de vista quantitativo. Ou seja, o pedido que, dentre os vários formulados, apresentar a maior expressão econômica ditará a configuração do valor da causa, ex vi do art. 259, III, do CPC.

Aduza-se que o dispositivo que se vem de citar não diz respeito ao pedido alternativo regulado pelo art. 288, do CPC, uma vez que neste o pedido é um só e, sendo assim, existe apenas um valor a considerar. De fato, segundo abalizada doutrina, "entre as alternativas de solução inexiste diferença quantitativa, podendo-se apenas falar em diferença qualitativa" ${ }^{468}$.

Na seara da cumulação eventual (ou subsidiária), a lei manda que seja observado, na atribuição de valor à causa, o proveito econômico que se pretende obter com o pedido primário (principal ou prioritário) ${ }^{469}$. Sendo assim, o pedido que revelar a preferência do autor ditará a conformação do valor da causa, mesmo que o pleito subsidiário ostente maior expressão econômica comparativamente ao pedido primário ${ }^{470}$.

(ii) reflexos da admissibilidade e da inadmissibilidade

Sobreleva notar, de outra parte, que a aferição da presença ou não dos requisitos de admissibilidade da cumulação, em todas as modalidades, faz-se, de regra, ex officio, porquanto a matéria reside no ambiente dos pressupostos de desenvolvimento válido e

\footnotetext{
${ }^{468}$ CALMON DE PASSOS, J. J. Comentários ao Código de Processo Civil, cit., vol. III, p. 190.

${ }^{469}$ Assim dispõe o art. 259, IV, do CPC.

${ }^{470}$ SOUZA, Gelson Amaro de. Do valor da causa. 3. ed. São Paulo: RT, 2002, p. 104-105. O autor citado formula interessante exemplo para se certificar do acerto da conclusão exposta no texto: determinado agricultor pede que seja mantido na posse de imóvel onde desenvolve lavoura até que possa colher os frutos da safra, mas, para o caso de não se acolher tal pedido, pleiteia, subsidiariamente, que lhe sejam ressarcidos os gastos derivados do preparo da safra. Nessa hipótese, pode acontecer de a produção ser pequena e os gastos com o preparo serem expressivos. Mesmo assim, o valor da causa corresponderá ao proveito econômico que se pretende obter com o acolhimento do pedido primário.
} 
regular do processo $(\mathrm{CPC} \text {, art. 267, IV })^{471}$, atraindo-se, via de consequência, a incidência da regra do art. 267, $\S 3^{\circ}$, do CPC. Relembre-se que algumas matérias arroladas no art. 301, do CPC, também respeitam ao tema da cumulação de pedidos, tais como o indeferimento da petição inicial (inc. I), a incompetência absoluta (inc. II) e a conexão (inc. VII). De resto, a incompatibilidade entre os pedidos e a inadequação do rito também configuram defeitos da petição inicial sindicáveis independentemente de arguição da parte contrária (CPC, art. 295, inc. IV e p. único, inc. IV).

Ainda que tais assuntos estejam ligados à atuação de ofício do julgador, impõe-se não olvidar que o juiz deve oportunizar à parte a ocasião adequada para sanar o vício (CPC, art. 284), seja para compatibilizar os pedidos na medida em que isso for possível, seja para desistir dos pedidos que não caibam no espectro da competência do órgão judicial, seja, ainda, para ajustar o procedimento, optando, se for o caso, pelo ordinário.

Pelo prisma da (in)competência relativa, como já se viu, a verificação da admissibilidade da cumulação não prescinde de alegação da parte interessada, já que a ausência de arguição da incompetência relativa opera a prorrogação da competência.

Quando a inviabilidade de cumulação deriva da aplicação de regras de competência abre-se a discussão sobre o destino da porção que não se subsume à margem de competência do órgão jurisdicional perante o qual foi instaurado o processo com cúmulo de pedidos.

Para CÂNDIDo DinAmARCo a solução ideal seria o desmembramento do processo em vez de sua extinção, precedida de consulta ao demandante ${ }^{472}$. De sua parte, ARAKEN DE Assis sustenta que o desmembramento ex officio afigura-se inviável, já que a remessa da "ação "cindida" ao órgão jurisdicional competente ofenderia o quanto disposto no artigo 262, do CPC. Em síntese, conclui o doutrinador gaúcho que a solução mais razoável impõe a "extinção da ação, para a qual não ostenta competência, pelo juízo incompetente", ressalvada ao autor a propositura da mesma demanda perante o órgão competente ${ }^{473}$.

\footnotetext{
${ }^{471}$ ASSIS, Araken de. Cumulação de ações, cit., p. 274.

${ }^{472}$ Instituições de direito processual civil, cit., vol. III, nº 996, p. 378.

473 Cumulação de ações, cit., p. 280. RICARDO TJÄDER também se inclina pelo indeferimento parcial da petição inicial nos casos em que a cumulação não se afigura possível (op. cit., p. 63-64).
} 
Parece correto afirmar que o desmembramento de ofício realmente se mostra exorbitante $^{474}$, mas nada impede que o autor requeira essa providência e, mediante traslado, a porção cindida seja encaminhada ao órgão jurisdicional competente. Mas, se o autor não se conduzir de semelhante modo, não restará ao julgador - que se reconhece incompetente em relação a um dos pedidos - outra via que não a exclusão dessa parcela do objeto do processo.

Poder-se-ia objetar que o órgão reconhecidamente incompetente em relação àquele pedido não teria competência para extingui-lo. A objeção, contudo, não procede, pois que, no específico caso, a extinção configura projeção da competência - de que todo órgão jurisdicional é investido - para reconhecimento de sua própria incompetência (KompetenzKompetenz dos alemães). Em acréscimo, aduza-se que tal solução não é totalmente estranha ao sistema processual brasileiro, uma vez que a Lei $\mathrm{n}^{\text {o }}$ 9.099/95 a admite expressamente (art. 51, III).

Lidando com a hipótese em que se cumulam pedidos nitidamente autônomos contra réus diferentes, ARAKEN DE ASSIS refere que a ausência de conexão subjetiva, nesse caso, implica a inadmissibilidade da cumulação, forte na disciplina do caput do art. 292, do CPC. Tal cenário põe em discussão, mais uma vez, o destino que se deve dar às demandas cumuladas: "qual delas o juiz escolherá como apta?" 475.

Ao mencionado doutrinador pareceu, sem ressalvas, que a situação enseja a extinção do processo em relação a todos os réus ${ }^{476}$. É possível acrescentar, todavia, que ao

\footnotetext{
${ }^{474}$ ROBERTO BEDAQUE cita exemplo pitoresco, extraído da jurisprudência do Tribunal de Justiça de São Paulo (Ap. Cível nº 268.460-5/2), em que determinado processo, inicialmente instaurado perante a Justiça do Trabalho, foi remetido, por traslado, à Justiça Comum estadual e ali teve processamento, chegando-se ao julgamento do mérito (improcedência). A remessa de cópia da reclamação trabalhista ao juízo estadual deveu-se ao fato de haver uma porção da demanda que se referia a período em que os autores estavam abrangidos pelo regime estatutário e não celetista; a parcela do litígio que tinha relação com a Justiça do Trabalho foi julgada pelo mérito nessa seara. Perante a Justiça Comum tratou-se, efetivamente, de processo instaurado de ofício, pois o autor não manejou qualquer demanda perante essa Justiça. Porém, como o réu teve oportunidade de se manifestar e, na fase recursal, acabou ingressando nos autos e não arguindo qualquer tipo de vício processual, entendeu-se que a eiva, conquanto gravíssima do ponto de vista processual, não comprometeu o resultado do processo (Efetividade do processo e técnica processual, cit., p. 214-216, especialmente a nota 58).

${ }^{475}$ Cumulação de ações, cit., p. 278.

${ }^{476}$ Id., ibid.
} 
juiz incumbiria, no decêndio previsto no art. 284, do CPC, ouvir o autor, colhendo-se deste a opção entre os possíveis réus. Havendo a escolha, aproveitam-se as atividades processuais até então desenvolvidas, verificando-se desistência em relação a um dos demandados (CPC, art. 267, VIII). Caso contrário, adequada se mostra a solução apregoada pela doutrina acima indicada: extinção do processo, sem resolução do mérito, em relação a todos os réus.

(iii) fase instrutória

Sob o enfoque procedimental, pode suceder que os questionamentos em torno do pedido primário não exijam produção de provas, de modo que o juiz, visualizando a procedência desse pedido, julgará o mérito da causa antecipadamente, na forma do art. 330, II, do CPC. O mesmo pode suceder no âmbito da cumulação alternativa, pois a viabilidade de julgamento antecipado quanto a um dos pedidos alternativos autoriza que o juiz desde logo o faça.

Daí a necessidade de que o julgador, vencida a fase preponderantemente saneadora, analise os postulados das partes e as provas documentais até ali produzidas com a devida cautela, tudo no afã de evitar um ingresso desnecessário na fase instrutória. E a desnecessidade da instrução poderá resultar, conforme o caso, da viabilidade de acolhimento antecipado do pedido primário (na cumulação eventual) ou de um dos pedidos alternativos (na cumulação alternativa).

Todavia, quando a hipótese exigir a produção de outras provas - além daquelas já trazidas na fase postulatória - deve-se compreender que a instrução desenvolver-se-á numa unidade, mesmo que se esteja diante de cumulação eventual ou alternativa de pedidos.

Implica dizer que as provas em relação a todos os pedidos (primário, subsidiário e alternativos) hão de ser produzidas em etapa procedimental única, não se podendo reservar momentos distintos para a prova referente a este ou àquele pedido ${ }^{477}$. Exemplificativamente, não pode o juiz determinar a produção de provas apenas em relação

\footnotetext{
${ }^{477}$ Faz-se tal observação porque não é incomum ver-se, no cotidiano forense, a produção de provas sobre o pedido primário e, só depois de verificada a possível rejeição desse pedido, sobrevir a colheita da prova - às vezes trabalhosa - alusiva ao pedido subsidiário.
} 
ao pedido primário e, depois de concluir pela rejeição desse pedido - ainda que só no campo de seus exercícios mentais, ou seja, sem manifestar tal conclusão nos autos -, impor a continuidade da instrução quanto ao pedido subsidiário.

Semelhante preocupação não se interpõe na seara da cumulação sucessiva de pedidos, uma vez que as pretensões aqui são somadas e o juiz, sempre que necessário for, haverá de oportunizar a produção de provas quanto a um e também quanto ao outro pedido.

O que pode suceder é que, no curso da etapa instrutória, o juiz se convença, à luz das provas até ali produzidas, pela inexistência da relação prejudicial que daria sustentação ao pedido subordinado. Nessas condições, parece razoável entender que a fase instrutória seja estancada antecipadamente e que sobrevenha, desde logo, decisão de mérito sobre os pedidos prejudicial e prejudicado ${ }^{478}$.

(iv) capítulos de sentença

Já se escreveu que a cumulação de pedidos dá margem a que o objeto do processo seja do tipo composto e, sendo assim, pode-se dizer que em todas as hipóteses de cumulação "haverá tantos capítulos na sentença quantos os pedidos cumulados" ${ }^{479}$. Sem olvidar a riqueza que o tema dos capítulos de sentença enseja e de suas notáveis repercussões em vários recônditos do processo $^{480}$, aqui se contenta com a análise de algumas situações derivadas do modo como os diversos capítulos podem influenciar o julgamento um do outro.

É nesse sentido que se justifica a classificação que desdobra os capítulos de sentença em dependentes e independentes. Isto porque existem situações em que um dos

\footnotetext{
${ }^{478}$ Pode-se figurar o exemplo em que, numa investigatória de paternidade cumulada com alimentos, no curso da instrução a respeito de ambos os aspectos o juiz se convença quanto à inexistência do vínculo biológico. Nessa hipótese, utilidade alguma se encontrará que justifique a continuidade da instrução quanto ao binômio necessidade/possibilidade respeitante à pensão alimentícia.

${ }^{479}$ DINAMARCO, Cândido Rangel. Capítulos de sentença. 1. ed., 2. tir. São Paulo: Malheiros, 2004, nº 25, p. 65.

${ }^{480}$ Vejam-se, por exemplo, as interessantes repercussões notadas por MARCELO J. M. BONÍCIO (Capítulos de sentença e efeitos dos recursos. São Paulo: RCS, 2006, passim).
} 
capítulos não pode logicamente subsistir se o outro for negado ${ }^{481}$. Importa considerar, ainda nesse aspecto, que o nível de influência nem sempre será assim tão contundente, pois o nexo de dependência mantém-se "nos limites do vínculo de ordem lógica que subordina um capítulo ao outro" 482 .

Sob o influxo dessas premissas, pode-se dizer que na cumulação eventual de pedidos a decisão pertinente ao pedido primário mostra-se independente em relação ao enfrentamento do pedido subsidiário. O inverso, porém, não se concretiza, já que o pedido subsidiário tem sua sorte atrelada ao que ficar assentado quanto ao pedido primário. De fato, o pedido subsidiário será possivelmente acolhido apenas na hipótese de não se ter acolhido o pedido primário.

Entre os pedidos alternativamente cumulados nota-se uma recíproca influência, porquanto o acolhimento de um afasta, necessariamente, o julgamento favorável em relação ao outro.

Mas é na cumulação sucessiva que o problema ganha em intensidade, dada a imbricação que existe com a temática da prejudicialidade. Com efeito, já se delineou que o pedido prejudicado tem sua sorte influenciada pelo que se decidir quanto ao pedido prejudicial. E o inverso não se verifica, pois a decisão do pedido prejudicado não está em ordem a influenciar o conteúdo da decisão pertinente ao prejudicial.

Desde que bem vistas as coisas, o resultado do julgamento quanto ao pedido prejudicial dá o tom do que se terá no conteúdo ou teor da decisão relativa ao pedido prejudicado. Em outras palavras, reforça-se a ideia de que a decisão do pedido prejudicial não se coloca em linha de preliminar quanto à apreciação do pedido prejudicado. Em verdade, o próprio mérito do pedido prejudicado é que fica subordinado à sorte do que se concluir a respeito do pedido prejudicial.

Essas noções, por ora, são suficientes para autorizar o desenvolvimento do trabalho, até porque se está mais interessado nas consequências dessa escansão da sentença em variados capítulos do que na própria teoria em si dos capítulos de sentença.

\footnotetext{
481 ARAÚJO CINTRA, Antonio Carlos de. Sobre os limites objetivos da apelação civil. Tese (Doutorado). São Paulo, USP, 1986, p. 49. Para aprofundamentos, consulte-se DINAMARCO, Cândido Rangel (Capítulos de sentença, cit., $\mathrm{n}^{\mathrm{o}} 15$, p. 43 et seq.).

${ }^{482}$ ARAÚJO CINTRA, Antonio Carlos de. Sobre os limites objetivos da apelação civil, cit., p. 49.
} 
Analisando especificamente alguns detalhes da cumulação de pedidos, interessante preocupação manifestou CRUZ E TUCCI ao trabalhar com a hipótese de o juiz deparar-se, no campo da cumulação eventual, com a procedência parcial do pedido primário e com a possibilidade de procedência integral do pedido subsidiário. Tal cenário demandará do juiz extremada cautela, impondo-se que, uma vez delineada a procedência parcial do pedido primário, seja analisado o pedido subsidiário, na consideração de que eventual procedência total deste poder apresentar-se como resultado mais benéfico ao autor. Nessa hipótese, o juiz outorgará ao autor, em vez da procedência parcial do pedido primário, a procedência integral do pedido subsidiário ${ }^{483}$.

Aduza-se, em acréscimo, que a procedência parcial pode variar em níveis, não causando surpresa alguma a afirmação de que o pedido primário pode ser rejeitado em porção mínima ${ }^{484}$. Haverá, sim, procedência parcial do pedido primário, mas o nível de rejeição desse pedido terá sido tão diminuto que ao juiz não será dado, então, ingressar na análise do pedido subsidiário.

Em suma, diante do cenário de procedência apenas parcial do pedido primário, ao juiz incumbirá elaborar, fundamentadamente, uma comparação entre as possíveis situações: (a) se a sucumbência do autor quanto ao pedido primário apresentar-se expressiva, impõe-se a análise do pedido subsidiário, pois a procedência integral deste preferirá à procedência parcial daquele; $(b)$ caso a sucumbência pertinente ao pedido primário seja mínima, há de se presumir que esse resultado transpareça mais favorável aos interesses do autor, ficando, pois, prejudicada a análise do pedido subsidiário.

Haja vista que a ordem de apreciação dos pedidos na cumulação eventual deriva da preferência manifestada pelo autor na petição inicial, entende-se correto que o juiz deva apreciar o pedido primário mesmo na hipótese de o réu reconhecer a procedência do pedido subsidiário $^{485}$. Com isso se reforça a noção de que o pedido subsidiário será

\footnotetext{
483 Reflexões sobre a cumulação subsidiária de pedidos, cit., p. 63. Adotando a mesma orientação, RICARDO TJÄDER acrescenta que, nessa hipótese, o juiz deve obrigatoriamente expor na sentença os motivos pelos quais acolheria apenas parcialmente o pedido primário e, depois, lançar as razões jurídicas do acolhimento integral do pleito subsidiário (op. cit., p. 83).

${ }^{484}$ Prova disso é o que se contém no parágrafo único do art. 21 do CPC, onde se trabalha com a noção de decaimento de parte mínima do pedido.

${ }^{485}$ CRUZ E TUCCI, José Rogério. Reflexões sobre a cumulação subsidiária de pedidos, cit., p. 62.
} 
apreciado se e somente se o primário for considerado improcedente, parcialmente procedente em porção mínima, ou inadmissível (carência da ação).

A propósito de sucumbência na seara da cumulação eventual, impende registrar a celeuma que envolve o assunto na hipótese de acolhimento apenas do pedido subsidiário. Haveria, na espécie, sucumbência recíproca ou sucumbência integral? A procedência do pedido subsidiário redundaria na condenação do autor a pagar, proporcionalmente, custas, despesas processuais e honorários advocatícios à parte adversa?

Partindo das premissas de que o pedido primário e o subsidiário "estão num mesmo plano de equivalência jurídica" e de que a preferência indicada na petição inicial quanto ao pedido primário configura simples conveniência e estratégia do autor, RICARDO TJÄDER verbera que a rejeição do pedido primário e o acolhimento do pedido subsidiário não colocam o autor na condição de vencido, razão pela qual não se condena o autor a pagar verbas de sucumbência ${ }^{486}$.

CÂNDIDO DinAmARCo, fundado embora em outro argumento, a saber, o de que os pedidos não são somados, também reconhece não haver lugar para condenação do autor quanto aos encargos da sucumbência, bastando o acolhimento de um dos pedidos para que o réu suporte, isolada e integralmente, os referidos encargos ${ }^{487}$.

Não soa despropositado afirmar, contudo, que a evidente distinção entre a cumulação eventual e a cumulação alternativa rende ensejo a que, no campo das consequências, igual diferenciação se verifique. Se é verdade que na cumulação alternativa o acolhimento de um ou de outro pedido mostra-se como um indiferente para o autor, semelhante realidade não se verifica na cumulação eventual.

${ }^{486}$ Op. cit., p. 88-91. A jurisprudência do STJ também é vacilante no tema, pois existem precedentes contemporâneos em ambos os sentidos: $a$ ) ocorre sucumbência integral quando se acolhe pedido subsidiário: REsp 619.918/MG, $1^{\text {a }}$ T., Rel. Min. Luiz Fux, j. 20.06.2006, DJ 01.08.2006, p. 367; REsp 776.648/MG, $1^{\text {a }}$ T., Rel. p/ Acórdão Min. Luiz Fux, j. 01.03.2007, DJe 08.5.2008; b) ocorre sucumbência recíproca quando se acolhe pedido subsidiário: REsp 193.278/PR, $3^{\mathrm{a}}$ T., Rel. Min. Antônio de Pádua Ribeiro, j. 23.04.2002, DJ 10.06.2002; REsp 618.637/SP, $3^{\text {a }}$ T., Rel. Min. Humberto Gomes de Barros, j. 05.06.2007, DJ 27.08.2007, p. 221.

${ }^{487}$ Instituições de direito processual civil, cit., vol. II, $\mathrm{n}^{\circ} 475$, p. 177. Na mesma toada, a prestigiosa lição de YUSSEF CAHALI: “Assim, se a cumulação objetiva de pedidos é alternativa ou eventual, de modo a prevalecer o de maior valor (CPC, art. 259, III), a denegação do pedido posto como opção (no pólo da alternatividade ou da eventualidade) não determina sucumbência recíproca" (Honorários advocatícios. 3. ed. São Paulo: RT, 1997, p. 446). 
A preferência manifestada pelo autor quanto ao pedido primário (ou prioritário) não ostenta conotação puramente de estratégia; não se cuida, semelhantemente, de opção calcada em simples conveniência. A preferência tem sentido jurídico e prático, sendo-lhe mais vantajoso, por esses dois prismas, que o pedido prioritário seja acolhido, tanto assim que o autor por último citado, exatamente porque não se está no campo da indiferença residente na cumulação alternativa, admite o interesse recursal do autor que teve o pedido subsidiário acolhido.

De fato, CÂNDIDO DinAmARCo expressa, às claras, que "a rejeição do pedido prioritário e procedência do eventual não têm o efeito de procedência integral da demanda, mas parcial"488. Nesse rumo, não parece acertado dizer que haverá, sempre e sempre, “equivalência jurídica” (RICARDO TJÄDER) entre os pedidos prioritário e subsidiário.

Então, uma vez que de procedência integral não se cogita, inegável que o autor experimenta alguma derrota e tal circunstância serve para justificar a incidência dos encargos de sucumbência, ex vi do art. 20, do CPC. Embora o sistema processual incentive a cumulação de pedidos, na exata consideração de que isso economiza processo, semelhante postura do autor cria os riscos que são inerentes a toda e qualquer empreitada judicial. A dúvida e a hesitação que estão à base da admissibilidade da cumulação eventual também não servem para afastar os riscos da demanda, que serão, em certa medida, suportados pelo autor diante da procedência meramente parcial de sua pretensão. Como se vê, também pelo prisma da causalidade chega-se à conclusão de que o autor há de suportar, proporcionalmente, os encargos de sucumbência quando apenas o pedido subsidiário seja acolhido.

Uma derradeira observação merece ser ainda pontuada: seja qual for a modalidade de cumulação de pedidos, o julgador sempre haverá de decidir explicitamente todas as pretensões, não se admitindo entre nós a subsistência das chamadas decisões implícitas.

Então, numa hipótese, $v . g$., de cumulação sucessiva, os vários pedidos formulados devem ser explicitamente decididos pelo julgador. A relação de dependência que existe entre esses pedidos - fruto, aliás, do nexo de prejudicialidade que está à base da cumulação sucessiva - não dispensa o juiz de analisá-los expressamente na sentença ${ }^{489}$. Não se corre

\footnotetext{
${ }^{488}$ Instituições de direito processual civil, cit., vol. II, nº 475, p. 177.

${ }^{489}$ BARBOSA MOREIRA, José Carlos. Ações cumuladas. Necessidade de julgamento explícito de todas, cit., p. 137.
} 
risco algum de errar quando se diz que a procedência do pedido subordinante não gera, automaticamente, o acolhimento também do pedido subordinado. Com maiores razões se dirá, então, que a procedência daquele não traz implícito o albergamento deste.

(v) apelação

Como reflexo da decomposição da sentença em capítulos é possível entrever nuances interessante na seara recursal. Esse riquíssimo tema - convém que se repita - não será tratado aqui em pormenores, pois, caso contrário, haveria espaço para uma monografia específica só para tal assunto ${ }^{490}$. Logo, serão abordados, de passagem, alguns aspectos que se supõe contribuir para a discussão em torno das modalidades litisconsorciais cogitadas.

Desenvolvendo, então, o objetivo previamente anunciado, é possível notar importante emanação da cumulação eventual de pedidos em sede de apelação, porquanto a rejeição do pedido primário e o acolhimento do subsidiário ensejam sucumbência recíproca, consoante se tentou demonstrar acima, de sorte que autor e réu ostentarão o interesse recursal: o autor com o intuito de ver acolhido o pedido primário; o réu com a finalidade de obter a improcedência integral dos pedidos ${ }^{491}$.

Na hipótese de sucumbência recíproca, tal como exemplificado no parágrafo antecedente, pode-se trabalhar com a interposição de apelação na forma adesiva, ex vi do art. 500, in fine, do CPC: o réu, por exemplo, que se contentava com a procedência apenas do pedido subsidiário, poderá apelar, adesivamente, quando se deparar com a apelação do autor tendente à obtenção do acolhimento do pedido primário.

\footnotetext{
${ }^{490}$ Confira-se, nesse aspecto, a obra de BONÍCIO, Marcelo José Magalhães (Capítulos de sentença e efeitos dos recursos).

491 CRUZ E TUCCI, José Rogério. Reflexões sobre a cumulação subsidiária de pedidos, cit., p. 62; DINAMARCO, Cândido Rangel. Instituição de direito processual civil, cit., vol. II, nº 475, p. 177. Em sentido oposto, RICARDO TJÄDER professa existir uma "linha de igualdade jurídica" entre os pedidos cumulados em forma eventual, "de tal forma que a concessão de qualquer um dos pedidos se constitua em resultado útil de sua provocação ao Poder Judiciário”. Daí não haver, consoante TJÄDER, sucumbência do autor quando, rejeitado o pedido primário, seja acolhido o pedido subsidiário, donde resulta a falta de interesse recursal por parte do demandante (op. cit., p. 98-99).
} 
Noutra perspectiva, pela regra hoje contida no art. $515, \S 3^{\circ}$, do $\mathrm{CPC}^{492}$, autoriza-se a interpretação ampliativa segundo a qual a apelação interposta pelo réu quanto à procedência do pedido primário não tolhe o órgão ad quem da apreciação do pedido subsidiário, desde que para tal não se exija a produção de outras provas na origem.

Implica dizer que o acolhimento da pretensão recursal do réu no que pertine ao pedido primário abre espaço para que o tribunal aprecie e acolha, se for o caso, o pedido subsidiário do autor ${ }^{493}$.

De fato, o autor que obteve a procedência do pedido primário não terá interesse recursal e o pedido subsidiário não terá sido analisado pelo julgador exatamente em razão do acolhimento do pleito preferencial. Mas o provimento da apelação interposta pelo réu fará emergir o interesse quanto ao pedido subsidiário formulado pelo autor. Assim, se o debate fático e jurídico, pertinente à pretensão subsidiária, já tiver ocorrido em primeiro grau de jurisdição e o não conhecimento desse pleito subsidiário resultar unicamente da circunstância de o pedido primário ter sido acolhido, concebe-se que o tribunal aprecie o mérito do pedido subsidiário ${ }^{494}$, acolhendo-o ou rejeitando-o, conforme o caso.

Suponha-se outra hipótese: o autor obtém, em primeira instância, a procedência do pedido subsidiário e apela para alcançar a procedência, em vez do subsidiário, do pedido primário. Nessas condições, o provimento da apelação do autor e a consequente procedência do seu pedido primário torna insubsistente a procedência reconhecida em primeiro grau quanto ao pleito subsidiário. Trata-se de consequência ínsita à própria noção de cumulação eventual de pedidos, já que apenas um dos pedidos pode ser concedido ao autor.

Relembre-se, de outra parte, que no campo da cumulação alternativa essas discussões, em certa medida, não terão lugar, uma vez que o acolhimento de um ou de

492 "Nos casos de extinção do processo sem julgamento do mérito (art. 267), o tribunal pode julgar desde logo a lide, se a causa versar questão exclusivamente de direito e estiver em condições de imediato julgamento".

${ }^{493}$ Diante da alteração legislativa imposta pela Lei $n^{\circ} 10.352 / 2001$, superadas parecem ter ficado as críticas da doutrina quanto à orientação jurisprudencial que já se formava, no sentido em que se lê no texto, antes mesmo da nova redação do art. 515, $\S 3^{\circ}$ (a respeito, cfr. CRUZ E TUCCI, José Rogério. Reflexões sobre a cumulação subsidiária de pedidos, cit., p. 65-66).

${ }^{494}$ SCARPINELLA BUENO, Cassio. Comentário ao art. 289, do CPC. In: MARCATO, Antonio Carlos (coord.). Código de Processo Civil interpretado. 3. ed. São Paulo: Atlas, 2008, p. 948-949. 
outro pedido satisfará plenamente os interesses do autor, afastando-se, assim, o interesse recursal deste ${ }^{495}$.

Mas aqui também se coloca a questão dos limites da apreciação do órgão ad quem na hipótese de apelação aviada pelo réu (que ficou vencido quanto a um dos pedidos alternativos), parecendo lícito assinalar que o reclamo recursal alusivo apenas ao pedido $X$ (formulado alternativamente com o pedido $Z$ ) não impede que o tribunal, rejeitando o pedido concedido na origem $(X)$, acolha o pedido $Z$, desde que para tanto não seja necessária a produção de outras provas. Pode-se trabalhar, mais uma vez, sob o estímulo do que preconiza o art. $515, \S 3^{\circ}$, do CPC.

No âmbito da cumulação sucessiva, por sua vez, o assunto impregna-se de cores ainda mais elegantes, de vez que o nexo de prejudicialidade que enlaça os pedidos cumulados torna a discussão bem mais rica e, por isso mesmo, envolta em grande celeuma interpretativa.

Constitui lição corrente que os capítulos de sentença não impugnados pelo recurso ficam atingidos pela preclusão, entendendo-se que a parte omissa tenha aquiescido com o conteúdo decisório daquele capítulo não atacado ${ }^{496}$. Porém, semelhante conclusão pode encontrar alguns temperamentos quando entre os capítulos de sentença se interponha um vínculo de antecedência lógica, de tal modo que uma faceta da decisão judicial não possa subsistir sem que esteja incólume a outra que a condiciona.

Imagine-se, por exemplo, uma demanda em que se formule pedido de reintegração de posse cumulado com indenização pelos danos impostos no imóvel esbulhado (CPC, art. 921, I). Ou, então, pense-se na conhecidíssima ação de investigação de paternidade cumulada com pedido de alimentos. Nesses casos, não é possível imaginar uma conclusão no sentido da existência da obrigação de indenizar sem o pressuposto do esbulho. Igualmente, impensável a condenação a pagar pensão alimentícia na ausência do vínculo de paternidade.

O debate que se propõe, para as finalidades deste trabalho, gira em torno da apelação parcial. É dizer, quando na presença de mais de um capítulo de sentença, dependentes entre si, a parte ataca na fase recursal apenas um dos capítulos, surgindo aguda discussão sobre a sorte que se deve dar ao outro capítulo não recorrido.

\footnotetext{
${ }^{495}$ SCARPINELLA BUENO, Cassio. Curso sistematizado de direito processual civil, cit., vol. 2, t. I, p. 83.

${ }^{496}$ CHIOVENDA, Giuseppe. Principii di diritto processuale civile, cit., p. 984.
} 
Bastante divulgada entre nós é a lição de CHIOvEnDA, segundo a qual a apelação pertinente ao capítulo subordinante, ainda que não haja recurso quanto ao capítulo subordinado, investe o órgão ad quem do poder de decidir sobre ambos ${ }^{497}$. Haveria, nessa conformidade, uma ampliação do efeito devolutivo da apelação para além dos lindes da matéria impugnada ${ }^{498}$.

Além da utilização de terminologia díspar, assiste-se a aguda divergência doutrinária no cenário brasileiro. Com efeito, tem-se aceitado que os capítulos "meramente acessórios" são alcançados pelo recurso aviado quanto ao capítulo principal ${ }^{499}$. Porém, onde não haja essa simples acessoriedade entre capítulos, sustenta-se que a contradição lógica entre eles não é capaz, por si só, de autorizar que a impugnação de um capítulo estenda-se a outro ${ }^{500}$.

${ }^{497}$ Principii di diritto processuale civile, cit., p. 988. Na doutrina italiana existe divergência sobre a exata localização sistemática do tema pertinente aos capítulos de sentença vinculados por prejudicialidade. Em famoso ensaio, ANGELO BONSIGNORI refere que os problemas da prejudicialidade não se resolvem mediante apelo à noção de capítulos dependentes [L'effetto devolutivo nell'ambito dei capi conessi (effetto esterno), Rivista trimestrale di diritto e procedura civile. Milano: Giuffrè, anno XXX, 1976, nº 4, p. 962 et seq.]. Porém, GIUSEPPE TARZIA estuda a prejudicialidade sob a perspectiva dos capítulos dependentes (Lineamenti del processo civile di cognizione. 4. ed. Milano: Giuffrè, 2009, $n^{\circ} 91$, p. 359). A postura daquele encontrou, entre nós, ressonância nas especulações de BONÍCIO, Marcelo José Magalhães (op. cit., p. 132 et seq.).

${ }^{498}$ Existe, contudo, orientação segundo a qual o problema e a respectiva solução não estão exatamente no campo da extensão do efeito devolutivo da apelação, mas sim na existência de uma eficácia expansiva da reforma do capítulo prejudicial e de sua "automática" implicação no capítulo prejudicado, tudo em razão de um "princípio de lógica elementar" [BONSIGNORI, Angelo. L'effetto devolutivo nell'ambito dei capi conessi (effetto esterno), cit., $n^{\circ} 3$, p. 957]. Para a crítica a tal postura, consulte-se LEITE, Clarisse Frechiani Lara (Prejudicialidade no processo civil. São Paulo: Saraiva, 2008, p. 205-207), com sólidos argumentos que afastam o simples transporte da orientação doutrinária italiana para o sistema brasileiro. NELSON NERY JUNIOR, de seu lado, alinha-se à orientação italiana, já que versa sobre o tema da prejudicialidade no campo do chamado efeito expansivo objetivo (interno e externo) e não sob o prisma do efeito devolutivo (Princípios fundamentais - teoria geral dos recursos, cit., p. 410 et seq.).

499 BARBOSA MOREIRA, José Carlos. Comentários ao Código de Processo Civil, cit., vol. v, no 196, p. 356. É o que acontece, por exemplo, com os juros moratórios e com as verbas de sucumbência em relação à condenação principal. Se a parte impugna a própria condenação principal, o recurso também "apanha as condenações acessórias e, no caso de provimento, elas ipso facto cessam" (id., n 196, p. 356). NERY JUNIOR explica o mesmo fenômeno valendo-se de terminologia diversa: "efeito expansivo objetivo interno" (Princípios fundamentais - teoria geral dos recursos, cit., p. 410).

${ }^{500}$ BARBOSA MOREIRA, José Carlos. Comentários ao Código de Processo Civil, cit., nº 196, p. 356. 
Exemplificativamente, o recurso interposto apenas quanto ao capítulo de sentença referente à ação declaratória incidental não devolve ao tribunal o conhecimento da matéria pertinente à ação principal. E a hipótese inversa segue a mesma regra, pois o recurso parcial relativo somente à ação principal não investe o órgão ad quem de poderes para apreciar o capítulo pertinente à declaratória incidental.

Nessa perspectiva, a falta de impugnação quanto à ação principal, no primeiro exemplo acima figurado, tornaria tal matéria já abrigada pela coisa julgada. Mas isso não impediria que o tribunal desse provimento à apelação parcial e reconhecesse, conforme o caso, a inexistência da relação jurídica prejudicial, objeto de discussão na declaratória incidental. Do mesmo modo, no segundo exemplo, o tribunal poderia ditar uma decisão sobre a ação principal inconciliável, no plano lógico, com aquela externada pelo juízo de primeiro grau e já atingida pela coisa julgada, exatamente em razão de ter havido mero recurso parcial ${ }^{501}$.

A exemplificação que se vem de expor coloca à mostra que "poderá eventualmente ocorrer contradição lógica entre o pronunciamento de grau inferior e o de grau superior, se neste se declarar inexistente a relação prejudicial, quando aquele reconheceu o direito dependente, ou vice-versa"502.

Não há dúvidas de que o ordenamento convive com as possíveis contradições lógicas entre os julgados, mas também não se pode deixar no olvido o fato de o sistema desejar a congruência lógica entre os julgados. Não por outro motivo é que o legislador determina que, havendo prejudicialidade externa, o juiz deva suspender o processo cuja decisão possa ser influenciada pela conclusão da questão prejudicial discutida noutro processo (CPC, art. 265, IV, alíneas “a" e “c”).

O fato de o legislador fixar um prazo máximo de suspensão, no que confirma a tolerância às contradições lógicas, não afasta a ideia matriz que é a de se procurar, tanto quanto possível, a harmonia dos julgados, em prol da respeitabilidade e da confiança mesmo nos pronunciamentos do Estado.

Tendo em vista que o nexo de prejudicialidade evidencia algum grau de conexão, recomenda-se também a reunião dos processos que assim estejam vinculados, ex vi do art.

501 NERY JUNIOR, Nelson. Princípios fundamentais - teoria geral dos recursos, cit., p. 410-411; BARBOSA MOREIRA, José Carlos. Comentários ao Código de Processo Civil, cit., nº 196, p. 356-357.

${ }^{502}$ BARBOSA MOREIRA, José Carlos. Comentários ao Código de Processo Civil, cit., no 196, p. 357. 
105, do CPC, em mais uma demonstração de que o sistema propende para a consecução da harmonia entre os julgados.

Esse valor - harmonia de julgados - fica ainda mais saliente quando a parte busca alcançá-lo por meio da instauração de um só processo, no âmbito do qual se pretenda a decisão sobre a questão prejudicial e também sobre a prejudicada. Ou seja, quando a parte cumula pedidos que se enlaçam pelo vínculo de prejudiciaidade (cumulação sucessiva) a tônica passa a ser, com superiores razões, a da não contradição lógica entre os capítulos de sentença.

Logo, o que justifica e fomenta a cumulação de pedidos nessa configuração sucessiva não pode ser simplesmente desconsiderado quando se passa do primeiro para o segundo grau de jurisdição ${ }^{503}$.

Conquanto o sistema brasileiro não contemple norma semelhante à do CPC italiano $(\text { art. 336) })^{504}$, mostra-se razoável entender, ainda que por exceção ao tantum devolutum quantum appellatum, que o capítulo de sentença referente à questão prejudicada (condicionada, subordinada ou dependente, não importando a terminologia que se empregue) fica abrangido pelo efeito devolutivo da apelação respeitante ao capítulo de sentença prejudicial, na medida exata da prejudicialidade e com os temperamentos a seguir expostos.

Num caso, por exemplo, em que se discuta a paternidade e a pensão alimentícia, o recurso do réu, declarado pai e condenado a pagar alimentos em primeiro grau de jurisdição, que impugne apenas o capítulo de sentença pertinente à investigação de paternidade possibilita que o tribunal, em caso de acolhimento da tese de que não exista o vínculo de parentesco, lance-se também a decidir sobre a condenação de pagar alimentos, ainda que essa questão não tenha sido objeto do recurso.

Semelhantemente, a apelação do réu, totalmente sucumbente em primeira instância, que impugne apenas o aspecto do debate possessório investe o tribunal da atribuição para

503 Assim diz CÂNDIDO DINAMARCO: "Mesmo sem norma expressa, todavia, essa devolução a maior deve ocorrer, porque seria incoerente reunir em um processo duas ou mais pretensões e dizer que isso é feito em nome da economia e da harmonia entre os julgados, para depois renunciar a essa harmonia e permitir que a causa prejudicada (dependente) ficasse afinal julgada de modo discrepante do julgamento da prejudicial (dominante)" (Capítulos de sentença, cit., no 51, p. 111 - grifos do original).

504 "La riforma o la cassazione parziale ha effetto anche sulle parti della sentenza dipendenti dalla parte riformata o cassata". 
decidir, também, a questão da indenização por perdas e danos (CPC, art. 921, I), desde que se conclua, na apelação, não ter existido o esbulho que é pressuposto da indenização ${ }^{505}$.

Mas o cenário se altera quando, no âmbito da apelação, se conclui pela existência da relação jurídica prejudicial que foi negada em primeira instância. Pense-se na hipótese de a sentença concluir pela improcedência de ambos os pedidos do autor (possessório e indenizatório), sob o argumento de não ter havido esbulho. O autor, nessas condições, apela quanto ao pedido possessório, deixando inatacado o capítulo referente à indenização por perdas e danos. Ainda que o órgão ad quem conclua pela existência do esbulho (capítulo prejudicial), não será possível estender o efeito devolutivo da apelação quanto ao capítulo das perdas e danos (capítulo prejudicado).

O mesmo se dá quando o filho, vencido em primeira instância tanto na investigação de paternidade quanto nos alimentos, interpõe apelação somente em relação à discussão sobre o vínculo biológico, deixando de impugnar os aspectos da pensão alimentícia. $\mathrm{O}$ tribunal poderá reconhecer, em sede de apelação, a existência do vínculo de paternidade, mas nem por isso estará autorizado a revolver o capítulo de sentença sobre os alimentos, o qual não lhe foi “devolvido" pela apelação parcial.

Assim deve ser porque, nas duas hipóteses acima anunciadas, a conclusão sobre a existência do esbulho convive com a ausência de indenização; e o vínculo de paternidade também convive com o não pagamento de pensão alimentícia.

Tenha-se presente, de outro lado, que o recurso endereçado apenas ao capítulo prejudicado em nada pode alterar o quanto decidido no capítulo prejudicial, que já terá ficado, a essa altura, abrigado pelo manto da coisa julgada ${ }^{506}$. Nesse caso, não se encontram justificativas para excepcionar a regra do art. 515 , caput, do $\mathrm{CPC}^{507}$, haja vista que a antecedência lógica dá-se no sentido do capítulo prejudicial para o prejudicado e não do prejudicado para o prejudicial.

Daí parecer razoável a conclusão a que chega CLARISSE F. L. LEITE, em recente monografia sobre o tema da prejudicialidade. Partindo da premissa de que a extensão do efeito devolutivo da apelação constitui hipótese de exceção, o esgarçamento que se propõe

\footnotetext{
${ }^{505}$ O exemplo é dado por CÂNDIDO DINAMARCO (Capítulos de sentença, cit., no ${ }^{\circ}$ 51, p. 111).

${ }^{506}$ BARbOSA MOREIRA, José Carlos. Comentários ao Código de Processo Civil, cit., vol. V, nº 196, p. 356-357.

${ }^{507}$ LEITE, Clarisse Frechiani Lara. Op. cit., p. 212.
} 
em torno da devolutividade há de se restringir ao "mínimo necessário à manutenção da coerência" advinda do nexo de prejudicialidade ${ }^{508}$.

Logo, na medida da validade das asserções acima, podem-se enumerar as seguintes proposições: (i) o recurso apenas em relação ao capítulo prejudicado gera o trânsito em julgado do capítulo prejudicial, circunstância que vinculará o órgão ad quem quanto à apreciação daquele capítulo isoladamente recorrido; (ii) o recurso interposto quanto ao capítulo prejudicial torna possível a extensão do efeito devolutivo à parcela não recorrida da decisão de primeiro grau, nos termos da seguinte distinção: (a) se a apreciação do tribunal redundar num dispositivo incompatível com o dispositivo afeto ao capítulo prejudicado tal como constante do pronunciamento de primeiro grau, o órgão ad quem deverá reformar o capítulo prejudicado nos limites da prejudicialidade; (b) se não se verificar a incompatibilidade entre os dispositivos, o capítulo prejudicado não terá sido devolvido à apreciação do órgão ad quem em razão do recurso pertinente ao capítulo prejudicial $^{509}$.

(vi) renovação da demanda

$\mathrm{Na}$ seara da cumulação eventual e da alternativa, exatamente por se tratar de cumulação imprópria de pedidos, já se averbou que o acolhimento de um dos pedidos implica o não conhecimento do(s) outro(s), que fica(m), assim, prejudicado(s). Resta saber se, uma vez não satisfeito o direito revelado pela procedência de um dos pedidos, abrir-seia oportunidade para nova formulação daquele(s) pedido(s) não apreciado(s).

Perceba-se que o pedido não apreciado, por força do acolhimento de outro deduzido em primazia ou em caráter alternativo, não se submete aos influxos da coisa julgada. Então, não se mostra despropositado pensar que, insatisfeito o direito proclamado em relação ao pedido acolhido na demanda em que se cumularam pedidos (na modalidade eventual ou alternativa), subsistirá o interesse de agir em relação ao pedido não apreciado.

\footnotetext{
${ }^{508}$ Op. cit., p. 211. Assim preleciona a autora: "O instrumento destinado a evitar as incoerências lógicas entre julgados em tais casos, mitigando excepcionalmente a regra da limitação da devolução recursal aos limites da impugnação, tem efeitos limitados, como toda exceção, não sendo capaz de afastar por completo os efeitos decorrentes da inércia da parte" (id., ibid.).

${ }^{509} I d .$, p. $214-215$.
} 
Daí que será viável o manejo de outra demanda por meio da qual se pleiteiem os pedidos não apreciados naquela "primeira" demanda.

Essa mesma questão ganha outros sabores quando se cogita das chamadas ações concorrentes $^{510}$ ou do concurso de ações ${ }^{511}$, o que para abalizada doutrina revela a existência de um verdadeiro concurso de direitos (CARNELUTTI) ${ }^{512}$. Pode-se exemplificar com as hipóteses de vícios redibitórios (CC, art. 441 e seguintes) ${ }^{513}$, de vícios do produto ou do serviço nas relações de consumo (CDC, art. $\left.18, \S 1^{\circ}\right)^{514}$, de aquisição de imóvel com cláusula ad mensuram (CC, art. 500, caput $)^{515}$ e de inadimplemento contratual ${ }^{516}$.

Nessas circunstâncias a causa de pedir, conquanto seja única, dá margem a variados pedidos $^{517}$. Evidente que esses pedidos múltiplos não podem ser cumulativamente fruídos,

${ }^{510}$ LIEBMAN, Enrico Tullio. Ações concorrentes. Eficácia e autoridade da sentença e outros escritos sobre a coisa julgada. Trad. Alfredo Buzaid e Benvindo Aires. 4. ed. Rio de Janeiro: Forense, 2006, p. 209-220.

${ }^{511}$ CRUZ E TUCCI, José Rogério. A causa petendi no processo civil, cit., p. 248. Em doutrina também se encontra a designação "concurso eletivo de ações" (ARRUDA ALVIM. Manual de direito processual civil, cit., vol. I, $\mathrm{n}^{\mathrm{o}} 134$, p. 421).

512 Esse aspecto foi noticiado por LIEBMAN, que aderiu à asserção de CARNELUTTI ao dizer: "Deriva dessas premissas que o concursus actionum se apresenta no direito moderno, ao menos no seu núcleo central, sub specie de um concurso de direitos" (Ações concorrentes, cit., p. 212). Confira-se, nesse mesmo sentido, importante ensaio de CÂNDIDO DINAMARCO ("Electa una via non datur regressus ad alteram". In: Fundamentos do processo civil moderno. 6. ed. São Paulo: Malheiros, 2010. t. I, p. 495-516).

${ }^{513} \mathrm{Na}$ presença de vícios ou defeitos ocultos que tornem a coisa, recebida em razão de contrato comutativo, imprópria ao uso a que é destinada ou lhe diminuam o valor, o adquirente pode enjeitar a coisa (redibir o contrato; ação redibitória) ou reclamar abatimento no preço (ação estimatória ou quanti minoris).

514 Não sendo o vício sanado no prazo de 30 dias, o consumidor tem, alternativamente, o direito (i) à substituição do produto por outro da mesma espécie, em perfeitas condições de uso, (ii) à restituição imediata da quantia paga, monetariamente atualizada, sem prejuízo de eventuais perdas e danos e (iii) ao abatimento proporcional do preço.

${ }^{515}$ O comprador, nas hipóteses de aquisição de bem imóvel com estipulação de preço por medida de extensão ou com determinação da respectiva área, tem direito ao complemento da área (actio ex empto) e, não sendo isso possível, à resolução do contrato (actio redhibitoria) ou ao abatimento proporcional ao preço (actio quanti minoris), para o caso de a área não corresponder às dimensões indicadas no contrato.

${ }^{516}$ Os contratos bilaterais, quando inadimplidos, geram para a parte inocente o direito à execução imperativa da avença ou à resolução por incumprimento. E mais, se houver cláusula penal para o caso de total inadimplemento, esta se converterá, também, em mais uma alternativa a benefício do credor (CC, art. 410). 517 FREDERICO MARQUES, José. Instituições de direito processual civil, cit., vol. III, no 577, p. 67. Relembre-se que LIEBMAN designou de "concurso impróprio de ações" a hipótese de os vários pedidos 
razão pela qual só tem sentido cogitar-se desse problema na seara mesmo da cumulação imprópria de pedidos (cumulação eventual e alternativa). Versando o assunto, LiEBMAN esclareceu que nada impede que os pedidos sejam cumulados num mesmo processo, desde que se faça sob a condição de que um deles seja formulado "em forma eventual" 518 .

A despeito da controvérsia que ainda grassa em torno do tema, afigura-se compatível com a noção de acesso à justiça e com a visão instrumental do processo a orientação segundo a qual a efetiva satisfação de um dos pedidos é que pode implicar a extinção dos demais direitos derivados da mesma situação jurídica, em ordem a se impor o falecimento do interesse de agir relativamente às outras pretensões.

Significa dizer, ao contrário do que professam ARRUDA ALVIM ${ }^{519}$ e FREDERICO MARQUES $^{520}$, que a simples procedência de um dos pedidos não afasta, por completo, o interesse de agir relativamente aos outros possíveis pedidos que, dado o acolhimento daquele, resultaram prejudicados. Basta imaginar - para confirmação da tese - a situação em que o direito reconhecido na sentença de procedência não seja satisfeito (execução infrutífera por algum motivo).

$\mathrm{Na}$ trilha do que se vem de defender, pondera-se que "é a extinção de um dos direitos concorrentes que produz a extinção dos demais" ${ }^{521}$ e não a simples pronúncia de procedência de um deles e nem mesmo o trânsito em julgado da decisão. Aliás, nem mesmo a propositura de execução relativa ao direito reconhecido na sentença produz a extinção dos direitos concorrentes, isto porque, consoante se tem enfatizado, “já ensinara

decorrerem de uma mesma causa de pedir. O concurso próprio de ações (ou concurso objetivo) ocorre quando existe multiplicidade de causa de pedir e um só pedido (Ações concorrentes, cit., p. 213-217).

${ }^{518}$ Ações concorrentes, cit., p. 214.

519 "Se, no caso, a lei permite optativamente à parte o uso de uma ou outra ação, se uma delas tiver sido usada, impossível, por falta de interesse protegível pelo direito, a utilização da outra" (Direito processual civil: teoria geral do processo de conhecimento. São Paulo: RT, 1972. vol. II, p. 380). "Se a ação concorrente foi julgada procedente, obviamente exauriu-se, do ponto de vista jurídico, o interesse do autor: a sua pretensão, que era fundada, recebeu sentença favorável. Não tem mais o autor, por essa razão, direito à outra ação concorrente" (Manual de direito processual civil, cit., vol. 1, nº 134, p. 423).

${ }^{520}$ Tratando da hipótese de vício redibitório, o autor enfatizou: "Claro está que condenado o vendedor ao abatimento do preço, não será dado ao autor pedir a resilição do contrato, mas isto por fôrça da res judicata" (Instituições de direito processual civil, cit., vol. III, nº 578, p. 68).

${ }^{521}$ DINAMARCO, Cândido Rangel. "Electa una via non datur regressus ad alteram”, cit., n 247, p. 506 (grifos do original). 
superiormente Chiovenda que o que extingue a ação concorrente é a efetiva satisfação do direito" ${ }^{522}$.

Daí se poder inferir que, mesmo no âmbito do chamado concurso de ações e tendo havido cumulação eventual ou alternativa de pedidos, aquelas pretensões que ficarem prejudicadas em virtude do acolhimento do pedido primário (no caso de cumulação eventual) ou de um dos pedidos (na cumulação alternativa) poderão ser, numa segunda demanda, outra vez formuladas na hipótese de não se alcançar a efetiva satisfação do direito reconhecido na primeira demanda.

\section{Conclusão do capítulo}

Acredita-se que as noções até aqui debatidas sejam úteis para o desenvolvimento do tema litisconsorcial proposto, na medida em que se tentará transplantar para o campo da complexidade subjetiva, no que couber, o paradigma teórico que já se tem por fixado em tema de cumulação de pedidos.

Afora o aporte teórico, as vicissitudes relativas aos requisitos de admissibilidade e às variadas consequências da cumulação de pedidos servirão de estrutura para a construção da ponte que se almeja estabelecer entre a cumulação eventual, alternativa e sucessiva de pedidos e o aqui chamado litisconsórcio eventual, alternativo e sucessivo.

Mas ainda é preciso refluir à visão instrumental do direito processual civil, entendido como instrumento para concretização do direito material, e traçar algumas noções extraídas diretamente de relações jurídicas substanciais, à luz das quais será possível verificar notáveis influências para o encaminhamento das ideias sobre as modalidades litisconsorciais aqui investigadas.

Conforme lúcida ponderação doutrinária, mais importante do que constatar a premissa de que o direito processual civil serve ao direito material é "fundamental criar condições para bem aplicá-la, realizá-la, torná-la eficaz, torná-la verdadeira" ${ }^{\natural 23}$. De fato, a

\footnotetext{
${ }^{522}$ DINAMARCO, Cândido Rangel. "Electa una via non datur regressus ad alteram”, cit., n 247, p. 506 (grifos do original).

${ }^{523}$ SCARPINELLA BUENO, Cassio. Curso sistematizado de direito processual civil, cit., vol. 1, p. 50.
} 
construção da técnica passa, inexoravelmente, pela verificação dos caracteres da crise de direito material que se busca solucionar no ambiente do processo ${ }^{524}$.

Daí a utilidade, ou melhor, a necessidade de se passar em revista, em seus aspectos básicos, como pressuposto para concretização da exigência exposta no parágrafo anterior, alguns institutos de direito material que tenderão a sedimentar o caminho que vai das necessidades do direito material até a conformação da técnica processual respeitante ao litisconsórcio. Disso se ocupa o próximo capítulo.

${ }^{524}$ BEDAQUE, José Roberto dos Santos. Direito e processo, cit., p. 22. 


\section{Capítulo III}

\section{NECESSIDADES ADVINDAS DO DIREITO MATERIAL}

\section{Nota prévia}

$\mathrm{Na}$ Introdução deste trabalho fez-se menção a que os casos não rotineiros e que não encontram respostas extraíveis a partir de um rápido raciocínio dedutivo permitem acentuar a utilidade da tópica jurídica, consistente num modo de pensar problemático, isto é, partindo-se do próprio problema para depois se construir a norma jurídica aplicável.

À medida que a sociedade incrementa o seu nível de complexidade, torna-se mais difícil encontrar soluções jurídicas pelo método subsuntivo da lógica clássica. Em tema de partes e de terceiros, por exemplo, já se afirmou alhures que as dificuldades tendem a se multiplicar, haja vista que as relações de direito material evidenciam-se cada vez mais complexas, em ordem a embaraçar o encarte preciso das variadas situações nas modalidades de intervenção de terceiros concebidas pelo legislador ${ }^{525}$.

E neste trabalho pretende-se avançar e dizer que um quadro semelhante ao anunciado no parágrafo antecedente pode gerar reflexos na seara do litisconsórcio, colocando-se a descoberto situações para as quais o legislador não tem soluções prontas.

Nessa perspectiva, não parece despropositado analisar-se, em primeira mão, o próprio problema e, a partir dele, "estabelecer os pressupostos de uma solução",526.

É bem verdade que esse modelo problemático não substitui e tampouco apequena o modo dedutivo de raciocinar, mas parece bem interessante notar que o método tópico encontra espaço propício para incidir "nos setores críticos de aplicação do Direito",527.

\footnotetext{
525 ARRUDA ALVIM WAMBIER, Teresa; WAMBIER, Luiz Rodrigues. Casos problemáticos: partes ou terceiros? (análise de algumas situações complexas de direito material), cit., p. 1035.

${ }^{526}$ ALVIM, Arruda. Argüição de relevância no recurso extraordinário. São Paulo: RT, 1988, p. 3.

${ }^{527}$ Id., p. 3. Para aprofundamentos, na doutrina brasileira, consulte-se MARTINS-COSTA, Judith ( $A$ boa fé no direito privado. São Paulo: RT, 1999, p. 355 et seq.), com ampla resenha bibliográfica.
} 
Eis o motivo pelo qual se optou por delinear alguns problemas advindos da própria conformação da relação de direito material para depois, à luz destes, buscar uma resposta processual que se possa extrair do sistema, já que na vertente litisconsorcial aqui estudada não se tem regra positivada pelo legislador.

Vale considerar, ainda, que uma das premissas fundamentais de toda a construção que virá adiante diz respeito à aproximação entre direito e processo $\left(\mathrm{n}^{\circ} 8\right.$, supra $)$, de sorte que, em certa medida, as noções expostas no presente Capítulo têm por finalidade demonstrar em que medida as peculiaridades de certas relações de direito material poderão realmente influenciar o específico tratamento do litisconsórcio eventual, alternativo e sucessivo.

Em suma, neste Capítulo contém-se um desdobramento da premissa concernente à necessária aproximação entre direito e processo. Por tal motivo optou-se por manter essa tratativa no âmbito da Parte que respeita ainda às premissas.

Poder-se-ia, noutra configuração metodológica, utilizar a exemplificação constante deste Capítulo como fonte de testagem de toda a construção litisconsorcial que virá. Porém, com base nos motivos acima vertidos, preferiu-se dar especial ênfase à justificação e, assim, conferir vida à noção de que o direito processual se deixa influenciar pela conformação do direito material.

Mas nem por isso se vai relegar ao esquecimento a necessária checagem quanto à aptidão das modalidades litisconsorciais eventual, alternativa e sucessiva para responder às específicas necessidades do direito material. Essa empreitada virá pouco a pouco, em forma de exemplificações, quando se ocupar do tema da dinâmica litisconsorcial (Parte III, Cap. IV).

A partir, então, dessa explicação prévia, sente-se à vontade para ingressar no inesgotável universo das dificuldades advindas do direito material, com anúncio singelo dos possíveis problemas gerados na órbita do processo, mais especificamente no campo do litisconsórcio. 


\section{Responsabilidade civil do incapaz: Código Civil de 2002}

Abeberando-se em fontes estrangeiras, o Código Civil em vigor disciplinou a responsabilidade civil do incapaz nos seguintes termos: "O incapaz responde pelos prejuízos que causar, se as pessoas por ele responsáveis não tiverem obrigação de fazê-lo ou não dispuserem de meios suficientes" (art. 928, caput). No parágrafo único do mesmo artigo, o legislador estabeleceu que a obrigação indenizatória que se impuser ao incapaz será equitativa e "não terá lugar se privar do necessário o incapaz ou as pessoas que dele dependam".

Consoante a doutrina especializada, entende-se que o Código Civil adotou um critério mitigado e subsidiário para responsabilização do incapaz que cause dano a outrem $^{528}$. Mitigado porque a regra em destaque, em tom de excepcionalidade, afasta-se daquela noção básica de que a indenização deve ser integral; subsidiário porquanto a obrigação indenizatória só se concretiza na pessoa do incapaz nos casos em que o seu representante não tenha obrigação de reparar o dano ${ }^{529}$ ou não ostente condições financeiras para fazê-lo.

JOSÉ FERNANDO SIMÃO, em obra voltada especificamente ao tema em pauta, arrola as hipóteses em que o incapaz responde pela indenização: a) quando não houver representante legal; $b$ ) quando o adolescente praticar ato infracional com reflexo

${ }^{528}$ CAVALIERI FILHO, Sergio. Programa de responsabilidade civil. 4. ed. São Paulo: Malheiros, 2003, p. 47; GONÇALVES, Carlos Roberto. Responsabilidade civil. 9. ed. São Paulo: Saraiva, 2005, p. 15. A antinomia entre o disposto no art. 928 e o que estabelece o art. 942, ambos do Código Civil, resolve-se pelo princípio da especialidade, de modo que, no caso, não há falar-se em solidariedade, mas, sim, em subsidiariedade (SIMÃO, José Fernando. Responsabilidade civil do incapaz. São Paulo: Atlas, 2008, p. 220). RUI STOCO, sem ver qualquer contradição entre tais dispositivos, também se inclina pela tese de que a responsabilidade do incapaz é subsidiária ou secundária (Tratado de responsabilidade civil: doutrina e jurisprudência. 7. ed. São Paulo: RT, 2007, p. 815). Em senso contrário, entendendo que se cuida de responsabilidade solidária, TAVARES DA SILVA, Regina Beatriz [In: FIUZA, Ricardo (coord.). Novo Código Civil Comentado. 2. ed. São Paulo: Saraiva, 2004, p. 843].

${ }^{529}$ Há, porém, manifestação doutrinária no sentido de que essa ressalva tornou-se inócua diante da regra do art. 933, do CC, onde se lê que a responsabilidade civil dos pais, tutores e curadores patenteia-se mesmo que não haja culpa de sua parte em relação ao comportamento danoso do terceiro (GONÇALVES, Carlos Roberto. Responsabilidade civil, cit., p. 15-16). 
patrimonial; c) quando os representantes não tiverem obrigação de fazê-lo; d) quando os representantes não dispuserem de meios para indenizar ${ }^{530}$.

Para o enfoque processual que se pretende dar ao assunto, interessa analisar com mais detença as duas últimas hipóteses acima aventadas: ausência de obrigação por parte dos representantes e falta de meios financeiros para cobrir o valor da indenização.

Tendo em vista que a legislação não anunciou as hipóteses em que se afasta a obrigação do representante do incapaz, a doutrina animou-se a indicar quatro situações fundamentais: $i$ ) dano causado pelo pródigo; $i$ ) filho menor que não está sob autoridade $\mathrm{e}$ na companhia dos pais; iii) emancipação do filho menor; iv) força maior ou caso fortuito $^{531}$.

Mais uma vez importa fazer um corte na apreciação dessas hipóteses, pois que a primeira e a última situações versadas no parágrafo anterior não guardam relevância para o estudo do litisconsórcio. Sendo assim, concentra-se a análise no ponto que diz respeito (1) à ausência de obrigação do representante porque o ofensor incapaz não está sob autoridade e companhia daquele e (2) também à hipótese em que há emancipação de filho menor.

Assim deve ser porque, segundo a tratativa que vem do direito material, existem condicionantes fáticas que, se presentes ou ausentes, vão determinar a responsabilização deste ou daquele sujeito (do representante ou do incapaz).

Como já sinalizado, o representante do incapaz (pai, tutor ou curador) só responde pelo dano causado por este quando o ofensor esteja sob sua autoridade e companhia, tal como determinam os incisos I e II do art. 932 do Código Civil ${ }^{532}$.

A expressão "autoridade" impregna-se de conteúdo exclusivamente jurídico, a implicar, no caso, que o filho está sob o poder familiar, que o pupilo está sob a tutela e o curatelado sob curatela ${ }^{533}$. "Autoridade, portanto, não é matéria de fato, mas, sim, de direito" $" 534$.

\footnotetext{
${ }^{530}$ Op. cit., p. 153 et seq.

${ }^{531}$ SIMÃO, José Fernando. Op. cit., p. 158 et seq. mesmas condições.

${ }^{533}$ SIMÃO, José Fernando. Op. cit., p. 162.

${ }^{534}$ Id., ibid.
}

${ }^{532}$ São também responsáveis pela reparação civil: I - os pais, pelos filhos menores que estiverem sob sua autoridade e em sua companhia; II - o tutor e o curador, pelos pupilos e curatelados, que se achem nas 
Diferentemente, a noção de “companhia" está envolta a condições predominantemente fáticas, muito embora a conotação jurídica também não se possa $\operatorname{afastar}^{535}$.

Essa discussão ganha relevância nos casos de pais separados, pois o guardião terá o filho sob sua autoridade e companhia, mas, durante o exercício da visitação, o outro genitor é que estará naquelas condições, tudo a ensejar, conforme o caso, a responsabilização civil de um ou de outro ${ }^{536}$.

Essas indagações em torno do fator "companhia" podem ser transportadas, $v . g$, para as relações entre curador e curatelado. Não são raras as situações - e aqueles que militam em Varas de Família o sabem bem - em que o incapaz tem um curador nomeado, mas, de fato, não fica na companhia deste, situação que, uma vez verificada, tem o condão de afastar a responsabilidade civil do curador e ensejar o reconhecimento de que a responsabilização tocará ao próprio incapaz.

Como se vê, o aspecto relacionado à "companhia" entrosa-se com variantes fáticas que, diante da divergência entre as asserções lançadas pelas partes na tela processual, estarão a demandar a produção de provas no âmbito já da instrução processual.

Portanto, saber se o responsável pela indenização, nas hipóteses aqui consideradas, será um ou outro sujeito dependerá da convicção que se formar à luz da prova produzida em torno das questões fáticas aqui ponderadas.

De outro lado, discute-se em doutrina sobre a possibilidade de a emancipação voluntária afastar a responsabilidade civil dos pais pelos atos dos filhos ainda menores. Há aqueles, como CARlos RoBERTO GONÇALVES, que propugnam no sentido de a emancipação não produzir o efeito de isentar os pais da responsabilidade pelos atos ilícitos perpetrados pelos filhos ${ }^{537}$. Porém, existe orientação igualmente prestigiosa segundo a qual

\footnotetext{
535 “A companhia é um elemento fático, mais que jurídico. Entretanto, não é meramente fático. Se assim fosse, só seria responsável o pai que estivesse na presença física do filho no momento em que este causou o dano. A companhia não é presença física e, dessa forma, o pai que viaja a trabalho continua responsável pelos atos de seu filho, pois mantém sua autoridade e companhia” (SIMÃO, José Fernando. Op. cit., p. 163). ${ }^{536} I d$., p. 165.

${ }^{537}$ Responsabilidade civil, cit., p. 18. No mesmo sentido parece ser a opinião que CAVALIERI FILHO externou no seu Programa de responsabilidade civil, cit., p. 191, uma vez que recebeu com aplausos o Enunciado $\mathrm{n}^{\mathrm{o}} 41$ da Jornada de Direito Civil promovida pelo Centro de Estudos do Conselho da Justiça Federal, que tem a seguinte redação: “A única hipótese em que poderá haver responsabilidade solidária do
} 
os pais de filho emancipado, de regra, não respondem civilmente pelo dano causado por este, ressalvada a hipótese em que a emancipação decorra de comportamento fraudulento ou culposo dos pais ${ }^{538-539}$.

Em síntese, a adoção da tese jurídica de que filho emancipado responde sozinho pelos prejuízos que causar cria ambiente propício ao afastamento da responsabilidade dos pais, de maneira que esta seria uma situação que, analisada sob a luz do art. 928, do Código Civil, implicaria a fixação, pelo juiz, da indenização equitativa a que alude o mencionado dispositivo. Porém, aceitando-se a postura interpretativa que vê na emancipação culposa ou fraudulenta - e aqui se entrosam ingredientes fáticos e jurídicos uma realidade apta a responsabilizar os pais, ficaria afastada, se provadas aquelas condições, a responsabilidade do filho, que é, como já visto, subsidiária.

Ainda na perspectiva do art. 928, do Código Civil, tem-se que a responsabilidade do incapaz só decola quando o seu responsável (pais, tutor ou curador) não tenha condições econômicas para fazer frente ao quantum da reparação ${ }^{540}$.

menor de 18 anos com seus pais é ter sido emancipado nos termos do art. $5^{\circ}$, parágrafo único, inciso I, do novo Código Civil". Porém, na mesma página acima indicada, o autor propõe que a "emancipação que se revelar como ato impensado não tem o condão de afastar a responsabilidade dos pais, segundo a melhor doutrina" (id., p. 191). Logo, o raciocínio do autor analisado a contrario sensu leva à conclusão de que a emancipação não reveladora de ato impensado rende ensejo ao afastamento da responsabilidade civil dos pais.

538 DIREITO, Carlos Alberto Menezes; CAVALIERI FILHO, Sergio. Comentários ao novo Código Civil. Rio de Janeiro: Forense, 2004, vol. XIII, p. 205. Adverte-se que nessa obra conjunta, muito provavelmente pela influência do pensamento que CAVALIERI FILHO já havia externado em seu Programa de responsabilidade civil, os autores retomam a adesão aos termos do Enunciado 41, da Jornada de Direito Civil.

${ }^{539}$ SIMÃO, José Fernando. Op. cit., p. 177. Para justificar a assertiva, o autor lança exemplos interessantes: "Exemplifica-se: o menor com 16 anos que é aprovado em exame vestibular e muda-se para outra cidade; a emancipação por iniciativa do pai, que permitirá a seu filho a prática de atos da vida civil sem a necessidade de assistência não tem caráter fraudulento. Essa emancipação deve produzir todos os efeitos, inclusive no tocante à responsabilidade pelos eventuais ilícitos praticados pelo filho. Imagine-se, ainda, situação do filho que resolve tentar a sorte em um longínquo Estado da federação e, para tanto, é emancipado pelos pais que perdem, inclusive, o contato com ele. Seria justo impor-lhes o dever de reparar o dano nos termos do art. 932 , I, do Código Civil?” (id., p. 176-177).

${ }^{540}$ A doutrina põe em dúvida se esse fator diz respeito propriamente à responsabilidade civil (aspecto de direito material) ou à responsabilidade patrimonial (questão processual). Sobre o ponto, consulte-se, com proveito, FERREIRA, William Santos [Aspectos materiais e processuais da responsabilidade patrimonial do 
Então, essa condicionante fática (compostura do patrimônio dos responsáveis) pode ingressar como elemento de dúvida objetivamente fundada em torno de quem possa ser o responsável pela indenização, partindo-se, evidentemente, daquela premissa segundo a qual a responsabilidade civil do incapaz é subsidiária. Mais uma vez, está-se diante de situação que, para ser solucionada com segurança, demanda dilação probatória que só se verificará já no âmbito do processo instaurado entre os possíveis litigantes.

Essas alusões provindas todas do direito material servem para pôr em evidência que o ofendido (autor da pretensão de cunho indenizatório) achar-se-á, nas situações acima elencadas, diante de dúvida fundada em torno de quem pode ser o efetivo responsável pela indenização reclamada, circunstância que influencia a configuração do polo passivo da relação processual já na fase de conhecimento, mas que só pode ser resolvida, como assinalado, depois de produzida a prova sobre aquelas condicionantes fáticas donde promanam a responsabilidade civil de um ou de outro sujeito (do próprio incapaz ou de seus representantes).

Não se descarta, outrossim, que a dúvida em torno do sujeito responsável pela indenização possa decorrer de incertezas no encaminhamento da matéria no âmbito da doutrina e da jurisprudência. Em outras palavras, a inclinação por esta ou por aquela orientação jurídica quanto à conformação do direito material dá azo a conclusões diversas sobre quem deva responder pelo dano ilicitamente causado pelo incapaz.

Por fim, importante considerar que na tela processual não se deve trabalhar com a ideia de que o incapaz só seria trazido ao processo já na fase de execução, isto é, depois de constatada a insuficiência do patrimônio de seus responsáveis, tendo estes, sozinhos, participado da fase de cognição. Em verdade, não se pode prescindir da inclusão do incapaz no polo passivo da demanda desde a fase cognitiva, pois só assim se formará contra ele o indispensável título executivo autorizador da deflagração dos atos constritivos de seu patrimônio ${ }^{541}$.

incapaz. In: DIDIER JR. Fredie; MAZZEI, Rodrigo (coord.). Reflexos do novo Código Civil no direito processual. 2. ed. Salvador: JusPodivm, 2007, p. 355 et seq.].

${ }^{541}$ YARSHELL, Flávio Luiz. Três temas de direito processual no âmbito do direito das obrigações e dos contratos. In: FILOMENO, José Geraldo Brito; WAGNER JUNIOR, Luiz Guilherme da Costa; GONÇALVES, Renato Afonso (coord.). O Código Civil e sua interdisciplinaridade: os reflexos do Código Civil nos demais ramos do direito. Belo Horizonte: Del Rey, 2004, p. 311. Mesmo sob a premissa de que o art. 928, do Código Civil, trate da responsabilidade patrimonial do incapaz - e não de sua responsabilidade 


\section{Responsabilidade dos pais pelos filhos: paternidade socioafetiva}

No atual estágio de evolução do Direito de Família apregoa-se que a paternidade não configura fruto exclusivo do vínculo biológico, em ordem a se reconhecer a existência de outros vínculos de significação tal que, em certos casos, sobrepujam aquela condição natural (biológica). Assim é que "o parentesco contém elementos biológicos, afetivos e jurídicos ${ }^{, 542}$.

Nesse rumo, o art. 1.593, do Código Civil, estabelece que o parentesco pode ser natural ou civil, conforme resulte de consanguinidade ou outra origem. Será natural quando derivar de vínculos biológicos; a adoção, por sua vez, constitui o exemplo clássico para o chamado parentesco civil.

Dessa forma, a doutrina enxerga na expressão "outra origem" um espaço aberto para o reconhecimento legal da parentalidade socioafetiva ${ }^{543}$, cuja emanação mais relevante pode verificar-se exatamente nos embates que envolvem a paternidade socioafetiva.

Considerados os limites e objetivos deste trabalho, importa que sejam estabelecidas as diretrizes doutrinárias acerca do que vem a ser a paternidade socioafetiva e, uma vez estabelecidas estas, constatar as consequências desse tipo de situação no campo da responsabilidade civil.

Nessa empreitada, inicia-se por afirmar que a paternidade socioafetiva, porquanto não atrelada à noção biológica, identifica-se com a chamada "posse do estado de filho", resultante da tríade nomen, tractus e fama $^{544}$. Cuida-se de relação não documentada, mas

civil pelo evento danoso - tem-se entendido que sua participação já na fase de cognição seja mesmo imprescindível (FERREIRA, William Santos. Aspectos materiais e processuais da responsabilidade patrimonial do incapaz, cit., p. 367).

${ }^{542}$ SIMÃO, José Fernando. Op. cit., p. 147.

${ }^{543}$ Id., p. 146.

${ }^{544} I d$., p. 148. Assim, conclui o autor citado, "para que haja a posse do estado, é necessário que carregue o nome da família, seja tratado como filho e que sua condição oriunda da filiação seja reconhecida socialmente. Afinal, quem cria um filho que não traz consigo laços biológicos pressupõe que o desejo permeou esta relação, construindo-se o afeto". Porém, adverte-se que "elemento nomen, nem sempre presente, muitas vezes não é considerado fator relevante na determinação da paternidade socioafetiva" (id., p. 148). 
que se exterioriza por comportamentos diários do relacionamento entre os pais e os filhos $^{545}$.

Pondere-se, contudo, que a paternidade socioafetiva distingue-se da mera afinidade que se estabelece entre madrastas e padrastos e seus enteados. "A relação jurídica, nessa hipótese, não é de filiação, mas, sim, de parentesco por afinidade" ${ }^{\natural 546}$, nos exatos termos do que dispõe o art. 1.595, do Código Civil. Eis o motivo por que a doutrina enfatiza, com razão, que o "pai socioafetivo é pai e não apenas padrasto",547.

Do exposto pode-se concluir que a paternidade socioafetiva, exatamente por não ser objeto de registro civil, exterioriza-se por elementos exclusivamente fáticos, não sendo possível excogitar-se, para fins processuais, da formação de alguma prova pré-constituída, como ocorre com a certidão de nascimento no âmbito da paternidade biológica registrada.

Remarque-se, outrossim, que o só fato da existência da paternidade socioafetiva não gera a extinção do vínculo biológico e muito menos implica, por si só, o cancelamento do registro civil da paternidade natural.

Pois bem. No campo das consequências do fato da paternidade socioafetiva prepondera a noção de que o pai socioafetivo responde pelos atos danosos causados pelo filho, conforme esclarece a doutrina civilista ${ }^{548}$.

À luz desse cenário, põe-se a questão de uma possível dúvida sobre a própria configuração da paternidade socioafetiva, a qual, como já se viu, deriva de elementos fáticos de variada ordem (nomen, tractus e fama). Tais elementos, como é intuitivo imaginar, só serão delineados, com a segurança desejável, após dilação probatória no âmbito do processo em que a questão for agitada.

Tendo em conta que a paternidade socioafetiva não exclui, por si só, a paternidade biológica documentada em registro de nascimento, surge um quadro de dúvida objetivamente fundada sobre quem deve ser o responsável pelo ato culposo e danoso do

545 "É aquele pai que mantém o sustento do menor, que lhe dá carinho sempre e que o repreende quando necessário, cuidando de sua educação e formação" (SIMÃO, José Fernando. Op. cit., p. 149).

${ }^{546} I d .$, ibid.

${ }^{547}$ Id., p. 150.

548 “Assim, nas hipóteses de reparação civil as conseqüências não podem ser diferentes. A paternidade socioafetiva gera as conseqüências da paternidade biológica, com a total e plena responsabilidade dos pais pelos atos dos filhos. Demandado, o pai socioafetivo, este não terá o direito de se escusar do dever de indenizar, alegando a inexistência de paternidade biológica ou jurídica" (Id., ibid). 
filho, tudo em razão das condicionantes fáticas que envolvem a noção de paternidade socioafetiva. E assim se dá porquanto a responsabilidade civil de um afasta a do outro.

\section{Responsabilidade civil subsidiária do Estado pelos atos de suas autarquias e das concessionárias ou permissionárias de serviço público}

Nos termos do art. $37, \S 6^{\circ}$, da Constituição Federal, as pessoas jurídicas de direito público e as de direito privado prestadoras de serviços públicos respondem pelos danos que seus agentes, nessa qualidade, causarem a terceiros.

Disso decorre que as autarquias, sendo pessoas jurídicas de direito público e dotadas de personalidade e patrimônio próprios, respondem diretamente pelos prejuízos que causarem. Nessa hipótese, a autarquia é quem será demanda, não o Estado ${ }^{549}$.

Tal cenário, porém, não afasta por completo a vinculação do Estado às consequências da responsabilidade de suas autarquias. Se é certo que o Estado não responde solidariamente, não menos correta é a noção de que não se dá o seu completo alheamento. Com efeito, exaurido o patrimônio da autarquia, "o Estado acorre, obrigatòriamente, para solver as obrigações não satisfeitas" ${ }^{550}$.

Dessa forma, havendo indícios sérios de exaurimento do patrimônio de uma determinada autarquia, exsurge nítida a possibilidade de responsabilização subsidiária do Estado (entidade política criadora da autarquia, seja ela Municipal, Estadual, Distrital ou Federal). Tal situação enseja, igualmente, a verificação de uma condicionante fática relacionada com a noção de exaurimento do patrimônio da autarquia, tudo a ensejar o aparecimento de dúvidas sobre a pessoa jurídica efetivamente apta a suportar o peso de uma eventual obrigação indenizatória.

No âmbito das empresas prestadoras de serviços públicos, verifica-se, ainda em razão do que se contém no art. $37, \S 6^{\circ}$, da Constituição Federal, que a responsabilidade civil é objetiva, sendo relevante pôr em evidência que aquelas pessoas jurídicas de direito privado respondem com seu próprio patrimônio em relação aos prejuízos que causarem aos

\footnotetext{
${ }^{549}$ BANDEIRA DE MELLO, Celso Antônio. Natureza e regime jurídico das autarquias. São Paulo: RT, 1968, p. 465.

${ }^{550} I d .$, p. 466, com ampla resenha bibliográfica.
} 
usuários ou a terceiros (art. 25, da Lei $\mathrm{n}^{\circ}$ 8.987/95). O Estado, nessas hipóteses, não responde por elas e tampouco com elas ${ }^{551}$.

Por isso a doutrina verbera que o Estado, no máximo, responde subsidiariamente pelos danos causados pelas concessionárias ou permissionárias de serviços públicos ${ }^{552}$, tomando-se por base o que dizia o art. 242, da Lei das Sociedades por Ações, à luz do qual a pessoa jurídica controladora responderia subsidiariamente pelas obrigações da sociedade de economia mista.

Celso Antônio Bandeira de Mello, depois de afirmar que o prestador de serviço público gere o serviço por sua conta, risco e perigos, sendo dele, portanto, a responsabilidade por eventuais danos que venha a causar, alude à hipótese em que a pessoa jurídica prestadora de serviço possa achar-se em situação de insolvência, caso em que “parece indubitável que o Estado terá que arcar com os ônus daí provenientes”, com a observação, porém, de que se deve "falar em responsabilidade subsidiária (não solidária) ${ }^{, 553}$ do Estado.

HELy LOPES MEIRELLES, ao tratar dos chamados agentes delegados, dentre os quais se destacam os concessionários e permissionários de obras e de serviços públicos, igualmente defendeu que a responsabilidade (subsidiária) do Estado só aflora quando "a vítima comprove a insolvência do delegado, devedor principal" ${ }^{554}$.

${ }^{551}$ CAVALIERI FILHO, Sergio. Op. cit., p. 251.

${ }^{552}$ Id., p. 252. Em sentido contrário manifesta-se GUSTAVO TEPEDINO, para quem o Código de Defesa do Consumidor (art. $3^{\circ}$ e art. 17) autoriza falar-se em responsabilidade solidária (A evolução da responsabilidade civil no direito brasileiro e suas controvérsias na atividade estatal. In: Temas de direito civil: Rio de Janeiro: Renovar, 1999, p. 197). A jurisprudência do STJ segue a orientação defendida no texto, conforme se verifica pelo teor da seguinte ementa: "Há responsabilidade subsidiária do Poder Concedente, em situações em que o concessionário não possuir meios de arcar com a indenização pelos prejuízos a que deu causa” (STJ, REsp 1.135.927/MG, $2^{\text {a }}$ T., Rel. Min. Castro Meira, j. 10.08.2010, DJe 19.08.2010).

553 Prestação de serviços públicos e administração indireta. São Paulo: RT, 1973, p. 57. Eis o parecer conclusivo do administrativista: "É razoável, então, concluir que os danos resultantes de atividade diretamente constitutiva do desempenho do serviço, ainda que realizado de modo faltoso, acarretam, no caso de insolvência do concessionário, responsabilidade subsidiária do poder concedente” (id., p. 57-58). De sua parte, YUSSEF CAHALI alerta que o Estado poderia responder direta e solidariamente quando demonstrado que a falha na escolha ou na fiscalização da concessionária tenha concorrido para a causação do resultado danoso (Responsabilidade civil do Estado. 3. ed. São Paulo: RT, 2007, p. 124).

554 Direito administrativo brasileiro. 26. ed. São Paulo: Malheiros, 2001, p. 76. No ponto, o autor foi enfático: "Note-se bem que a responsabilidade do delegante não é conjunta nem solidária com a do delegado; 
Partindo-se, então, da premissa de que a responsabilidade do Estado, nesses casos, desponta subsidiária e que a insolvência do concessionário (ou permissionário) constitui uma questão de fato a ser dirimida depois de ampla atividade probatória, surge, uma vez mais, a dúvida objetivamente fundada sobre quem deva responder pelo dano afirmado pelo ofendido.

Com efeito, a existência de sinais de insolvência não serve para indicar, com segurança, a existência desse quadro economicamente deficitário, mas dá margem a séria dúvida acerca da presença do fator que desencadeia a aludida responsabilidade subsidiária do poder concedente.

\section{Colisões múltiplas em acidente de trânsito}

A doutrina refere casos de tríplice colisão entre veículos, sugerindo o exemplo em que um automóvel encontra-se estacionado e dois outros se envolvem em colisão que resulta no atingimento do primeiro. Mostra-se bem possível, nessas hipóteses, que o prejudicado tenha sérias dúvidas sobre o efetivo causador do acidente, de sorte que, receoso pela derrota caso ajuíze a demanda contra um só dos envolvidos na colisão, acaba deduzindo pretensão indenizatória contra ambos, muito embora seja notável que o autor não está seguro - e por isso nem chega a afirmar tal situação - quanto ao fato de ambos os réus serem igualmente culpados pelo evento ${ }^{555}$.

\section{Ainda a responsabilidade civil}

Ao julgar o Recurso Especial $\mathrm{n}^{\mathrm{o}} 48.175 / \mathrm{MG}^{556}$, a Terceira Turma do Superior Tribunal de Justiça proferiu decisão nos termos da ementa que segue parcialmente transcrita:

é subsidiária, ou seja, supletiva da do causador do dano na execução da delegação, se este se revelar incapaz de satisfazer a indenização devida" (id., p. 76).

${ }^{555}$ DINAMARCO, Cândido Rangel. Litisconsórcio, cit., $\mathrm{n}^{\circ}$ 187, p. 467. Exemplo semelhante vem exposto por TROCKER, Nicolò (L'intervento per ordine del giudice, cit., p. 212, nota 80).

${ }^{556}$ Rel. Min. Carlos Alberto Menezes Direito, j. 27.08.1996, DJ 14.10.1996. 
“(...) É perfeitamente possível, sob o manto da chamada cumulação eventual, pedir a declaração de nulidade de subscrição de ações de banco que teve sua liquidação extrajudicial posteriormente decretada, com a devolução dos valores já pagos, ou, não sendo nula a subscrição, a responsabilidade do Banco Central do Brasil, sob a alegação de negligência na fiscalização das instituições financeiras".

O caso versava sobre demanda movida em face do Banco Auxiliar S/A e do Banco Auxiliar de Investimentos S/A, componentes do mesmo grupo financeiro, por meio da qual se buscava a anulação de títulos de ações preferenciais nominativas e, subsidiariamente, para a hipótese de não se acolher o pleito concernente à anulação dos títulos, pedia-se a condenação do Banco Central do Brasil a pagar pelos prejuízos experimentados pelos autores, com base na tese de que teria havido negligência na fiscalização e/ou conivência na operação engendrada entre os citados bancos.

Uma das teses agitadas pelo Banco Central, quando da interposição do recurso especial, consistiu na alegação de que os pedidos "alternativos" eram incompatíveis entre si e que, além disso, tinham como destinatários réus diversos.

A tais argumentos o Superior Tribunal de Justiça respondeu que a ausência de nulidade da subscrição não seria suficiente para descartar a responsabilidade civil do Banco Central, de sorte que todas essas questões deveriam ser apreciadas no processo de conhecimento, sem que houvesse obstáculo à cumulação de pedidos tal como formulada pelos autores da demanda, forte no que dispõe o art. 289, do Código de Processo Civil.

\section{Desconsideração da personalidade jurídica no sistema brasileiro}

Independentemente da concepção teórica que se adote em torno da natureza da pessoa jurídica (teorias pré-normativistas: orgânica e da realidade objetiva; teorias normativistas: da ficção e da realidade jurídica), o que se tem em conta, para os fins aqui 
propostos, é que a pessoa jurídica ostenta personalidade e patrimônio distintos dos de seus integrantes pessoas físicas ${ }^{557}$.

Por isso, em linha de princípio, a pessoa jurídica responde com seu próprio patrimônio pelas obrigações que assumir, quer as de natureza contratual, quer as de índole extracontratual $^{558}$. Semelhantemente, as obrigações a que se vinculam as pessoas físicas integrantes da pessoa jurídica pertinem, com exclusividade, àquelas e não a esta.

Porém, não é de hoje que se debruça sobre a necessidade de, em certos casos, superar-se o dogma da personalização da pessoa jurídica, em ordem a se atingir o patrimônio das pessoas físicas que, escondidas atrás do véu da aludida personificação, utilizam-se dessa construção jurídica para causar prejuízos a outrem.

Com efeito, à luz da experiência jurisprudencial norte-americana, o alemão ROLF SERICK asseverou, entre os anos de 1952 e 1953, que se mantém a essência da pessoa jurídica mesmo quando, em situações excepcionais, sejam adotadas medidas que afetem a situação das pessoas físicas que se encontram atrás dela. $\mathrm{O}$ citado autor ainda acrescentou que seria inconciliável com o próprio sentido do ordenamento jurídico o respeito à independência da pessoa jurídica quando, por meio dela, fossem perseguidas finalidades contrárias àquelas que motivaram a admissão de sua personalidade independente ${ }^{559}$.

557 Aliás, nem mesmo para o estudo da desconsideração da personalidade jurídica, considerados os limites desta investigação, faz-se necessário inclinar-se por esta ou aquela teoria sobre a natureza da pessoa jurídica. Adota-se, aqui, a advertência de JUSTEN FILHO: “Com estrema felicidade, Verrucoli observou que não há um vínculo necessário entre o conceito de pessoa jurídica e o problema da desconsideração. Ao menos, não há possibilidade de resolver o problema da desconsideração a partir de uma determinada teoria acerca da natureza jurídica da pessoa jurídica. Em outros termos, queria indicar que a desconsideração permaneceria tal como posta, independentemente de adotar-se teoria da ficção ou teoria da realidade ou qualquer outra orientação filosófica para o conceito de pessoa jurídica" (Desconsideração da personalidade societária no direito brasileiro. São Paulo: RT, 1987, p. 58). Porém, numa tentativa de entrosar o conceito de pessoa jurídica com o instituto da desconsideração de sua personalidade, FÁBIO ULHOA COELHO assim se expressa: "Nesse sentido, completando-se o conceito de pessoa jurídica, poder-se-ia consignar que esta é 'o sujeito de direito personalizado, incorpóreo e cujo ato constitutivo pode ser episodicamente ineficaz, se servir de instrumento para a realização de fraude ou abuso de direito" (Desconsideração da personalidade jurídica. São Paulo: RT, 1989, p. 89).

${ }^{558}$ COELHO, Fábio Ulhoa. Curso de direito comercial. 11. ed. São Paulo: Saraiva, 2008, vol. 2, p. 16.

${ }^{559}$ Aparencia y realidad en las sociedades mercantiles: el abuso de derecho por medio de la persona jurídica. Trad. José Puig Brutau, Barcelona: ARIEL, 1958, p. 100. No campo da doutrina estrangeira há de se destacar, outrossim, a contribuição de PIERO VERRUCOLI (Il superamento della personalità giuridica 
Entre nós, RUBENS REQUião, em famoso estudo publicado pela Revista dos Tribunais (vol. 410/12), destacou que o juiz brasileiro, com base em seu livre convencimento, teria a prerrogativa de desprezar a personalidade jurídica do ente coletivo e, "penetrando em seu âmago, alcançar as pessoas e bens que dentro dela se escondem para fins ilícitos" ${ }^{\$ 60}$. Em outra passagem igualmente elucidativa, advertiu-se que não se cuida de operar uma anulação da personalidade jurídica, mas sim de se impor a sua ineficácia para determinado efeito, "em virtude de o uso legítimo da personalidade ter sido desviado de sua legítima finalidade (abuso de direito) ou para prejudicar credores ou violar a lei (fraude)" ${ }^{961}$.

Os seguidores de SERICK são catalogados como adeptos de uma teoria subjetiva da desconsideração, isto porque o levantamento da personalidade jurídica exigiria "um abuso consciente da pessoa colectiva, não bastando, em princípio, a não obtenção do escopo objectivo duma norma ou dum negócio" ${ }^{, 562}$.

Critica-se essa postura interpretativa, basicamente, por dois motivos: (i) a manipulação objetiva da pessoa jurídica fora dos limites sistemáticos de sua função, só por si, já constituiria um abuso; (ii) a exigência da intencionalidade do agente dificultaria demasiadamente a prova do fator desencadeante da superação da personalidade jurídica ${ }^{563}$. Pode-se acrescentar, com J. LAMARTINE CORRÊA DE OliVEIRA, que a tese de SERICK incluiu na doutrina da desconsideração situações "perfeitamente remediáveis pela terapêutica clássica de Direito Civil”, fazendo-se referência, por exemplo, à invocação da teoria da aparência, de regras sobre simulação ou de hipóteses enquadráveis na noção de abuso de direito, como se dá no âmbito do venire contra factum proprium ${ }^{564}$.

Na tentativa de conferir ares mais objetivos à teoria da desconsideração, KONDER COMPARATO, em obra também de referência, externou críticas à concepção que vê no elemento intencional (subjetivo) o centro único de irradiação apto a lastrear toda a

della società di capitali nella "Common Law" e nella "Civil Law". Milano: Giuffrè, 1964), cujo pensamento, em linhas gerais é sumariado, entre nós, por ULHOA COELHO (Desconsideração da personalidade jurídica, cit., p. 23-33).

${ }^{560}$ Abuso de direito e fraude através da personalidade jurídica. Revista dos Tribunais, vol. 410, p. 14.

${ }^{561} I d .$, p. 17.

562 MENEZES CORDEIRO, António. O levantamento da personalidade colectiva no direito civil e comercial. Coimbra: Almedina, 2000, $\S 13^{\circ}, \mathrm{n}^{\circ} 38$, p. 126.

${ }^{563} I d ., \S 13^{\circ}, \mathrm{n}^{\mathrm{o}} 38$, p. $126-127$.

${ }^{564}$ A dupla crise da pessoa jurídica. São Paulo: Saraiva, 1979, p. 610. 
construção teórica do instituto. Em contribuição, pôs ênfase no elemento objetivo da confusão patrimonial como sendo a mola propulsora da aplicação da disregard doctrine $e^{565}$. Invoca-se, para justificar a desconsideração por esse prisma objetivo, o desvio de função da pessoa jurídica. É que a personalidade jurídica tem por função deflagrar a criação de "um centro de interesses autônomo", o qual, se ausente, abre o flanco à desconsideração da personalidade jurídica ${ }^{566}$.

Dá-se notícia ainda acerca da chamada teoria da aplicação das normas (MüLLERFREIENSFELS), à luz da qual a desconsideração não seria um problema afeto à personalidade coletiva, mas sim de uma questão pertinente à aplicação das diversas normas jurídicas: "haveria levantamento sempre que, por exigência duma norma concretamente prevalente, não tivesse aplicação uma norma própria da personalidade colectiva" ${ }^{\text {"567 }}$.

Conforme esclarece SALOMÃo FILHO, a desconsideração - na doutrina de MÜLLERFREIENSFELS - não consiste apenas numa reação a atitudes fraudulentas, mas também numa técnica legislativa ou num método de aplicação de normas que possibilita valorar distintamente os diversos conjuntos normativos ${ }^{568}$.

Após agrupar as variadas hipóteses de desconsideração em três posições básicas, MENEZES CORDEIRO conclui que "as diversas teorias documentam facetas próprias do levantamento, correspondendo a progressões da mesma ideia. Elas não se opõem: completam-se ${ }^{569}$.

No estágio atual do desenvolvimento jurídico brasileiro, a desconsideração da personalidade jurídica tem foros de cidadania e, segundo autorizada doutrina, pode ser assim conceituada:

\footnotetext{
${ }^{565}$ O poder de controle na sociedade anônima. 5. ed. Rio de Janeiro: Forense, 2008, p. 450.

${ }^{566}$ SALOMÃo FILHO, Calixto. O novo direito societário. 3. ed. São Paulo: Malheiros, 2006, p. 227. A doutrina de J. LAMARTINE CORRÊA DE OLIVEIRA (A dupla crise da pessoa jurídica) coloca-se simetricamente à opção teórica de KONDER COMPARATO.

${ }^{567}$ MENEZES CORDEIRO, António. Op. cit., $§ 13^{\circ}, \mathrm{n}^{\circ}$ 40, p. 128-129. Haveria ainda uma quarta orientação negando à desconsideração o caráter de instituto autônomo. Daí chamar-se teoria negativista (WILHELM), consoante explicação de MENEZES CORDEIRO (Op. cit., § 13º, nº 41, p. 129-130).

${ }^{568}$ Op. cit., p. 217. O autor alude a esse pensamento como sendo expressão da "teoria dos centros de imputação".

${ }^{569}$ Op. cit., § 16, n $\mathrm{n}^{\mathrm{0}}$ 51, p. 152.
} 
"Usualmente, utiliza-se a expressão 'desconsideração da pessoa jurídica' (ou outra equivalente, como 'superação', 'penetração', 'levantamento do véu societário’ etc.) para indicar a ignorância, para um caso concreto, da personificação societária. Vale dizer, aprecia-se a situação jurídica tal como se a pessoa jurídica não existisse, o que significa que se trata a sociedade e o sócio como se fossem uma mesma e única pessoa. Atribuem-se ao sócio ou à sociedade condutas (ou efeitos jurídicos de conduta) que, não fosse a desconsideração, seriam atribuídos (respectivamente) à sociedade ou ao sócio", ${ }^{, 570}$.

Sob o foco dessas luzes, o legislador brasileiro, em diversos passos, fez referência expressa ao instituto da desconsideração da personalidade jurídica: (a) art. 28, caput e $\S 5^{\circ}$, do Código de Defesa do Consumidor (Lei no 8.078/90) ${ }^{571}$; (b) art. 18, da Lei $n^{\circ} 8.884 / 94$ (Lei Antitruste) $^{572}$; (c) art. $4^{\text {o }}$, da Lei $n^{\circ}$ 9.605/98 (Lei do Meio Ambiente) ${ }^{573}$; (d) art. 50, do Código Civil ${ }^{574-575}$.

${ }^{570}$ JUSTEN FILHO, Marçal. Op. cit., p. 55.

571 "O juiz poderá desconsiderar a personalidade jurídica da sociedade quando, em detrimento do consumidor, houver abuso de direito, excesso de poder, infração da lei, fato ou ato ilícito ou violação dos estatutos ou contrato social. A desconsideração também será efetivada quando houver falência, estado de insolvência, encerramento ou inatividade da pessoa jurídica provocados por má administração. (...) $\S 5^{\circ}$ Também poderá ser desconsiderada a pessoa jurídica sempre que sua personalidade for, de alguma forma, obstáculo ao ressarcimento do prejuízo causados aos consumidores".

572 “A personalidade jurídica do responsável por infração de ordem econômica poderá ser desconsiderada quando houver da parte deste abuso de direito, excesso de poder, infração da lei, fato ou ato ilícito ou violação dos estatutos ou contrato social. A desconsideração também será efetivada quando houver falência, estado de insolvência, encerramento ou inatividade da pessoa jurídica provocados por má administração".

573 "Poderá ser desconsiderada a pessoa jurídica sempre que sua personalidade for obstáculo ao ressarcimento de prejuízos causados à qualidade do meio ambiente".

574 "Em casos de abuso da personalidade jurídica, caracterizado pelo desvio de finalidade, ou pela confusão patrimonial, pode o juiz decidir, a requerimento da parte, ou do Ministério Público quando lhe couber intervir no processo, que os efeitos de certas e determinadas relações de obrigações sejam estendidos aos bens particulares dos administradores ou sócios da pessoa jurídica".

${ }^{575}$ Para uma análise crítica sobre essas diversas formulações legislativas, consulte-se COELHO, Fábio Ulhoa (Curso de direito comercial, cit., vol. 2, Cap. 17, p. 49-55). Aliás, para o citado autor, seguindo as pegadas de RUBENS REQUIÃO, a "aplicação da teoria da desconsideração da personalidade jurídica independe de previsão legal”, pois que, em última análise, “o juiz está autorizado a ignorar a autonomia patrimonial da 
Considerados os limites intencionalmente fixados no âmbito desta pesquisa, mostram-se desnecessários aprofundamentos em torno de tão riquíssimo tema, razão pela qual não se examinam todas as especificidades que a legislação em vigor pode ensejar.

Entretanto, dados os seus reflexos processuais, não se pode deixar de aludir à sistematização promovida pela doutrina nacional em tema de desconsideração da personalidade jurídica. Está-se a referir às cognominadas teorias maior e menor da superação da personalidade jurídica.

No campo da teoria maior, apregoa-se que a superação episódica da autonomia patrimonial só pode decorrer de situações em que a personalização da pessoa jurídica vem empregada para fins abusivos ou fraudulentos ${ }^{576}$. Pode-se, outrossim, alocar a confusão patrimonial como sendo mais um dos fundamentos, agora com aspecto mais objetivo, dessa mesma teoria maior ${ }^{577}$.

De sua parte, a teoria menor condiciona a penetração do véu daquela mesma autonomia patrimonial à simples inexistência de bens suficientes da pessoa jurídica para saldar suas obrigações. Na lição de UlHOA COELHO, autoriza-se, por esse viés menor, a desconsideração da personalidade jurídica mediante a "demonstração pelo credor da inexistência de bens sociais e da solvência de qualquer sócio" ${ }^{\text {578 }}$.

À luz desses enunciados teóricos, constata-se que, do ponto de vista processual, haverá desenvolvimento probatório mais ou menos intenso se se estiver diante de aplicação da teoria maior ou da teoria menor da desconsideração. É que, em linha de princípio, há mais dificuldades para se provar o intuito abusivo ou fraudulento do que para se demonstrar a simples insolvabilidade de uma sociedade empresária. Até mesmo pelo enfoque objetivo da teoria maior - fundado na confusão patrimonial - pode-se verificar dificuldade probatória de monta: basta figurar o exemplo em que, para prova da confusão

pessoa jurídica sempre que ela for fraudulentamente manipulada para frustrar interesse legítimo de credor" (id., p. 55).

${ }^{576}$ COELHO, Fábio Ulhoa. Curso de direito comercial, cit., vol. 2, p. 36.

577 "Subdivide-se a teoria maior em teoria maior objetiva e teoria maior subjetiva, a depender da exigência, ou não, do elemento anímico para a desconsideração" (FARIAS, Cristiano Chaves de; ROSENVALD, Nelson. Direito civil: teoria geral. 7. ed. Rio de Janeiro: Lumen Juris, 2008, p. 312).

${ }^{578}$ Curso de direito comercial, cit., p. 36 e 47. 
patrimonial, se exija análise contábil aprofundada da movimentação bancária da pessoa jurídica $^{579}$.

Ainda do ponto de vista teórico - a partir do que podem exsurgir relevantes consequências práticas - põe-se a questão de saber se o sujeito alvo da desconsideração responde por dívida própria ou alheia. Em outras palavras: a desconsideração da personalidade jurídica provoca a extensão da responsabilidade patrimonial?

Para SALOMÃo FILHO a desconsideração "não pode ser confundida com uma aplicação da teoria dualista da obrigação, ou seja, da imputação da responsabilidade a pessoa diferente do devedor" 580 . Então, o sujeito apanhado em desconsideração "responde por dívida própria, decorrente não de um ato mas de uma atividade abusiva. Trata-se de responsabilidade societária, que não pode ser confundida com a responsabilidade civil nem tampouco com a responsabilidade civil aplicada ao direito societário" ${ }^{\$ 51}$.

Uma vez negado o dualismo, o autor citado concebe que o sujeito atingido pela desconsideração pode ser responsabilizado em via principal pelo credor. "É devedor e não apenas garante ou responsável. Pelos mesmos motivos, é impossível o exercício de direito de regresso contra a sociedade (ou o sócio)" ${ }^{\text {"582. }}$.

Em sentido diverso, J. LAMARTine CORRÊA DE Oliveira professa que a desconsideração da personalidade jurídica enseja o resgate da noção de responsabilidade patrimonial, apelando-se para a dicotomia débito e responsabilidade. Eis o teor de suas próprias palavras: "Para que se possa falar de verdadeira técnica desconsiderante, em tema de responsabilidade, será necessária a presença do princípio da subsidiariedade, explicitado

\footnotetext{
${ }^{579}$ Com adaptações, o exemplo é fornecido por ULHOA COELHO (Curso de direito comercial, cit., p. 4445).

${ }^{580}$ Op. cit., p. 236.

${ }^{581}$ SALOMÃO FILHO, Calixto. Op. cit., p. 236-237.

582 Id., p. 238. O autor ainda explica: "Característica fundamental da responsabilidade sem dívida é a possibilidade de ressarcimento do sujeito obrigado a pagar perante o devedor. Nas hipóteses de desconsideração aventadas, evidentemente não é possível imaginar a possibilidade de ressarcimento do sócio perante a sociedade. Até mesmo do ponto de vista eqüitativo. Basta pensar que, em se admitindo o regresso do sócio contra a sociedade, essa seria onerada por uma situação que teve como beneficiário apenas o acionista controlador" (id., p. 236). CAMIÑA MOREIRA inclinou-se também por essa tese (op. cit., p. 144145).
} 
à luz de uma concepção dualista de obrigação: responsabilidade subsidiária por dívida alheia" $" 583$.

Seja como for - e os questionamentos a esse respeito ainda estão em aberto na doutrina nacional, demandando-se maior aprofundamento que desborda dos limites singelos deste trabalho -, o próprio SALOMÃO FILHO reconhece que, na experiência brasileira, a desconsideração da personalidade jurídica vem tratada, jurisprudencial e legislativamente, como um assunto reduzido às hipóteses de responsabilidade patrimonial $^{584}$, razão pela qual se opta por trilhar essa linha de pensamento. Ou seja, estuda-se a desconsideração da personalidade jurídica pela angulação da responsabilidade patrimonial.

Todos os questionamentos até aqui alinhavados surgirão também no quadro da chamada desconsideração em sentido inverso ${ }^{585}$, hipótese em que se buscarão no patrimônio da pessoa jurídica bens necessários à satisfação de obrigações de pessoas físicas que a integram ${ }^{586}$.

Trata-se de hipótese bastante frequente na seara do Direito de Família e das Sucessões, conforme retratado, com profundidade, por ROLF MADALENO ${ }^{587} \mathrm{em}$ significativos exemplos, dentre vários outros: (i) cônjuge que transfere para a sociedade da qual participa e controla bens que, em caso de separação ou dissolução de união estável, comporiam o acervo destinado à meação do outro consorte; (ii) devedor de pensão alimentícia que, sob o véu empresarial, mantém vida econômica notoriamente confortável,

${ }^{583}$ A dupla crise da pessoa jurídica, p. 610. Note-se, porém, que no pensamento de J. LAMARTINE CORRÊA DE OLIVEIRA não se ajustam à figura da desconsideração os casos em que se tem "mera imputação de ato", isto é, nas hipóteses em que a pessoa jurídica é utilizada como "mero instrumento de alguém que sobre ela detenha poder de controle incontrastável". Para tais situações - que para SERICK configurariam fatores de desconsideração - o doutrinador brasileiro visualiza solução com base na teoria da aparência ou pela aplicação do venire contra factum proprium (Op. cit., p. 610-611).

${ }^{584}$ Op. cit., p. 233.

${ }^{585}$ COMPARATO, Fábio Konder; SALOMÃO FILHO, Calixto. Op. cit., p. 464.

586 “A fraude que a desconsideração invertida coíbe é, basicamente, o desvio de bens. O devedor transfere seus bens para a pessoa jurídica sobre a qual detém absoluto controle. Desse modo, continua a usufruí-los, apesar de não serem de sua propriedade, mas da pessoa jurídica controlada. Os seus credores, em princípio, não podem responsabilizá-lo executando tais bens" (COELHO, Fábio Ulhoa. Curso de direito comercial, cit., vol. 2, p. 46).

${ }^{587}$ A desconsideração judicial da pessoa jurídica e da interposta pessoa física no direito de família e no direito das sucessões. Rio de Janeiro: Forense, 2009, passim. 
já que seu patrimônio está todo vertido para o ente coletivo, ao passo que ele próprio (pessoa física) demonstra parcos rendimentos (pro labore ínfimo diante da realidade econômica da sociedade empresária); (iii) o pai constitui, com dois de seus três filhos, uma sociedade empresária e somente ele (o pai) concorre efetivamente com aportes financeiros, transferindo, assim, porção significativa (às vezes a totalidade) de seus bens pessoais; ao falecer, todos os filhos (inclusive aquele não participante da sociedade) herdarão as quotas pertencentes ao falecido pai, mas é evidente que, por meio desse estratagema, o filho excluído quando da constituição da sociedade será um sócio minoritário, enquanto que os demais deterão a maior parte do capital social (sócios majoritários) ${ }^{588}$.

Mesmo que se admita, embora com reservas, a desconsideração da personalidade jurídica no âmbito da própria execução (processo executivo ou fase executiva) ${ }^{589}$, não se afasta a possibilidade de já na fase de conhecimento vir à tona o debate sobre a incidência da disregard theory, caso em que a situação fático-jurídica pertinente a um determinado sujeito (pessoa jurídica, p. ex.) terá o condão de implicar consequências na esfera de outro sujeito (pessoa física, p. ex.). Nessa perspectiva, irrompe a dúvida quanto à configuração do polo passivo da demanda condenatória a ser proposta.

${ }^{588}$ Segundo a jurisprudência do STJ, a desconsideração inversa tem seu fundamento legal também no art. 50, do Código Civil, conclusão que se alcança por meio de interpretação teleológica. Confira-se a parte relevante da ementa: "IV - Considerando-se que a finalidade da disregard doctrine é combater a utilização indevida do ente societário por seus sócios, o que pode ocorrer também nos casos em que o sócio controlador esvazia o seu patrimônio pessoa e o integraliza na pessoa jurídica, conclui-se, de uma interpretação teleológica do art. 50 do CC/02, ser possível a desconsideração inversa da personalidade jurídica, de modo a atingir bens da sociedade em razão de dívidas contraídas pelo sócio controlador, conquanto preenchidos os requisitos previstos na norma” (STJ, REsp 948.117/MS, 3ª T., Rel. Min. Nancy Andrighi, j. 22.06.2010).

${ }^{589}$ SOUZA, André Pagani de. Aspectos processuais da desconsideração da personalidade jurídica do art. 50 do Código Civil. Dissertação (Mestrado), Pontifícia Universidade Católica de São Paulo, 2007, p. 132 e 135136; MOREIRA, Alberto Camiña. Op. cit., p. 140-142; BRUSCHI, Gilberto Gomes. Aspectos processuais da desconsideração da personalidade jurídica. 2. ed. São Paulo: Saraiva, 2009, p. 83 e 96-101; LOPES, João Batista. Desconsideração da personalidade jurídica no novo Código Civil. Revista dos Tribunais, vol. 818, p. 44. Em sentido contrário, manifestando-se pela exigência sempre de ação cognitiva, por todos, GRINOVER, Ada Pellegrini [Da desconsideração da pessoa jurídica (Aspectos de direito material e processual). Revista Forense, vol. 371, p. 15]. 


\section{Contrato de fiança que contemple o benefício de ordem}

Segundo estabelece o art. 827, do Código Civil, o fiador demandado pelo pagamento da dívida tem direito a exigir, até o momento da contestação, que sejam primeiro executados os bens do devedor principal, para o que deverá nomear bens do devedor situados no mesmo município, livres e desembargados, quantos bastem para solver o débito.

De igual modo, o art. 595, do Código de Processo Civil, dispõe que o fiador, quando executado, poderá nomear à penhora bens livres e desembargados do devedor ${ }^{590}$, com a observação de que os bens daquele estarão sujeitos à execução na hipótese de os bens deste não serem suficientes para satisfação integral do direito do exequente ${ }^{591}$.

\footnotetext{
${ }^{590}$ Diferentemente do que preconiza a lei civil, o Código de Processo Civil não exige que os bens do devedor, para que possam ser indicados à penhora pelo fiador, estejam no mesmo município. Porém, como o instituto do benefício de ordem tem natureza material, os requisitos para o seu regular exercício também são ditados por normas de índole civil, não sendo possível que a lei processual promova alterações na própria configuração do instituto. Daí não nos parecer adequado o entendimento exposto por CARLOS ALBERTO CARMONA, para quem se exige do fiador apenas a indicação de bens livres de desembargados, "não que estejam situados na mesma comarca em que se processa a demanda executiva" [In: MARCATO, Antonio Carlos (coord.). Código de Processo Civil Interpretado, cit., p. 1954]. Convém observar, de outro lado, que a alteração promovida pela Lei n ${ }^{\circ}$ 11.382/2006 implicou a extinção da fase da indicação de bens à penhora pelo executado, o qual é simplesmente citado para, em três dias, pagar o débito, podendo em 15 dias opor embargos. "Apesar desta nova dinâmica do processo de execução calcado em título extrajudicial, parece que o fiador deverá conservar seu direito de, citado, nomear bens do devedor no tríduo legal, fazendo valer seu direito ao benefício de ordem" (CARMONA, Carlos Alberto. Op. cit., p. 1954). Essa conclusão enaltece a ideia de que o processo deve conformar-se às necessidades ditadas pelo direito material. Sendo assim, não pode o sistema processual servir de empeço ao exercício de posições jurídicas ditadas por norma de direito material. Ao contrário, as leis do processo devem oferecer o adequado ambiente para fruição das situações de vantagens outorgadas pelo direito material.

${ }^{591}$ No campo da execução de título extrajudicial, interessante acrescentar que o fiador pode indicar bens do devedor mesmo que este não participe do processo executivo (CARMONA, Carlos Alberto. Op. cit., p. 1953), mas, em sentido contrário, ATHOS GUSMÃO CARNEIRO professa que, nessa hipótese, o exequente estará obrigado a aditar a execução, "promovendo-a também contra o afiançado" (op. cit., p. 174, nota 5). Se, diferentemente, o fiador for demandado, sozinho, em processo de conhecimento de índole condenatória, exercita-se o benefício de excussão por intermédio do chamamento ao processo, nos termos do artigo 77 , inciso I, do CPC (ARRUDA ALVIM. Manual de direito processual civil, cit., vol. 2, p. 193-194; CHEIM JORGE, Flávio. Chamamento ao processo. 2. ed. São Paulo: RT, 1999, p. 80-84; GRECO FILHO, Vicente.
} 
Os dispositivos acima citados tratam do conhecido benefício de ordem ou benefício de excussão, à luz do qual se põe em relevo o caráter acessório e subsidiário da responsabilidade do fiador. Em palavras diretas, o aludido benefício consiste no direito, titularizado pelo fiador, de que sejam primeiro afetados os bens do devedor ${ }^{592}$.

Contudo, se o devedor não tem bens suficientes para suportar a obrigação de pagar, de nada aproveita ao fiador o benefício da excussão, mesmo que ele seja mero garante e não tenha renunciado ao aludido benefício, ex vi do art. 828, III, do Código Civil.

De outra parte, importa deixar bem assentada a ideia de que o fiador só pode ser executado por título judicial quando tenha participado da fase de cognição, isto é, tenha sido parte na demanda de onde adveio o título executivo que o guindou à posição efetiva de devedor ${ }^{593}$.

À luz dessas premissas, transparece conveniente, na perspectiva do processo de conhecimento condenatório, que o credor aja, a um só tempo, em face tanto do devedor quanto do responsável, presente a peculiaridade de que a situação jurídica deste estará vinculada àquela condicionante fática imbricada com a suficiência ou não do patrimônio do devedor para fazer frente, total ou parcialmente, à obrigação assumida.

Interessante notar, ainda uma vez, que a questão fática acima referida só será dirimida com segurança no âmbito próprio do processo em que se busca a satisfação da obrigação.

Da intervenção de terceiros, cit., p. 97; CARNEIRO, Athos Gusmão. Op. cit., p. 173-174; SCARPINELLA BUENO, Cassio. Partes e terceiros no processo civil brasileiro, cit., p. 328). Em senso diverso, pela inadequação do chamamento ao processo nos casos em que o fiador tenha a seu favor o benefício de ordem, confira-se DINAMARCO, Cândido Rangel (Instituições de direito processual civil, cit., vol. II, $\mathrm{n}^{\circ}$ 610, p. 426).

${ }^{592}$ GONÇALVES, Carlos Roberto. Direito civil brasileiro. São Paulo: Saraiva, 2004, vol. III, p. 532.

${ }^{593}$ NERY JUNIOR, Nelson; ANDRADE NERY, Rosa Maria de. Código de Processo Civil comentado e legislação extravagante, cit., nota 1 ao art. 595, p. 1006. "Sendo o título executivo sentença judicial, não poderá o fiador ser guindado ao pólo passivo da execução se não figurar, no processo de conhecimento condenatório, como réu. Inútil a mera cientificação do fiador se a intenção for executar também contra ele a sentença condenatória, como ocorre com certa frequêencia nas demandas de despejo cumuladas com cobrança. É de rigor, portanto, em tais hipóteses, a inclusão do fiador no pólo passivo daquelas demandas, sob pena de executar-se a sentença exclusivamente em face do locatário" [CARMONA, Carlos Alberto. In: MARCATO, Antonio Carlos (coord.). Código de Processo Civil Interpretado, cit., p. 1954]. No âmbito dos contratos de locação, essa solução ficou cristalizada pelo enunciado 268, da Súmula do STJ: "O fiador que não integrou a relação processual na ação de despejo não responde pela execução do julgado". 


\section{Assunção de dívida}

Mesmo sob a égide do Código Civil de 1916 a doutrina admitia, com tranquilidade, o fenômeno jurídico da assunção de dívida, de sorte que a codificação de 2002 veio apenas declarar aquilo que já existia em nosso ordenamento civil ${ }^{594}$. Não se cuida, como bem se percebe, de matéria nova, mas o certo é que o Código Civil de 2002 trouxe enunciações normativas aptas a gerar dúvidas no tratamento processual do assunto.

Antes da análise específica dos dispositivos geradores de interessantes nuanças processuais, convém aclarar alguns aspectos de direito material.

Entende-se por assunção de dívida, cessão de dívida ou cessão de débito, que tem por efeito operar a sucessão singular no débito, o negócio jurídico por meio do qual, numa relação obrigacional válida, alguém assume, com a concordância do credor, o dever de adimplir a obrigação no lugar do primitivo devedor, sem que essa alteração subjetiva passiva altere a compostura da obrigação, a qual, desta forma, permanece a mesma. Vê-se, então, que a mudança ocorre, tão-somente, no polo passivo da relação obrigacional, pois o vínculo jurídico, em si, persiste tal como antes constituído, característica, aliás, que distingue claramente a assunção de dívida da novação.

Conquanto seja possível que a sucessão singular no débito opere-se em razão de disposição legal e também de ato judicial, a análise aqui proposta concentra-se na sucessão decorrente de ato negocial.

As principais características da assunção de dívida podem ser assim resumidas: “a) a liberação do antigo devedor, que sai da relação obrigatória; b) a entrada de novo devedor no mesmo lugar e condições do anterior; c) o idem debitum, isto é, a identidade absoluta da obrigação, que persevera a mesma, não obstante a mudança de devedor" ${ }^{295}$.

\footnotetext{
${ }^{594}$ ORLANDO GOMES. Obrigações. 11. ed. Rio de Janeiro: Forense, 1996, p. 224-226; SILVA PEREIRA, Caio Mário da. Instituições de direito civil. 15. ed. Rio de Janeiro: Forense, 1997, vol. II, p. 266.

${ }^{595}$ FREITAS GOMES, Luiz Roldão de. Da assunção de dívida e sua estrutura negocial. 2. ed. Rio de Janeiro: Lumen Juris, 1998, p. 82.
} 
A assunção de dívida comporta duas espécies: $a$ ) assunção privativa ou liberatória (também chamada assunção tout court); $b$ ) assunção cumulativa ou co-assunção (também chamada adesão ou adjunção).

$\mathrm{Na}$ primeira espécie de assunção (privativa ou liberatória) o novo devedor (assuntor) assume a posição passiva da relação obrigacional e, com isso, exonera o primitivo devedor, ao passo que na assunção cumulativa o novo devedor integrará a relação obrigacional, do lado passivo, em adesão ao primitivo devedor, ou seja, sem exonerá-lo.

A espécie de que ora se ocupa consiste na assunção privativa ou liberatória, que acarreta a sucessão singular em dívida alheia. Portanto, quando se refere no texto à assunção de dívida, sem qualificá-la, está-se tratando da privativa ou liberatória.

Além daquelas espécies, a assunção de dívida ainda pode exteriorizar-se por formas distintas, surgindo daí duas modalidades que se distinguem nos requisitos e nos efeitos.

De fato, a assunção de dívida pode decorrer de contrato entre o terceiro (assuntor) e o credor, acarretando a exoneração do antigo devedor. Segundo PONTES DE MIRANDA, designa-se "assunção unifigurativa de dívida, tomada de dívida, a de um ramo só ou de um galho, a assunção em que a relação jurídica é entre terceiro e credor, de jeito que não mais se precisa de qualquer ato para que a substituição do devedor se dê". ${ }^{596}$ A doutrina também identifica essa modalidade como assunção de dívida por expromissão, porquanto "una colaboración del anterior deudor es en este caso inecessaria"597.

A outra modalidade origina-se de contrato entre o devedor primitivo e o terceiro que se propõe a substituí-lo, sujeito à ratificação do credor, para que ocorra a liberação do primeiro e se tenha a sucessão singular no débito. PONTES DE MIRANDA denomina essa modalidade de assunção bifigurativa de dívida e justifica sua nomenclatura na circunstância de que o contrato havido entre o devedor e o terceiro, para operar a eficácia translativa da dívida e a exoneração do primitivo devedor, necessita que o credor admita a substituição $^{598}$. Aqui se fala, também, em assunção por delegação, pois o devedor

\footnotetext{
${ }^{596}$ Tratado de direito privado. Rio de Janeiro: Borsoi, 1958. t. XXIII, p. 375.

${ }^{597}$ MEDICUS, Dieter. Tratado de las relaciones obligacionales. Trad. Ángel Martínez Sarrión. Barcelona: Bosch, 1995. vol. I, p. 342.

${ }^{598}$ Tratado de direito privado, cit., p. 376.
} 
(delegante) transfere, delega o débito a terceiro (delegado), com o assentimento do credor (delegatário) $^{599}$.

Partindo-se da compreensão do que seja a assunção de dívida liberatória por delegação (exoneração do devedor primitivo por ato deste com o terceiro, sujeito à concordância do credor), depara-se com o texto do art. 299, caput, do Código Civil, que assim dispõe: "É facultado a terceiro assumir a obrigação do devedor, com o consentimento expresso do credor, ficando exonerado o devedor primitivo, salvo se aquele, ao tempo da assunção, era insolvente e o credor o ignorava".

A teor da disciplina legal, tem-se que o devedor primitivo estará, de regra, exonerado do vínculo obrigacional mantido com o credor, razão pela qual tocará ao credor demandar - caso não haja satisfação voluntária da obrigação - em face do assuntor/delegado.

Porém, a lei civil retira a eficácia da exoneração do devedor primitivo na hipótese em que o assuntor já fosse insolvente, ao tempo da assunção, e o credor ignorasse tal estado patrimonial.

Então, na presença de sinais de insolvência, o credor pode recear quanto à efetiva satisfação da obrigação por meio do patrimônio do delegado (assuntor), pairando-se séria dúvida sobre a manutenção ou não daquela exoneração do devedor primitivo. O que parece estreme de dúvidas é que a solução da questão dependerá da prova que se produzir no âmbito de processo movido em face do próprio assuntor, hipótese em que, provado o estado de insolvência, do qual ignorava o credor, ressurgirá incólume a responsabilidade obrigacional do devedor primitivo.

Como se percebe, nessa modalidade de assunção de dívida a eficácia extintiva da obrigação em relação ao devedor primitivo vincula-se àquelas condicionantes fáticas pertinentes à insolvência do assuntor e à ignorância desse estado por parte do credor, tudo ao tempo da assunção.

Mostra-se possível, destarte, que o credor, diante da ignorância sobre um possível estado patrimonial deficitário já existente ao tempo da assunção, duvide quanto à figura do responsável pelo adimplemento da obrigação, pois que na dependência da demonstração da

${ }^{599}$ GONÇALVES, Carlos Roberto. Direito civil brasileiro, cit., vol. II, p. 220. 
insolvência do assuntor extrair-se-á a conclusão acerca da subsistência da obrigação perante o devedor primitivo ${ }^{600}$.

\section{Consignação em pagamento: dúvida sobre a pessoa do credor}

Prevê o art. 334, do Código Civil, que se considera pagamento, apto a extinguir a obrigação, o depósito judicial ou em estabelecimento bancário da coisa devida, na forma que dispuser a lei ${ }^{601}$. Trata-se do conhecido instituto da consignação em pagamento, que na lição do civilista BARROS MONTEIRO configura instituto simultaneamente de direito civil e de processo $^{602}$, muito embora se possa dizer, com apoio em doutrina abalizada, que a eficácia liberatória do depósito aceito ou judicialmente reconhecido caracteriza a consignação como modalidade de extinção anormal da obrigação, razão pela qual se cuida, inegavelmente, de instituto de direito material ${ }^{603}$.

Dentre as várias hipóteses em que se mostra cabível a consignação, interessa aqui a catalogada no inciso IV do art. 335, do Código Civil: "se ocorrer dúvida sobre quem deva legitimamente receber o objeto do pagamento". Nessa contingência, apresentam-se dois ou mais credores e não pode o devedor dar preferência a qualquer dos pretendentes. Toca ao devedor, pois, o ônus ${ }^{604}$ de consignar em juízo o quantum de seu débito, "a ser levantado oportunamente por quem de direito"

Considerada essa peculiaridade advinda do direito material, o Código de Processo Civil prevê, dentre os procedimentos especiais de jurisdição contenciosa, a chamada "ação de consignação em pagamento" (art. 890 e seguintes). No que importa para o estudo em pauta, o art. 895 assim dispõe: "Se ocorrer dúvida sobre quem deva legitimamente receber

\footnotetext{
${ }^{600}$ Indagações análogas, atinentes ao estado de dúvida sobre a eficácia da sucessão no débito, são lembradas pela doutrina italiana (TROCKER, Nicolò. L'intervento per ordine del giudice, cit., p. 216, nota 84).

${ }^{601} \mathrm{O}$ art. 67, da Lei ${ }^{\circ}$ 8.245/91, também prevê a consignação de aluguel e acessórios da locação.

${ }^{602}$ Curso de direito civil, cit., vol. 4, p. 279.

${ }^{603}$ MARCATO, Antonio Carlos. Ação de consignação em pagamento. 5. ed. São Paulo: Malheiros, $1996, \mathrm{p}$. 15-16. Em senso parelho manifesta-se RICARDO LEONEL (Tutela jurisdicional diferenciada. São Paulo: RT, 2010, p. 91), apoiando-se em segura doutrina de ADROALDO FURTADO FABRÍCIO e de OVÍDIO A. BATISTA DA SILVA.

${ }^{604}$ MARCATO, Antonio Carlos. Ação de consignação em pagamento, cit., p. 16-17.

${ }^{605}$ BARROS MONTEIRO, Washington de. Op. cit., p. 281.
} 
o pagamento, o autor requererá o depósito e a citação dos que o disputam para provarem o seu direito".

Segundo a lição de SERPA LOPES, essa dúvida “deve ser fundada em motivos sérios, ocorrendo sobretudo quando há sérias razões para temer que há mais de uma pessoa intitulando-se credora" ${ }^{\prime 606}$. Diante desse cenário, embora queira pagar, o devedor não pode fazê-lo a qualquer dos pretendentes, sob o risco de pagar mal e experimentar as consequências jurídicas daí advenientes ${ }^{607}$.

Veja-se que a dúvida residente na base de conformação do próprio instituto de direito material lança inequívocos reflexos no modo de atuar da jurisdição, podendo-se adequadamente falar na existência de uma verdadeira técnica diferenciada de tutela jurisdicional $^{608}$.

\section{Expurgo inflacionário: instituição financeira em liquidação (caso Bamerindus)}

Certa feita deparou-se com questionamento de determinada instituição financeira caracterizada como sucessora do Banco Bamerindus, estando este em liquidação extrajudicial. Ocorre que os fatos agitados na demanda diziam respeito à época anterior à aludida sucessão, de modo que se instalou dúvida quanto à amplitude da responsabilidade obrigacional da instituição sucessora, especialmente pela manutenção da personalidade jurídica do banco sob liquidação.

Tal questão só foi dirimida com informação enviada pelo Banco Central, já no bojo do iter procedimental, quanto à exata conformação da responsabilidade da instituição financeira sucessora.

Do ponto de vista do autor da demanda e diante da dificuldade em obter ele próprio (sem a intervenção judicial) informação precisa do Banco Central acerca da responsabilidade de uma e de outra instituição financeira, afigura-se razoável conceber a existência de séria dúvida, ao se propor a demanda, sobre quem deva responder pelas

\footnotetext{
${ }^{606}$ Curso de direito civil, cit., vol. II, p. 200.

${ }^{607}$ MARCATO, Antonio Carlos. Ação de consignação em pagamento, cit., p. 100.

${ }^{608}$ Sobre a qualificação da ação de consignação em pagamento como uma forma de tutela jurisdicional diferenciada, consulte-se LEONEL, Ricardo de Barros (Tutela jurisdicional diferenciada, cit., p. 93-99).
} 
perdas derivadas de expurgos inflacionários ocorridos na época em que determinada instituição financeira atuava com regularidade, mas que, posteriormente, veio a ser objeto de liquidação extrajudicial, sendo parte de suas obrigações assumida por outra instituição financeira.

\section{Pensão alimentícia: aspectos subjetivos}

“A obrigação alimentar não é solidária”. Essa afirmação categórica de YUSSEF SAID CAHALI $^{609}$, aliada à noção de que vários podem ser os sujeitos obrigados ao pensionamento (CC, arts. 1.696 e 1.697), traz à balha antiga polêmica em torno da responsabilidade subsidiária e complementar dos parentes de grau mais distante.

O Código Civil de 1916 silenciava sobre a questão, à sombra do que se desencadeou funda divergência doutrinária e jurisprudencial ${ }^{610}$. Na tentativa de espancar dúvidas, o Código Civil em vigor disciplinou a matéria no art. 1.698, cuja dicção é a seguinte: "Se o parente, que deve alimentos em primeiro lugar, não estiver em condições de suportar totalmente o encargo, serão chamados a concorrer os de grau imediato; sendo várias as pessoas obrigadas a prestar alimentos, todas deverão concorrer na proporção dos respectivos recursos, e, intentada ação contra uma delas, poderão as demais ser chamadas a integrar a lide" 611 .

Pelo que se depreende do texto legal, o alimentário (parente necessitado) deve buscar a satisfação de suas necessidades perante aquele parente mais próximo e só na ausência deste ou na sua falta de condições para suportar totalmente o encargo financeiro é

\footnotetext{
${ }^{609}$ Dos alimentos. 5. ed. São Paulo: RT, 2006, p. 118, com ampla referência bibliográfica. Apenas no âmbito do Estatuto do Idoso (art. 12, da Lei $\mathrm{n}^{\circ} 10.741 / 2003$ ) é que a obrigação alimentar ganha o colorido da solidariedade.

${ }^{610}$ Para visualização da celeuma, confira-se YUSSEF CAHALI (Dos alimentos, cit., p. 118-131).

${ }^{611}$ Para os fins propostos nesta pesquisa não será necessário enveredar para a discussão que grassa em torno do reflexo processual da parte final do dispositivo transcrito, no ponto em que admite o "chamamento" de outros sujeitos para "integrar a lide". Sobre o tema, com amplo referencial bibliográfico, confira-se MACHADO DE MELO, Diogo Leonardo [O art. 1.698 do Código Civil: repercussões processuais à luz do direito material. In: SCARPINELLA BUENO, Cassio (coord.). Impactos processuais do direito civil. São Paulo: Saraiva, 2008, p. 393-440].
} 
que se podem chamar à responsabilidade (integral ou complementar) os parentes de grau mais remoto.

Sendo assim, a possibilidade de participação (total ou parcial) de determinados sujeitos (parentes de grau mais distante) no adimplemento da obrigação alimentar depende de circunstâncias fáticas que envolvem outro(s) sujeito(s), isto é, a situação financeira dos parentes mais próximos.

Nessas circunstâncias, poder-se-ia conceber que o parente necessitado ajuizasse demanda em face do parente mais remoto, com a incumbência, porém, de "fazer a prova de que o obrigado em primeiro lugar não estaria em condições de suportar totalmente o encargo" ${ }^{\prime 612}$. De qualquer forma, haveria aí o risco de não se conseguir demonstrar tal situação fática, o que implicaria a improcedência do pedido formulado em face do parente mais remoto.

No aspecto processual ensejado pelo tema ainda se poderia cogitar de o alimentário, mesmo diante da existência de outros parentes de grau mais distante, propor ação em face apenas do devedor "principal", correndo-se o risco, outra vez, de se ver demonstrada a insuficiência financeira desse parente mais próximo.

Assim, a condicionante fática relativa a aspectos financeiros do(s) parente(s) mais próximo(s), que só pode ser resolvida satisfatoriamente no ambiente de instrução contraditória, tenderá a solucionar, na dependência do que se verificar em termos probantes, a questão sobre a existência ou não de responsabilidade alimentar dos parentes mais remotos. Contudo, evidencia-se que antes do ajuizamento podem pairar sérias dúvidas sobre a configuração do polo passivo da demanda, pois que, antes de se produzir a prova sobre a situação do parente mais próximo, não se pode inferir quanto à titularidade passiva da relação alimentar respeitante aos parentes mais remotos.

\section{Ainda o direito de família: investigação de paternidade}

Voltando a analisar questões extraídas do riquíssimo âmbito do Direito de Família, pode-se deparar com a situação em que o filho tenha direito ao reconhecimento da paternidade e sua mãe ostente o direito ao ressarcimento, também em face do suposto pai,

${ }^{612}$ CAHALI, Yussef Said. Dos alimentos, cit., p. 135. 
pelas despesas com o parto ${ }^{613}$. A solução que se der quanto à pretensão do filho vai influenciar a decisão sobre o pedido da mãe.

A vida forense demonstra que muitas vezes surgem situações inusitadas, às quais é preciso, mesmo assim, dar respostas jurídicas coerentes. Figura-se, então, um novo exemplo: uma adolescente finda um relacionamento amoroso com determinado rapaz e, como é próprio da adolescência, no intuito de lhe fazer ciúmes ou mesmo vingar-se de uma infidelidade, arranja outro rapaz com quem se relaciona intimamente; em poucas semanas, mas dentro do mesmo mês, a garota mantém relação sexual com dois namorados, sobrevindo gravidez. Quem será o pai?

É inegável que o filho terá direito ao reconhecimento de sua origem paterna, mas certamente as condições em que verificada a concepção trarão incertezas quanto à própria definição de quem seja o suposto pai ${ }^{614}$.

Ainda é possível dar outro enfoque à questão da investigação de paternidade. É que existe uma presunção legal de paternidade em relação aos filhos nascidos na constância do casamento (art. 1.597, I e II, do Código Civil) ${ }^{615}$. A mesma presunção resulta da letra do art. 1.598, do mesmo Codex: "Salvo prova em contrário, se, antes de decorrido o prazo

${ }^{613}$ Esse exemplo foi inspirado em outro semelhante exposto por ARAKEN DE ASSIS, segundo o qual mãe e filho poderiam ajuizar, em conjunto, ação de alimentos e de ressarcimento das despesas do parto, hipótese em que a procedência da ação de alimentos tem como pressuposto a obrigação do pai no que toca às despesas do parto, já que o fundamento da fixação da pensão alimentícia será a existência da paternidade (Cumulação de ações, cit., p. 169). Não se veiculou esse exemplo no texto em razão das dificuldades que poderiam surgir quanto à admissibilidade de cumulação da ação de alimentos, que tem procedimento especialíssimo, com outra de viés desenganadamente ordinário (indenizatória das despesas do parto). Ademais, não se pode descartar, mesmo na hipótese de improcedência do pedido de alimentos, que o pedido indenizatório seja acolhido, bastando que se esteja diante de pai sem condições financeiras para suportar o encargo alimentar. Nessas condições, o pedido de pensão alimentícia formulado pelo filho seria julgado improcedente e o pedido indenizatório manifestado pela mãe poderia ser, ainda assim, procedente.

${ }^{614}$ Essa mesma dúvida, consideradas as peculiaridades fáticas delineadas no texto, pode eclodir na demanda que envolva a pretensão aos chamados "alimentos gravídicos", já que a Lei no 11.804/2008 lida com a noção de "indícios" de paternidade. Tais indícios, como é curial, podem recair, em determinadas situações, sobre mais de uma pessoa.

615 “Presumem-se concebidos na constância do casamento os filhos: I - nascidos 180 (cento e oitenta) dias, pelo menos, depois de estabelecida a convivência conjugal; II - nascidos nos 300 (trezentos) dias subsequentes à dissolução da sociedade conjugal, por morte, separação judicial, nulidade e anulação do casamento". 
previsto no inciso II do art. 1.523, a mulher contrair novas núpcias e lhe nascer algum filho, este se presume do primeiro marido, se nascido dentro dos 300 (trezentos) dias a contar da data do falecimento deste e, do segundo, se o nascimento ocorrer após esse período e já decorrido o prazo a que se refere o inciso I do art. 1.597”.

A par disso, a ninguém se autoriza vindicar estado contrário ao que resulta do registro de nascimento, salvo provando-se erro ou falsidade do registro (CC, art. 1.604).

Dúvidas não há, entretanto, de que o filho tem o direito de investigar sua origem biológica, no afã de estabelecer o compasso entre a situação vertida no registro civil e à chamada "verdade biológica". Daí a viabilidade, mesmo diante das presunções acima delineadas, do manejo, pelo filho, da conhecida ação de investigação de paternidade.

Conforme se tem reiteradamente decidido, a procedência da investigação de paternidade gera, automaticamente - isto é, sem a necessidade de cumulação de pedidos -, a anulação do registro civil no ponto em que faz referência à paternidade ${ }^{616}$.

Todavia, não se pode negar que o pai registral, diante da eventual procedência do pedido de reconhecimento de "nova" paternidade, terá sua esfera jurídica afetada, já que o reconhecimento da paternidade em relação a terceiro implica a anulação ou cancelamento da paternidade registral. Daí a necessidade de o cognominado pai registral figurar no polo passivo da demanda envolvendo a investigação de paternidade proposta pelo filho em face de terceiro ${ }^{617}$.

616 “O cancelamento da paternidade constante do registro civil é decorrência lógica e jurídica da eventual procedência do pedido de reconhecimento da nova paternidade, o que torna dispensável o prévio ajuizamento de ação com tal finalidade" (STJ, REsp nº 693.230/MG, 3ª T., Rel. Min. Nancy Andrighi, j. 11.04.2006, DJ 02.05.2006). Conquanto não seja necessária a cumulação de pedidos, mostra-se admissível tal cumulação: "Processo civil. Recurso especial. Ação de investigação de paternidade. Registro em nome de terceiro. Cumulação de pedidos contra réus diversos. Possibilidade. Aditamento da inicial. A ação de investigação de paternidade independe do prévio ajuizamento da ação de anulação de registro, cujo pedido é apenas conseqüência lógica da procedência da demanda investigatória. Precedentes. A pretensão concomitante de ver declarada a paternidade e ver anulado o registro de nascimento não configura cumulação de pedidos, mas cumulação de ações. (...) Em demanda objetivando a declaração de paternidade e anulação de registro, o suposto pai biológico e aquele que figura como pai na certidão de nascimento devem ocupar, em litisconsórcio unitário, o pólo passivo. Recurso especial não conhecido" (STJ, REsp n n 507.626/SP, $3^{\mathrm{a}}$ T., Rel. Min. Nancy Andrighi, j. 05.10.2004, DJ 06.12.2004).

617 “CIVIL E PROCESSUAL. REGISTRO PÚBLICO. AÇÃO INVESTIGATÓRIA DE PATERNIDADE. 'PAI REGISTRAL' NÃO CITADO PARA A LIDE. LITISCONSÓRCIO PASSIVO NECESSÁRIO. 
O que se impõe encarecer, considerados os objetivos desta pesquisa, é que a manutenção ou o afastamento daquelas presunções legais de paternidade verificar-se-á na dependência do que se estabelecer quanto à paternidade atribuída a outrem. Está aí o liame de prejudicialidade que envolve relações jurídicas titularizadas por sujeitos diversos (pai registral e o suposto pai biológico).

\section{Um caso de direito tributário}

No julgamento do Recurso Especial $\mathrm{n}^{\mathrm{o}} 727.233 / \mathrm{SP}^{618}$, o Superior Tribunal de Justiça deparou-se com a situação de pessoa jurídica prestadora de serviço de engenharia que atuara no Município de São Paulo, no âmbito do qual recolhera o imposto sobre serviços de qualquer natureza (ISSQN). Ocorre que, posteriormente, a mesma empresa fora surpreendida com a notificação de lançamento tributário enviada pelo Município de Jundiaí, relativamente à exação derivada daquela mesmíssima prestação de serviços e daquele idêntico tributo.

Diante desse quadro, de duas uma: ou o débito fiscal anunciado pelo Município de Jundiaí fora lançado indevidamente ou, se não o foi, o Município de São Paulo deveria restituir ao contribuinte aqueles valores recolhidos indevidamente.

NULIDADE PROCESSUAL. CPC, ART. 47, § ÚNICO. CC (de 1916), ART. 348. LEI No 6.015/73, ART. 113. I. O registro público, pela importância dos dados nele assinalados, empresta estabilidade e segurança à organização, social e jurídica do país, e é gerador de direitos e deveres dos mais diversos e relevantes, inclusive em face do efeito erga omnes que conferem. II. De outra parte, seja em face das exigências contidas

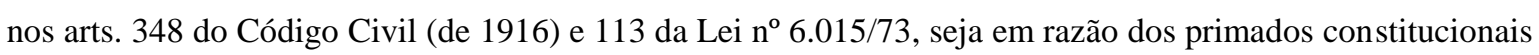
do devido processo legal e da amplitude do direito de defesa, necessária a presença, no pólo passivo de ação investigatória de paternidade, do pai registral, interessado direto no resultado da demanda, onde é concomitantemente postulada a sua desconstituição de tal qualidade. III. A não citação do pai registral para a lide acarreta a nulidade processual, nos termos do art. 47, parágrafo único, do CPC. IV Recurso especial conhecido e parcialmente provido" (STJ, REsp n ${ }^{\mathrm{o}}$ 117.129/RS, 4 ${ }^{\mathrm{a}}$ T., Rel. Min. Aldir Passarinho Junior, j. 05.06.2001, DJ 24.09.2001). No mesmo sentido: STJ, REsp n ${ }^{\mathrm{o}}$ 402.859/SP, $4^{\mathrm{a}}$ T., Rel. Min. Barros Monteiro, j. 22.02.2005, DJ 28.03.2005, p. 260.

$6182^{\mathrm{a}}$ Turma, Rel. Min. Castro Meira, j. 19.03.2009, DJe 23.04.2009, v.u. Cfr., ainda a respeito desse precedente, breve comentário elaborado pelo autor deste trabalho e publicado na Revista de Processo $\mathrm{n}^{\circ} 175$, p. 279-285. 
Veja-se que a situação de direito material decorrente de um único encadeamento fático-jurídico (prestação de serviços de engenharia) pôs em evidência a problemática envolvendo, de um lado, uma empresa e, de outro, dois entes políticos, com a peculiaridade de que a definição jurídica quanto a uma das pessoas políticas influencia, de maneira contundente, a própria existência da relação jurídico-material pertinente ao outro ente tributante.

No caso analisado, a autora da demanda formulou pedido de anulação de débito fiscal em face do Município de Jundiaí e, para o caso de improcedência desse pedido, deduziu, no mesmo processo, pedido de repetição de indébito em desfavor do Município de São Paulo.

\section{Mandado de injunção: hipótese do art. $8^{\circ}$, § $3^{\circ}$, do ADCT}

Desde que forjado pela Constituição de 1988, o mandado de injunção vem experimentando evolução especial no ponto relativo aos efeitos da decisão concessiva da ordem injuncional. Com efeito, no espectro da jurisprudência do Supremo Tribunal Federal, à postura primitiva de igualar os efeitos do mandado de injunção ao que se dava no âmbito da ação de inconstitucionalidade por omissão ${ }^{619}$ seguiu-se a tendência concretizadora dos direitos e liberdades constitucionais e das prerrogativas inerentes à nacionalidade, à soberania e à cidadania, mesmo diante da falta da norma regulamentadora $\left(\mathrm{CF}, \text { art. } 5^{\circ}, \mathrm{LXXI}\right)^{620}$.

\footnotetext{
${ }^{619}$ Fundamental, nesse sentido, foi a decisão proferida pelo STF no Mandado de Injunção no $107-3 / \mathrm{DF}$, de que fora relator o ministro Moreira Alves, ocasião em que se assentou, às escâncaras, que essa ação constitucional tinha por efeito a singela cientificação - e nada mais - de que o ente legislativo estaria em mora quanto à edição de norma exigida pela Constituição Federal. Na esteira desse raciocínio, o Poder Judiciário não poderia criar as condições necessárias à fruição de um direito reconhecido constitucionalmente, suportando o interessado as agruras de uma omissão institucionalizada. A doutrina, desde o início, externou críticas à tese de que o mandado de injunção não passaria de uma ação de inconstitucionalidade por omissão subsidiária (por todos: AFONSO DA SILVA, José. Curso de direito constitucional positivo. 20. ed. São Paulo: Malheiros, 2002, p. 446-451).

${ }^{620}$ Nesse sentido, o Supremo Tribunal Federal, reconhecendo a omissão legislativa quanto à exigência de norma prevista no art. 195, $\S 7^{\circ}$, da Constituição da República, acabou integrando o sistema com a solução segundo a qual, uma vez expirado o prazo de seis meses e mantida a omissão legislativa, o interessado
} 
No ponto em que interessa para este trabalho, deve-se pôr em destaque a norma contida no art. $8^{\circ}, \S 3^{\circ}$, do Ato das Disposições Constitucionais Transitórias: “Aos cidadãos que foram impedidos de exercer, na vida civil, atividade profissional específica, em decorrência das Portarias Reservadas do Ministério da Aeronáutica nº S-50-GM5, de 19 de junho de 1964, e nº S-285-GM5 será concedida reparação de natureza econômica, na forma que dispuser lei de iniciativa do Congresso Nacional e a entrar em vigor no prazo de doze meses a contar da promulgação da Constituição".

Em 1991, quando do julgamento do mandado de injunção no 283-5/DF, o Supremo Tribunal Federal reconheceu a mora do Congresso Nacional em editar a norma regulamentadora exigida pelo dispositivo acima transcrito ${ }^{621}$. E o mais interessante é que no mandado de injunção $n^{\circ}$ 562-9/RS, ao tratar novamente do tema, a Corte Constitucional brasileira, a par de proclamar aquele estado de mora do Congresso Nacional, reconheceu o direito de indenização titularizado pelos impetrantes e determinou, enfaticamente, que os interessados deveriam apenas liquidar os danos perante o órgão judiciário competente, fixando-se o quantum devido.

Dada a relevância do caso para o desenvolvimento das ideias que virão, permite-se a transcrição de parte da ementa:

\begin{abstract}
"Reconhecimento da mora legislativa do Congresso Nacional em editar a norma prevista no parágrafo $3^{\circ}$ do art. $8^{\circ}$ do ADCT, assegurando-se, aos impetrantes, o exercício da ação de reparação patrimonial, nos termos do direito comum ou ordinário, sem prejuízo de que se venham, no futuro, a beneficiar de tudo quanto, na lei a ser editada, lhes possa ser mais favorável que o disposto na decisão judicial. O pleito deverá ser
\end{abstract}

passaria a gozar da imunidade aludida no texto da Constituição (Mandado de Injunção no 232-1/RJ, Pleno, Rel. Min. Moreira Alves, j. 02.08.1991, DJ 27.03.1992, p. 3800; RTJ 137/965). Essa tendência de integração judicial da norma regulamentadora faltante também se verificou nos casos envolvendo direito de greve e de aposentadoria especial dos servidores públicos (respectivamente, arts. 37 , VII, e 40, $\S 4^{\text {o }}$, da CF/88). Sobre o ponto, conferir os seguintes julgados: STF, Mandado de Injunção no 721/DF, Pleno, Rel. Min. Marco Aurélio, j. 30.08.2007, DJe 30.11.2007, RTJ 203/11; STF, Mandado de Injunção nº 708/DF, Pleno, Rel. Min. Gilmar Mendes, j. 25.10.2007, DJe 31.10.2008, com notícia ampla da evolução jurisprudencial em tema de concretização de direitos via mandado de injunção.

621 STF, Mandado de Injunção nº 283-5/DF, Pleno, Rel. Min. Sepúlveda Pertence, j. 20.03.1991, DJ 14.11.1991, RTJ 135/882. 
veiculado diretamente mediante ação de liquidação, dando como certos os fatos constitutivos do direito, limitada, portanto, a atividade judicial à fixação do 'quantum' devido"622.

RODRIGO MAZZEI, ao versar especificamente sobre o caso acima transcrito, asseverou, com acerto, que a decisão do Supremo Tribunal Federal deu margem à formação de título executivo judicial, dada a carga condenatória de que se revestiu o dispositivo do acórdão. De fato, concluiu o citado autor, a decisão "não teve natureza puramente declaratória, uma vez que, ao definir a existência do direito no caso particular, o acórdão criou norma concreta que garantiu aos requerentes o direito à indenização" ${ }^{\text {,623 }}$.

Ocorre que o título executivo judicial que se formou no mandado de injunção, em cujo polo passivo figurava o Congresso Nacional (órgão responsável pela edição da norma regulamentadora), endereçou-se ao patrimônio da União, pondo-se em debate a necessidade, ou não, da integração do polo passivo do mandado de injunção pela União ${ }^{624}$.

Parece acertado dizer, ao menos para o caso aqui enfocado, que a União deveria mesmo integrar o polo passivo do mandado de injunção (litisconsórcio obrigatório) ${ }^{625}$, pondo-se em relevo a peculiaridade de que sua situação jurídica só haveria de ser afetada na eventualidade do reconhecimento, pelo Tribunal, da omissão legislativa do Congresso Nacional. Ou seja, para o caso de procedência do pedido em relação ao Congresso Nacional é que surgiria ambiente para o estabelecimento da indenização a ser suportada pela União. Em outras palavras, a formação de título executivo judicial em relação a um

${ }^{622}$ STF, Mandado de Injunção n o 562-9/RS, Pleno, Rel. p/ Acórdão Min. Ellen Gracie, j. 20.02.2003, DJ 20.06.2003, p. 58 .

623 Título executivo, liquidação de sentença e coisa julgada no mandado de injunção: análise a partir dos precedentes do Supremo Tribunal Federal (art. $8^{\circ}, \S 3^{\circ}$, ADCT). In: DIDIER JR, Fredie (coord.). Execução civil: estudos em homenagem ao Professor Paulo Furtado, p. 290-291.

${ }^{624}$ No caso específico do MI no 562-9/RS, o ministro originariamente sorteado como relator (Marco Aurélio), verificando o possível atingimento da esfera jurídica da União, determinou a inclusão desta no polo passivo da demanda injuncional. Tanto é verdade que na epígrafe do acórdão citado o Presidente do Congresso Nacional aparece como "impetrado", enquanto que a União surge como "parte passiva".

${ }^{625}$ MAZZEI, Rodrigo Reis. Título executivo, liquidação de sentença e coisa julgada no mandado de injunção: análise a partir dos precedentes do Supremo Tribunal Federal (art. $8^{\circ}$, § 3º ADCT), cit., p. 296, com ampla citação bibliográfica. 
sujeito (União) teria como pressuposto a verificação, em termos positivos, da omissão legislativa do Congresso Nacional.

\section{Benefícios previdenciários originários de união estável}

O benefício previdenciário denominado pensão por morte é devido ao conjunto de dependentes do segurado que falecer ${ }^{626}$. Nos termos da legislação de regência, considerase dependente do segurado, por presunção legal, o companheiro ou companheira, assim entendida a pessoa que, sem ser casada, mantém união estável com o segurado ou com a segurada $^{627}$.

A existência de união estável e da qualidade de segurado configura questão geralmente controvertida em ações movidas em face da autarquia previdenciária (INSS). E o embate que se coloca diz respeito a condicionantes fáticas, em ordem a se exigir dilação probatória.

Sendo assim, pode-se figurar, exemplificativamente, a situação em que determinada pessoa, afirmando-se dependente de segurado falecido, com quem mantivera união estável, almeja o reconhecimento judicial da convivência em nível de entidade familiar para fins sucessórios e também para fins previdenciários.

Para conferir maior ênfase à situação da autarquia previdenciária, basta imaginar como sói de acontecer - que sejam negadas, na seara administrativa, a qualidade de segurado em relação ao falecido convivente (v. g., trata-se de trabalhador rural sem registro em Carteira de Trabalho) e também a condição de dependente, sob o argumento de inexistência da união estável.

Em termos sucessórios, suponha-se que, no mesmo caso, os familiares do extinto também não reconheçam a propalada união estável, de modo que a solução da controvérsia não pode ser obtida no âmbito do inventário, já que se está diante de "questão de alta indagação".

\footnotetext{
${ }^{626}$ Art. 74, caput, da Lei $\mathrm{n}^{\mathrm{o}} 8.213 / 91$.

${ }^{627}$ Art. 16 , I e $\S \S 3^{\circ}$ e $4^{\circ}$, da Lei $n^{\circ} 8.213 / 91$.
} 
Seria de se perquirir sobre a possibilidade de se veicular, no mesmo processo $^{628}$, mediante a afirmação de existência da união estável, os seguintes pedidos: $a$ ) reconhecimento da convivência familiar em face dos outros sucessores do falecido; $b$ ) imposição da obrigação de o INSS implantar o benefício e pagar as verbas atrasadas, acrescentando-se, como causa de pedir em relação a essa pretensão, a afirmação de que o falecido era mesmo segurado do INSS, porquanto trabalhador rural sem carteira assinada.

Observe-se que o segundo pedido (letra $b$ ), embora também lastreado na afirmada união estável, vem formulado em face de sujeito diverso, agregando-se uma outra causa de pedir (qualidade de segurado). Evidencia-se, nessa hipótese, a influência que o julgamento do pedido formulado em face dos sucessores do falecido segurado exercerá quanto à apreciação da pretensão manejada em face da autarquia previdenciária.

\section{Fechamento do Capítulo e da Parte II}

Com base na ideia de que o processo tem por escopo, ao lado de outros, de realizar o direito objetivo, a exposição até aqui desenvolvida buscou demonstrar a existência de particularidades em algumas relações de direito material aptas a conturbar o entendimento sobre quem efetivamente titulariza esta ou aquela posição subjetiva. Em inúmeras situações, catalogadas exemplificativamente e sem a ambição da exaustão, transparece evidente que num primeiro momento a discussão irrompe com pluralidade de sujeitos, sendo necessário desvendar circunstâncias fáticas e/ou jurídicas para só então se chegar a uma conformação subjetiva mais precisa da relação de direito material.

Nesses casos, vislumbra-se a presença de uma dúvida, objetivamente aferível, acerca da exata configuração subjetiva de uma dada relação de direito material, algo que vai, ineludivelmente, refletir na composição dos polos da relação processual em caso de eventual demanda judicial.

\footnotetext{
${ }^{628}$ As dificuldades em termos competência (Justiça Federal em relação ao pleito em face do INSS; Justiça Estadual quanto ao reconhecimento da união estável) seriam solucionadas pela inclusão de um dado no problema aventado: a comarca onde reside o autor ou autora da demanda não é sede de vara da Justiça Federal, circunstância que agrega "competência delegada" aos órgãos da Justiça Estadual, ex vi do art. 109, § $3^{\circ}$, da Constituição Federal.
} 
Interessante notar que esses problemas emergem em variados setores do direito material, desde as mais comuns situações de responsabilidade civil e de direito de família até as relações intrincadas de direito tributário e previdenciário, numa demonstração de que se está a exigir do sistema processual uma resposta adequada a tais necessidades, que, como visto, não são isoladas.

Noutra variante, catalogaram-se situações, também advindas da conformação da relação material, em que a posição jurídica de um sujeito, na medida em que seja solucionada desta ou daquela forma, produz inequívoca influência na configuração da posição jurídica ocupada por outro sujeito, exsurgindo daí o tema da prejudicialidade entre relações de direito material que envolvem sujeitos distintos.

Então, na medida em que se pretenda solucionar a maior parte possível de uma dada relação litigiosa, põe-se em causa o método processual apto a dar vazão a esse tipo de demanda subjetivamente plural, particularizada, contudo, pela nota da prejudicialidade.

Patenteadas as premissas de direito material, convém sejam recordados, num breve aceno e à guisa de conclusão dessa Parte II, os polos metodológicos relacionados com o acesso à justiça e seus desdobramentos, pondo-se em revelo o aspecto da razoável duração dos processos em geral. Importa, então, considerar que o acesso à justiça não se reduz à outorga de acesso a qualquer processo, ou a qualquer decisão de mérito proferida em qualquer tempo, efetivada ou executada por qualquer meio. Delineia-se relevante, portanto, o acesso ao justo processo, tanto na perspectiva do autor quanto na do réu, já que a noção de processo civil de resultados não pode desvirtuar-se para a de um processo civil construído para o autor.

Numa postura mais verticalizada, procurou-se também demonstrar que o sistema processual, do modo como está hoje constituído, lida não raras vezes com a noção de dúvida, situação para a qual o mesmo sistema engendra soluções inteligentes, tudo com o objetivo de não embaraçar o acesso à ordem jurídica justa. É nessa perspectiva que se expuseram, mais uma vez sem a pretensão de exaustão, algumas emanações da técnica da fungibilidade como antídoto aos estados de perplexidade em que são colocados os destinatários dos serviços jurisdicionais em razão de situações criadas pelo próprio sistema jurídico. Ou seja, não se trata de dúvidas criadas ou imaginadas pelo intérprete ou operador do direito, daí podendo-se falar em dúvida objetivamente aferível. 
Já se disse - e agora convém reprisar - que as dúvidas geradas na economia interna do processo são enfrentadas por mecanismos também criados pelo sistema processual. E essa é uma constatação razoavelmente tranquila, conforme se tentou revelar alhures (Cap. $\mathrm{I}, \mathrm{n}^{\mathrm{o}} 4$, supra). O que se impõe verificar, doravante, e com base nas premissas de direito material também já aludidas, são os mecanismos de enfrentamento processual paras as hipóteses em que a dúvida, objetivamente aferível, vem da conformação da relação de direito material! É por essa via marcadamente instrumental que segue o presente estudo.

Do ponto de vista teórico e também da conformação legislativa em vigor, sobreleva notar a contribuição que se pode extrair de tudo quanto já se produziu em torno da cumulação eventual, alternativa e sucessiva de pedidos (Cap. II, supra), sendo possível, conforme se crê, o transporte do paradigma desse tipo de cumulação objetiva para o campo da cumulação subjetiva.

Então, com o arsenal de informações até aqui coletado tentar-se-á desenvolver, na próxima Parte do trabalho, uma construção processual que seja teoricamente aceitável e útil em termos práticos, cumprindo-se assim a missão de contribuir, de alguma forma, para o estudo das modalidades litisconsorciais eventual, alternativa e sucessiva. 
PARTE III

\section{OUTRAS MODALIDADES LITISCONSORCIAIS}

\section{Capítulo I}

\section{LITISCONSÓRCIO EVENTUAL}

\section{Noção e terminologia}

A partir da noção de cumulação eventual de pedidos, tal como explicitada no Cap. II da Parte II, pode-se alinhavar uma construção, agora sob a perspectiva subjetiva, segundo a qual o litisconsórcio eventual caracteriza-se pela formulação de pedido em face de um determinado sujeito e, para o evento de não ser possível o acolhimento dessa pretensão primária, formula-se o mesmo ou diverso pedido, em caráter subsidiário, em face de sujeito distinto daquele primitivo.

Essa tomada de empréstimo da noção de cumulação eventual de pedidos acaba gerando a impressão de que o litisconsórcio eventual dá-se apenas no polo passivo da demanda. É que, de regra, os pedidos são formulados pelo autor, de sorte que, feito o transporte da noção para o campo do litisconsórcio, ter-se-ia a subsidiariedade radicada apenas no polo passivo da relação processual, mediante a preferência manifestada pelo autor: pede-se algo em face de Augusto e, subsidiariamente, para a hipótese de não acolhimento do pedido primário, pede-se algo em face de Bruno.

Mas não se pode descartar, aprioristicamente, que o litisconsórcio eventual verifique-se também no polo ativo. Nada obsta a que dois litigantes componentes do polo ativo ajuízem a demanda conjunta e formulem suas pretensões em ordem de preferência em face do mesmo réu ou de um conjunto de réus. $\mathrm{O}$ autor Antônio formula pedido em face de Benedito, mas para a hipótese de não ser acolhido esse pedido, já existe a pretensão 
subsidiária de Carlos também em face de Benedito ${ }^{629}$. Ter-se-ia, nesse contexto, litisconsórcio eventual ativo.

Daí que, diferentemente das aparências, o litisconsórcio eventual encontra ambiente para se verificar tanto no polo ativo quanto no passivo da relação processual ${ }^{630}$. Tudo estará na dependência da vontade manifestada pelo sujeito ou pelos sujeitos que figurarem como autor ou autores da demanda.

Percebe-se, desde logo, que esse tipo de aglutinação de partes situa-se no campo mais abrangente do litisconsórcio facultativo, pois não se vislumbra a indispensabilidade da demanda conjunta, seja pela imperiosidade adveniente de algum preceito normativo, seja pela necessidade derivada da conformação da relação de direito material discutida. Em outras palavras, afiguram-se incompatíveis as noções de litisconsórcio eventual e de litisconsórcio necessário.

Para conferir sustentação ao que se vem de anunciar, bem é de ver que a figura do litisconsórcio eventual ou subsidiário não é de todo desconhecida da doutrina nacional e estrangeira.

Em texto publicado em 1943, ENRICO REDENTI fez anotações a um julgado da Corte di Cassazioni e se debruçou mais especificamente sobre o aspecto da competência num caso em que determinada pessoa jurídica buscava o reembolso de valores em face de dois entes da administração pública (Comissariato di Bologna e Intendenza di Udine), muito embora a situação desses sujeitos passivos tenha sido colocada em tom de alternatividade, porquanto, segundo a demanda incoada, um dos dois haveria de responder pelos valores reclamados pelo autor e não ambos ${ }^{631}$.

Lidando com a noção de alternatividade subjetiva, REDENTI chamou a atenção para o que designou de "falsa (spuria) alternatività", hipótese em que o autor ajuíza demanda

\footnotetext{
${ }^{629}$ Vem da doutrina portuguesa a seguinte hipótese: "se, por exemplo, duas sociedades pertencentes ao mesmo grupo tiverem dúvidas sobre quem é o verdadeiro credor, ambas podem instaurar a acção de dívida e atribuir a uma a posição de credor principal e a outra a de credor subsidiário" (TEIXEIRA DE SOUSA, Miguel. Estudos sobre o novo processo civil. 2. ed. Lisboa: LEX, 1997, p. 166-167).

${ }^{630}$ Aceitando apenas o litisconsórcio eventual passivo, cfr. RODRIGUES BASTOS, Jacinto Fernandes (Notas ao Código de Processo Civil. 3. ed. Lisboa: Almedina, 1999, vol. I, p. 86) e ASSIS, Araken de (Cumulação de ações, cit., § 12, nº 41, p. 168).

${ }^{631}$ Problemi di competenza in cassazione. Rivista di diritto processuale civile, vol. XX, parte II, 1943, $\mathrm{n}^{\circ} 1$, p. $81-82$.
} 
com base num determinado título (causa de pedir) contra um certo sujeito passivo e, para o caso desse título revelar-se insubsistente (rejeitado por qualquer motivo), aduz-se a existência de um outro título, agora em face de outro sujeito ${ }^{632}$. Vê-se nessa proposição uma pluralidade de sujeitos compondo o polo passivo da relação processual, sendo a situação jurídica de um deles valorada na medida em que rejeitada a pretensão deduzida em face de outro. Conquanto mediante terminologia diversa, o fenômeno vislumbrado por REDENTI configura, em linhas gerais, o instituto aqui estudado.

Não escapou à argúcia de ALLORIO o fenômeno do litisconsórcio eventual, cuja tratativa deu-se apenas de passagem no ensaio Litisconsorzio alternativo passivo $e$ impugnazione incidentale ${ }^{633}$. Partiu-se da orientação de REDENTI, quanto à existência de uma alternatividade subjetiva vera e outra spuria, para aclarar que diante de uma preferência manifestada pelo autor entre um ou outro demandado dar-se-á o litisconsórcio eventual, que no dizer de ALLORIO também é "perfettamente ammissibile"634. Na espécie, explica o autor, verificam-se duas demandas endereçadas a réus diversos e submetidas, em certa medida, a uma condição: "nel litisconsorzio eventuale, condizionata sola la seconda al mancato accoglimento della prima" ${ }^{, 635}$. Então, o fenômeno aqui delineado, que para REDENTI significaria uma alternatividade subjetiva espúria, configura o litisconsórcio eventual segundo a linguagem mais coerente de ALLORIO.

Também de relance foi a lembrança feita por GIUSEPPE TARZIA num estudo específico sobre demandas alternativas, oportunidade em que o doutrinador italiano remarcou o ambiente limítrofe em que residem o litisconsórcio eventual e o alternativo, pondo-se em relevo a incerteza suscitada em torno da identidade do verdadeiro titular ativo ou passivo da relação material controvertida ${ }^{636}$. Já em outra obra clássica, o autor voltou ao

\footnotetext{
${ }^{632}$ Problemi di competenza in cassazione, cit., $\mathrm{n}^{\mathrm{o}}$ 10, p. 97-98. Sobre a "vera alternatività" serão feitas considerações quando do estudo do litisconsórcio alternativo (Cap. II, $\mathrm{n}^{\circ}$ 37, infra).

${ }^{633}$ L'ordinamento giuridico nel prisma dell'accertamento giudiziale e altri studi. Milano: Giuffrè, 1957, p. 515 et seq.

${ }^{634} I d .$, p. 515.

${ }^{635}$ Id., ibid.

${ }^{636}$ Appunti sulle domande alternative. Rivista di diritto processuale, vol. XIX, 1964, no 7, p. 293. Na nota 120 desse mesmo texto, TARZIA utiliza expressamente o termo litisconsorzio eventuale (p. 293).
} 
tema e esclareceu que o litisconsórcio eventual deriva de um cúmulo de demandas entre sujeitos diversos, sendo uma delas intentada para o caso de ser rechaçada a outra ${ }^{637}$.

De outra parte, encontra-se na doutrina alemã rápida passagem de SCHÖNKE, o qual explica que a acumulação subjetiva eventual se verifica quando a demanda manejada contra o segundo réu só se considera formulada para o caso de não se ter curso a intentada em face do primeiro réu. Interessante notar que tal preleção foi incluída especificamente na parte destinada ao estudo do litisconsórcio ${ }^{638}$.

Ao tratar da pluralidade de demandas, LENT conferiu maior ênfase à hipótese de demandas subordinadas, que se verificam quando são propostas, conjuntamente, duas demandas e a segunda delas não pode ser examinada senão depois de rejeitada a primeira. Para exemplificar, figurou-se a situação em que o autor esteja incerto quanto a determinado acontecimento ajustar-se a uma fattispecie normativa ou a outra, de modo que não se saiba, conseguintemente, qual dentre os dois efeitos jurídicos afirmados seja justo. Semelhante situação dá margem ao instituto chamado Eventualhäufung, o qual, na tradução italiana de EDOARDO RICCI, significa subordinazione $e^{639}$.

Presente essa noção, LENT noticia ser discutível a admissão dessa subordinação entre duas demandas endereçadas a pessoas diversas. Mesmo sem externar sua opinião sobre o assunto, o citado autor formula um exemplo também interessante que pode ser catalogado como de litisconsórcio eventual: "Si pensi al caso in cui l'attore desideri agire in primo luogo contro il nuovo debitore A ed in subordine contro l'antico B, essendo dubbia l'efficacia dell'atto con cui il primo si è assunto il debito del secondo"640.

Na Espanha, RAmos MÉNDEZ, desde a primeira edição de seu Derecho procesal civil, anunciou que o litisconsórcio subsidiário tem lugar quando se demande em caráter principal a uma pessoa e, para o caso de resultar desacolhido esse pedido primário, se dirija

\footnotetext{
${ }^{637}$ Il litisconsorzio facoltativo nel processo di primo grado, cit., p. 43. Ainda na Itália, GIAN FRANCO RICCI investigou recentemente os reflexos recursais dessa configuração litisconsorcial (Il litisconsorzio nelle fasi di impugnazione. Milano: Giuffrè, 2005, p. 289 et seq.).

${ }^{638}$ Derecho procesal civil, cit., $§ 26$, III, $\mathrm{n}^{\circ} 1$, p. 95.

${ }^{639}$ LENT, Friedrich. Diritto processuale civile tedesco, cit., § 88, III, p. 326-327.

${ }^{640} I d$., $§ 88$, III, p. 327. Na doutrina alemã mais recente também se encontram referências ao instituto em apreço (BLOMEYER, Arwed. Zivilprozessrecht - Erkenntnisverfahren. Berlin-Göttingen-Heidelberg: Springer-Verlag, 1963, § 109, p. 611 et seq.; ROSENBERG, Leo; SCHWAB, Karl Heinz. Zivilprozessrecht. München: C. H. Beck, 1986, § 49, p. 279 et seq.).
} 
também a ação contra outra, ad cautelam $^{641}$. Vê-se, pois, que nesse tipo de litisconsórcio “existe una pretensión perfecta y outra sujeta a condición. Solo podrá discutirse la segunda cuando la primera haya sido rechazada" ${ }^{, 642}$.

Por sua vez, a redação atual do art. 31-B, do Código de Processo Civil português, traz o seguinte discurso normativo: "É admitida a dedução subsidiária do mesmo pedido, ou a dedução de pedido subsidiário, por autor ou contra réu diverso do que demanda ou é demandado a título principal, no caso de dúvida fundamentada sobre o sujeito da relação controvertida",643.

Fala-se em doutrina que tal dispositivo introduziu no ordenamento processual português "a figura do chamado litisconsórcio eventual ou subsidiário" "644. Nessa conformidade, diz-se que determinado litigante será titular de uma situação jurídica se o outro não o for ou, então, que um réu será condenado caso o pedido não seja procedente quanto ao outro demandado ${ }^{645}$.

Propagam-se entre nós semelhantes ensinanças. De fato, não é de hoje que CÂNDIDO DINAMARCO, com base em expressiva resenha bibliográfica estrangeira e depois de criticar o silêncio da doutrina brasileira, verbera a possibilidade de se construir a noção de litisconsórcio eventual partindo-se da projeção que o tema do cúmulo objetivo enceta na teoria do litisconsórcio facultativo. Infere-se que litisconsórcio eventual, ativo ou passivo, configura uma inevitável irradiação do quanto se diz no art. 289, do CPC, em ordem a se concluir que determinado pedido envolvendo um litigante só será apreciado pelo julgador na hipótese eventual de não ter sido acolhido o pedido formulado por ou em face de outro litigante $^{646}$. Tratando-se de hipótese de litisconsórcio facultativo comum, ter-se-ia, a um só tempo, "cúmulo subjetivo e também objetivo de demandas"647.

\footnotetext{
${ }^{641}$ Cap. 13, III, no 3, p. 270. No mesmo sentido: VIDAL PÉREZ, María Fernanda. Op. cit., p. 95.

${ }^{642}$ SERRA DOMINGUEZ, Manuel. Concepto y regulación positiva del litisconsorcio. Revista de derecho procesal iberoamericana, $\mathrm{n}^{\circ} 3,1971$, p. 582.

${ }^{643}$ Redação conferida pelo Decreto-Lei no $329-\mathrm{A}$, de 12 de dezembro de 1995.

${ }^{644}$ RODRIGUES BASTOS, Jacinto Fernandes. Op. cit., vol. I, p. 85. Assim também referem REMÉDIO MARQUES, João Paulo (Acção declarativa à luz do Código revisto. 2. ed. Coimbra: Coimbra, 2009, nº 102, p. 384) e BAPTISTA, José João (Processo civil. 8. ed. Coimbra: Coimbra, 2006, vol. I, p. 183-185).

${ }^{645}$ TEIXEIRA DE SOUSA, Miguel. Op. cit., p. 166. Lembrando-se que em Portugal se faz distinção entre coligação e litisconsórcio, entende-se que o art. 31-B, do CPC lusitano, dá margem tanto à coligação subsidiária como ao litisconsórcio subsidiário.

${ }^{646}$ Litisconsórcio, cit., $\mathrm{n}^{\circ} 182-183$, p. 457 et seq.
} 
De seu turno, ARAKEN DE ASSIS assinala que o litisconsórcio adquire a forma eventual quando uma das ações em face de réus distintos tem colocação subsidiária, admitindo-se essa modalidade litisconsorcial tão somente no campo do litisconsórcio passivo $^{648}$. Elucida o autor, em ensaio específico sobre o litisconsórcio, que a dúvida $a$ priori acerca da legitimidade, ativa ou passiva, é que serve de pressuposto para esse tipo de litisconsórcio, propondo-se que o juiz a resolva a posteriori ${ }^{649}$.

Mais recentemente, encontra-se referência ao litisconsórcio eventual na obra de CASSio SCARPINELla BuENo, que promove a ubiquação da matéria no espectro mais largo do litisconsórcio facultativo e concebe a formação desse tipo de litisconsórcio tanto no polo ativo quanto no passivo da relação processual ${ }^{650}$. Evocando o instituto da desconsideração da personalidade jurídica ${ }^{651}$, o autor comenta que o credor poderia formular pedido condenatório em face da pessoa jurídica e, desde logo, formular também pedido subsidiário em face das pessoas físicas que a integram, para a eventualidade de ficar demonstrada a ocorrência de algum fator de desconsideração da personalidade jurídica $^{652}$.

Também já se escreveu que o litisconsórcio eventual, diversamente da configuração até aqui anunciada, pode resultar de aspectos pertinentes à responsabilidade patrimonial. $\mathrm{O}$

\footnotetext{
${ }^{647}$ Litisconsórcio, cit., $\mathrm{n}^{\circ} 182$, p. 459.

${ }^{648}$ Cumulação de ações, cit., § 12, nº 41, p. 165 et seq.

649 Do litisconsórcio no Código de Processo Civil, cit., nº 4.3, p. 555. Com a merecida profundidade, RONNIE PREUSS DUARTE também versou o tema em artigo intitulado "Litisconsórcios alternativo e subsidiário no processo civil brasileiro" (cit., no 147, p. 27-49).

${ }^{650}$ Partes e terceiros no processo civil brasileiro, cit., p. 98 et seq.

${ }^{651}$ Cfr. Parte II, Cap. III, nº 22.

${ }^{652}$ Partes e terceiros no processo civil brasileiro, cit., p. 103. Afora os autores destacados no texto, ATHOS GUSMÃO CARNEIRO (op. cit., p. 13-14) e FREDIE DIDIER JR. (Curso de direito processual civil. 7. ed. Salvador: JusPodivm, 2007, vol. 1, p. 282-283) também aludiram à modalidade litisconsorcial aqui considerada, mas o fizerem sem grande contribuição pessoal, porquanto suas referências remontam à preleção já sumariada neste rápido aceno sobre o panorama doutrinário brasileiro. Com algum proveito, consulte-se ainda: NEGRÃO, Theotonio; GOUVÊA, José Roberto F.; BONDIOLI, Luiz Guilherme A. (Código de Processo Civil e legislação processual em vigor. 42. ed., São Paulo: Saraiva, 2010, nota $1 b$ ao art. 46 do CPC, p. 172); SIMÃO, José Fernando (Responsabilidade civil do incapaz, cit., p. 236 et seq.); ASSUMPÇÃO NEVES, Daniel Amorim (Ações probatórias autônomas. São Paulo: Saraiva, 2008, p. 409 et seq.). Em tom de desconfiança quanto à efetiva existência de litisconsórcio eventual, confira-se OVÍDIO A. BAPTISTA DA SILVA (Comentários ao Código de Processo Civil, cit., vol. 1, p. 203-205).
} 
fenômeno dar-se-ia na hipótese em que, diante de responsabilidade patrimonial subsidiária, um dos litigantes é convocado a solver uma dívida ad eventum de o responsável principal não reunir condições patrimoniais para fazê-lo.

Veja-se que nessa compostura não se está diante da rejeição (pelo mérito ou por alguma deficiência processual) do pedido atrelado ao litigante primário. A condição para que se atinja o litigante subsidiário está em que não se ache no patrimônio do "devedor principal" o quantum suficiente para satisfação de um crédito ${ }^{653}$.

Sob o aspecto terminológico, já se disse, e convém sempre relembrar, que o grau de desenvolvimento de uma ciência afere-se pelo maior ou menor refinamento de seu particularizado vocabulário ${ }^{654}$, impondo-se, num prisma prático do cotidiano do profissional do direito, o imprescindível conhecimento e a adequada utilização das palavras, "com integral consciência de seu significado, sob pena de mau entendimento dos textos postos em leitura" $" 655$.

Presente essa necessidade, oportuno esclarecer que a expressão litisconsórcio eventual, ao menos no seio da Língua Portuguesa, pode abranger variadas acepções. Com efeito, eventual traduz a ideia daquilo que pode ou não vir a ser ou acontecer, não se podendo descartar, ainda, uma compreensão que projete uma noção de facultatividade, no sentido de que se possa ou não fazer alguma coisa. Eventual também remete à noção de ocasional, como se diz quando alguém exerce, por exemplo, uma atividade eventual ${ }^{656}$.

\footnotetext{
${ }^{653}$ CAMIÑA MOREIRA expõe tal peculiaridade, embora para o campo do processo de execução, e refere que o caso também é de litisconsórcio eventual. O autor exemplifica com duas hipóteses: (a) o terceiro hipotecante torna-se parte na execução só depois de se verificar que o devedor não honrou a dívida (eis aí a eventualidade); (b) o cônjuge do executado só integrará a execução, respondendo com seu patrimônio particular, na eventualidade de o patrimônio do executado não ser suficiente para saldar a dívida, desde que presente, também, segundo as regras de direito material, fundamento para que haja tal responsabilidade subsidiária (Litisconsórcio no processo de execução, cit., p. 212 et seq.).

654 DINAMARCO, Cândido Rangel. Vocabulário de direito processual. In: Fundamentos do processo civil moderno. 5. ed., São Paulo: Malheiros, 2000, t. I, p. 136.

${ }^{655}$ DINAMARCO, Cândido Rangel. Vocabulário do processo civil, cit., nº 1, p. 25.

${ }^{656}$ No Direito do Trabalho, por exemplo, existe a figura do trabalhador eventual.
} 
Não por outro motivo é que se vê em abalizada doutrina o emprego da expressão litisconsórcio seguida do adjetivo eventual para designar hipótese de litisconsórcio facultativo $^{657}$.

Mas já se pôde perceber que, para os fins deste estudo, não é nesse sentido que se vale da expressão litisconsórcio eventual. A eventualidade aqui considerada tem sim relação com aquilo que pode ou não acontecer, isto porque a apreciação do pedido subsidiariamente formulado em face de um sujeito pode ou não se verificar, tudo na dependência do destino que se der ao pedido primário endereçado a outro sujeito (hipótese de litisconsórcio eventual passivo). Ainda se pode pensar que a decisão pertinente ao pedido relativo ao litigante subsidiário terá este ou aquele conteúdo desde que não se tenha acolhido o pleito que diga respeito ao litigante primário.

Daí ser válido também o emprego da expressão litisconsórcio subsidiário como sinônima de litisconsórcio eventual, como prefere a doutrina portuguesa ${ }^{658}$.

Opta-se, desde o título da dissertação, pela designação litisconsórcio eventual em razão da influência e da projeção que a cumulação eventual de pedidos ${ }^{659}$ exerce sobre o tema aqui estudado. Ademais, o já tradicional princípio da eventualidade serve também como fator apto a recomendar a expressão litisconsórcio eventual. Com este termo o leitor brasileiro logo é remetido à noção de que a apreciação judicial respeitante a um determinado sujeito só ocorre ad eventum, ou seja, na eventualidade de a situação jurídica de outro sujeito não ter sido positivamente valorada (rectius, acolhida).

Adite-se que litisconsórcio eventual não se confunde com litisconsórcio alternativo $^{660}$, assim como cumulação eventual de pedidos não se confunde com cumulação alternativa de pedidos, nos termos do que já se delineou alhures (Cap. II, Parte II).

${ }^{657}$ FAZZALARI, Elio. Istituzioni di diritto processuale, cit., p. 335.

${ }^{658}$ REMÉDIO MARQUES, João Paulo. Op. cit., nº 102, p. 384; TEIXEIRA DE SOUSA, Miguel. Op. cit., p. 166. Na doutrina italiana, como já se viu nos textos de TARZIA e de ALLORIO, prefere-se a expressão litisconsórcio eventual. Assim também refere NICOLÒ TROCKER (L 'intervento per ordine del giudice, cit., p. 213, nota 81$)$.

${ }^{659}$ Cfr. Cap. II da Parte II, onde se encontram os fundamentos para o emprego da expressão.

${ }^{660}$ Recomenda-se desde logo essa observação porque certa doutrina vale-se das expressões litisconsórcio eventual e litisconsórcio alternativo para explicar o mesmo fenômeno, apresentando a distinção apenas pelo prisma topológico: se a pluralidade de partes ocorre no pólo ativo, chama-se litisconsórcio alternativo; se se verifica no polo passivo, designa-se litisconsórcio eventual (ASSIS, Araken de. Cumulação de ações, cit., § 


\section{Admissibilidade no processo civil brasileiro: fundamentos}

$\mathrm{Na}$ Parte II deste trabalho foram expostas, com alguma detença, as premissas julgadas importantes para a construção de um raciocínio que, segundo se crê, desemboca na admissibilidade do litisconsórcio eventual no sistema processual civil brasileiro, consoante se tentará doravante justificar.

Diversamente do que ocorre em Portugal ${ }^{661}$, a legislação brasileira não contempla, em termos expressos e genéricos, a previsão de um litisconsórcio eventual. Porém, a partir da matriz irradiante que se contém na noção de acesso à justiça pode-se facilmente chegar à conclusão de que o sistema processual deve conformar-se de tal maneira que seja capaz de abrigar soluções instrumentais eficazes. Fortemente ligada a tal entendimento está a necessidade de universalização da jurisdição em termos verticais ou qualitativos, de modo que a técnica processual há de corresponder às necessidades que os litígios apresentam. Já se mencionou na ocasião apropriada que o acesso à justiça, entendido no seu real significado, só se traduz num efetivo direito fundamental na medida em que garanta a construção de uma via processual adequada à tuição dos valores alojados no seio da própria Constituição Federal.

Daí que, à luz do modelo constitucional do processo civil brasileiro, impõe-se voltar os olhos para o princípio do devido processo legal e enxergar nele uma ponte que leva à noção de razoável duração dos processos em geral. Com efeito, a par de se combater o tempo patológico no âmbito de cada processo em si considerado, melhor ainda é que sejam buscadas soluções que tendam a operar no sistema como um todo, no afã de se alcançar a já mencionada razoável duração dos processos em geral.

Por esse prisma marcadamente constitucional já se percebe a viabilidade e utilidade da construção de uma técnica processual que consinta com a formulação, em processo

$12, \mathrm{n}^{\circ} 41$, p. 168). De sua parte, REDENTI vale-se da expressão alternatividade espúria para designar o que se chama neste trabalho de eventualidade, na esteira da lição já lembrada de ALLORIO (Litisconsorzio alternativo passivo e impugnazione incidentale. In: L'ordinamento giuridico nel prisma dell'accertamento giudiziale e altri studi. Milano: Giuffrè, 1957, p. 515). O enfoque distintivo entre as modalidades eventual, alternativa e sucessiva de litisconsórcio será mais detidamente percebido no Cap. III, $\mathrm{n}^{\circ} 41$, infra.

${ }^{661}$ Art. 31-B, do Código de Processo Civil. 
único, de pedidos primário e subsidiário relacionados a sujeitos diversos, em ordem a se admitir que, rechaçado o pedido preferencial em relação a um sujeito, prossiga-se na análise do pedido subsidiário manifestado por ou em face de outro sujeito. Eis aí a técnica do litisconsórcio eventual, inteiramente afinada com o "direito à efetividade temporal do processo",662.

Não se nega, contudo, que o autor da demanda possa não desejar que toda a lide seja trazida à apreciação do julgador. De fato, os limites do objeto litigioso do processo são traçados inicialmente pelo autor, com plena liberdade de atuação. Para ficar num exemplo singelo, é bem possível que o filho queira apenas verificar sua origem biológica mediante investigação de paternidade e não formular demanda respeitante à petição de herança. Porém, na medida em que se queira jurisdicionalizar todas as implicações de direito material advenientes de um só conjunto de fatos, o sistema há de estar apto a acolher e dar vazão à lide integral.

Portanto, não surpreende e tampouco escandaliza a afirmação segundo a qual o ordenamento deve admitir, na presença de uma configuração subjetivamente plural das questões envoltas em dada relação de direito material, a impostação de demanda mediante pedidos diversos relacionados a sujeitos diversos, manifestados, porém, numa escala de preferências segundo o alvitre acolhido na petição inicial.

Numa outra ordem de considerações, a partir do quanto se expôs no item anterior (noção e terminologia), percebe-se que a mola propulsora da solução aqui preconizada assenta-se na noção de dúvida objetivamente aferível. As situações de hesitação, criadas geralmente pelas incongruências da legislação e também pelos embates doutrinários e jurisprudenciais, exigem que o sistema processual confira soluções adequadas para cada uma delas.

Bem é de ver, nessa perspectiva, que algumas das situações de perplexidade, de dúvida ou hesitação vêm adequadamente solucionadas pela técnica da fungibilidade recursal, da fungibilidade na tutela de urgência e em outras exemplificativamente anunciadas noutra parte do trabalho (Cap. I, Parte II, $\mathrm{n}^{\circ} 11$ ).

Na tratativa das questões imbricadas com a noção de dúvida objetiva o sistema consente que se trabalhe com outra noção importante, que é a de eventualidade. Porque

${ }^{662}$ DUARTE, Ronnie Preuss. Litisconsórcios alternativo e subsidiário no processo civil brasileiro. Revista de Processo, no 147, p. 39. 
existe uma dúvida aferível objetivamente no campo do processo, permite-se que a parte, para o evento de acontecer isso ou aquilo, adote esta ou aquela postura processual. Vale acrescentar que essas posturas processuais permitidas pelo sistema, ainda que incompatíveis entre si, são adotáveis simultaneamente. Sinal eloquente dessa configuração está na eventualidade que se tem na contestação, conforme salientado alhures (Cap. I, Parte II, nº 11, vii).

De relevância ímpar para o estudo em pauta caracteriza-se a denunciação da lide manifestada pelo autor, ex vi dos arts. 71 e 74, do Código de Processo Civil. O autor formula um pedido preferencial em face do réu e, para o evento de se ver derrotado nessa pretensão primária, desde logo formula outro pedido, subsidiário, contra o denunciado. Para abalizada doutrina, esse exemplo não configura verdadeira intervenção de terceiros, mas pura hipótese de litisconsórcio eventual ${ }^{663}$. Cabe ainda remarcar, na tentativa de justificar o que se vem de dizer, que a ausência de antagonismo entre os litigantes não é coessencial à construção do litisconsórcio ${ }^{664}$.

Outro ponto relevante diz respeito à reunião de causas animada pela conexão (art. 105, CPC), uma vez que os pedidos formulados por autores diversos ou em face de réus diversos, se isolados em processos autônomos, renderiam ensejo à aglutinação posterior, dando margem, uma vez mais, à formação de litisconsórcio ulterior ${ }^{665}$, na modalidade eventual.

Figure-se o exemplo em que cedente e cessionário, em dúvida sobre a eficácia ou a validade da cessão de crédito, ajuízem demandas autônomas em face do mesmo réu, buscando a condenação deste ao adimplemento da obrigação pecuniária. Nesse cenário haveria inexoravelmente conexão, em ordem a se admitir a reunião de causas num único processo, a bem da economia processual e, desenganadamente, da harmonia de julgados. Implica dizer que, mesmo sob as vestes de um litisconsórcio ulterior, essa reunião de causas daria margem, também, ao litisconsórcio eventual, isto porque não se teria, no exemplo figurado, o acolhimento da pretensão de ambos os autores.

\footnotetext{
${ }^{663}$ DINAMARCO, Cândido Rangel. Litisconsórcio, cit., nº 6, p. 34 (texto e nota 33). Não se quer com isso dizer que o litisconsórcio eventual tenha sua admissibilidade reduzida exclusivamente às hipóteses de direito regressivo.

${ }^{664}$ Cfr. Parte I, Cap. Único, $n^{\circ}$ 6, onde está lançada a noção de litisconsórcio.

${ }^{665}$ DINAMARCO, Cândido Rangel. Litisconsórcio, cit., nº 184, p. 464.
} 
Como enfaticamente diz CÂNDIDo DinAMARCO, seria "ridiculamente desairosa ao Poder Judiciário a sucessiva sucumbência do mesmo autor, em litígios contra dois possíveis devedores, cada um destes obtendo a declaração de que a obrigação recai sobre o outro; e igualmente ridícula, a hipótese inversa" ${ }^{\text {} 666}$.

Noutra perspectiva, tem-se que o tratamento dispensado pelo legislador ao tema da cumulação eventual de pedidos serve bem ao desiderato de justificar, agora pelo aspecto subjetivo, a admissão do litisconsórcio eventual. Com efeito, as razões que animam a cumulação eventual de pedidos são as mesmas que estão à base de conformação do litisconsórcio eventual: a veiculação de pedido subsidiário, relacionado a um sujeito, para a hipótese de rejeição do pedido primário, pertinente a outro sujeito.

Valem aqui as mesmas considerações respeitantes à economia processual e à harmonia de julgados que, de certo modo, justificam o quanto se dispõe no sistema em torno da cumulação subsidiária de pedidos, lembrando-se, ainda uma vez, que não existem razões suficientes, tanto do ponto vista prático como do científico, para tratar em compartimentos estanques os institutos da cumulação objetiva e subjetiva.

Sobreleva notar, ainda nesse ambiente de aproximação do litisconsórcio eventual com a cumulação eventual de pedidos, que o estado de dúvida em que se coloca o autor de pedidos primário e subsidiário, seja no que concerne à situação fática, seja no que se refere ao enquadramento jurídico desses fatos ${ }^{667}$, configura o mesmo estado de dúvida que dá margem à construção da aglutinação subjetiva eventual aqui preconizada.

Então, seguindo advertência de KAZUO WATANABE, parece adequado valer-se da seguinte técnica hermenêutica: "quando uma lei adota solução explícita para determinada hipótese, não quer isso significar que a mesma solução esteja excluída para outras hipóteses análogas" ${ }^{\text {668 }}$.

Se tudo quanto se expôs aqui estiver correto, afigura-se coerente concluir que existem fortes argumentos que sinalizam a existência de harmonia entre o litisconsórcio

\footnotetext{
${ }^{666}$ Litisconsórcio, cit., $\mathrm{n}^{\mathrm{o}} 185$, p. 465.

${ }^{667}$ CALMON DE PASSOS, J. J. Comentários ao Código de Processo Civil, cit., vol. III, p. 205.

${ }^{668}$ Tutela jurisdicional dos interesses difusos: a legitimação para agir, cit., p. 92.
} 
eventual e o sistema processual civil brasileiro, mesmo que à falta de legislação que especificamente trate do tema em termos de generalidade ${ }^{669}$.

Como se não bastassem os argumentos até aqui alinhados, pondera-se, em acréscimo, que nuances residentes no plano do direito material são capazes de apresentar um quadro de dúvida objetivamente aferível no que respeita à titularidade ativa ou passiva da relação substancial. É nesse ponto que as exigências advindas do direito material (Cap. III, Parte II, supra) entrelaçam-se com o enfoque processual, tudo em obséquio àquela necessária aproximação, também já referida, entre direito e processo.

De fato, parece razoável consentir com a formação de litisconsórcio passivo eventual quando se discuta sobre a responsabilidade civil por ato danoso praticado por incapaz, a fim de que o autor (ofendido), para o evento de ser vencido no seu pleito quanto aos representantes do incapaz, promova desde logo sua pretensão em desfavor do causador direto do dano (incapaz), tendo-se por pano de fundo o quanto disposto no art. 928, do Código Civil $^{670}$ (Parte II, Cap. III, no 17 , supra).

Também não parece despropositado, ainda em tema de responsabilidade civil, que o "pai biológico" e o "pai sócio-afetivo" sejam chamados, em litisconsórcio eventual, para responder pelo ato danoso praticado pelo filho. $\mathrm{O}$ autor da demanda, nessas condições, formularia pedido preferencial em relação a um e o pleito subsidiário seria direcionado a outro. No bojo do processo é que seria resolvida a dúvida, objetivamente aferível, sobre a própria existência da mencionada paternidade sócio-afetiva (Parte II, Cap. III, nº 18).

Semelhante conclusão pode ser extraída do caso em que investidores pediram a anulação de subscrição de ações e a consequente devolução de valores em face de determinada instituição financeira. Ocorre que, para o caso de rejeição de tais pleitos, os

\footnotetext{
${ }^{669} \mathrm{Na}$ jurisprudência do Superior Tribunal de Justiça, pela admissão do litisconsórcio eventual, confira-se o emblemático julgamento do REsp no 727.233/SP, $2^{\text {a }}$ Turma, Rel. Min. Castro Meira, j. 19.03.2009, DJe 23.04.2009, v.u (cf. Parte II, Cap. III, $\mathrm{n}^{\circ}$ 10). Sem fazer referência expressa ao instituto do litisconsórcio eventual, o Superior Tribunal de Justiça também admitiu tal construção ao julgar o REsp nº 48.175/MG, Rel. Min. Carlos Alberto Menezes Direito, j. 27.08.1996, DJ 14.10.1996 (cfr. Cap. III, Parte II, nº 21).

${ }^{670}$ Seria absurdo exigir-se que, primeiro, o autor fizesse uma tentativa de responsabilização dos representantes para, só depois de inviabilizada tal responsabilização, fosse buscado o reconhecimento da responsabilidade do incapaz. Realmente, uma postura desse quilate, considerada a duração média dos processos, muito provavelmente redundaria no reconhecimento da prescrição quando o incapaz fosse acionado isoladamente, já que, em tema de responsabilidade civil, o prazo de prescrição é de três anos, a teor do art. 206, § $3^{\circ}$, V, do Código Civil.
} 
autores propugnaram pela condenação do Banco Central a lhes ressarcir os prejuízos, isso em razão da ineficiente fiscalização que estava a cargo deste (Parte II, Cap. III, nº 21).

No campo do direito de família também existe a interessante hipótese em que o filho pede alimentos em face do pai e, para a hipótese de este não ter condições de pagar a pensão (rejeição do pedido em relação ao pai), formula-se desde logo pedido subsidiário em face dos parentes de grau mais distante (Parte II, Cap. III, $\mathrm{n}^{\circ} 28$ ).

Significativo também o exemplo em que determinada pessoa jurídica pediu o reconhecimento de inexigibilidade de crédito tributário objeto de lançamento realizado por um Município. Para o caso de improcedência deste pleito principal, pediu-se, subsidiariamente, a condenação de outro Município - para quem já havia sido pago aquele mesmo tributo - a restituição dos valores recolhidos (Parte II, Cap. III, nº 29).

Como se percebe, as peculiaridades fáticas e/ou jurídicas que envolvem certas situações problemáticas no plano do direito material estimulam ainda mais a construção de litisconsórcio eventual. Os exemplos acima lembrados servem para demonstrar o que se vem de dizer, sem prejuízo de outros que poderiam ser vislumbrados a partir do elenco exposto no Capítulo III, da Parte II.

\section{Ainda a admissibilidade: requisitos}

Averbou-se na ocasião própria que o litisconsórcio facultativo, conquanto caracterizado por uma facultatividade, pode ser formado apenas na presença das hipóteses taxativamente veiculadas nos incisos do art. 46, do Código de Processo Civil. Vale destacar, nesta oportunidade, que o litisconsórcio facultativo tem condições de se implementar quando os direitos ou as obrigações derivarem do mesmo fundamento de fato ou de direito (inc. II do art. 46) e, também, quando entre as causas houver conexão pelo objeto ou pela causa de pedir (inc. III do art. 46).

Mesmo sem a necessidade de se fazer um corte preciso entre essas duas hipóteses legais ${ }^{671}$, não é difícil verificar que as situações anunciadas no item precedente, todas elas retiradas da conformação da relação de direito material, podem perfeitamente encaixar-se

${ }^{671}$ Cfr. Cap. Único, Parte I, nº 6. 
na moldura de um daqueles incisos do art. 46, do CPC, circunstância que já autorizaria a formação do litisconsórcio eventual.

A conexão, num grau mais ou menos acentuado, resultante da imbricação verificável entre a situação de um e de outro colitigante, confere margem tranquila à formação de litisconsórcio eventual, até porque a dúvida objetiva que anima esse tipo de construção litisconsorcial resulta da configuração fática e/ou jurídica de uma dada relação material integrada por mais de um sujeito.

De um mesmo evento danoso, por exemplo, pode-se extrair a responsabilidade civil dos pais ou do incapaz abastado, desde que se verifiquem algumas circunstâncias situadas na conformação da relação de direito material (art. 928, caput, do Código Civil) ${ }^{672}$. Então, numa formulação de litisconsórcio eventual para essa específica hipótese, poder-se-ia imaginar o autor demandando preferencialmente contra os pais, mas, para o caso de não se acolher o pedido em relação a estes, admitir-se a formulação de pedido subsidiário em face do incapaz, com base no mesmo evento (daí a conexão).

Os exemplos poderiam se multiplicar, conforme explicitado no item anterior, mas a nota comum em todos eles seria a de que um mínimo de conexão estaria a vincular a situação dos diversos litigantes aglutinados em litisconsórcio eventual.

Portanto, além de se interpor como um requisito, o discurso normativo que se contém no art. 46, do CPC, serve também para reforçar o que se preconiza aqui em torno da admissão dessa modalidade litisconsorcial no processo civil brasileiro.

A par disso, na esteira do que se desenvolveu acerca da cumulação eventual de pedidos, exige-se para formação de litisconsórcio subsidiário que o órgão jurisdicional seja competente para conhecer tanto do pedido primário quanto do subsidiário (art. 292, § $1^{\circ}$, II, do (PC). Então, seja no que concerne às matérias debatidas na causa, seja no que pertine à qualidade das partes litigantes, toda a situação há de caber nos limites das atribuições do órgão perante o qual se pretende demandar.

Aqui impende distinguir as hipóteses de (in)competência absoluta e relativa. Se para ambos os pedidos (primário e subsidiário) existirem regras distintas de competência absoluta, inviável será a formação de litisconsórcio eventual. Entretanto, se para um dos pedidos houver fixação de competência relativa, a conexão verificável à base do

${ }^{672}$ Cfr. Cap. III, Parte II, no 17. 
litisconsórcio subsidiário pode redundar na modificação da competência e, dessa forma, autorizar a aglutinação eventual de sujeitos. A equação fica ainda mais fácil de solucionar quando as regras de competência pertinentes aos vários sujeitos componentes do litisconsórcio ostentam caráter relativo, pois que, nessa configuração, a conexão fatalmente ensejará a modificação da competência, concentrando-se a competência perante o juízo prevento.

Ademais, a ausência de exceção declinatória nas hipóteses de incompetência relativa faz com que se prorrogue a competência, de sorte que o órgão abstratamente incompetente passa a ser, in concreto, competente.

Ainda com apoio na diretriz do art. 292, do CPC, aplicada aqui por analogia, notase que o litisconsórcio eventual tem sua formação atrelada à noção de identidade de procedimento para os pedidos cumulados em relação a litisconsortes diversos $\left(\S 1^{\circ}\right.$, inc. III), salvo se, diante de previsão de ritos distintos para a situação dos litisconsortes, os pedidos primário e subsidiário puderem tramitar sob os influxos do procedimento ordinário $\left(\S 2^{\circ}\right.$ do art. 292).

Como é intuitivo, no âmbito da cumulação eventual o requisito da compatibilidade entre os pedidos (art. 292, § $1^{\circ}$, I, do CPC) não se põe à baila, uma vez que a apreciação do pedido respeitante ao litisconsorte subsidiário só decola mediante a rejeição, pelo mérito ou por outro motivo de índole processual, do pedido preferencial pertinente ao litisconsorte primário.

Além desses requisitos marcadamente procedimentais, importa considerar também como requisito aquilo que está na base de justificação do próprio instituto do litisconsórcio eventual: a dúvida objetivamente aferível.

Valem aqui as palavras empregadas quando se tratou de fungibilidade como premissa de direito processual apta a incrementar o arsenal de motivos que justificam o litisconsórcio eventual (Parte II, Cap. I, $\mathrm{n}^{\circ}$ 4). Naquele estágio do trabalho encareceu-se a ideia de que o sistema processual convive com incertezas e incongruências de variada estirpe. Esse estado de dúvida geralmente deriva de impropriedades legislativas e de disceptações doutrinárias e jurisprudenciais verificáveis num mesmo contexto temporal.

Como se vê, não se cuida de uma dúvida pessoal do intérprete ou operador do direito (dúvida subjetiva), mas sim de uma celeuma radicada no próprio sistema, analisado como um todo. Daí não se poder imputar a dúvida à incúria do intérprete. 
Às vezes a dúvida eclode não só à luz das nuanças jurídicas, mas sim a partir de circunstâncias de índole fática. Como refere abalizada doutrina espanhola, "es posible que los hechos no sean plenamente conocidos, provocando diversas consecuencias jurídicas según logren o no acreditarse"

O panorama fático de uma determinada relação de direito material, por exemplo, pode traduzir-se numa situação titubeante, cuja solução só se vai alcançar depois de produzidas as provas em ambiente contraditório. E é interessante observar que essas circunstâncias fáticas dúbias são valoradas pelo direito, como acontece, por exemplo, com a responsabilidade civil do incapaz: este responde pelo prejuízo suportado pelo ofendido se (está aí a dúvida) seus responsáveis não tiverem condições de fazê-lo (art. 928, caput, do Código Civil) ${ }^{674}$.

Na hipótese já lembrada de tríplice colisão de veículos ${ }^{675}$, a dúvida que se abate sobre o efetivo causador do acidente só se debela mediante profícua atividade instrutória, de sorte que não se pode imputá-la ao autor da demanda que, em litisconsórcio eventual passivo, formule pedidos em ordem de preferência em relação a réus diversos ${ }^{676}$.

Tudo considerado, pode-se validamente afirmar que os sujeitos interessados na formação de litisconsórcio eventual carregam consigo o ônus de justificar a presença de um quadro de dúvida objetivamente aferível, quanto aos fatos e/ou quanto ao direito aplicável, com projeção sobre os aspectos subjetivos do litígio. Fora dos quadrantes dessa dúvida verificável em termos objetivos, estar-se-á diante de dúvida meramente subjetiva, de todo inapta a autorizar a modalidade de litisconsórcio aqui estudada.

\section{Objeções: tentativa de superação}

Na Parte I deste trabalho chamou-se a atenção para o fato de o litisconsórcio não pressupor uma "communanza di sorti" e, apesar de a nomenclatura sugerir, não existe também um "consorzio" entre os litigantes. Observou-se, ademais, que a ausência de

${ }^{673}$ SERRA DOMINGUEZ, Manuel. Concepto y regulación positiva del litisconsorcio, p. 581.

${ }^{674}$ Cfr. Parte II, Cap. III, $n^{\circ} 17$.

${ }^{675}$ Cfr. Parte II, Cap. III, $n^{\circ} 20$.

${ }^{676} \mathrm{O}$ que se disse em torno de paternidade socioafetiva também serve para justificar essa ordem de ideias (Cfr. Parte II, Cap. III, n ${ }^{\circ} 18$ ). 
antagonismo entre os litisconsortes não é coessencial à construção desse tipo de pluralidade de partes. Daí que a suposta "afinidade de interesses" como característica inafastável do litisconsórcio não parece ser uma construção válida.

Forte nessa postura interpretativa em torno da própria noção de litisconsórcio, transparece exagerada a afirmação segundo a qual no litisconsórcio eventual, dada a presença de antagonismo entre os litisconsortes, não se teria verdadeiro fenômeno litisconsorcial $^{677}$.

Mesmo que se abrisse alguma concessão à postura interpretativa que põe à base do litisconsórcio uma "afinidade de interesses", ter-se-ia de considerar que os litisconsortes primário e subsidiário ostentam também, nalguma medida, o interesse de se sagrarem vitoriosos em face do adversário comum. Implica dizer que, na relação com o adversário comum, há mesmo aquela decantada "afinidade de interesses", embora no relacionamento entre os próprios litisconsortes possa haver posturas antagônicas.

Aqui se sustenta, então, que os colitigantes primário e subsidiário, conquanto possam contender nalgum ponto das variadas questões postas na demanda, são mesmo litisconsortes. Tal entendimento em nada agride o sistema processual brasileiro, especialmente na consideração de que o art. 509, caput, do Código de Processo Civil, alude a litisconsortes com distintos ou opostos interesses ${ }^{678}$.

Em oposição ao que se tem aqui sustentado, costuma-se aludir, de outro lado, à impossibilidade de uma demanda submeter-se à condição. Com base na experiência jurisprudencial trabalhista alemã, ScHÖNKE afirma inadmissível o litisconsórcio eventual $^{679}$, esclarecendo, em outro passo da obra citada, que nenhuma demanda pode ser apresentada condicionalmente ${ }^{680}$.

A tal arguição pode-se responder, com alguma dose de vantagem, que a condição situada na base de conformação do litisconsórcio eventual não diz respeito à postura do juiz, se ele deve ou não julgar a causa. Com efeito, não se tem qualquer insegurança a

${ }^{677}$ SILVA, Ovídio A. Baptista da. Comentários ao Código de Processo Civil, cit., vol. 1, p. 205.

${ }^{678}$ As premissas desse raciocínio, com suas referências bibliográficas, estão na Parte I, Cap. Único, no 6.

${ }^{679}$ Derecho procesal civil, § 26, III, p. 95.

680 "Cuando el actor demanda conjuntamente, a dos personas, pero pide la condena del segundo solamente para el caso de que se desestime la demanda contra el primero, es de estimar que la demanda contra el segundo sólo ha sido presentada condicionalmente, debiendo ser desestimada como inadmisible" (Op. cit., § 43, I, 3, p. 150). 
respeito da efetiva formulação de pedidos relacionados a sujeitos diversos, um preferencialmente ao outro. A incerteza, como aduz ALLORIO, está em saber sobre qual dos pedidos o juiz deva pronunciar-se quanto ao mérito ${ }^{681}$.

É que, nos termos da lição do citado autor italiano, se acolhido o pedido respeitante ao litisconsorte primário (e aí radica a incerteza), não haverá mais interesse processual para apreciação do pedido relativo ao litisconsorte subsidiário. Portanto, não se tem aqui demanda condicional, mas sim demanda efetiva e concretamente ajuizada, com a peculiaridade de que a apreciação do pedido relativo ao litisconsorte subsidiário está sob condição, qual seja: a rejeição do pedido alusivo ao litisconsorte primário ${ }^{682}$.

Noutra perspectiva, alude-se a que pretensões alternativas não podem ser admitidas, porquanto elas devem resultar necessariamente de diversos relatos de fatos que se excluem mutuamente, impondo-se, então, a rejeição da demanda como um todo ${ }^{683}$.

Porém, conforme se crê, de um mesmo relato de fato podem ser extraídas consequências jurídicas diversas aptas a atingir sujeitos diversos, segundo seja a interpretação que se adote como adequada para o caso ${ }^{684}$. Realmente, para ficar apenas num exemplo, a celeuma interpretativa que grassa em torno das consequências jurídicas da emancipação de filhos para fins de responsabilidade civil faz com que de um mesmo fato ou conjunto de fatos possam surgir consequências jurídicas atreladas a sujeitos diversos, tudo a depender da postura interpretativa que se adote sobre um tema jurídico ainda não resolvido pela doutrina e tampouco pela jurisprudência ${ }^{685}$.

${ }^{681}$ ALLORIO, Enrico. Litisconsorzio alternativo passivo e impugnazione incidentale, cit., p. 516-517. Nessa mesma ordem de considerações, TARZIA acrescenta que a aposição de uma condição na "demanda eventual" não introduz qualquer incerteza para o juiz quanto ao objeto da decisão (Appunti sulle domande alternative, cit., nota 120, p. 293), sendo superáveis, também para TARZIA, as objeções da doutrina alemã.

${ }^{682}$ Aqui não se está tomando partido quanto ao fundamento da tese de ALLORIO. É possível, então, aceitar a conclusão a que chega o autor, no sentido de que não há mesmo um ajuizamento condicional de demanda. Todavia, consoante se tentará demonstrar adiante, existem casos nos quais o acolhimento do pedido relativo ao litisconsorte primário, em vez de redundar na falta de interesse processual quanto ao subsidiário, implica a improcedência quanto a este (Cfr. Cap. IV, $\mathrm{n}^{\circ} 54$, infra).

${ }^{683}$ SCANDIANI, Ugo. Patologia della posizione del fatto nel processo. Rivista di diritto processuale civile, vol. VIII, parte II, 1931, p. 182 e 186.

${ }^{684}$ ALLORIO, Enrico. Litisconsorzio alternativo passivo e impugnazione incidentale, cit., p. 518.

${ }^{685}$ Cf. Parte II, Cap. III, $\mathrm{n}^{\circ} 17$. 
Não se pode obliterar, consoante já se expôs anteriormente, que os fatos podem não ser inteiramente conhecidos no momento da propositura da demanda, disso resultando consequências jurídicas diversas, no plano subjetivo, segundo a sua comprovação ou não no contraditório instaurado perante o julgador ${ }^{686}$.

Então, embora os fatos ou conjunto de fatos possam se excluir mutuamente e exatamente porque eles se excluem, abre-se espaço para o litígio preferencial em relação a um sujeito, com base numa configuração fática, e também para o litígio, em processo simultâneo, mas em caráter subsidiário, em relação a outro sujeito, com base noutra configuração fática.

Sendo assim, não parece adequada a crítica que vê na formulação de relatos fáticos que se excluem mutuamente um obstáculo à formação de litisconsórcio eventual.

Poder-se-ia argumentar, ainda em contraposição ao que se sustenta neste trabalho, que ao abrigo do litisconsórcio eventual a parte acaba por admitir, implicitamente, que pelo menos em relação a algum litisconsorte há carência de ação ${ }^{687}$.

Sob o prisma do interesse processual, aduz-se que a idoneidade e a necessidade da prestação jurisdicional só se patenteiam diante de um interesse concreto e atual, de modo que, na presença de uma lesão eventual ou de um direito hipotético, a intervenção judicial não se justificaria e a pretendida atuação jurisdicional seria inidônea ou mesmo desnecessária $^{688}$. Então, admitido que fosse o litisconsórcio eventual, ter-se-ia que a necessidade de prestação jurisdicional em relação ao litisconsorte subsidiário não seria atual, mas meramente eventual.

Na perspectiva da legitimidade ad causam, a formulação de litisconsórcio eventual traduzir-se-ia na aceitação de que um dos litisconsortes não se encontra abrigado por uma situação legitimante advinda da compostura da relação de direito material. De fato, na hipótese em que a dúvida abate-se sobre a legitimidade ad causam $^{689}$, consente-se, desde o

${ }^{686}$ SERRA DOMINGUEZ, Manuel. Op. cit., p. 581.

${ }^{687}$ DUARTE, Ronnie Preuss. Litisconsórcios alternativo e subsidiário no processo civil brasileiro, cit., p. 41 42.

${ }^{688}$ COMOGLIO, Luigi Paolo; FERRI, Corrado; TARUFFO, Michele. Op. cit., vol. I, p. 242.

${ }^{689}$ Para ARAKEN DE ASSIS, a dúvida sobre a legitimidade ad causam é que justificaria a construção do litisconsórcio eventual [Do litisconsórcio no Código de Processo Civil, cit., no 4.3, p. 555]. O tema será retomado no Cap. IV, $\mathrm{n}^{\circ}$ 54, infra, de modo que aqui não se está a encampar, pura e simplesmente, a preleção de ARAKEN DE ASSIS. 
nascedouro da demanda, que ao menos um dos litigantes será considerado parte ilegítima, situação que se mostraria incompatível com as noções adotadas pelo processo civil brasileiro em tema de condições da ação.

Contudo, a doutrina já estabeleceu o lugar adequado para as condições da ação, pondo em realce o seu aspecto teleológico, mais precisamente o de evitar demandas inócuas, fadadas ao insucesso e à inutilidade. Daí o estreito liame entre as condições da ação e a noção de economia processual, valendo destacar, ainda, o caráter indiscutivelmente instrumental daquelas. Em palavras outras, as condições da ação, em última análise, servem de meio para concretização da economia processual ${ }^{690}$.

À vista disso, pode-se dizer que num patamar acima da técnica das condições da ação estão as necessidades advindas da relação de direito material que se quer discutir no processo. Enquanto não se dissipa a dúvida que justifica a própria formação do litisconsórcio eventual, seja pela adoção de uma dada posição jurídica, seja pela produção de provas que mais bem delineiem a situação fática, remanescerá o interesse de agir em relação ao litisconsorte primário e ao subsidiário ${ }^{691}$.

Então, não há ambiente para se falar em carência de ação quando é do próprio sistema que se extrai a dúvida em torno da qual gravita a formação do litisconsórcio subsidiário. Inseguranças não podem pairar, então, quanto à efetiva utilidade e necessidade da prestação jurisdicional em relação aos colitigantes primário e subsidiário.

Ademais, ao menos no âmbito do direito brasileiro, o instituto da denunciação da lide pelo autor demonstra bem que o interesse de agir está presente mesmo quando se pretende a apreciação da relação jurídica pertinente a um sujeito ad eventum de ser desacolhido o pedido formulado em relação a outro sujeito.

Sob o aspecto da legitimidade, considera-se que a afirmação de uma dúvida objetivamente aferível a partir da conformação fático-jurídica da demanda confere lastro suficiente para se concluir, positivamente, quanto ao preenchimento dessa condição da ação ${ }^{692}$.

\footnotetext{
${ }^{690}$ BEDAQUE, José Roberto dos Santos. Efetividade do processo e técnica processual, cit., p. 402-405.

${ }^{691}$ Essa discussão voltará a ser enfrentada, como já revelado em notas anteriores, no Cap. IV, no 54, infra.

${ }^{692}$ DUARTE, Ronnie Preuss. Litisconsórcios alternativo e subsidiário no processo civil brasileiro, cit., p. 44.
} 
Então, a partir da visualização correta da função que as condições da ação exercem no sistema processual ${ }^{693}$, parece lícito considerar que a formação de litisconsórcio eventual não agride a construção legislativa ainda em vigor no Brasil em tema de condições da ação.

De outra parte, não se pretende colocar em segundo plano a existência de outros mecanismos igualmente hábeis a solucionar eventuais dúvidas que se abatam sobre a configuração subjetivamente plural de determinada relação de direito material. De fato, existem mesmo outros institutos processuais capazes de debelar incertezas fáticas que seriam solucionadas apenas no curso da instrução processual. Está-se a referir ao direito autônomo à prova, segundo a feliz construção de FLÁviO YARSHELL ${ }^{694}$, e também às chamadas ações probatórias autônomas, de que nos dá conta DANIEL ASSUMPÇÃO NEVES ${ }^{695}$.

Evidente que a existência de um direito autônomo à prova, exercitável antecipadamente mesmo fora dos casos de urgência, ostenta suficiente aptidão para delinear, com a segurança que se espera, quem seja efetivamente o titular de dada relação de direito material. Por esse prisma é possível identificar, por exemplo, se existe ou não uma relação que se caracterize como paternidade sócio-afetiva, em ordem a se poder concluir, em tese, pela responsabilização civil do pai pelo ato danoso praticado pelo filho que não traz a carga genética daquele. Nessas condições, estaria afastada a responsabilidade civil do pai biológico, ficando resolvido, com alguma dose de segurança, o problema que se teria para composição do polo passivo de eventual demanda indenizatória.

Porém, diferentemente do que já se fez em doutrina recente ${ }^{696}$, não parece relevante tentar aferir se a técnica do litisconsórcio eventual é melhor ou pior do que a das ações probatórias autônomas. Basta, para bem da ciência processual, delinear que o litisconsórcio

\footnotetext{
693 "[P]ossibilitar ao juiz, de preferência logo no início do procedimento, de ofício, examinar aspectos da relação material e impedir o prosseguimento inútil do processo" (BEDAQUE, José Roberto dos Santos. Efetividade do processo e técnica processual, cit., p. 405 - grifou-se).

${ }^{694}$ Antecipação da prova sem o requisito da urgência e direito autônomo à prova. São Paulo: Malheiros, 2009, esp. Cap. VI, p. 309 et seq.

${ }^{695}$ Ações probatórias autônomas, cit., passim.

${ }^{696}$ Id., p. 424.
} 
eventual configura mais um instrumento à disposição das partes, no intuito de concretizar os anseios por um processo civil efetivo ${ }^{697}$.

Acrescente-se, por último, que o litisconsórcio eventual congrega em seu âmago situações que vão além da dúvida pertinente a fatos, pois já se averbou que as disceptações jurídicas também podem ser obviadas mediante a utilização dessa modalidade litisconsorcial. Daí que a existência de outros mecanismos igualmente aptos a debelar algumas incertezas no plano dos fatos não se erige como fator de esmaecimento da utilidade do litisconsórcio eventual.

${ }^{697}$ A expressão "processo civil efetivo" está aqui empregada segundo a diretriz básica delineada em conhecida passagem de BARBOSA MOREIRA, já citada neste trabalho (Efetividade do processo e técnica processual, cit., p. 17-18). 


\section{Capítulo II}

\section{LITISCONSÓRCIO ALTERNATIVO}

\section{Noção e terminologia}

Se no litisconsórcio eventual transparece nítida uma relação que envolve um litigante primário e outro subsidiário, no litisconsórcio alternativo, apesar da existência de mais de um pedido endereçado a ou formulado por mais de um litigante, esses pleitos não são escalonados numa ordem de preferência. Será válido afirmar, portanto, ainda uma vez sob influência da cumulação alternativa de pedidos, que o litisconsórcio alternativo resulta da presença de colitigantes no polo ativo ou passivo da relação processual, com a peculiaridade de que a apreciação ou mesmo o acolhimento do pedido envolvendo este $o u$ aquele litigante fica ao alvedrio do julgador, porquanto presente a alternatividade que caracteriza essa modalidade litisconsorcial.

Evidente que esse "alvedrio do julgador" não quer significar discricionariedade, porquanto a análise do caso concreto, numa apreciação destituída de subjetivismos, é que ditará a solução do caso, se em relação a este $o u$ àquele litisconsorte ${ }^{698}$.

Há, por assim dizer, uma indiferença, do ponto de vista da vontade manifestada na petição inicial, entre o acolhimento $\operatorname{do}(\mathrm{s})$ pedido(s) em relação a um ou a outro litisconsorte. Destaca-se, outrossim, a característica segundo a qual as demandas subjetivamente plúrimas, ajuizadas sob o timbre da alternatividade, apresentam-se numa perspectiva de recíproca exclusão, na medida em que o acolhimento de uma importa, necessariamente, o não acolhimento da outra.

O estado de incerteza que pode advir tanto do plano dos fatos quanto do panorama jurídico imbricados com a causa faz com que o pedido, apesar de formulado em relação a todos os sujeitos, ativos ou passivos, só possa ser acolhido em favor de ou em confronto com um dos litisconsortes alternativos.

\footnotetext{
${ }^{698}$ Para aprofundamento da ideia, cfr. Cap. IV, no 54 , infra.
} 
Numa demanda condenatória, por exemplo, o autor pede não a condenação de ambos os litisconsortes passivos, mas apenas de um deles, muito embora as causas de todos estejam postas em juízo. O diferencial, como já apregoado, resulta da circunstância de tais causas serem colocadas e apreciadas num prisma de alternatividade.

Visto assim, com muita nitidez se infere que o litisconsórcio alternativo abriga-se no ambiente do litisconsórcio facultativo ${ }^{699}$ e comum (não unitário), em ordem a se concluir pela presença, numa só experiência processual, de um cúmulo objetivo e também subjetivo de demandas ${ }^{700}$.

A contribuição doutrinária respeitante ao assunto vem de longa data. Escrevendo sobre o interesse recursal em sede de apelação civil, LUDOVICO MORTARA referiu-se à hipótese em que duas pessoas propõem, em conjunto, em face dum ou mais sujeitos, uma demanda alternativa, por meio da qual se busca obter um provimento favorável a um ou a outro dos componentes do polo ativo da relação processual. Nessas condições, o interesse dos autores, manifestado de modo alternativo, estará completamente satisfeito desde que o julgador acolha o pedido formulado por um deles, mesmo que tal postura implique o não conhecimento do pedido formulado pelo outro demandante. Aliás, desde o manejo da demanda já se previa - e se pretendia - que o pedido formulado por um dos contendores resultasse prejudicado, razão pela qual não há cogitar-se, no caso, de sucumbência em relação àquele autor que teve seu pedido prejudicado por força do acolhimento do pedido formulado pelo outro demandante ${ }^{701}$.

No estágio atual do trabalho não importa tanto o aspecto recursal sublinhado por MORTARA, valendo pôr em destaque, tão somente, a alusão à demanda alternativa entre sujeitos diversos. Fácil perceber que o autor citado não labora, no ponto aqui considerado,

\footnotetext{
${ }^{699}$ Sobre o ponto, consulte-se TROCKER, Nicolò (L'intervento per ordine del giudice, cit., p. 211, nota 77).

${ }^{700}$ Em posição diversa, ARAKEN DE ASSIS refere inexistir "cumulação de ações no pedido alternativo", pois o objeto litigioso não se traduz, no caso, numa pluralidade característica do cúmulo. Para o citado autor, a alternatividade estaria situada apenas nos "objetos mediatos diversos", algo insuficiente para caracterizar o cúmulo de ações (Cumulação de ações, cit., § 12, nº 41, p. 167). Entretanto, como já se teve oportunidade de encarecer, existem diferenças entre "pedido alternativo" (art. 288 do CPC) e "cumulação alternativa de pedidos" (Parte II, Cap. II, $\mathrm{n}^{\circ}$ 12), peculiaridade suficiente para afastar a pregação de ARAKEN DE ASSIS, mantendo-se firme a postura interpretativa que se lê no texto.

${ }^{701}$ Appello civile (verbete). In: Il digesto italiano. Torino: UTET, 1890. vol. terzo, parte seconda, $\mathrm{n}^{\circ}$ 1553, $\mathrm{p}$. 972.
} 
com o cúmulo objetivo de demandas, mas lida com o cúmulo subjetivo, particularizado, ademais, pela nota da alternatividade ${ }^{702}$.

Como já sinalizado no Capítulo em que se estudou o litisconsórcio eventual, a par de uma falsa alternatividade, ENRICO REDENTI professou existir uma verdadeira alternatividade, cuja verificação dá-se quando, com base num mesmo título (ou causa de pedir) e com o objetivo de se alcançar uma prestação objetivamente única ou um resultado único em seu favor, o autor esteja incerto contra qual dos dois ou mais sujeitos possa fazer valer aquele afirmado direito. Acrescenta o doutrinador peninsular que, no âmbito dessa vera alternatività, a identificação do sujeito que efetivamente deva prestar ou suportar o quanto pretendido pelo autor depende da verificação de determinado evento, da conclusão ou não de um negócio ou da decisão de certa controvérsia envolvendo a relação interna desses sujeitos passivos ${ }^{703}$.

Analisado embora sob o ângulo específico da competência, a decisão comentada por REDENTI ${ }^{704}$ bem reflete situação de um possível litisconsórcio alternativo, porquanto se pôs em juízo a demanda de uma pessoa jurídica em face de dois entes públicos, sediados em cidades diferentes (daí o problema da competência). A autora pretendia o reembolso de uma diferença de taxas cobradas indevidamente, mas havia incerteza quanto a qual das duas entidades haveria de fazê-lo, porquanto ambas tinham participado do negócio base à luz do qual emanou o litígio. Então, dizia a autora da demanda: "Qualcuno mi dovrà la differenza. $O$ condannate l'amministrazione finanziaria, $o$ altrimenti condannate quella militare"

Publicado inicialmente em 1947, no periódico Giurisprudenza italiana, o ensaio de ENRICO ALlORIO sobre o litisconsórcio alternativo reapareceu em 1957, agora no seu L'ordinamento giuridico nel prisma dell'accertamento giudiziale e altri studi ${ }^{706}$. Nesse

\footnotetext{
${ }^{702}$ Em texto antigo sobre acertamento alternativo em matéria penal, PASQUALE SARACENO aludiu ao exercício de ação civil contra pessoas alternativamente indicadas como sujeitos passivos (L'accertamento alternativo. Rivista italiana di diritto penale, vol. XVII, 1939, p. 192).

${ }^{703}$ Problemi di competenza in cassazione, cit., $\mathrm{n}^{\circ}$ 10, p. 97.

${ }^{704}$ Corte di Cassazione, Sez. $3^{\text {a }}$, 28 gennaio 1942: Soc. distilleria agraria friulana Canciani versus Ministeri della guerra e delle finanze.

${ }^{705}$ REDENTI, Enrico. Problemi di competenza in cassazione, cit., $\mathrm{n}^{\mathrm{o}}$ 1, p. 82 (grifos do original). No seu Diritto processuale civile, REDENTI faz alusões importantes sobre o tema das causas postas em alternativa (vol. II, no 88, II, p. 92-93).

${ }^{706}$ Litisconsorzio alternativo passivo e impugnazione incidentale, cit., p. 515 et seq.
} 
estudo o autor registra, com todas as letras, a plena cidadania do litisconsórcio alternativo passivo no ordenamento processual italiano ${ }^{707}$, a partir de cuja constatação debruça-se, mais detidamente, sobre a viabilidade da "impugnazione incidentale", algo que pode ser assimilável ao nosso recurso adesivo.

O autor não deixou de externar sua perplexidade frente ao silêncio da doutrina italiana em torno de assunto tão relevante na prática forense e referiu que CHIOvENDA tratara apenas do cúmulo alternativo de demandas do ponto de vista objetivo.

Allorio parte da premissa de que em certas situações existe "incertezza intorno alla persona del soggetto passivo del rapporto controverso", sendo tal dubiedade, em certos casos, objetivamente aferível e adveniente de acontecimentos ou comportamentos que se confundem, podendo-se imputar tal estado, às vezes, ao modo de agir dos próprios réus. É o que ocorre, por exemplo, quando não se sabe se determinado sujeito negociou como representante de outrem, obrigando-o, ou se em nome próprio, vinculando-se pessoalmente ${ }^{708}$.

Numa formulação mais genérica, ALLORIO figura o seguinte exemplo, emblemático em toda a doutrina que cuida desse tema:

\begin{abstract}
"Rosso chiede che sia emanato un provvedimento giurisdizionale (solitamente la condanna all'adempimento di un'obbligazione) nei confronti di Verde o d'Azzurro, manifestando così una incertezza intorno alla persona del soggetto passivo del rapporto controverso" ${ }^{\text {709. }}$.
\end{abstract}

Diante do cenário proposto, o autor explica que acolhida que seja a demanda em face do réu Verde não se pede a rejeição pelo mérito da outra demanda cumulada, endereçada ao réu Azul. O que se pretende, em vez disso, é uma "revoca in anticipo" desta última demanda, a significar que o juiz não "absolverá no mérito o segundo réu, com provimento capaz de formar coisa julgada sobre a relação controvertida" ${ }^{710}$. Em realidade, acolhido o pedido formulado em face de um dos réus, o julgador pronuncia "una semplice

\footnotetext{
${ }^{707}$ ALLORIO, Enrico. Litisconsorzio alternativo passivo e impugnazione incidentale, cit., p. 518.

${ }^{708}$ Id., p. 515.

${ }^{709}$ Id., ibid.

${ }^{710} I d .$, p. 516 (tradução livre).
} 
absolutio ab instantia" relativamente ao outro demandado, o que se traduz "in una sopravvenuta mancanza d'interesse" ${ }^{, 711}$.

Em acréscimo, Allorio destaca que o estado de incerteza que autoriza o litisconsórcio alternativo passivo nem sempre decorre de uma questão fática, podendo exsurgir, outrossim, à luz de questões de direito. Para demonstrar o acerto de seu raciocínio, figurou o exemplo em que uma empresa fornecedora de couro pretendia o pagamento desse produto, fornecido para o fabrico de sapatos militares, em face do comitente Ministério da Guerra ou do fabricante dos calçados, que havia executado o serviço com o couro ${ }^{712}$.

Outro renomado processualista italiano ponderou que o litisconsórcio alternativo pode mesmo verificar-se tanto no polo passivo quanto no ativo da relação processual, bastando que se tenha presente, para caracterização de semelhante forma litisconsorcial, a proposição de mais de uma demanda por vários autores ou contra diversos réus, havendo entre essas demandas uma relação tal que, segundo a vontade manifestada por um ou mais autores, apenas uma deva ser acolhida, a favor de um ou de outro autor, ou contra um ou outro réu ${ }^{713}$. Pelo prisma do litisconsórcio alternativo ativo, pede-se que o bem da vida seja reconhecido a um ou a outro demandante, "rimettendo al giudice di stabilire quale di essi vi abbia diritto" 714 . Correlativamente, no litisconsórcio alternativo passivo aspira-se a que o pedido seja acolhido em confronto com um ou outro réu, "ma non di tutti"715.

Importante considerar, ainda segundo os ensinamentos de TARZIA, que o pressuposto básico para esse modo de demandar advém da incompatibilidade entre as

\footnotetext{
711 ALLORIO, Enrico. Litisconsorzio alternativo passivo e impugnazione incidentale, cit., p. 516-517.

712 “Ora la decisione su ciò dipendeva non dalla scelta fra confliggenti affermazioni di fatto, bensì dalla soluzione che si dava alla questione di diritto relativa all'efficacia d'un certo provvedimento dell'amministrazione militare, che secondo questa avrebbe avuto per conseguenza una novazione soggettiva dell'obbligazione" (ALLORIO, Enrico. Litisconsorzio alternativo passivo e impugnazione incidentale, cit., p. 518 - grifos do original).

713 TARZIA, Giuseppe. Appunti sulle domande alternative, cit., no 7, p. 292. Sobre o assunto, consulte-se ainda, do mesmo autor, Il litisconsorzio facoltativo nel processo di primo grado, cit., p. 43-44.

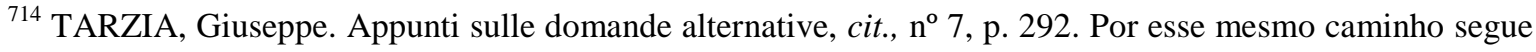
a preleção de ALBERTO RONCO, para quem no litisconsórcio alternativo "le parti non indicano al giudice alcun ordine preferenziale per l'accoglimento dell'una o dell'altra domanda" (op. cit., p. 907).

${ }^{715}$ TARZIA, Giuseppe. Appunti sulle domande alternative, cit., nº 7, p. 292.
} 
pretensões assim deduzidas e que a alternatividade de postulação encontra raízes no direito substancial $^{716}$.

Por sua vez, NiCOLÒ TROCKER pondera que a incerteza quanto à titularidade passiva de determinada relação jurídica, não só no sentido de quem seja o titular passivo, mas notadamente sobre qual dentre dois ou mais sujeitos ostenta aquela qualidade, pode desaguar na proposição de demandas contra diversos réus, com a característica de que a vontade inicial do autor consubstancia-se em que uma só delas venha acolhida, contra um ou contra o outro réu ${ }^{717}$. O doutrinador italiano ainda registra que a incerteza que está à base da configuração desse tipo litisconsorcial pode referir-se tanto a questões de fato quanto a questões de direito $^{718}$. Afastando-se da orientação exposta por REDENTI e propendendo para a construção teórica de TARZIA e de ALLORIO, TROCKER propugna que o litisconsórcio alternativo encontra ambiente para se verificar mesmo quando as relações jurídicas atreladas aos diversos litisconsortes alternativos sejam distintas. Daí se dizer que no litisconsórcio alternativo, para além de uma pluralidade de partes, há também pluralidade de demandas possivelmente atreladas a causas de pedir distintas, ou a títulos distintos, como se prefere aludir na doutrina italiana ${ }^{719}$.

De origem espanhola tem-se novamente a passagem em que RAMOS MÉNDEZ refere-se à demanda intentada contra várias pessoas alternativamente, para o fim de que seja condenada apenas uma delas. A tal hipótese o autor confere a nomenclatura de litisconsórcio alternativo ${ }^{720}$, seguindo as pegadas de outro renomado processualista espanhol $^{721}$.

\footnotetext{
${ }^{716}$ Appunti sulle domande alternative, cit., $\mathrm{n}^{\circ}$ 7, p. 295. Sobre esse mesmo tema debruçou-se ALBERTO RONCO (Studio sul litisconsorzio alternativo, cit., p. 905-945). Sob a angulação recursal, importantes as também recentes considerações de GIAN FRANCO RICCI (op. cit., p. 337 et seq.).

717 L'intervento per ordine del giudice, cit., p. 210-211. Observe-se que a explicação do autor diz exclusivamente com a hipótese de litisconsórcio alternativo passivo, mas neste trabalho sustenta-se a viabilidade dessa modalidade litisconsorcial tanto no polo ativo quanto no passivo.

${ }^{718} I d$., p. 213 , texto e nota 81.

${ }^{719} I d .$, p. $215-216$.

${ }^{720}$ Derecho procesal civil. Barcelona: Bosch, 1980, p. 270. Em igual sentido: VIDAL PÉREZ, María Fernanda (op. cit., p. 95).

${ }^{721}$ SERRA DOMINGUEZ, Manuel. Op. cit., p. 580.
} 
Em plagas lusitanas, sob influência da dicção do art. 31-B, do $\mathrm{CPC}^{722}$ e com base na mesma dúvida que anima a eclosão do litisconsórcio subsidiário, alude-se também ao litisconsórcio alternativo, mediante a asserção de que os litisconsortes, em vez de aparecerem numa posição de subsidiariedade em relação ao outro, podem apresentar-se, no polo ativo ou passivo, numa relação de alternatividade ${ }^{723}$.

É possível encontrar referência ao que se tem chamado de litisconsórcio alternativo também nos sistemas processuais apegados à common law. De fato, GIUSEPPE TARZIA, já no estudo que empreendera em 1964, registrou que o instituto vem pacificamente admitido não só pela doutrina como também pelas normas reguladoras do processo nos Estados Unidos e na Inglaterra $^{724}$.

Nessa perspectiva, bem é de ver que nos Estados Unidos a Rule 20, das Federal Rules of Civil Procedure, de $1^{\mathrm{o}}$ de dezembro de 2009, ao tratar do instituto chamado permissive joinder of parties, contém a seguinte proposição normativa:

“(1) Plaintiffs. Persons may join in one action as plaintiffs if: (A) they assert any right to rilief jointly, severally, or in the alternative with respect to or arising out of the same transaction, occurrence, or series of transactions or occurrences; (...) (2) Defendants. Persons - as well as a vessel, cargo, or other property subject to admiralty process in rem may be joined in one action as defendants if: (A) any right to relief is asserted against them jointly, severally, or in the alternative with respect to or arising out of the same transaction, occurrence, or series of transactions or occurrences $(\ldots)^{, 725}$ - grifou-se.

\footnotetext{
722 "É admitida a dedução subsidiária do mesmo pedido, ou a dedução de pedido subsidiário, por autor ou contra réu diverso do que demanda ou é demandado a título principal, no caso de dúvida fundamentada sobre o sujeito da relação controvertida".

${ }^{723}$ TEIXEIRA DE SOUSA, Miguel. Op. cit., p. 167; REMÉDIO MARQUES, João Paulo. Op. cit., nº 102, p. 385. Mais uma vez é preciso chamar a atenção para a distinção que se faz em Portugal entre litisconsórcio e coligação, sendo válido então afirmar que, a par do litisconsórcio alternativo, o art. 31-B, do CPC, contempla também a possibilidade de coligação alternativa.

${ }^{724}$ Appunti sulle domande alternative, cit., p. 294-295, notas 122-127, com ampla referência bibliográfica e jurisprudencial.

725 Tenha-se presente que a expressão "permissive joinder of plaintiffs" equivale ao que chamamos de litisconsórcio facultativo ativo, enquanto que "permissive joinder of defendants" corresponde ao
} 
Mas a experiência americana nessa temática não é de hoje. WILLIAM W. BLuME revela que mesmo antes das Federal Rules de 1938 alguns estados americanos mantinham legislação própria que permitia o litisconsórcio passivo alternativo (joinder of defendants in the alternative $)^{726}$.

Com base em jurisprudência da década de 40, do século passado, a doutrina estadunidense expõe hipótese em que determinada pessoa duvidava sobre se reaveria o valor desembolsado para pagamento de um tributo em face do coletor ou de uma determinada corporação. O fato é que, abstraídas as peculiaridades do sistema jurídico americano, se presente determinada circunstância, o coletor haveria de restituir o tributo, mas, caso contrário, o reembolso haveria de ser feito pela corporação ${ }^{727}$.

Interessante observar que na época em que não era admitido o litisconsórcio alternativo no sistema norte-americano surgiu manifestação jurisprudencial reveladora de séria insatisfação com tal estado de coisas. Dizia-se, com efeito, que a não aceitação dessa modalidade litisconsorcial redundava em frequentes falhas da justiça, isto porque, mesmo diante da dúvida sobre a responsabilidade de uma ou de outra pessoa, impunha-se ao autor litigar primeiro contra um e, depois de verificado o insucesso, ajuizar ação contra o outro. Ocorria, porém, de não raras vezes o autor sagrar-se vencido nos dois casos ${ }^{728}$.

Para os casos de dúvida em relação a quem o autor deva endereçar sua pretensão, a doutrina inglesa também admite a possibilidade do litígio em face de duas ou mais pessoas

litisconsórcio facultativo passivo, consoante se infere das lições de HAZARD, Geoffrey C.; TARUFFO, Michele (La giustizia civile negli Stati Uniti. Bologna: Il Mulino, 1993, p. 177-178). Para aprofundamentos sobre o tema na doutrina norte americana, consulte-se FRIEDENTHAL, Jack H.; KANE, Mary Kay; MILLER, Arthur R. (Civil procedure. 3. ed. St. Paul: West Group, 1999, § 6.4, p. 342-343).

${ }^{726}$ American civil procedure. Englewood Cliffs: Prentice-Hall, 1955, p. 338. O autor cita os estados em que se permitia o litisconsórcio alternativo, com informação ainda da época em que tal se verificou: Rhode Island (1876); Connecticut (1879); New Jersey (1912); Wisconsin (1915); New York (1920); California (1927); Illinois (1933).

${ }^{727}$ BLUME, William W. Op. cit., p. 338.

${ }^{728}$ A passagem, em tom de desabafo, verificou-se em Lukken v. Hanover Fire Ins. Co., julgado no estado de Wisconsin, em 1928, consoante o relato de BLUME (Op. cit., p. 338-339). 
e precedentes há que fazem menção a causas propostas em alternativa contra mais de um réu desde $1904^{729}$.

Conquanto escassa em termos numéricos, a doutrina nacional teve ocasião para versar o assunto. De CÂNDIDO DINAMARCO vem a mais expressiva contribuição, podendose extrair a noção de litisconsórcio alternativo a partir da seguinte indagação formulada pelo autor: "Será lícito comparecerem dois autores, na dúvida sobre qual deles seja o verdadeiro credor, pedindo que o juiz emita um provimento contra o adversário comum, em benefício de um dos dois (cúmulo alternativo)?"730.

Colocou-se em pedestal, mais uma vez, a ideia de ausência de preferência entre as demandas alternativas expostas à apreciação do julgador, sendo possível a verificação dum litisconsórcio alternativo tanto no polo ativo quanto no passivo da relação processual ${ }^{731}$. O doutrinador citado ainda adverte que tal modalidade litisconsorcial configura hipótese de litisconsórcio facultativo e comum (não unitário) ${ }^{732}$.

Numa perspectiva terminológica, pouca coisa há a dizer, uma vez que improvável algum baralhamento de ideias a partir da expressão litisconsórcio alternativo. Com efeito, não se tem na literatura outro significado que se possa emprestar ao termo, de modo que aqui a simetria com a expressão cumulação alternativa de pedidos, já tradicional entre nós, põe-se mais suavemente. Crê-se que a nomenclatura empregada neste trabalho serve bem

\footnotetext{
${ }^{729}$ BUTTS, G. M. Modern conty court procedure. 6. ed. London: Oyez Publications, 1966, p. 24.

${ }^{730}$ Litisconsórcio, cit., $\mathrm{n}^{\mathrm{o}}$ 182, p. 458 (grifos do original).

731 DINAMARCO, Cândido Rangel. Litisconsórcio, cit., nº 183, p. 462-463. Suspeita-se, porém, que a hipótese de litisconsórcio alternativo sugerida pelo autor em sua mais recente obra não se ajusta perfeitamente à noção que ele próprio expôs sobre o instituto (Processo civil empresarial. São Paulo: Malheiros, 2010, no 781 et seq., p. 1134 et seq.).

732 DINAMARCO, Cândido Rangel. Litisconsórcio, cit., $\mathrm{n}^{\circ}$ 185, p. 466. Alusão ao instituto, sem considerações substancialmente diversas das até aqui apresentadas, também se encontra nas obras de ARAKEN DE ASSIS (Cumulação de ações, cit., § 12, n 41, p. 165 et seq.; Do litisconsórcio no Código de Processo Civil, $\mathrm{n}^{\circ}$ 4.3, p. 555-556) e de SCARPINELLA BUENO (Partes e terceiros no processo civil brasileiro, cit., p. 98 et seq.; Curso sistematizado de direito processual civil, cit., vol. 2, tomo I, p. 456-459). Sobre o assunto ainda consta uma nota no famoso Código de Processo Civil e legislação processual em vigor de THEOTONIO NEGRÃO et alli (nota $1 a$ ao art. 46, do CPC, p. 172) e alguma referência em SIMÃO, José Fernando (op. cit., p. 236 et seq.) e em ASSUMPÇÃO NEVES, Daniel Amorim (op. cit., p. 409 et seq.). Para uma análise mais aprofundada, consulte-se DUARTE, Ronnie Preuss (Litisconsórcios alternativo e subsidiário no processo civil brasileiro, cit., p. 27-49).
} 
ao desiderato de anunciar o instituto e de possibilitar ao leitor uma rápida e clara conscientização do que se está a tratar.

\section{Admissibilidade no processo civil brasileiro: fundamentos}

A mesma ordem de considerações lançadas a respeito do litisconsórcio eventual cabe na seara do litisconsórcio alternativo, uma vez que a diferença entre essas modalidades litisconsorciais, como já se pôde perceber, está na manifestação de uma preferência no litisconsórcio eventual e na ausência dessa característica no campo do litisconsórcio alternativo. Quanto ao mais, a configuração estrutural dos institutos é bem semelhante, havendo distinções que serão sentidas mais de perto quando da tratativa da dinâmica desses tipos de litisconsórcio (Cap. IV, infra).

Logo, forte nas premissas de direito processual visualizadas na Parte II deste trabalho, o que justifica a admissibilidade do litisconsórcio alternativo no sistema processual pátrio, mesmo diante da configuração legislativa atual, são os influxos que descendem, num primeiro momento, do próprio modelo constitucional de processo civil. Com efeito, as noções a respeito de acesso à justiça, de universalização vertical ou qualitativa da jurisdição, de devido processo legal e, como corolário, de razoável duração dos processos em geral conferem lastro seguro à construção que aqui se propõe ${ }^{733}$.

Mostra-se útil lembrar, ainda nesse aspecto mais genérico, da necessidade que se tem de concretizar o princípio da economia processual e a exigência, importante para a própria manutenção do prestígio da jurisdição, de harmonia de julgados.

Realmente, diante de dúvida objetiva que se abata sobre fatos ou sobre a interpretação jurídica de um determinado instituto de direito material, não convém que o Estado-juiz, numa demanda de Antonio versus Joaquim, pronuncie que a titularidade da relação de direito material concirna a Francisco e que, numa outra demanda também de Antonio versus Francisco, o mesmo Estado-juiz conclua que a relação material diga respeito, em verdade, a Joaquim e não a Francisco.

\footnotetext{
${ }^{733} \mathrm{Na}$ doutrina italiana encontra-se manifestação no sentido da admissibilidade do litisconsórcio alternativo mesmo diante do silêncio da legislação, algo que se explica à luz de "esigenze di effettività della tutela giurisdizionale" (TROCKER, Nicolò. L'intervento per ordine del giudice, cit., p. 212).
} 
Nessas condições, como já se referiu neste trabalho, fomentaria demais o desprestígio do Poder Judiciário uma sucumbência sucessiva do mesmo autor em litígios distintos contra potenciais devedores, cada um destes obtendo o reconhecimento de que a obrigação diz respeito ao outro ${ }^{734}$.

Pelo prisma infraconstitucional, tem-se que a cumulação alternativa de pedidos, tal como admitida tranquilamente em nosso sistema (Parte II, Cap. II), também serve de ponte segura para se chegar à admissão da alternatividade nos quadrantes subjetivos. Levando em conta a aproximação que se crê existir entre o cúmulo objetivo e o cúmulo subjetivo ${ }^{735}$, parece haver ponderáveis razões para se aceitar a modalidade alternativa de litisconsórcio.

De fato, o legislador consente com a técnica da cumulação simples de pedidos mesmo na ausência de conexão objetiva (art. 292, caput, do CPC) e é possível antecipar que no litisconsórcio alternativo haverá alguma dose de conexidade entre a situação dos colitigantes alternativos frente a uma dada relação de direito material. Daí ser razoável inferir que a admissão, por texto expresso da lei, de um cúmulo de pedidos mesmo sem o quesito da conexão serve de apoio para a edificação de uma estrutura processual que permita a cumulação subjetiva alternativa na presença de conexidade. Como enfatiza DinAmARCo, se a cumulação simples, que prescinde de conexidade objetiva, vem permitida expressamente pelo Código de Processo Civil, com maiores razões é de se admitir, perante o sistema processual em vigor, o cúmulo subjetivo que envolva a noção de alternatividade ${ }^{736}$.

Noutra perspectiva, acredita-se que tenha ficado suficientemente demonstrado que nas hipóteses de litisconsórcio comum (não unitário) verifica-se, numa só experiência processual, um cúmulo objetivo e também subjetivo de demandas ${ }^{737}$, situação que se vê com bastante nitidez também no campo do litisconsórcio alternativo. É que, para ficar num exemplo de litisconsórcio passivo, o autor formula, numa modulação embora alternativa, pedidos em face de réus diversos, donde se extrai, inequivocamente, uma cumulação de pedidos (porquanto há mais de um) e uma aglutinação de partes (cúmulo subjetivo).

Evidenciada a ausência de contraposição entre o cúmulo objetivo e o subjetivo de demandas e, além disso, positivada a estreita similitude das situações que envolvem essas

\footnotetext{
${ }^{734}$ DINAMARCO, Cândido Rangel. Litisconsórcio, cit., nº 185, p. 465.

${ }^{735}$ Cfr. Parte I, Cap. Único, $n^{\circ} 6$.

${ }^{736}$ Litisconsórcio, cit., $\mathrm{n}^{\circ} 183$, p. 462.

${ }^{737} I d ., \mathrm{n}^{\circ} 182$, p. 459.
} 
espécies de cúmulo, afigura-se mais adequado propender para uma construção que retire do instituto da cumulação alternativa de pedidos mais uma preponderante justificação para a admissibilidade do litisconsórcio alternativo. E isso se dá nos moldes em que a legislação está hoje posta, ou seja, sem necessidade de qualquer inovação legislativa ${ }^{738}$.

Bem é de ver, ademais, que a alternatividade atrelada a aspectos subjetivos da demanda não vem ignorada pela sistemática processual em vigor, tanto que a dúvida sobre quem seja o efetivo credor pode dar margem à chamada ação de consignação em pagamento, cujo polo passivo será integrado pelos potenciais credores (art. 335, IV, do Código Civil; art. 895, do CPC). Embora a lei consinta com o efeito liberatório (extinção da obrigação) já na primeira fase da consignatória (art. 898, do CPC), o certo é que a efetiva e verdadeira desvinculação jurídica do devedor incidirá não em relação a ambos os réus (pretensos credores), mas sim àquele que efetivamente for o credor. Daí que a consignatória, nessa específica hipótese, ecoa num tom de alternatividade em relação aos potenciais credores $^{739}$.

Interessante ainda observar que nos idos de 1986, em coletânea de jurisprudência e de doutrina sobre assistência e litisconsórcio, publicou-se julgado do extinto Primeiro Tribunal de Alçada Civil de São Paulo em que se admitiu o litisconsórcio alternativo ${ }^{740}$. O acórdão está assim ementado: "Em ação movida, contra seguradora e contra o banco intermediário do seguro admite-se o litisconsórcio passivo alternativo, pois não sabe o autor a quem será imputada a responsabilidade e, sendo um exonerado da obrigação de reparar, pode ser condenado o outro" ${ }^{, 741}$.

Afora essas colocações de índole estritamente processual, todas elas abrigadas de algum modo no ambiente constitucional em que se assenta toda a construção jurídico-

\footnotetext{
${ }^{738}$ Nesse ponto, é bom relembrar que a noção de acesso à ordem jurídica justa como emanação de um direito fundamental faz com que os enunciados tendentes à concretização desse desiderato constitucional tenham aplicação imediata e independentemente de construções legislativas infraconstitucionais, ex vi do art. $5^{\circ}, \S 1^{\circ}$, da Constituição da República (SICA, Heitor V. M. O direito de defesa no processo civil brasileiro, cit., $\mathrm{n}^{\circ}$ 3.5 , p. 56).

739 “Ao julgar a controvérsia entre os dois réus, indicará o juiz qual deles era legitimado perante o autor e qual não, eliminando com isso a dúvida que motivara a vinda do devedor a juízo" (DINAMARCO, Cândido Rangel. Litisconsórcio, cit., nº 182, p. 460-461).

740 ALVIM, Arruda; ARRUDA ALVIM PINTO, Teresa. Assistência - litisconsórcio: repertório de jurisprudência e doutrina. São Paulo: RT, 1986, p. 125-127.

${ }^{741}$ Ap. Cível no $327.860,5^{\text {a }}$ Câmara, Rel. Scarance Fernandes, j. 15.08.1984, v.u.
} 
processual, há ainda espaço para lembrar que certas peculiaridades extraídas da conformação do direito material incrementam o discurso que deságua na admissibilidade do litisconsórcio alternativo no processo civil brasileiro.

Realmente, não se pode conceber fiquem sem uma resposta processual adequada situações como estas a seguir exemplificadas.

Diante da dúvida sobre quem seja o pai, o filho cuja mãe tenha se relacionado, no mesmo período, com mais de um homem teria sérias razões para, numa mesma iniciativa processual, promover a investigação de paternidade contra mais de uma pessoa, para que a sentença reconheça o vínculo biológico em relação a um ou a outro (Parte II, Cap. III, $\mathrm{n}^{\circ}$ 28).

Presente a dúvida sobre a eficácia de uma assunção de dívida, o credor poderia formular demanda em face do assuntor e também do devedor originário, estes figurando, porém, como litisconsortes numa modulação alternativa. Com isso, o credor buscaria a condenação de um ou de outro a pagar a dívida (Parte II, Cap. III, nº 24).

Fazendo-se uma ligeira modificação no exemplo anterior, seria possível imaginar um ambiente de dúvida sobre a eficácia de uma cessão de crédito, de molde a se admitir que o cedente e o cessionário, em litisconsórcio ativo alternativo, ajuízem demanda contra o devedor, a fim de que a sentença condene o réu a pagar a um ou a outro autor.

Já no campo da responsabilidade civil, seria possível vislumbrar uma tríplice colisão de veículos em que o ofendido não estivesse seguro sobre qual dos dois outros motoristas teria causado o acidente. Nessa perspectiva, seria legítima a construção dum litisconsórcio passivo alternativo, no afã de se obter a condenação de um ou de outro ao ressarcimento dos prejuízos (Parte II, Cap. III, nº 20).

Acredita-se, portanto, que não está fora de propósito considerar que problemas residentes no plano do direito material estimulam ainda mais a construção do litisconsórcio alternativo. E os exemplos acima lembrados servem para demonstrar o que se acaba de expor, muito embora outras variadas situações pudessem ser ainda vislumbradas a partir do elenco delineado no Capítulo III, da Parte II. 


\section{Ainda a admissibilidade: requisitos}

Assentadas as noções de litisconsórcio alternativo e visitados os fundamentos teórico-práticos de sua admissibilidade no sistema processual brasileiro em sua configuração legislativa atual, importa delinear os requisitos à luz dos quais se permitiria a formação dessa modalidade litisconsorcial num caso concreto.

A partir dos exemplos coletados no campo do direito material (Cap. III, Parte II) pode-se observar a existência de um vínculo de conexidade entre a posição dos litisconsortes alternativos frente a uma dada relação de direito material. Deveras, a dúvida objetiva que dá azo a esse tipo de construção litisconsorcial traduz-se na incerteza quanto à efetiva titularidade de uma dada relação jurídica material. Portanto, num grau mais ou menos acentuado, a conexão estará presente.

Infere-se desse raciocínio que o requisito para instituição de litisconsórcio estará configurado, porquanto a situação dos colitigantes alternativos poderá ajustar-se a uma das hipóteses contempladas nos incisos II ou III do art. 46 do Código de Processo Civil ${ }^{742}$. Então, a construção do litisconsórcio alternativo dá-se no âmbito estrito daquele rol taxativo de hipóteses residente no art. 46, do CPC, sendo imprescindível, de partida, que uma daquelas hipóteses esteja configurada; caso contrário, inviabiliza-se a formação litisconsorcial.

A doutrina italiana levanta interessante questão sobre se, para formação de litisconsórcio alternativo, impõe-se a presença de mesmo título e mesmo objeto, modulando-se, em alternativa, apenas os aspectos subjetivos, ou se seria factível que os títulos e objetos fossem também alternativos ${ }^{743}$.

Levando em conta que na seara do litisconsórcio comum (não unitário) verifica-se, ao mesmo tempo, um cúmulo objetivo e subjetivo de demandas, não parece haver razão

\footnotetext{
${ }^{742}$ Quanto aos requisitos do litisconsórcio em geral, cfr. Parte I, Cap. Único, ${ }^{\circ} 6$.

${ }^{743}$ TARZIA, Giuseppe. Appunti sulle domande alternative, cit., p. 292-293. De sua parte, REDENTI refere que haveria uma verdadeira alternatividade subjetiva quando o título e o objeto são os mesmos, alternando-se apenas o aspecto subjetivo da demanda, ao passo que uma espúria alternatividade ocorreria quando o autor levantasse em face de um sujeito um determinado título e, para o caso de não acolhimento do pedido com base nesse título, já se lançaria mão de outro título para litigar contra outro sujeito (Problemi di competenza in cassazione, cit., p. 96-98).
} 
para se rejeitar, pura e simplesmente, um litisconsórcio alternativo que venha lastreado em causas de pedir um tanto quanto distintas, cada qual imbricada com a situação deste ou daquele litisconsorte. Além disso, afigura-se razoável conceber que a diversidade de pedidos frente aos litisconsortes alternativos seja também factível.

A partir de um exemplo extraído da jurisprudência do Superior Tribunal de Justiça - já citado neste trabalho ${ }^{744}$ - mostra-se possível construir a hipótese que se delineou no parágrafo antecedente. Na situação concreta, decidiu-se assim:

“(...) É perfeitamente possível, sob o manto da chamada cumulação eventual, pedir a declaração de nulidade de subscrição de ações de banco que teve sua liquidação extrajudicial posteriormente decretada, com a devolução dos valores já pagos, ou, não sendo nula a subscrição, a responsabilidade do Banco Central do Brasil, sob a alegação de negligência na fiscalização das instituições financeiras" ${ }^{\text {745 }}$.

Fazendo-se uma ligeira adaptação, poder-se-ia imaginar o ajuizamento dessa mesma demanda em tom de alternatividade e não de subsidiariedade, como está no exemplo original. Sendo assim, os investidores pediriam, sem manifestação de preferência, a declaração de nulidade de subscrição de ações e a condenação à restituição dos valores pagos em face da instituição financeira, e, em caráter alternativo, pediriam a condenação do Banco Central do Brasil a ressarcir os prejuízos suportados, sob o argumento de que este não se desincumbira satisfatoriamente do seu dever de fiscalização.

Veja-se que nesse exemplo adaptado - cuja ocorrência bem que poderia verificar-se - os pedidos respeitantes à instituição financeira não são idênticos àquele formulado em alternativa com relação ao Banco Central. E mais, as causas de pedir (ou títulos, consoante se lê na doutrina italiana) em relação à instituição financeira e ao Banco Central não são perfeitamente as mesmas, embora se originem de um acontecimento comum (liquidação extrajudicial de instituição financeira, com prejuízos para os investidores).

Disso se extrai que o litisconsórcio alternativo pode resultar não só de uma simples alternatividade subjetiva, porquanto a esta podem ser agregadas, também em alternativa,

\footnotetext{
${ }^{744}$ Parte II, Cap. III, n ${ }^{\mathbf{o}} 21$.

${ }^{745}$ REsp no 48.175/MG, Rel. Min. Carlos Alberto Menezes Direito, j. 27.08.1996, DJ 14.10.1996.
} 
diversidades de pedido e de causa de pedir (objeto e título). Dizendo com outras palavras, não se introduz como requisito desse tipo litisconsorcial que a alternatividade resida exclusivamente no aspecto subjetivo e que o objeto e o título sejam fixos.

A par dos requisitos até aqui anunciados, põem-se também as questões alusivas ao procedimento e à competência. Isso porque, considerada a possível alternatividade radicada também na causa de pedir e no pedido, não se descarta que peculiaridades afetas à qualidade das partes ou à natureza da relação controvertida interfiram na definição da competência e na configuração do procedimento. Nessas condições, impõe-se que em relação à integralidade da demanda sejam fixadas as mesmas regras de competência e previsto o mesmo procedimento.

Fica a ressalva, porém, quanto às regras de competência relativa, cuja conformação pode alterar-se na presença de conexão e também por força da prorrogação (ausência de impugnação pelo interessado, por exemplo). Do ponto de vista do procedimento, havendo diversidade de ritos em relação a cada uma da situação dos litisconsortes alternativos, supera-se o óbice na medida em que se adote, em sendo possível, o procedimento ordinário para toda a demanda. Como se decalca, necessário é que sejam preenchidos, em relação ao litisconsórcio alternativo, os requisitos previstos no art. 292, § $1^{\text {o }}$, II e III, com os temperamentos do $\S 2^{\circ}$ do mesmo artigo.

Requisito essencial para a construção aqui estudada concerne à dúvida objetivamente aferível, cuja demonstração há de se desincumbir a parte interessada nessa formulação litisconsorcial alternativa. Assim como se dá no litisconsórcio eventual, o estado de incerteza quanto à conformação subjetiva de determinada relação de direito material é que infunde utilidade e justificação ao instituto.

A dúvida que se abata sobre as consequências jurídicas de um fato ou conjunto de fatos pode dar azo também ao litisconsórcio alternativo. No exemplo acima lembrado acionistas demandando contra a instituição financeira e também contra o Banco Central sob diversos fundamentos, conquanto conexos -, a dúvida objetiva diz respeito às consequências extraíveis daquele conjunto de fatos. Se adotada uma solução, a discussão de direito material resolve-se no âmbito de um determinado sujeito (instituição financeira); mas, se se conferir outra solução a respeito do debate de direito material, a decisão converge para a esfera jurídica de outro sujeito (Banco Central). 
Seja como for, a constante que se verifica diz respeito à efetiva ocorrência de uma dúvida, objetivamente aferível e não simplesmente imaginada pelo intérprete ou operador do direito, sobre a conformação fática ou sobre as derivações jurídicas implicadas com sujeitos distintos.

Então, na presença dessas condições ou requisitos - criteriosamente trabalhados pela parte que se interessa na formulação de demanda em litisconsórcio alternativo haverá espaço para a admissão dessa modalidade litisconsorcial.

\section{Objeções: tentativa de superação}

Semelhantemente ao que sucede com o litisconsórcio eventual, as possíveis críticas à figura do litisconsórcio alternativo, conquanto respeitáveis, não alcançam em estatura os benefícios que essa modalidade litisconsorcial pode trazer ao sistema como um todo.

Mas ainda assim é preciso confrontar as objeções do ponto de vista científico, presente o objetivo de se criar um ambiente teoricamente seguro para enfrentamento de questões práticas que pululam no foro.

De início, considera-se bem demonstrado que a condição que existe no litisconsórcio alternativo não delineia propriamente uma demanda condicional, como pareceu a SCHÖNKE ${ }^{746}$. É verdade que a apreciação da relação material respeitante a um dos litisconsortes alternativos só será valorada, positiva ou negativamente, se (aqui está a condição) o pedido não tiver sido já acolhido em relação ao outro litisconsorte que demanda ou que foi demandado em alternativa. Não se trata, pois, à semelhança do que ocorre no litisconsórcio eventual, de um ajuizamento condicional de demanda. Delineia-se, portanto, que o juiz não tem sua atuação sujeita a alguma condição e, nesse cenário, terá de apreciar a demanda como um todo. O que se mostra duvidoso e de certa forma submetido à condição diz respeito ao conteúdo da decisão judicial relativamente aos litisconsortes.

Com efeito, segundo a exposição de AlLORIO, havendo o acolhimento da pretensão respeitante a um dos litisconsortes alternativos, isso será suficiente para implementar a condição que impede - porquanto desnecessária - a análise do mérito respeitante ao(s) outro(s) litisconsorte(s). Em suma, acolhido que seja o pedido em relação a um dos

${ }^{746}$ Derecho procesal civil, cit., § 43, I, 3, p. 150. 
litisconsortes verifica-se a ausência superveniente de interesse de agir em relação ao outro litisconsorte $^{747}$, em tudo igual ao que se verifica no campo da cumulação alternativa de pedidos.

Noutra perspectiva teórica e prática, também apta a demonstrar que no litisconsórcio alternativo não se trabalha com a hipótese de ajuizamento de demanda condicional, TARZIA ${ }^{748}$ e TROCKER ${ }^{749}$ referem que o acolhimento de um dos pedidos atrelados a determinado litisconsorte alternativo cria a condição necessária para que seja desacolhido, pelo mérito, o pedido respeitante ao(s) outro(s) litisconsortes. Implica dizer, de conseguinte, que a objeção de SchÖNKE esbarra na consideração de que, no litisconsórcio alternativo, todas as demandas são sujeitas a acertamento e a decisão de mérito $^{750}$.

UGo SCANDIANI, em ensaio já citado, objetou que pretensões alternativas não podem ser admitidas, porquanto elas devem resultar necessariamente de diversos relatos de fatos que se excluem mutuamente, impondo-se, então, a rejeição da demanda como um todo $^{751}$. Entretanto, vem também da doutrina italiana ${ }^{752}$ a argumentação, suficientemente vantajosa, segundo a qual a alternatividade pode advir de uma mesma conformação fática, bastando que sejam debatidas as consequências jurídicas desses fatos, em ordem a se estabelecer a titularidade deste ou daquele sujeito na dependência da solução que se der ao debate jurídico. Nessas condições, a alternatividade subjetiva encontraria ambiente para se verificar mesmo que o panorama fático fosse único.

De qualquer forma, convém registrar que o desenvolvimento atual dos relacionamentos jurídicos não ostenta a mesma simplicidade subjetiva que provavelmente se verificava na época em que SCANDIANI desenvolveu seu escrito. Nos dias que correm, as relações são cada vez mais complexas, inclusive do ponto de vista subjetivo, não sendo desarrazoado supor que em certas situações haverá mesmo dúvida sobre a conformação

\footnotetext{
${ }^{747}$ Litisconsorzio alternativo passivo e impugnazione incidentale, cit., p. 516-517.

${ }^{748}$ Appunti sulle domande alternative, cit., p. 288 et seq.

${ }^{749}$ L'intervento per ordine del giudice, cit., p. 214.

${ }^{750}$ Id., ibid. Essa discussão sobre se toda a demanda, conquanto exposta em alternativa, deve ser ou não apreciada pelo mérito será objeto de análise mais adiante (Cap. IV, nº 54, infra).

${ }^{751}$ SCANDIANI, Ugo. Op. cit., p. 182 e 186.

752 ALLORIO, Enrico. Litisconsorzio alternativo passivo e impugnazione incidentale, cit., p. 518; TROCKER, Nicolò. L'intervento per ordine del giudice, cit., p. 213.
} 
fática. E a afirmação dessa dúvida, em vez de revelar uma postura processual desleal, como pareceu a SCANDIANI, traduz-se num comportamento afinado com a eticidade que se exige na trama processual.

Realmente, não é pecado algum ter dúvida e muito menos será o fato de externá-la objetivamente quando da propositura da demanda. Evidente que a dúvida de que se cuida é aquela aferível objetivamente, não se tratando, pois, de mera dúvida subjetiva.

Então, se levado às últimas consequências o "rigorismo de SCANDIANI",753 ter-se-ia de proscrever a cumulação alternativa de pedidos e até mesmo a consignação em pagamento na hipótese de dúvida sobre a pessoa do efetivo credor, já que, em certa medida, tais institutos têm em sua base de formação um estado de perplexidade fática que não chega a escandalizar.

Tenha-se em devida conta, ainda, que certas dúvidas em torno da conformação fática de uma dada relação jurídica são propositalmente criadas pela parte adversa (v. $g$., a confusão patrimonial nas hipóteses de desconsideração da personalidade jurídica), algo que de maneira alguma pode ficar à margem de uma solução processualmente adequada, sob pena de se fazer tábula rasa de tudo quanto se afirmou sobre efetividade e instrumentalidade do processo.

Pelo prisma da suposta "afinidade de interesses" como característica necessária a todo e qualquer litisconsórcio, crê-se ter ficado suficientemente assentado que esse dogma não convence, sendo, pois, insuficiente para obstaculizar a construção que se reputa válida em torno do litisconsórcio alternativo. Litisconsórcio não significa, com efeito, consórcio na lide e muito menos consórcio de litigantes. Mais uma vez se repete acertada lição de que a ausência de antagonismo não é coessencial à existência de litisconsórcio. Implica dizer que, mesmo na presença de algum índice de antagonismo entre os litisconsortes alternativos, não se terá por afastada a admissibilidade da espécie litisconsorcial em estudo.

O enfoque das condições da ação também não se erige como obstáculo à admissibilidade do litisconsórcio alternativo. A bem da verdade, o que enseja a construção dessa modalidade litisconsorcial tem relação com aspectos de direito material, a cujo serviço está o processo. Então, só mesmo uma inversão de valores, colocando-se o meio (técnica das condições da ação) em patamar mais elevado que o fim (realização do direito

753 As aspas justificam-se porque as expressões foram emblematicamente utilizadas por ALLORIO (Litisconsorzio alternativo passivo e impugnazione incidentale, cit., p. 518). 
material), poderia redundar na proscrição do litisconsórcio alternativo sob o argumento de que em tal construção a propositura da demanda já viria contaminada, desde o nascedouro, pela ilegitimidade de um dos litisconsortes alternativos e também pela falta de interesse de agir quanto a um dos pedidos alternativos.

Alguém poderia argumentar, noutro vértice, que o problema do litisconsórcio alternativo poderia ser facilmente superado pelo ajuizamento de demandas sucessivas: o autor, por exemplo, demandaria contra o réu $A$ e, depois de assentada a derrota em relação a este, proporia nova demanda em face do réu $B$. Entretanto, conforme tantas vezes repetido neste trabalho, a noção de economia processual e de razoável duração dos processos em geral não consente com semelhante construção interpretativa. Abalizada doutrina já salientou que essas sucessivas investidas processuais, além de gerarem o risco da dupla sucumbência em razão dos possíveis julgamentos contraditórios, desnudam a ineficiência da prestação jurisdicional. Para se chegar a tal conclusão basta pensar no inafastável decurso de tempo entre uma demanda e outra e na inexorável fluência de prazo prescricional $^{754}$, isso, é claro, nos casos em que se busca a satisfação de pretensões.

Na perspectiva do "princípio dispositivo" poder-se-ia argumentar que ao julgador não se pode abrir qualquer espaço para exercício de uma discricionariedade quanto à ordem com que são analisados os pedidos formulados pelo autor ou autores, de vez que a resposta judicial há de se confinar nos limites precisos em que vazada a demanda ${ }^{755}$.

Contudo, afora a celeuma que grassa em torno da própria noção de princípio dispositivo $^{756}$, afigura-se importante ajustar o foco de análise para uma perspectiva afinada

754 TROCKER, Nicolò. L'intervento per ordine del giudice, cit., p. 212, nota 79.

${ }^{755}$ RONCO, Alberto. Studio sul litisconsorzio alternativo, cit., p. 910-911. Manteve-se no texto a expressão "princípio dispositivo" por conta da terminologia adotada pelo autor que se vem de citar. Todavia, parece mais adequada, pelo ângulo terminológico, a utilização da expressão “princípio da demanda" para expressar a noção de que o processo começa por iniciativa da parte, a quem compete, por isso mesmo, tracejar os limites do objeto litigioso do processo. Reserva-se à expressão "princípio dispositivo" a designação concernente à prerrogativa que as partes ostentam de dispor de certas posições jurídicas já no curso do processo (BARBOSA MOREIRA, José Carlos. O problema da “divisão do trabalho” entre juiz e partes: aspectos terminológicos. In: Temas de direito processual, quarta série. São Paulo: Saraiva, 1989, p. 42).

${ }^{756}$ Cfr. BEDAQUE, José Roberto dos Santos. Poderes instrutórios do juiz. 4. ed. São Paulo: RT, 2009, p. 87 et seq.; CASTRO LOPES, Maria Elizabeth de. O juiz e o princípio dispositivo. São Paulo: RT, 2006, p. 91 et seq.; BARBOSA MOREIRA, José Carlos. O problema da “divisão do trabalho" entre juiz e partes: aspectos terminológicos, cit., p. 38 et seq. 
com a noção de que o processo tem por escopo pacificar os conflitos intersubjetivos, de sorte que, na medida em que o próprio demandante, envolto em situação de dúvida objetiva, consente com o acolhimento de uma ou de outra demanda, não se teria maltrato ao princípio dispositivo só pelo fato de caber ao juiz a tarefa de escolher entre os vários pedidos efetivamente formulados pelos ou contra os litisconsortes alternativos ${ }^{757}$.

De fato, a parte que não esteja em condições de resolver, com a segurança necessária, a dúvida sobre a titularidade passiva (ou ativa) do direito material objeto de controvérsia deve ter a oportunidade para encontrar a solução definitiva desse estado titubeante na sede institucional apropriada e predisposta a tanto, ou seja, no ambiente do processo instaurado perante o órgão jurisdicional competente ${ }^{758}$.

O que não se concebe, portanto, como já se pôde entrever por tudo quanto se expôs, é o acolhimento de todos os pedidos formulados em alternativa, pois que aí sim haveria pronunciamento extra petita e, consectariamente, violação ao "princípio da demanda".

${ }^{757}$ RONCO, Alberto. Op. cit., p. 910-911.

${ }^{758}$ TROCKER, Nicolò. L'intervento per ordine del giudice, cit., p. 212, nota 79. 


\section{Capítulo III}

\section{LITISCONSÓRCIO SUCESSIVO}

\section{Noção e terminologia}

À vista do que se definiu em tema de cumulação de pedidos ${ }^{759}$, mais uma vez é possível valer-se da luz projetada por tal foco de irradiação para desenhar a figura do chamado litisconsórcio sucessivo, caracterizado, genericamente, pela existência de uma pluralidade de partes na demanda e, especificamente, pela apreciação de um pedido pertinente a um sujeito na pressuposição de que um pedido anterior, relativo a outro sujeito, tenha sido julgado procedente, tudo de maneira englobada no mesmo processo.

Como se decalca desse enunciado, ocorre uma transposição da ideia de cumulação sucessiva de pedidos para o campo da aglutinação subjetiva, autorizando-se, dessa forma, o esgarçamento das classificações de litisconsórcio.

Em outras palavras, no litisconsórcio sucessivo o acolhimento do pedido em relação a um sujeito irrompe como fator apto a influenciar o conteúdo do provimento respeitante ao pedido atrelado a outro sujeito. Reside aí, tal como sucede na cumulação sucessiva de pedidos, a noção de prejudicialidade ${ }^{760}$. O primeiro pedido, com pertinência a um sujeito, mostra-se prejudicial em relação ao pedido sucessivo e relacionado a outro sujeito. A peculiaridade, como se nota, está em que os pedidos submetidos à apreciação do julgador pertinem a sujeitos diversos, de modo que, ao se passar ao exame do pedido posterior, deflagra-se uma “análise subjetiva diversa daquela realizada em sede do pedido antecessor" $^{, 761}$.

Facilmente se percebe que tal fenômeno dá-se, precipuamente, na seara do litisconsórcio facultativo, sendo comum (não unitário) o seu regime. Daí se poder concluir,

\footnotetext{
${ }^{759}$ Cap. II, Parte II.

${ }^{760}$ Remete-se o leitor ao quanto foi dito por ocasião do estabelecimento das premissas (Parte II, Cap. II).

${ }^{761}$ MAZZEI, Rodrigo. Litisconsórcio sucessivo: breves considerações. In: DIDIER JR., Fredie; MAZZEI, Rodrigo (org.). Processo e direito material. Salvador: JusPodivm, 2009, p. 232-233.
} 
na esteira do que se defendeu no trato do litisconsórcio eventual e do alternativo, que se forma a um só tempo um cúmulo objetivo e também subjetivo de demandas.

Sob o prisma da (in)dispensabilidade de formação do litisconsórcio, não se deve pensar, em tom apriorístico, que o litisconsórcio sucessivo seja incompatível com a noção de litisconsórcio necessário. Quando se tratou das necessidades de direito material fez-se alusão a precedentes do Supremo Tribunal Federal em sede de mandado de injunção endereçado ao Congresso Nacional (parte passiva), ocasião em que se trabalhou com a hipótese de formação de título executivo ilíquido contra a União. Então, na hipótese de procedência do mandado de injunção endereçado ao Congresso Nacional abriu-se o caminho para formação de título executivo em face da União. Poder-se-ia inferir, então, com alguma dose de razoabilidade e ao menos à luz desse exemplo, que a manifestação de um litisconsórcio sucessivo não destoa, em termos absolutos, da configuração de um possível litisconsórcio necessário ${ }^{762}$.

A construção dessa modalidade litisconsorcial é de rara aparição na doutrina nacional e, ressalvada pesquisa bibliográfica mais minuciosa, parece ser silente a doutrina estrangeira, ao menos pelo prisma e pelo significado que aqui se dá ao termo litisconsórcio sucessivo. GIUSEPPE TARZIA chegou a enunciar as mesmas ideias aqui referidas, porém sob a designação litisconsórcio condicional, ou seja, "un cumulo di domande tra diversi soggetti proposte l'una condizionatamente all'accoglimento dell'altra"763.

Partindo de um exemplo, ARAKEN DE ASSIS estabelece os traços do litisconsórcio sucessivo e põe em relevo o caráter prejudicial da situação de um sujeito em relação à do outro. No exemplo figurado pelo autor mãe e filho, em conjunto (litisconsórcio ativo), litigam contra o suposto pai; o filho pede alimentos e a mãe o ressarcimento das despesas do parto. Para justificar seu raciocínio, o autor diz que "a procedência da ação de alimentos pressupõe a obrigação do pai quanto às despesas, pois, na raiz do dever de prestar alimentos, se situa a paternidade que, desengadamente, não se pôs em causa"764.

\footnotetext{
${ }^{762}$ Cfr. Parte II, Cap. III, no 30.

763 Il litisconsorzio facoltativo nel processo di primo grado, cit., p. 43. Para o citado autor, a expressão litisconsórcio sucessivo emprega-se para designar o que nós chamamos de litisconsórcio ulterior (id., p. 4445).

${ }^{764}$ Cumulação de ações, cit., $\S 12, \mathrm{n}^{\circ}$ 43, p. 169. Em texto mais recente, o mesmo autor assim conceitua: "Há litisconsórcio sucessivo quando a ação de um dos litisconsortes assume caráter prejudicial, relativamente à ação do outro" [Do litisconsórcio no Código de Processo Civil, cit., n 4.2, p. 555].
} 
Embora o exemplo sirva para dar uma noção acertada do que seja o litisconsórcio sucessivo, não se vê a mesma correção quando se diz que a procedência da ação de alimentos sirva de pressuposto para a conclusão quanto à responsabilidade pelas despesas do parto. Com efeito, mesmo na hipótese de improcedência da ação de alimentos - figurese o caso em que o filho não necessite dos alimentos ou em que o pai não tem condições de pagá-los - será ainda possível cogitar-se da responsabilização pelas despesas do parto. Em verdade, a prejudicialidade que se divisa é a existente entre a relação de paternidade e as demais consequências daí advindas (pensão alimentícia e ressarcimento das despesas do parto).

Em tom mais adequado, poder-se-ia vislumbrar a hipótese em que o filho investiga a paternidade em face do suposto pai (a conhecidíssima "ação de investigação de paternidade") e, no mesmo processo e para o caso de ser acolhido o pedido do filho, a mãe formula o seu pedido de ressarcimento das despesas do parto.

Por inspiração de outra passagem de ARAKEN DE ASSIS ${ }^{765}$, vislumbra-se a hipótese em que, numa compra e venda de imóvel, o vendedor ceda seu crédito a terceiro e este cessionário crie óbices quanto ao pagamento do preço pelo comprador. Seria possível cogitar, em semelhante cenário, de um pedido de consignação em pagamento contra o cessionário e, no mesmo processo, de adjudicação compulsória contra o cedente/vendedor. Haveria, aí, litisconsórcio sucessivo passivo.

"Justamente em virtude da cumulação sucessiva que caracteriza o pleito, somente se avançará para o patrimônio do segundo litigante após a análise positiva (de resultado) em relação ao primeiro. Mister se fará que conste, primeiramente, comando decisório (aqui, = capítulo de sentença) positivo quanto ao primeiro litisconsorte, para, após, se adentrar no segundo pedido que é concernente ao litigante que está em litisconsórcio sucessivo" ${ }^{\text {766 }}$.

Impressionado com as vicissitudes hauridas da conformação do direito material, SCARPINELLA BUENO também se debruçou sobre o assunto e chegou exatamente à

\footnotetext{
${ }^{765}$ Do litisconsórcio no Código de Processo Civil, cit., no 7, p. 562.

${ }^{766}$ MAZZEI, Rodrigo. Litisconsórcio sucessivo: breves considerações, cit., p. 233.
} 
conclusão que se vem de anunciar. Acresceu, todavia, e com inegável acerto, que a formação de litisconsórcio sucessivo dar-se-á segundo a vontade manifestada na petição inicial, mediante a análise da relação de direito material tal como traduzida na tela processual. Daí a acertada preleção de que uma mesma situação concreta poderá dar margem à construção de litisconsórcio eventual ou sucessivo, tudo a depender da conformação do pedido exposto na petição inicial ${ }^{767}$.

Mais uma vez, e agora com mais vigor, põe-se a discussão terminológica, porquanto é costumeira, aqui e alhures, a utilização da expressão litisconsórcio sucessivo como designativa de litisconsórcio ulterior ${ }^{768}$.

Assim se dá porque o termo sucessivo remete à noção do que vem depois. E esse viés cronológico presente na ideia de sucessividade turva um pouco a visão do que se quer mostrar com a expressão litisconsórcio sucessivo.

Porém, com base no quanto se desenvolveu acerca da cumulação sucessiva de pedidos, assunto de terminologia já tradicional em plagas brasileiras, não é de se escandalizar com o aproveitamento daquela noção e aplicá-la na seara do litisconsórcio.

Como já se destacou em doutrina, a sucessividade residente na noção de litisconsórcio sucessivo prende-se ao nexo que há entre as demandas dos colitigantes e não ao momento da intervenção desta ou daquela parte ${ }^{769}$.

Reputa-se, pois, de nenhum prejuízo à compreensão, seja do acadêmico, do estudioso ou mesmo do profissional do direito, a nomenclatura utilizada neste estudo. Quando menos, a designação aqui empregada tem a vantagem de estar em simetria com a utilizada para dar nome a instituto bem semelhante, que é o da cumulação sucessiva de pedidos.

\footnotetext{
${ }^{767}$ Partes e terceiros no processo civil brasileiro, cit., p. 98 et seq.

${ }^{768}$ FAZZALARI, Elio. Istituzioni di diritto processuale, cit., p. 330; LÓPEZ JIMÉNEZ, Raquel. Op. cit., p. 33; REMÉDIO MARQUES, João Paulo. Op. cit., $\mathrm{n}^{\circ}$ 103, p. 385 et seq.; LOPES DA COSTA, Alfredo Araújo. Direito processual civil brasileiro, cit., vol. I, p. 436-437; DINAMARCO, Cândido Rangel. Litisconsórcio, cit., $\mathrm{n}^{\circ}$ 28, p. 80; SILVA, Ovídio A. Baptista da. Comentários ao Código de Processo Civil, cit., vol. 1, p. 196.

${ }^{769}$ ASSIS, Araken de. Do litisconsórcio no Código de Processo Civil, cit., nº 4.2, p. 555.
} 
Depois de visualizadas as noções de litisconsórcio eventual, alternativo e sucessivo, é chegada oportunidade de distingui-los entre si, uma vez que a afinidade que está à base das noções já alinhavadas torna imperiosa a tarefa de discrímen.

À semelhança do que sucede com a cumulação de pedidos, as modalidades litisconsorciais estudadas neste trabalho não se confundem. Já se pôde perceber que na seara do litisconsórcio eventual e do alternativo subjaz uma dúvida, objetivamente aferível, a ponto de se autorizar o litígio em conjunto, havendo ciência e desejo prévios de que os pedidos não sejam concedidos ou julgados procedentes em relação a todos os litisconsortes. No eventual, porém, surge um escalonamento em termos de preferência por este ou aquele litigante, algo com que não se depara na modalidade alternativa.

No espectro do litisconsórcio sucessivo, a dúvida vem substituída pela prejudicialidade que envolve a situação dos colitigantes. Ademais, não se coloca aqui a presença ou ausência de preferência entre os vários litigantes, uma vez que se almeja, em verdade, a apreciação da relação de direito material alusiva a todos os colitigantes, muito embora o conteúdo do julgamento de um seja influenciado pela decisão relativa ao outro.

Afora a distinção conceptual, não se pode, contudo, catalogar aprioristicamente as hipóteses concretas em que se dará uma ou outra modalidade de litisconsórcio. Com efeito, na esteira de arguta manifestação doutrinária, a visualização exata da modalidade litisconsorcial com que se depara (se eventual, alternativa ou sucessiva) relaciona-se com a forma pela qual a relação de direito material vem afirmada em juízo. Implica dizer que a identificação do litisconsórcio eventual, alternativo e sucessivo não se faz aprioristicamente, mas sim à luz das escolhas coerentemente formuladas pelo demandante, pois a este cabe identificar "se o julgamento em face de um ou de outro réu assume para ele, autor, algum grau de prejudicialidade, subsidiariedade ou não"770.

Sob o enfoque específico da desconsideração da personalidade jurídica, SCARPINELLA BUENO vislumbra um caso típico de litisconsórcio eventual, "na exata medida em que o credor, na petição inicial, formule pedido em face da pessoa jurídica $e$ formule pedido também (e desde logo) em face das pessoas físicas que a compõem, demonstrando, para tanto, a ocorrência da hipótese valorada pelo precitado art. 50, isto é, a

${ }^{770}$ SCARPINELLA BUENO, Cassio. Curso sistematizado de direito processual civil, cit., vol. 2, t. I, p. 457. 
necessidade de ser desconsiderada a personalidade jurídica (causa de pedir)",771. Não se descarta, contudo, que mesmo na hipótese de desconsideração da personalidade jurídica possa encartar-se o litisconsórcio alternativo ou mesmo o sucessivo, "sempre a depender do que o autor pediu (pedido), a partir de que fatos (causa de pedir), em face de quem (partes) $)^{\text {,772 }}$.

\section{Admissibilidade no processo civil brasileiro: fundamentos}

Os influxos que descendem do modelo constitucional de processo civil dão margem a que se entenda que as crises jurídicas advindas de diversas relações atreladas a sujeitos distintos sejam dissipadas o quanto antes possível e mediante o menor desgaste possível de atividades das partes e do Poder Judiciário. A concretização do valor economia processual e, de conseguinte, a proporcional implementação da razoável duração dos processos em geral já infundem a crença de que o sistema processual compactua com a técnica do litisconsórcio sucessivo, buscando-se otimizar os resultados que possam advir duma única experiência processual.

A interdependência que está à base dessa modalidade de construção lança reflexos, também notáveis, no campo da harmonia de julgados, algo que vem estreitamente vinculado ao prestígio que interessa erigir em torno da atuação do Poder Judiciário. A noção de convicção única em torno de relações díspares, mas vinculadas por prejudicialidade, bem demonstra a relevância de se dar maior rendimento aos casos de litisconsórcio.

De outro lado, as estruturas teóricas que conformam a cumulação sucessiva de pedidos asseguram que análoga construção, embora em termos subjetivos, não entraria em rota de colisão com o sistema processual hoje em vigor. Com efeito, o sistema em vigor engendra soluções adequadas e economicamente justificáveis quando se está diante de prejudicialidade, não surpreendendo, então, que na presença de outras implicações advindas da mesma prejudicialidade o sistema adote novas soluções, muito embora sem o reforço da expressa previsão legal.

\footnotetext{
${ }^{771}$ SCARPINELLA BUENO, Cassio. Curso sistematizado de direito processual civil, cit., p. 458 (grifos do original).

${ }^{772}$ Id., ibid.
} 
Lícito é dizer, ainda uma vez, que os predicados que afloram de certas relações de direito material exigem da ciência do processo respostas satisfatórias, a fim de que a própria situação de vantagem, tal como desenhada no plano material, não fique esmaecida diante da frustrante insuficiência da técnica processual.

Logo, o filho pode muito bem investigar a paternidade contra o suposto pai e, para a hipótese de procedência deste pleito, pedir alimentos em face dos avós, num caso que configura inequívoco litisconsórcio sucessivo passivo (Parte II, Cap. III, $n^{\circ}$ 27).

Em tema de direito previdenciário, o convivente de segurado falecido pode, numa única experiência processual, buscar o reconhecimento da união estável e, uma vez acolhido tal pedido, pleitear contra o instituto de previdência a concessão de benefício previdenciário que tenha como pressuposto aquela relação de dependência (Parte II, Cap. III, $\left.\mathrm{n}^{\mathrm{o}} 31\right)$.

A riqueza de situações geradas pela prejudicialidade poderia fazer com que se multiplicassem as justificações com base nas necessidades advindas do direito material. Mas, para os fins conscientemente adotados neste trabalho, é suficiente lembrar, por último, do caso examinado pelo STF em sede de mandado de injunção (Parte II, Cap. III, $\left.n^{\circ} 30\right)$.

Na ocasião, a decisão ditada pela Corte veiculou capítulos distintos e vinculados a partes diversas, porquanto se dispôs sobre a omissão legislativa quanto ao Congresso Nacional e, por causa disso, condenou-se a União a pagar a indenização prevista no art. $8^{\circ}$, $\S 3^{\circ}$, do ADCT.

Acredita-se que o cenário resultante da necessária aproximação entre direito e processo legitima o raciocínio que vê no litisconsórcio sucessivo uma técnica processual aceitável no sistema processual brasileiro, mesmo sob a égide de uma legislação que não o contempla expressamente.

E assim se deve pensar porque, além de o instituto não atritar com os princípios reinantes dentro do modelo processual concebido entre nós, o fenômeno percorre um caminho que conduz à otimização da prestação jurisdicional. Em última análise, calibra-se a técnica de tal modo que ela sirva bem aos desideratos de sua própria existência. 


\section{Ainda a admissibilidade: requisitos}

Em várias passagens desse estudo fez-se questão de advertir que o litisconsórcio, mesmo quando caracterizado pela facultatividade, há de estar lastreado nalguma das hipóteses de cabimento previstas no art. 46, do Código de Processo Civil, entendido, aliás, como exteriorização de um rol taxativo. Daí a necessidade de se enquadrar a hipótese aqui versada num dos incisos daquele dispositivo legal.

Já se pôde perceber que a síntese da justificação dessa especial modalidade de litisconsórcio conduz à noção de prejudicialidade, algo que revela, por consectário, a presença de conexidade, em ordem a se concluir como perfeitamente admissível que as situações envolvendo litisconsortes sucessivos resultarão num vínculo mais ou menos intenso de conexidade.

A interdependência entre as relações de direito material conotadas a sujeitos diversos traz à baila a constatação de que os incisos II e III do art. 46 do CPC podem constituir aporte seguro de fundamentação para a formação de litisconsórcio sucessivo.

Buscando novamente o paradigma da cumulação de pedidos, tem-se que no litisconsórcio sucessivo almeja-se que todos os pedidos relacionados aos diversos sujeitos sejam acolhidos pelo julgador, diferentemente do que sucede no litisconsórcio eventual e no alternativo. Sendo assim, interpõe-se como requisito de admissibilidade daquele a compatibilidade entre os pedidos, tal como ocorre na seara da cumulação simples de $\operatorname{pedidos}^{773}$.

Os requisitos da competência e da similitude de procedimento também se colocam aqui como elementos importantes para definição da admissibilidade ou não do litisconsórcio sucessivo, sendo relevantes $(i)$ a distinção entre as hipóteses de competência absoluta e relativa e (ii) a possibilidade de os vários pedidos acomodarem-se segundo os trâmites do procedimento ordinário.

Além disso, o requisito que surge com maior significado, porque dele se extrai a própria noção e a justificação de um litisconsórcio sucessivo, diz com a demonstração do

\footnotetext{
${ }^{773}$ As premissas desse raciocínio estão lançadas no Cap. II da Parte II.
} 
vínculo de prejudicialidade ${ }^{774}$, ou seja, exige-se, à luz da conformação da relação de direito material, que o pronunciamento judicial relacionado a um sujeito interfira necessariamente no conteúdo da decisão respeitante a outro sujeito, sendo a decisão subordinante logicamente antecedente à decisão subordinada ${ }^{775}$.

Ausente essa particularidade, ainda que se possa trabalhar com a hipótese de litisconsórcio formado por outros motivos, não se estará diante de um litisconsórcio sucessivo.

\footnotetext{
${ }^{774}$ Vale a pena relembrar que a prejudicialidade exterioriza "em sua essência, uma prioridade lògicamente necessária na solução de determinadas questões, em razão do condicionamento que daí resulta para a de outras e que se refletirá especìficamente no sentido em que essas outras hão de ser, por sua vez, resolvidas" (BARBOSA MOREIRA, José Carlos. Questões prejudiciais e coisa julgada, cit., p. 41-42).

${ }^{775}$ Cfr. Parte II, Cap. II. O assunto voltará a ser tratado no Cap. IV, n 45, “i”, quando da análise da dinâmica das modalidades litisconsorciais aqui investigadas.
} 


\section{Capitulo IV}

\section{DINÂMICA DO LITISCONSÓRCIO EVENTUAL, ALTERNATIVO E SUCESSIVO}

\section{Plano do capítulo}

Como já se ponderou em doutrina, o estudo do litisconsórcio, para ser o mais completo possível, não pode prescindir da análise de como o instituto ganha vida no terreno concreto da experiência processual ${ }^{776}$. Em outras palavras, é preciso discernir as variadas maneiras pelas quais o instituto influencia a dinâmica processual, moldando a atuação concreta dos protagonistas da trama processual.

Nisso consiste a proposta deste Capítulo final, voltado ao exame da disciplina processual do litisconsórcio eventual, alternativo e sucessivo.

Crê-se que o aspecto estático do assunto esteja suficientemente delineado nos Capítulos precedentes, impondo-se, doravante, uma postura tendente a explicar, à luz dos fundamentos teóricos já anunciados, as vicissitudes práticas da adoção das modalidades litisconsorciais aqui estudadas. Não se pretende dizer, com isso, que o regime litisconsorcial aqui examinado possa trazer uma verdadeira desconfiguração de tudo quanto já se produziu sobre a dinâmica processual do litisconsórcio em suas modalidades fundamentais. Não se trata, pois, de uma ruptura com a construção já conhecida a respeito do litisconsórcio.

Todavia, ainda que seja para demonstrar a ausência de alterações no plano da dinâmica processual, importa que sejam expostos os variados e possíveis problemas práticos envoltos nessa temática e, num segundo momento, que sejam traçadas possíveis soluções coerentes com os enunciados teóricos antes dispostos, tudo isso sob iluminação constante das noções advenientes dos contornos constitucionais que animam a própria admissibilidade, no sistema brasileiro, das modalidades eventual, alternativa e sucessiva de litisconsórcio.

\footnotetext{
${ }^{776}$ DINAMARCO, Cândido Rangel. Litisconsórcio, cit., p. 15.
} 
Convém advertir, desde logo, que as inúmeras consequências derivadas do regime jurídico do litisconsórcio em sua roupagem clássica não serão compendiadas neste Capítulo. Serão apenas lembradas e analisadas quando indispensável à tentativa de construção do regime jurídico específico do litisconsórcio eventual, alternativo e sucessivo.

Para atingir os objetivos acima traçados e numa tentativa de se manter alguma sistematização, procurar-se-á dispor as matérias segundo a divisão tradicional das etapas lógicas da fase cognitiva de um processo individual: postulatória; saneadora; instrutória; decisória e recursal.

Para além da fase recursal, serão levantadas algumas questões que podem eclodir no âmbito de ação rescisória ou de reclamação constitucional aforadas contra sentença judicial ditada em ambiente de litisconsórcio eventual, alternativo e sucessivo.

\section{Juízo de admissibilidade}

Fincada a premissa de que as modalidades litisconsorciais anunciadas nos Capítulos precedentes são admissíveis no sistema processual brasileiro, mesmo sem a necessidade de alterações legislativas, e considerando-se que o direito positivo nacional encampa a teoria da ação segundo a formulação de LIEBMAN $^{777}$, constata-se nítido relacionamento entre as específicas modalidades de pluralidade de partes aqui estudadas e o assunto das condições da ação, com ênfase ao interesse de agir e à legitimidade ad $_{\text {causam }}{ }^{778}$.

Haja vista não se conceber que alguém litigue em juízo sem que ostente interesse e legitimidade, importa verificar se a figura dos litisconsortes eventuais, alternativos e sucessivos emoldura-se no quadro dessas condições da ação. Em outras palavras, é preciso discernir se a posição dos colitigantes, conectada àquelas noções de eventualidade,

\footnotetext{
${ }^{777}$ Expressão disso está na dicção dos arts. $3^{\circ}, 267$, VI, 295, II, III e p. único, III, e 301, X, todos do CPC. Mesmo no Projeto de Lei do Senado $n^{\circ}$ 8.046/2010 (projeto do novo CPC), em trâmite no Congresso Nacional, mantém-se a sistemática preconizada por LIEBMAN, atualizada pela exclusão da possibilidade jurídica do pedido como condição da ação (arts. 17, 305, II e III, e 327, XI, do PLS no 8.046/2010).

${ }^{778}$ Embora a possibilidade jurídica possa ser apreciada à luz de peculiaridades respeitantes às partes (cfr. DINAMARCO, Cândido Rangel. Execução civil, cit., n 248, p. 384 et seq.), não se vê tanta influência desse aspecto das condições da ação na tratativa do litisconsórcio eventual, alternativo e sucessivo. Daí a ausência, no texto, de explanação específica sobre o assunto.
} 
alternatividade e sucessividade, realiza o padrão legal de interesse de agir e de legitimidade ad causam.

Na perspectiva do litisconsórcio eventual, indaga-se sobre uma possível falta de interesse de agir respeitante ao litisconsorte subsidiário quando ainda nem se sabe se o pleito principal [relativo ao litisconsorte primário] será acolhido ou não. Rememore-se que, nessa modalidade litisconsorcial, o litigante subsidiário vem incluído na demanda exatamente por conta da dúvida sobre se a posição do litigante primário será ou não valorada positivamente, de sorte que o julgador debruçar-se-á sobre as questões envolvendo o litigante subsidiário se e somente se a pretensão imbricada com o litigante primário não for acolhida. Ou seja, para a hipótese de o pedido respeitante ao litigante primário não ser acolhido é que se abre espaço para apreciação da posição jurídica do litisconsorte eventual.

Nessas condições, haveria então uma hipotética necessidade de prestação jurisdicional relacionada ao litisconsorte eventual? Sendo essa necessidade meramente hipotética, estaria mesmo presente, desde o início da demanda, o interesse de agir em relação ao litigante subsidiário?

Costuma-se ponderar que a idoneidade e a necessidade do provimento jurisdicional passam, necessariamente, pela constatação da existência de um interesse concreto e atual. Caso contrário, onde houvesse a narrativa de uma lesão puramente eventual e futura ou quando o direito reclamado viesse caracterizado como meramente hipotético, a intervenção do Estado-juiz seria inidônea e, sobretudo, desnecessária, pondo em evidência a inadmissibilidade da demanda ${ }^{779}$.

Na tentativa de demonstrar a compatibilidade do litisconsórcio eventual com a noção de concreta e atual necessidade de intervenção judicial convém, antes de tudo, recordar que as condições da ação situam-se numa faixa de estrangulamento entre o direito material e o processual ${ }^{780}$, tanto assim que "a aferição das chamadas condições da ação nada mais é do que um exame, apriorístico e superficial, da própria relação material ou de dados relevantes colhidos no plano substancial" ${ }^{, 781}$.

\footnotetext{
${ }^{779}$ COMOGLIO, Luigi Paolo; FERRI, Corrado; TARUFFO, Michele. Op. cit., vol. I, p. 242.

${ }^{780}$ DINAMARCO, Cândido Rangel. Execução civil, cit., nº 242, p. 376; DINAMARCO, Cândido Rangel. Instituições de direito processual civil, cit., vol. II, nº 542, p. 307.

${ }^{781}$ YARSHELL, Flávio Luiz. Tutela jurisdicional. 2. ed. São Paulo: DPJ, 2006, p. 106-107.
} 
Demais disso, a técnica das condições da ação ostenta uma característica desenganadamente instrumental ${ }^{782}$, haja vista que sua finalidade consiste em evitar o desencadeamento de atividades processuais nos casos em que a prestação jurisdicional se mostra desde logo inócua. Reside aí a estreita vinculação entre a técnica das condições da ação e o princípio da economia processual $^{783}$. Com efeito, economiza-se energia [tempo, dinheiro e atividades estatais] quando se estanca, desde logo, o desenvolvimento de demandas absolutamente fadadas ao insucesso.

Pois bem. Como já se procurou demonstrar anteriormente, a base de conformação do litisconsórcio eventual imbrica-se com a dúvida objetiva que paira sobre as posições dos litisconsortes (primário e subsidiário). E essa dúvida advém da própria configuração da relação de direito material objeto da controvérsia que se pretende resolver mediante a atuação jurisdicional. Ou seja, a necessidade de se desvendar a exata e fiel configuração da relação substancial, nos seus aspectos subjetivos, é que anima a construção segundo a qual se permite a dedução de pretensão por ou em face de litisconsorte subsidiário para a hipótese de a mesma ou outra pretensão ser desacolhida em relação ao litisconsorte primário, desde que tudo isso se extraia do mesmo conjunto de elementos fáticos e/ou jurídicos relacionados a uma dada relação jurídica substancial.

Noutra perspectiva, admite-se que a construção do litisconsórcio eventual esteja vinculada também à noção de economia processual. Na medida em que se aceita, em processo simultâneo, a definição global da controvérsia envolvendo vários litigantes, evitando-se assim o desdobramento da mesma controvérsia em sucessivas demandas, tende-se a concretizar a almejada economia processual.

Logo se vê, então, que a dedução de pedido pelo ou em face do litisconsorte subsidiário deriva de uma necessidade do direito material. E é exatamente para atender às necessidades do direito material que o processo - em toda sua técnica - está estruturado numa feição nitidamente instrumental. Então, se uma exigência conotada com a relação de direito material evoca a conveniência de se decidir sobre a esfera jurídica de vários

\footnotetext{
782 “É dentro da perspectiva instrumental que deve ser buscada a verdadeira natureza jurídica das condições da ação. A simples perquirição formal do conteúdo desse instituto, desvinculada de qualquer compromisso teleológico, não mais se legitima, diante da visão publicista do processo" (COSTA, Susana Henriques da. $O p$. cit., p. 123).

${ }^{783}$ BEDAQUE, José Roberto dos Santos. Efetividade do processo e técnica processual, cit., p. 238; YARSHELL, Flávio Luiz. Tutela jurisdicional, cit., p. 106.
} 
litigantes, ainda que envolvidos por um prisma de subsidiariedade, não tem sentido algum erigir barreiras técnicas em contraposição aos objetivos de todo o sistema. Dizendo de outra maneira, somente uma nefasta inversão de valores poderia antepor a técnica das condições da ação às necessidades advenientes da conformação do direito material.

No mais, o mesmo objetivo presente na utilização da técnica das condições da ação (economia processual) está presente no encaminhamento das ideias que animam a construção do litisconsórcio eventual, consoante já se demonstrou anteriormente $\left(\mathrm{n}^{\mathrm{o}} 10\right.$, supra). De resto, essa mesma teleologia está presente no plano da cumulação subsidiária de pedidos (CPC, art. 289) e da denunciação da lide pelo autor (CPC, art. 71), cujas conformações servem de lastro para a postura interpretativa que vê o litisconsórcio eventual como fenômeno plenamente compatível com a sistemática processual civil em vigor.

Assim, pode-se concluir que a narrativa de uma situação concreta envolta em dúvida objetivamente aferível sobre a exata configuração subjetiva daquela específica relação substancial posta em juízo cria um ambiente propício à afirmação de que a prestação jurisdicional em relação ao litisconsorte eventual é idônea e necessária, realizando-se, assim, a exigência do interesse de $\operatorname{agir}^{784}$. Mesmo que o exame sobre a situação jurídica do litisconsorte subsidiário ocorra apenas ad eventum de o pleito primário não ter sido acolhido, infere-se a utilidade de sua presença num dos polos da relação processual e de dedução de pedido que reflita sobre a esfera jurídica dele, única forma de, num processo só, ser debelada toda a crise de direito material que angustia os contendores $^{785}$.

\footnotetext{
${ }^{784}$ Em senso parelho, cfr. DUARTE, Ronnie Preuss (Litisconsórcios alternativo e subsidiário no processo civil brasileiro, cit., p. 41 et seq.).

${ }^{785}$ Vale a pena lembrar passagem de BARBOSA MOREIRA, segundo a qual "no campo do processo, tal ou qual providência deve reputar-se útil não tanto por ser capaz, em tese, de acarretar um proveito qualquer para quem a pede, mas na medida em que, por sua natureza, verdadeiramente se revele - sempre em tese - apta a tutelar, de maneira tão completa quanto possível, a situação jurídica do requerente" (Ação declaratória e interêsse. In: Direito processual civil: ensaios e pareceres. Rio de Janeiro: Borsoi, 1971, p. 17, grifos do original). Essa aptidão de tutela potencial, o mais ampla quanto possível, de toda a situação jurídica dos contendores está também em compasso com a noção doutrinária de que o "interesse de agir é fruto da utilidade potencial da jurisdição, tanto para o autor quanto para o Estado" (FREIRE, Rodrigo da Cunha Lima. Op. cit., p. 167).
} 
Sob o aspecto da legitimidade ad causam, parece correto inserir tanto o litisconsorte primário quanto o subsidiário no campo daqueles sujeitos que experimentarão a incidência direta do comando da sentença, uma vez que a situação litigiosa lamentada na petição inicial a eles tem imediata referência. Apesar de a esfera de um colitigante ser examinada apenas na hipótese de rejeição do pleito relacionado a outro litisconsorte (presente aí o vínculo de subsidiariedade), o fato é que o nascedouro da posição jurídica de ambos está conotado com a mesma relação jurídica de direito material afirmada na petição inicial $^{786}$.

No âmbito da responsabilidade civil do incapaz, por exemplo, as discussões fáticas e/ou jurídicas que envolvem o tema ${ }^{787}$, se agitadas à luz de um caso concreto descrito coerentemente na petição inicial, resultam na constatação de que o objeto do litígio tem sua projeção subjetiva e processual sobre os litisconsortes primário e subsidiário.

Nos casos em que, segundo os ditames do direito material, o reconhecimento da responsabilidade civil de um sujeito exclui a responsabilidade de outro, fica patente que o objeto litigioso do processo (pedido, entendido à luz da respectiva causa de pedir) constitui-se também da própria discussão sobre quem seja o efetivo responsável civil, em ordem a se concluir pela legitimidade ad causam de ambos, ainda que o autor realize um escalonamento de preferência entre os possíveis responsáveis.

Em outras palavras, presente a dúvida sobre a exata configuração subjetiva da relação material em debate, tem-se que antes da eliminação dessa dúvida - por meio do exame do mérito da causa - os litisconsortes primário e subsidiário ostentam a qualidade jurídica resultante da situação legitimante que os habilita a figurar como autores ou réus em determinada demanda.

As mesmas palavras utilizadas para o enfrentamento da matéria pertinente ao juízo de admissibilidade, pelo enfoque das condições da ação, do litisconsórcio eventual servem para justificar semelhante postura no que toca ao litisconsórcio alternativo.

\footnotetext{
${ }^{786}$ Assim como a denunciação da lide pelo autor implica uma ampliação do objeto litigioso do processo (DINAMARCO, Cândido Rangel. Intervenção de terceiros, cit., $\mathrm{n}^{\circ}$ 86, p. 167), no litisconsórcio eventual patenteia-se mesmíssima realidade. Então, dada a referibilidade do objeto litigioso do processo àquele determinado sujeito (litisconsorte subsidiário), dúvida não pode haver quanto a sua efetiva legitimidade $a d$ causam.

${ }^{787}$ Cfr. Cap. III, Parte II, nº 17.
} 
Com efeito, a dúvida objetivamente aferível que ronda os aspectos subjetivos de uma concreta relação de direito material litigiosa, cuja solução só se alcança mediante atividade jurisdicional, infunde a crença de que a construção de litisconsórcio em tom de alternatividade não esbarra na noção de interesse de agir. A necessidade da via jurisdicional resulta da imperiosa exigência, adveniente dos próprios contornos da relação substancial, de que seja superado aquele flanco de dúvida sobre se o direito material pertine a este ou àquele sujeito.

Presente esse estado de coisas, afigura-se coerente ponderar que a análise dos elementos do plano substancial, em cognição superficial e tal como concretamente afirmados na petição inicial, revelarão a "pertinência subjetiva da ação" no que toca aos litisconsortes alternativos.

Muito embora antecipando algumas conclusões que serão justificadas mais adiante, tem-se que, no plano da ação, os litisconsortes alternativos são todos legitimados (ativa ou passivamente), visto que a dúvida sobre os aspectos subjetivos da relação litigiosa refere-se à posição jurídica deles (litisconsortes). Daí que, in status assertionis, a situação legitimante adveniente dos aspectos do plano material, apreciados em cognição não exauriente, autoriza o exercício regular da ação pelos ou em face dos litisconsortes alternativos $^{788}$. Já a elucidação ou definição da real compostura subjetiva dessa relação de direito material, mediante a eliminação daquela dúvida pertinente aos fatos ou a aspectos jurídicos, será abarcada pelo exame do mérito da causa.

Por isso é que a formação de litisconsórcio alternativo não implica a admissão de que, ao menos em relação a um dos colitigantes, haveria ausência de legitimidade $a d$ causam, reconhecida antecipadamente pelo próprio teor da petição inicial.

Sob a angulação do litisconsórcio sucessivo, cuja sustentação repousa sobre a ideia de prejudicialidade, percebe-se que o interesse de agir resulta do vínculo, mais ou menos intenso, que conota a situação dos litisconsortes, a ponto de a decisão pertinente a um sujeito influenciar o conteúdo da decisão relativa a outro. Esse liame faz com que se reconheça a conexão entre as situações dos litisconsortes sucessivos, de molde a ensejar

\footnotetext{
${ }^{788}$ Nesse sentido é que se admite a propositura de consignação em pagamento em tom de alternatividade subjetiva, nos casos em que a situação de direito material faça transparecer dúvida sobre a pessoa do efetivo credor (CPC, art. 895), sem que isso implique aceitação apriorística de que em relação a um dos litisconsortes incida a mácula da ilegitimidade passiva ad causam.
} 
unidade de convencimento, derivado de uma única experiência instrutória, e a desaguar num só pronunciamento judicial sobre a integralidade do litígio que a todos envolve.

Semelhantemente, a possibilidade de relações que se vinculem por prejudicialidade serem atreladas a sujeitos diversos faz com que se atribua a tais sujeitos a legitimidade para figurar como partes na demanda em que se discutam aquelas relações, desde que afirmada a influência que a decisão sobre uma relação exerce sobre o teor da outra. Tendo em vista que tanto a relação prejudicial quanto a prejudicada compõem o objeto litigioso do processo, a vinculação dessas relações a sujeitos diversos autoriza a sustentação de que os litisconsortes sucessivos ostentam legitimidade ad causam.

Convém registrar, ainda em tema de litisconsórcio sucessivo, que "a existência e o tratamento processual da prejudicialidade independem da efetiva existência das relações

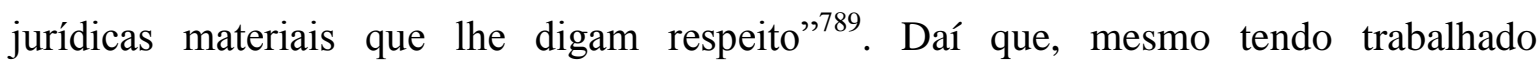
processualmente com os reflexos da afirmada prejudicialidade, será possível que ao final o julgador se convença no sentido da inexistência daquelas relações materiais.

Sob o influxo dessas ideias pode-se conceber a construção de litisconsórcio sucessivo mesmo que, ao final, se delineiem inexistentes as relações jurídicas que deram margem à eclosão da prejudicialidade. "Em tais hipóteses, é visível que, embora as relações materiais inexistissem como realidades, a prejudicialidade existiu como fenômeno processual e produziu efeitos processuais específicos" ${ }^{\text {790 }}$.

Noutra perspectiva, embora pareça até intuitivo, convém, mesmo assim, averbar que as modalidades litisconsorciais eventual, alternativa e sucessiva não se mostram incompatíveis com o regime da legitimidade extraordinária. Nada obsta, por exemplo, que o litisconsórcio eventual abrigue em seu âmbito situação em que o colitigante subsidiário compareça em nome próprio, mas na defesa de direito alheio, desde que assim consinta a lei.

Seja como for, impende renovar, coerentemente com o que já se expôs alhures, que o exame das condições da ação, para fins de construção concreta de casos de litisconsórcio eventual, alternativo ou sucessivo, deve levar em conta as nuanças advindas da relação de

\footnotetext{
${ }^{789}$ LEITE, Clarisse Frechiani Lara. Op. cit., $\mathrm{n}^{\mathrm{o}}$ 10, p. 58.

${ }^{790}$ Id., ibid. No mesmo sentido: SCARANCE FERNANDES, Antonio (op. cit., p. 28).
} 
direito material afirmada na petição inicial ${ }^{791}$, todas analisadas mediante cognição superficial, dando-se ênfase aos aspectos da dúvida objetivamente aferível, no litisconsórcio eventual e no alternativo, e da prejudicialidade no litisconsórcio sucessivo.

(i) dúvida objetiva e prejudicialidade: como demonstrar?

Já se pôde perceber que, segundo a orientação adotada no decorrer de toda a exposição, a pedra de toque da admissibilidade da demanda em que se pretenda formar litisconsórcio eventual ou litisconsórcio alternativo traduz-se na noção de dúvida objetiva, ou, com mais precisão terminológica, dúvida objetivamente aferível. De sua parte, o litisconsórcio sucessivo encontra sua raiz de sustentação na ideia de prejudicialidade.

Apesar de assentadas tais premissas, ainda se faz necessário repercutir sobre a maneira como a parte se desincumbe do ônus de demonstrar a presença daqueles elementos que vão animar o reconhecimento da regularidade de formação dessas modalidades litisconsorciais.

Por simples comodidade para exposição, principia-se a análise pela angulação do litisconsórcio sucessivo atrelado à noção de prejudicialidade.

A partir das ideias já expostas anteriormente sobre o significado de prejudicialidade $^{792}$, pode-se afirmar coerentemente que a narrativa exteriorizada na petição inicial contemplando uma situação concreta vinculada a outra do ponto de vista lógicojurídico, sendo uma dessas situações capaz, ao menos em tese, de influenciar a compostura jurídica da outra situação, bastará para demonstrar o nexo de prejudicialidade. Em outras palavras, a aferição da presença da prejudicialidade faz-se in status assertionis.

Então, uma vez traduzidas na petição inicial as relações jurídicas (prejudicial e prejudicada) concernentes a sujeitos diversos, aberto estará o espaço para se trabalhar com a modalidade sucessiva de litisconsórcio. Bem é de ver que tal situação, uma vez delineada nos autos, servirá não só para balizar a própria formação do litisconsórcio sucessivo como

\footnotetext{
${ }^{791}$ Mais adiante será discutida a possibilidade de formação dessas modalidades litisconsorciais no âmbito de reconvenção. Por ora, convém trabalhar apenas com a situação mais comum, consistente na formação de litisconsórcio por obra do que se contém na petição inicial.

${ }^{792}$ Cfr. Cap. II, Parte II, n 12.
} 
também para evidenciar a legitimidade ativa ou passiva dos colitigantes. Daí que, ainda uma vez, é preciso apelar para a noção de cognição superficial (não exauriente) para bem entender e encaminhar a solução do problema de que ora se cogita. Será de todo inadequada, em sede de juízo de admissibilidade da demanda deduzida em litisconsórcio sucessivo, uma verificação aprofundada do caso a ponto de se perquirir quanto à efetiva existência ou não das relações jurídicas afirmadamente relacionados por prejudicialidade.

De outra parte, no campo do litisconsórcio eventual e do alternativo o critério fixado como mola propulsora de sua admissibilidade radicado está no elemento dúvida objetivamente aferível. Cabe relembrar, apenas de passagem, que o estado de hesitação exigido pode residir tanto em questões fáticas quanto em embates jurídicos ${ }^{793}$.

No aspecto fático, do qual podem decorrer dúvidas sobre a configuração subjetiva de dada relação de direito material a ser discutida no processo, tem-se que a admissibilidade do litisconsórcio eventual ou do alternativo prescinde de um exame mais aprofundado sobre a conformação fática da demanda. Admite-se, com efeito, que a situação concretamente narrada na petição inicial seja apta a demonstrar que os fatos ainda não totalmente conhecidos geram perplexidades na exata compostura subjetiva da relação de direito material que se vai discutir no processo, de molde a possibilitar, nessas condições, a veiculação de pedido(s) relacionado(s) a sujeitos diversos, solicitando-se o acolhimento de um para a hipótese de não poder ser acolhido o outro (litisconsórcio eventual), ou, noutra configuração, acolhendo-se um ou outro dos pedidos relacionados aos sujeitos distintos (litisconsórcio alternativo).

Quando se pensa na desconsideração da personalidade jurídica bem se nota que a perplexidade sobre a presença dos fatores que autorizam a aplicação da disregard doctrine, imbricados com questões fáticas, vai desaguar na necessidade de que em juízo se produza a prova, v. g., sobre uma afirmada confusão patrimonial. Então, a partir de dados concretos afirmados pela parte e analisados in status assertionis será possível entrever um estado de dúvida que só se debela mediante instrução em juízo.

\footnotetext{
${ }^{793}$ Não se quer com isso dizer que tais aspectos devam ser analisados ou devam aparecer nitidamente em separado, como se fato e direito fossem elementos compartimentados de modo estanque. É possível, pois, que de uma complexidade fática, envolta em dúvidas não supríveis pela atuação pura e simples dos litigantes, o panorama jurídico também se delineie dúbio, exatamente em razão daquela conformação fática titubeante. Portanto, não é preciso, para fins de demonstração da admissibilidade da demanda em litisconsórcio eventual ou alternativo, isolar completamente o que seja fato e o que seja direito.
} 
A celeuma adveniente de uma possível paternidade sócio-afetiva, afirmada com base em dados concretos do cotidiano dos envolvidos, mas não cabalmente delineada, pode trazer notáveis consequências no campo da responsabilidade civil dos pais pelos atos dos filhos ${ }^{794}$. Realmente, os fatos ainda não completamente delineados acerca da paternidade sócio-afetiva, se comprovados durante a instrução, farão com que se afaste a responsabilidade civil do pai que figura no assento de nascimento do filho.

Imagine-se a hipótese em que o autor duvide, com base em elementos objetivos (o comportamento de um dos possíveis réus, por exemplo), sobre a eficácia de uma assunção de dívida, tomando-se por base uma provável insolvência do assuntor, existente já ao tempo da assunção e ignorada pelo credor, apta a fazer com que, em tese, persista a obrigação do devedor primitivo, ex vi do art. 299, do Código Civil ${ }^{795}$. A conformação fática dessa específica relação negocial, porquanto envolta em ambiente de dúvida objetivamente aferível sobre a responsabilidade do terceiro assuntor e a do devedor originário, possibilita que o sedizente credor litigue contra o assuntor e também contra o primitivo devedor, não para que ambos sejam condenados a lhe pagar a dívida, mas para que um ou outro o seja (litisconsórcio alternativo).

Essa exemplificação denuncia que, do ponto de vista da admissibilidade da demanda em litisconsórcio alternativo ou eventual, não se pode exigir mais que a afirmação do autor quanto à presença do estado de dúvida que se extrai de elementos objetivamente colocados à apreciação do julgador e analisados superficialmente, mediante cognição rasteira.

Quando a dúvida, em vez da conformação fática, advém da compostura jurídica do tema que se vai debater em juízo, o problema acaba ganhando outras cores. Com efeito, as chamadas zonas de penumbra criadas no seio do próprio sistema jurídico indicam que, para um único caso, apresentam-se mais de uma solução possível, tudo a depender da postura interpretativa pela qual se incline na solução de dado problema jurídico.

Começando por uma abordagem bem superficial, tem-se que a quantidade assustadora de leis federais e também, nalguns casos, de medidas provisórias contribui significativamente para o surgimento de celeumas que podem desaguar em diversidade de

\footnotetext{
${ }^{794}$ Tal situação foi exposta no Cap. III, Parte II, no 18.

795 "É facultado a terceiro assumir a obrigação do devedor, com o consentimento expresso do credor, ficando exonerado o devedor primitivo, salvo se aquele, ao tempo da assunção, era insolvente e o credor o ignorava". Para aprofundamentos sobre o tema, cfr. Cap. III, Parte II, nº 24.
} 
configuração subjetiva de relações jurídicas ${ }^{796}$. Ou seja, as discrepâncias encontradas na própria legislação vão animar a existência de dúvidas sobre se este ou aquele sujeito responde ou pode ser afetado por determinada consequência jurídico-material.

É bem possível, todavia, que a utilização dos critérios de superação das antinomias seja apta a resolver, sem grandes complicações, os antagonismos encontrados nos textos normativos. Adotando-se, então, os critérios da cronologia, da especialidade e da hierarquia chega-se, possivelmente, a uma compreensão sobre qual deva ser a norma aplicada, afastando-se, pois, aquele estado de dúvida animador do litisconsórcio eventual e do alternativo.

Mas, em contrapartida, também não se pode descartar que a utilização daqueles critérios seja insuficiente para suplantar a incongruência, já que não se mostra tão linear o caminho que leva à aplicação de um daqueles critérios em detrimento do outro. E mais, a abertura do sistema jurídico para a contemplação das chamadas cláusulas gerais e de textos dotados de vagueza semântica, a ser preenchida pela atuação do julgador ${ }^{797}$, contribui para a suposição de que, em certos casos, a própria lei isoladamente considerada abrigará ambiente para disceptações, em ordem a se demonstrar o cabimento do litisconsórcio eventual ou do alternativo.

Seja como for, o que se quer evidenciar é que a demonstração da dúvida aferível objetivamente a partir da conformação dos textos legislativos, encarada aqui como requisito de admissibilidade do litisconsórcio eventual e do litisconsórcio alternativo, não enseja grandes especulações. Bastará à parte trazer ao conhecimento do julgador a existência de normas contemporaneamente em vigor e capazes de gerar soluções díspares em torno da submissão deste ou daquele sujeito aos influxos da relação substancial que se quer fazer valer em juízo.

\footnotetext{
796 Em estudo recente, RICARDO LEONEL enfatiza: "Não se pode negar que atualmente, o grau de insegurança jurídica alcança patamares anteriormente não observados. No ordenamento jurídico contemporâneo, a complexidade, a obscuridade, e por vezes a incerteza, bem como dificuldade de determinação das diretrizes concretas das normas positivadas, são problemas recorrentes. Isto está associado com aquilo que pode ser apontado como um fenômeno de verdadeira 'inflação legislativa', ou ainda, se preferirmos, excessiva, desorganizada, e muitas vezes desnecessária profusão normativa" [Reclamação constitucional, Tese (livre-docência), São Paulo: USP, 2010, nº 6, nota 1, p. 61].

${ }^{797}$ Sobre esse particular aspecto, cfr. ARRUDA ALVIM (Argüição de relevância no recurso extraordinário, cit., $\left.\mathrm{n}^{\circ} 11, \mathrm{p} .14-15\right)$ e ARRUDA ALVIM WAMBIER, Teresa (Recurso especial, recurso extraordinário e ação rescisória, cit., Cap. II, p. 99 et seq.).
} 
Evidente que o problema tornar-se-á mais sintomático caso a celeuma agitada pela parte encontre ressonância na doutrina e/ou na jurisprudência!

Na perspectiva das divergências doutrinárias, propõe-se que a demonstração da dúvida objetiva consista na apresentação de opiniões conflitantes e fundamentadas de autores que sejam contemporâneos, isto é, que tenham lançado seus escritos num mesmo ambiente político, social, econômico e, sobretudo, jurídico. Para ficar num exemplo emblemático, não se poderia cogitar de uma comparação, para fins de demonstração de dúvida objetiva, entre o que escreveu PONTES DE MIRANDA ${ }^{798}$ e o que acaba de escrever JOSÉ FERNANDO SIMÃO ${ }^{799}$ em torno da responsabilidade civil de incapazes.

A realidade tem demonstrado que a vertiginosa sucessão de leis pode muito facilmente transformar uma belíssima obra doutrinária em peça decorativa de biblioteca, circunstância que haverá de ser levada em conta na análise da contemporaneidade dos escritos doutrinários por meio dos quais se pretenda delinear a dúvida objetiva.

No pertinente às divergências jurisprudenciais ${ }^{800}$, o encaminhamento da questão relativa ao método de demonstração da dúvida objetiva conta com o referencial aproveitável que se extrai de mecanismos já existentes no sistema processual em vigor. Está-se a referir ao recurso especial fundado na alínea "c" do inciso III do art. 105, da Constituição da República, e também ao incidente de uniformização de jurisprudência previsto no art. 476 , do CPC.

Para a hipótese de recurso especial lastreado na alegação de divergência jurisprudencial, o legislador infraconstitucional traz regulamentação específica quanto ao método de demonstração do dissídio pretoriano, nos seguintes termos: "Quando o recurso fundar-se em dissídio jurisprudencial, o recorrente fará a prova da divergência mediante certidão, cópia autenticada ou pela citação do repositório de jurisprudência, oficial ou credenciada, inclusive em mídia eletrônica, em que tiver sido publicada a decisão

\footnotetext{
${ }^{798}$ Tratado de direito privado, cit., t. LIII, § 5.498, nº 6, p. 21-23.

${ }^{799}$ Responsabilidade civil do incapaz, cit., passim.

${ }^{800}$ Embora seja uma realidade incontrastável que o nosso sistema tenda, cada vez mais, para a valorização dos precedentes, não resta dúvida de que o caminho que vai do surgimento de uma celeuma interpretativa até a edição de súmulas de jurisprudência ou mesmo da formação de "jurisprudência dominante" não é tão curto. Daí que, entre esses dois termos, as disceptações interpretativas podem render ensejo à formação dos tipos litisconsorciais aqui estudados, sem que isso implique negação àquela tendência de se buscar, tanto quanto possível, a segurança jurídica por meio da consolidação de entendimentos jurisprudenciais.
} 
divergente, ou ainda pela reprodução de julgado disponível na internet, com indicação da respectiva fonte, mencionando as circunstâncias que identifiquem ou assemelhem os casos confrontados" $" 801$.

Na perspectiva do incidente de uniformização de jurisprudência, bem é de ver que a parte poderá, ao arrazoar o recurso ou em petição avulsa, requerer, fundamentadamente, que o julgamento obedeça à disciplina contida na cabeça do art. 476, do CPC, ou seja, que o tribunal se pronuncie previamente acerca da interpretação do direito quando haja, a seu respeito, divergência (inc. I do citado artigo). Tal divergência pode se materializar, como diz a lei, quando "no julgamento recorrido a interpretação for diversa da que lhe haja dado outra turma, câmara, grupo de câmaras ou câmaras cíveis reunidas” (inc. II do art. 476) ${ }^{802}$.

Chama a atenção o fato de o legislador exigir, coerentemente, que a parte, ao requerer a instauração do incidente de uniformização da jurisprudência intra muros ${ }^{803}$, o faça fundamentadamente. Daí que, seja nas razões, nas contrarrazões, ou seja em petição avulsa, a parte carrega consigo o ônus de demonstrar a divergência, isto é, a "existência de julgado(s) de outro órgão fracionário, em que a interpretação dada a alguma regra jurídica relevante para a apreciação da espécie tenha sido diversa da que lhe deu a decisão recorrida" ${ }^{, 04}$.

À falta de disciplina legal específica, a doutrina orienta-se no sentido de que a "prova da divergência pode ser feita por certidão do(s) julgado(s) que a parte invoca, ou pela indicação do número e da página de repositório de jurisprudência que o(s) tenha publicado" ${ }^{, 805}$.

${ }^{801}$ Art. 541, p. único, do CPC, com a redação dada pela Lei n ${ }^{\circ} 11.341$, de 7.8.2006. O Regimento Interno do Superior Tribunal de Justiça também trata desse assunto no art. 255 , $\S \S 1^{\circ} \mathrm{e} 2^{\circ}$.

${ }^{802}$ Embora o legislador se valha de dois incisos para tratar da divergência jurisprudencial, convém lembrar, com BARBOSA MOREIRA, que o "círculo de incidência do inciso I é maior que o do inciso II" (Comentários ao Código de Processo Civil, cit., vol. V, $\mathrm{n}^{\circ}$ 8, p. 12), de sorte que, para o autor, seria dispensável a letra do inciso II. Entendendo, porém, que as hipóteses têm campo de atuação diversa, cfr. VIGLIAR, José Marcelo Menezes (In: MARCATO, Antonio Carlos (coord.). Código de Processo Civil interpretado. 3. ed. São Paulo: Atlas, 2008, p. 1635).

${ }^{803}$ A expressão é de BARBOSA MOREIRA, a significar que o dissídio relevante, na espécie, "é unicamente o que oponha julgados de órgãos do mesmo tribunal" (Comentários ao Código de Processo Civil. cit., nº 8, p. 13 - grifos do original).

${ }^{804}$ BARBOSA MOREIRA, José Carlos. Comentários ao Código de Processo Civil, cit., n 11, p. 17. ${ }^{805}$ Id., ibid. 
Tomando-se por empréstimo esses referenciais, parece aconselhável, por medida de prudência, que a parte interessada na formação de litisconsórcio eventual ou alternativo, mediante arguição de dúvida extraível de manifestações pretorianas, traga com seu arrazoado elementos comprobatórios da divergência compatíveis com aqueles exigidos para fins de admissibilidade do recurso especial fundado em divergência jurisprudencial ou para fins de fundamentação do requerimento de instauração do incidente de uniformização de jurisprudência.

Não se quer com isso dizer que seja exigível, para fins de formação de litisconsórcio nas modalidades aqui estudadas, a adoção da mesma técnica prevista para o recurso especial e para a uniformização de jurisprudência em tema de "prova da divergência". A ideia aqui proposta tende, pura e simplesmente, a conferir mais segurança na veiculação de argumentos necessários à configuração da dúvida objetiva que dá azo ao litisconsórcio eventual e ao alternativo.

Deve-se sublinhar, por fim, que as manifestações jurisprudenciais em contraste, viabilizadoras da deflagração da dúvida de que se cogita, hão de ser contemporâneas, em ordem a se concluir que uma delas não poderá representar orientação superada no âmbito da jurisprudência. Dito de outro modo, impõe-se que a discussão pretoriana não tenha sido ainda suplantada por alguma manifestação representativa de um provável "ponto final", como se daria na hipótese de haver uma orientação já sumulada ou sufragada no âmbito dos chamados "recursos repetitivos" (CPC, arts. 543-B e 543-C).

Ainda nesse aspecto, há que se dizer que o só fato de uma manifestação jurisprudencial apresentar-se como antiga não lhe retira a aptidão para configurar a divergência $^{806}$ que, em comparação com outro(s) julgado(s) recente(s), fomenta a admissibilidade do litisconsórcio eventual e do alternativo.

\footnotetext{
${ }^{806}$ Embora se referindo ao recurso especial, abalizada doutrina confere ótimo referencial que se pode adotar também aqui no estudo do litisconsórcio: "Não se trata de problema ligado à antigüidade da decisão. Esta pode ter sido proferida há muitos anos e será adequada para o confronto se se referir ao mesmo texto legal. $\mathrm{O}$ que não se admite é a utilização de jurisprudência ultrapassada, quando o tema já foi interpretado de maneira diferente no próprio Tribunal, no Supremo Tribunal Federal ou no Superior Tribunal de Justiça" (GRECO FILHO, Vicente. Direito processual civil brasileiro. 16. ed. São Paulo: Saraiva, 2003, vol. 2, p. 338). No mesmo sentido, cfr. MANCUSO, Rodolfo de Camargo (Recurso extraordinário e recurso especial, cit., p. 335-336).
} 
(ii) litisconsórcio ulterior e estabilização da demanda

Ainda do ponto de vista da admissibilidade da demanda, seria de se indagar sobre a viabilidade de construção das modalidades litisconsorciais aqui estudadas já no curso do procedimento e até mesmo depois de superado o momento da estabilização da demanda (CPC, art. 264, caput).

Nessa proposta de discussão é preciso distinguir duas hipóteses: (a) formação de litisconsórcio ulterior (eventual, alternativo ou sucessivo) na fase anterior à estabilização da demanda, ou seja, até a realização da citação; (b) formação de litisconsórcio (eventual, alternativo ou sucessivo) após a fase de estabilização da demanda, compreendendo-se todas as etapas posteriores à citação, com enfoque especial para as fases de saneamento e de instrução.

Quanto à primeira hipótese mencionada no parágrafo anterior, transparece mais tranquila a aceitação de que a inclusão de litisconsortes passivos, em momento ulterior ao da propositura da demanda, compatibiliza-se com o ordenamento processual em vigor. Então, numa atitude que poderia redundar numa singela emenda ou complementação da petição inicial, o autor poderia fazer incluir no polo passivo um ou mais litisconsorte eventual, alternativo ou sucessivo.

Para ficar numa exemplificação extraída da legislação em vigor, a hipótese que se vem de mencionar seria assimilável à denunciação da lide, pelo autor, manejada depois da propositura da demanda, mas desde que antes da citação. Segundo a construção adotada neste trabalho, a situação indicada retrataria litisconsórcio passivo eventual ulterior.

Não tão tranquila, de outra parte, configura a admissão de litisconsórcio ativo ulterior. Todavia, a despeito das discussões e da firme posição jurisprudencial ${ }^{807}$ em senso contrário ao que se sustenta neste trabalho, crê-se ter ficado demonstrado, na oportunidade própria $^{808}$, que o sistema processual em vigor no Brasil não pode ser refratário à noção de litisconsórcio ativo ulterior.

\footnotetext{
${ }^{807}$ Cfr. anotação de NEGRÃO; Theotonio; GOUVÊA, José Roberto F.; BONDIOLI, Luis Guilherme A. (op. cit., nota 1 ao art. 46 do CPC, p. 172).

${ }^{808}$ Cfr. Parte I, Cap. Único, no 6.
} 
A par dos argumentos já expostos anteriormente, fixa-se o pensamento exclusivamente na dicção do art. 253, II, do CPC, segundo o qual se distribuirão por dependência as causas de qualquer natureza quando, tendo sido extinto o processo, sem julgamento de mérito, for reiterado o pedido, ainda que em litisconsórcio com outros autores ou que sejam parcialmente alterados os réus da demanda.

É possível imaginar-se, sob a influência da regra citada, a hipótese em que determinado servidor promova demanda fundada em discussão que repercuta na esfera jurídica de outro(s) colega(s). Pois bem. Como a jurisprudência não admite o litisconsórcio ativo ulterior, abrir-se-ia a possibilidade de aquele autor - que propôs sua demanda isoladamente - desistir da ação (CPC, art. 267, VIII) e, no dia seguinte, agora litisconsorciado com outros demandantes, renovar aquela mesmíssima demanda. A pergunta que fica é: para qual juízo seria destinada essa "nova” demanda?

Sob os auspícios do citado art. 253, II, do CPC, não há dúvidas de que haveria uma distribuição por dependência, em razão da prevenção desencadeada por aquela demanda anterior, simplesmente renovada de modo subjetivamente ampliado. Essa regra contém disciplina de competência funcional e, portanto, absoluta ${ }^{809}$.

Ora, se isso é possível, desejado e exigido pelo legislador, precisamente em obséquio aos princípios da isonomia e do juiz natural ${ }^{810}$, por qual motivo não se deveria admitir, naquela ação primitiva, a inclusão de litisconsortes ativos ulteriores? Parece não haver argumento válido que ampare a insistente postura jurisprudencial que vê no litisconsórcio ativo ulterior algum maltrato ao postulado do juiz natural ${ }^{811}$.

Sendo assim, em nada surpreende a afirmação segundo a qual, mesmo depois da propositura da demanda, o autor pode se juntar a terceiro(s) para litigar em tom de eventualidade, alternatividade ou sucessividade litisconsorcial. Em outras palavras, não há motivos para se rejeitar as modalidades litisconsorciais eventual, alternativa e sucessiva quando construídas ulteriormente, inclusive no polo ativo.

\footnotetext{
${ }^{809}$ DINAMARCO, Cândido Rangel. A reforma da reforma, cit., nº 32, p. 74-75.

${ }^{810}$ WAMBIER, Luiz Rodrigues; ALVIM WAMBIER, Teresa Arruda; MEDINA, José Miguel Garcia. Breves comentários à nova sistemática processual civil, cit., $\mathrm{n}^{\circ} 2$, p. 47 . Também com referência expressa a que o texto do CPC tende a concretizar o princípio do juiz natural, cfr. SCARPINELLA BUENO, Cassio (A nova etapa da reforma do Código de Processo Civil, cit., vol. 2, p. 101 et seq.).

${ }^{811}$ Nesse sentido, SCARPINELLA BUENO, Cassio (Partes e terceiros no processo civil brasileiro, cit., p. 146).
} 
Evidente que, admitidas essas hipóteses de litisconsórcio ulterior, incumbirá ao(s) autor(es) complementar as custas processuais daí decorrentes, consoante lhe(s) impõe o art. 294, do Código de Processo Civil.

Um pouco mais delicada transparece a discussão pertinente à formação de litisconsórcio ulterior - eventual, alternativo ou sucessivo - após a fase de estabilização da demanda.

Dúvidas não pairam sobre a utilidade sistemática das regras que disciplinam a chamada estabilização da demanda, destinadas que são a evitar contramarchas indevidas no iter procedimental e, sobretudo, a impedir que mutações nos elementos da demanda, por ato de quem exerce o direito de ação, comprometam o exercício pleno do contraditório pela parte adversa, na medida em que, de regra, a defesa concentra-se num só momento ou ato processual $^{812}$.

Tais regras estão intimamente relacionadas às noções de preclusão e de eventualidade. Implica dizer que a superação de uma determinada fase impede o retrocesso a etapas anteriores, seja pelo esgotamento do tempo em que se poderia exercitar alguma faculdade, seja pela adoção de um comportamento incompatível com o interesse de praticar determinado ato, ou, por fim, seja pela consumação do exercício da faculdade por certos meios, inviabilizando-se, assim, a adoção de outros meios diversos daquele já escolhido. Em linhas bem singelas, o que se acaba de dizer representa a noção de preclusão $^{813}$. O que se deve pôr em relevo, além disso, é que a preclusão gera a consolidação de situações jurídicas numa tendência de incentivo ao avanço da marcha procedimental rumo ao seu ponto culminante ${ }^{814}$.

Aliado a isso, como já se pôde entrever, a regra da eventualidade impõe que as deduções das partes e também suas atividades probatórias verifiquem-se dentro de balizas

${ }^{812}$ Segundo averba CRUZ E TUCCI: "Diferentemente de outras legislações, em especial a alemã e a italiana, nas quais sempre predominou a liberdade das partes na apresentação de suas respectivas alegações, é da tradição do processo brasileiro a adoção da regra da eventualidade, impondo aos demandantes o dever de propor, em um mesmo momento, todos os meios de ataque e de defesa" ( $A$ causa petendi no processo civil, cit., p. 158).

${ }^{813}$ Para aprofundamentos, consulte-se SICA, Heitor V. M. (Preclusão processual civil. 16. ed. São Paulo: Saraiva, 2003, passim).

${ }^{814}$ LEONEL, Ricardo de Barros. Causa de pedir e pedido: o direito superveniente, cit., p. 120. O citado autor aplaude a "afirmação de que é fundamental a adoção do sistema de preclusões, sem o qual nenhum processo chegaria a seu fim" (id., p. 125). 
temporais e de etapas bem delineadas pela legislação, sob pena de, assim não ocorrendo, não se poder mais lançar mão da correlativa faculdade. Interessante notar que tal exigência concretiza o escopo de se "evitar no processo a desordem, a insegurança e a deslealdade na conduta dos litigantes, conferindo-se ainda igualdade de tratamento a eles com relação aos debates $" 815$.

Vem da doutrina a advertência de que a adoção de rígidas fórmulas de preclusão e de eventualidade contribui sim para a celeridade processual, mas não pode ficar no olvido a circunstância de que essa rigidez pode redundar em obstáculos ao atingimento de resultados processuais mais justos, em termos finais e concretos ${ }^{816}$. Então, se é verdade que o sistema de preclusões propende para a agilidade e ainda evita posturas dilatórias e desleais das partes, não menos correta é a percepção de que isso "pode dificultar a solução da crise verificada no direito material (relação jurídica controversa) em uma única demanda" ${ }^{, 817}$.

Ao se falar em "única demanda", no âmbito da qual se poderia resolver definitivamente o litígio em sua maior amplitude possível, logo vêm à memória os enunciados respeitantes ao princípio da razoável duração dos processos em geral, tal como explicitados anteriormente ${ }^{818}$. As premissas lançadas alhures permitem que agora se possa avançar e considerar que o objetivo de se alcançar a economia processual, em vez de ser encarado como pura técnica processual, passa a ter status de direito fundamental à razoável duração do processo (CF, art. $5^{\circ}$, LXXVIII), numa demonstração de que houve uma transposição do campo da técnica para o campo de um postulado político-constitucional merecedor de pronta concretização ${ }^{819}$.

Daí se poder concluir que o nosso sistema propende para a imutabilidade dos elementos objetivos e subjetivos da demanda, depois de superada certa fase procedimental. Mas isso não impede uma construção que, nalguns casos específicos, suplante essa rigidez

\footnotetext{
${ }^{815}$ LEONEL, Ricardo de Barros. Causa de pedir e pedido: o direito superveniente, cit., p. 121.

${ }^{816}$ ALVARO DE OLIVEIRA, Carlos Alberto. Do formalismo no processo civil, cit., p. 205. Nas palavras do autor, "[a] concentração dos atos processuais, decorrente da aplicação da regra da eventualidade, representa ao mesmo tempo garantia e obstáculo a um processo justo, adequado a refletir da melhor maneira possível a situação jurídica fora do processo" (id., ibid.).

${ }^{817}$ LEONEL, Ricardo de Barros. Causa de pedir e pedido: o direito superveniente, cit., p. 123.

${ }^{818}$ Cfr. Cap. I, Parte II, $\mathrm{n}^{\mathrm{o}} 10$.

${ }^{819}$ Nesse sentido, CRUZ E TUCCI, José Rogério (A causa petendi no processo civil, cit., p. 188).
} 
e autorize modulações naqueles elementos, de molde a concretizar, com mais vigor, o postulado da razoável duração dos processos em geral. Isso porque a maior delonga para conclusão do processo em que ocorra essa possível mutação "vem compensada pela eliminação prévia de ulterior e desnecessária demanda" ${ }^{\text {820 }}$.

Bem é de ver, portanto, que o binômio preclusão-eventualidade há de ser considerado como técnica processual ${ }^{821}$. E a técnica no processo tem valor na medida em que atinge as finalidades para as quais fora programada ${ }^{822}$. Donde exsurge a correta observação de que aludido binômio não ostenta caráter absoluto, devendo ser entendido e aplicado "em função de suas finalidades" ${ }^{\prime 23}$, lembrando-se, ademais, que os valores segurança e celeridade não são os únicos a orbitar na esfera processual, de vez que a noção de efetividade do processo e da jurisdição abarca também o valor "justiça das decisões" 824 ,

${ }^{820}$ CRUZ E TUCCI, José Rogério. A causa petendi no processo civil, cit., p. 190. DANIEL MITIDIERO também apregoa a flexibilização da regra que impede a modificação dos elementos objetivos da demanda em fase posterior ao saneamento, mas, para tanto, antevê a necessidade de reforma legislativa (Colaboração no processo civil: pressupostos sociais, lógicos e éticos. São Paulo: RT, 2009, p. 115-116).

821 “Como outros institutos ligados à técnica processual, a preclusão é simples mecanismo de que se vale o legislador, com a finalidade de melhor organizar o método por ele adotado para solucionar as crises verificadas no plano material. Não se justifica interpretar as regras instrumentais com rigor formal exagerado, de modo a comprometer o próprio resultado pretendido. Sempre que isso ocorrer, os meios transformam-se em óbices" (BEDAQUE, José Roberto dos Santos. Efetividade do processo e técnica processual, cit., p. 129).

${ }^{822}$ Para aprofundamentos, consulte-se a já referida tese de BEDAQUE, José Roberto dos Santos (Efetividade do processo e técnica processual, cit., passim).

${ }^{823}$ LEONEL, Ricardo de Barros. Causa de pedir e pedido, cit., p. 128. Veja-se que tal tendência chegou a ser encampada pela Comissão de Juristas que elaborou o Projeto de novo Código de Processo Civil (PL do Senado no 166/2010), cujo art. 314 estava assim projetado: “O autor poderá, enquanto não proferida a sentença, aditar ou alterar o pedido e a causa de pedir, desde que o faça de boa-fé e que não importe em prejuízo ao réu, assegurado o contraditório mediante a possibilidade de manifestação deste no prazo mínimo de quinze dias, facultada a produção de prova suplementar”. O parágrafo único do artigo projetado estabeleceria que essa mesma diretriz seria aplicável ao pedido contraposto e à respectiva causa de pedir. Essa novidade foi aplaudida por MARINONI e MITIDIERO ( $O$ projeto do CPC: crítica e propostas. São Paulo: RT, 2010, p. 114-115). Porém, o Substitutivo do Projeto, tal como aprovado no Senado e enviado à Câmara dos Deputados (PLS nº 8.046/2010), não contemplou a regra acima transcrita.

${ }^{824}$ SICA, Heitor V. M. Preclusão processual civil, cit., p. 4. 
tudo a ensejar a busca por "uma concordância prática entre todos os valores que se encontram em jogo" 825 .

Forte nessas considerações, extraídas basicamente do arsenal doutrinário forjado em torno da relativização das regras pertinentes à estabilização objetiva da demanda, encoraja-se para dizer que a mesma postura interpretativa pode ser proveitosamente adotada no aspecto subjetivo. Em outros termos, parece haver ambiente também para a construção segundo a qual as modalidades litisconsorciais eventual, alternativa e sucessiva podem ser formadas em etapa posterior àquela designada como de estabilização da demanda.

Com efeito, a dúvida objetiva que anima o litisconsórcio eventual e o alternativo pode surgir a partir da defesa apresentada pelo réu, extraindo-se de suas alegações e também dos elementos de convicção aí aportados um estado de perplexidade significativo, incapaz de ser suplantado apenas pela argúcia da parte e do profissional que a representa em juízo.

Em caso concreto com que já se deparou no dia-a-dia do foro, determinada pessoa intentara pedido indenizatório em face de outrem, isto porque, segundo narrava a petição inicial, o advogado do réu enviara ao autor notificação extrajudicial de cunho depreciativo, circunstância que, ao aviso do demandante, gerava prejuízos morais de certa monta. Depois de citado, o réu formulou contestação e argumentou que, em verdade, não existiu qualquer ato de sua parte, já que a notificação, muito embora redigida como se fora em seu nome, havia sido fruto exclusivo da atuação do advogado, a quem o réu sequer havia outorgado mandato!

Tendo em vista que as alegações do réu, nesse caso, vieram acompanhadas de elementos aptos a conferir-lhe certa dose de verossimilhança, instalou-se séria dúvida sobre quem, do ponto de vista material, haveria de responder civilmente pela afirmada ofensa moral.

Alterando-se um pouco o exemplo, seria possível imaginar que o estado titubeante, pautado sempre em elementos objetivamente aferíveis, surgisse já no curso da instrução, depois de um depoimento pessoal ou da inquirição de certa testemunha.

${ }^{825}$ MITIDIERO, Daniel. Op. cit., p. 113. 
Diante desse cenário exemplificativo, não se vê motivo que impeça a inclusão, mesmo tardia, de um litisconsorte eventual ou alternativo (o advogado), com o intuito de que, mediante convicção única, seja solucionada de vez a relação de direito material que envolve essa multiplicidade de sujeitos, evitando-se, com esse proceder, a multiplicação de demandas e, ao mesmo tempo, garantindo-se a harmonia de julgamentos.

Essa mesma argumentação serve para os casos em que a dúvida objetiva radique no espectro ativo da configuração subjetiva da demanda. Em acréscimo, nada obsta a que semelhante postura seja adotada no campo da prejudicialidade conformadora do litisconsórcio sucessivo.

É claro que tal prática ensejaria uma temporária, mas diminuta, estagnação da marcha procedimental, já que seria necessária a citação de novo(s) réu(s) ou a abertura de oportunidade de manifestação do réu sobre a inclusão de novo(s) autor(es). Contudo, se considerados os prazos previstos no CPC para a prática desses atos ${ }^{826}$, evidencia-se mais vantajosa a mutação subjetiva incidental do que a necessidade da propositura de nova demanda. Ou seja, uma apoucada delonga no iter procedimental vem compensada pela desnecessidade de outra demanda e, de conseguinte, com a superação dos riscos que uma nova demanda enseja em termos de contradição de julgados.

Há que se relembrar, ainda uma vez, que essa investida do autor no sentido da ampliação subjetiva da demanda, seja no polo ativo ou no passivo, pode implicar desdobramentos financeiros, os quais serão suportados pelo interessado, na forma do art. 294, do CPC, aplicado por analogia.

Indagação interessante resulta da dicção do art. 264, caput, do CPC, consonante o qual as mutações objetivas operadas após a citação submetem-se à concordância do réu. Seria de se questionar, então, se as modificações subjetivas pretendidas pelo autor após a citação do réu submeter-se-iam à concordância deste.

Nessa perspectiva, dúvidas não podem pairar sobre a necessidade de oitiva do réu quanto à modificação subjetiva pretendida pelo autor. Mas isso não significa que o réu possa simplesmente discordar da ampliação subjetiva almejada. É preciso que tal manifestação seja sempre e sempre fundamentada, exatamente como ocorre em relação à

\footnotetext{
${ }^{826}$ É claro que a realidade estrutural deste ou daquele juízo implicará maior ou menor delonga, mas o fato é que a observância dos prazos previstos no CPC e nas normas que organizam o funcionamento dos cartórios judiciais autoriza a conclusão assentada no texto.
} 
manifestação do réu sobre a desistência da ação (CPC, art. $\left.267, \S 4^{\circ}\right)^{827}$. De modo que a discordância pura e simples não se erigirá como óbice à ampliação subjetiva da demanda em termos de eventualidade, alternatividade e sucessividade.

À falta de uma normatividade específica, o réu pode, no afã de sustentar sua posição restritiva à ampliação pretendida pelo autor, trabalhar com as noções inscritas no art. 46, p. único, do Código de Processo Civil. Ou seja, propõe-se que o réu demonstre a inviabilidade da ampliação subjetiva mediante argumentos que revelem a desvantagem da ampliação, seja pelo exagerado comprometimento da rápida solução do litígio, seja pela significativa dificuldade de defesa gerada pela proposta de ampliação.

Então, será à luz das especificidades do caso concreto que o juiz habilitar-se-á a se pronunciar pela admissibilidade ou não da construção tardia de litisconsórcio eventual, alternativo ou sucessivo, sem que se lhe possam impor vedações apriorísticas ${ }^{828}$.

(iii) reconvenção subjetivamente ampliativa

No tema da admissibilidade das modalidades litisconsorciais aqui estudadas trabalhou-se primordialmente com a noção de que o demandante, caso queira litigar em conjunto e do modo especial como aqui se cogita, haverá de cumprir o ônus de demonstrar a presença dos fatores aptos a autorizar a formação litisconsorcial eventual, alternativa ou sucessiva.

Com esse discurso parece haver uma inclinação, ainda que talvez até mesmo inconsciente, em sobrelevar demasiadamente a posição do autor, ou seja, daquele que, por uma questão ou por outra, tomou a iniciativa de buscar tutela jurisdicional.

\footnotetext{
${ }^{827}$ NERY JUNIOR, Nelson; ANDRADE NERY, Rosa Maria de. Código de Processo Civil comentado e legislação extravagante, cit., p. 513. Na jurisprudência, dentre outros, confira-se: STJ, REsp 864.432, $1^{\text {a }}$ T., Rel. Min. Luiz Fux, j. 12.02.2008, DJU 27.03.2008, apud NEGRÃO, Theotonio; GOUVÊA, José Roberto F.; BONDIOLI, Luis Guilherme A. (op. cit., nota 60 ao art. 267, § $4^{\circ}$, do CPC, p. 367).

${ }^{828}$ Embora em outro contexto, CRUZ E TUCCI lança abalizado entendimento a esse respeito: "Não é preciso dizer que, nestas hipóteses, a postura proativa do juiz, afinada com o anseio de efetividade da prestação jurisdicional, não acarretará qualquer prejuízo às garantias processuais do réu e tampouco haverá infringência à regra da estabilização da demanda" (A causa petendi no processo civil, cit., p. 192).
} 
Todavia, e agora falando muito conscientemente, aqui não se deixa ao largo a posição do réu, pois certamente a ciência processual não pode ser pensada e muito menos construída simplesmente pela perspectiva do autor. Aliás, não é de hoje o alerta segundo o qual a "parificação conceitual de ação e defesa" fomenta o repúdio ao chamado processo civil do autor ${ }^{829}$.

Daí a necessidade de algum enfoque sobre a viabilidade de formação de litisconsórcio eventual, alternativo ou sucessivo por ato do réu. Conquanto não se descarte o estudo dessa questão também pelo prisma do pedido contraposto e das ações dúplices, prefere-se examinar o dilema pela angulação da reconvenção subjetivamente ampliativa, até porque as conclusões que forem encontradas a respeito desta serão facilmente transportadas para o âmbito daqueles.

Como se sabe, vem de abalizada doutrina a ideia de que a reconvenção traduz-se numa "contra-ação", ou, mais precisamente, na "ação do réu contra a do autor, no mesmo processo da ação originária" ${ }^{830}$, podendo-se acrescer a tal enunciado a noção de conexão que deve haver entre o pleito reconvencional e a ação do autor ou o fundamento da $\operatorname{defesa}^{831}$.

Segundo a legislação em vigor, o réu pode reconvir ao autor no mesmo processo, toda vez que a reconvenção seja conexa com a ação principal ou com o fundamento da defesa (CPC, art. 315, caput).

Para os limites deste trabalho, interessa o tema concernente à legitimidade ativa e passiva para a reconvenção, pois o que se pretende inferir é se no campo da reconvenção haveria espaço para formação originária de litisconsórcio eventual, alternativo ou sucessivo. Em outras palavras, almeja-se verificar se é possível inaugurar essas modalidades litisconsorciais por meio de reconvenção.

${ }^{829}$ DINAMARCO, Cândido Rangel. Instituições de direito processual civil, cit., vol. II, nº 539, p. 301. Nesse mesmo tópico, o autor acrescenta: “O processo civil não é feito para dar razão a este [autor] ou para oferecer tutela jurisdicional necessariamente a quem a pediu em primeiro lugar, mas a quem tiver razão (supra, $\mathrm{n}^{\mathbf{0}} 39$ ). Já é tempo de, uma vez reveladas e já amadurecidas essas idéias inerentes à isonomia processual, retificar os conceitos e eliminar as grandes distinções conceituais que a doutrina tradicional estabelece entre ação e defesa" (id., ibid.). Para aprofundamentos, cfr. SICA, Heitor V. M. (O direito de defesa no processo civil brasileiro, cit., passim).

${ }^{830}$ AMARAL SANTOS, Moacyr. Da reconvenção no direito brasileiro. 2. tir, São Paulo: Max Limonad, 1958, n $^{\circ} 41$, p. 110.

${ }^{831}$ CRUZ E TUCCI, José Rogério. Da reconvenção. São Paulo: Saraiva, 1984, p. 58. 
Consoante o discurso normativo vigente, o réu pode reconvir ao autor, de sorte que em sede doutrinária pronuncia-se no sentido de que somente o réu (ou réus, em caso de litisconsórcio passivo já existente) ostenta legitimidade para reconvir e, de outra parte, somente o autor (ou autores, na hipótese de litisconsórcio ativo já formado) detém legitimidade passiva na reconvenção ${ }^{832}$.

Numa postura intermediária, ERNANE FIDÉLIS DOS SANTOS argumenta que não se admite o chamamento de litisconsortes mediante reconvenção, mas consente com a ampliação subjetiva nos casos de "litisconsórcio necessário unitário" 833 . Sob a égide do CPC/39, e alimentado pelo referencial doutrinário italiano, GuILHERME ESTELLITA professou que a necessidade de formação de litisconsórcio no âmbito da reconvenção, em certos casos, milita em favor da aceitação da tese ampliativa ${ }^{834}$.

Já em sentido mais elástico, em sintonia com a ideia de parificação conceitual e prática entre as posições de autor e réu, há aqueles que sinalizam uma admissibilidade da reconvenção subjetivamente ampliativa mesmo fora dos quadrantes do litisconsórcio

${ }^{832}$ FORNACIARI JR., Clito. Da reconvenção no direito processual civil brasileiro. São Paulo: Saraiva, 1979, p. 97-98. Parece ter sido essa orientação mais restritiva a encampada por BARBOSA MOREIRA no seu $O$ novo processo civil brasileiro, cit., p. 44, muito embora, escrevendo sob a égide do CPC/39, o mesmo autor tenha propagado ensinamento diverso, aceitando a reconvenção subjetivamente ampliativa nos casos de formação necessária de litisconsórcio (Reconvenção. In: Direito processual civil: ensaios e pareceres. Rio de Janeiro: Borsoi, 1971, p. 121). FREDIE DIDIER JR., embora demonstre alguma concessão à ampliação subjetiva em sede de reconvenção quando esta for conexa com a ação principal, manifesta predileção à postura restritiva (Curso de direito processual civil, cit., p. 453-454).

${ }^{833}$ Manual de direito processual civil. 12. ed. São Paulo: Saraiva, 2008, p. 482. Eis o exemplo do doutrinador: "O autor pede pagamento de multa por ter o réu se negado a receber o imóvel em locação a que se vinculara, negando também o pagamento de qualquer aluguel (CC/2002, art. 565). Contestando, o réu alega nulidade do contrato, dizendo que o imóvel é de sua propriedade, e reconvém, reivindicando-o. Neste caso, a mulher do autor necessariamente deverá ser citada para a reconvenção, bem como necessitará o réu de outorga uxória para reconvir" (id., ibid.). Assim também já se pronunciou CRUZ E TUCCI (Da reconvenção, cit., nota 60, p. 59-60), trabalhando com a hipótese de a ação principal ter sido aforada por um dos vários credores solidários e de a reconvenção versar sobre pretensão redibitória (vícios ocultos), a ensejar a vinda para os autos de todos os pretensos credores solidários.

${ }^{834}$ Op. cit., p. 211-212. 
necessário $^{835}$. É dizer, admite-se a inauguração de litisconsórcio facultativo por meio de reconvenção.

Nesse ponto, vale a transcrição de passagem em que CÂNDIDO DINAMARCO elucida e, segundo parece, resolve a questão:

"A admissibilidade da reconvenção subjetivamente ampliativa é expressão da legítima tendência de universalizar a tutela jurisdicional, procurando extrair do processo o máximo de proveito útil que ele seja capaz de oferecer (...). É ditame do princípio da economia processual a busca do máximo de resultado na atuação do direito com o mínimo emprego possivel de atividades processuais (...). As possíveis demoras que a ampliação subjetiva possa causar não são suficientes para afastar sua admissibilidade, porque o processo não tem a destinação de oferecer tutela rápida ao autor a todo custo mas, acima disso, a de realizar a pacificação social mais ampla possível; invocar a urgência do autor como fundamento da recusa às reconvenções ampliativas é filiar-se inconscientemente às superadas premissas do processo civil do autor (...); é também, em última análise, negar a utilidade do próprio instituto da reconvenção" 836 .

Nesses termos, afigura-se preferível a adoção desta última posição, seja porque afinada com as ideias de universalização da jurisdição e de superação do dogma do

\footnotetext{
835 "Quer nos casos de litisconsórcio necessário, quer nos casos de litisconsórcio facultativo, a demanda reconvencional subjetivamente ampliativa apresenta todas as vantagens inerentes ao instituto da reconvenção (supra, $\mathrm{n}^{\circ}$ 2). Ela traz para o processo um extrato mais substancioso das relações de direito material e permite uma solução global e coerente do litígio. É freqüente que na base do litisconsórcio estejam questões comuns a serem enfrentadas. Ademais, a reconvenção subjetivamente ampliativa evita a instauração de um novo processo, que teria por objeto a pretensão dedutível em face da pessoa que não pôde ser inserida na demanda reconvencional. E é sabido que um processo mais complexo demanda menos atividade e energia para o seu desfecho do que um conjunto de processos sobre o mesmo tema" (BONDIOLI, Luis Guilherme Aidar. Reconvenção no processo civil. São Paulo: Saraiva, 2009, p. 111). Assim também, com sólidos fundamentos, SICA, Heitor V. M. (O direito de defesa no processo civil brasileiro, cit., p. 294-296).

${ }^{836}$ Instituições de direito processual civil, cit., vol. III, $\mathrm{n}^{\circ} 1.100$, p. 528 - grifos do original.
} 
processo civil do autor, seja porque em compasso com a tendência de sistemas estrangeiros avançados, como o são o espanhol ${ }^{837}$ e o português ${ }^{838}$.

Transpondo a discussão para o campo do litisconsórcio eventual, alternativo e sucessivo, parece também não haver motivos legítimos que sirvam de empeço à formação, em reconvenção, dessas modalidades litisconsorciais.

Como já se procurou demonstrar anteriormente, à base de conformação das espécies litisconsorciais aqui estudadas existe, nalguma medida, um grau mais ou menos acentuado de conexidade a vincular a posição dos vários colitigantes.

Pois bem. Partindo-se da premissa segundo a qual a reconvenção precisa ser conexa com a ação principal ou com a causa excipiendi veiculada na contestação ${ }^{839}$, tem-se que a existência de algum vínculo - também caracterizador de conexão - entre a situação jurídica do reconvinte [animadora da admissibilidade da reconvenção] e a posição jurídicosubstancial de outros sujeitos [terceiros ainda não presentes na relação processual de que se cogita] faz com que, em última análise, toda essa relação global e subjetivamente complexa apresente-se entrelaçada, nalguma medida, pela conexidade autorizadora da formação de litisconsórcio. Daí que a conexão entre a posição do reconvinte e a de

${ }^{837}$ Art. 407, I, da LEC. Na doutrina, cfr. VIDAL PEREZ, Maria Fernanda (op. cit., p. 313).

838 Art. 274.2, do CPC. Em doutrina, consultem-se: REMÉDIO MARQUES, João Paulo. Op. cit., p. 458; LEBRE DE FREITAS, José; REDINHA, João; PINTO, Rui. Código de Processo Civil anotado. 2. ed. Coimbra: Coimbra, 2008, vol. 1, p. 532, com ampla citação bibliográfica e jurisprudencial.

${ }^{839}$ Sobre a conexão em tema de reconvenção, consulte-se BARBOSA MOREIRA, José Carlos (A conexão de causas como pressuposto da reconvenção, cit., passim). Convém relembrar, nesse passo, que a conexão exigida para fins de admissibilidade da reconvenção não está adstrita às balizas previstas no art. 103, do CPC, consoante a conclusão a que chegara BARBOSA MOREIRA, in verbis: "Todos os vetores apontam no mesmo sentido, e com isso temos por demonstrada a nossa proposição central, a saber, a de que o conceito de conexão entre causas, como pressuposto da admissibilidade da reconvenção, é mais amplo do que o conceito subministrado pelo art. 103, não reclamando a identidade de qualquer dos elementos de individualização das ações" (id., n $\mathrm{n}^{\circ}$ 96, p. 168). Por isso é que o autor, em tom exemplificativo, anota as "hipóteses sensíveis" em que seria razoável admitir a conexão capaz de ensejar a reconvenção: “(a) as [hipóteses] de identidade (total ou parcial) do objeto ou da causa de pedir na ação originária e na reconvenção; (b) as de comunhão ou entrelaçamento de questões relevantes, com aproveitamento da atividade instrutória, indispensável ao respectivo deslinde, para a formação do convencimento judicial em ambas as causas; (c) as de inter-relação lógica entre os julgamentos, com perigo de contradição nesse plano, se decididas separadamente as lides" (id., nº 94 , p. 164). 
terceiros fará irromper a conexão entre a posição jurídica desse terceiro e a ação principal ou os motivos da defesa do réu/reconvinte.

Ora, se fora do âmbito da reconvenção o surgimento de litisconsórcio eventual, alternativo ou sucessivo seria possível na hipótese considerada, dúvida não pode remanescer sobre a admissibilidade também de o litisconsórcio configurar-se quando se transplanta o exercício do direito de ação para o campo da reconvenção ${ }^{840}$.

Um exemplo pode bem esclarecer eventuais dúvidas remanescentes, não por falta de entendimento do leitor, mas sim pelas dificuldades de representar em palavras os pensamentos que vagueiam pela mente do escritor.

Tomando por empréstimo uma hipótese já anunciada neste trabalho, agora com adaptações intencionais, pode-se supor o seguinte: Antonio move em face de Bento ação cobrando verbas locatícias (aluguéis e indenização por deteriorações) derivadas de uma afirmada locação de imóvel residencial; em defesa, Bento alega nada dever, uma vez que, além de jamais ter havido a propalada locação, o imóvel considerado lhe pertence; daí que, em reconvenção, Bento reivindica o imóvel e, para a hipótese de sucumbir nessa sua pretensão reconvencional, formula desde logo, no mesmo processo e na mesma peça reconvencional, pedido subsidiário de indenização em face de Carlos, a pessoa que lhe vendera o imóvel.

Ter-se-á por formado, nessas condições, litisconsórcio passivo eventual mediante reconvenção, com a peculiaridade de que o litisconsorte subsidiário, que não fazia parte da relação processual até então, será introduzido no processo por força exclusiva da reconvenção, ampliando-se, dessarte, a configuração objetiva e subjetiva da demanda ${ }^{841}$.

${ }^{840}$ É possível, nesse ponto, tomar por empréstimo, mutatis mutandis, a argumentação de HEITOR V. M. SICA: "Afinal, ao autor é conferido o poder de formular a demanda inicial incluindo no polo ativo ou passivo uma pluralidade de sujeitos mesmo que apenas ligados por simples 'afinidade de questões por um ponto comum de fato ou de direito' (CPC, art. 46, IV), que é, de longe, o mais tênue critério para formulação do litisconsórcio facultativo (a ponto de haver doutrina que o considera um litisconsórcio impróprio). Nem é preciso chegar tão longe na delimitação dos poderes do réu. Propõe-se que, havendo conexidade de sua demanda com aquela ajuizada pelo autor, deve ser admitida a ampliação subjetiva" ( $O$ direito de defesa no processo civil brasileiro, cit., p. 295 - grifo do original).

${ }^{841}$ A hipótese figurada pode muito bem ajustar-se à denunciação da lide surgida em reconvenção. Convém relembrar que, para os termos deste estudo, a denunciação da lide pelo autor representa nada mais que hipótese de litisconsórcio eventual, conforme também já expôs CÂNDIDO DINAMARCO (Litisconsórcio, 
GIUSEPPE TARZIA, ao tratar do litisconsórcio alternativo, adere expressamente à orientação segundo a qual se admite formar esse tipo litisconsorcial na reconvenção. Esclarece o autor, com efeito, à luz do art. 36, do CPC italiano, que os elementos de conexão requeridos pela norma citada, uma vez presentes, fazem com que não subsistam

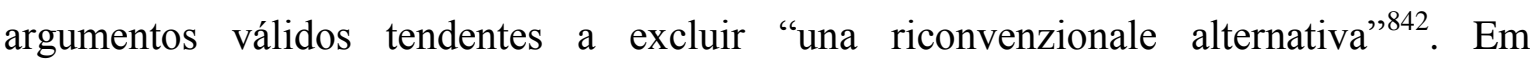
acréscimo, o doutrinador italiano enfatiza que a formação litisconsorcial alternativa no âmbito da reconvenção pode dar-se tanto no polo ativo quanto no passivo, mediante a inclusão de terceiro ao lado do autor-reconvindo ou do réu-reconvinte ${ }^{843}$.

A partir, então, do referencial teórico deixado por aqueles que se debruçaram sobre o tema da reconvenção subjetivamente ampliativa, afigura-se possível pensar num litisconsórcio eventual, alternativo ou sucessivo inaugurado por ato do réu no âmbito de reconvenção, tudo a depender da presença, in status assertionis, do vínculo de conexidade entre as várias posições jurídico-substanciais dos colitigantes.

Por derradeiro, acentua-se que os argumentos expostos neste tópico servem para igual construção no âmbito do chamado pedido contraposto, admitindo-se a ampliação subjetiva da demanda por ato do réu, em suas variantes eventual, alternativa e sucessiva.

\section{Valor da causa}

No estudo do litisconsórcio geralmente não se faz menção aos desdobramentos do tema em relação ao valor da causa, uma vez que o sistema processual em vigor apega-se, para configuração do aludido valor, a um aspecto objetivo da demanda, mais precisamente a "expressão econômica da relação jurídica material que o autor quer opor ao réu" "844. Em outras palavras, importa mais, nesse assunto, a conformação econômica da relação de direito material que se pretende debater em juízo, circunstância que nem sempre coincide

cit., $\mathrm{n}^{\circ}$ 182, p. 460). Transpondo-se a discussão para o âmbito da reconvenção, lícito é afirmar que o exemplo citado no texto configura reconvenção subjetivamente ampliativa, com a peculiaridade de que haverá, na hipótese, litisconsórcio eventual surgido a partir da reconvenção.

${ }^{842}$ Appunti sulle domande alternative, cit., p. 299. Em termos genéricos - isto é, fora do espectro do litisconsórcio alternativo - o mesmo autor admitiu a reconvenção subjetivamente ampliativa no seu famoso $I l$ litisconsorzio facoltativo nel processo del primo grado, cit., p. 45-46.

${ }^{843}$ Appunti sulle domanda alternative, cit., p. 299-300.

${ }^{844}$ THEODORO JÚNIOR, Humberto. Curso de direito processual civil, 21. ed., cit., vol. I, p. 310. 
com o valor do objeto, material ou imaterial, pretendido pela parte (bem da vida almejado $^{845}$.

Da própria lei se pode extrair semelhante conclusão, porquanto nos dispositivos que regulam a matéria ${ }^{846}$ não se veiculam circunstâncias atreladas à conformação subjetiva da demanda ${ }^{847}$. Nesse sentido, a doutrina especializada professa que, para fins de atribuição de valor à causa, "somente interessa a cumulação de pedidos e não a cumulação subjetiva" $" 848$.

Contudo, a vertente litisconsorcial aqui investigada congrega em seu âmbito, a par de uma singela cumulação subjetiva, uma notória cumulação objetiva, consoante se procurou demonstrar anteriormente. Daí que a formação de litisconsórcio eventual, alternativo ou sucessivo acaba ganhando pertinência em tema de atribuição de valor à causa, o que passa a ser objeto de ligeira análise, sem a pretensão, evidentemente, de esgotar o tema do valor da causa.

Em etapa anterior deste trabalho já se fez menção às consequências da cumulação de pedidos no campo do valor da causa ${ }^{849}$, de sorte que as premissas lá fixadas são simplesmente retomadas aqui, sem a preocupação com novas explicações, bastando a visualização do mesmo assunto agora sob o específico prisma do litisconsórcio eventual, alternativo e sucessivo.

Mais uma vez por comodidade de exposição, principia-se a análise pelo ângulo do litisconsórcio sucessivo, que abarca, sob o aspecto objetivo, uma cumulação própria de pedidos veiculados por ou em face de sujeitos distintos. Nessa configuração litisconsorcial fica visível a pretensão de que todos os pedidos relacionados aos litisconsortes sucessivos

\footnotetext{
${ }^{845}$ THEODORO JÚNIOR, Humberto. Curso de direito processual civil, 21. ed., cit., vol. I, p. 310.

${ }^{846} \mathrm{CPC}$, art. 258 e seguintes.

${ }^{847}$ Para fins tributários, registra-se que o art. $4^{\mathrm{o}}, \S \S 10$ e 11 , da Lei estadual $\mathrm{n}^{\mathbf{o}} 11.608 / 2003$, que regula a taxa judiciária na Justiça Comum do Estado de São Paulo, traz a seguinte disciplina: “§ 10 - Na hipótese de litisconsórcio ativo voluntário, além dos valores previstos nos incisos I e II, será cobrada a parcela equivalente a 19 (dez) Unidades Fiscais do Estado de São Paulo - UFESPs, para cada grupo de dez autores, ou fração, que exceder a primeira dezena. $§ 11$ - Nos casos de admissão de litisconsorte ativo voluntário ulterior e de assistente, cada qual deverá recolher o mesmo valor pago, até aquele momento, pelo autor da ação". Como se vê, no Estado de São Paulo o tema do litisconsórcio ativo, embora não influa na atribuição de valor à causa, gera consequências na órbita da taxa judiciária.
}

${ }^{848}$ SOUZA, Gelson Amaro de. Do valor da causa, cit., p. 129.

${ }^{849}$ Cfr. n ${ }^{\text {14 }}$, “i”, supra (Cap. II, Parte II). 
sejam conhecidos e acolhidos pelo julgador, tudo a demonstrar um somatório de pretensões, ligadas, como já visto, por prejudicialidade.

Nessas condições, parece válido considerar que o valor da causa será representado pela soma de todos os pedidos veiculados na petição inicial, adotando-se o referencial do art. 259, II, do CPC, segundo o qual, "havendo cumulação de pedidos", o valor da causa coincide com "a quantia correspondente à soma dos valores de todos eles" 850 .

Pelo prisma do litisconsórcio eventual e do alternativo, cuja conformação toma por empréstimo o referencial da cumulação subsidiária e alternativa de pedidos, o valor da causa há de obedecer aos critérios previstos no art. 259, incisos III e IV, do CPC.

Realmente, a experiência dum litisconsórcio eventual redunda na veiculação de pedido relativo a um litisconsorte primário, agregando-se, in simultaneus processus, outro ou o mesmo pedido, já agora em caráter subsidiário, relacionado a sujeito distinto. Então, apenas para a hipótese de não ser acolhido o pedido que diz respeito ao litisconsorte primário é que se lançarão luzes sobre o pedido pertinente ao litisconsorte subsidiário. Disso decorre que, pelo aspecto objetivo, os pedidos só mesmo impropriamente podem ser considerados cumulados.

Pode-se, então, transpor para o campo do litisconsórcio eventual a regra consoante a qual o valor da causa resultará da conformação econômica do pedido principal (ou primário), ex vi do art. 259, IV, do CPC.

Situação bem semelhante advém da configuração do litisconsórcio alternativo, por intermédio de cuja formação não se pretende que todos os pedidos veiculados em relação aos litisconsortes sejam acolhidos. Com efeito, busca-se que relativamente a um ou outro litisconsorte a pretensão seja acolhida. Anima-se a propugnar, nesse cenário, pela adoção do critério de atribuição de valor à causa previsto no art. 259, III, do CPC. De modo que, no litisconsórcio alternativo, o valor da causa resultará da análise de qual seja o "maior valor" dentre os pedidos relacionados aos litisconsortes.

Evidente que para bem manejar a construção do valor da causa, em todos os aspectos aqui considerados, devem ser lembradas os demais critérios legais que comandam

\footnotetext{
${ }^{850}$ No sentido de que na cumulação sucessiva de pedidos adota-se esse critério, cfr. BARBOSA MOREIRA, José Carlos (O novo processo civil brasileiro, cit., p. 20).
} 
o tema (CPC, art. 259 e 260) e também as hipóteses em que a atribuição de valor à causa se diz voluntária ${ }^{851}$, isto é, se faz mediante estimativa razoável do(s) autor(es) ${ }^{852}$.

Vale lembrar, por fim, na esteira do que se defendeu em torno da formação ulterior de litisconsórcio eventual, alternativo ou sucessivo ${ }^{853}$, que o valor da causa poderá sofrer mutações supervenientes na medida em que forem agregados novos litisconsortes, já que a inclusão de litisconsorte, consideradas as modalidades objeto deste estudo, pode gerar reflexos na composição econômica da demanda, caso em que serão aplicadas as diretrizes expostas acima.

As mesmas considerações lançadas genericamente nesta etapa do trabalho servem para comandar o regramento de atribuição de valor à reconvenção, seguindo-se a orientação aqui adotada quanto à admissibilidade de reconvenção subjetivamente ampliativa $^{854}$.

\section{Citação: termo inicial do prazo para resposta}

Em oportunidade anterior já se procurou demonstrar que as modalidades litisconsorciais aqui estudadas podem ocorrer tanto no polo ativo quanto passivo da relação processual. Quando se está diante de litisconsórcio ativo o problema da citação não se coloca, porquanto o instrumento da demanda (petição inicial) já trará consigo o efeito de integrar os vários autores na posição de partes na demanda e também no processo.

Como é intuitivo, os desdobramentos que o assunto da citação pode ensejar neste estudo dizem respeito ao campo do litisconsórcio passivo, em suas vertentes eventual, alternativa e sucessiva.

Segundo a dicção legal, a citação é o ato pelo qual se chama a juízo o réu ou o interessado a fim de se defender (CPC, art. 213). Embora aqui não se esteja interessado em

\footnotetext{
${ }^{851}$ BARBOSA MOREIRA, José Carlos. O novo processo civil brasileiro, cit., p. 20.

${ }^{852}$ DINAMARCO, Cândido Rangel. Instituições de direito processual civil, cit., vol. III, nº 998, p. 384.

${ }^{853}$ Cfr. $\mathrm{n}^{\circ} 45$, ii, supra.

${ }^{854} \mathrm{Cfr} . \mathrm{n}^{\circ} 45$, iii, supra.
} 
discussões conceituais, convém salientar que a visão doutrinária sobre a citação vai além das fronteiras linguísticas ditadas pela lei ${ }^{855}$.

Então, convém chamar a atenção para o fato, também intuitivo, de que no litisconsórcio passivo as citações dos colitigantes podem verificar-se em momentos distintos e, além disso, mesmo que ocorram simultaneamente, as citações podem ser documentadas nos autos em ocasiões diversas. Tais situações, como se sabe, estão aptas a refletir na contagem do prazo para a resposta.

Não por outro motivo é que o legislador cuidou de enunciar a regra segundo a qual o prazo começa a correr, quando houver vários réus, da data de juntada aos autos do último aviso de recebimento ou mandado citatório cumprido (CPC, art. 241, III). Numa interpretação sistemática deve-se também trabalhar com a noção de citação por edital, hipótese em que o prazo para resposta, para os litisconsortes, contar-se-á depois de finda a última dilação assinada pelo juiz (CPC, art. 241, V). Se houver mescla de modalidades de citações para os vários litisconsortes (por mandado, por carta e por edital), a contagem do prazo para todos inicia-se com o aperfeiçoamento da última citação documentada nos $\operatorname{autos}^{856}$.

No campo específico do litisconsórcio eventual, alternativo e sucessivo não se vê razões para afastar a incidência das regras acima enunciadas. Uma vez que a situação retratada nas modalidades litisconsorciais aqui discutidas dá ensejo à formação de efetivo litisconsórcio, o prazo para resposta dos vários réus conta-se da implementação da última citação documentada nos autos, observadas as regras pertinentes a cada uma das modalidades citatórias, especialmente quando intervém hipótese de citação por edital.

Em palavras diretas, aplica-se ao litisconsórcio eventual, alternativo e sucessivo, quando verificado no polo passivo, a diretriz que vem da regra contida no art. 241, III, do Código de Processo Civil.

\footnotetext{
${ }^{855}$ Nessa perspectiva, eis o conceito doutrinário: "Portanto, parece correto afirmar que a citação é ato judicial que tem por finalidade comunicar ao sujeito passivo da relação processual (réu e litisconsorte) ou aos interessados, que foi ajuizada demanda ou procedimento de jurisdição voluntária, a fim de que possam, querendo, vir a se defender ou se manifestar, dando-se-lhes oportunidade, dessa forma, de exercer o fundamental direito ao contraditório (no caso do réu e litisconsortes passivos) ou o fundamental direito de ação (no caso dos interessados em integrar a lide)" (CORREIA, André de Luizi. A citação no direito processual civil brasileiro. São Paulo: RT, 2001, p. 33).

${ }^{856}$ Para aprofundamentos, cfr. CORREIA, André de Luizi (op. cit., p. 365 et seq.).
} 
Esse panorama pode sofrer alguma alteração caso o litisconsórcio, nas modalidades aqui consideradas, seja formado ulteriormente. Se isto se verificar antes da citação do(s) réu(s) originário(s), aplicam-se as diretrizes que vem de ser anunciadas, de vez que, nessa hipótese, a citação de todos ocorrerá ainda no limiar do procedimento. Porém, se o litisconsórcio ulterior verificar-se após a citação do(s) réu(s) originário(s), há de se compreender que o prazo para resposta abrir-se-á a partir do aperfeiçoamento (rectius, documentação nos autos) da citação por último realizada.

No campo da reconvenção subjetivamente ampliativa, conforme se tentou demonstrar alhures, também há espaço para formação das espécies litisconsorciais objeto deste estudo, de sorte que a ampliação subjetiva que ocorrer no polo passivo da reconvenção demandará alguns ajustes procedimentais em tema de citação e de contagem do prazo para resposta.

É que o autor reconvindo, nos termos do art. 316, do CPC, será "intimado", na pessoa de seu procurador, para que apresente contestação no prazo de 15 dias ${ }^{857}$. Então, pelo prisma do reconvindo que já está representado nos autos por advogado, sua citação dá-se na pessoa do causídico. Contudo, para o reconvindo que ainda não está nos autos daí a noção de reconvenção subjetivamente ampliativa - deve-se lançar mão dos métodos de citação tradicionais (por mandado, por carta ou por edital), aplicando-se, de conseguinte, as regras antes anunciadas. Disso decorre que, no específico campo da reconvenção subjetivamente ampliativa, o prazo para resposta será deflagrado a partir do momento da documentação do último ato citatório.

Ainda no aspecto da citação e do termo inicial do prazo para resposta, convém elucidar outras questões que advém da noção, antes afirmada, de que a denunciação da lide pelo autor é assimilável ao fenômeno do litisconsórcio eventual. Sendo assim, seria de se indagar quanto à utilidade do referencial legislativo previsto para a denunciação da lide em tema de conformação do procedimento no litisconsórcio eventual.

Pois bem. No campo da denunciação da lide pelo autor, a petição inicial já traz no polo passivo da demanda o réu e o denunciado ${ }^{858}$, tanto que, segundo a legislação em

${ }^{857}$ Atente-se para o fato de que a "intimação" referida na lei tem natureza de citação e que onde se escreveu "contestação" se deve ler "resposta", consoante apregoa abalizada doutrina (CRUZ E TUCCI, José Rogério. Da reconvenção, cit., p. 79).

${ }^{858}$ Por tal motivo é que CÂNDIDO DINAMARCO professa não haver, na denunciação da lide, verdadeira intervenção de terceiro (Instituições de direito processual civil, cit., vol. II, nº 604, p. 414-415). 
vigor, a citação do denunciado será requerida juntamente com a do réu, se o denunciante for o autor (CPC, art. 71). Nessas condições, primeiro será realizada a citação do denunciado, para que ele possa adotar os comportamentos processuais que a lei lhe confere: defender-se quanto aos termos da ação regressiva e/ou assumir a posição de "litisconsorte" do autor, podendo até mesmo aditar a petição inicial ${ }^{859}$. Só depois disso é que vem a citação do réu, consoante explicita o art. 74, do CPC.

Embora haja notáveis semelhanças entre o litisconsórcio passivo eventual e a denunciação da lide pelo autor, importante considerar que aquele não está confinado nos lindes desta, de sorte que, a despeito do procedimento específico da citação e do prazo para resposta em sede de denunciação da lide, a disciplina da citação e do prazo para resposta em tema de litisconsórcio eventual há de ser aquela indicada no texto aqui desenvolvido.

Assim, apenas para o caso de o litisconsórcio eventual vir sob as vestes de denunciação da lide é que se adotará o regramento específico previsto no art. 74, do CPC.

À luz dessa distinção procedimental poder-se-ia imaginar que o autor, no afã de burlar o procedimento da denunciação da lide, em vez de conferir roupagem de intervenção de terceiros ao seu pleito, formulasse petição inicial veiculando hipótese nítida de litisconsórcio passivo eventual, isto é, sem apelo à disciplina dos artigos 71 e 74, do CPC.

Em primeiro lugar, crê-se que a existência da disciplina pertinente à denunciação da lide não irrompe como óbice, mesmo para aqueles casos previstos no rol do art. 70, do CPC, à formulação de litisconsórcio eventual nos moldes aqui apregoados. Vale dizer, aceita a premissa da admissibilidade do litisconsórcio eventual no sistema processual em vigor, o autor não estaria obrigatoriamente vinculado a dar vestes de denunciação da lide ao seu pleito primário e subsidiário em face de sujeitos diversos naquelas hipóteses contempladas pelo art. 70, do CPC.

Mas a indagação que remanesce, conforme já adiantado, é se nesse caso o procedimento a adotar haveria de ser aquele proposto pela redação do art. 74 , do $\mathrm{CPC}^{860}$,

\footnotetext{
${ }^{859}$ CARNEIRO, Athos Gusmão. Op. cit., p. 135. Sobre a discussão em torno da posição do denunciado frente à causa pendente, consulte-se, por todos, CÂNDIDO DINAMARCO (Intervenção de terceiros, cit., $\mathrm{n}^{\mathrm{o}}$ 85, p. 164 et seq.).

${ }^{860}$ Importante, nesse passo, a transcrição da regra: "Feita a denunciação pelo autor, o denunciado, comparecendo, assumirá a posição de litisconsorte do denunciante e poderá aditar a petição inicial, procedendo-se em seguida à citação do réu".
} 
ou se se admitiria a adoção do procedimento construído a partir da disciplina genérica do litisconsórcio, conforme se pregou acima.

Para responder a tal celeuma, é preciso partir da premissa de que o procedimento existe não como fim em si mesmo e que toda a técnica processual vem modelada para garantir a concretização dos valores tidos por caros em toda a sistemática processual.

Então, adotada a disciplina genérica do litisconsórcio eventual, ambos os réus (primário e subsidiário) seriam citados na mesma oportunidade, isto é, sem a sequência prevista no art. 74, do CPC. Daí que o prazo para resposta em relação a ambos seria deflagrado após aperfeiçoada a última citação.

Mesmo nessas condições, nada impediria que o litisconsorte subsidiário exatamente para evitar a sucumbência do autor em relação ao litisconsorte primário trouxesse em sua contestação novos argumentos tendentes a reforçar a tese estampada na petição inicial. Ou seja, a possibilidade que existe na denunciação da lide de o denunciado aditar a petição inicial equivale-se, em termos práticos, à inclusão na contestação do litisconsorte subsidiário de motivos outros direcionados a enrijecer as teses sustentadas pelo autor em relação ao litisconsorte primário.

Em outras palavras, a técnica do aditamento da petição inicial, conforme a previsão do art. 74, do CPC, exatamente porque vinculada apenas a novos fundamentos e não a novos pedidos, equivale-se, do ponto de vista das finalidades, à inclusão desses mesmíssimos outros argumentos em sede de contestação. Então, pelo prisma do litisconsorte subsidiário, parece não haver qualquer prejuízo em comparação com a postura que lhe seria proposta caso estivesse atuando sob as vestes de denunciado. Ou seja, embora por outro caminho, chega-se ao mesmo resultado pretendido pelo sistema, circunstância que afasta a postura mental que poderia enxergar, nessa modulação procedimental, algum maltrato às regras pertinentes à denunciação da lide.

Na perspectiva do litisconsorte primário (que seria o réu da causa pendente na hipótese de denunciação da lide pelo autor), parece também não haver obstáculos à proposta aqui anunciada. Com efeito, a sucessão de citações no âmbito da denunciação da lide (primeiro cita-se o denunciado e, depois, cita-se o réu, nos termos do art. 74, do CPC) tem por finalidade oportunizar ao réu a chance de se contrapor às alegações do denunciado, que poderá ter aditado a petição inicial, incluindo novos argumentos tendentes incrementar as teses sustentadas pelo autor. 
Já adiantando noções que serão lançadas por ocasião do estudo das "providências preliminares", tem-se que a possibilidade de a postura processual dos litisconsortes primário e subsidiário revelar verdadeiro antagonismo entre eles impõe, em obséquio ao efetivo contraditório, que o juiz dê oportunidade para que cada qual se manifeste sobre o teor da defesa do outro. Assim, embora sem a roupagem de contestação propriamente dita (tal como ocorreria na denunciação da lide), o litisconsorte primário há de ter oportunidade para contrapor argumentos àqueles que o litisconsorte subsidiário eventualmente tenha agregado como reforço às teses levantadas pelo autor.

Essa manifestação do litisconsorte primário seria assimilável a uma réplica à contestação do outro litisconsorte (subsidiário), com vistas a incrementar o contraditório e, assim, possibilitar que a instrução seja a mais ampla possível e o julgamento, ao final, abarque toda a globalidade da controvérsia envolvendo o plexo de sujeitos e suas respectivas posições jurídicas.

Seria necessário, ainda no âmbito dessa proposta, operar-se uma diminuta modulação no prazo para a réplica, já que, em linhas gerais, tal prazo seria de dez dias (CPC, art. 326 e 327), ao passo que a contestação do réu na denunciação da lide pelo autor poderia ser apresentada em 15 dias (CPC, art. 74, in fine, c.c. art. 297). Então, a concessão de um prazo de 15 dias para que o litisconsorte primário teça suas considerações defensivas quanto ao que foi agregado pelo litisconsorte subsidiário tem a aptidão de conformar o procedimento de tal modo que nenhum prejuízo seja sentido por quaisquer dos litigantes.

Portanto, pode-se entrever uma fungibilidade entre a incoação de pedidos subsidiários, em face de réus diversos, pelo método da denunciação da lide e pela técnica do litisconsórcio eventual, isso nos casos delineados no art. 70, do CPC. A opção pela moldura do litisconsórcio eventual ensejará, porém, ajustes procedimentais necessários à garantia do efetivo contraditório, de sorte que, mesmo por caminho não expressamente vislumbrado pelo legislador, serão alcançadas as finalidades para as quais cada um desses atos do procedimento fora concebido.

O referencial teórico em que se sustenta semelhante proposição advém do princípio da adaptabilidade do procedimento às necessidades da causa, à luz do qual se concebe um “modelo procedimental flexível, passível de adaptação às circunstâncias apresentadas pela 
relação substancial" 861 , sempre na consideração de que "a maior ou menor complexidade do litígio exige sejam tomadas providências diferentes, a fim de se obter o resultado do processo" ${ }^{\$ 62}$. Ainda segundo abalizada doutrina, a justificativa principal para essa noção “encontra-se, sem dúvida, na necessidade de se emprestar a maior efetividade possível ao direito processual no desempenho de sua tarefa básica de realização do direito material e de outorga de justiça"863.

É por essa perspectiva que se mostra viável trabalhar com a noção de um procedimento adaptável às peculiaridades da causa e com reforço dos poderes do juiz, em colaboração com as partes, para definir o iter que melhor se afeiçoe às nuanças e dificuldades da causa posta em juízo ${ }^{864}$.

\section{Prazo em dobro}

Consoante se vem defendendo neste estudo, a pluralidade de partes em exame reflete efetiva hipótese de litisconsórcio, mesmo que na economia interna da relação entre os colitigantes haja algum índice de antagonismo. Então, como de litisconsórcio realmente se cuida, lícito é considerar que o prazo em dobro previsto no art. 191, do CPC, aplica-se também no espectro do litisconsórcio eventual, alternativo e sucessivo, isso na hipótese de os colitigantes terem seus interesses patrocinados por advogados distintos.

\footnotetext{
${ }^{861}$ BEDAQUE, José Roberto dos Santos. Direito e processo, cit., nº 17, p. 69.

862 Id., ibid. Sobre a adaptabilidade procedimental em tema de prazos processuais, assim professa FERNANDO GAJARDONI: “As circunstâncias da causa recomendam, ainda que inexistente autorização legal, que os prazos sejam adaptados judicialmente conforme a complexidade da matéria de fato e de direito debatido (direito material), ou, ainda, conforme as particularidades pessoais da parte litigante. A flexibilização judicial do prazo, além disso, potencializa o alcance dos princípios do contraditório e da ampla defesa" (op. cit., p. 211).

${ }^{863}$ ALVARO DE OLIVEIRA, Carlos Alberto. Do formalismo no processo civil, cit., p. 134.

${ }^{864} I d$., nota 173, p. 134. Para FERNANDO GAJARDONI, “[o] procedimento só por si é fórmula vazia. É o contraditório útil que lhe preenche o conteúdo e lhe dá poder para legitimar a decisão. Por isso, a flexibilização procedimental, com alteração do rito padrão estabelecido por lei ou com a construção de um novo modelo ritual, não afeta o poder legitimante da decisão, desde que no processo tenha sido assegurada aos litigantes efetiva participação em contraditório" (op. cit., p. 98).
} 
O mesmo expediente deve ser adotado quando o litisconsórcio, nas modalidades aqui consideradas, formar-se ulteriormente, cabendo atentar para o encaminhamento de soluções a depender da situação verificada: (a) se a inclusão de um só litisconsorte der-se antes da citação do réu originário, o prazo de resposta para ambos poderá ser dobrado, caso haja procuradores diversos; (b) se a inclusão de um só litisconsorte ocorrer depois da citação do réu originário, mas antes de escoado o prazo simples para resposta, parece razoável entender que o prazo de resposta para ambos poderá dobrar-se; (c) na hipótese de a inclusão de um só litisconsorte verificar-se após o prazo de resposta para o réu primitivo, não haverá motivos para a dobra do prazo na forma do art. 191, do CPC; (d) caso a inclusão ocorra depois do prazo para resposta do réu originário e o litisconsórcio ulterior envolva mais de um litigante com procuradores diversos, então para eles o prazo de resposta será dobrado.

Todavia, nas demais situações em que os litisconsortes tiverem oportunidade para "falar nos autos" será irrelevante o momento específico da inclusão de litisconsorte ulterior. Importará, sim, a singela verificação de que, naquele específico momento de "falar nos autos", já esteja formado o litisconsórcio e os litigantes tenham procuradores diversos, abrindo-se espaço, então, para incidência da regra do art. 191, do CPC.

Vale lembrar, por oportuno, que se um dos litisconsortes for a Fazenda Pública ou o Ministério Público não se poderão cumular as prerrogativas do art. 188 com as do art. 191, ambos do Código de Processo Civil, no que respeita ao prazo para responder e para recorrer. Prevalecerá, para esses entes públicos, a prerrogativa do prazo em quádruplo para responder ${ }^{865}$ e em dobro para recorrer. Contudo, no que se refere ao prazo para "falar nos autos", afigura-se viável trabalhar com a ideia do prazo em dobro previsto no art. 191, do $\mathrm{CPC}^{866}$.

De outro lado, a doutrina especializada apregoa, com acerto, que no âmbito da reconvenção subjetivamente ampliativa também existe espaço para aplicação da regra do art. 191, do $\mathrm{CPC}^{867}$.

${ }^{865}$ MONIZ DE ARAGÃO, Egas Dirceu. Comentários ao Código de Processo Civil. 9. ed. Rio de Janeiro: Forense, 1998, vol. II, no 131, p. 109-110.

${ }^{866}$ NERY JUNIOR, Nelson; ANDRADE NERY, Rosa Maria de Andrade. Código de Processo Civil e legislação extravagante, cit., nota 7 ao art. 191, do CPC, p. 456.

${ }^{867}$ BONDIOLI, Luis Guilherme Aidar. Op. cit., p. 222-223. 
Seja como for, o que impõe registrar é que o só fato de o litisconsórcio caracterizarse como eventual, alternativo ou sucessivo não afasta a incidência das regras gerais inerentes aos prazos processuais, não sendo preciso, nesse campo, engendrar outra interpretação que vá além daquela já forjada para o litisconsórcio genericamente considerado.

\section{Desistência da ação: aquiescência do(s) outro(s) litisconsorte(s)}

Vem da própria configuração do litisconsórcio eventual e do alternativo a possibilidade de se verificar algum antagonismo entre os colitigantes, já que cada qual pode ter sérias razões para tentar infundir na convicção do julgador a tese de que seria realmente o outro, e não ele, o responsável por aquilo que se pede na petição inicial.

É a partir dessa constatação que se coloca a questão envolvendo a desistência da ação em relação a um ou alguns dos componentes de litisconsórcio eventual ou alternativo.

Segundo a dicção legal em vigor, depois de decorrido o prazo para a resposta, o autor não poderá, sem o consentimento do réu, desistir da ação (CPC, art. 267, § $4^{\circ}$ ). Afora a celeuma que grassa em torno da exegese da expressão "decorrido o prazo para a resposta" ${ }^{868}$, tem-se que o consentimento, nos casos em que exigível, refere-se ao réu que seja alvo da desistência. Ou seja, os eventuais litisconsortes passivos que não forem atingidos pela desistência não precisariam aquiescer com a desistência da ação manifestada pelo autor. Essa seria a diretriz adequada para os casos de litisconsórcio não abrangidos pelas peculiaridades versadas neste estudo.

Contudo, ao menos no campo do litisconsórcio eventual e do alternativo, em cuja seara pode verificar-se antagonismo mais intenso do que o verificado em relação à parte contrária (autor da demanda), parece razoável propor uma inflexão no padrão legal para se exigir também que se ouça(m) o(s) outro(s) litisconsorte(s) a respeito da desistência manifestada pelo autor em relação um ou alguns dos colitigantes.

${ }^{868}$ MONIZ DE ARAGÃO, Egas Dirceu. Op. cit., vol. II, n 532-533, p. 409 et seq.; NERY JUNIOR, Nelson; ANDRADE NERY, Rosa Maria de. Código de Processo Civil e legislação extravagante, nota 30 ao art. 267, $\S 4^{\circ}$, do CPC, p. 506; MARINONI, Luiz Guilherme; MITIDIERO, Daniel. Código de Processo Civil comentado artigo por artigo, cit., nota 13 ao art. 267, do CPC, p. 261; MARCATO, Antonio Carlos (coord.). Código de Processo Civil interpretado. 3. ed. São Paulo: Atlas, 2008, p. 809-810. 
Evidente que a discordância porventura apresentada por esses outros litisconsortes há de ser fundamentada, tal como se exige do próprio réu que seja alvo da desistência da ação.

Poder-se-ia objetar que essa postura interpretativa, além de se desviar do modelo legal, acaba por impor ao autor o exercício de demanda em face de quem ele não mais deseja, cerceando-se sua liberdade de agir. Convém redarguir, porém, que não é incompatível com o sistema processual brasileiro a ideia de o autor ter que demandar perante sujeito não desejado a priori. É o caso, por exemplo, do chamamento ao processo provocado pelo réu (CPC, art. 78), situação de litisconsórcio ulterior formado por iniciativa do réu, isto é, independentemente da vontade do autor.

Mesmo fora do âmbito do litisconsórcio, expondo o réu motivos ponderosos para que se dê continuidade ao processo, a desistência da ação manifestada pelo autor será ineficaz e, de uma forma ou de outra, a trama processual seguirá rumo à definição judicial mesmo sem a vontade do autor.

Então, não destoa do sistema processual em vigor a imposição de continuidade do processo mesmo diante do arrefecimento da vontade do autor em litigar contra este ou aquele litisconsorte, desde que o nível de litigiosidade entre os próprios colitigantes como pode ser ínsito ao litisconsórcio eventual e ao alternativo - recomende, a bem do próprio interesse público na solução global do litígio, o prosseguimento do feito.

Com efeito, o mesmo interesse que o demandante titulariza quando propõe a demanda numa configuração de litisconsórcio eventual ou alternativo, no afã de alcançar, numa só experiência processual, a solução integral do litígio que se apresenta subjetivamente complexo, existe também em favor daquele réu componente de litisconsórcio eventual ou alternativo que não seja alvo da desistência da ação.

Ademais, para o litisconsorte (eventual ou alternativo) que permanecesse no processo, caso implementada a desistência da ação em relação ao outro, poderia ser prejudicial lidar com o outro litisconsorte na condição terceiro e não na de parte. Com efeito, a par das diferenças no tratamento de questões probatórias ( $v . g$., a exibição de documentos solicitada em face de quem é parte ou de quem é terceiro), outras posturas processuais do litisconsorte que seria alvo da desistência da ação (confissão ficta, derivada do não comparecimento em juízo quando do depoimento pessoal) podem contribuir para a 
formação do convencimento judicial, tudo a influir positivamente, ao menos em tese, na solução do litígio frente ao outro litisconsorte eventual ou alternativo.

Daí que, por obséquio também à maior amplitude possível que se possa conferir ao contraditório e ao efetivo diálogo entre todas as partes e o juiz, se recomenda a oitiva de todos os litisconsortes eventuais ou alternativos para o caso de a desistência da ação manifestada pelo autor endereçar-se a apenas um ou alguns dos demais litisconsortes.

Esse mesmo problema pode ser vislumbrado no âmbito do litisconsórcio sucessivo, na hipótese em que o autor procure desistir da ação quanto ao litisconsorte em relação a quem se afirma a titularidade da relação prejudicial.

Para facilitar a explicação e para bem delinear a necessária distinção que se deve operar, rememore-se o exemplo já citado neste trabalho em que o autor investiga a paternidade em relação ao suposto pai e, sucessivamente, pede alimentos em face dos avós, na consideração de que o pai não ostenta qualquer condição para suportar o encargo alimentar.

Se o autor, nessas condições, desistir da ação em relação aos avós, que são, in statu assertionis, titulares da relação prejudicada (atinente aos alimentos), nenhuma influência isso trará para o suposto pai, vinculado que está à relação prejudicial (investigação de paternidade). Daí que não será necessário ouvi-lo sobre a desistência manifestada pelo autor.

O contrário, porém, não parece ser verdadeiro, já que o destino do pedido atrelado ao suposto pai (investigação de paternidade) influencia o conteúdo da decisão a ser proferida quanto aos avós (pedido de alimentos). Daí que os avós, nesse cenário, ostentam o legítimo interesse em que a relação prejudicial seja mesmo julgada pelo mérito, a fim de que se debele, de uma vez, toda a controvérsia que, na dependência do que se decidir, pode afetar a esfera jurídica deles.

Sendo assim, transparece válida a construção que impõe a oitiva do litisconsorte atrelado ao pedido prejudicado quando se verifique a desistência da ação referentemente ao litisconsorte titular da relação prejudicial, nos moldes preconizados pelo art. $267, \S 4^{\circ}$, do CPC. 


\section{Revelia: reflexos}

Ninguém duvida que a pluralidade de sujeitos no polo passivo da demanda mostrase relevante para o estudo da revelia, a ponto de se alterar a disciplina desta por causa daquela $^{869}$. Antes, porém, de analisar os específicos reflexos que os tipos litisconsorciais eventual, alternativo e sucessivo podem gerar no enfrentamento da revelia, convém relembrar algumas premissas.

A autonomia que envolve a atuação processual de cada litisconsorte encontra sua disciplina legal nos seguintes termos: "Salvo disposição em contrário, os litisconsortes serão considerados, em suas relações com a parte adversa, como litigantes distintos; os atos e as omissões de um não prejudicarão nem beneficiarão os outros" (CPC, art. 48).

Como já se anotou no lugar próprio, as modalidades litisconsorciais aqui investigadas não participam do regime do litisconsórcio unitário, haja vista a desnecessidade de que a decisão de mérito contemple os litisconsortes de modo uniforme no plano da relação de direito material. Assim, os tipos litisconsorciais eventual, alternativo e sucessivo ajustam-se, dentro de conhecida e já mencionada classificação, ao que se denomina litisconsórcio simples ou comum.

Vem de abalizada doutrina a correta afirmação de que a autonomia a que alude o art. 48, do CPC, não prevalece no campo do litisconsórcio unitário e que na esfera do litisconsórcio comum referida autonomia caracteriza-se como relativa ${ }^{870}$. Então, é com base nessa ideia de autonomia relativa que se deve enfrentar a questão pertinente à contumácia de algum litisconsorte passivo no âmbito das modalidades de aglutinação de partes aqui estudadas.

Segundo a dicção do art. 319, do CPC, se o réu não contestar a ação, reputar-se-ão verdadeiros os fatos afirmados pelo autor. Todavia, no art. 320, inc. I, existe a disciplina conforme a qual a revelia não induz o efeito mencionado no artigo antecedente se, havendo pluralidade de réus, algum deles contestar a ação.

\footnotetext{
${ }^{869}$ CALMON DE PASSOS, José Joaquim. Da revelia do demandado. Salvador: Livraria Progresso Editora, $1960, \mathrm{n}^{\circ} 25$, p. 63.

870 DINAMARCO, Cândido Rangel. Litisconsórcio, cit., $\mathrm{n}^{\mathrm{o}}$ 62, p. 146. Mais amplamente, cfr. DINAMARCO, Cândido Rangel. Instituições de direito processual civil, cit., vol. II, nº 571, p. 354 et seq.
} 
À luz da doutrina, e a despeito da singeleza com que a questão vem tratada pela legislação, pode-se dizer que na generalidade dos casos de litisconsórcio comum (não unitário) a revelia de um dos réus enseja a procedência do pedido do autor em relação a esse réu que não contestou, muito embora o juiz possa, quanto aos demais litisconsortes passivos, julgar segundo a convicção que vier a ser formada mediante a livre apreciação dos dados probatórios constantes dos autos, circunstância que permitirá diversidade de conteúdo no pronunciamento em relação ao revel e em relação ao comparecente ${ }^{871}$.

Todavia, se se estiver diante de litisconsórcio unitário, o comportamento determinante (ou causativo) advindo da revelia de um dos litigantes não gera o efeito típico consubstanciado na presunção de veracidade dos fatos afirmados pela parte contrária. É que esse efeito típico só decola quando a conduta causativa é praticada pela totalidade dos litisconsortes. Sendo assim, na presença de revelia de um ou alguns dos litisconsortes passivos unitários (mas não de todos), o pronunciamento de mérito haverá de ser uniforme para todos os litisconsortes, de modo que o julgador acolherá ou rejeitará o pedido “de acordo com a convicção que haja formado, valorando livremente as provas ${ }^{\text {} 872}$.

Transpondo a questão para o âmbito do litisconsórcio eventual, alternativo e sucessivo, tem-se que o regime comum (não unitário) desses tipos litisconsorciais induz à conclusão de que a conduta causativa pertinente à revelia de um ou de alguns gera os respectivos efeitos típicos apenas em relação aos apanhados em contumácia. E o só fato de os outros colitigantes terem ofertado contestação não irrompe como suficiente para afastar os efeitos típicos advindos da revelia.

Evidente que, tal como já anunciado, a autonomia que se apresenta mais pujante no campo do litisconsórcio comum (não unitário) não chega a ser uma autonomia absoluta. Configura emanação dessa ideia a construção segundo a qual a revelia de um dos litisconsortes passivos também não implica automática procedência, em relação a ele, do pedido formulado pelo autor. Realmente, elide-se o efeito previsto no art. 319, do CPC, quando um dos litisconsortes oferece contestação e sua defesa apresenta fatores comuns em relação à posição jurídica do réu revel ${ }^{873}$.

\footnotetext{
${ }^{871}$ BARBOSA MOREIRA, José Carlos. Litisconsórcio unitário, cit., nº 117, p. 192.

${ }^{872}$ Id., $\mathrm{n}^{\circ} 117$, p. 193. Embora escrevendo sob a égide do CPC/39, CALMON DE PASSOS deixou relevantes lições sobre essa temática (Da revelia do demandado, cit., $\mathrm{n}^{\circ} 25$, p. 63 et seq.).

${ }^{873}$ GIANESINI, Rita. Da revelia no processo civil brasileiro. São Paulo: RT, 1977, p. 87.
} 
É possível, nessas mesmas condições, que os elementos de convicção trazidos com a resposta dos demais litisconsortes e aqueles outros produzidos durante regular instrução gerem no espírito do julgador um juízo contrário àquele resultante da presunção relativa de veracidade decorrente da revelia.

Sendo assim, no campo do litisconsórcio alternativo passivo, por exemplo, a revelia de um contendor não gera a automática procedência do pedido do autor em relação ao réu revel. Figure-se a hipótese, já esmiuçada neste trabalho ${ }^{874}$, de tríplice colisão de veículos em que o autor, duvidando seriamente quanto ao nexo de causalidade, formule pedido condenatório numa modulação subjetivamente alternativa. É bem possível, diante dessa configuração, que a prova levada ao conhecimento do julgador desvele uma realidade diferente daquela extraível da presunção decorrente da revelia. A depender do caso concreto, não se vê impossibilidade de o juiz julgar improcedente o pedido do autor em relação a todos os litisconsortes alternativos ou até mesmo julgar o pedido procedente em relação ao litisconsorte alternativo que ofereceu contestação.

Igualmente, no litisconsórcio eventual passivo pode ocorrer de os elementos trazidos na contestação do litisconsorte subsidiário apresentarem-se aptos a gerar uma crença, pautada na livre valoração da prova, destoante daquele juízo presuntivo de veracidade causado pela revelia do litisconsorte primário. Daí que, novamente a depender da conformação do caso, a revelia de um litisconsorte poderá não evitar o desate de improcedência global dos pedidos formulados pelo autor ou, noutro viés, ensejar a procedência do pedido em relação ao litisconsorte subsidiário (aquele que efetivamente respondeu).

Vale lembrar que a construção de litisconsórcio eventual e de litisconsórcio alternativo lastreia-se na noção de uma dúvida objetivamente aferível que nem sempre recai sobre fatos. Dessa forma, como os efeitos da revelia são sentidos no plano do convencimento do juiz respeitante a fatos, convém afirmar que a contumácia de um ou outro réu pode não surtir efeito algum quanto à solução da controvérsia no plano do direito material.

Seja como for, importante considerar, de outra parte, que a revelia de um ou de alguns dos litisconsortes passivos não tem o condão de ensejar o julgamento antecipado do mérito quando for necessária, em relação aos litisconsortes comparecentes e por força da

${ }^{874}$ Cfr. Cap. III, Parte II, no 20. 
configuração da defesa destes, a produção de provas em etapa posterior àquela prevista no art. 330, do CPC. Em outras palavras, não convém que se opere a cisão do julgamento do mérito nos casos em que seja necessária atividade instrutória posterior para enfrentamento da posição ou situação jurídica de outros litisconsortes. E isso fica bem patente ao se imaginar hipótese de litisconsórcio sucessivo.

\section{Providências preliminares: réplica}

Mais uma vez a possibilidade de antagonismo entre os próprios litisconsortes componentes de um mesmo polo processual enseja modulações procedimentais, no afã de se conferir a maior amplitude possível ao contraditório. Aliás, somente se respeitado esse amplo contraditório é que o juiz terá condições de legitimamente pronunciar-se sobre a integralidade das relações objetiva e subjetivamente complexas trazidas ao seu conhecimento.

A problemática aqui anunciada tem que ver mais precisamente com o litisconsórcio eventual e com o alternativo, pelos motivos tantas vezes aqui admitidos.

Segundo as regras codificadas (CPC, art. 326 e 327), o autor tem direito à réplica quando o réu, na contestação, levanta questões dentre aquelas listadas no art. 301, do CPC, e/ou quando o réu, reconhecendo o fato em que se funda o pleito do autor, afirma outro impeditivo, modificativo ou extintivo do direito do autor (defesa de mérito indireta). Presentes tais circunstâncias, o autor tem o prazo de 10 dias para replicar, valendo lembrar que os prazos dos arts. 326 e 327 não se somam $^{875}$.

Importa observar que esse momento processual designado comumente por réplica vem carregado de significação jurídico-processual, especialmente quando tal manifestação é determinada pela circunstância de o réu ter lançado defesa de mérito indireta (CPC, art. 326). E assim o é porque ao autor incumbe, na réplica, impugnar especificamente cada um dos fatos impeditivos, modificativos ou extintivos narrados pelo réu, sob pena de se atrair a incidência do quanto disposto no art. 302, do CPC (presunção de veracidade dos fatos não

${ }^{875}$ MARINONI, Luiz Guilherme; MITIDIERO, Daniel. Código de Processo Civil comentado artigo por artigo, cit., nota 1 ao art. 327 do CPC, p. 328. 
impugnados $)^{876}$. É verdade que, segundo a sistemática vigente, ao réu incumbe a prova dos fatos impeditivos, modificativos ou extintivos, nos termos do art. 333, II, do CPC, mas o certo é que esse ônus só vem a pelo caso as circunstâncias fáticas levantadas pelo réu tenham sido impugnadas pelo autor.

Se o quanto está dito até aqui for correto, afigura-se lícito construir uma peculiar interpretação quando se está diante de litisconsórcio eventual ou de litisconsórcio alternativo.

Com efeito, a possível litigiosidade que surgir entre tais litisconsortes traz ínsito o convite a que os colitigantes manifestem-se uns sobre as alegações dos outros, como forma de se concretizar o contraditório à base do qual o juiz estará legitimado a se pronunciar sobre a totalidade do litígio.

Realmente, a dúvida objetiva que envolve a situação dos litisconsortes passivos, nas modalidades eventual e alternativa, pode muito bem fazer com que um lance argumentos tendentes a demonstrar que a titularidade passiva da relação de direito material discutida no processo pertença ao outro. E esse outro litisconsorte pode também expor argumentação direcionada a demonstrar exatamente o contrário do que propagou aquele.

É desse embate de alegações e do quanto um corréu arguir em face das teses defensivas do outro que o juiz terá condições de bem dispor sobre os pontos controvertidos e, assim, delinear os limites adequados da instrução. Mais que isso, advém dessa abertura de oportunidade de manifestação entre os corréus a concretização do amplo contraditório e, ao final, a viabilização de que o julgador esteja apto a se pronunciar sobre a globalidade do litígio.

A postura interpretativa aqui proposta pode ser facilmente inferida a partir da diretriz procedimental que o CPC prevê para a denunciação da lide pelo autor, lembrandose, ainda uma vez, que o litisconsórcio eventual assemelha-se muito a essa modalidade de intervenção de terceiros. Lá, como se sabe, o réu (adversário direto do denunciante) é citado para responder aos termos da demanda só depois da citação e da eventual resposta apresentada pelo denunciado (CPC, art. 74, in fine), exatamente porque este pode agregar fundamentos reforçadores da tese de que o pedido do autor deve mesmo ser acolhido em

\footnotetext{
${ }^{876}$ MARINONI, Luiz Guilherme; MITIDIERO, Daniel. Código de Processo Civil comentado artigo por artigo, cit., nota 1 ao art. 327 do CPC, p. 328.
} 
face do réu, evitando-se, assim, a sucumbência do autor quanto ao réu, circunstância que afasta a apreciação da lide secundária endereçada ao denunciado.

Diante dessas considerações, a proposta aqui anunciada não repugna ao sistema processual legislado já em vigor e, a par disso, põe em pedestal a necessária concretização do indispensável e amplo contraditório entre todos os litigantes. Essa construção também tem a vantagem de se apresentar em linha de conformação com a tendência moderna de um processo civil cooperativo.

Mesmo que para o litisconsórcio alternativo não se tenha uma referência procedimental equivalente àquela que a denunciação da lide pelo autor confere ao litisconsórcio eventual, o certo é que essas duas modalidades litisconsorciais, no que interessa para o aspecto procedimental, guardam similitudes tais que permitem estender a disciplina de um ao outro. Em outras palavras, se a réplica entre os litisconsortes primário e subsidiário, pelos motivos já expostos, torna-se indispensável no campo do litisconsórcio eventual, não há motivos para que se entenda de modo diverso nos quadrantes do litisconsórcio alternativo.

De outra parte, quando essas modalidades litisconsorciais advierem do manejo de reconvenção subjetivamente ampliativa o mesmo deve suceder. Cada um dos componentes do polo passivo da reconvenção haverá de ter oportunidade para falar sobre o conteúdo da contestação do outro reconvindo, tudo a depender do nível de litigiosidade que se instale entre eles. Ou seja, haverá necessidade de réplica entre os reconvindos.

Noutra perspectiva, procurou-se demonstrar anteriormente a viabilidade de formação de litisconsórcio ulterior nas modalidades aqui estudadas. Seguindo essa trilha, convém agora relembrar que o litisconsórcio passivo ulterior pode eclodir depois de já apresentada contestação pelo réu originário. Nessa hipótese, e mais uma vez na suposição de antagonismos entre o litisconsorte primário e o subsidiário e também entre os litisconsortes alternativos, razoável parece oportunizar ao réu que por primeiro apareceu no polo passivo da demanda a ocasião adequada para se manifestar sobre o conteúdo da contestação porventura apresentada pelo réu que por último ingressou no processo. Seria o mesmo que conceder àquele o direito à réplica frente à contestação do outro litisconsorte.

Em síntese, as modalidades litisconsorciais eventual e alternativa ensejam um convite à reflexão sobre a necessidade de um efetivo contraditório que se deve instalar entre os colitigantes. Mesmo que sejam componentes do mesmo polo na relação 
processual, aos corréus formadores de litisconsórcio eventual ou alternativo se deve oportunizar espaço para réplica em relação à contestação um do outro.

\section{Saneamento: postura do juiz}

Sabe-se que no procedimento comum ordinário - que vem sendo o referencial básico do quanto se expõem - a ocasião adequada para se ter o saneamento do processo dáse na audiência preliminar (CPC, art. 331, $\S 2^{\circ}$ ). Todavia, o sistema legislado consente que em certos casos tal audiência não seja designada (CPC, art. $331, \S 3^{\circ}$ ), de sorte que a atividade judicial em termos de saneamento do processo traduzir-se-á em decisão lançada fora da audiência, dando margem ao que comumente se chama de despacho saneador ${ }^{877}$.

Seja como for, interessante vislumbrar as nuances que a formação das modalidades litisconsorciais aqui estudadas pode ensejar nessa fase preponderantemente saneadora.

Rememore-se que na base de conformação do litisconsórcio eventual e do alternativo radica a noção de dúvida objetivamente aferível sobre circunstâncias fáticas e/ou jurídicas relacionadas com a titularidade da relação de direito material que se quer discutir no processo. De outro lado, no litisconsórcio sucessivo patenteia-se um nexo de prejudicialidade entre as relações substantivas referenciadas a sujeitos diversos.

Cabe ainda ter em mente que a vantagem da construção dessas modalidades litisconsorciais reside na possibilidade de o julgador apreciar, pelo mérito, a máxima porção possível do litígio global trazido ao seu conhecimento, aproveitando-se da convicção única formada pelo embate argumentativo dos litigantes e do arsenal probatório constituído no decorrer do iter procedimental. Pretende-se, como já tantas vezes anunciado, evitar-se a renovação de demandas e, com isso, concretizar-se o princípio da razoável duração dos processos em geral.

Presentes tais premissas, oportuno observar que o juiz, ao se deparar com a fase preponderantemente saneadora, haverá de adotar uma postura que seja conforme aos

\footnotetext{
${ }^{877}$ Não se quer dizer, com isso, que o pronunciamento judicial a esse respeito seja traduzido em verdadeiro “despacho"; trata-se, a rigor, de decisão saneadora, consoante já ensinava GALENO LACERDA em seu famoso Despacho saneador. 3. ed. Porto Alegre: Sergio Fabris, 1990, p. 12. Portanto, utilizou-se a expressão “despacho saneador” apenas em homenagem à tradição.
} 
objetivos da construção litisconsorcial objeto deste estudo. Mas essa noção precisa ser mais bem explicitada.

Partindo-se do referencial do litisconsórcio eventual e do alternativo, é bem possível que o juiz, no momento de promover a atividade saneadora, depare-se com alegações sobre a ilegitimidade de partes, sob o argumento de não haver a propalada dúvida objetivamente aferível acerca de circunstâncias fáticas ou jurídicas.

No campo do litisconsórcio sucessivo também se mostra possível que o julgador deva enfrentar alegações pertinentes à ausência do nexo de prejudicialidade que dá margem à formação desse tipo litisconsorcial.

Diante dos cenários acima apresentados e considerados os objetivos definidos em relação à construção litisconsorcial aqui estudada, convém que o juiz analise os aspectos relacionados à admissibilidade do prosseguimento do processo sem se aprofundar no exame da dúvida objetiva - que dá contornos aos litisconsórcios eventual e alternativo - e na análise da efetiva presença de prejudicialidade - que sustenta a construção do litisconsórcio sucessivo.

Vale a pena novamente acentuar quanto à razoabilidade de se aplicar um raciocínio de base hipotética, isto é, partindo-se das afirmações da parte que construiu as modalidades litisconsorciais objeto deste estudo, permitindo-se ao juiz, nessa fase, uma análise superficial dos elementos de convicção até então disponíveis.

Se à luz das afirmações das partes e dos elementos de convicção analisados mediante cognição rasa o juiz não puder, de pronto, afastar a dúvida objetiva conotada com a ideia de litisconsórcio eventual ou alternativo, bem assim o nexo de prejudicialidade imbricado com a noção de litisconsórcio sucessivo, impõe-se um juízo positivo quanto à admissibilidade do julgamento do mérito ${ }^{878}$.

O problema parece ficar mais agudo quando, no litisconsórcio eventual ou no alternativo, o juiz depara-se com a dúvida objetiva afirmada a partir de disceptações na interpretação jurídica relacionada a algum tema que, a depender da solução interpretativa, gera consequências sobre pessoas diversas.

\footnotetext{
${ }^{878}$ Acerca dos elementos sobre os quais o juiz deve se debruçar na análise da admissibilidade das espécies litisconsorciais aqui estudadas, cfr. $\mathrm{n}^{\circ} 45$, supra.
} 
Para exemplificar, lembre-se da discussão em torno dos efeitos da emancipação em tema de responsabilidade civil $^{879}$, de cujo encaminhamento pode surgir diversidade de responsáveis civis, dando azo à formação de litisconsórcio eventual nos termos seguintes: o autor formula pedido primário em face dos pais e, para a hipótese de rejeição desse pedido com base na suposta eficácia jurídica da emancipação, formula também pedido subsidiário em face do filho emancipado.

$\mathrm{Na}$ fase saneadora, diante das argumentações jurídicas dos corréus e mesmo sem aprofundamentos em termos de cognição acerca dos fatos, o juiz pode estar convencido de que o encaminhamento jurídico da questão aponta para a responsabilidade civil de um dos litisconsortes (os pais ou o filho). Nessa conformação, qual a postura que se espera do juiz? Afasta, desde logo, um desses corréus do processo ou determina o prosseguimento rumo à sentença de mérito em relação a todos?

Parece razoável entender que o juiz deva indagar tão somente sobre se existe ou não, em termos objetivos, a dúvida em torno daquela questão jurídica da responsabilização civil deste ou daquele sujeito. Pressuposta a dúvida objetivamente aferível, independentemente da postura interpretativa que o juiz entenda mais correta, impõe-se que o julgador não estanque o iter procedimental em relação a um ou alguns dos litisconsortes nessa fase intermediária do processo.

Em outros termos, ainda que o juiz esteja convicto sobre a ausência de responsabilidade civil dos pais, por exemplo, deve ele atentar, mesmo assim, para o fato de que efetivamente existe uma celeuma objetivamente aferível dentro do sistema jurídico que precisa ser resolvida não prematuramente, mas sim por ocasião do julgamento do próprio mérito da causa, em termos de definitividade.

Tal como se tem no campo da fungibilidade recursal, a dúvida objetiva sobre o cabimento deste ou daquele recurso, por si só, faz com que se aceite um recurso pelo outro, mesmo que o julgador que vá apreciar o recurso esteja - ele próprio - convicto do cabimento de um só dos recursos. O que importa, como se vê, não é a dúvida subjetiva do julgador, o qual, aliás, pode não ter dúvida alguma! A celeuma está no sistema e tal constatação não pode ficar ao largo do raciocínio judicial em torno do cabimento deste ou daquele recurso.

${ }^{879}$ Cfr. Cap. III, Parte II, no 17. 
É essa análise que fomenta a percepção que aqui se constrói em torno do juízo de admissibilidade do litisconsórcio eventual ou alternativo lastreado na noção de dúvida objetivamente aferível sobre questões jurídicas.

Assim, no tema das modalidades litisconsorciais em que pressuposta a dúvida objetiva, afigura-se mais acertada a postura que não se coloque em rota de colisão com aquele objetivo primordial de toda a construção litisconsorcial aqui estudada, que é o de um julgamento de mérito mais amplo possível, construído a partir de convicção única respeitante a uma relação de direito material objetiva e subjetivamente complexa.

\section{Instrução: peculiaridades}

Mesmo que não se estivesse diante das peculiaridades dos tipos litisconsorciais aqui investigados já se teria bastante espaço para elucubrações em torno da influência que um litígio subjetivamente complexo deita sobre a conformação da instrução. Em grande medida, o estado de perplexidade que se abate sobre o intérprete advém da aparente autonomia absoluta dos comportamentos processuais dos litisconsortes em tema probatório.

Contudo, a despeito dos termos com que vazada a diretriz do art. 48, do $\mathrm{CPC}^{880}$, consente-se com a ideia de que o dispositivo é condutor de um exagero que não se harmoniza com o sistema processual analisado como um todo ${ }^{881}$.

Em síntese, no campo do convencimento judicial, o comportamento mais ou menos diligente de um dos litisconsortes pode sim influenciar a situação do(s) outro(s), sobretudo na consideração de que a prova, uma vez produzida, é adquirida pelo processo ${ }^{882}$ e, além disso, o convencimento judicial forma-se livremente à luz da prova constante dos autos, sendo indiferente se o elemento de convicção produziu-se por ato desta ou daquela parte, ou mesmo por iniciativa do próprio juiz ${ }^{883}$.

\footnotetext{
880 "Salvo disposição em contrário, os litisconsortes serão considerados, em suas relações com a parte adversa, como litigantes distintos; os atos e as omissões de um não prejudicarão nem beneficiarão os outros". ${ }^{881}$ DINAMARCO, Cândido Rangel. Instituições de direito processual civil, cit., vol. II, nº 571, p. 354.

${ }^{882}$ CAMBI, Eduardo. A prova civil: admissibilidade e relevância. São Paulo: RT, 2006, p. 319 et seq.

${ }^{883}$ É o que se extrai da dicção do art. 131, do CPC, consagrador do princípio do livre convencimento motivado.
} 
A partir desse influxo é que se propõe analisar alguns pontos sensíveis da instrução probatória na presença de litisconsórcio eventual, alternativo e sucessivo.

Seguindo a ordem com que os vários temas probatórios aparecem no CPC, principia-se pela análise do depoimento pessoal. Nos termos da matriz legislativa, compete a cada parte requerer o depoimento pessoal da outra, a fim de interrogá-la na audiência de instrução e julgamento (CPC, art. 343, caput).

Levando-se em conta que o depoimento pessoal consiste no meio de prova destinado a obtenção de confissão da parte adversa ${ }^{884}$, vem à baila a indagação sobre se não seria adequado admitir-se o requerimento de depoimento pessoal por um litisconsorte em relação ao outro.

Para os casos de litisconsórcio em geral, doutrina e jurisprudência orientam-se no sentido da inadmissibilidade de "o litisconsorte pedir o depoimento pessoal do seu colitigante ${ }^{885}$, situação que até poderia se sustentar caso o litisconsórcio não pudesse abrigar verdadeiro litígio entre os componentes do mesmo grupo litisconsorcial.

Porém, como tantas vezes já referido, os tipos litisconsorciais aqui estudados abrigam um possível grau de antagonismo entre os próprios colitigantes, circunstância que fica bem saliente no âmbito do litisconsórcio passivo eventual ou alternativo.

Presente essa peculiar característica, sente-se à vontade para sugerir, em tom de evolução quanto ao que já se construiu nos pretórios e na doutrina, o entendimento de que os litisconsortes, nas modalidades objeto deste estudo, estão autorizados a requerer o depoimento pessoal um do outro, já que, em certa medida, o índice de conflituosidade que os abarca pode tranquilamente guindá-los à condição de adversários $^{886}$. E essa postura

${ }^{884}$ LOPES, João Batista. A prova no direito processual civil. 3. ed. São Paulo: RT, 2007, p. 102. Vale lembrar, por oportuno, que o depoimento pessoal difere do chamado interrogatório livre, que se traduz em “expediente utilizado pelo juiz para aclarar pontos duvidosos ou obscuros das alegações e das provas” (id., p. 107).

${ }^{885}$ RTJ 107/729 e RT 581/235, apud NEGRÃO, Theotonio; GOUVÊA, José Roberto F.; BONDIOLI, Luis Guilherme A. Código de Processo Civil e legislação processual vigor, cit., nota 3a ao art. 343, do CPC, p. 454. Na doutrina, cfr. NERY JUNIOR, Nelson; ANDRADE NERY, Rosa Maria de. Código de Processo Civil comentado e legislação extravagante, cit., nota 2 ao art. 343, do CPC, p. 619.

886 Embora partindo de premissa diversa daquela adotada neste trabalho (noção de litisconsórcio), MARINONI e MITIDIERO consentem que a presença de "interesses divergentes" entre os componentes do 
interpretativa, além de não se chocar com o sistema legislado em vigor, ostenta a vantagem de se conformar com a opção metodológica de incremento do contraditório e, por conseguinte, de se afinar também com a noção de amplo direito de provar.

Numa outra ordem de ideias, é preciso também pensar nas particularidades que envolvem o intrincado tema da confissão, pois que, segundo a dicção legal, a confissão judicial faz prova contra o confitente, não prejudicando, todavia, os litisconsortes (CPC, art. 350, caput). Daí o inegável e necessário diálogo entre as modalidades de litisconsórcio aqui estudadas e o tema da confissão.

Muito embora se ache em doutrina a percepção de que a confissão judicial vincula inescapavelmente o juiz ${ }^{887}$, parece lícito crer que as coisas não se passam realmente assim, forte na premissa de que a convicção judicial forma-se livremente à luz de todo o arsenal probatório existente nos autos, não sendo a confissão a rainha das provas ${ }^{888}$.

No âmbito específico do litisconsórcio, adere-se à posição consoante a qual a eficácia da confissão depende mais da força persuasiva que se lhe empresta do que da apreciação do tipo de litisconsórcio que se forma (se unitário ou comum). Por isso é que, seja lá qual for o tipo litisconsorcial com que se trabalhe ${ }^{889}$, a confissão de um litisconsorte

"mesmo pólo processual" autoriza uma das partes a pedir o depoimento pessoal da outra (Código de Processo Civil comentado artigo por artigo, cit., nota 2 ao art. 343, p. 347).

${ }^{887}$ ARAujo CINTRA, Antonio Carlos de. Comentários ao Código de Processo Civil. Rio de Janeiro: Forense, 2000, vol. IV, n ${ }^{\circ}$ 51, p. 64. Sem discrepar, AMARAL SANTOS ensinava: "Pela confissão, expressa e clara, a certeza moral buscada pela instrução da causa é substituída pela certeza legal, a que o juiz não pode repelir" (Prova judiciária no cível e comercial. 2. ed. São Paulo: Max Limonad, 1954, vol. II, p. 255).

${ }^{888}$ Aliás, parece prevalecer na doutrina a noção segundo a qual a confissão nem se constitui em efetivo meio de prova (LOPES, João Batista. A prova no direito processual civil, cit., p. 99; DINAMARCO, Cândido Rangel. Instituições de direito processual civil, cit., vol. III, no 812, p. 98-99). Segundo a percepção de MARINONI e de ARENHART, a confissão ostenta dupla natureza, sendo, ao mesmo tempo, uma declaração de ciência sobre fato e uma manifestação de vontade. Daí que, para o aludido autor, a confissão vincula o confitente em virtude do aspecto volitivo de que se impregna o ato, de sorte que o confitente não teria legítimo interesse em produzir prova contrária ao que consta da confissão. Porém, tal vinculação não atingiria o juiz, forte no princípio da persuasão racional (Prova. São Paulo: RT, 2009, p. 436-437). Em sentido diverso, CÂNDIDO DINAMARCO, calcado em lições de CARNELUTTI e de LIEBMAN, não vê declaração de vontade no ato da confissão (Instituiçães de direito processual civil, cit., vol. III, $\mathrm{n}^{\circ} 1.195$, p. 650-651), razão pela qual seria possível ao confitente pretender produzir provas contrárias ao conteúdo do que se declarou no ato da confissão.

${ }^{889}$ DINAMARCO, Cândido Rangel. Instituições de direito processual civil, cit., vol. III, nº 1.199, p. 658. 
pode sim prejudicar seus pares, tudo na dependência do "valor que o juiz empreste a essa confissão" ${ }^{, 890}$.

O exemplo figurado por CÂNDIDO DINAMARCO parece bem elucidar essa questão: "Movo demanda ao dono de um veículo e à pessoa que o dirigia, em relação a um acidente de que fui vítima. Um deles confessa a conduta culposa alegada na inicial e outro, não. Apesar de esse ser um litisconsórcio desenganadamente comum, não unitário, a sentença só pode concluir que a culpa do condutor do veículo houve, ou que não houve" ${ }^{891}$. Nessas condições, o pronunciamento judicial não pode em seu próprio seio conter "a afirmação e a negação do mesmo fato, o que seria um grande absurdo, desmerecedor da credibilidade do Poder Judiciário",892.

Então, mesmo diante da consideração de que as modalidades litisconsorciais aqui estudadas estejam no âmbito do litisconsórcio comum (não unitário), é de se entender que a confissão de um litisconsorte pode ou não influenciar a convicção do juiz no que pertine aos outros colitigantes, tudo na dependência do valor que essas informações infundirem no espírito do julgador, mediante o cotejo com os demais elementos de convicção levados à apreciação judicial.

Se o que se vem de dizer estiver correto, pode-se entender que a confissão do litisconsorte primário sobre os fatos contra si afirmados não impede que as impugnações lançadas pelo litisconsorte subsidiário sejam levadas em conta pelo julgador, a ponto de, se for o caso, suplantar-se a confissão e se formar um convencimento diverso daquele que resultaria dos termos da confissão. Semelhantemente, a confissão externada pelo litisconsorte subsidiário sobre algum aspecto que seja comum ao litisconsorte primário pode render ensejo a que tal declaração erija-se como elemento apto a convencer o julgador quanto à procedência do pedido veiculado ao litisconsorte primário.

No âmbito do litisconsórcio alternativo, em que se mostra indiferente para o(s) autor(es) o acolhimento do pedido em relação a este ou àquele litisconsorte, a confissão de um litisconsorte não se traduz em obstáculo intransponível a que o julgador se convença opostamente à versão fática derivada da confissão. Num caso de litisconsórcio alternativo passivo, nada impede que, a despeito da confissão de um litigante, o juiz julgue

\footnotetext{
${ }^{890}$ MARINONI, Luiz Guilherme; ARENHART, Sérgio Cruz. Prova, cit., p. 447.

${ }^{891}$ Instituições de direito processual civil, cit., vol. III, nº 1.199, p. 658.

${ }^{892}$ Id., ibid.
} 
improcedente o pedido em relação a todos os litisconsortes alternativos, isso com base nos elementos de convicção trazidos pelo(s) outro(s) litisconsorte(s).

Semelhante constatação se verifica no espectro do litisconsórcio sucessivo. Reafirmada a noção de que tal modalidade litisconsorcial caracteriza-se pelo nexo de prejudicialidade que envolve as situações de direito material relacionadas aos litisconsortes, mostra-se lícita a conclusão de que a confissão de um pode não ser suficiente para ensejar o acolhimento do pedido mesmo em relação ao confitente ou, então, a depender do caso concreto, pode até redundar no acolhimento do pedido em relação a outro litisconsorte.

Ainda segundo a diretriz que norteia grande parte da construção aqui engendrada (ampla possibilidade de participação em contraditório), admite-se que cada litisconsorte (eventual, alternativo ou sucessivo) ostenta legitimidade e interesse para pedir a exibição de documentos em face do outro. Pense-se, numa exemplificação de litisconsórcio passivo eventual, no caso em que o autor (que se diz credor) duvide sobre a eficácia de uma assunção de dívida, dada a presença de sinais de insolvência do assuntor, circunstância que era desconhecida do credor ao tempo da assunção (art. 299, do Código Civil) ${ }^{893}$. Na demanda em que sejam réus o assuntor (litisconsorte primário) e o primitivo devedor (litisconsorte subsidiário), é bem possível que os demandados digladiem-se em torno de quem seja o efetivo responsável pelo cumprimento da obrigação transmitida.

Daí que, para debelar a dúvida em torno daquele afirmado e suspeito estado de insolvência do assuntor, do qual supostamente o credor desconhecia ao tempo da transmissão, parece válido trabalhar com a hipótese de um litisconsorte almejar a exibição de documento que esteja em poder do outro colitigante, podendo-se extrair da ausência injustificada da exibição a consequência prevista na cabeça do art. 359, do CPC. Como facilmente se pode inferir, tal estado de coisas certamente serviria como importante dado influenciador do convencimento judicial.

No campo estrito da prova documental, interessante é observar que o antagonismo já referido anteriormente também dá margem a que um dos litisconsortes apresente documento "contra o outro" 894 , hipótese em que se poderia falar, validamente, no

\footnotetext{
${ }^{893}$ Tal assunto foi examinado na Parte II, Cap. III, $\mathrm{n}^{\mathbf{o}} 24$.

${ }^{894}$ A expressão vem inspirada pela dicção do art. 390, do CPC, assim redigido: “O incidente de falsidade tem lugar em qualquer tempo e grau de jurisdição, incumbindo à parte, contra quem foi produzido o documento,
} 
cabimento do incidente de falsidade manifestado por um litisconsorte em face do outro. $\mathrm{O}$ exemplo que serviu para ilustrar a hipótese de exibição de documentos entre os litisconsortes (dúvida sobre a eficácia jurídica da assunção de dívida) também se afigura adequado para demonstrar o quanto se vem de dizer em tema de arguição de falsidade documental.

Com efeito, o documento juntado pelo primitivo devedor (litisconsorte subsidiário no exemplo acima figurado) com intuito de demonstrar a ciência prévia do credor sobre o estado de insolvência do assuntor poderia muito bem ser alvo de arguição de falsidade pelo litisconsorte primário (assuntor), já que este tem interesse em demonstrar a tese de que a eficácia da cessão de débito não incidiu no caso concreto, sendo a dívida, pois, de inteira responsabilidade do primitivo devedor (litisconsorte subsidiário) ${ }^{895}$.

E é sob o influxo dessas mesmas ideias que se impõe a abertura de oportunidade para que, em relação aos documentos juntados por um dos litisconsortes, tanto a parte contrária quanto os demais litisconsortes se manifestem, ex vi do art. 398, do CPC.

Versando sobre a prova testemunhal, o legislador disciplina que é lícito à parte contraditar a testemunha, arguindo-lhe a incapacidade, o impedimento ou a suspeição (CPC, art. 414, $\S 1^{\circ}$ ). A despeito das disceptações que pairam sobre a possibilidade de a parte que arrolou a testemunha poder ou não contraditá-la ${ }^{896}$, parece estar fora de dúvida que os litisconsortes têm legitimidade e interesse para impugnar a oitiva de testemunhas arroladas pelos outros colitigantes, sempre na consideração de que os elementos de convicção apresentados por um dos litisconsortes pode influenciar significativamente a posição processual do(s) outro(s) e, especialmente, o destino do próprio julgamento do mérito.

suscitá-lo na contestação ou no prazo de 10 (dez) dias, contados da intimação da sua juntada aos autos" ênfase proposital.

895 Tratando da legitimidade e do interesse para o manejo do incidente de falsidade, MARINONI e ARENHART expõem lição que se presta a incrementar a postura argumentativa aqui defendida: "Da mesma forma, pode acontecer que o litisconsorte daquele contra quem foi apresentado o documento seja admitido a oferecer a impugnação. Isso somente ocorrerá se o documento possa vir a influenciar, de alguma maneira, o seu específico interesse na demanda, afetando a situação de sua pretensão ou de sua defesa. Não poderá, portanto, o litisconsorte daquele a quem prejudica o documento oferecer o incidente, se essa prova não gerar nenhum reflexo para a sua própria situação processual" (Prova, cit., p. 673).

${ }^{896}$ AMARAL SANTOS, Moacyr. Prova judiciária no cível e comercial, cit., vol. III, no 199, p. 396-397; LOPES, João Batista. A prova no direito processual civil, cit., p. 152. 
Por fim, consciente de que o rol de hipóteses ora levantado não é exaustivo e nem abarca toda a potencialidade de problemas que as modalidades litisconsorciais aqui estudadas podem gerar em tema probatório, há de ser lembrado, ainda, que em tema de prova pericial os litisconsortes gozam da prerrogativa de indicar seus próprios assistentes técnicos. Então, diferentemente do que ocorria conforme a redação originária do $\S 2^{\circ}$ do art. 421 do CPC, não mais se exige que todos os litisconsortes estejam concordes quanto ao nome do assistente técnico único e que, na falta de concordância, seja adotada a posição da maioria ou, em caso de empate, que se apele para o sorteio ${ }^{897}$.

Sendo assim, diante da modificação legislativa operada pela Lei $\mathrm{n}^{\circ}$ 8.455/92, que conferiu nova redação ao dispositivo acima citado, não há mais espaço para dúvidas, em ordem a se concluir que cada um dos litisconsortes (eventual, alternativo ou sucessivo) terá a prerrogativa de indicar seu próprio assistente técnico, exatamente como sucede na tratativa desse tema em face do litisconsórcio em geral.

\section{Sentença}

O regime jurídico das modalidades litisconsorciais aqui estudadas ainda enseja preocupações quanto ao adequado direcionamento que o julgador deve dar à sentença. Com efeito, depois de superadas as discussões em torno da própria admissibilidade do julgamento do mérito, o juiz é convocado a ditar a solução do caso posto sob sua apreciação, enfrentando, agora não mais in status assertionis, as questões imbricadas com a dúvida objetivamente aferível (no litisconsórcio eventual e no alternativo) e com a prejudicialidade (no litisconsórcio sucessivo). Nesse passo culminante do procedimento em primeiro grau de jurisdição, deve-se então resolver ou debelar a dúvida objetiva tantas vezes aqui referida e, noutra perspectiva, verificar a efetiva existência da prejudicialidade e suas reais consequências.

\footnotetext{
${ }^{897}$ A antiga redação era a seguinte: "Havendo pluralidade de autores ou de réus, far-se-á a escolha pelo voto da maioria de cada grupo; ocorrendo empate, decidirá a sorte”. PONTES DE MIRANDA, em comentário a esse dispositivo, assim apregoava: "Quem indica o assistente técnico é a parte. Autor e réu indicam as pessoas que querem, ou, se chegarem a acordo, um só assistente técnico. Se há pluralidade de autores, têm eles de resolver pelo voto da maioria; se há empate, sorteia-se, com os nomes dos indicados. Dá-se o mesmo se a pluralidade é de réus. Observa-se que se trata de matéria do interesse de todos os autores, ou de todos os réus" (Comentários ao Código de Processo Civil, cit., t. IV, p. 480).
} 
À primeira vista, não se enxergariam grandes complicações nesse exercício de solucionar as questões acima mencionadas. Todavia, algumas perplexidades podem ser divisadas e o debate doutrinário sobre as próprias noções de litisconsórcio eventual e alternativo, por exemplo, conduzem a enfrentamentos e a soluções diversos no campo da sentença e de seus possíveis e variados capítulos.

Mais uma vez por simples comodidade, inicia-se a discussão pelo prisma do litisconsórcio sucessivo, envolto na já conhecida noção de prejudicialidade. Vale, então, lembrar que nessa modalidade litisconsorcial o que se pretende é que o julgador aprecie o mérito de todos os pedidos e em relação a todos os litigantes, com a peculiaridade de que o acolhimento de um primeiro pedido, relacionado a um determinado sujeito, condiciona o teor do julgamento pertinente a um pedido sucessivo e relacionado a sujeito diverso daquele.

Partindo-se, então, da premissa de que todos os requisitos de admissibilidade do julgamento do mérito estejam presentes, o julgador poderá deparar-se, à luz do caso concreto e na hipótese específica de litisconsórcio sucessivo, com as seguintes possibilidades de julgamento do mérito: (a) acolhimento, parcial ou integral, do pedido prejudicial (condicionante) e acolhimento também do pedido prejudicado (condicionado), parcial ou integralmente; (b) acolhimento, parcial ou integral, do pedido prejudicial e rejeição do pedido prejudicado; (c) rejeição de todos os pedidos.

Evidentemente que, em razão do vínculo de prejudicialidade que enlaça os litisconsortes sucessivos, não se mostra possível, a rigor, a rejeição do pedido condicionante e o acolhimento do pedido condicionado. Advirta-se, porém, na esteira do que já se defendeu alhures ${ }^{898}$, que o vínculo de prejudicialidade afirmado como justificativa para o desenvolvimento da demanda mediante litisconsórcio sucessivo pode ser reputado, quando da sentença, inexistente. Então, só na hipótese por último figurada é que se poderia cogitar de a rejeição do primeiro pedido não impedir o acolhimento do pedido sucessivo.

Para bem discernir as hipóteses em que a prejudicialidade vem afirmada e fica efetivamente caracterizada - e essa é a situação que interessa para desenvolvimento da investigação aqui proposta -, convém relembrar exemplos emblemáticos de litisconsórcio sucessivo verificado no polo ativo e no passivo: (i) mãe e filho pleiteiam, num só processo

${ }^{898}$ Cfr. no 45, “i”, supra. 
(daí o litisconsórcio), o reconhecimento da paternidade que se relaciona ao filho e, para a hipótese de procedência desse pedido condicionante, a condenação do pai ao ressarcimento das despesas que a mãe experimentou com o parto; (ii) o filho ajuíza ação para investigar a paternidade em face do suposto pai e, para a hipótese de procedência desse pleito prejudicial, também pede a condenação dos avós a lhe pagar pensão alimentícia, dada a incapacidade de o pai arcar com o encargo alimentar.

No primeiro caso (litisconsórcio sucessivo ativo), a improcedência do pedido pertinente ao filho inviabiliza por completo o acolhimento do pedido sucessivo, relativo ao ressarcimento das despesas do parto. Já na hipótese de procedência do pedido de investigação de paternidade, abrir-se-á ocasião para acolhimento (mesmo que parcial) ou rejeição do pedido sucessivo relacionado à mãe, tudo na dependência do caso concreto.

Para a segunda hipótese aventada (litisconsórcio sucessivo passivo), a mesma ordem de considerações se mostra possível. Da rejeição do pedido alusivo à investigação de paternidade decorre, inexoravelmente, a improcedência também do pedido sucessivo atrelado aos avós. Porém, se procedente a investigação de paternidade, declarando-se o autor como filho do primeiro réu (suposto pai), abrem-se as portas para a verificação sobre a procedência (ainda que parcial) ou a improcedência do pedido de alimentos formulado aos avós.

Remarque-se que, bem vistas as coisas, não há espaço para que da rejeição (improcedência) do pedido condicionante advenha o não conhecimento do pedido condicionado. Em outros termos, a improcedência do pedido condicionante não torna prejudicado o exame, pelo mérito, do pedido sucessivo (condicionado). E isso é assim em razão da própria noção de prejudicialidade.

Seguindo essa ordem de ideias, mas com ligeira alteração de foco, é chegada hora de tomar partido numa discussão doutrinária que está à base da própria noção de litisconsórcio eventual e de litisconsórcio alternativo, com notáveis reflexos no campo da sentença. Daí que o assunto foi deixado para esse momento da investigação.

Cabe lembrar, apenas de relance, que o litisconsórcio eventual constrói-se mediante a formulação de pedido relacionado a um litigante preferencial e, para o caso de não acolhimento desse pleito, pede-se desde logo a procedência do mesmo ou de outro pedido pertinente a um litigante subsidiário. Pelo prisma do litisconsórcio alternativo, a construção é basicamente a mesma, com a peculiaridade de que entre os colitigantes não há uma 
manifestação de preferência, razão pela qual se trabalha com a formulação de pedidos para que sejam acolhidos em relação a um ou a outro litisconsorte.

Então, as questões a que se propõe debater são aparentemente simples: (a) no litisconsórcio eventual, se julgado procedente o pedido em relação ao litisconsorte primário, o que sucede com o litisconsorte subsidiário? O pedido relacionado a este também é julgado improcedente ou fica prejudicado (sem resolução do mérito)?

Noutro vértice, se o julgador pronuncia a procedência do pedido relacionado a um litisconsorte alternativo, qual destino se dará ao pedido pertinente ao outro litisconsorte alternativo? Será este improcedente ou prejudicado?

Sejam lá quais forem as respostas para os questionamentos supra referidos, ainda se mostra pertinente indagar se e em que medida as respostas alcançadas são invariáveis ou se, na dependência da conformação da relação de direito material agitada sob os auspícios de litisconsórcio eventual ou alternativo, pode haver modulações naquelas respostas.

Antes de investigar as possíveis soluções para tais questões convém sumariar as diversas posições doutrinárias acerca dos temas ventilados, observando-se que tais opiniões já foram, de alguma forma, vistas em outras passagens do texto. Porém, os dados já coletados são agora agrupados e analisados especificamente com vistas a dar suporte ao encaminhamento das respostas às indagações referidas, principiando-se pelo litisconsórcio eventual.

Está bem claro para ALLORIO que o litisconsórcio eventual congrega uma incerteza sobre qual dos pedidos, atrelados a sujeitos diversos, o juiz terá de apreciar pelo mérito ${ }^{899}$. Isto porque, se acolhido o pedido respeitante ao litisconsorte primário, falece interesse processual para o exame do pedido pertinente ao litisconsorte subsidiário. Ou seja, na hipótese de procedência em relação ao litisconsorte primário, o capítulo de sentença relativo ao outro litisconsorte conterá, sempre e sempre, um teor meramente processual, já que o juiz não apreciará o mérito dessa porção subsidiária da demanda ${ }^{900}$.

Nessa configuração, haveria o transporte, puro e simples, das noções de cumulação subsidiária de pedidos para a seara do litisconsórcio eventual. O raciocínio seria assim: haja vista que a procedência do pedido primário (na cumulação de pedidos) importa que o

\footnotetext{
${ }^{899}$ Litisconsorzio alternativo passivo e impugnazione incidentale, cit., p. 516-517.

${ }^{900}$ GIUSEPPE TARZIA, em brevíssimo aceno, deixou transparecer sua inclinação por esse entendimento (Appunti sulle domande alternative, cit., $\mathrm{n}^{\mathrm{o}}$ 7, nota 132, p. 297).
} 
pedido subsidiário resulte prejudicado (não conhecido), o acolhimento do pedido em relação ao litisconsorte primário também prejudica o exame do mérito quanto ao litisconsorte subsidiário.

Conforme já visto anteriormente, ARAKEN DE ASSIS professa que o litisconsórcio eventual justifica-se na medida em que haja uma dúvida acerca da legitimidade ad causam,

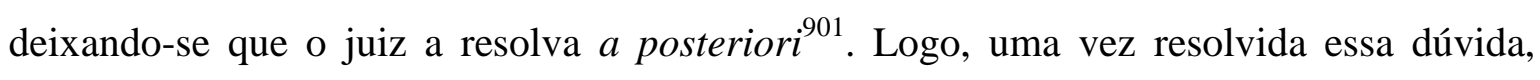
apenas um dos litisconsortes (o primário ou o subsidiário) será efetivamente parte legítima para a causa, impondo-se o não conhecimento do mérito em relação ao outro.

Em CÂNDIDo Dinamarco lê-se passagem, em nota de rodapé, da qual se pode inferir que o autor perfilhou, em algum momento de sua trajetória acadêmica, o entendimento de que a procedência do pleito referente ao litisconsorte primário implica a rejeição, pelo mérito, do pedido relacionado ao colitigante eventual ${ }^{902}$. Para ilustrar seu pensamento, o autor figura o exemplo em que o autor de ação reivindicatória ajuizada em face de determinado sujeito demanda também em face do alienante, buscando indenização deste para o caso de sucumbência em relação àquele. Se o autor sagrar-se vencedor quanto ao primeiro réu (da reivindicatória), não será credor do segundo (alienante) ${ }^{903}$. Daí que, em palavras diretas, a procedência em relação ao litisconsorte primário redunda na improcedência em relação ao subsidiário.

Cumpre anotar, contudo, que em outra conhecida obra, o mesmo autor, sem promover qualquer distinção, aduz que na denunciação da lide pelo autor (assimilável ao litisconsórcio passivo eventual) "sendo julgada procedente a demanda do autor perante o réu, a denunciação da lide feita por aquele [autor] não comportará julgamento pelo mérito, estando também prejudicada" 904 .

\footnotetext{
${ }^{901}$ Do litisconsórcio no Código de Processo Civil, cit., p. 555.

${ }^{902}$ Litisconsórcio, cit., nº 183, nota 154, p. 462-463.

903 O autor referido, na exposição de seu pensamento, trabalha com a hipótese de denunciação da lide em ação reivindicatória, mas aqui se optou por fazer-se a ponte direta com o litisconsórcio eventual, sem o apelo à figura da denunciação. Daí que a exemplificação utilizada no texto é resultado de pequena adaptação, com vistas a facilitar o entendimento, sem deturpar, contudo, o discurso do doutrinador citado. Vale lembrar que CÂNDIDO DINAMARCO faz uma significativa aproximação entre a denunciação da lide pelo autor e o litisconsórcio passivo eventual, lição que também vem adotada neste trabalho.

904 Intervenção de terceiros, cit., $\mathrm{n}^{\circ}$ 86, p. 168 - grifo do original. Nesse passo é preciso observar a advertência feita pelo próprio autor quanto ao tempo em que foi escrito o ensaio sobre a denunciação da lide: "Ele [o ensaio] foi concebido no momento de transição de um Código para outro (1974). (...) Sem embargo
} 
Mais recentemente, CÂNDIDO DINAMARCO voltou ao tema e repetiu o que expôs na obra por último citada. Realmente, em suas Instituições de direito processual civil o autor, sem fazer distinções entre a denunciação pelo autor e a denunciação pelo réu, prega o seguinte: "É claro que, sendo a demanda principal julgada em favor da parte que denunciou a lide ao terceiro, nada tem aquela a receber deste e a litisdenunciação estará prejudicada"905.

Sendo assim, uma leitura atualizada da obra global de CÂNDIDO DinAMARCO permite inferir, diferentemente do que resulta da leitura do seu Litisconsórcio, que o autor propõe o não conhecimento do pedido em relação ao litisconsorte subsidiário caso seja procedente o pedido atrelado ao litisconsorte primário. Isto é, o acolhimento do pleito formulado por ou deduzido contra o litisconsorte primário torna prejudicado o exame do mérito da pretensão atinente ao colitigante eventual ou subsidiário.

Antes de emprestar adesão a essa ou àquela postura interpretativa, impõe-se ainda anunciar o panorama doutrinário que envolve esse mesmo tema, mas agora sob o prisma do litisconsórcio alternativo. E assim deve ser porque as noções desenvolvidas sobre o litisconsórcio alternativo também servem, nalguma medida, para a elucidação de como devem ser as coisas no campo do litisconsórcio eventual.

Nessa outra perspectiva, vem de AlloRIO a advertência segundo a qual, no litisconsórcio alternativo, o acolhimento do pedido em relação a um dos litisconsortes provoca uma superveniente ausência de interesse processual quanto aos outros colitigantes $^{906}$. Figurando-se uma hipótese de litisconsórcio alternativo passivo, a

da remodelação feita, quero que este seja um estudo do seu tempo, ou seja, uma obra de apresentação do instituto da denunciação da lide quando ela chegou ao direito brasileiro" (id., n ${ }^{\circ} 72$, nota 1, p. 147 - grifou-se propositadamente).

${ }^{905}$ Vol. II, no 607 , p. 420. Convém anotar, ainda, que essa conclusão do autor está calcada na afirmação de que a ação principal e a denunciação da lide estão vinculadas por prejudicialidade, de sorte que - segundo ele - o acolhimento da principal faz com que fique prejudicada a segunda. Ocorre que, em obra diversa dessas até aqui citadas, o mesmo autor parece emprestar ao fenômeno da prejudicialidade outro significado, agora mais coerente com o pensamento corrente na doutrina (Capítulos de sentença, cit., n ${ }^{\circ}$ 15, p. 44-45, texto e nota 20). A par disso, quando o autor refere que um pedido fica prejudicado em virtude do que se decidiu em relação a outro (id., n ${ }^{\circ}$ 15, p. 45), o significado da expressão tem dimensão destoante daquele explicitado em outras obras (Instituições de direito processual civil, cit., vol. II, $\mathrm{n}^{\circ} 607$, p. 420; Intervenção de terceiros, $\mathrm{n}^{\circ} 86$, p. 168).

${ }^{906}$ Litisconsorzio alternativo passivo e impugnazione incidentale, cit., p. 516-517. 
procedência do pedido em face de um dos réus resulta numa "semplice absolutio ab instantia" em relação ao(s) outro(s), provocada por uma "sopravvenuta mancanza d'interesse" ${ }^{907}$. Ou seja, não haverá resolução de mérito no que pertine aos demais réus alternativos, exatamente por força do acolhimento do pedido em relação a outro litisconsorte.

Parece ser este também o pensamento de CÂNDIDO DinAMARCO, o qual faz expressa referência à passagem de ALLORIO acima lembrada. Para justificar sua posição, o doutrinador brasileiro, figurando uma hipótese de litisconsórcio passivo alternativo, esclarece: "ao afirmar que a titularidade da situação de direito material é de um dos réus apenas (...), está o juiz concluindo que perante o outro não há sequer de apreciar o mérito reputando-se prejudicado o pedido em relação a este"908. Ao tratar de hipótese de litisconsórcio alternativo formado no polo ativo, o autor professa que o acolhimento do pedido em relação a um dos litisconsortes desnuda que, em relação aos demais, ocorre ilegitimidade ativa ad causam ${ }^{909}$.

Em formulação divergente, TARZIA propõe que o litisconsórcio alternativo não significa a busca por decisão de mérito sobre uma ou sobre outra demanda atrelada a litigantes diversos. Em verdade, o litisconsórcio alternativo "esprime la richiesta dell'accertamento di entrambe e dell'accoglimento di una sola"910. Ou seja, na hipótese de litisconsórcio ativo alternativo, por exemplo, os autores desejam o enfrentamento da situação substancial de todos, mas consentem, antecipadamente, que só em relação a um deles será acolhido o pedido, rejeitando-se, pelo mérito, em relação aos demais ${ }^{911}$.

\footnotetext{
${ }^{907}$ Litisconsorzio alternativo passivo e impugnazione incidentale, cit., p. 516-517.

${ }^{908}$ Litisconsórcio, cit., n⿳0 183 , nota 154, p. 462 - grifo do original.

${ }^{909}$ Id., $\mathrm{n}^{\mathrm{o}}$ 183, p. 462. Nas Instituições de direito processual civil (vol. II, $\mathrm{n}^{\circ}$ 581, p. 370, texto e nota 29), DINAMARCO volta a afirmar que a incerteza, no litisconsórcio alternativo passivo, gira em torno da legitimidade para agir, de sorte que o pedido do autor consiste em que a sentença "se enderece a um ou outro conforme venha a resultar da instrução do processo e da convicção do juiz". Então, se a sentença “endereçarse" a um, o outro será, conseguintemente, "declarado parte ilegítima para figurar no pólo passivo da relação processual".

${ }^{910}$ Appunti sulle domande alternative, cit., $\mathrm{n}^{\mathbf{0}}$ 7, p. 297.

911 Em outra passagem do mesmo ensaio, TARZIA esclarece que "la soluzione di una questione comune, di diritto o di fatto, è sempre determinante per l'infondatezza dell'una o dell'altra pretesa" (Appunti sulle domande alternative, cit., $\mathrm{n}^{\mathrm{o}}$ 7, p. 297). E conclui refutando a opinião de ALLORIO: "Non ritengo pertanto
} 
Por sua vez, NicOlò TROCKER acentua que é necessário, de partida, ter em devida conta a distinção existente entre a legitimação para agir e a titularidade do próprio direito material. Daí que "a afirmação contida na demanda judicial de que existe uma adequada situação legitimante é, por si só, condição necessária e suficiente para provocar uma pronúncia sobre o mérito da controvérsia"912.

Então, numa construção de litisconsórcio alternativo passivo, o demandante lança afirmações que revelam situações legitimantes imbricadas com a posição de cada um dos litisconsortes alternativos, fundando-se aí a legitimidade ad causam de cada um deles ${ }^{913}$. De modo que a incompatibilidade de pretensões - o julgador só pode acolher uma ou outra, mas não ambas - não gravita em torno da legitimidade para agir, mas sim e tão somente "quanto alla loro fondatezza materiale" 914.

Em síntese, quando se investiga em torno do litisconsórcio alternativo, convergem as posições de TARZIA e de TROCKER, já que para este, assim como para aquele, “l'attore sconta in anticipo che una sola potrà essere accolta, dovendosi l'altra, o le altre,

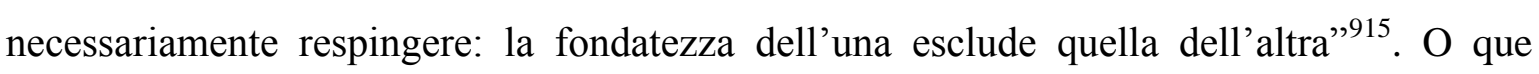
importa, então, é que as pretensões referenciadas aos litisconsortes alternativos sujeitam-se a "accertamento e a decisione nel merito" 916 .

Seguindo outra trilha, que se mostra menos radical em comparação com as até agora expostas, ALBERTO RONCO, trabalhando ainda com a hipótese de litisconsórcio alternativo, apregoa que existem situações indicativas de uma incompatibilidade entre as posições dos litisconsortes alternativos, de modo que a procedência em relação a um redunda, inexoravelmente, na improcedência em relação a outro. Para justificar seu enunciado, o autor italiano reporta-se ao caso em que dois autores, duvidando sobre a existência, validade ou eficácia de uma cessão de crédito, litigam, em litisconsórcio alternativo ativo, em face de um suposto devedor comum. No instante em que o juiz

che la proposizione alternativa comporti la revoca anticipata della pretesa che risulterà infondata, di modo che su di essa non possa decidersi nel merito" (id., nº 7, nota 135, p. 298).

${ }^{912}$ L'intervento per ordine del giudice, cit., p. 217, texto e nota 85 - tradução livre.

${ }^{913}$ Id., p. 214. Em acréscimo, aduz o autor: “Ognuno di essi viene inserito con una propria legittimazione nel giudizio, ognuno di essi ha il potere di ottenere dal giudice una pronuncia sul merito della causa che lo riguarda" (id., ibid.).

914 TROCKER, Nicolò. L'intervento per ordine del giudice, cit., p. 214.

${ }^{915}$ Id., ibid.

${ }^{916}$ Id., ibid. 
formar uma convicção de que a cessão de crédito existe, é válida e eficaz, ter-se-á um pronunciamento favorável ao cessionário em face daquele devedor; disso resulta, conseguintemente, um juízo de rejeição da pretensão aviada pelo cedente. E o contrário também é verdadeiro: caso o juiz se convença da inexistência, invalidade ou ineficácia da cessão de crédito - desde que exista o crédito, evidentemente -, a pretensão do cedente será fundada, ao passo que a pretensão do cessionário não o será ${ }^{917}$.

Diante desse cenário, ALBERTO RONCO considera que o pronunciamento judicial deve englobar o mérito em relação a todos os litisconsortes alternativos ${ }^{918}$, patenteando-se a presença do que se chama cúmulo condicionado de demandas ou cumulo alternativo por incompatibilidade ${ }^{919}$.

Contudo, há também situações em cujo âmbito não se verifica a aludida incompatibilidade, em ordem a se admitir que o acolhimento em relação a um litisconsorte não gera, inelutavelmente, a rejeição quanto ao outro. Para bem entender essa nova proposição, ALBERTO RONCO exemplifica com a hipótese de ação indenizatória em que o demandante formula pedido em ambiente de litisconsórcio passivo alternativo, sustentando que apenas um dos corréus tenha praticado o evento ilícito e danoso, mas não se sabendo ainda qual deles o tenha feito ${ }^{920}$.

Tendo em vista que a dúvida aferível objetivamente - e que anima a própria construção do litisconsórcio alternativo para o caso - pode recair sobre o nexo de causalidade, tem-se que um juízo negativo em relação a um dos réus não implica, necessariamente, um juízo positivo em relação ao outro. E o contrário também é verdadeiro.

\footnotetext{
${ }^{917}$ Op. cit., $\mathrm{n}^{\text {o } 3, \text { p. } 913 .}$

918 Id., $\mathrm{n}^{\text {o }}$ 3, p. 914. Antes de chegar a essa conclusão, o autor indaga: "questa doppia ed inevitabile cognizione si traduce inevitabilmente in una doppia decisione di merito o possiamo ipotizzare che su una delle due domande non si formi una pronuncia foriera della cosa giudicata?” (id., p. 913). E a resposta vem a seguir: "Pur con qualche dubbio, riterremmo di risolverla nel senso della necessaria decisione di merito anche per la domanda riconosciuta come infondata. Riterremmo cioè che la volontà di far decidere soltanto la domanda che il giudice ritenga fondata sai priva di effetto, allo stesso modo in cui lo sarebbe una volontà che, accompagnando la formulazione di una sola domanda, si esprimesse nel seguente modo: "si decida la domanda ove la si ritenga fondata, la si dichiari anammissibile (ovvero, la si assorba) nel caso contratio"” (id., p. 914).

${ }^{919} I d ., \mathrm{n}^{\mathrm{o}} 4, \mathrm{p} .917$.

${ }^{920}$ Id., ibid. Esse exemplo guarda semelhança com aquele da tríplice colisão de veículos (cfr. no 20, supra).
} 
Além disso, não se pode descartar que o juiz se convença da presença do nexo de causalidade em relação a ambos os réus, de sorte que o pedido do autor seria fundado quanto a todos os litisconsortes alternativos ${ }^{921}$.

À luz dessas observações, que descendem em grande medida da própria configuração da relação de direito material discutida e da exata localização do elemento "dúvida objetiva”, o doutrinador que se vem de citar propõe uma distinção apta a ensejar cinco possibilidades de julgamento para o caso de litisconsórcio alternativo: (a) o pronunciamento é de mérito relativamente à integralidade da demanda quando em relação a todos os litisconsortes a pretensão é infundada, isto é, quando se reconhece a improcedência integral do pedido formulado por ou contra os litisconsortes alternativos; (b) o pronunciamento é de mérito também quanto à totalidade da demanda quando, por força da natureza da relação substancial, o acolhimento do pedido em relação a um implica a automática e inevitável rejeição em relação a outro, resultante daquela incompatibilidade antes mencionada; $(c)$ o pronunciamento judicial também deve ser de mérito, em relação à demanda como um todo, mesmo que fora das hipóteses anunciadas nos itens anteriores $(a$ e $b$ ), caso o réu ou réus tenham adotado a postura de requerer o efetivo julgamento do mérito e apenas uma só das demandas alternativas seja fundada; $(d)$ o pronunciamento não será de mérito em relação à demanda diversa daquela considerada fundada se o réu, atrelado a esse pedido não acolhido, não tiver formulado um expresso requerimento a que se julgue o mérito, isto é, quando esse réu tiver apresentado defesa meramente processual, por exemplo; $(e)$ se ao aviso do julgador as pretensões em relação a todos os litisconsortes apresentarem-se fundadas, não será possível a análise do mérito em relação a todas, ficando uma delas sem resolução de mérito, em homenagem ao princípio da demanda e à vontade do autor ou autores ${ }^{922}$.

Num rápido resumo das posições expostas, tem-se certo consenso em torno do litisconsórcio eventual: o acolhimento do pleito relacionado ao litisconsorte primário rende ensejo ao não conhecimento da situação do litisconsorte subsidiário ${ }^{923}$. Já em tema de

921 Nas palavras de ALBERTO RONCO: "Ad esempio: dei più convenutti, alternativamente indicati dall'attore come unici autori dell'illecito, emerge dall'istruttoria che effettivamente uno soltanto ha agito, ma che uno degli altri ha partecipato psicologicamente alla realizzazione del comportamento dannoso" (Studio sul litisconsorzio alternativo, cit., nº 4, p. 917).

922 Studio sul litisconsorzio alternativo, cit., $\mathrm{n}^{\mathrm{o}} 5$, p. 921.

923 ALLORIO, Enrico. Litisconsorzio alternativo passivo e impugnazione incidentale, cit., p. 516-517; TARZIA, Giuseppe. Appunti sulle domande alternative, cit., nº 7, nota 132, p. 297; ASSIS, Araken de. Do 
litisconsórcio alternativo, o panorama mostra-se um pouco mais conturbado: (i) alguns pensam que o acolhimento do pedido em relação a um dos litisconsortes alternativos implica o não conhecimento da situação jurídica dos demais, seja por ilegitimidade $a d$ causam, seja pela superveniente ausência de interesse de agir ${ }^{924}$; (ii) outros, porém, propugnam que o acolhimento da pretensão quanto a um dos litisconsortes alternativos redunda na improcedência em relação aos outros ${ }^{925}$; (iii) há ainda a orientação segundo a qual tudo está a depender da natureza da relação substancial, da localização do elemento “dúvida objetiva" e da postura adotada pelo réu ao se defender ${ }^{926}$.

Conforme se procurou delinear no início deste estudo, as coordenadas que balizam a construção das modalidades litisconsorciais objeto de análise advêm da aproximação entre direito material e processo, com ênfase na ponderação de que o sistema processual, encarado por um prisma marcadamente instrumental, existe e se movimenta para atender às necessidades do direito material. Outra noção cara e que está na base de justificação das especificidades do litisconsórcio aqui vislumbrado diz respeito ao interesse de todo o sistema no sentido da razoável duração dos processos em geral, objetivo que se alcança, dentre outros fatores, evitando-se o ajuizamento fragmentado de várias demandas que versem sobre questões ligadas por algum grau de conexão.

Então, o enfrentamento das indagações levantadas em torno da adequada postura do juiz na construção dos capítulos de sentença passa, necessariamente, pelo filtro das premissas fundamentais de toda a construção que aqui se engendra.

Daí a utilidade de invocação de alguns exemplos - já lembrados anteriormente extraídos da conformação do direito material e de submissão deles ao teste da adequação à luz das várias posturas interpretativas sumariadas acima.

Considere-se, por exemplo, a hipótese de tríplice colisão de veículos, em que o autor da demanda indenizatória esteja diante de séria dúvida acerca de quem seja o efetivo

litisconsórcio no Código de Processo Civil, cit., p. 555; DINAMARCO, Cândido Rangel. Intervenção de terceiros, cit., $\mathrm{n}^{\circ}$ 86, p. 168. Observe-se, porém, que não foi essa a orientação deixada por DINAMARCO no seu Litisconsórcio ( $\mathrm{n}^{\circ} 183$, nota 154, p. 462-463).

924 ALLORIO, Enrico. Litisconsorzio alternativo passivo e impugnazione incidentale, cit., p. 516-517;

DINAMARCO, Cândido Rangel. Litisconsórcio, cit., nº 183, texto e nota 154, p. 462.

925 TARZIA, Giuseppe. Appunti sulle domande alternative, cit., $\mathrm{n}^{\circ}$ 7, p. 297; TROCKER, Nicolò. L'intervento per ordine del giudice, cit., p. 217, texto e nota 85.

${ }^{926}$ RONCO, Alberto. Op. cit., no 5, p. 921. 
causador do evento danoso ("automóvel estacionado, dois colidem entre si e o atingem") $)^{927}$, em ordem a construir o polo passivo da demanda em termos de alternatividade (litisconsórcio passivo alternativo) ${ }^{928}$.

Seja lembrada também a hipótese em que se duvide sobre a eficácia liberatória de uma assunção de dívida ${ }^{929}$, autorizando-se que o credor promova a demanda em face do assuntor e do primitivo devedor, presente a hesitação sobre a insolvência do assuntor ao tempo da transmissão da obrigação, sem conhecimento por parte do credor (art. 299 do Código Civil). Nessas condições, o autor formularia pedido para que um ou outro réu fosse condenado a pagar o débito, mas não os dois.

Os exemplos poderiam se multiplicar, mas se contenta, para o momento, com a lembrança de mais dois casos emblemáticos.

Em tema de direito de família, figure-se a hipótese em que o filho move ação para investigação de paternidade em face de dois réus, numa modulação alternativa, mediante o argumento de que a mãe, no mesmo período, mantivera relacionamento íntimo com $\operatorname{ambos}^{930}$. Por fim, relembre-se o caso apreciado pelo Superior Tribunal de Justiça em tema de direito tributário, oportunidade em que certa pessoa jurídica moveu ação em face de dois Municípios, manifestando a dúvida sobre se determinada exação tributária seria da competência deste ou daquele ente tributante. No caso, como o tributo já havia sido pago a um deles, o autor da demanda pediu o reconhecimento da ilegalidade da cobrança promovida por um dos Municípios e, para o caso de improcedência desse pleito, pediu a restituição dos valores que foram pagos ao outro Município a título do mesmo tributo ${ }^{931}$.

Parece estar fora de dúvida que no exemplo da tríplice colisão de veículos a decisão que pronunciar a responsabilidade de um dos corréus (mediante a afirmação de que este fora o único causador do acidente) estará por reconhecer a ausência de responsabilidade civil do outro. Então, quem, segundo a prova dos autos, causou o acidente responde

${ }^{927}$ O exemplo, com adaptações, é de CÂNDIDO DINAMARCO (Litisconsórcio, cit., nº 187, p. 467). Cfr. $n^{\circ}$ 20, supra.

${ }^{928}$ Nesse exemplo, não seria de se descartar a viabilidade de construção, também, de litisconsórcio eventual, desde que o autor manifestasse a preferência na condenação de um dos corréus.

${ }^{929} \mathrm{Cfr} \mathrm{n}^{\circ}$ 24, supra. Esse mesmo exemplo poderia ser adaptado para a cessão de crédito, circunstância em que seria possível a formação de litisconsórcio alternativo no polo ativo.

${ }^{930} \mathrm{Cfr}$. $\mathrm{n}^{\circ} 28$, supra.

${ }^{931}$ Cfr. $n^{\circ} 29$, supra. 
civilmente pelos prejuízos e, nesse aspecto, o pedido indenizatório é procedente em relação a este. Quem, diversamente, não causou o acidente, não responde pelo evento, sendo o pedido em relação a este improcedente.

Como se vê, seria ilógico raciocinar assim: se deu causa ao acidente, responde civilmente por ele, tendo-se decisão de mérito; se não deu causa, trata-se de parte ilegítima ou, em outros termos, falta interesse de agir em relação ao sujeito que não foi o causador do evento.

No caso da dúvida sobre a eficácia liberatória da assunção de dívida é possível tracejar o seguinte panorama: presente a solvência do assuntor (novo devedor) ou, então, mesmo diante da insolvência deste, provado que o credor já o sabia ao tempo da transmissão da obrigação, responderá o assuntor pela obrigação, sendo o pedido do credor acolhido pelo mérito; porém, se o cenário for diverso deste (demonstração de insolvência do assuntor, da qual o credor não tinha ciência ao tempo da assunção), não se terá operado a liberação do antigo devedor, que responderá, então, pela obrigação, sendo o pedido do credor acolhido em relação a este.

Mais uma vez é possível concluir pela ilogicidade de um raciocínio assim: se demonstrada a eficácia liberatória da assunção, responde o assuntor, julgando-se o mérito em face deste; mas, se demonstrada a subsistência do vínculo originário, o assuntor é parte ilegítima ou, quanto a ele, faleceu supervenientemente o interesse de agir.

O exemplo da investigação de paternidade em face de dois supostos pais é emblemático. Se provada a paternidade em relação a um dos réus, este será declarado pai, com julgamento de mérito; mas, se provada a paternidade em relação ao outro, evidentemente que o primeiro não será pai. Haveria, nessas condições, espaço para se considerar parte ilegítima este réu cuja paternidade não foi atestada à luz da prova que veio dissipar a dúvida objetiva anteriormente existente?

Na figurada hipótese de direito tributário, a demonstração de que o crédito tributário não pertine ao Município que fez a cobrança por último (procedência do pleito declaratório) revela a subsistência da obrigação tributária em relação ao outro Município que já recebera o valor referente à obrigação tributária, de sorte a não se poder falar em repetição de indébito. Nessa configuração, uma vez julgado procedente o pedido em relação ao litisconsorte primário, seria o litisconsorte subsidiário parte ilegítima quanto à 
pretensão de repetição de indébito? Ou teria mesmo havido perda superveniente do interesse de agir acerca da repetição de indébito?

Lícito é acreditar que os exemplos acima anunciados servem, quando menos, para fomentar uma séria reflexão sobre a proposta daqueles que, numa formulação de litisconsórcio eventual ou alternativo, entendem que o acolhimento do pedido, em favor do litisconsorte primário ou de um dos litisconsortes alternativos, gera, sempre e sempre, o não conhecimento do mérito em relação ao(s) outro(s) litisconsorte(s).

Em primeiro lugar, não parece tão seguro teorizar no sentido de que o litisconsórcio eventual e o litisconsórcio alternativo teriam por pressuposto uma dúvida a priori sobre a legitimidade ad causam, cuja solução dar-se-ia a posteriori pelo juiz. Não se descarta que, diante de certos cenários nebulosos, a própria descoberta da situação legitimante imbricada com a noção de legitimidade ad causam pode ser objeto de uma dúvida aferível objetivamente, ensejando-se a construção de litisconsórcio eventual ou alternativo. Todavia, o que não se pode conceber é que tais modalidades litisconsorciais estejam confinadas nesse casulo de dúvida sobre a legitimidade para agir.

$\mathrm{Na}$ realidade, os institutos aqui estudados ganham mais potencialidade, confirmando-se a vocação para a otimização da prestação jurisdicional, quando invocados e aplicados em razão de dúvidas que pertinem não ao campo do processo, mas sim ao espectro do próprio direito material controvertido.

Como se pôde perceber à luz dos exemplos antes citados, as soluções encontradas pelo julgador após o enfrentamento das várias questões oriundas da dúvida objetiva residem em aspectos sensíveis do plano material: nexo de causalidade; eficácia jurídica da transmissão de obrigações; relação de paternidade; titularidade de crédito tributário.

Implica dizer que a resolução dessas questões constitui-se no julgamento do próprio mérito da causa. Postura interpretativa diversa ensejaria um flerte perigoso com a noção de falsas $_{\text {carências }}{ }^{932}$.

${ }^{932}$ BEDAQUE, José Roberto dos Santos. Efetividade do processo e técnica processual, cit., p. 253-255; DINAMARCO, Cândido Rangel. Instituições de direito processual civil, cit., vol. II, nº 554-A, p. 326-327. Com muito proveito, consulte-se ainda: DINAMARCO, Cândido Rangel. Ação rescisória contra sentença terminativa. In: Fundamentos do processo civil moderno. 6. ed. São Paulo: Malheiros, 2010, t. II, nº 694, p. 1242-1243. 
Numa outra ordem de ideias, convém relembrar que o não conhecimento do pedido em relação a um dos litisconsortes (o subsidiário ou um dos alternativos) deixa em aberto a discussão, circunstância que autorizaria, ao menos em tese, a propositura de nova demanda quanto àquela porção não julgada pelo mérito. Ora, semelhante postura vai de encontro com as premissas que justificam toda a construção das modalidades litisconsorciais aqui estudadas.

Com efeito, a noção de razoável duração dos processos em geral passa necessariamente pela exigência de que, na medida do possível, sejam evitadas repetições de demandas. Exatamente por isso é que se deve admitir postulação subjetivamente alternativa ou em caráter eventual, a fim de que todo o litígio, em sua complexidade objetivo-subjetiva, seja resolvido de uma vez só. Então, admitir a formação de litisconsórcio eventual ou alternativo e depois consentir com a possibilidade sistemática de repropositura não parece ser uma postura coerente.

Dúvida não paira sobre a circunstância de o julgamento do mérito, mediante exame da situação de direito material, ser apto a eliminar o litígio e a concretizar o escopo de pacificação. Esse primordial objetivo não se alcança, porém, com as sentenças de carência $^{933}$.

Vale, então, mais uma vez chamar a atenção para o fato de que a técnica das condições da ação configura uma construção útil na medida em que potencializa o ideário da economia processual, buscando-se, por meio dessa especial técnica, estancar o desenvolvimento inútil da atividade jurisdicional.

Nos casos aqui examinados, fica patente a utilidade do desenvolvimento da atividade jurisdicional, pois é por meio dessa mesma atividade que se resolverá a dúvida objetiva que anima toda a construção litisconsorcial posta em debate. Ou seja, enquanto não verificada a solução da dúvida que fomenta o litisconsórcio eventual e o alternativo não se pode dizer, a rigor, que a atividade jurisdicional seja inútil.

933 BEDAQUE, José Roberto dos Santos. Efetividade do processo e técnica processual, cit., p. 259. Exatamente em razão do que se contém no texto, o autor citado conclui: "Talvez seja correto afirmar que a ausência de uma das condições da ação pode importar solução de uma pequena parcela da situação de direito material controvertida. Mas sua abrangência é bem menor que aquela alcançada pela sentença de mérito propriamente dita" (id., ibid.). 
Então, não convém que o julgador consinta com todo o desenrolar da atividade jurisdicional, exatamente por ser útil à solução daquela dúvida objetiva tantas vezes aqui referida, e ao final, no momento procedimental em que se sinta apto a espancar a dúvida objetiva, conclua que sua atividade agora não seja mais útil, proclamando a carência da ação, seja por ilegitimidade ou por falta superveniente de interesse de agir.

Sendo assim, descortina-se um quadro de ponderáveis razões para se aceitar a construção de TROCKER e de TARZIA, já sumariada acima, consoante a qual o acolhimento do pedido frente a um dos litisconsortes alternativos enseja a rejeição, pelo mérito, da pretensão pertinente ao outro(s) litisconsorte(s). Só assim, com efeito, será possível extrair desse tipo litisconsorcial toda a sua potencialidade, tanto em termos de pacificação global do conflito, quanto em termos de economia processual ${ }^{934}$.

Aliás, trabalhando-se com uma hipótese de litisconsórcio alternativo passivo, que é a mais comum de se verificar em termos práticos, impende relembrar que toda a construção que se engendra não focaliza o problema apenas sob a perspectiva do autor, já que o processo civil não pode ser pensado pelo prisma de resultados ótimos apenas para o autor. Logo, há fortes razões para se atribuir aos outros litisconsortes passivos (que não estejam vinculados à procedência do pedido do autor) o direito a um provimento de resolução do mérito ${ }^{935}$, conferindo-se a estes também a tutela jurisdicional mediante a rejeição do pedido do autor ${ }^{936}$.

Essa mesma conclusão parece ser válida quando se está diante de litisconsórcio eventual. Ou seja, pelos motivos acima expostos, convém que o julgador, ao pronunciar o

\footnotetext{
${ }^{934}$ Parafraseando a lição de TARZIA, registra-se que a decisão que exaure verdadeiramente a lide é somente aquela que se investe quanto ao mérito de uma e de outra demanda, quando postas em alternativa (Appunti sulle domande alternative, cit., p. 298). Tal formulação ainda ostenta a vantagem de superar as críticas dos autores alemães quanto à admissibilidade da demanda posta em alternativa. Nos termos da preleção de TARZIA, caso não se trabalhe com o julgamento do mérito quanto à demanda global, "l'alternativa sarebbe di certo una creazione processuale della parte, la quale chiderebbe al giudice di pronunziarsi su questa pretesa; ma ciò indurrebbe - come spero di avere ormai dimostrato - una inammissibile incertezza sull'oggetto del processo. Questa incertezza è evitata se le domande sono formulate in modo da essere tutte e due sottoposte a decisione, e sono collegate fra loro da quel nesso di interdipendenza - sostanziale e no meramente processuale - che impone al giudice, accogliendone una, di respingere l'altra" (id., ibid.).

${ }^{935}$ Em senso conforme, TROCKER (L'intervento per ordine del giudice, cit., p. 214, nota 82).

${ }^{936}$ Para aprofundamentos em torno da ideia de tutela jurisdicional em favor do réu, consulte-se SICA, Heitor V. Mendonça ( $O$ direito de defesa no processo civil brasileiro, cit., esp. Cap. 10, p. 205 et seq.).
} 
acolhimento do pleito em relação ao litisconsorte primário, conclua pela rejeição, de meritis, quanto ao litisconsorte subsidiário.

Poder-se-ia argumentar, em contraposição ao que se defende no texto, que o demandante constrói o objeto do processo, de modo que o juiz não poderia, então, suplantar aqueles limites tracejados pela demanda posta na petição inicial. Para bem entender essa possível objeção, cabe aqui uma ligeira explicação.

Quando o autor formula demanda em litisconsórcio eventual, pede-se o acolhimento do pedido atrelado ao litisconsorte primordial, aquele da preferência do demandante; para o caso de rejeição desse pedido é que se formula, ao mesmo tempo e no mesmo processo, a pretensão frente ao litisconsorte subsidiário.

Sendo assim, poderia transparecer que o autor, desde a petição inicial, forjaria amarras à atuação do juiz, em ordem a se concluir que o mérito em relação ao litisconsorte subsidiário somente poderia ser apreciado em caso de rejeição quanto ao litisconsorte primário, dada a preferência expressamente manifestada na petição inicial. Daí que, julgado procedente o pedido em relação ao litisconsorte primário, inviabilizar-se-ia a pronúncia sobre o mérito quanto ao colitigante subsidiário, sob pena de maltrato à noção de correlação entre sentença e pedido.

Porém, parece não haver razões para se pensar de semelhante modo. Embora o autor esteja autorizado a estruturar o objeto litigioso do processo, isso não significa que esteja autorizado a vincular o pronunciamento judicial sobre todo o mérito da causa ou só sobre parte dele. Assim, afigura-se mais correto entender que o julgador não extrapola os limites do objeto do processo caso aprecie o mérito também da situação material imbricada com a posição do litisconsorte subsidiário, ainda que o pleito pertinente ao litisconsorte primário tenha sido julgado procedente.

Em outras palavras, a situação material de todos os litisconsortes compõe desde o início o objeto litigioso do processo, razão pela qual o juiz está sim autorizado a julgar o mérito de toda a causa posta sob sua apreciação, mesmo diante da preferência formulada pelo autor quando da propositura.

Logo, o que extrapolaria os limites da demanda seria o acolhimento da pretensão em relação a todos os litisconsortes (primário e subsidiário). Mas o acolhimento em relação ao litisconsorte primário e a rejeição quanto ao subsidiário não importa maltrato ao princípio da correlação. 
As conclusões a que se chega servem, quando menos, para pôr à mostra a dificuldade de se teorizar sobre a exata natureza dos capítulos de sentença quando do enfrentamento do litisconsórcio eventual e do alternativo. Parece coerente aceitar, portanto, que um olhar mais detido sobre a compostura da relação de direito material é que poderá fornecer elementos mais seguros sobre se todos os pedidos serão analisados pelo mérito ou não ${ }^{937}$.

Renova-se, porém, a noção antes anunciada de que, em linha de princípio, proveito maior será alcançado, em termos de pacificação e de economia processual, mediante a análise do mérito em relação a todos os litisconsortes.

Mas como toda generalização é sempre perigosa, convém relembrar a oportuna advertência de ALBERTO RonCO, no sentido de que em algumas situações a decisão que conclui ser fundado o pedido em relação a um litisconsorte não implica, inexoravelmente, que seja infundado em relação a outro, sendo possível até mesmo que se considere que a pretensão em relação a todos os litisconsortes seja fundada, muito embora o autor tenha formulado demanda para que apenas em relação a um litigante fosse acolhido o pedido ${ }^{938}$.

Então, ao menos nessa particular hipótese de julgamento que seria favorável quanto a todos os litisconsortes, resultante da compatibilidade dessa conclusão por força da natureza da relação substancial discutida, o juiz ver-se-ia na contingência de acolher, pelo mérito, o pedido em relação a um litisconsorte e simplesmente reconhecer prejudicada a análise do mérito em relação a outro ou outros.

Noutra ordem de consideração, não se pode olvidar que no campo do litisconsórcio passivo eventual o juiz pode deparar-se com a possibilidade de procedência parcial em relação ao litisconsorte primário e de procedência integral quanto ao litisconsorte subsidiário. Nessas condições, à semelhança do que ocorre na cumulação subsidiária de pedidos, razoável impor-se ao juiz uma delicada tarefa de comparação entre os benefícios que uma ou outra postura pode significar para o autor da demanda: (a) se a sucumbência do

\footnotetext{
${ }^{937}$ Nesse sentido, cfr. ALBERTO RONCO (op. cit., n n 5, p. 921).

${ }^{938}$ Figure-se, novamente, a já lembrada hipótese em que numa tríplice colisão de veículos o autor promova a demanda, em alternativa, contra dois réus, pugnando pela condenação de apenas um deles, mediante a argumentação de que um só deles - não se sabe ainda qual - tenha dado causa ao acidente. Durante a instrução, contudo, verifica-se que ambos deram causa ao acidente, de sorte que o pedido do autor seria fundado em relação a todos. Mesmo assim, não poderá o juiz acolher o pedido em relação a todos os litisconsortes, sob pena de maltrato ao princípio da correlação.
} 
autor frente ao litisconsorte primário transparecer mínima, incumbe ao juiz concluir pela procedência parcial frente a este; (b) se a sucumbência do autor frente ao litisconsorte primário mostrar-se significativa, a procedência integral frente ao litisconsorte subsidiário prefere à procedência parcial em relação ao litisconsorte primário.

O que se tem por relevante é que, seja lá qual for o grau de sucumbência pertinente ao litisconsorte primário, deve o juiz, antes de se pronunciar apenas quanto a este, verificar também qual o resultado que poderia ser alcançado em relação ao litisconsorte subsidiário. Tenha-se presente, ademais, que essa valoração comparativa há de ser fundamentadamente exposta pelo julgador.

Mudando o foco de observação, ainda convém lançar luz sobre um ponto que pode deixar o julgador em estado de perplexidade. É que no litisconsórcio alternativo, como já tantas vezes sinalizado, não existe uma preferência exposta na petição inicial em relação a qual dos litisconsortes a demanda deva ser examinada em primeiro lugar. A rigor, descende da própria noção de alternatividade essa característica do "tanto faz", da indiferença quanto ao pedido ser analisado primeiramente em relação a este ou àquele, uma vez que, seja como for, para o autor ou autores da demanda, o que se pretende é o acolhimento do pleito em relação a um ou a outro litisconsorte.

Nessa perspectiva, surgiria para o juiz, ao menos dentro do espaço aberto pela configuração alternativa do litígio, a perplexidade de ter, ele próprio, que avaliar a mais conveniente das posturas. E a ausência de paradigmas objetivos faz mesmo com que o espírito do julgador se perturbe de algum modo.

Daí não parecer fora de propósito a tentativa de construção de um roteiro que convide o juiz a extrair algum dado objetivo com base no qual possa avaliar a conveniência desta ou daquela postura, deixando-se de lado, tanto quanto possível, um juízo de conveniência pautado exclusivamente na percepção pessoal do julgador.

É nesse sentido que a moderna doutrina italiana adverte que o litisconsórcio alternativo nem sempre implica para o juiz um puro arbítrio na escolha de qual das demandas deva ser conhecida em primeiro lugar ${ }^{939}$. Impõe-se reconhecer, então, que há algum proveito no estabelecimento de diretrizes, ditadas apenas em tom de exemplificação e sem a intenção de engendrar uma teoria sobre o assunto, até porque não se almeja assentar qualquer ordem de relevância entre os critérios que serão expostos.

${ }^{939}$ RONCO, Alberto. Op. cit., no 5, p. 920. 
Segundo salienta a doutrina ${ }^{940}$, nos casos em que o acolhimento da pretensão pertinente a um dos litisconsortes alternativos redunda na inexorável rejeição do pedido em relação ao outro (sejam lembrados os exemplos da investigação de paternidade em face de dois réus e da eficácia liberatória da assunção de dívida), não há motivos para se impor alguma ordem de precedência na análise da situação dos colitigantes alternativos. É que, seja lá qual for a ordem do exame promovido pelo julgador, o resultado em nada será alterado.

Entretanto, não sendo esse o caso, pode-se adotar a postura de se definir, em primeiro plano, a situação do réu que tenha feito um requerimento expresso quanto ao julgamento do mérito, isso na hipótese de litisconsórcio passivo. Em outras palavras, entre o réu que ofertou defesa de mérito e aquele que não o fez, o julgador deve preferir a análise, em primeiro lugar, da situação daquele que enfrentou o mérito.

É possível crer que a análise desde logo da situação daquele réu que apenas ofereceu defesas processuais seria até mais fácil, ao menos do ponto de vista da abrangência das atividades lógicas operadas pelo julgador. Contudo, em obséquio à noção de que o réu também titulariza o direito a uma resposta judicial o mais ampla quanto possível, capaz de regular definitivamente a solução do litígio, parece coerente aceitar-se o critério de primazia formulado pela doutrina italiana que vem sendo citada ${ }^{941}$.

Ainda é possível extrair da conformação do litígio um dado objetivo que se refira à economia processual, cogitando-se de mais um critério posto à disposição do julgador. Nessa perspectiva, o juiz faria a análise, em primeiro lugar, da porção da demanda cuja resposta judicial fosse a mais rapidamente alcançável. Num caso em que se buscasse a condenação ao pagamento de quantia, por exemplo, caberia ao juiz então preferir o julgamento em relação ao litisconsorte que se mostrasse dotado de maior capacidade financeira, presente a tendência de que em relação a este o resultado prático do comando sentencial fosse mais agilmente alcançado.

\footnotetext{
${ }^{940}$ Todos os critérios a seguir aduzidos foram extraídos do ensaio já referido de ALBERTO RONCO (Op. cit., n $^{\circ} 5$, p. 920).

${ }^{941}$ Com base mais uma vez nos influxos que advêm da repulsa ao chamado processo civil do autor, deve-se considerar que a indiferença existente na postura do demandante que litiga mediante litisconsórcio alternativo não deságua numa indiferença também para os réus. Daí que a postura adotada pelos réus, chamados em litisconsórcio alternativo, pode muito bem servir de guia para o juiz no momento de definir em relação a qual deles deva apreciar por primeiro a causa.
} 
Mas, na falta de outro aporte objetivo que possa auxiliar o juiz nessa tarefa de escolha, consente-se que a decisão seja pautada no seu prudente arbítrio.

Não se poderia fechar a análise dos capítulos de sentença sem antes tecer algumas considerações sobre as verbas de sucumbência. Porém, dadas as especificidades desse tema, o enfrentamento dar-se-á em tópico apartado (nº 56, infra).

\section{Sentença: condenação para o futuro}

Especificamente no ambiente do litisconsórcio eventual, mas não exatamente por causa dessa modalidade litisconsorcial, parece possível estabelecer algum vínculo entre o litígio subjetivamente complexo e o tema da condenação para o futuro. Mas também não se descarta a ideia de que os casos a seguir referidos possam, de alguma forma, amoldar-se à noção de litisconsórcio sucessivo.

Como já se viu anteriormente, em alguns casos a dúvida objetivamente aferível que dá margem à eclosão de litisconsórcio eventual advém de uma hesitação sobre se determinado sujeito terá patrimônio suficiente para responder por certa obrigação. E o tema litisconsorcial, nesses casos, vem à baila por força da previsão, no plano do direito material, de um outro sujeito que se responsabiliza subsidiariamente na hipótese de incapacidade financeira do sujeito obrigado em caráter principal.

Aqui não se ocupa do debate sobre se a responsabilidade patrimonial radica nos quadrantes do processo ou da relação material. Contenta-se com alguns dados que se extraem de normas de direito material e que são suficientes para ensejar as reflexões que seguem, em torno da responsabilidade subsidiária por obrigações de pagar quantia.

Quando se tratou da responsabilidade civil do Estado por comportamentos danosos perpetrados pelas concessionárias de serviços públicos, chegou-se à conclusão de que o patrimônio daquele só seria afetado quando não fosse suficiente o patrimônio da prestadora dos serviços públicos (nº 19, supra).

Nas obrigações garantidas por fiança, igualmente, o patrimônio do fiador, que não renunciou ao benefício de ordem, só é alcançado pelas atividades expropriatórias quando não seja suficiente o patrimônio do afiançado ( $\mathrm{n}^{\circ} 23$, supra). 
Eloquente, ainda nessa perspectiva, é o exemplo da responsabilidade civil do incapaz, cuja vinculação à satisfação da obrigação de indenizar só decola, em certas situações, quando os seus representantes legais "não dispuserem de meios suficientes", ex vi do art. 928, caput, do Código Civil (nº 17, supra).

Interessante observar que, embora a responsabilidade patrimonial só se revele concretamente aferível na fase de execução, não se admite a condenação isolada do devedor principal e posterior execução em desfavor dos responsáveis subsidiários. Faltaria, quanto a estes, o indispensável título executivo.

É nesse sentido, aliás, que a jurisprudência consolidada do Superior Tribunal de Justiça não permite, nos contratos de locação, a execução das verbas locatícias em face do fiador que não foi alvo de condenação na fase cognitiva ${ }^{942}$. Relativamente à responsabilidade civil dos incapazes, a doutrina também reforça a ideia de que é indispensável a condenação do próprio incapaz, cujo patrimônio será afetado, em execução, se o patrimônio de seus representantes não for suficiente para fazer frente à indenização fixada ${ }^{943}$.

O cenário acima delineado revela que, muito embora a condenação deva ser ditada desde logo e também em face dos responsáveis subsidiários, a exigibilidade em relação a eles dependerá de circunstâncias referentes a outros sujeitos também integrantes do contraditório e igualmente atingidos pela condenação, tudo a depender do que se verificar em sede de cumprimento de sentença.

\footnotetext{
${ }^{942}$ Súmula 268/STJ: "O fiador que não integrou a relação processual na ação de despejo não responde pela execução do julgado". Na doutrina, cfr. CRUZ E TUCCI, José Rogério (Inquilino e fiador como litisconsortes passivos. In: Questões práticas de processo civil. São Paulo: Atlas, 1998, p. 67 et seq.). Perceba-se que, relativamente à existência em si da obrigação (discussão objeto da fase cognitiva), o litisconsórcio entre locador e fiador tem cores de sucessividade (pois a procedência do pedido condenatório em face do locador constitui pressuposto para a condenação também do fiador), mas, no que pertine à responsabilidade patrimonial, in executivis, o litisconsórcio mostra-se eventual (busca-se o patrimônio do fiador se não for suficiente o patrimônio do locador). Parece razoável concluir, nessa perspectiva, que o sistema processual não é refratário à verificação de um litisconsórcio sucessivo quanto a uma porção ou aspecto da demanda judicial e também de um litisconsórcio eventual no que se refere a outro aspecto da mesma demanda.

${ }^{943}$ YARSHELL, Flávio Luiz. Três temas de direito processual no âmbito do direito das obrigações e dos contratos, cit., p. 311; FERREIRA, William Santos. Aspectos materiais e processuais da responsabilidade patrimonial do incapaz, cit., p. 367.
} 
Como se vê, as peculiaridades advindas do plano material, nos casos acima considerados, geram a necessidade de que o sistema processual, ainda que em tom de excepcionalidade, trabalhe com a noção de condenação para o futuro.

Em termos conceituais, tem-se afirmado que a condenação para o futuro "é aquela que se refere a um direito previsível mas ainda inexistente, ou existente mas inexigível no momento de sua prolação" 944 . Nesses casos, "no momento da prolação da sentença existem empecilhos ao pronto exercício [do direito] pelo titular"945.

O caráter excepcional dessa construção traduz-se no surgimento de sentença condenatória mesmo sem o requisito da prévia violação de um direito atual ${ }^{946}$. De certo modo, a condenação irrompe antecipada, a significar que referida pronúncia precede ao inadimplemento $^{947}$. Daí se dizer que o sistema, em casos tais, alarga a noção de interesse de agir para alcançar as situações em que existe a probabilidade de inadimplemento ${ }^{948}$.

Ajunte-se, noutra perspectiva, que a ideia de uma condenação para o futuro não atrita com a estrutura da execução (ou fase de cumprimento de sentença), uma vez que para se deflagrar o procedimento in executivis basta a existência do título executivo. E do título executivo, que de per si é suficiente para autorizar a execução, não se pode extrair a certeza de um inadimplemento atual, sobretudo na consideração de que entre a formação do título e o início da execução pode muito bem verificar-se o adimplemento por parte do devedor. Então, na ausência de um controle prévio sobre o início da execução, no que respeita especificamente ao inadimplemento, é bem possível que se deflagrem atos constritivos, típicos de execução forçada, mesmo diante de uma obrigação já satisfeita. $\mathrm{O}$ título executivo, por si só, terá exercido, nessas condições, a função de autorizar a prática de atos constritivos, mesmo que ausente o inadimplemento atual ${ }^{949}$.

\footnotetext{
${ }^{944}$ DINAMARCO, Cândido Rangel. Instituições de direito processual civil, cit., vol. III, nº 916, p. 243. ${ }^{945} I d ., \mathrm{n}^{\circ} 916$, p. 244.

946 Como anota CHIOVENDA, hipóteses "há em que se pode agir por uma prestação ainda não devida, e que só será devida depois da condenação, pelo que não há nenhuma violação do direito no momento da sentença" (Instituições de direito processual civil, cit., vol. I, no 48, p. 191).

${ }^{947}$ LIEBMAN, Enrico Tullio. Manuale di diritto processuale civile, cit., vol. 1, no 84, p. 170.

${ }^{948}$ MANDRIOLI, Crisanto. Diritto processuale civile, cit., vol. I, p. 73.

949 PROTO PISANI, Andrea. La tutela di condanna. In: Le tutele giurisdizionali dei diritti: studi. Napoli: Jovene, 2003, p. 135-136. Para rematar, o autor anuncia o seguinte: "Concludendo su questo punto mi sembra si possa con tutta tranquillità rilevare che la struttura del nostro processo di esecuzione forzata non si oppone alla ammissibilità come figura generale della condanna in futuro, poichè non richiede mai che il titolo
} 
Costuma-se objetar, porém, que a admissibilidade de uma condenação para o futuro criaria, do ponto de vista prático, o sério risco de o autor abusar de sua posição jurídica e vexar o devedor mediante a utilização do processo. De outra parte, considerando-se a mera probabilidade do inadimplemento, a atividade judicial ver-se-ia comprometida ainda mais com o peso de demandas que, no futuro, teriam sido desnecessárias.

A tais objeções respondeu PROTO PISANI com interessante argumento: os riscos mencionados efetivamente existem, mas eles não são diversos e nem mais significativos do que os riscos inerentes a toda e qualquer modalidade de atividade jurisdicional ${ }^{950}$.

Embora o sistema brasileiro não contenha regra semelhante à do art. 662, $\mathrm{n}^{\circ} 1$, do CPC português ${ }^{951}$, e à do $§ 259$, da ZPO alemã ${ }^{952}$, a doutrina nacional reflete a orientação que vem de plagas italianas ${ }^{953}$ e consente com a admissibilidade duma condenação para o futuro $^{954}$. Então, conquanto a sentença condenatória para o futuro não possa deflagrar imediata execução, dúvidas não pairam de que tal sentença forma título executivo ${ }^{955}$, exatamente como se dá na generalidade das sentenças condenatórias.

Exemplificativamente, o legislador pátrio lida com tal mecanismo ao estabelecer que a condenação pode abranger as prestações periódicas que se vencerem no futuro,

esecutivo offra con riferimento alla attualità dell'inadempimento quella stessa certezza che invece deve offrire in ordine all esistenza del credito" (id., p. 137).

${ }^{950}$ PROTO PISANI, Andrea. La tutela di condanna, cit., p. 138.

951 "O facto de não ser exigível, no momento em que a acção foi proposta, não impede que se conheça da existência da obrigação, desde que o réu a conteste, nem que este seja condenado a satisfazer a prestação no momento próprio". Na doutrina lusitana, cfr. LEBRE DE FREITAS, MONTALVÃO MACHADO e RUI PINTO (Código de Processo Civil anotado, cit., vol. 2, p. 684 et seq.).

952 "Demanda por temor a falta de cumplimiento oportuno de la prestación. La demanda para cumplimiento futuro puede ser interpuesta además de los casos de los $\S 257$ y 258, cuando sea justificado el temor, basándose en las circunstancias de que el deudor no cumplirá la prestación en tiempo" (versão espanhola elaborada pela Fundación Konrad Adenauer). Na doutrina alemã, cfr. LENT, Friedrich (op. cit., p. 141-143). ${ }^{953}$ Além do referencial doutrinário já citado, destaca-se a monografia de VIRGINIO ROGNONI, no âmbito da qual se enfatiza a compatibilidade da condenação para o futuro com a estrutura da condenação em geral (La condanna in futuro. Milano: Giuffrè, 1958, p. 114-115).

${ }^{954}$ DINAMARCO, Cândido Rangel. Instituições de direito processual civil, cit., vol. III, no 916, p. 243 et seq.; CARVALHO, Milton Paulo de. Op. cit., p. 120; CALMON DE PASSOS, José Joaquim. Comentários ao Código de Processo Civil, cit., vol. III, n 137, p. 194-195; GONÇALVES NETO, Diógenes M. Tutela condenatória civil e condenação para o futuro. São Paulo: Quartier Latin, 2010, p. 96 et seq.

${ }^{955}$ DINAMARCO, Cândido Rangel. Execução civil, cit., nº 340, p. 506. 
enquanto durar a obrigação (CPC, art. 290, in fine). A condenação ao pagamento de prestação alimentícia também desponta como bom exemplo de condenação para o futuro.

$\mathrm{O}$ art. 572, do CPC, também convida o intérprete a aceitar a condenação para o futuro. É que a sentença (condenatória) que julgar relação jurídica sujeita a condição ou a termo só poderá ser objeto de execução na hipótese de o credor provar que se realizou a condição ou que ocorreu o termo. Bem vistas as coisas, tem-se que a condenação exsurge no plano jurídico antes mesmo de se verificar a exigibilidade do crédito.

Retomando uma noção lançada já no início desta tratativa, veja-se bem que o tema da condenação para o futuro não irrompe por obra e arte do litisconsórcio eventual. A peculiaridade que adjetiva a sentença condenatória para o futuro situa-se na própria conformação da relação de direito material e não em algum dado ínsito à própria sentença, até porque o art. 460, parágrafo único, do CPC, é enfático ao ditar que a sentença deve ser certa, ainda quando decida relação jurídica condicional.

Embora o sistema proscreva a sentença condicional (CPC, art. 460, p. único) ${ }^{956}$, não há obstáculos à condenação condicional ou à condenação para o futuro, desde que assim o exija a relação de direito material à luz da qual emerge o direito de crédito ${ }^{957}$.

As hipóteses relembradas no início deste número e que já foram esmiuçadas em oportunidade anterior ( $\mathrm{n}^{\mathrm{o}}$ 17, 19 e 23, supra), todas elas desencadeadoras de litisconsórcio eventual, revelam que a exigibilidade respeitante a um sujeito está submetida a uma condição atrelada à situação financeira de outro litigante, o que evidencia o caráter subsidiário da responsabilidade patrimonial nos casos considerados.

Bem é de ver, em remate, que as hipóteses em que se demanda por condenação para o futuro contêm um elemento comum em relação ao litisconsórcio eventual, que é o aspecto da dúvida objetiva. Em recente pesquisa sobre o tema, constatou-se que a necessidade/utilidade duma condenação para o futuro lastreia-se na "alegação de dúvida objetiva, baseada em argumentação e exposição robusta, relativa ao risco provável de não cumprimento a tempo e modo da prestação devida"958. Com isso, o credor fica munido de

\footnotetext{
${ }^{956}$ DINAMARCO, Cândido Rangel. Instituições de direito processual civil, cit., vol. III, nº 900, p. 218-219.

${ }^{957}$ Costuma-se repetir, no pormenor, a frase emblemática de MOACYR LOBO DA COSTA: “Condicional é o direito, não a sentença” (Sentença condicional. Revista de direito processual civil, vol. 1, 1960, p. 102).

958 GONÇALVES NETO, Diógenes M. Op. cit., p. 115.
} 
um "título executivo apto a ser exigido tão logo advenha a concreta e expectada crise de adimplemento" $" 959$.

Assim, num caso envolvendo a responsabilidade subsidiária do Estado pelos prejuízos causados por uma concessionária de serviço público, a dúvida objetiva sobre a suficiência patrimonial da concessionária há de se verificar já na fase cognitiva, de molde a possibilitar a formação de litisconsórcio eventual. Porém, a certeza sobre a compostura patrimonial da concessionária, na dependência do que serão abertas ou não as portas da execução em relação ao Estado, só será verificada no futuro, isto é, quando da tentativa de expropriação de seus bens.

O mesmo pode ocorrer quando se imaginam embates em torno da responsabilidade civil do incapaz e de seus representantes. Durante a fase cognitiva tem-se como suficiente para eclosão do litisconsórcio eventual a dúvida objetiva, cuja superação cabal só se dará em sede de execução. A exigibilidade em relação ao incapaz surgirá, neste caso, a partir da verificação da insuficiência patrimonial respeitante aos representantes legais ${ }^{960}$.

\section{Sentença: verbas de sucumbência}

Conforme o discurso normativo do art. 20, caput, do CPC, a sentença condenará o vencido a pagar ao vencedor as despesas que antecipou e os honorários advocatícios, lembrando-se que, para o ambiente litisconsorcial, o legislador especifica que os vencidos respondem pelas despesas e honorários em proporção (CPC, art. 23).

Embora o legislador trabalhe com as noções de vencido e de vencedor, prepondera entre nós a orientação segundo a qual o sistema de distribuição dos custos do processo vem pautado na ideia mais ampla de causalidade e não necessariamente na noção isolada de

\footnotetext{
959 GONÇALVES NETO, Diógenes M. Op. cit., p. 115.

960 Ainda está em aberto na doutrina especializada o enfrentamento da seguinte questão: uma vez surgida a exigibilidade em relação ao incapaz, porque o patrimônio de seus representantes não é suficiente para suportar a condenação, seria possível alterar o valor da condenação em sede de execução de sentença já transitada em julgado? A indagação tem sentido porque, em relação ao incapaz, a indenização deve ser equitativa. Também é interessante pensar num impedimento à execução contra o incapaz diante da possibilidade de a expropriação de bens, naquele momento, privar o incapaz, ou as pessoas que dele dependam, do necessário à subsistência (CC, art. 928, p. único).
} 
sucumbência ${ }^{961}$. Daí que o dado objetivo da sucumbência seria apenas um indício de causalidade $^{962}$, havendo espaço, portanto, para o exame de outras nuances do caso concreto aptas a comandar a distribuição dos encargos financeiros do processo.

É a partir dessa premissa fundamental que se propõe analisar os possíveis desdobramentos de um julgamento na presença de litisconsórcio eventual, alternativo ou sucessivo.

No campo do litisconsórcio sucessivo, haja vista a verificação de um somatório de pretensões, endereçadas a todos os colitigantes sob o pálio do vínculo de prejudicialidade, mostra-se possível tomar por empréstimo o raciocínio que se utiliza no campo da cumulação sucessiva de pedidos. Então, deve-se analisar a situação de cada litisconsorte isoladamente e verificar, em primeira mão, o grau de derrota ou de vitória em relação ao(s) adversário(s).

Assim, se o litisconsórcio sucessivo verificar-se no polo ativo, os autores poderão sagrar-se inteiramente vencedores e, nessa condição, terão em seu favor a fixação integral das verbas de sucumbência. Caso os litisconsortes sejam derrotados, eles é que terão de pagar ao vencedor as despesas processuais e os honorários advocatícios.

Todavia, na medida em que apenas um dos litisconsortes seja vencido, este ficará incumbido de pagar as verbas sucumbenciais na proporção de seus interesses no litígio. Em contrapartida, nessa mesma situação, o adversário do litisconsorte vencedor pagará as verbas atreladas à situação deste litisconsorte vitorioso.

Lembrando-se do já conhecido exemplo em que mãe e filho litigam contra o suposto pai, aquela buscando o ressarcimento das despesas do parto e este buscando o

${ }^{961}$ Como diz BEDAQUE, uma interpretação isolada do art. 20, caput, do CPC, poderia dar ensejo à errada conclusão de que as despesas do processo sempre estariam vinculadas à sucumbência. Porém, mais adequado é pensar que aludida regra constitui emanação do princípio da causalidade, "segundo o qual responde por tais verbas aquele que indevidamente deu causa ao processo" [In: MARCATO, Antonio Carlos (coord.). Código de Processo Civil interpretado, cit., p. 71]. Invocando a insuficiência do critério da sucumbência para solução dos variados casos, NELSON NERY e ROSA NERY também referem o princípio da causalidade como sendo o norteador da distribuição dos custos do processo (Código de Processo Civil comentado e legislação extravagante, cit., nota 7 ao art. 20, do CPC, p. 222).

962 DINAMARCO, Cândido Rangel. Instituições de direito processual civil, cit., vol. II, no 748 , p. 666; CAHALI, Yussef Said. Honorários advocatícios, cit., no 14, p. 43; LOPES, Bruno Vasconcelos Carrilho. Honorários advocatícios no processo civil. São Paulo: Saraiva, 2008, no 14, p. 45-46 (com proveitosa resenha bibliográfica). 
reconhecimento da paternidade, pode-se engendrar o seguinte cenário: (a) se os pedidos da mãe e do filho forem procedentes, o réu pagará sozinho as verbas de sucumbência, recebendo aqueles proporcionalmente aos seus interesses no litígio; (b) se os pedidos da mãe e do filho forem rejeitados, ambos pagarão ao réu as despesas processuais e os honorários advocatícios, mantida também a proporcionalidade a que alude o art. 23 do CPC; (c) imaginando-se que apenas a mãe seja sucumbente - porque não provada a existência de despesas a ressarcir, por exemplo - , apenas aquela será obrigada a pagar as já mencionadas verbas ao réu, observado-se também a regra do art. 23 do CPC. A regra exposta no item (c) não afasta, evidentemente, a obrigação de o réu arcar com as quantias pertinentes ao litisconsorte vencedor, no caso o filho.

As conclusões acima indicadas servem também para a hipótese em que o litisconsórcio sucessivo vem formado no polo passivo. Pense-se no exemplo em que a criança investiga a paternidade em face do suposto pai e, sucessivamente, pede a condenação dos avós a pagar a pensão alimentícia, haja vista a falta de condições financeiras do imputado genitor. Sem muito esforço, é possível transportar para cá os enunciados a que se chegou no parágrafo anterior: (a) se a criança sagrar-se vencedora em relação a ambos os réus (pai e avós), estes arcarão proporcionalmente ao seus interesses com as despesas e com os honorários advocatícios; (b) se a criança, diversamente, sucumbir diante do suposto pai e também dos possíveis avós, aquela pagará todas as despesas e os honorários advocatícios; (c) caso a criança vença em relação ao pai (investigação de paternidade) e perca em face dos avós (alimentos), somente a estes aquela haverá de ressarcir as despesas e de pagar os honorários, cumprindo ao pai, de outro lado, suportar os encargos de sucumbência relativos tão somente à investigação de paternidade.

Na perspectiva do litisconsórcio eventual e do alternativo, contudo, já não parece tão tranquila a singela transposição das soluções encontradas pela doutrina em tema de cumulação eventual e alternativa de pedidos.

Apenas para relembrar, pois o assunto foi mais bem tratado em outra sede, tem-se entendido que na cumulação alternativa de pedidos a vitória do autor em relação a um deles é suficiente para deflagrar a procedência integral da pretensão, de sorte que vencido seria o réu e, de conseguinte, arcaria este com as verbas de sucumbência.

Na órbita da cumulação eventual de pedidos, semelhantemente, a doutrina majoritária disserta que a procedência em relação a quaisquer dos pedidos (o principal ou o 
subsidiário) enseja a procedência integral da pretensão do autor, razão pela qual este nada pagaria ao réu em termos de verbas de sucumbência.

Aqui é possível entrever um reforço à impressão de que não se pode simplesmente transpor todo o arcabouço de problemas e suas respectivas soluções da cumulação eventual e alternativa de pedidos para o espectro do litisconsórcio eventual e do litisconsórcio alternativo.

Com efeito, a presença de litigantes diversos relacionados com pedidos diversos, seja num escalonamento primário-subsidiário, seja numa feição de alternatividade, faz toda a diferença na equação que se quer resolver.

Realmente, não parece razoável entender que o autor, ao sagrar-se vencedor em relação a um dos litisconsortes passivos alternativos, seja vencedor quanto à integralidade da demanda que propôs. De igual modo, o réu que resultar vitorioso em relação a um dos litisconsortes alternativos do polo ativo não o será na inteireza de sua pretensão defensiva.

Então, porque os fenômenos aqui estudados são realmente litisconsorciais, consoante se procurou demonstrar no início do trabalho ${ }^{963}$, o destino que se deve dar ao problema das verbas de sucumbência há de ser encontrado no ambiente normativo do litisconsórcio. Tenha-se presente, pois, que o princípio da autonomia dos litisconsortes impõe que cada qual seja considerado como litigante independente em relação ao adversário (CPC, art. 48).

Em outras palavras, cada litisconsorte será considerado vencido ou vencedor na exata medida de sua derrota ou de sua vitória na porção da demanda que a ele se refira. Trocando em miúdos, cada litisconsorte alternativo será vencido ou vencedor quanto ao pedido que lhe toca, extraindo-se daí a conclusão sobre se receberá ou se pagará despesas processuais e honorários advocatícios à parte adversa. Igualmente, os litisconsortes primário e subsidiário, integrantes do polo ativo ou passivo, serão atingidos pelas verbas de sucumbência na medida em que se sagrem derrotados ou vitoriosos em relação à específica porção do litígio que lhes afeta.

Assim, quando se tenha litisconsórcio alternativo passivo, a procedência do pedido do autor em relação a um dos litisconsortes implica vitória parcial, de modo que o autor haverá de pagar as verbas de sucumbência em relação àquele litisconsorte não atingido

${ }^{963}$ Cfr. Parte I, Cap. Único, $n^{\circ} 6$. 
pelo desfecho de procedência. A situação será a mesma, caso o litisconsórcio alternativo se verifique no polo ativo.

O mesmo cenário aparece quando se está diante de litisconsórcio eventual, haja vista que a procedência do pedido atrelado ao litisconsorte primário não encobre o fato da sucumbência em relação ao litisconsorte subsidiário. E a recíproca também é verdadeira.

Sendo assim, numa formulação de litisconsórcio eventual passivo, o autor que se sair vencedor em relação ao litisconsorte primário haverá, mesmo assim, de arcar com as despesas e com os honorários advocatícios gerados em relação ao litisconsorte subsidiário. Caso o autor obtenha a procedência apenas quanto ao litisconsorte subsidiário, também terá de pagar as despesas e os honorários pertinentes ao litisconsorte primário. Essas mesmas conclusões serão encontradas na hipótese de o litisconsórcio eventual formar-se no polo ativo ${ }^{964}$.

Evocando novamente o princípio da causalidade, o qual tende a comandar mais amplamente a definição sobre os custos do processo, ainda é possível trabalhar com a hipótese em que o autor litigue contra dois litisconsortes, numa modulação eventual ou alternativa, obtenha a procedência do seu pedido em relação a um dado litigante e consiga demonstrar que havia fundados motivos para chamar ambos em juízo. Ou, então, seria possível imaginar que o elemento dúvida objetiva, que anima toda a construção litisconsorcial eventual e alternativa, tenha eclodido a partir do comportamento daquele litisconsorte alcançado pela procedência do pedido do autor.

Nessas condições, indaga-se sobre a possibilidade de o autor recuperar do litisconsorte vencido (um dos réus) as despesas processuais e os honorários advocatícios desembolsados em relação ao outro litisconsorte (vencedor).

Segundo abalizada opinião doutrinária, a resposta a tal indagação há de ser positiva $^{965}$. Em acréscimo, pondera-se que o caso concreto pode revelar que toda dúvida

\footnotetext{
964 No sentido do texto, tanto em relação ao litisconsórcio alternativo quanto ao eventual, consulte-se DUARTE, Ronnie Preuss (Litisconsórcios alternativo e subsidiário no processo civil brasileiro, cit., $\mathrm{n}^{\circ} 5$, $\mathrm{p}$. 46-47).

965 Com base na experiência americana e inglesa, TARZIA assim escreve: "Nel caso più comune di litisconsorzio passivo, l'attore deve poi rifondere le spese al convenuto assolto, salva la possibilittà di recuperarle dal convenuto condannato, se può dimostrare di avere avuto fondati motivi per chiamare in giudizio entrambi i soggetti” (Appunti sulle domande alternative, cit., nº 7, p. 295).
} 
objetiva que ensejou a formação do litisconsórcio eventual ou alternativo tenha sido causada exatamente por aquele litigante vencido.

Para facilitar a visualização do que se vem de dizer, figure-se, mais uma vez, o exemplo já considerado neste trabalho ${ }^{966}$ em que determinada pessoa jurídica tenha recolhido o valor de tributo em favor de determinado Município (aqui designado por $X$ ), em razão de um acontecimento juridicamente relevante do ponto de vista tributário, e outro Município (designado por $Z$ ), à luz daquele mesmo acontecimento, tenha promovido outro lançamento tributário em desfavor daquele mesmo contribuinte. Nessas condições, conforme sustentado alhures, a pessoa jurídica moveria demanda em face dos dois Municípios, numa modulação subsidiária, argumentando que o lançamento efetuado por $Z$ é ilegítimo e, por isso, deve ser reconhecida a inexigibilidade do suposto crédito tributário. Esse Município seria o litisconsorte primário ou principal. Todavia, para o evento de ser desacolhido o pedido formulado a $Z$, o contribuinte formula pedido de repetição de indébito em relação ao Município $X$, que será, então, o litisconsorte subsidiário.

Supondo-se que, na sentença, se reconheça que a dívida manifestada por $Z$ realmente não exista, haja vista que a titularidade ativa do tributo seja mesmo do Município $X$, pode-se argumentar que toda a celeuma fora causada pelo Município $Z$, que instaurou procedimento administrativo e, ao final, promoveu o lançamento tributário em desfavor daquele contribuinte.

Ocorre que tal lançamento tributário demonstrou-se ilegítimo, sendo, pois, procedente o pedido do contribuinte no sentido da inexigibilidade do crédito. Daí, por conseguinte, o desacolhimento do pedido de repetição de indébito pertinente ao outro Município, o qual, nesse cenário, sagrou-se vencedor em relação ao autor.

Não há dúvida de que o autor deverá pagar, consoante se pretendeu demonstrar acima, as verbas de sucumbência relacionadas ao Município $X$ (vencedor quanto ao pleito de repetição de indébito). Mas o fato é que tal sucumbência, em última análise, advém do comportamento do outro réu ( $Z$ : litisconsorte primário), que não tinha razões jurídicas para promover um lançamento tributário ilegítimo.

Nessas condições, transparece coerente afirmar que a verba de sucumbência (despesas e honorários advocatícios) pertinente ao litisconsorte subsidiário, que o autor haverá de pagar, pode ser carreada como despesa processual em relação ao litisconsorte

${ }^{966}$ Cfr. n ${ }^{\text {2 } 29, ~ s u p r a . ~}$ 
primário, efetivo causador da demanda objetiva e subjetivamente complexa. Assim, o autor paga ao litisconsorte subsidiário as despesas processuais e os honorários advocatícios respectivos, mas se reembolsa desses mesmos valores em relação ao litisconsorte primário.

Poder-se-ia argumentar, em senso contrário ao que se defendeu até aqui, que mesmo nas condições acima exemplificadas - em que se imputa a causação da demanda a um dos litisconsortes - a opção pela demanda em litisconsórcio eventual ou alternativo, em todo e qualquer caso, deve dar-se por conta e risco do autor ou autores. Isto porque o autor, em vez de propor a demanda mediante cúmulo subjetivo, poderia muito bem deduzir uma demanda isolada em face daquele que seria o litisconsorte primário e, sendo improcedente esse seu pleito, apenas nesse momento mover outra demanda contra aquele que seria o litisconsorte subsidiário.

Tendo em vista, então, que ao autor não se impõe o litígio mediante cumulação subjetiva (pois o caso é de litisconsórcio facultativo), será ele, sempre e sempre, o causador da demanda em face do litisconsorte que se sagrar vencedor. Em outras palavras, o risco da demanda em litisconsórcio eventual ou alternativo seria sempre do autor, configurando-se irrelevante o comportamento dos colitigantes que figurarem no polo passivo.

A tal modo de pensar pode-se redarguir, talvez com vantagem, que uma solução assim poderia servir de desestímulo à utilização da técnica litisconsorcial aqui estudada. Quer parecer, à luz de toda a justificação constitucional e infraconstitucional que anima o fenômeno litisconsorcial eventual e alternativo, que as soluções desejáveis são aquelas afinadas com a tendência de fomento à utilização desses tipos litisconsorciais.

Por esse prisma, então, convém validar a construção que permite analisar, diante do caso concreto, se o litisconsorte vencido em relação ao autor deva também ressarcir em favor deste as verbas devidas em relação à sucumbência verificada quanto ao outro litisconsorte (vencedor em relação ao autor).

Às considerações por último mencionadas não se pretende impregnar uma característica de generalização, mas, quando menos, elas servem para fomentar uma reflexão sobre os desdobramentos do princípio da causalidade em matéria de custo financeiro do processo diante do fenômeno litisconsorcial eventual e alternativo. 


\section{Apelação: generalidades}

Quando se põe em debate o tema recursal vinculado a algum aspecto de cumulação objetiva ou subjetiva depara-se, evidentemente, com inúmeras dificuldades. Em grande parte, as perplexidades resultam do deficitário enfrentamento legislativo, mas não se pode deixar de compreender, de outra parte, que a riqueza dos fenômenos processuais, no plano prático, sempre está a gerar surpresas para aqueles que, como o legislador, tentam imaginar hipóteses e suas respectivas soluções.

No lugar apropriado deste estudo teve-se oportunidade de analisar aspectos controvertidos da matéria recursal em tema de cumulação de pedidos. Viu-se que a experiência recursal, na dependência do tipo de cumulação de pedidos com que se trabalhe (eventual, alternativa ou sucessiva), tende a se amoldar às exigências ditadas pelas especificidades de cada modalidade de cumulação.

Do ponto de vista do litisconsórcio em geral, a par da questão do prazo em dobro para recorrer (CPC, art. 191), muitos debates ainda existem acerca da autonomia dos litisconsortes e suas implicações no segmento recursal, assim como a influência que a apelação de um colitigante pode ensejar na esfera jurídico-processual de outro nas hipóteses de litisconsórcio unitário ou de litisconsortes com interesses comuns, tal como sucede, por exemplo, no âmbito da solidariedade (CPC, art. 509, p. único).

Semelhantes preocupações exsurgem do tema da desistência de recurso interposto e da renúncia ao direito de recorrer quando na presença de litisconsórcio (CPC, arts. 501 e 502).

Mas, como não poderia deixar de ser, o enfretamento que se propõe agora não tem por escopo revisitar as dificuldades recursais em tema de litisconsórcio em geral e tampouco em tema de cumulação de pedidos. O que se pretende é avançar, com base nas premissas anteriormente assentadas, na discussão em torno das vicissitudes recursais que o litisconsórcio eventual, alternativo e sucessivo pode gerar.

Observe-se, desde logo, que as especulações centram-se, doravante, no estudo da apelação, que se traduz no recurso mais relevante para o enfrentamento das questões que as modalidades litisconsorciais aqui investigadas ensejam. Ademais, uma vez estudadas essas questões sob o prisma da apelação, será bem possível transpô-las, com proveito, para o 
âmbito de outros recursos, sobretudo porque a apelação constitui-se no "recurso ordinário por excelência no processo civil brasileiro" 967 .

Importa relembrar, ainda uma vez, que as modalidades litisconsorciais aqui investigadas não constituem emanação de litisconsórcio unitário, razão pela qual o enfrentamento das vicissitudes recursais aqui propostas não se funda naquilo que a doutrina já construiu sobre as relações jurídicas caracterizadas como incindíveis, no âmbito das quais, havendo litisconsórcio, a decisão quanto ao mérito há de ser uniforme em relação aos litisconsortes.

Seja como for, a premissa que há de ficar devidamente assentada, em tema de apelação, traduz-se no quanto dispõe o art. 515, caput, do CPC, consoante o qual a apelação devolverá ao tribunal o conhecimento da matéria impugnada. Pertinente, nesse ponto, lembrar da máxima tantum devolutum quantum apellatum.

Analisar o efeito devolutivo consiste necessariamente numa dupla apreciação, pois se deve aferir o aspecto da extensão e também o da profundidade. Impõe-se, com efeito, verificar "o que se submete, por força do recurso, ao julgamento do órgão ad quem"968 e também examinar “com que material há de trabalhar o órgão ad quem para julgar"969. É por esse enfoque que se autoriza a distinção entre as perspectivas horizontal e vertical do efeito devolutivo na apelação, à semelhança do que sucede no âmbito da conhecida classificação da cognição judicial $^{970}$.

No ponto em que interessa para o desenvolvimento do estudo aqui proposto, devese basicamente trabalhar com a noção do efeito devolutivo em sua perspectiva horizontal. Importante relembrar a regra segundo a qual a extensão do conhecimento do órgão ad quem fica enclausurada nos limites da impugnação lançada na apelação. É dizer, matéria

\footnotetext{
${ }^{967}$ NERY JUNIOR, Nelson. Princípios fundamentais - teoria geral dos recursos, cit., p. 372. De fato, a "singular posição" que a apelação ocupa no cenário dos recursos faz com que seja "considerada pela doutrina como o recurso por excelência" (ARAÚJO CINTRA, Antonio Carlos de. Sobre os limites objetivos da apelação civil, cit., p. 2).

968 BARBOSA MOREIRA, José Carlos. Comentários ao Código de Processo Civil, cit., vol. v, n 237, p. 430 - grifo do original.

${ }^{969}$ Id., ibid. - grifo do original.

${ }^{970}$ WATANABE, Kazuo. Da cognição no processo civil. 2. ed. Campinas: Bookseller, 2000, nº 21, p. 111113.
} 
não veiculada na apelação não pode, de regra, ser objeto de apreciação pelo órgão $a d$ quem $^{971}$.

Tal ordem de coisas constitui emanação do princípio dispositivo, já que o "direito de recorrer é prolongamento do direito de ação" ${ }^{\text {"972 }}$. Então, se o juiz de primeiro grau só presta jurisdição mediante provocação das partes $\left(\mathrm{CPC}\right.$, art. $\left.2^{\circ}\right)$ e se a atividade jurisdicional acomoda-se aos limites do pedido formulado pela parte (CPC, arts. 128 e 460), assim também se verifica no âmbito recursal, onde o "recurso interposto devolve ao órgão julgador ad quem apenas o conhecimento da matéria que tiver sido objeto do recurso" $" 973$.

Tem-se ainda que a matéria impugnável na apelação não pode extrapolar os lindes da matéria decidida, razão pela qual, também em linha de princípio, o julgamento do tribunal não terá "objeto mais extenso que o da sentença apelada",974.

Esse quadro alterou-se substancialmente com o advento da Lei 10.352/2011, que acrescentou o $\S 3^{\circ}$ ao art. 515, do CPC. Segundo o discurso normativo, nos casos de extinção do processo sem julgamento do mérito, o tribunal pode julgar desde logo a lide, se a causa versar questão exclusivamente de direito e estiver em condições de imediato julgamento.

À luz desse dispositivo, que em boa hora foi introduzido no sistema recursal brasileiro, permite-se que o âmbito de devolutividade extrapole o quanto se decidiu na origem, resultando, se for o caso, numa decisão do órgão ad quem com objeto mais extenso do que aquele exteriorizado pelo órgão a quo ${ }^{975}$.

971 “Caso o órgão destinatário do recurso extrapole o pedido de nova decisão, constante das razões do recurso, estará julgando extra, ultra ou citra petita, conforme o grau e a qualidade do vício em que incorrer" (NERY JUNIOR, Nelson. Princípios fundamentais - teoria geral dos recursos, cit., p. 415). Relembre-se que as matérias de ordem pública, porquanto não submetidas à preclusão, são apreciáveis pelo órgão $a d$ quem por força do que se tem chamado de efeito translativo, mesmo que ausente impugnação específica nas razões do recurso (id., p. 415 et seq.).

972 MEDINA, José Miguel Garcia; ARRUDA ALVIM WAMBIER, Teresa. Recursos e ações autônomas de impugnação. São Paulo: RT, 2008, p. 103.

${ }^{973}$ Id., ibid.

974 BARBOSA MOREIRA, José Carlos. Comentários ao Código de Processo Civil, cit., vol. V, nº 238, p. 432 - grifo do original.

975 Para aprofundamentos, cfr. DINAMARCO, Cândido Rangel (A reforma da reforma, cit., Cap. XVI, p. 150 et seq.) e SCARPINELLA BUENO, Cassio [Efeitos dos recursos. In: NERY JR., Nelson; ARRUDA 
Já se viu, na ocasião apropriada, que o $§ 3^{\circ}$ do art. 515 do CPC ostenta notável relevância em tema de cumulação eventual e alternativa de pedidos ${ }^{976}$. Também já foram sumariadas as disceptações doutrinárias em torno do âmbito de devolutividade da apelação quando em presença de cumulação sucessiva de pedidos, trabalhando-se com o instigante tema da prejudicialidade ${ }^{977}$.

Resta agora debruçar sobre as implicações que a presença de outros litigantes, caracterizados por uma vinculação subsidiária, alternativa ou sucessiva, pode ensejar no já intrincado tema da extensão do efeito devolutivo na apelação.

E o debate vem à baila por força da adoção, pelos ordenamentos jurídicos contemporâneos, do sistema da personalidade dos recursos, em contraposição ao sistema da realidade. Segundo explica LIEBMAN, no direito romano e também no direito comum vigorava a noção de que o recurso interposto por ou contra um só dos litigantes era suficiente para levar à apreciação do órgão ad quem de toda a demanda, em sua integral complexidade $^{978}$. Ocorre que, a partir dos influxos da Revolução Francesa e da concepção individualista de que se impregnou o Direito desde então, passou-se a entender, em linha de princípio, que o reexame em sede recursal circunscreve-se à posição dos sujeitos proponentes ou em confronto dos quais se interpõe o recurso ${ }^{979}$.

A primeira configuração representa adoção do sistema da realidade, enquanto que a segunda constitui emanação do sistema da personalidade, adotado também no Brasil, embora com temperamentos, a teor do discurso normativo que se contém no art. 509, do $\mathrm{CPC}^{980}$.

Para o sistema brasileiro, no âmbito do qual os recursos não são endereçados à parte adversa e sim a um órgão jurisdicional, tem-se entendido que o sistema não exige a

ALVIM WAMBIER, Teresa (coord.). Aspectos polêmicos e atuais dos recursos cíveis e assuntos afins. São Paulo: RT, 2006, vol. 10, p. 81-84].

${ }^{976}$ Cfr. Parte II, Cap. II, no 14, “v”.

977 Cfr. Parte II, Cap. II, no 14, “v”.

978 Nos termos da lição do mestre italiano, o recurso afeto a um só dos litigantes "reproduceva la lite nell'istanza superiore in tutta la sua ampiezza, portava cioè ad una nuova decisione che valeva per tutti e nei confronti di tutti i precedente litisconsorti” (Manuale di diritto processuale civile, cit., vol. II, no 303, p. 278). No mesmo sentido professou TITO CARNACINI (Il litisconsorzio nelle fasi di gravame. Padova: CEDAM, 1937, p. 3).

${ }^{979}$ LIEBMAN, Enrico Tullio. Manuale di diritto processuale civile, cit., no 303, p. 278.

${ }^{980}$ DINAMARCO, Cândido Rangel. Litisconsórcio, cit., n $\mathrm{n}^{\text {7 }}$ 74, p. 178 et seq. 
indicação precisa, no ato de interposição do recurso, dos nomes das partes. E mais, no silêncio do recorrente, presume-se que a impugnação atinge a totalidade dos litisconsortes vitoriosos, se mais de um houver ${ }^{981}$.

Entretanto, no espectro da apelação - que é o recurso que mais de perto interessa para o debate aqui proposto - o legislador exige que a petição de interposição contenha o nome das partes (CPC, art. 514, I). E as partes a que alude o mencionado dispositivo "são $\mathrm{o}(\mathrm{s})$ apelante(s) e o(s) apelado(s) ${ }^{, 982}$, donde exsurge a conclusão de que a apelação pode ser parcial também pelo aspecto subjetivo. Tal particularidade é que dá margem às especulações que serão logo adiante examinadas.

Dada a diversidade de tratativas e também porque os enunciados teóricos são, em certa medida, distintos, ocupar-se-á da apelação no litisconsórcio eventual e no alternativo em tópico separado em relação ao mesmo assunto no âmbito do litisconsórcio sucessivo. E a base fundamental para esse discrímen advém da noção de prejudicialidade, que é a marca precípua deste e não daqueles.

\section{Apelação: litisconsórcio eventual e alternativo}

Defende-se neste trabalho que as modalidades litisconsorciais eventual e alternativa podem ocorrer tanto no polo ativo quanto no passivo da relação processual. Cabe rememorar, ainda, que no litisconsórcio eventual existe um escalonamento, exposto desde a petição inicial, quanto ao acolhimento do pedido pertinente aos litisconsortes: quer-se, em primeiro plano, a procedência do pedido em relação ao litisconsorte primário e, para o caso de ser impossível alcançar tal desiderato, pretende-se o acolhimento do pleito quanto ao litisconsorte subsidiário. Na perspectiva do litisconsórcio alternativo, porém, as coisas passam-se de modo diverso, porquanto aqui não há a exposição daquela preferência, trabalhando-se, em vez disso, com a noção de indiferença, na perspectiva do autor ou dos autores, quanto à procedência do pedido em relação a um ou outro litisconsorte.

\footnotetext{
${ }^{981}$ BARBOSA MOREIRA, José Carlos. Comentários ao Código de Processo Civil, cit., vol. v, nº 215, p. 387.

${ }^{982} I d ., \mathrm{n}^{\circ} 235$, p. 424.
} 
Tanto num quanto noutro caso, o que anima e justifica a formulação de demanda em litisconsórcio eventual ou alternativo diz respeito à dúvida objetiva tantas vezes referida ao longo deste trabalho.

Para o adequado enfrentamento do tema proposto neste tópico, convém ter por premissa o quanto ficou exposto quando se tratou dos capítulos de sentença ( $\mathrm{n}^{\circ}$ 54, supra), já que, conforme salienta abalizada doutrina, estão na teoria da sentença os enunciados teóricos que vão comandar os reflexos do tema em matéria recursal ${ }^{983}$.

Então, considerando-se as variações de capítulos de sentença na presença de litisconsórcio eventual e de alternativo, inicia-se com a apreciação da hipótese em que todos os pleitos são rejeitados pelo juízo de primeiro grau ${ }^{984}$.

Nessas condições [rejeição integral do(s) pedido(s)], pode-se ter ainda a variante de o litisconsórcio ter-se verificado no polo ativo ou no passivo.

Se o litisconsórcio for ativo (eventual ou alternativo), os autores terão interesse e legitimidade para impugnar a decisão na porção do litígio que lhes afeta, devolvendo-se, assim, ao órgão ad quem a inteireza da discussão travada em primeiro grau. Mantém-se, nessa hipótese, a subsidiariedade e a alternatividade com que se formulou a demanda na origem.

Caso apenas um dos litisconsortes interponha sua apelação, estará quebrado o vínculo de subsidiariedade ou de alternatividade antes existente. Com efeito, na medida em que um dos autores não interpõe apelação, a porção da demanda a ele referida fica sob o abrigo da imunização decorrente da coisa julgada.

Suponha-se a demanda em que Antonio e Benedito, atuando em litisconsórcio ativo alternativo, promovem a Carlos. No mesmo caso, Antonio e Benedito, em vez de atuarem em litisconsórcio alternativo, poderiam litigar em litisconsórcio ativo eventual. Nessas condições, a sentença que dê pela improcedência em relação aos litisconsortes Antonio e

\footnotetext{
${ }^{983}$ DINAMARCO, Cândido Rangel. Capítulos de sentença, cit., nº 2, p. 13-14.

${ }^{984}$ No tratamento do assunto a que se dedica serão imaginadas situações em que há apenas um litisconsorte primário e outro subsidiário, seguindo semelhante trilha no campo do litisconsórcio alternativo, no âmbito do qual serão figuradas hipóteses de apenas dois litisconsortes alternativos. Essa postura visa apenas à facilitação da exposição, mas em nada compromete o conteúdo da investigação. Implica dizer que as soluções aqui encontradas podem ser transplantadas para os casos em que há grupos de sujeitos na condição de litisconsortes primários, na de subsidiários ou na de alternativos.
} 
Benedito, caso seja impugnada por apenas um deles, passará em julgado quanto ao outro. Em palavras diversas, o capítulo de sentença pertinente a um dos litisconsortes não se presume impugnado na apelação aviada pelo outro. É dizer, a extensão do efeito devolutivo da apelação de um litisconsorte não contempla a porção da demanda pertinente ao outro.

Noutra configuração, o litisconsórcio, na modalidade eventual ou na alternativa, pode dar-se no polo passivo. Daí que a improcedência integral do(s) pedido(s) abre espaço a que o autor formule sua apelação em face dos litisconsortes, situação que será suficiente para manter, também perante o órgão ad quem, a característica da subsidiariedade e da alternatividade entre os litisconsortes passivos.

Porém, se o autor recorre apenas quanto a um dos litisconsortes passivos vitoriosos, finda estará aquela noção de subsidiariedade ou de alternatividade, já que em relação a um dos litisconsortes passivos o litígio estará definitivamente julgado pelo órgão de primeira instância. Mais uma vez tem-se que o capítulo de sentença não impugnado transita em julgado, em virtude do caráter parcial da apelação na hipótese figurada.

Em caso de procedência em relação a algum dos litisconsortes, é preciso distinguir entre o litisconsórcio eventual e o alternativo, pois as soluções podem ser diferentes.

Suponha-se, de início, o litisconsórcio eventual ativo em que o litisconsorte primário seja vencedor, ficando o pedido pertinente ao litisconsorte subsidiário rejeitado, seja pelo mérito ou não, conforme o caso e consoante a concepção que se tenha sobre o tema ${ }^{985}$. Pelo prisma do litisconsorte primário, não haverá interesse recursal, porquanto se sagrou vencedor já em primeiro grau de jurisdição. Nessas condições, parece também não haver espaço para recurso independente por parte do litisconsorte ativo subsidiário, na medida em que, desde a propositura, manifestou sua opção em aderir a uma demanda colocada em grau de subsidiariedade, ou seja, o acolhimento do seu pedido só surgiria como possível se desacolhido o pedido pertinente ao litisconsorte primário.

Então, tocará apenas ao réu a interposição de apelação em relação ao capítulo de sentença que concluiu pela procedência do pedido formulado pelo litisconsorte ativo primário, pois reside aí a sucumbência do réu. No que pertine ao litisconsorte ativo

\footnotetext{
${ }^{985}$ Quanto à discussão sobre se o juiz aprecia ou não o mérito quanto ao litisconsorte subsidiário, cfr. $\mathrm{n}^{\circ} 54$, supra.
} 
subsidiário, o réu terá sido vencedor, não havendo cogitar-se de recurso deste em relação àquele.

A dúvida que remanesce gira em torno da posição do litisconsorte ativo subsidiário frente à possibilidade de provimento da apelação interposta pelo réu no que se refere ao litisconsorte ativo primário. É que o julgamento favorável ao litisconsorte primário, obtido em primeira instância, pode ser invertido em razão do provimento do recurso do réu, surgindo espaço, então, para eventual alteração no panorama jurídico do litisconsorte subsidiário. Essa instigante questão será analisada mais adiante $\left(\mathrm{n}^{\circ} 59\right.$, infra).

No campo do litisconsórcio eventual ativo ainda pode acontecer de a procedência recair sobre a pretensão do litisconsorte subsidiário, situação que colocará o litisconsorte primário na posição de sucumbente frente ao réu. Daí a possibilidade de interposição de recurso pelo litisconsorte primário, no afã de fazer prevalecer o grau de preferência exteriorizado na demanda inicial, com o qual o litisconsorte subsidiário desde o início aquiescera. Interessante notar que o provimento da apelação do litisconsorte primário fará com que fique rejeitado o pedido formulado pelo litisconsorte subsidiário, mesmo que não tenha havido recurso do réu em relação ao que se decidiu em favor do litisconsorte subsidiário.

Em outras palavras, o capítulo de sentença favorável ao litisconsorte ativo subsidiário não se consolida enquanto também não consolidado o capítulo desfavorável ao litisconsorte ativo primário. Por isso é que o provimento do recurso deste faz com que pereça o acolhimento do pedido em relação àquele. E não há motivos para o litisconsorte subsidiário insurgir-se quanto a essa conclusão, uma vez que desde a petição inicial ele próprio pôs sua pretensão em caráter subsidiário à do litisconsorte primário.

Então, do ponto de vista do conjunto de litisconsortes ativos (primário e subsidiário), transparece mais favorável, para ambos, o acolhimento do pleito formulado pelo litisconsorte primário, pois esse era o propósito manifestado desde a petição inicial ${ }^{986}$.

\footnotetext{
986 Veja-se que, embora o litisconsorte subsidiário não participe do segmento recursal, o provimento da apelação do litisconsorte ativo primário o beneficia, razão pela qual não haveria, na hipótese, maltrato ao princípio do contraditório. Mutatis mutandis, a solução adotada assemelha-se muito ao que se tem no art. 285-A, do CPC, em que o réu, embora não participando do contraditório, obtém para si um julgamento favorável.
} 
Ainda em tema de litisconsórcio eventual, figure-se a hipótese de sua verificação no polo passivo (Álvaro demanda em face de Bento, mas, para a hipótese de não acolhimento desse pleito primordial, formula desde logo pretensão subsidiária em face de Celso). Aqui, diferentemente do que ocorre no litisconsórcio eventual ativo, os litisconsortes não consentem desde o início com a ordem de preferência manifestada pelo autor, podendo surgir entre os colitigantes passivos um verdadeiro antagonismo.

Pois bem. Supondo-se que o pedido do autor seja procedente em relação ao litisconsorte passivo primário, apenas este terá interesse recursal, porquanto patenteada sua sucumbência. O litisconsorte subsidiário, porquanto vencedor no capítulo de sentença a ele referido, não terá do que recorrer, ressalva feita às verbas de sucumbência.

O autor, diante da vitória frente ao litisconsorte primário, também terá recebido do juízo a quo tudo o que esperava obter, inviabilizando-se pensar em recurso de sua parte, seja em relação ao litisconsorte primário, seja em relação ao subsidiário.

A elegante questão que sobrevive radica em torno do interesse de o autor, para se precaver quanto ao eventual provimento da apelação do litisconsorte passivo primário, manifestar alguma impugnação pertinente ao litisconsorte subsidiário. Tal discussão, porquanto atrelada a um possível cabimento de recurso adesivo, também será objeto de análise adiante $\left(n^{\circ} 59\right.$, infra).

Noutra configuração, pode-se imaginar o acolhimento do pedido pertinente ao litisconsorte subsidiário, pressupondo-se, evidentemente, a rejeição do pedido endereçado ao litisconsorte primário. Viabiliza-se, nesse quadro, o recurso do autor, com o objetivo de fazer prevalecer a primazia manifestada na petição inicial, isto é, a de que o pedido frente ao litisconsorte primário seja acolhido.

Uma vez que se dê provimento à apelação do autor frente ao litisconsorte primário, a situação jurídica do litisconsorte subsidiário será atingida para melhor, porquanto o acolhimento do pedido formulado ao corréu primário inviabiliza, por completo, a manutenção da procedência do pedido endereçado ao corréu subsidiário. Mais uma vez é preciso dizer que a posição jurídica do litisconsorte subsidiário só se consolida quando também consolidada a situação do litisconsorte primário.

Pense-se no seguinte exemplo: Antonio move ação indenizatória em face de Berenice e de Carlos, em razão de ato ilícito praticado por Daniel, que é filho incapaz dos primeiros réus; no mesmo processo, Daniel figura como litisconsorte subsidiário, isso para 
o evento de se considerar que seus pais não tenham obrigação, conforme estatui o art. 928, caput, do Código Civil. Se o pedido de Antonio for julgado procedente em relação a Daniel (litisconsorte eventual), dúvidas não pairam quanto ao interesse de o autor recorrer em relação aos pais (Berenice e Carlos), de sorte que eventual provimento desta apelação deita reflexos sobre a situação jurídica de Daniel ${ }^{987}$.

Mas, mantendo-se o mesmo exemplo, além do autor que sucumbiu frente ao litisconsorte primário, tem-se que o litisconsorte subsidiário também é vencido em relação ao autor, em ordem a se concluir pela existência de interesse recursal por parte do litisconsorte derrotado. Quanto à correção desta afirmação parece não remanescer dúvida alguma.

A discussão que se pode levantar, ainda na hipótese considerada, diz respeito à interposição de recurso apenas pelo litisconsorte subsidiário derrotado, sem que o autor tenha impugnado, em apelação independente, o capítulo de sentença que se refere à rejeição do seu pedido frente ao litisconsorte primário. E a dificuldade aparece em virtude da constatação de que o capítulo de sentença atrelado ao litisconsorte primário e não atacado por recurso do autor transita em julgado. Aqui também transparece relevante voltar os olhos para o campo do recurso adesivo, conforme se exporá em seguida ( $n^{\circ} 59$, infra).

Sobre esse tema recursal em matéria de litisconsórcio eventual passivo, a doutrina portuguesa orienta-se no sentido de que, em todo e qualquer caso de procedência, o recurso do réu sucumbente (litisconsorte primário ou subsidiário) há de se endereçar, necessariamente, tanto ao autor quanto ao outro litisconsorte, já que o réu recorrente estaria interessado em demonstrar a improcedência do pedido do autor e tal objetivo poderia ensejar o reconhecimento de que a procedência haveria de atingir o outro demandado $^{988}$.

Não se empresta adesão a semelhante postura interpretativa, uma vez que a ausência de tempestivo recurso do autor em relação a um dos litisconsortes passivos faz com que se imunize a decisão contida nesse específico capítulo de sentença.

\footnotetext{
${ }^{987}$ Essa mesma situação poderia ser figurada em tema de assunção de dívida. Basta que se pense na dúvida sobre a eficácia da transmissão do débito para que o credor mova, num escalonamento típico de litisconsórcio eventual, demanda em face do assuntor e do devedor originário, recaindo a preferência do autor sobre um desses sujeitos. O provimento da apelação do autor frente ao litisconsorte primário redundará na rejeição do pedido frente ao litisconsorte subsidiário.

988 TEIXEIRA DE SOUSA, Miguel. Estudos sobre o novo processo civil, cit., p. 505.
} 
Exemplificativamente, ainda que no exame do recurso exclusivo do litisconsorte passivo primário (que sucumbiu em primeiro grau de jurisdição) fique alvitrado que a titularidade passiva da relação de direito material pertine ao litisconsorte subsidiário, isso não implicará que o órgão ad quem estará apto a reapreciar o capítulo de sentença pertinente ao litisconsorte subsidiário, dada a ausência de impugnação desse capítulo por recurso do autor. Em outras palavras, o recurso de um réu não pode implicar modificação, para pior, da decisão de primeiro grau pertinente ao colitigante passivo. Nessas condições, só mesmo mediante recurso do autor é que o capítulo de sentença pertinente ao litisconsorte subsidiário pode ser reexaminado pelo órgão ad quem.

Mas, como já sinalizado anteriormente, essa discussão será mais bem direcionada no tópico seguinte, quando da aferição de cabimento de recurso adesivo cruzado (em face do litisconsorte que não recorreu pela via principal) e condicionado (para o evento de ser provido o apelo do colitigante que recorreu na via principal). Adianta-se que tal parece ser a postura mais adequada para o sistema recursal brasileiro, mas o enfrentamento específico do tema fica diferido para o tópico seguinte.

Já pelo espectro do litisconsórcio alternativo, as mesmas possibilidades e variantes fazem-se presentes, impondo-se a busca de soluções que se sustentem do ponto de vista teórico e que sejam razoáveis por um enfoque prático.

Suponha-se, em primeiro lugar, que o litisconsórcio alternativo se verifique no polo ativo. Aqui os autores terão aquiescido, desde o início, com o acolhimento do(s) pedido(s) quanto a um ou ao outro. Reside aí a indiferença inúmeras vezes referida neste estudo.

O acolhimento do pedido manifestado por um dos autores, por si só, gera o melhor dos resultados esperados por ambos os litisconsortes ativos, donde falecer interesse recursal quanto aos componentes do polo ativo. Não será assim, todavia, para o réu, que terá legitimidade e interesse recursal frente àquele autor que se sagrou vencedor em primeiro grau de jurisdição.

O problema que se entrevê, nessa particular situação, resulta da ausência de interesse recursal por parte dos autores e a possibilidade de a apelação do réu vir a ser provida quanto ao capítulo de sentença atrelado ao litisconsorte ativo que se sagrara vencedor em primeira instância. A indagação que fica é se o órgão ad quem, ao dar provimento ao recurso do réu frente a um dos litisconsortes ativos, poderá, em razão disso, ingressar na análise da situação jurídica do outro litisconsorte ativo, julgando o pedido 
deste, se for o caso, procedente. Mais uma vez abre-se convite para aprofundamento em tema de recurso adesivo ( ${ }^{\circ}$ 59, infra).

Caso o litisconsórcio alternativo seja passivo, cabe relembrar, ainda uma vez, que a indiferença quanto ao acolhimento do pedido em relação a um ou a outro só existe na perspectiva do autor e não na dos réus!

Pois bem. Se em primeiro grau de jurisdição o autor sair-se vitorioso em relação a um dos litisconsortes alternativos, evidencia-se que o demandante não terá interesse recursal algum. E isso se dá em relação a ambos os litisconsortes alternativos passivos, já que o autor obteve tudo quanto poderia obter, segundo a formulação da demanda exposta na petição inicial.

Também não terá interesse recursal o corréu não alcançado pela procedência do pedido do autor. Surgiria, então, apenas a possibilidade do recurso daquele litisconsorte alternativo atingido pela vitória do demandante, com devolução ao órgão ad quem da matéria afeta a esse específico litisconsorte alternativo passivo. Daí novamente os riscos, para o autor que se sagrou vencedor em primeiro grau, advenientes do possível provimento da apelação do corréu, dado que a ausência do outro litisconsorte passivo no segmento recursal impede que o tribunal embrenhe-se no exame da posição deste. Portanto, mais uma vez, é preciso investigar a necessidade ou não do recurso adesivo ( $\mathrm{n}^{\circ} 59$, infra).

Para finalizar, convém registrar que o litisconsórcio eventual e o alternativo não impõem modificações em tema de desistência de recurso já interposto e tampouco de renúncia ao direito de recorrer, lembrando-se sempre que as modalidades litisconsorciais aqui estudadas não configuram hipóteses de litisconsórcio unitário.

Logo, o recorrente poderá, a qualquer tempo, mesmo sem a anuência dos litisconsortes, desistir do recurso que interpôs (CPC, art. 501). Muito embora em algumas poucas situações o recurso de um litisconsorte, caso fosse provido, pudesse beneficiar o outro litisconsorte - conforme defendido neste mesmo tópico -, isso não significa que o recorrente tenha que buscar anuência do colitigante para só então ser aperfeiçoada sua manifestação de vontade no sentido da desistência. E assim é porque, cessada a causa recurso de um dos litisconsortes -, cessa também seu possível efeito - benefício em favor do outro colitigante. 
A mesma lógica deve ser observada no campo da renúncia ao direito de recorrer, pois, segundo se lê em doutrina, a renúncia não se condiciona à aquiescência dos litisconsortes do renunciante ${ }^{989}$.

\section{Apelação adesiva: litisconsórcio eventual e alternativo}

Como se pôde perceber pela tratativa anunciada no número anterior, a modulação eventual e alternativa de litisconsórcio enseja aguda reflexão em tema recursal e é possível entrever alguns pontos duvidosos que não se dissipam pelo prisma isolado da apelação independente. Daí o convite a que se pense em soluções que podem estar mais precisamente no ambiente da apelação adesiva (CPC, art. 500, in fine).

Para retomar o fio condutor do raciocínio, convém isolar as hipóteses que impõem uma reflexão mais aprofundada no tema ora analisado.

A primeira hipótese pode ser assim sintetizada: o autor litiga em face de dois réus e manifesta preferência quanto à procedência do pedido em relação a um deles, sendo a posição do outro meramente subsidiária ${ }^{990}$; o pedido do autor é julgado procedente em relação ao réu primário (ou principal), de maneira que o pedido em relação ao réu subsidiário fica prejudicado ou rejeitado pelo mérito; o réu sucumbente apela, na busca pela improcedência do pedido do autor. Nessas condições, o que faz o autor para, em caso de provimento da apelação do réu que sucumbiu em primeiro grau, buscar, ao menos, a procedência do seu pedido quanto ao litisconsorte subsidiário?

A segunda hipótese pode ser traduzida assim: o autor sucumbe em relação ao litisconsorte primário e se sagra vencedor quanto ao litisconsorte subsidiário ${ }^{991}$; diante desse resultado de primeira instância, o autor se contenta com o resultado, mas o réu subsidiário interpõe apelação. Surge, então, para o autor, agora diante da possibilidade de ser provida a apelação do litisconsorte subsidiário, o interesse em ver reconhecida a procedência quanto ao litisconsorte primário.

\footnotetext{
989 BARBOSA MOREIRA, José Carlos. Comentários ao Código de Processo Civil, cit., vol. V, nº 187, p. 345.

${ }^{990}$ O caso é de litisconsórcio eventual passivo.

${ }^{991} \mathrm{O}$ exemplo também é de litisconsórcio eventual passivo.
} 
As duas hipóteses acima figuradas poderiam ser transformadas em situação de litisconsórcio eventual ativo, que é mais rara de ocorrer. Mas, seja como for, o problema é o mesmo e as soluções buscadas neste tópico servirão para ambas as situações.

Numa terceira formulação, agora partindo para o campo do litisconsórcio alternativo ativo, suponha-se que um dos autores seja vencedor em primeiro grau, sobrevindo apelação do réu que almeja obter uma decisão de rejeição do pedido formulado por aquele específico autor. Indaga-se sobre a viabilidade de alguma manifestação recursal por parte do outro autor, para a hipótese de provimento da apelação do réu frente ao litisconsorte ativo diverso.

Um quarto exemplo ainda é possível imaginar: em sede de litisconsórcio alternativo passivo, a vitória do autor em primeiro grau de jurisdição em relação a um dos litisconsortes dá ensejo à apelação deste réu alcançado pela procedência do pedido do autor. Daí a pergunta sobre se o autor, para o evento de ser provida a apelação daquele réu sucumbente, pode interpor recurso para que se lhe conceda o que foi pedido quanto ao outro litisconsorte passivo alternativo.

Conquanto as hipóteses possam se multiplicar, mostra-se possível delinear toda a celeuma já a partir dos casos acima vislumbrados ${ }^{992}$.

É preciso discernir, então, quanto aos limites da devolutividade da apelação independente, pois até onde a extensão do efeito devolutivo desta alcançar não será necessária a interposição do recurso adesivo.

Ao lidar com situação de litisconsórcio alternativo ativo em que se dera a procedência em favor de um dos colitigantes, antiga doutrina italiana sinalizava, sob a égide do Codice de 1865, que o autor cuja demanda não foi acolhida em primeiro grau deveria ser chamado para se defender diante da apelação principal interposta pelo réu. Ou seja, o réu que sucumbiu frente a um dos litisconsortes alternativos deve apelar também em

992 O problema foi assim resumido por CÂNDIDO DINAMARCO: "Nesses casos tem-se sentido uma dificuldade (que, de resto, surgirá em qualquer hipótese de litisconsórcio alternativo ou eventual), no que se refere aos limites do julgamento em segundo grau, quando um dos litisconsortes passivos é vencido e só ele apela. $\mathrm{O}$ autor, tendo pedido a condenação de ambos (ou, alternativamente, de algum deles), ordinariamente deixa de apelar quando só um é condenado e o outro não. O problema surge quando em grau de apelação se reconhece que a obrigação não era do apelante mas de seu litisconsorte: a apelação interposta por aquele é provida mas fica impossível ao tribunal pronunciar a procedência da ação quanto ao outro réu, simplesmente porque o autor, que poderia pleiteá-la, não apelou" (Litisconsórcio, cit., nº 188, p. 468 - grifos do original). 
relação àquele adversário cuja demanda não fora examinada ou fora mesmo rejeitada. Disso decorre que o autor não atingido pela procedência do pedido está autorizado em virtude do apelo principal a repropor sua demanda em segundo grau de jurisdição, sem a necessidade de apelar incidentalmente ${ }^{993}$.

Em senso diverso, ponderou-se, agora sob os influxos do Codice de 1940, que em situação de litisconsórcio alternativo passivo a condenação de um dos codemandados (caso a demanda seja condenatória) autoriza a apelação deste réu que sucumbiu perante o autor. E, para se precaver quanto ao possível acolhimento desse apelo principal, o autor deve valer-se do chamado "gravame incidentale" $" 994$.

Recentemente, GIAN FRANCO RICCI explica que, em situação de litisconsórcio alternativo passivo, o autor que se sagra vencedor em relação a um dos réus não tem interesse para interpor recurso independente. Mas, para o demandante, o problema surge diante do recurso daquele réu alcançado pela procedência do pedido. Em tal hipótese, diz o doutrinador italiano, não se pode negar que para o autor surge aí o interesse, que inicialmente não existia, de recorrer em via incidental em relação ao outro réu ${ }^{995}$.

Entre nós, CÂNDIDO DinAMARCo propõe que, para os casos acima enumerados, a demanda só se considera reproposta em toda a sua extensão perante o órgão ad quem mediante a interposição de recurso adesivo. Só assim será possível ao tribunal julgar a causa com todo o leque de possibilidades manifestado em primeiro grau de jurisdição. Pondera-se, ainda na perspectiva dessa opção interpretativa, que o recurso adesivo "terá

${ }^{993}$ MORTARA, Ludovico. Appello civile, cit., n ${ }^{\text {o }} 1553$, p. 972. No mesmo trecho, o autor ainda explicita: "In altre parole, è lo stesso appello principale che, anche in questo caso, investe il giudice superiore del potere di riesaminare la lite nello stato integrale in cui era stata discusa in primo grado".

${ }^{994}$ ALLORIO, Enrico. Litisconsorzio alternativo passivo e impugnazione incidentale, cit., no 4, p. 520. Assim também se manifestou GIUSEPPE TARZIA: "Se il litisconsorte B, condannato in primo grado, vince in appello contro l'attore con la motivazione che non $\mathrm{B}$, ma A è il debitore, non esisterebbe per il giudice d'appello la possibilità di condannare ora A: ma vedremo che l'ostaculo è eliminato, almeno nel nostro diritto, con l'istituto dell'impugnazione incidentale" (Appunti sulle domande alternative, cit., n 7 , nota 120, p. 293).

995 Op. cit., p. 343. Interessa notar, ademais, que aludido autor admite o chamado recurso incidental condicionado: "Ciò al fine di evitare che nell'eventuale ipotesi di assoluzione in sede di gravame del secondo convenuto, l'attore non debba restari a mani vuote. Come si vede, si trata del classico caso dell'impugnazione incidentale 'condizionata', quell'impugnazione cioè non consentita in via principale per difetto di interesse ed in cui questo sorge sola a seguito dell'impugnazione altrui” (id., ibid.). Assim também COMOGLIO; FERRI e TARUFFO (Lezioni sul processo civile, cit., vol. I, p. 605). 
caráter eventual", pois que o interesse recursal no âmbito deste recurso só se deflagrará na medida em que provida a apelação independente ${ }^{996}$.

Como se vê, a doutrina por último citada segue a trilha da orientação italiana, fazendo-se, evidentemente, as adaptações que decorrem da diversidade de tratamento legislativo entre o sistema recursal peninsular e o brasileiro ${ }^{997}$.

Conquanto se concorde com a preleção que se vem de expor, é preciso aprofundar no exame dos aspectos que a possam justificar.

É que, segundo se tem em doutrina, o nosso recurso adesivo consiste numa impugnação contraposta à da parte adversa, manifestada por quem inicialmente se dispunha a não atacar a decisão, só vindo a fazê-lo em razão do recurso do outro litigante $^{998}$. Não se trata, pois, de um recurso que reforça a posição daquele que por primeiro recorreu - como poderia transparecer em razão do termo "adesivo"999.

Aflui da doutrina oportuna asserção consoante a qual o recurso adesivo não configura, a rigor, um verdadeiro recurso. Antes disso, trata-se de modalidade especial de interposição $^{1000}$ de alguns recursos previstos pelo legislador. Nesse aspecto, JOSÉ AFONSO DA SILVA é enfático: “O recurso adesivo brasileiro não tem, em si, natureza de recurso. (...)

\footnotetext{
${ }^{996}$ Litisconsórcio, cit., no 188 , p. 469.

997 Para bem entender o sistema da impugnação incidental italiana, em comparação com o nosso recurso adesivo, consulte-se, com proveito, a obra de JOSÉ AFONSO DA SILVA (Do recurso adesivo no processo civil brasileiro. 2. ed. São Paulo: RT, 1977, p. 51 et seq.). BARBOSA MOREIRA também faz relevante paralelo entre o sistema nacional e o italiano (Comentários ao Código de Processo Civil, cit., vol. V, $\mathrm{n}^{\circ} 170$, p. 310-311).

${ }^{998}$ BARBOSA MOREIRA, José Carlos. Comentários ao Código de Processo Civil, cit., no 169, p. 310. Em verdade, a despeito do nomen iuris, o recurso adesivo não exterioriza efetiva adesão. O que se tem, na realidade, é uma contraposição. Por isso também não se pode confundir o recurso adesivo do CPC brasileiro com a "adesão ao recurso" de que trata o art. $683^{\circ}, \mathrm{n}^{\circ} 2$, do CPC português. O recurso adesivo do sistema brasileiro é equivalente ao "recurso subordinado" do sistema português, este previsto no art. $682^{\circ}$ do CPC lusitano.

${ }^{999}$ BARBOSA MOREIRA, José Carlos. Comentários ao Código de Processo Civil, cit., no 171, p. 315-316. ${ }^{1000}$ ARAGÃO, Paulo Cezar. Recurso adesivo. São Paulo: Saraiva, 1974, p. 5-6.
} 
É um procedimento recursal aplicado a três recursos: apelação, embargos infringentes e recurso extraordinário" ${ }^{\prime 1001}$.

Ainda segundo lição corrente, registra-se não ser requisito de admissibilidade do recurso adesivo a verificação de "vínculo substancial" entre a matéria nele debatida e aquela suscitada no recurso independente ou principal ${ }^{1002}$.

Ao cabo desse anúncio das peculiaridades do recurso adesivo que interessam à presente investigação, ainda se impõe considerar que, ressalvados os casos de litisconsórcio unitário, o litisconsorte (ativo ou passivo) não atingido pelo recurso independente interposto pelo adversário comum não pode interpor recurso adesivo. Semelhantemente, caso apenas um litisconsorte seja derrotado, ao recurso independente deste não pode aderir o adversário para querer atingir os demais ${ }^{1003}$. Não por outro motivo é que a legitimação passiva no recurso adesivo é da parte que recorreu de modo independente ${ }^{1004}$.

Diante desse cenário, haveria de se concluir pela inadmissibilidade, no sistema recursal pátrio, do recurso adesivo cruzado, ou seja, aquele por meio do qual se busca rever decisão sob a perspectiva de um litigante que não é o sujeito ativo do recurso principal ou independente.

Contudo, quando se colocam essas premissas - adotadas no âmbito do litisconsórcio em geral - diante da rica gama de possibilidades oriunda dos embates em litisconsórcio eventual e alternativo, o intérprete defronta-se com significativa perplexidade.

${ }^{1001}$ Do recurso adesivo no processo civil brasileiro, cit., p. 117. Tenha-se presente que a monografia citada é anterior à CF/88, que introduziu no nosso sistema o recurso especial endereçado ao STJ. Logo, na atualidade são quatro recursos que admitem a forma de interposição adesiva, ex vi do art. 500, inc. II, do CPC.

1002 BARBOSA MOREIRA, José Carlos. Comentários ao Código de Processo Civil, cit., no 173, p. 318.

${ }^{1003} I d ., \mathrm{n}^{\mathrm{o}} 174$, p. 319.

${ }^{1004}$ Em acórdão da relatoria do Min. Athos Gusmão Carneiro, o STJ assim decidiu: "Se o recurso principal é manifestado pelo réu condenado ao ressarcimento, não cabe ao autor interpor recurso adesivo impugnando a improcedência da demanda relativamente ao outro réu. O recurso adesivo vincula-se ao principal, em relação de subordinação (CPC, art. 500, III); o recorrente no recurso principal deverá estar como recorrido no recurso adesivo” (STJ, REsp nº 27.319/GO, 4 T., Rel. Min. Athos Gusmão Carneiro, j. 27.04.1993, DJ 31.05.1993, v.u.). 
Retome-se um só exemplo: Alberto promove demanda condenatória em face de Benedito e de Carlos, mediante formulação alternativa de litisconsórcio passivo; a sentença condena Benedito e, exatamente por causa disso, julga improcedente o pedido de Alberto em relação a Carlos, resolvendo-se a dúvida objetiva que pairava anteriormente; Benedito interpõe apelação, buscando a reversão do julgamento, inclusive pelo fundamento de que Carlos e não ele (Benedito) seria o responsável pelo evento gerador da condenação.

Como se vê, por força da decisão de primeiro grau, desfez-se a alternatividade que estava pendente até o específico momento do pronunciamento judicial sobre a dúvida objetiva que animava a construção litisconsorcial alternativa. Agora, com a sentença, apenas um dos réus deve alguma coisa ao autor.

Todavia, em virtude da apelação do litisconsorte condenado, a celeuma em torno daquela "dúvida objetiva" passa a ser objeto de aferição pelo órgão ad quem, sem que este possa, de sua parte, resolver a questão segundo a alternatividade que se colocou em primeiro grau de jurisdição, pelo simples fato de não haver recurso do autor.

Aliás, uma eventual apelação independente interposta pelo autor, nessas condições, nem seria cabível, haja vista a ausência de sucumbência que o autorizasse.

Daí a utilidade de se buscar no procedimento do recurso adesivo a técnica adequada a fazer com que a porção da demanda não vinculada ao recorrente principal seja também objeto de exame pelo órgão ad quem. Voltando ao exemplo figurado, por força da apelação interposta por Benedito (réu condenado em primeira instância), o autor (Alberto) que não recorreu de modo independente poderia, mesmo assim, apresentar sua apelação adesiva em relação ao corréu Carlos, a fim de que, uma vez provida a apelação de Benedito, fosse apreciado o litígio sob a perspectiva do outro colitigante (Carlos).

Ora, não aceitar, em semelhante situação, a interposição do recurso adesivo, mesmo com esse viés cruzado, significaria o mesmo que não admitir a formulação de litisconsórcio eventual ou de alternativo na fase recursal. Ou seja, o litigante teria um "meio direito", capaz de autorizá-lo a manejar demanda em litisconsórcio eventual ou alternativo em primeira instância, mas tal "direito de ação" jamais poderia ser exteriorizado perante a superior instância.

É verdade que a forma de interposição adesiva de apelação pressupõe, segundo a legislação em vigor, a ideia de sucumbência recíproca. Mas, como se trata de procedimento e não propriamente de um recurso autônomo, as hipóteses de cabimento podem ser 
nalguma medida alargadas ou, quando menos, flexibilizadas para que se alcance o objetivo de concretizar todos os valores que estão na base de sustentação da própria formulação eventual e alternativa de litisconsórcio.

O que se tem chamado aqui de recurso adesivo cruzado deve-se ao quanto exposto por PEDRo MiRANDA DE OliveIRA no ensaio intitulado "Recurso excepcional adesivo cruzado" ${ }^{1005}$. No campo dos recursos extraordinário e especial, o articulista citado propõe interessantíssima reflexão, animada por situação assim exemplificada: o autor propõe contra a fazenda pública uma demanda versando teses tributárias, uma de quilate legal e outra de ordem constitucional; o tribunal, ao julgar apelação, acolhe a tese do contribuinte e afirma a ilegalidade do tributo questionado, de sorte que, na perspectiva do autor, não há qualquer interesse recursal; todavia, a fazenda pública interpõe recurso especial, no intuito de afastar a conclusão quanto à ilegalidade da exação.

A partir da interposição do recurso especial, "surge o interesse recursal para o contribuinte interpor recurso extraordinário adesivo ao recurso especial do Fisco, a fim de que a tese da inconstitucionalidade seja analisada no STF, caso o STJ afaste a ilegalidade" ${ }^{1006}$. E assim deve ser porque, caso não haja o recurso extraordinário adesivo, “o contribuinte verá sua tese de inconstitucionalidade precluir com o prazo de apresentação das contra-razões ao recurso especial" ${ }^{, 1007}$.

Outro exemplo ainda pode ser figurado: numa ação que versa sobre contrato bancário, o autor argumenta com a redução dos juros cobrados, no intuito de limitá-los segundo a Constituição Federal (art. 192, § 3º, em sua redação originária) e segundo a legislação infraconstitucional (Lei de Usura); o tribunal acolhe o pedido com base no argumento constitucional, em ordem a se concluir pela ausência de interesse recursal por parte do autor, que se sagra plenamente vitorioso; contudo, a instituição financeira maneja recurso extraordinário, abrindo-se a possibilidade de o correntista interpor recurso especial adesivo, a fim de ver apreciada a questão dos juros agora sob a perspectiva da Lei de Usura $^{1008}$.

1005 In: NERY JR., Nelson; ARRUDA ALVIM WAMBIER, Teresa. Aspectos polêmicos e atuais dos recursos cíveis e de outros meios de impugnação às decisões judiciais. São Paulo: RT, 2005, vol. 8, p. 609 et seq.

${ }^{1006}$ OLIVEIRA, Pedro Miranda de. Op. cit., p. 631.

${ }^{1007}$ Id., ibid.

${ }^{1008}$ Id., p. 631-632. 
Tendo em vista que, no espectro dos recursos extraordinário e especial, a devolutividade é restrita nos moldes das balizas constitucionais, não haveria como num recurso ser enfrentada matéria afeta ao outro, inclusive porque tais recursos são da competência de Tribunais Superiores diversos (STF e STJ).

Pelo visto, a noção de recurso adesivo cruzado não repugna ao sistema recursal brasileiro, erigindo-se, em alguns casos, como uma verdadeira necessidade para possibilitar acesso da parte às instâncias extraordinárias ${ }^{1009}$.

Sob o comando desse influxo, parece coerente afirmar que a divisão da sentença em capítulos relacionados a sujeitos diversos, envolvidos numa formulação alternativa ou subsidiária, autoriza a interposição de recurso adesivo pela parte que, não fosse o recurso principal de um dos litigantes adversários, não teria razão alguma para recorrer. E a peculiaridade que conota a interposição cruzada de recurso adesivo diz com o alcance subjetivo deste, haja vista que o recurso adesivo subjetivamente cruzado endereça-se a um litigante diverso daquele que está na posição de recorrente no recurso principal.

E a ninguém pode surpreender a afirmação de que o interesse recursal daquele que almeja valer-se do recurso adesivo está efetivamente presente. É que o interesse em recorrer pela forma adesiva, segundo diz BARBOSA MOREIRA, "afere-se à luz da função processual do recurso adesivo, que é a de levar à cognição do órgão ad quem matéria ainda não abrangida pelo efeito devolutivo do recurso principal, e que portanto ficaria preclusa em não ocorrendo a adesão" ${ }^{\prime 1010}$.

Outra peculiaridade que se constata na forma adesiva de apelação aqui considerada atrela-se ao seu caráter condicionado. Com efeito, a apreciação do mérito do recurso adesivamente interposto fica condicionada ao provimento do recurso principal, de sorte que a apelação adesiva é interposta para o evento de ser provido o recurso independente. Fala-se, então, numa interposição do recurso adesivo ad cautelam, isto é, para que seja

\footnotetext{
1009 Assim também a conclusão do autor por último citado: “Como se constata, o recurso excepcional adesivo cruzado é, atualmente, imprescindível para a harmonização do sistema recursal que implementou no Brasil, sob pena de descaracterizar o alcance e a utilidade prática do referido instituto, bem como de vedar acesso às instâncias extraordinárias" (Op. cit., p. 633).

${ }^{1010}$ Comentários ao Código de Processo Civil, cit., vol. V, nº 175, p. 320.
} 
julgado "unicamente no caso de convencer-se o órgão ad quem da procedência do recurso principal"1011.

Semelhante postura mostra-se admissível porque a condicionante envolvida no ato processual de interposição do recurso reside na economia interna do processo considerado. E, como refere a doutrina, apenas as condicionantes externas é que se poderiam levantar como óbices à prática de atos processuais condicionados ${ }^{1012}$.

Não bastassem a própria letra do art. 289 do CPC e toda a construção que aqui se erigiu em torno do litisconsórcio eventual e do alternativo, ainda é preciso observar que o sistema recursal brasileiro não está infenso à interposição de recurso assim condicionado.

Veja-se que no espectro dos recursos extraordinário e especial a existência no acórdão de fundamentação constitucional e infraconstitucional, sendo qualquer delas suficiente, por si só, para justificar a conclusão ditada no pronunciamento que se quer atacar, impõe que a parte vencida apresente ambos os recursos. Evidencia-se, nessa configuração, que o recurso extraordinário vem interposto ad cautelam, ou seja, para o evento de não ser provido o especial ${ }^{1013}$.

É que, sendo um dos fundamentos suficiente, de per si, para manter íntegra a conclusão do julgado, a ausência de recurso quanto ao aspecto constitucional, por exemplo, torna preclusa toda a discussão, mesmo na presença de recurso quanto ao aspecto infraconstitucional $^{1014}$. Não há dúvidas, pois, de que a parte sucumbente ostenta interesse quanto ao recurso extraordinário exatamente por hesitar sobre a sorte que se vai reservar ao recurso especial. E a utilidade do recurso extraordinário resulta da percepção de que a ausência de impugnação quanto ao fundamento constitucional adotado no acórdão faz tal pronunciamento transitar em julgado.

${ }^{1011}$ BARBOSA MOREIRA, José Carlos. Comentários ao Código de Processo Civil, cit., no 179, p. 329 grifo do original.

${ }^{1012} I d ., \mathrm{n}^{\circ} 179$, p. 330.

${ }^{1013}$ Consulte-se, sobre o ponto, o que ficou assentado nas premissas das modalidades litisconsorciais objeto de estudo (Parte II, Cap. I, no 11, “v").

1014 O verbete 283 da Súmula do STF assim orienta: "É inadmissível o recurso extraordinário, quando a decisão recorrida assenta em mais de um fundamento suficiente e o recurso não abrange todos eles". Em modo consoante, o enunciado 126 da Súmula do STJ dispõe: "É inadmissível o recurso especial, quando o acórdão recorrido assenta em fundamentos constitucional e infraconstitucional, qualquer deles suficiente, por si só, para mantê-lo, e a parte vencida não manifesta recurso extraordinário". Na doutrina, cfr. MANCUSO, Rodolfo de Camargo (Recurso extraordinário e recurso especial, cit., p. 383 et seq.). 
De igual modo, o agravo retido configura eloquente sinal de que o sistema recursal pátrio convive com o já mencionado condicionamento intraprocessual ${ }^{1015}$. Realmente, o agravante vê-se na contingência de agravar pelo modo retido sob pena de presenciar a preclusão daquela específica matéria. Mas está fora de dúvida que, no momento da interposição do agravo, o recorrente nem sabe qual será o resultado do julgamento do mérito da causa e tampouco se haverá o recurso de apelação necessário para que o agravo retido seja, em tese, conhecido. Ninguém se surpreende, pois, com a afirmação de que o agravo retido traduz, nesses termos, hipótese de recurso condicionado.

Daí que parece razoável, em tema de litisconsórcio eventual e de litisconsórcio alternativo, a construção que não vê empeço na interposição de apelação na forma adesiva, ainda que tal manifestação recursal ocorra para o evento de ser provido o recurso principal ou independente ${ }^{1016}$.

Em conclusão, lícito é entender que a aceitação do recurso adesivo subjetivamente cruzado e condicionado constitui projeção para a instância superior da admissibilidade do litisconsórcio eventual e alternativo em primeiro grau de jurisdição. Tal objetivo se alcança, como já visto, mediante uma flexibilização procedimental ${ }^{1017}$ que não repugna ao sistema processual em vigor, antes concretiza os valores pertinentes ao acesso à justiça nos vários graus de jurisdição.

\section{Apelação: litisconsórcio sucessivo}

No momento próprio foi traçado o panorama da cumulação sucessiva de pedidos e seus significativos reflexos no âmbito da extensão do efeito devolutivo da apelação ${ }^{1018}$. Se

${ }^{1015}$ A expressão é de BARBOSA MOREIRA (Comentários ao Código de Processo Civil, cit., vol. V, nº 179, p. 330).

${ }^{1016}$ No sentido da admissão de recurso adesivo condicionado, cfr. BARBOSA MOREIRA (Comentários ao Código de Processo Civil, cit., no 179, p. 329-330) e PAULO CEZAR ARAGÃO (op. cit., p. 50-54).

${ }^{1017}$ Mais uma vez se evoca o princípio da elasticidade processual para, em obséquio às necessidades da causa, esquadrinhar um adequado tratamento procedimental, sobretudo quando está em jogo necessidades que advêm da própria compostura da relação de direito material. Sobre o assunto, consulte-se, por todos, BEDAQUE, José Roberto dos Santos (Direito e processo, cit., $\mathrm{n}^{\circ}$ 17, p. 68-70). De forma mais ampla, confira-se GAJARDONI, Fernando da Fonseca (op. cit., passim).

${ }^{1018}$ Cfr. Parte II, Cap. II, no 14, “v”. 
lá a discussão já se mostrava intrincada e de difícil encaminhamento, é possível entrever maiores perplexidades no espectro do litisconsórcio sucessivo, já que aqui o vínculo de prejudicialidade, como já se viu à saciedade, envolve sujeitos distintos ${ }^{1019}$. É dizer, o capítulo de sentença prejudicial pertine a um sujeito e o capítulo prejudicado relaciona-se a sujeito distinto, trazendo-se à tona, agora com revigorada força, o problema do destino que se pode (ou se deve?) dar aos capítulos de sentença dependentes, condicionados ou subordinados.

Inicia-se com a rápida lembrança de que no litisconsórcio sucessivo verificado no polo passivo o autor postula a procedência em relação a todos os litisconsortes, com a peculiaridade de que o acolhimento do pedido feito ao litisconsorte sucessivo pressupõe a procedência também do pedido atrelado ao outro litisconsorte (antecedente). Seja lembrada, a título de exemplo, a hipótese de investigação de paternidade em face do suposto pai inválido para o trabalho, cumulada com pedido de alimentos em face dos avós $^{1020}$.

Diversamente, no campo do litisconsórcio sucessivo ativo dois autores demandam contra um réu comum, com a especificidade de que o acolhimento do pedido pertinente a um dos autores constitui-se em pressuposto necessário para o acolhimento do pedido incoado pelo coautor. Relembre-se a emblemática situação em que mãe e filho litigam em face do suposto pai: o filho investiga a paternidade e a mãe busca o ressarcimento das despesas do parto.

${ }^{1019}$ É o que ALLORIO chama de nexo de prejudicialidade entre relações subjetivamente diversas ( $L a$ cosa giudicata rispetto ai terzi. Milano: Giuffrè, 1992, nº 32, p. 70). CRUZ E TUCCI enfrenta essa questão sob a perspectiva dos limites subjetivos da eficácia da sentença e da coisa julgada (Limites subjetivos da eficácia da sentença e da coisa julgada civil, cit., p. 191 et seq.).

${ }^{1020}$ É verdade que esse exemplo põe em pauta o problemático art. 472, parte final, do CPC, que diz: "Nas causas relativas ao estado de pessoa, se houverem sido citados no processo, em litisconsórcio necessário, todos os interessados, a sentença produz coisa julgada em relação a terceiros". Contudo, a doutrina especializada preleciona que tal dispositivo não fomenta qualquer peculiaridade no campo dos limites subjetivos da coisa julgada, razão pela qual o sistema sobreviveria, tal como hoje está, mesmo sem o discurso linguístico que acaba de ser transcrito. Nesse sentido, por todos, cfr. CRUZ E TUCCI (Limites subjetivos da eficácia da sentença e da coisa julgada civil, cit., p. 291 et seq.). Daí que se pode trabalhar com o exemplo citado no texto sem o risco de nele existir alguma peculiaridade que pudesse alterar todo o panorama e o encaminhamento das possíveis soluções. 
Mais uma vez se interpõe o problema da apelação parcial e da possível extensão de seu efeito devolutivo para atingir capítulo de sentença não impugnado e atrelado a sujeito diverso daquele figurante da apelação ${ }^{1021}$. Importa relembrar que o apelante pode não só fazer decotes objetivos no recurso, limitando a matéria que se devolve ao conhecimento do órgão ad quem (CPC, art. 505), como também exclusões subjetivas, impondo balizas acerca dos sujeitos em relação aos quais se poderá decidir a causa em segunda instância $^{1022}$. Seria lícito falar, então, em apelação objetivamente parcial e também em apelação subjetivamente parcial, nada impedindo que, em certos casos, se verifique apelação objetiva e subjetivamente parcial.

Há certo consenso sobre que a eficácia subjetivamente extensiva a que alude o art. 509, do CPC, seja aplicável exclusivamente ao litisconsórcio unitário, por conta da indispensável uniformidade de disciplina que o Estado-juiz deve conferir à situação litigiosa $^{1023}$. E a previsão contida no parágrafo único do mesmo art. 509, que não se explica pelo prisma do litisconsórcio unitário, constituiria uma exceção ao sistema da personalidade dos recursos ${ }^{1024}$, fruto de expressa opção legislativa ${ }^{1025}$.

Como se decalca das afirmações acima, os questionamentos que o litisconsórcio sucessivo propõe na tela recursal não podem ser equacionados pelo prisma da unitariedade do litisconsórcio, pela simples constatação de que aquele não compartilha da natureza deste, consoante já se procurou demonstrar alhures.

Então, mais uma vez resta o apelo à prejudicialidade para se tentar construir, na medida do estritamente necessário, a excepcionalidade de o efeito devolutivo da apelação estender-se para além dos lindes objetivos e subjetivos em que manifestada pelo recorrente.

\footnotetext{
${ }^{1021}$ Há quem analise essa mesma temática sob o ângulo do chamado efeito expansivo subjetivo (NERY JUNIOR, Nelson. Princípios fundamentais - teoria geral dos recursos, cit., p. 411-414).

1022 Tal conclusão advém do quanto exposto no art. 514, I, do CPC.

1023 BARBOSA MOREIRA, José Carlos. Comentários ao Código de Processo Civil, cit., vol. V, nº 211, p. 381-383; NERY JUNIOR, Nelson. Princípios fundamentais - teoria geral dos recursos, cit., p. 412; DINAMARCO, Cândido Rangel. Litisconsórcio, cit., nº 74, p. 181.

${ }^{1024}$ Ao sistema da personalidade contrapõe-se o sistema da realidade, segundo o qual o recurso de um só dos vários sucumbentes contra um só dos eventuais vencedores autoriza uma pronúncia que valha para todos os litigantes (CARNACINI, Tito. Op. cit., nº 2, p. 3).

1025 Como refere BARBOSA MOREIRA, nos casos de solidariedade, "a eventual ruptura da uniformidade no julgamento acarretaria simples contradição lógica, cuja possibilidade não representa circunstância relevante para o regime do litisconsórcio" (Comentários ao Código de Processo Civil, cit., no 212, p. 384).
} 
Assim como ocorre na cumulação sucessiva de pedidos, aqui também não há autorização legislativa expressa que permita a extensão do efeito devolutivo da apelação à matéria não impugnada e a sujeito não participante do segmento recursal. Mas nem por isso se deve dar a tal cenário um significado de impossibilidade de extensão do efeito devolutivo quando na presença de prejudicialidade.

Com efeito, mais uma vez é preciso realçar a ideia de que a cumulação subjetiva (litisconsórcio) em termos de sucessividade só se compreende na medida em que interessa para o sistema a busca de harmonia entre os julgados. Logo, na medida do estritamente necessário à manutenção da compatibilidade entre as decisões de primeiro e de segundo grau, por força de uma apelação parcial, deve-se dar significativo valor ao nexo de prejudicialidade para, em casos excepcionais, ampliar o espectro de devolutividade da apelação.

As várias situações possíveis serão a seguir esquadrinhadas, formulando-se as respectivas soluções, coerentemente com o que se sustentou por ocasião do mesmo problema no campo da cumulação sucessiva de pedidos ${ }^{1026}$.

Na hipótese de litisconsórcio sucessivo passivo, a sentença pode dar pela procedência em relação a ambos os réus, acolhendo-se, pois, tanto a causa prejudicial quanto a prejudicada. Evidente que o autor não terá interesse recursal, já que se sagrara inteiramente vencedor. Os réus, porém, terão legitimidade e interesse para recorrer. Se ambos assim fizerem, o órgão ad quem estará investido do poder de reapreciar a causa em sua complexidade objetiva e subjetiva.

Contudo, se a apelação for interposta apenas pelo corréu atrelado ao capítulo de sentença prejudicado (condicionado ou subordinado), não se terá por devolvido ao tribunal o reexame do capítulo prejudicial, que assim estará definitivamente julgado pela sentença. A eventual reforma do capítulo pertinente ao corréu recorrente em nada alterará o quanto decidido em primeiro grau de jurisdição quanto ao capítulo prejudicial.

Se, porém, a apelação exclusiva do réu atrelado ao capítulo prejudicial for provida, reconhecendo-se a inexistência da relação prejudicial reputada existente em primeira instância, abrir-se-á caminho para o enfrentamento também do capítulo prejudicado vinculado ou outro corréu inerte. Assim será feito em obséquio ao valor atrelado à

${ }^{1026}$ As justificativas não serão repetidas nesta sede, razão pela qual se remete o leitor ao quanto se expôs no n 14 , "v", do Cap. II, da Parte II. 
harmonia dos julgados, na exata medida da conformação das relações de direito material vinculadas por prejudicialidade. Vale considerar que semelhante resultado beneficiará o litigante que não participou do segmento recursal, razão pela qual não entra em jogo qualquer empeço relativo ao princípio do contraditório.

Ou seja, mesmo sem ter participado do contraditório instalado perante o tribunal, o litisconsorte sucessivo terá sua relação atingida, para melhor, pelo que tiver sido decidido na apelação aviada pelo colitigante titular da relação prejudicial.

Noutro viés, mas ainda na hipótese de litisconsórcio sucessivo passivo, se os litisconsortes passivos foram inteiramente vencedores (improcedência total dos pedidos do autor) não se terá lugar para apelação dos réus. O autor, por sua vez, poderá apelar e levar ao tribunal a discussão do litígio em sua integralidade, tanto na perspectiva objetiva quanto na subjetiva, de molde a investir o órgão de segunda instância do poder-dever de decidir a causa tal como formulada em primeiro grau.

Contudo, nada obsta que o autor, que sucumbiu em relação a ambos os réus, opte por uma apelação parcial. Assim, caso a apelação se enderece apenas ao réu vinculado à causa subordinante, o provimento que se dê ao pleito do autor na seara recursal não pode interferir de modo gravoso em relação ao corréu atrelado ao capítulo de sentença prejudicado.

Aqui, ainda que possa existir a contradição lógica entre a conclusão do acórdão e a da sentença, impossível evitar tal resultado em face da ausência de recurso do autor contra o capítulo de sentença pertinente à causa prejudicada. E isso se deve ao fato de o réu não submetido ao contraditório na fase recursal não poder ser colhido, de surpresa, com a alteração do pronunciamento judicial que lhe beneficiava ${ }^{1027}$. Pode-se dizer, então, que a almejada harmonia de julgados não pode sobrepor-se ao primado mais elevado, que é o do

\footnotetext{
${ }^{1027}$ Como refere abalizada doutrina, a nova fase a que dá lugar a interposição do recurso deve também se desenvolver em contraditório, oportunizando-se que a contraparte possa expor suas próprias razões (REDENTI, Enrico. Diritto processuale civile, cit., vol. II, n 149, p. 330-331). Dessa conclusão não se pode mesmo escapar porque o "traço distintivo que realmente conota o processo judicial é o contraditório, cujo pressuposto básico é que ele se desenvolva num plano de absoluta paridade entre as partes" (CRUZ E TUCCI, José Rogério. Limites subjetivos da eficácia da sentença e da coisa julgada civil, cit., p. 109). Em acréscimo, o autor por último citado ainda lembra lição de TROCKER, segundo a qual o direito de defesa constitui garantia objetiva do processo e traduz-se em "direito inviolável em qualquer estado e grau do procedimento" (id., p. 110).
} 
contraditório. Realmente, na escala de valores do sistema, o contraditório ocupa posição de superlativo destaque, não merecendo ceder passo diante da conveniência da não contradição lógica entre julgados.

Caso, porém, a apelação do autor direcione-se apenas ao litisconsorte vinculado à causa prejudicada, isso fará com que a causa prejudicial, objeto do capítulo de sentença não impugnado, transite em julgado. Uma vez negada a existência da relação prejudicial (objeto do capítulo de sentença não atacado), isso redundará na inevitável rejeição também do recurso parcial aviado pelo autor quanto ao capítulo de sentença pertinente à relação subordinada e atrelada ao litisconsorte sucessivo ${ }^{1028}$. Pense-se no caso em que a sentença nega a existência da obrigação em relação ao devedor principal e o autor recorra apenas em face do fiador. Inescapável a conclusão de que, nessa perspectiva, a insubsistência da relação prejudicial, tal como reconhecida na sentença transitada em julgado, verterá reflexos intransponíveis para a decisão quanto ao capítulo prejudicado.

Invocando agora a modalidade de litisconsórcio sucessivo ativo, pode-se ter que a sentença acolha integralmente os pedidos dos autores, os quais, evidentemente, não terão interesse recursal, ressalva feita a algum aspecto sucumbencial. O réu, entretanto, terá vivo interesse de recorrer em face de ambos os autores e, se o fizer, ensejará que o órgão ad quem reaprecie o litígio em toda sua complexidade objetiva e subjetiva.

Mais uma vez o problema advém da possibilidade de se ter apelação parcial por parte do réu sucumbente.

Com efeito, se o réu apelar em relação ao autor vinculado ao capítulo prejudicial, dúvidas não há de que o juízo ad quem poderá decidir com liberdade tal questão, concluindo até mesmo pela inexistência da relação prejudicial. É verdade que, nessa hipótese, a decisão de primeiro grau favorável ao autor vinculado à causa prejudicada (em relação a quem não se recorreu) terá conteúdo assimétrico frente ao pronunciamento do tribunal quanto à causa prejudicial (objeto da apelação). Haverá, inescapavelmente, uma contradição lógica entre os julgados de primeiro e de segundo grau, tudo no bojo de um mesmo processo. Todavia, mais uma vez o valor pertinente à harmonia de julgados haverá de ceder passo diante do dogma do contraditório. Exsurge, pois, a conclusão de que a

1028 Seria possível até mesmo suspeitar da efetiva existência de interesse recursal do autor que impugne apenas o capítulo prejudicado quando o capítulo prejudicial já esteja definitivamente julgado, com reconhecimento da inexistência da relação prejudicial que serviria de suporte necessário para a relação subordinada. 
prejudicialidade, no caso considerado, não terá o efeito de devolver ao tribunal a análise do capítulo de sentença pertinente ao litisconsorte não alcançado pela apelação.

Diversamente, a apelação do réu direcionada apenas ao litisconsorte jungido ao capítulo prejudicado não terá o condão de investir o juízo ad quem do poder de reexaminar a posição jurídica já definida em primeiro grau quanto ao litisconsorte subordinante, visto que a antecedência lógica extraível da prejudicialidade transita no sentido inverso do aqui considerado. Em outras palavras, o julgamento do capítulo prejudicado não influencia o conteúdo da decisão pertinente ao capítulo prejudicial.

Pode suceder, ainda em sede de litisconsórcio sucessivo ativo, que a sentença rejeite integralmente os pedidos dos demandantes, abrindo-se possibilidade de os autores, em conjunto, interpor apelação contra o réu comum. Nenhuma conturbação se entrevê em semelhante hipótese.

Contudo, pode-se ter novamente a hipótese de apelação subjetivamente parcial, interposta apenas por um dos litisconsortes ativos sucumbentes.

Suponha-se, então, que para a improcedência dos pedidos dos autores se tenha concluído pela inexistência da relação prejudicial. A apelação do autor vinculado ao capítulo subordinante (prejudicial) só devolverá ao tribunal essa específica porção do litígio e não se poderá imaginar que, uma vez provida a apelação do autor recorrente (reconhecendo-se a existência da relação prejudicial), o réu veja o tribunal avançar numa seara sobre a qual não se instalou o regular contraditório ${ }^{1029}$. É dizer, não ocorre a extensão do efeito devolutivo da apelação do autor atrelado ao capítulo prejudicial com relação ao outro demandante titular da relação prejudicada. O tribunal, se não se conduzir nesses lindes, atuará extra petita.

Por fim, ainda é possível vislumbrar uma apelação interposta apenas pelo litisconsorte ativo vinculado ao capítulo prejudicado, situação que evidentemente não colocará o tribunal na posição de validamente decidir quanto ao litisconsorte inerte, titular da relação jurídica pertinente ao capítulo prejudicial. Novamente é preciso dizer que a decisão do capítulo prejudicado não influencia o teor do julgamento do capítulo

\footnotetext{
${ }^{1029}$ Tenha-se presente que na apelação restrita do autor vinculado ao capítulo prejudicial o réu (recorrido) não terá motivos para lançar argumentos defensivos imbricados com a situação do litisconsorte sucessivo (vinculado ao capítulo prejudicado). Daí por que se fala, no texto, em não instalação de regular contraditório em favor do réu/recorrido.
} 
prejudicial. Porém, mais relevante que isso se mostra a circunstância de o réu (recorrido) não ter sido chamado a contradizer sobre os aspectos conotados com a relação prejudicial atrelada ao litisconsorte que não recorreu. Daí que o primado do contraditório estaria também a impedir qualquer iniciativa de o tribunal, na apelação de um litisconsorte, açambarcar, em detrimento do recorrido, a situação do outro colitigante.

Se tudo quanto afirmado acima estiver correto, pode-se concluir que a prejudicialidade em sede de litisconsórcio sucessivo só pode servir de fundamento para autorizar, com o timbre da excepcionalidade, a extensão do efeito devolutivo da apelação quando seja para beneficiar o réu inerte, titular da relação prejudicada, quando se reconheça, no recurso, a inexistência da relação prejudicial imbricada com o litisconsorte recorrente.

Mesmo na hipótese considerada no parágrafo antecedente, o litigante que recorrer pode perfeitamente desistir do recurso interposto e será prescindível, para tanto, a aquiescência do outro colitigante. Cabe relembrar que o nexo de prejudicialidade não transpõe o litisconsórcio comum para o patamar de litisconsórcio unitário.

Assim também se pode dizer quanto à renúncia ao direito de recorrer. Cada um dos litisconsortes, cuja relação jurídica vincule-se à do outro por prejudicialidade, conserva para si a prerrogativa de renunciar, segundo seu particular alvitre, ao direito de recorrer, sendo irrelevante a aquiescência do outro.

A demonstrar ainda mais a riqueza do tema da prejudicialidade, sobretudo quando envolvidos sujeitos diversos nessa relação de subordinação lógico-jurídica, põe-se em foco o grau de vinculação que o capítulo de sentença prejudicial não atacado pelo recurso enseja quanto à análise, pelo juízo ad quem, do capítulo prejudicado e objeto de recurso objetiva e subjetivamente parcial. Noutros termos, indaga-se qual a repercussão da estabilização do capítulo prejudicial, relacionado a um dos litisconsortes, no que se refere ao reexame do capítulo de sentença pertinente ao litisconsorte sucessivo (titular da relação prejudicada).

Embora versando o assunto pelo prisma de processos autônomos, isto é, quando as causas prejudicial (atrelada a um sujeito) e prejudicada (vinculada a outro sujeito) são analisadas em processos distintos, a doutrina especializada expõe preleção útil ao enfrentamento da questão na perspectiva do litisconsórcio sucessivo. Reconhece-se, 
todavia, que a heterogeneidade de situações advindas das multifárias relações de direito material pode alterar o panorama das possíveis soluções ${ }^{1030}$.

Então, ao menos em linha de princípio, pode-se dizer, na esteira do que sustenta CRUZ E TUCCI, que o reconhecimento da inexistência da relação prejudicial põe o órgão ad quem na contingência de não poder suplantar tal conclusão quando for julgar, no âmbito do recurso parcial, a relação prejudicada. Não se trataria de uma expansão da autoridade da coisa julgada para além dos seus limites subjetivos, mas sim de uma ampliação da eficácia da conclusão contida no capítulo prejudicial ${ }^{1031}$.

Diferentemente, se o capítulo de sentença não impugnado contiver o reconhecimento da existência da relação prejudicial, a apelação parcial do litisconsorte vinculado à causa prejudicada habilita o órgão de segunda instância a decidir livremente sobre a subsistência ou não da relação material pertinente ao recorrente.

Exemplifica-se com a hipótese de o credor mover ação contra o devedor principal e também em face do fiador deste ${ }^{1032}$. O reconhecimento, em primeiro grau de jurisdição, da inexistência da obrigação principal (atrelada ao réu titular da relação prejudicial) impede que o tribunal a dê por existente no âmbito de um recurso aviado pelo credor apenas ao fiador (litisconsorte sucessivo).

Porém, no mesmo exemplo, se a obrigação principal for reconhecida como existente em primeira instância, no recurso que se refira apenas ao fiador o órgão ad quem não ficará vinculado quer à eficácia daquele pronunciamento prejudicial, quer à coisa julgada que lá se tenha operado quanto ao colitigante titular da relação subordinante.

\footnotetext{
${ }^{1030}$ Não haveria lugar, nesta dissertação, para expandir o estudo em tão delicado tema, de molde a abranger todas as suas potencialidades. Contenta-se, mesmo ciente da provável insuficiência do enfoque, dada a riqueza de situações prejudiciais geradas por esta ou aquela relação de direito material, com a exposição lançada no texto, bastante em si para demonstrar a necessidade de aprofundamento das discussões que o litisconsórcio sucessivo enseja.

${ }^{1031}$ Limites subjetivos da eficácia da sentença e da coisa julgada civil, cit., p. 195.

${ }^{1032}$ A hipótese é sugerida por CRUZ E TUCCI (Limites subjetivos da eficácia da sentença e da coisa julgada civil, cit., p. 195).
} 


\section{Ação rescisória}

Tem-se como dado assente que o tema dos capítulos de sentença influencia amiúde a teoria e a prática da ação rescisória ${ }^{1033}$. Também já se viu que as modalidades litisconsorciais aqui estudadas possibilitam, na medida de suas especificidades, a visualização precisa de capítulos de sentença distintos e pertinentes aos litisconsortes. Daí o indispensável aporte de reflexos do litisconsórcio eventual, alternativo e sucessivo também no espectro da ação autônoma de impugnação ora cogitada.

É preciso salientar, de início e ao menos como ideia geral, que apenas os capítulos de sentença que tenham ferido o mérito submetem-se, após o trânsito em julgado, à impugnação pela via da rescisória, ex vi do art. 485, caput, do $\mathrm{CPC}^{1034}$.

Põe-se, então, desde logo, a temática das falsas carências a que se aludiu quando do enfrentamento dos aspectos relacionados à sentença ( $\mathrm{n}^{\circ} 54$, supra), para onde se remete o leitor, com o escopo de evitar repetições desnecessárias. Segundo se crê, ainda que o órgão julgador, ao apreciar caso de litisconsórcio alternativo, por exemplo, tenha exposto sua conclusão com base no art. 267, VI, do CPC (falta de interesse superveniente ou ilegitimidade ad causam), nota-se que em certos casos todo o caminho lógico percorrido pelo julgador estará imbricado, necessariamente, com o próprio mérito da causa relativamente àquele específico litisconsorte. Significa dizer que a atecnia da linguagem empregada na sentença não altera a natureza das coisas. O que é mérito será sempre mérito, mesmo que o julgador tenha empregado rótulo diverso na tentativa de exprimir o conteúdo de sua decisão ${ }^{1035}$.

\footnotetext{
${ }^{1033}$ DINAMARCO, Cândido Rangel. Capítulos de sentença, cit., nº 58, p. 120.

${ }^{1034}$ Para aprofundamentos nesse pormenor, confira-se YARSHELL, Flávio Luiz (Ação rescisória, cit., p. 157 et seq.).

1035 No ponto, cfr. DINAMARCO, Cândido Rangel (Ação rescisória contra sentença terminativa, cit., $\mathrm{n}^{\circ}$ 694, p. 1242-1243). "Para a aferição da rescindibilidade é irrelevante o eventual erro de qualificação cometido pelo órgão que decidiu. O que se tem de levar em conta é a verdadeira natureza da decisão. Assim, v.g., embora não sejam de mérito (art. 267, n VI), nem pois rescindíveis as sentenças de 'carência de ação', como a que indefere a inicial por ilegitimidade de partes, a situação muda de figura se o juiz, com impropriedade, dissera julgar o autor 'carecedor de ação', quando na realidade estava a declarar improcedente o pedido. Corretamente interpretada a sentença, evidencia-se o cabimento da ação rescisória, tal qual se evidenciaria,
} 
Afora esse aspecto, tenha-se presente que as partes legítimas para a ação rescisória são exatamente aquelas figurantes no processo em cujo âmbito exsurgiu a decisão rescindível, além, é claro, do terceiro prejudicado e do Ministério Público, segundo as especificações do art. 587, do CPC.

Aqui não se vai trabalhar com a hipótese de ação rescisória movida pelo Ministério Público e nem pelo terceiro prejudicado. Convém pensar, para um enfoque litisconsorcial, exclusivamente nos casos de ação rescisória que envolva as partes do processo originário.

Assim como ocorre na seara recursal, nota-se que a celeuma pode eclodir quando na presença de ação rescisória parcial, haja vista que, nessas condições, "a rescisão só poderá ser parcial, jamais indo além dos capítulos cuja rescisão se houver pedido"1036 , sob pena de maltrato ao princípio da correlação entre o pedido e o pronunciamento judicial (CPC, arts. $2^{\circ}, 128$ e 460). E tal limitação, segundo corretamente adverte a doutrina, cobre tanto o aspecto objetivo quanto o subjetivo da demanda de rescisão ${ }^{1037}$.

Sendo assim, para ficar num exemplo de litisconsórcio alternativo passivo, se o autor tiver alcançado vitória em relação a um dos réus, culminando-se com a rejeição do pedido em relação ao outro, a eventual ação rescisória ajuizada pelo réu vencido só atingirá o capítulo de sentença (ou do acórdão) respeitante a ele e não ao outro corréu.

Pensando-se num caso de litisconsórcio eventual formado no polo passivo, pode-se figurar que o litisconsorte primário, que tenha sido condenado pela decisão já transitada em julgado, promova ação rescisória em face do autor, de modo que apenas o capítulo envolvendo tais litigantes é que poderá ser objeto de apreciação pelo tribunal. Sendo assim, a rejeição do pedido formulado, na ação originária, ao litisconsorte subsidiário permanecerá hígida a despeito do que venha a ser decidido na rescisória pertinente ao litisconsorte primário.

na hipótese inversa, o descabimento" (BARBOSA MOREIRA, José Carlos. Comentários ao Código de Processo Civil, cit., vol. V, no 69, p. 111-112).

${ }^{1036}$ DINAMARCO, Cândido Rangel. Capítulos de sentença, cit., n $\mathrm{n}^{\mathrm{0}}$ 58, p. 122.

${ }^{1037}$ DINAMARCO, Cândido Rangel. Id., nº 58, p. 122. Já se escreveu, acertadamente, que o litisconsórcio comum (não unitário) construído na ação originária não projeta para o campo da rescisória a necessidade de formação de litisconsórcio (YARSHELL, Flávio Luiz. Ação rescisória, cit., nº 46, p. 142). Daí que, na hipótese de litisconsórcio eventual e alternativo - que não se ajusta à moldura do litisconsórcio unitário -, a ação rescisória parcial mostra-se tranquilamente aceitável. Também nesse sentido é a preleção de BARBOSA MOREIRA, José Carlos (Comentários ao Código de Processo Civil, cit., vol. V, nº 101, p. 175). 
Emerge dessa consideração o possível interesse do réu da ação rescisória (que terá sido autor da ação originária nos dois exemplos acima figurados) em ampliar os limites objetivos e subjetivos da rescisória. É dizer, para o evento de a rescisória ser julgada procedente, com inversão do julgamento originário no âmbito do chamado juízo rescisório, o réu terá nítido interesse em fazer com que a porção da demanda originária respeitante ao outro litisconsorte alternativo ou subsidiário seja também submetida ao crivo do iudicium rescindens e, especialmente, do iudicium rescissorium.

Figure-se a hipótese em que o litisconsórcio alternativo passivo entre Aurélio e Bento tenha-se formado originariamente em razão de dúvida objetiva quanto à exata configuração dos fatos, de sorte que, após regular instrução, se conclua pela procedência em relação a Aurélio e pela improcedência quanto a Bento. Assim transita em julgado a decisão da causa. Sobrevém ação rescisória manejada por Aurélio (atingido pela procedência da demanda originária), sob o argumento de existir documento novo capaz de, nos termos do art. 485, VII, lhe garantir um pronunciamento favorável, isto porque Bento e não Aurélio seria o efetivo responsável (em sentido lato) pelo evento agitado na ação originária.

Veja-se que numa ação rescisória de corte parcial, como se dá no caso acima exposto, a possível inversão do julgamento inicial no âmbito do iudicium rescissorium (improcedência do pedido do autor em relação a Aurélio) não traz qualquer modificação no capítulo de sentença pertinente ao outro litigante (Bento). Daí que, a despeito dos fundamentos adotados no juízo rescisório para se concluir pela improcedência do pedido originário endereçado a Aurélio, não se tem espaço para avançar no julgamento e, assim, julgar procedente o pedido originário quanto a Bento.

Para casos semelhantes a esse, a doutrina enfatiza que o réu da ação rescisória, para ampliar o objeto litigioso dessa específica ação autônoma de impugnação, deve manejar reconvenção, a fim de que seja submetida ao tribunal, como objeto mesmo do juízo, a outra porção da demanda originária ${ }^{1038}$. Em outras palavras, a rescisória parcial pode tornar-se uma rescisória total se e somente se for manifestado o pleito reconvencional, ao menos na hipótese acima apreciada ${ }^{1039}$.

${ }^{1038}$ DINAMARCO, Cândido Rangel. Capítulos de sentença, cit., nº 58, p. 122.

1039 Nos casos de sucumbência recíproca verificada no âmbito da sentença ou do acórdão objeto da rescisória, a doutrina admite o manejo de reconvenção. Assim o diz BARBOSA MOREIRA: "se houve 
E aqui, no campo do litisconsórcio eventual e alternativo, volta à tona o assunto da reconvenção subjetivamente ampliativa, cuja admissibilidade já foi defendida neste trabalho ( $n^{\circ} 45$, iii, supra). Parece coerente afirmar, então, que, na presença de todos os demais requisitos de admissibilidade, o réu da ação rescisória encontra espaço propício para apresentar sua reconvenção em face do outro litisconsorte passivo da ação originária, a fim de que seja mantida, também no âmbito da rescisória, a configuração eventual ou alternativa de litisconsórcio.

Para aqueles que entendem que o acolhimento do pedido relacionado ao litisconsorte primário ou a um dos litisconsortes alternativos enseja o não conhecimento do pedido quanto ao outro litisconsorte (subsidiário ou alternativo), a solução preconizada acima ainda assim permanece válida. Com efeito, os influxos advindos da redação do art. $515, \S 3^{\circ}$, do CPC, permitem uma construção consoante a qual, mesmo no âmbito da rescisória, o tribunal estaria habilitado a julgar diretamente o mérito daquele capítulo não examinado na origem ${ }^{1040}$.

Confira-se um exemplo: Fernanda promove ação contra Cláudia e Daniela, havendo no polo passivo litisconsórcio eventual; o pedido da autora é julgado procedente quanto à litisconsorte primária (Cláudia), de sorte que resulta prejudicado (não apreciado no mérito) o pedido em relação à litisconsorte subsidiária (Daniela). Após o trânsito em julgado, sobrevém ação rescisória de Cláudia, na busca de um pronunciamento não só rescindente como também rescisório, com vistas à inversão do julgado originário, dada a presença de documento novo que revela ser Daniela e não Cláudia a titular passiva da obrigação sob exame. A ré da ação rescisória (Fernanda) poderá, em conformidade com o que vem sendo exposto, promover reconvenção e pedir que, uma vez alterado o teor do julgamento em

\footnotetext{
'sucumbência recíproca' e um dos litigantes pleiteia a rescisão da parte da sentença que lhe foi desfavorável, pode o adversário reconvir quanto à outra parte" (Comentários ao Código de Processo Civil, cit., vol. V, $\mathrm{n}^{\circ}$ 113, p. 193). Sobre o assunto, confira-se ainda AMORIM, Aderbal Torres de. Reconvenção, cumulação de ações e ação rescisória. Revista dos Tribunais, vol. 581, p. 268-270.

1040 Sobre o tema, consulte-se, com proveito, a preleção de YARSHELL, Flávio Luiz (Ação rescisória, cit., $\mathrm{n}^{\circ}$ 127, p. 375-378). Em outro trecho da mesma obra, o autor citado manifesta opinião que, de certo modo, também serve para justificar o que se expôs no texto: "se a cassação da sentença (ainda que sem julgar o mérito em relação a dado sujeito) levar a um novo julgamento que diga respeito ao litisconsorte em relação a quem antes o mérito não fora julgado, então, parece fora de dúvida que ele deverá ser trazido para a relação processual do processo na rescisória” (id., nº 46, p. 143).
} 
relação a Cláudia, o tribunal aprecie já o mérito em relação a Daniela (litisconsorte subsidiária na ação originária).

Na mesma proporção de elegância, vem a pelo os reflexos que a ação rescisória referente exclusivamente ao litisconsorte titular da relação prejudicial pode gerar quanto ao litisconsorte vinculado à relação prejudicada. Como se percebe, as mesmas dificuldades que o litisconsórcio sucessivo provoca no campo da apelação são também sentidas quando se trabalha com a prejudicialidade na perspectiva da ação rescisória.

Não se põe em dúvida o fato de a ação rescisória constituir ação autônoma e nisso distinguir-se dos recursos. Porém, dada a presença, no campo da rescisória, do chamado iudicium rescissorium, que se traduz no "rejulgamento da demanda apreciada pela decisão rescindida" ${ }^{1041}$, tem-se também no âmbito da ação rescisória o efeito substitutivo, de sorte que o litígio objeto da demanda originária ficará, ao final, solucionado nos termos do dispositivo do acórdão prolatado na ação rescisória.

Implica dizer que a própria demanda originária, uma vez ultrapassado o iudicium rescindens mediante a cassação da decisão transitada em julgado, é devolvida à apreciação do tribunal no espectro agora do iudicium rescissorium ${ }^{1042}$.

Por esse prisma - e só por este - não se pode trabalhar com o tema da prejudicialidade no âmbito da ação rescisória levando às últimas consequências o fato de a rescisória constituir verdadeira ação autônoma. Segundo se crê, parece mais adequado, no ponto que envolve a prejudicialidade, pensar na rescisória “como se fosse" uma apelação.

Aqui se impõe uma reflexão mais detida, pois não se quer, de modo algum, transformar a ação rescisória naquilo que ela efetivamente não é.

Pois bem. Sabe-se que o fenômeno da prejudicialidade pode manifestar-se interna ou externamente. Fala-se, pois, em prejudicialidade interna quando o nexo de dependência lógica verifica-se no âmbito de um único processo considerado (como se dá nos casos de litisconsórcio sucessivo), enquanto que a prejudicialidade externa advém da circunstância de as relações prejudicial e prejudicada constituírem objeto de exame em processos distintos.

\footnotetext{
${ }^{1041}$ RIZZI, Sérgio. Ação rescisória. São Paulo: RT, 1979, nº 2, p. 7.

1042 Não se quer dizer, com isso, que em toda ação rescisória sejam cumuláveis as pretensões rescindente e rescisória. Mas, para o enfoque litisconsorcial que se quer emprestar à matéria, a situação que interessa é a de cumulação do iudicium rescindens com o iudicium rescissorium, a teor do art. 488, I, do CPC.
} 
Prepondera na doutrina a afirmação de que, em caso de prejudicialidade externa, a decisão da relação prejudicial que sobrevier ao trânsito em julgado da decisão sobre a relação prejudicada em nada afeta a configuração desta ${ }^{1043}$.

Nessas condições, ao se levar às últimas consequências a natureza autônoma do processo instaurado pelo ajuizamento de ação rescisória, haveria de se entender pela existência de prejudicialidade externa, uma vez que a decisão prejudicada afeta a um sujeito terá sido proferida num processo e o novo julgamento da causa prejudicial relacionado a outro sujeito - ocorrerá noutro processo, surgido em virtude da ação rescisória parcial.

Daí que, na esteira dessa premissa, o pronunciamento do tribunal no campo do iudicium rescissorium (pertinente à causa prejudicial) em nada afetaria a configuração do julgado relativo à causa prejudicada (que não faz parte do objeto da rescisória).

Entretanto, considerando-se que a manifestação exarada no iudicium rescissorium acaba por substituir o quanto decidido na origem, é possível entender que a reapreciação da porção rescindida da sentença ou do acórdão integra o decisório originário em sua unidade.

Conquanto a relação prejudicada tenha sido julgada mediante ato processual (sentença ou acórdão originário) distinto daquele que resolve a causa prejudicial (acórdão que julga a ação rescisória), tais pronunciamentos judiciais vertem efeitos a partir dum só processo, a saber, o originário, no âmbito do qual se cumularam as causas (prejudicial e prejudicada) atreladas a sujeitos diferentes (litisconsortes sucessivos).

A despeito de serem formal e materialmente distintas, as decisões da causa prejudicada (objeto da porção não submetida à rescisória) e da causa prejudicial (levada ao crivo do tribunal em sede de rescisória parcial) formam uma unidade que permite concluir que a hipótese considerada não retrata prejudicialidade externa, mas antes prejudicialidade interna.

\footnotetext{
1043 “Isso significa que a prolação e o trânsito em julgado posteriores de uma decisão logicamente prejudicial à causa já decidida não produzem sobre ela qualquer efeito. Se, p. ex., o juiz condenara o réu a pagar a prestação prevista no contrato com decisão trânsita em julgado, sobrevindo posteriormente o trânsito em julgado da decisão de nulidade do mesmo contrato, a primeira decisão mantém a sua plena eficácia, autorizando inclusive a execução do julgado que ainda não se tenha promovido" (LEITE, Clarisse Frechiani Lara. Prejudicialidade no processo civil, cit., p. 196).
} 
Na medida, pois, da correção de tal raciocínio, permite-se concluir que, em tema de litisconsórcio sucessivo, o julgamento da rescisória envolvendo apenas o litisconsorte da relação subordinante (prejudicial) pode, ainda que excepcionalmente e nos mesmos termos do que se defendeu no âmbito da apelação parcial ( $\mathrm{n}^{\circ}$ 60, supra), gerar efeitos na posição jurídica do litisconsorte atrelado à relação prejudicada. As coisas se passariam, na rescisória, à semelhança do que sucede com a extensão do efeito devolutivo da apelação, tudo por obra e arte do vínculo de prejudicidalidade.

\section{Reclamação constitucional}

À primeira vista, essas mesmas preocupações, pertinentes à ação rescisória, poderiam ser imaginadas no campo da reclamação constitucional ${ }^{1044}$, bastando que se pensasse na hipótese factível duma reclamação parcial, isto é, envolvendo apenas a decisão pertinente a um dos litisconsortes sucessivos ${ }^{1045}$. Contudo, é preciso ter em devida conta que na reclamação constitucional não há espaço para o iudicium rescissorium, tal como ocorre na ação rescisória.

Realmente, o art. 17, da Lei $n^{\circ} 8.038 / 90$, e o art. $7^{\circ}, \S 2^{\circ}$, da Lei $n^{\circ} 11.417 / 2006$, autorizam uma só conclusão: a decisão que acolher a reclamação cassará o pronunciamento judicial impugnado. Como refere a doutrina especializada, “a decisão proferida pelo STF ou pelo STJ na reclamação não ocupa o lugar do ato impugnado, pois não é emitida para substituí-lo, apenas o anula ou cassa, determinando providências pertinentes quando isso for necessário"1046.

Outra circunstância que particulariza o enfoque na perspectiva da reclamação constitucional gira em torno da inadmissibilidade de incidência do instituto quando já se

\footnotetext{
${ }^{1044}$ Embora o instituto, à luz de suas hipóteses de cabimento, ganhe outras potencialidades, aqui se contenta com a hipótese de reclamação aviada em face de ato judicial objetiva e subjetivamente complexo que, por exemplo, tenha desrespeitado o enunciado de Súmula Vinculante num desses capítulos isoladamente considerado.

1045 Deixam-se de lado as modalidades eventual e alternativa porque seria difícil aceitar, já no juízo de admissibilidade desses tipos litisconsorciais, a existência de dúvida objetiva num tema em que incidisse, por exemplo, uma Súmula Vinculante.

${ }^{1046}$ LEONEL, Ricardo de Barros. Reclamação constitucional, cit., nº 50, p. 372.
} 
tenha decisão judicial transitada em julgado ${ }^{1047}$, pondo-se em relevo, ademais, a noção de que a reclamação não tem natureza recursal ${ }^{1048}$.

Então, supondo-se que se queira impugnar, via reclamação, um dos capítulos de uma sentença que julgue o mérito das relações conotadas por prejudicialidade entre sujeitos distintos (hipótese de litisconsórcio sucessivo), deve-se ter bem presente que a reclamação não terá o efeito de obstar o trânsito em julgado da decisão caso a parte interessada não interponha a apelação cabível. E, de qualquer forma, se o trânsito em julgado da decisão impugnada eclodir antes de proferida a decisão no âmbito da reclamação, ter-se-á por perdido o objeto da reclamação.

Essas observações servem para justificar a conclusão segundo a qual o acolhimento de reclamação constitucional parcial - referenciada ao capítulo de sentença atrelado ao litisconsorte titular da relação subordinante - não trará qualquer influência imediata sobre a posição jurídica do outro litisconsorte, uma vez que, seja como for, a decisão da reclamação há de pressupor a ausência de trânsito em julgado quanto ao capítulo de sentença impugnado.

Sendo assim, sem prejuízo da reclamação, a parte interessada, exatamente para obstar a imunização por efeito do trânsito em julgado, terá de interpor a apelação em face da sentença de que se cuida, a teor da disciplina contida no art. $7^{\circ}$, caput, da Lei $\mathrm{n}^{\circ}$ $11.417 / 2006^{1049}$.

Disso se extrai que, seja lá qual for o conteúdo do pronunciamento na reclamação parcial, os reflexos da decisão do capítulo prejudicial sobre o capítulo prejudicado, relacionados com sujeitos distintos, serão sentidos, aplicados e solucionados pela perspectiva recursal e não por força da decisão propriamente da reclamação ${ }^{1050}$.

Logo, estará baseado em falsa pista quem supuser que o tratamento da questão proposta pelo prisma da reclamação constitucional seja equivalente ao que se reservou, no mesmo assunto, à ação rescisória. Na verdade, como já adiantado, tudo se resolverá no

1047 Assim o enunciado 734, da Súmula do STF: "Não cabe reclamação quando já houver transitado em julgado o ato judicial que se alega tenha desrespeitado decisão do Supremo Tribunal Federal”.

${ }^{1048}$ LEONEL, Ricardo de Barros. Reclamação constitucional, cit., nº 25, p. 200 et seq.

1049 "Da decisão judicial ou ato administrativo que contrariar enunciado de súmula vinculante, negar-lhe vigência ou aplicá-lo indevidamente caberá reclamação ao Supremo Tribunal Federal, sem prejuízo dos recursos ou outros meios admissíveis de impugnação".

${ }^{1050}$ Sobre os aspectos recursais que o tema enseja, cfr. $n^{\circ} 59$, supra. 
campo dos recursos, haja vista que a impugnação parcial de sentença pela via da reclamação pressupõe a existência de recurso pendente, capaz de obstar o trânsito em julgado. Caso contrário, não há lugar sequer para decisão sobre o mérito da reclamação. 


\section{CONCLUSÃO}

Após o exame do conteúdo proposto na Introdução, tem-se a impressão de que não seja necessário sumariar, ponto por ponto, os variados enfoques proporcionados pela adoção, segundo se crê, das modalidades litisconsorciais eventual, alternativa e sucessiva no cenário processual brasileiro.

A percepção a que se chega, ao cabo desta empreitada, consiste na ideia de que mesmo um tema clássico, como é o litisconsórcio, ainda hoje está a desafiar a argúcia da doutrina, exigindo-se, mais e mais, enfoques variados e capazes de orientar para a concretização, no plano empírico, do almejado processo justo.

Pensa-se que a técnica aqui estudada serve bem ao desiderato de construção de um sistema processual que responda adequadamente às exigências do direito material. De modo que, ladeando outros institutos que lidam também com a dúvida objetiva e com a prejudicialidade, os litisconsórcios do tipo eventual, alternativo e sucessivo ingressam numa rota de consolidação da ideia de que a técnica processual só pode ser bem avaliada quando se mostra tendencialmente capaz de servir aos anseios hauridos do direito material.

Logo, a utilidade de toda a construção anunciada neste trabalho será medida pela capacidade que tiver para, no plano dos fenômenos, dar vazão aos embates jurídicos envoltos numa complexidade objetivo-subjetiva que não se resolve pela perspectiva pura e simples da cumulação de pedidos e tampouco do litisconsórcio em geral.

Nisso consiste, ao que parece, a conclusão mais relevante de toda a investigação: delinear a autonomia das modalidades litisconsorciais eventual, alternativa e sucessiva.

Aqui é preciso confessar que, de início, suspeitava-se que o tema tratado resumirse-ia num singelo aspecto da cumulação de pedidos. Em outro momento, imaginou-se que tudo não passaria de uma peculiaridade do litisconsórcio, em nada discrepante daquilo que já se consolidou em doutrina a tal respeito.

Todavia, acredita-se que, não obstante o indispensável aporte de premissas que advém da cumulação de pedidos e do litisconsórcio, a investigação leva para um caminho que deságua em "outras modalidades litisconsorciais", capazes de autorizar, quando menos, uma classificação autônoma. 
Para além de uma mera classificação autônoma de litisconsórcio, percebe-se que a presença de sujeitos distintos envolvidos em subsidiariedade, alternatividade ou sucessividade implica a necessidade de novos aportes teóricos, de sorte que os fundamentos dogmáticos da construção não são exatamente os mesmos que conformam o estudo da cumulação de pedidos. Significa dizer que não se pode trabalhar com a ideia de subsidiariedade, alternatividade e sucessividade subjetiva apenas pela angulação do cúmulo objetivo. É verdade que o tema aqui tratado envolve também o cúmulo objetivo. Mas não é só isso.

A análise procedimental desenvolvida no Capítulo IV, da Parte III, vem reforçar essa noção de autonomia. Isto porque a presença de um plexo de sujeitos vinculados, no polo ativo ou no passivo, por algum índice de subsidiariedade, de alternatividade ou de prejudicialidade faz com que o procedimento ganhe certos contornos não imaginados - e até mesmo impróprios - se se tentasse resolver as diversas questões apenas pelo prisma do cúmulo objetivo.

Coerente é dizer, então, que não se mostra possível transpor, pura e simplesmente, para o campo do litisconsórcio eventual, alternativo e sucessivo todas as soluções práticas que se encontram no âmbito da cumulação eventual, alternativa e sucessiva de pedidos.

Do ponto de vista do litisconsórcio, também parece razoável exigir-se um enfoque particularizado, já que a conformação das modalidades objeto desta investigação dá um colorido todo especial ao litígio subjetivamente complexo, a ponto de revelar ao estudioso, ao intérprete e, sobretudo, ao operador do processo diferentes confrontos e, por isso mesmo, convidar a novas reflexões teóricas, na tentativa de construir soluções práticas condizentes com as exigências de um processo justo. 


\section{BIBLIOGRAFIA}

ABREU FILHO, Saulo de Castro. A suspensão da execução de lei ou ato normativo pelo Senado Federal e a coisa julgada material no controle concentrado da constitucionalidade. Revista de Processo, ano 19, nº 74, abr.-jun./1994, p. 7-19.

AFONSO DA SILVA, José. Curso de direito constitucional positivo. 20. ed. São Paulo: Malheiros, 2002.

. Do recurso adesivo no processo civil brasileiro. 2. ed. São Paulo: RT, 1977.

ALBERTO DOS REIS, José. Comentário ao Código de Processo Civil. Coimbra: Coimbra Editora, 1946. vol. 3.

ALEXY, Robert. Teoria dos direitos fundamentais. Trad. Virgílio Afonso da Silva. São Paulo: Malheiros, 2008.

ALLORIO, Enrico. La cosa giudicata rispetto ai terzi. Milano: Giuffrè, 1992 (ristampa).

. Litisconsorzio alternativo passivo e impugnazione incidentale. In: L'ordinamento giuridico nel prisma dell'accertamento giudiziale e altri studi. Milano: Giuffrè, 1957, p. 515-525.

ALMEIDA JUNIOR, João Mendes de. O processo criminal brazileiro. 2 . ed. Rio de Janeiro: Francisco Alves, 1911.

ALVARO DE OLIVEIRA, Carlos Alberto. Do formalismo no processo civil: proposta de um formalismo-valorativo. 3. ed. São Paulo: Saraiva, 2009.

. Efetividade e processo de conhecimento. Revista de Processo, ano 24, no 96, out.-dez./1999, p. 59-69.

O processo civil na perspectiva dos direitos fundamentais. Revista Forense, vol. 372, mar.-abr./2004, p. 77-86.

Teoria e prática da tutela jurisdicional. Rio de Janeiro: Forense, 2008.

ALVIM, Arruda. Ação civil pública. Revista de Processo, nº 87, ano 22, jul-set./1997, p. 149-165.

. A argüição de relevância no recurso extraordinário. São Paulo: RT, 1988.

. Código de Processo Civil comentado. São Paulo: RT, 1975. vol. II. 
Direito processual civil: teoria geral do processo de conhecimento. São Paulo: RT, 1972. vol. II.

. Manual de direito processual civil. 10. ed. São Paulo: Saraiva, 2006. vol. 1 e 2.

. O art. 268 do CPC, a ilegitimidade e a ocorrência de coisa julgada: critério de interpretação. In: DIDIER JR., Fredie et alli (coord.). O terceiro no processo civil brasileiro e assuntos correlatos: estudos em homenagem ao Professor Athos Gusmão Carneiro. São Paulo: RT, 2010, p. 124-141.

. Tratado de direito processual civil. 2. ed. São Paulo: RT, 1996. vol. 2.

; ARRUDA ALVIM PINTO, Teresa. Assistência - litisconsórcio: repertório de jurisprudência e doutrina. São Paulo: RT, 1986.

ALVIM, Thereza. O direito processual de estar em juízo. São Paulo; RT, 1996.

Questões prévias e os limites objetivos da coisa julgada. São Paulo: RT, 1977.

AMARAL SANTOS, Moacyr. Da reconvenção no direito brasileiro. 2. tir. São Paulo: Max Limonad, 1958.

. Primeiras linhas de direito processual civil. 23. ed. São Paulo: Saraiva, 2004. vols. 1 e 2 .

. Prova judiciária no cível e comercial. 2. ed. São Paulo: Max Limonad, 1954. vols. II e III.

AMORIM, Aderbal Torres de. Reconvenção, cumulação de ações e ação rescisória. Revista dos Tribunais. São Paulo: RT, ano 73, mar/84, vol. 581, p. 268-270.

ARAGÃO, Paulo Cezar. Recurso adesivo. São Paulo: Saraiva, 1974.

ARAÚJO CINTRA, Antonio Carlos de. Comentários ao Código de Processo Civil. Rio de Janeiro: Forense, 2000. vol. IV.

. Do chamamento à autoria: denunciação da lide. São Paulo: RT, 1973.

. Sobre os limites objetivos da apelação civil. Tese (Doutorado). São Paulo, Faculdade de Direito da USP, 1986.

ARMELIN, Donaldo. Legitimidade para agir no direito processual civil brasileiro. São Paulo: RT, 1979. 
. O acesso à justiça. Revista da Procuradoria Geral do Estado de São Paulo, $\mathrm{n}^{\circ}$ 31, jun/1989, p. 171-182.

ARMENTA DEU, Teresa. La acumulación de autos (reunión de procesos conexos). Madrid: Montecorvo, 1983.

ARRUDA ALVIM PINTO, Teresa. "Dúvida" objetiva: único pressuposto para a aplicação do princípio da fungibilidade. Revista de Processo, ano 17, nº 65, jan.-mar./1992, p. 56-74.

ARRUDA ALVIM WAMBIER, Teresa. Casos problemáticos: partes ou terceiros? (análise de algumas situações complexas de direito material). In: DIDIER JR., Fredie; ARRUDA ALVIM WAMBIER, Teresa (coord.). Aspectos polêmicos e atuais sobre os terceiros no processo civil e assuntos afins. São Paulo: RT, 2004, p. 1035-1048.

. Fungibilidade de "meios": uma outra dimensão do princípio da fungibilidade. In: NERY JR., Nelson; ARRUDA ALVIM WAMBIER, Teresa (coord.). Aspectos polêmicos e atuais dos recursos cíveis e de outras formas de impugnação às decisões judiciais. São Paulo: RT, 2001. vol. 4, p. 1090-1144.

Nulidades do processo e da sentença. 5. ed. São Paulo: RT, 2004.

. Recurso especial, recurso extraordinário e ação rescisória. 2. ed. São Paulo: RT, 2008.

ASSIS, Araken de. Cumulação de ações. 4. ed. São Paulo: RT, 2002.

Do litisconsórcio no Código de Processo Civil. In: MARINONI, Luiz Guilherme (coord.). Estudos de direito processual civil: homenagem ao professor Egas Dirceu Moniz de Aragão. São Paulo: RT, 2005, p. 551-575.

Duração razoável do processo e reformas da lei processual civil. In: FUX, Luiz; NERY JR., Nelson; ALVIM WAMBIER, Teresa Arruda. Processo e Constituição: estudos em homenagem ao Professor José Carlos Barbosa Moreira. São Paulo: RT, 2006, p. 195-204.

Fungibilidade das medidas inominadas cautelares e satisfativas. Revista de Processo, ano 25, n⿳0 100, out.-dez./2000, p. 33-60.

. Manual da execução. 11. ed. São Paulo: RT, 2007. 
ASSUMPÇÃO NEVES, Daniel Amorim. Ações probatórias autônomas. São Paulo: Saraiva, 2008.

ATTARDI, Aldo. Legittimazione ad agire (verbete). In: Novissimo digesto italiano. Torino: Torinense, 1963. vol. IX.

BANDEIRA DE MELLO, Celso Antônio. Natureza e regime jurídico das autarquias. São Paulo: RT, 1968. Prestação de serviços públicos e administração indireta. São Paulo: RT, 1973.

BAPTISTA, José João. Processo civil: parte geral e processo declarativo. 8. ed. Coimbra: Coimbra, 2006. vol. I.

BARBI, Celso Agrícola. Comentários ao Código de Processo Civil. 10. ed. Rio de Janeiro: Forense, 1998. vol. I.

BARBOSA MOREIRA, José Carlos. A conexão de causas como pressuposto da reconvenção. São Paulo: Saraiva, 1979.

. Ação declaratória e interêsse. In: Direito processual civil: ensaios e pareceres. Rio de Janeiro: Borsoi, 1971, p. 9-20.

Ações cumuladas. Necessidade de julgamento explícito de todas. In: Temas de direito processual, segunda série. São Paulo: Saraiva, 1980, p. 133-145.

Apontamentos para um estudo sistemático da legitimação extraordinária. In: Direito processual civil: ensaios e pareceres. Rio de Janeiro: Borsoi, 1971, p. 58-72. Comentários ao Código de Processo Civil. 14. ed. Rio de Janeiro: Forense, 2008. vol. V.

. Efetividade do processo e técnica processual. In: Temas de direito processual, sexta série. São Paulo: Saraiva, 1997, p. 17-29.

. Intervenção litisconsorcial voluntária. In: Direito processual civil: ensaios e pareceres. Rio de Janeiro: Borsoi, 1971, p. 21-38.

. Litisconsórcio unitário. Rio de Janeiro: Forense, 1972.

. Notas sobre o problema da "efetividade" do processo. In: Temas de direito processual, terceira série. São Paulo: Saraiva, 1984, p. 27-42. 
. O novo Código Civil e o direito processual. In: Temas de direito processual, nona série. São Paulo: Saraiva, 2007, p. 1-20.

. O novo processo civil brasileiro. 27. ed. Rio de Janeiro: Forense, 2008.

. O problema da "divisão do trabalho" entre juiz e partes: aspectos terminológicos. In: Temas de direito processual, quarta série. São Paulo: Saraiva, 1989, p. 35-44.

. O problema da duração dos processos: premissas para uma discussão séria. In: Temas de direito processual, nona série. São Paulo: Saraiva, 2007, p. 367-377.

. O processo civil, hoje: um Congresso da Associação Internacional de Direito

Processual. In: Temas de direito processual, quinta série. São Paulo: Saraiva, 1994, p. 233-241.

. Questões prejudiciais e coisa julgada. Rio de Janeiro: Borsoi, 1967.

- Questões prejudiciais e questões preliminares. In: Direito processual civil: ensaios e pareceres. Rio de Janeiro: Borsoi, 1971, p. 73-93.

. Reconvenção. In: Direito processual civil: ensaios e pareceres. Rio de Janeiro: Borsoi, 1971, p. 112-132.

. Solidariedade ativa: efeitos da sentença e coisa julgada na ação de cobrança proposta por um único credor. In: Temas de direito processual, nona série. São Paulo: Saraiva, 2007.

BARROS MOTEIRO, Washington de. Curso de direito civil: direito das obrigações. 28. ed. São Paulo: Saraiva, 1995. vol. 4.

BARROSO, Luís Roberto. O controle de constitucionalidade no direito brasileiro. São Paulo: Saraiva, 2004.

BAZILONI, Nilton Luiz de Freitas. A coisa julgada nas ações coletivas. São Paulo: Juarez de Oliveira, 2004.

BEDAQUE, José Roberto dos Santos. Direito e processo: influência do direito material sobre o processo. 5. ed. São Paulo: Malheiros, 2009.

. Efetividade do processo e técnica processual. São Paulo: Malheiros, 2006. . Poderes instrutórios do juiz. 4. ed. São Paulo: RT, 2009. 
Tutela cautelar e tutela antecipada: tutelas sumárias e de urgência (tentativa de sistematização). 4. ed. São Paulo: Malheiros, 2006.

BIDART, Adolfo Gelsi. El tiempo y el proceso. Revista de Processo, ano 6, $\mathrm{n}^{\circ}$ 23, jul.set./1981, p. 100-121.

Incidencia constitucional sobre el proceso. Revista de Processo, ano 8, $\mathrm{n}^{\mathrm{o}}$ 30, abr.-jun./1983, p. 193-205.

BLOMEYER, Arwed. Zivilprozessrecht - Erkenntnisverfahren. Berlin-GöttingenHeidelberg: Springer-Verlag, 1963.

BLUME, William Wirt. American civil procedure. Englewood Cliffs: Prentice-Hall, 1955.

BONDIOLI, Luis Guilherme Aidar. Reconvenção no processo civil. São Paulo: Saraiva, 2009.

BONÍCIO, Marcelo José Magalhães. Capítulos de sentença e efeitos dos recursos. São Paulo: RCS, 2006.

BONSIGNORI, Angelo. L'effetto devolutivo nell'ambito dei capi connessi (effetto esterno). Rivista trimestrale di diritto e procedura civile. Milano: Giuffrè, anno XXX, 1976, p. 944-975.

BRUSCHI, Gilberto Gomes. Aspectos processuais da desconsideração da personalidade jurídica. 2. ed. São Paulo: Saraiva, 2009.

BUTTS, G. M. Modern county court procedure. 6. ed. London: Oyez Publications, 1966.

CAHALI, Yussef Said. Dos alimentos. 5. ed. São Paulo: RT, 2006. Honorários advocatícios. 3. ed. São Paulo: RT, 1997. Responsabilidade civil do Estado. 3. ed. São Paulo: RT, 2007.

CALAMANDREI, Piero. Instituciones de derecho procesal civil. Trad. Santiago Sentís Melendo. Buenos Aires: El Foro, 1996. vol. II. . Istituzioni di diritto processuale civile. In: Opere giuridiche. Napoli: Morano, 1970. vol. IV.

CALDAS AULETE. Dicionário contemporâneo da língua portuguesa. 2. ed. brasileira. Rio de Janeiro: Delta, 1964. vol. IV. 
CALMON DE PASSOS, José Joaquim. Comentários ao Código de Processo Civil. 8. ed. Rio de Janeiro: Forense, 1998. vol. III. Da revelia do demandado. Salvador: Livraria Progresso Editora, 1960.

CAMBI, Eduardo. A prova civil: admissibilidade e relevância. São Paulo: RT, 2006.

CAMPOS JR., Ephraim de. Substituição processual. São Paulo: RT, 1985.

CANOtilho, J. J. Gomes. Direito constitucional e teoria da Constituição. 2. ed. Coimbra: Almedina, 1998.

CAPELLETTI, Mauro; GARTH, Bryan. Acesso à justiça. Trad. Ellen Gracie Northfleet. Porto Alegre: SAFE, 2002 (reimpressão).

CARMONA, Carlos Alberto. Código de Processo Civil interpretado. Coord. Antonio Carlos Marcato. 3. ed. São Paulo: Atlas, 2008.

CARNACINI, Tito. Il litisconsorzio nelle fasi di gravami. Padova: CEDAM, 1937.

CARNEIRO, Athos Gusmão. Intervenção de terceiros. 19. ed. São Paulo: Saraiva, 2010.

CARNELUTTI, Francesco. Instituciones del nuevo proceso civil italiano. Trad. Jaime Guasp. Barcelona: Bosch, 1942. . Instituciones del proceso civil. Trad. Santiago Sentis Melendo. Buenos Aires: EJEA, 1973. vol. I. . Lezioni di diritto processuale civile. Padova: CEDAM, 1933. vol. 4 (ristampa). . Sistema del diritto processuale civile. Padova: CEDAM, 1936. vol. 1.

CARVALHO, Milton Paulo de. Do pedido no processo civil. Porto Alegre: SAFE/FIEO, 1992.

CASTAGNA, Ricardo Alessandro. Tutela de urgência: análise teórica e dogmática. São Paulo: RT, 2008.

CASTRO LOPES, Maria Elizabeth de. O juiz e o princípio dispositivo. São Paulo: RT, 2006.

CAVALIERI FILHO, Sergio. Programa de responsabilidade civil. 4. ed. São Paulo: Malheiros, 2003.

CHEIM JORGE, Flávio. Chamamento ao processo. 2. ed. São Paulo: RT, 1999. 
CHIOVENDA, Giuseppe. Instituições de direito processual civil. Trad. J. Guimarães Menegale. 2. ed. São Paulo: Saraiva, 1965. vol. II. . Principii di diritto processuale civile. Napoli: Jovene, 1965. . Sull litisconsorzio necessario. In: Saggi di diritto processuale civile. Milano: Giuffrè, 1993. vol. 2, p. 427-455.

CLÈVE, Clèmerson Merlin. A fiscalização abstrata da constitucionalidade no direito brasileiro. 2. ed. São Paulo: RT, 2000.

COELHO, Fábio Ulhoa. Curso de direito comercial: direito de empresa. 11. ed. São Paulo: Saraiva, 2008. vol. 2. Desconsideração da personalidade jurídica. São Paulo: RT, 1989.

COMOGLIO, Luigi Paolo. Il principio di economia processuale. Padova: CEDAM, 1980. vol. I.

; FERRI, Corrado; TARUFFO, Michele. Lezioni sul processo civile. 4. ed. Bologna: Il Mulino, 2006. vol. I.

COMPARATO, Fábio Konder; SALOMÃO FILHO, Calixto. O poder de controle na sociedade anônima. 5. ed. Rio de Janeiro: Forense, 2008.

CORREAA DE OLIVEIRA, José Lamartine. A dupla crise da pessoa jurídica. São Paulo: Saraiva, 1979.

CORREIA, André de Luizi. A citação no direito processual civil brasileiro. São Paulo: RT, 2001.

COSTA, Sergio. Parti (verbete). In: Novissimo digesto italiano. Torino: Torinense, 1976. vol. XII.

COSTA, Susana Henriques da. Condições da ação. São Paulo: Quartier Latin, 2005.

CRUZ E TUCCI, José Rogério. A causa petendi no processo civil. 3. ed. São Paulo: RT, 2009.

- A denominada "situação substancial" como objeto do processo na obra de Fazzalari. Revista de Processo, ano 17, nº 68, out.-dez./1992, p. 271-281. 
. Comentário ao art. $3^{\circ}$, da nova Lei do Mandado de Segurança. In: MAIA FILHO, Napoleão Nunes; ROCHA, Caio Cesar Vieira; LIMA, Tiago Asfor Rocha (org.). Comentários à nova lei do mandado de segurança. São Paulo: RT, 2010, p. 69-77. . Da reconvenção. São Paulo: Saraiva, 1984.

- Garantias do processo sem dilações indevidas. In: (coord). Garantias constitucionais do processo civil. São Paulo: RT, 1999, p. 234-262.

- Inquilino e fiador como litisconsortes passivos. In: Questões práticas de processo civil. São Paulo: Atlas, 1998, p. 67-73.

. Limites subjetivos da eficácia da sentença e da coisa julgada. São Paulo: RT, 2006.

. Reflexões sobre a cumulação subsidiária de pedidos. Revista dos Tribunais, ano 90, vol. 786, abril/2001, p. 57-67.

- Tempo e processo: uma análise empírica das repercussões do tempo na fenomenologia processual (civil e penal). São Paulo: RT, 1997.

; AZEVEDO, Luiz Carlos de. Lições de processo civil canônico: história e direito vigente. São Paulo: RT, 2001.

DAL POZZO, Antonio Araldo Ferraz. Reflexões sobre o litisconsórcio. Justitia, ano 44, vol. 116, jan./mar. 1982, p. 166-200.

DE CRESCI SOBRINHO, Elício. Litisconsórcio: doutrina e jurisprudência. Porto Alegre: SAFE, 1990.

DIDIER JR., Fredie. Curso de direito processual civil. 7. ed. Salvador: JusPodivm, 2007. vol. 1.

- Pressupostos processuais e condições da ação: o juízo de admissibilidade do processo. São Paulo: Saraiva, 2005.

. Regras processuais no novo Código Civil. São Paulo: Saraiva, 2004.

DINAMARCO, Cândido Rangel. A instrumentalidade do processo. 14. ed. São Paulo: Malheiros, 2009. . A reforma da reforma. 5. ed. São Paulo: Malheiros, 2003. . A reforma do Código de Processo Civil. São Paulo: Malheiros, 1995. 
Ação rescisória contra sentença terminativa. In: Fundamentos do processo civil moderno. 6. ed. São Paulo: Malheiros, 2010. t. II, p. 1228-1243.

. Capítulos de sentença. 1. ed., 2. tir. São Paulo: Malheiros, 2004.

. "Electa una via non datur regressus ad alteram". In: Fundamentos do processo civil moderno. 6. ed. São Paulo: Malheiros, 2010. t. I, p. 495-516.

. Execução civil. 7. ed. São Paulo: Malheiros, 2000.

. Intervenção de terceiros. 5. ed. São Paulo: Malheiros, 2009.

. Instituições de direito processual civil. 6. ed. São Paulo: Malheiros, 2009. vol. I, II e III.

. Litisconsórcio. 8. ed. São Paulo: Malheiros, 2009.

. O conceito de mérito em processo civil. In: Fundamentos do processo civil moderno. 5. ed. São Paulo: Malheiros, 2002. t. I, p. 232-276.

. O princípio do contraditório e sua dupla destinação. In: Fundamentos do processo civil moderno. 5. ed. São Paulo: Malheiros, 2002. t. I, p. 124-135.

. Processo civil empresarial. São Paulo: Malheiros, 2010.

. Universalizar a tutela jurisdicional. In: Fundamentos do processo civil moderno. 3. ed. São Paulo: Malheiros, 2000. t. II, p. 838-875.

. Vocabulário de direito processual. In: Fundamentos do processo civil moderno. 5. ed. São Paulo: Malheiros, 2000. t. I, p. 136-231.

. Vocabulário do processo civil. São Paulo: Malheiros, 2009.

DINAMARCO, Pedro da Silva. Ação civil pública. São Paulo: Saraiva, 2001.

DIREITO, Carlos Alberto Menezes; CAVALIERI FILHO; Sergio. Comentários ao novo Código Civil. Coord. Sálvio de Figueiredo Teixeira. Rio de Janeiro: Forense, 2004. vol. XIII.

DUARTE, Ronnie Preuss. Garantia de acesso à justiça: os direitos processuais fundamentais. Coimbra: Almedina, 2007.

. Litisconsórcios alternativo e subsidiário no processo civil brasileiro. Revista de Processo, ano 32, n 147, maio/2007, p. 27-49. 
ESTELLITA, Guilherme. Do litisconsórcio no direito brasileiro. Rio de Janeiro: Freitas Bastos, 1955.

FARIAS, Cristiano Chaves de; ROSENVALD, Nelson. Direito civil: teoria geral. 7. ed. Rio de Janeiro: Lumen Juris, 2008.

FAZZALARI, Elio. Istituzioni di diritto processuale. 7. ed. Padova: CEDAM, 1994. Note in tema di diritto e processo. Milano: Giuffrè, 1957.

FERREIRA, William Santos. Aspectos materiais e processuais da responsabilidade patrimonial do incapaz. In: DIDIER JR., Fredie; MAZZEI, Rodrigo (coord.). Reflexos do novo Código Civil no direito processual. 2. ed. Salvador: JusPodivm, 2007, p. 355-372.

FERRO E SILVA, Michel. Litisconsórcio multitudinário. Curitiba: Juruá, 2009.

FIDÉLIS DOS SANTOS, Ernane. Manual de direito processual civil. 12. ed. São Paulo: Saraiva, 2008. vol. 1.

FORNACIARI JÚNIOR, Clito. Da reconvenção no direito processual civil brasileiro. São Paulo: Saraiva, 1979.

FRAGA, Affonso. Instituições do processo civil do Brasil. São Paulo: Saraiva \& Cia, 1940. t. II.

FREDERICO MARQUES, José. Ensaio sôbre a jurisdição voluntária. 2. ed. São Paulo: Saraiva, 1959. Instituições de direito processual civil. 2. ed. Rio de Janeiro: Forense, 1962. vol. I e III. . Manual de direito processual civil. São Paulo: Saraiva, 1974. vol. 1.

FREIRE, Rodrigo da Cunha Lima. Condições da ação: enfoque sobre o interesse de agir. 3. ed. São Paulo: RT, 2005.

FREITAS GOMES, Luiz Roldão de. Da assunção de dívida e sua estrutura negocial. 2. ed. Rio de Janeiro; Lumen Juris, 1998.

FRIEDENTHAL, Jack H.; KANE, Mary Kay; MILLER, Arthur R. Civil procedure. 3. ed. St. Paul: West Group, 1999. 
GAJARDONI, Fernando da Fonseca. Flexibilização procedimental: um novo enfoque para o estudo do procedimento em matéria processual, de acordo com as recentes reformas do CPC. São Paulo: Atlas, 2008.

GARBAGNATI, Edoardo. La sostituzione processuale nel nuovo Codice di Procedura Civile. Milano: Giuffrè, 1942.

GIANESINI, Rita. Da revelia no processo civil brasileiro. São Paulo: RT, 1977.

GOMES, Fábio. Carência de ação. São Paulo: RT, 1999.

GOMES, Orlando. Obrigações. 11. ed. Rio de Janeiro: Forense, 1996.

GOMES DA CRUZ, José Raimundo. Pluralidade de partes e intervenção de terceiros. São Paulo: RT, 1991.

GONÇALVES, Carlos Roberto. Direito civil brasileiro. São Paulo: Saraiva, 2004. vol. II e III.

Responsabilidade civil. 9. ed. São Paulo: Saraiva, 2005.

GONÇALVES NETO, Diógenes M. Tutela condenatória civil e condenação para o futuro. São Paulo: Quartier Latin, 2010.

GRECO, Leonardo. A teoria da ação no processo civil. São Paulo: Dialética, 2003.

GRECO FILHO, Vicente. Da intervenção de terceiros. 3. ed. São Paulo: Saraiva, 1991. . Direito processual civil brasileiro. 16. ed. São Paulo: Saraiva, 2003. vol. 2.

GRINOVER, Ada Pellegrini. Da desconsideração da pessoa jurídica (aspectos de direito material e processual). Revista Forense, vol. 371, jan.-fev./2004, p. 3-15.

O controle difuso da constitucionalidade e a coisa julgada erga omnes das ações coletivas. In: O processo: estudos e pareceres. 2. ed. São Paulo: DPJ, 2009, p. 231237.

. Os princípios constitucionais e o Código de Processo Civil. São Paulo: Bushatsky, 1975.

GUASP, Jaime. Derecho procesal civil. 3. ed. Madrid: Instituto de Estudios Politicos, 1968. t. I.

; ARAGONESES, Pedro. Derecho procesal civil. 7. ed. Thomson-Civitas, 2005. t. I. 
HAZARD, Geoffrey C.; TARUFFO, Michele. La giustizia civile negli Stati Uniti. Bologna: Il Mulino, 1993.

HOUAISS, Antônio; VILlAR, Mauro de Salles. Dicionário Houaiss da língua portuguesa. Rio de Janeiro: Objetiva, 2001.

JAUERNIG, Othmar. Direito processual civil. Trad. F. Silveira Ramos. 25. ed. totalmente refundida da obra de Friedrich Lent. Coimbra: Almedina, 2002.

JUSTEN FILHO, Marçal. Desconsideração da personalidade societária no direito brasileiro. São Paulo: RT, 1987.

KOMATSU, Roque. Da invalidade no processo civil. São Paulo: RT, 1991.

LACERDA, Galeno. Despacho saneador. 3. ed. Porto Alegre: Sergio Fabris, 1990.

LAMBAUER, Mathias. Do litisconsórcio necessário. São Paulo: Saraiva, 1982.

LEBRE DE FREITAS, José; RODINHA, José; PINTO, Rui. Código de Processo Civil anotado. 2. ed. Coimbra: Coimbra Editora, 2008. vol. 1.

; MACHADO, A. Montalvão; Código de Processo Civil anotado. 2. ed. Coimbra: Coimbra Editora, 2008. vol. 2.

LEITE, Clarisse Frechiani Lara. Prejudicialidade no processo civil. São Paulo: Saraiva, 2008.

LENT, Friedrich. Diritto processuale civile tedesco. Trad. da 9. ed. alemã por Edoardo F. Ricci. Napoli: Morano, 1962.

LEONEL, Ricardo de Barros. Causa de pedir e pedido: o direito superveniente. São Paulo: Método, 2006. . Manual do processo coletivo. 2. ed. São Paulo: RT, 2011. . Reclamação constitucional. Tese (Livre-docência). São Paulo, Faculdade de Direito da USP, 2010. . Tutela jurisdicional diferenciada. São Paulo: RT, 2010.

LIEBMAN, Enrico Tullio. Ações concorrentes. In: Eficácia e autoridade da sentença e outros escritos sobre a coisa julgada. Trad. Alfredo Buzaid e Benvindo Aires. 4. ed. Rio de Janeiro: Forense, 2006, p. 209-220. 
Manuale di diritto processuale civile: principi. 6. ed. a cura di Vittorio Colesanti, Elena Merlin e Edoardo F. Ricci. Milano: Giuffrè, 2002. vol. I.

. Manuale di diritto processuale civile. 4. ed. (ristampa). Milano: Giuffrè, 1984. vol. II.

LOBO DA COSTA, Moacyr. Sentença condicional. Revista de direito processual civil, ano I, jan.-jun./1960, vol. 1, São Paulo: Saraiva, p. 92-104.

LOPES, Bruno Vasconcelos Carrilho. Honorários advocatícios no processo civil. São Paulo: Saraiva, 2008.

LOPES, João Batista. A prova no direito processual civil. 3. ed. São Paulo: RT, 2007.

Desconsideração da personalidade jurídica no novo Código Civil. Revista dos Tribunais, ano 92, vol. 818, dez./2003, p. 36-46.

. Efetividade da tutela jurisdicional à luz da constitucionalização do processo civil. Revista de Processo, ano 29, n 116, jul.-ago./2004, p. 29-39.

LOPES DA COSTA, Alfredo de Araújo. Da intervenção de terceiros no processo. São Paulo: C. Teixeira \& Cia, 1930.

Direito processual civil brasileiro. 2. ed. Rio de Janeiro: Forense, 1959. vol. I e II.

LÓPEZ JIMÉNEZ, Raquel. El litisconsorcio. Valencia: Tirant lo Blanch, 2009.

LUCON, Paulo Henrique dos Santos. Embargos à execução. São Paulo: Saraiva, 1996.

MACHADO DE MELO, Diogo Leonardo. O art. 1.698 do Código Civil: repercussões processuais à luz do direito material. In: SCARPINELLA BUENO, Cassio. Impactos processuais do direito civil. São Paulo: Saraiva, 2008, p. 393-440.

MACHADO GUIMARÃES, Luiz de Macedo Soares. As três figuras do litisconsórcio. Separata do vol. II dos Estudos Jurídicos em Honra de Soriano Neto. Recife: Imprensa Oficial, 1962, p. 393-410.

MADALENO, Rolf. A desconsideração judicial da pessoa jurídica e da interposta pessoa física no direito de família e no direito das sucessões. Rio de Janeiro: Forense, 2009.

MANCUSO, Rodolfo de Camargo. Jurisdição coletiva e coisa julgada: teoria geral das ações coletivas. São Paulo: RT, 2006. 
Recurso extraordinário e recurso especial. 10. ed. São Paulo: RT, 2007.

MANDRIOLI, Crisanto. Diritto processuale civile. 18. ed. Torino: Giappichelli, 2006. vol. I.

MARCATO, Antonio Carlos. Ação de consignação em pagamento. 5. ed. São Paulo: Malheiros, 1996. (coord). Código de Processo Civil interpretado. 3. ed. São Paulo: Atlas, 2008

MARINONI, Luiz Guilherme. Antecipação de tutela. 9. ed. São Paulo: RT, 2006.

. Garantia da tempestividade da tutela jurisdicional e duplo grau de jurisdição. In: CRUZ E TUCCI, José Rogério (coord). Garantias constitucionais do processo civil. São Paulo: RT, 1999, p. 207-233.

Novas linhas do processo civil: o acesso à Justiça e os institutos fundamentais do direito processual. São Paulo: RT, 1993.

; ARENHART, Sérgio Cruz. Manual do processo de conhecimento: a tutela jurisdicional através do processo de conhecimento. São Paulo: RT, 2001.

; _ Prova. São Paulo: RT, 2009.

; MITIDIERO, Daniel. Código de Processo Civil comentado artigo por artigo. 2. ed. São Paulo: RT, 2010.

; ___ _ O projeto do CPC: crítica e propostas. São Paulo: RT, 2010.

MARIZ DE OLIVEIRA JR., Waldemar. Substituição processual. São Paulo: RT, 1971.

MARTINS, Ives Gandra da Silva; MENDES, Gilmar Ferreira. Controle concentrado de constitucionalidade: comentários à Lei $\mathrm{n}^{\circ}$ 9.868, de 10.11.1999. São Paulo: Saraiva, 2001.

MARTINS-COSTA, Judith. A boa-fé no direito privado. São Paulo: RT, 1999.

MAZZEI, Rodrigo. Litisconsórcio sucessivo: breves considerações. In: DIDIER JR., Fredie; MAZZEI, Rodrigo (org.). Processo e direito material. Salvador: JusPodivm, 2009, p. 223-246.

- Título executivo, liquidação de sentença e coisa julgada no mandado de injunção: análise a partir dos precedentes do Supremo Tribunal Federal (art. $8^{\circ}, \S 3^{\circ}$, ADCT). In: DIDIER JR, Fredie (coord). Execução civil: estudos em homenagem ao Professor Paulo Furtado. Rio de Janeiro: Lumen Juris, 2006, p. 279-316. 
MEDICUS, Dieter. Tratado de las relaciones obligacionales. Trad. Ángel Martínez Sarrión. Barcelona: Bosch, 1995. vol. I.

MEDINA, José Miguel Garcia; ARRUDA ALVIM WAMBIER, Teresa. Recursos e ações autônomas de impugnação. São Paulo: RT, 2008.

MEDINA LIMA, Ignácio. Partes procesales (verbete). In: Enciclopedia jurídica latinoamericana. Santa Fe: Rubinzal Culzoni/Universidad Nacional Autónoma de México, 2007. vol. VIII, p. 171-175.

MEIRELLES, Hely Lopes. Direito administrativo brasileiro. 26. ed. São Paulo: Malheiros, 2001.

MENCHINI, Sergio. Il processo litisconsortile: struttura e poteri delle parti. Milano: Giuffrè, 1993.

MENDONÇA LIMA, Alcides de. Recursos cíveis: sistema de normas gerais. Rio de Janeiro/São Paulo: Freitas Bastos, 1963.

MENEZES CORDEIRO, António. O levantamento da personalidade colectiva no direito civil e comercial. Coimbra: Almedina, 2000.

MESQUITA, José Ignácio Botelho de. Da ação civil. São Paulo: RT, 1975.

MICHELI, Gian Antonio. Corso di diritto processuale civile. Milano: Giuffrè, 1959. vol. I.

MILMAN, Fabio. O novo conceito legal de sentença e suas repercussões recursais: primeiras experiências com a apelação por instrumento. Revista de Processo, ano 32, $\mathrm{n}^{\circ} 150$, agosto/2007, p. 160-174.

MIRANDA, Jorge. Constituição e processo civil. Revista de Processo, ano 25, nº 98, abr.jun./2000, p. 29-42.

MITIDIERO, Daniel. Colaboração no processo civil: pressupostos sociais, lógicos e éticos. São Paulo: RT, 2009.

MONIZ DE ARAGÃO, Egas Dirceu. Comentários ao Código de Processo Civil. 9. ed. Rio de Janeiro: Forense, 1998. vol. II.

MONTERO AROCA, Juan. De la legitimación en el proceso civil. Barcelona: Bosch, 2007.

La intervención adhesiva simple: contribución al estudio de la pluralidad de partes en el proceso civil. Barcelona: Editorial Hispano Europea, 1972. 
MOREIRA, Alberto Camiña. Litisconsórcio no processo de execução. Tese (Doutorado). Pontifícia Universidade Católica de São Paulo, 2001.

MORTARA, Ludovico. Appello civile (verbete). In: Il digesto italiano. Torino: UTET, 1890. vol. terzo, parte seconda.

MOURÃO, Luiz Eduardo Ribeiro. Coisa julgada. Belo Horizonte: Editora Fórum, 2008.

NEGRÃO, Theotonio; GOUVÊA, José Roberto F.; BONDIOLI, Luiz Guilherme A. Código de Processo Civil e legislação processual em vigor. 42. ed. São Paulo: Saraiva, 2010.

NERY JUNIOR, Nelson. Princípios do processo na Constituição Federal. 9. ed. São Paulo: RT, 2009.

. Princípios fundamentais - teoria geral dos recursos. 5. ed. São Paulo: RT, 2000.

. Questões de ordem pública e o julgamento do mérito dos recursos extraordinário e especial: anotações sobre a aplicação do direito à espécie (STF 456 e RISTJ 257). In: MEDINA, José Miguel Garcia et alli (coord.). Os poderes do juiz e o controle das decisões judiciais: estudos em homenagem à Professora Teresa Arruda Alvim Wambier. São Paulo: RT, 2008, p. 966-975.

; ANDRADE NERY, Rosa Maria de. Código de Processo Civil comentado e legislação extravagante. 10. ed. São Paulo: RT, 2007.

OLIVEIRA, Pedro Miranda de. Recurso excepcional adesivo cruzado. In: NERY JR., Nelson; ARRUDA ALVIM WAMBIER, Teresa (coord.). Aspectos polêmicos e atuais dos recursos cíveis e de outros meios de impugnação às decisões judiciais. São Paulo: RT, 2005. vol. 8, p. 609-637.

OLIVEIRA NETO, Olavo de. Conexão por prejudicialidade. São Paulo: RT, 1994.

PAZZAGLINI FILHO, Marino; ELIAS ROSA, Márcio Fernando; FAZZIO JÚNIOR, Waldo. Improbidade administrativa: aspectos jurídicos da defesa do patrimônio público. 4. ed. São Paulo: Atlas, 1999.

PINTO, Nelson Luiz. Manual dos recursos cíveis. 3. ed. São Paulo: Malheiros, 2003.

PONTES DE MIRANDA, Francisco Cavalcanti. Comentários ao Código de Processo Civil. 3. ed. atual. Sergio Bermudes. Rio de Janeiro: Forense, 1995. t. I; t. IV, 1996. Tratado de direito privado. Rio de Janeiro: Borsoi, 1958. t. XXIII; 1966, t. LIII. 
PRIETO-CASTRO Y FERRÁNDIZ, Leonardo. Derecho procesal civil. 2. ed. Madrid: Tecnos, 1974. vol. 1.

PRIORI POSADA, Giovanni F. El proceso en el Estado Constitucional. In: Constituición y processo: Actas del Seminario Internacional de Derecho Procesal Constituición y processo llevada a cabo en el Campus de la Pontificia Universidad Católica del Perú entre el 22 y el 25 de setiembre de 2009. Lima: ARA Editores, 2009, p. 339-361.

PROTO PISANI, Andrea. Lezioni di diritto processuale civile. 5. ed. Napoli: Jovene, 2006. La tutela di condanna. In: Le tutele giurisdizionali dei diritti: studi. Napoli: Jovene, 2003, p. 75-155.

RAMOS MÉNDEZ, Francisco. Derecho procesal civil. Barcelona: Bosch, 1980.

REDENTI, Enrico. Diritto processuale civile. Milano: Giuffrè, 1957 (ristampa della seconda edizione). vol. II.

. Il giudizio civile con pluralità di parti. Milano: Giuffrè, 1960 (ristampa della prima edizione).

Problemi di competenza in cassazione. Rivista di diritto processuale civile. Padova: CEDAM, 1943. vol. XX, parte II, p. 81-100.

REMÉDIO MARQUES, João Paulo. Acção declarativa à luz do Código revisto. 2. ed. Coimbra: Coimbra Editora, 2009.

REQUIÃO, Rubens. Abuso de direito e fraude através da personalidade jurídica. Revista dos Tribunais, ano 58, dez./1969, vol. 410, p. 12-24.

RICCI, Edoardo F. Princípio do contraditório e questões que o juiz pode propor de ofício. In: FUX, Luiz; NERY JR., Nelson; ARRUDA ALVIM WAMBIER, Teresa (coord). Processo e Constituição: estudos em homenagem ao professor José Carlos Barbosa Moreira. São Paulo: RT, 2006, p. 495-499.

RICCI, Gian Franco. Il litisconsorzio nelle fasi di impugnazione. Milano: Giuffrè, 2005.

RIZZI, Sérgio. Ação rescisória. São Paulo: RT, 1979.

RODRIGUES BASTOS, Jacinto Fernandes. Notas ao Código de Processo Civil. 3. ed. Lisboa: Almedina, 1999.

ROGNONI, Virginio. La condanna in futuro. Milano: Giuffrè, 1958. 
RONCO, Alberto. Studio sul litisconsorzio alternativo. Rivista trimestrale di diritto $e$ procedura civile. Milano: Giuffrè, anno LVIII, no 3, settembre 2004, p. 905-945.

ROSENBERG, Leo. Tratado de derecho procesal civil. Trad. Angela Romera Vera, Buenos Aires: EJEA, 1955. t. I. ; SCHWAB, Karl Heinz. Zivilprozessrecht. München: C. H. Beck, 1986.

SALOMÃO FILHO, Calixto. O novo direito societário. 3. ed. São Paulo: Malheiros, 2006.

SANCHES, Sydney. Denunciação da lide no direito processual civil brasileiro. São Paulo: RT, 1984.

SANTOS, Silas S. Litisconsórcio eventual: decisão pioneira do STJ. Revista de Processo, ano $34, \mathrm{n}^{\circ} 175$, set./2009, p. 279-285.

SARACENO, Pasquale. L'accertamento alternativo. Rivista italiana di diritto penale. Padova: CEDAM, 1939, vol. XVII, p. 177-193.

SATTA, Salvatore. Diritto processuale civile. 8. ed. Padova: CEDAM, 1973.

SCANDIANI, Ugo. Patologia della posizione del fatto nel processo. Rivista di diritto processuale civile. Padova: CEDAM, vol. VIII, parte II, 1931, p. 174-191.

SCARANCE FERNANDES, Antonio. Prejudicialidade: conceito, natureza jurídica, espécies de prejudiciais. São Paulo: RT, 1988.

SCARPINELLA BUENO, Cassio. Amicus curiae no processo civil brasileiro: um terceiro enigmático. São Paulo: Saraiva, 2006.

A nova etapa da reforma do Código de Processo Civil. São Paulo: Saraiva, 2006. vol. 1 e 2 .

. Curso sistematizado de direito processual civil. São Paulo: Saraiva, 2007. vol. 1; vol. 2 , t. I.

. Efeitos dos recursos. In: NERY JR., Nelson; ARRUDA ALVIM WAMBIER, Teresa (coord.). Aspectos polêmicos e atuais dos recursos cíveis e assuntos afins. São Paulo: RT, 2006. vol. 10, p. 66-90.

(org.). Impactos processuais do direito civil. São Paulo: Saraiva, 2008.

. Partes e terceiros no processo civil brasileiro. 2. ed. São Paulo: Saraiva, 2006. 
SCHÖNKE, Adolfo. Derecho procesal civil. Trad. da 5. ed. alemã por Prieto-Castro e Fairén Guillén. Barcelona: BOSCH, 1950.

SERICK, Rolf. Aparencia y realidad en las sociedades mercantiles: el abuso de derecho por medio de la persona jurídica. Trad. José Puig Brutau. Barcelona: ARIEL, 1958.

SERPA LOPES, Miguel Maria de. Curso de direito civil: obrigações em geral. 6. ed. Rio de Janeiro: Freitas Bastos, 1995. vol. II.

SERRA DOMINGUEZ, Manuel. Concepto y regulación positiva del litisconsorcio. Revista

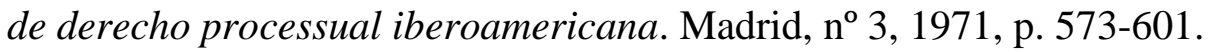

SICA, Heitor Vitor Mendonça. $O$ direito de defesa no processo civil brasileiro: um estudo sobre a posição do réu. São Paulo: Atlas, 2011. Preclusão processual civil. 2. ed. São Paulo: Atlas, 2008.

. Notas críticas ao sistema de pluralidade de partes no processo civil brasileiro. No prelo.

SILVA, Ovídio A. Baptista da. Comentários ao Código de Processo Civil: do processo de conhecimento, arts. $1^{\circ}$ a 100. São Paulo: RT, 2000. vol. 1.

SILVA PEREIRA, Caio Mário da. Instituições de direito civil. 15. ed. Rio de Janeiro: Forense, 1997. vol. II.

SIMÃO, José Fernando. Responsabilidade civil do incapaz. São Paulo: Atlas, 2008.

SOUZA, André Pagani de. Aspectos processuais da desconsideração da personalidade jurídica do art. 50 do Código Civil. Dissertação (Mestrado). Faculdade de Direito da Pontifícia Universidade Católica de São Paulo, 2007.

SOUZA, Gelson Amaro de. Do valor da causa. 3. ed. São Paulo: RT, 2002.

SPADONI, Joaquim Felipe. Fungibilidade das tutelas de urgência. Revista de Processo, ano 28, no 110, abr.-jun./2003, p. 72-94.

STOCO, Rui. Tratado de responsabilidade civil: doutrina e jurisprudência. 7. ed. São Paulo: RT, 2007.

TARZIA, Giuseppe. Appunti sulle domande alternative. Rivista di diritto processuale. Padova: CEDAM, 1964, vol. XIX, p. 253-303. Il litisconsorzio facoltativo nel processo di primo grado. Milano: Giuffrè, 1972. 
. Lineamenti del processo civile di cognizione. 4. ed. Milano: Giuffrè, 2009.

TAVARES DA SILVA, Regina Beatriz. Da responsabilidade civil. In: FIUZA, Ricardo (coord.). Novo Código Civil comentado. 2. ed. São Paulo: Saraiva, 2004.

TEIXEIRA, Guilherme Freire de Barros. O princípio da eventualidade no processo civil. São Paulo: RT, 2005.

Teoria do princípio da fungibilidade. São Paulo: RT, 2008.

TEIXEIRA DE SOUSA, Miguel. Estudos sobre o novo processo civil. 2. ed. Lisboa: LEX, 1997.

TEPEDINO, Gustavo. A evolução da responsabilidade civil no direito brasileiro e suas controvérsias na atividade estatal. In: Temas de direito civil. Rio de Janeiro: Renovar, 1999, p. 173-197.

THEODORO JÚNIOR, Humberto. Curso de direito processual civil. 21. ed. Rio de Janeiro: Forense, 1997. vol. I; 39. ed., 2006, vol. II.

TJÄDER, Ricardo Luiz da Costa. Cumulação eventual de pedidos: art. 289 do CPC sem segredos. Porto Alegre: Livraria do Advogado, 1998.

TROCKER, Nicolò. L'intervento per ordine del giudice. Milano: Giuffrè, 1984.

Processo civile e costituzione: problemi di diritto tedesco e italiano. Milano: Giuffrè, 1974.

TUCCI, Rogério Lauria. Parte (verbete). In: Enciclopédia Saraiva do Direito. São Paulo: Saraiva, 1977. vol. 57.

; CRUZ E TUCCI, José Rogério. Devido processo legal e tutela jurisdicional. São Paulo: RT, 1993.

VASCONCELOS, Rita de Cássia Corrêa de. Princípio da fungibilidade: hipóteses de incidência no processo civil brasileiro contemporâneo. São Paulo: RT, 2007.

VERDE, Giovanni. Profili del processo civile: parte generale. Napoli: Jovene, 2002. vol. 1.

VIDAL PÉREZ, María Fernanda. El litisconsorcio en el proceso civil. Madrid: La Ley, 2007.

VIGLIAR, José Marcelo Menezes. Código de Processo Civil interpretado. Coord. Antonio Carlos Marcato. 3. ed. São Paulo: Atlas, 2008. 
VON TUHR, A. Tratado de las obligaciones. Trad. W. Roces. 1. ed. (reimpressão). Madrid: REUS, 1999. t. I.

WAMBIER, Luiz Rodrigues; ARRUDA ALVIM WAMBIER, Teresa; MEDINA, José Miguel Garcia. Breves comentários à nova sistemática processual civil: $\mathrm{n}^{\circ} 2$. São Paulo: RT, 2006.

WATANABE, Kazuo. Da cognição no processo civil. 2. ed. Campinas: Bookseller, 2000. . Tutela jurisdicional dos interesses difusos: a legitimação para agir. In: GRINOVER, Ada Pellegrini (coord.). A tutela dos interesses difusos. São Paulo: Max Limonad, 1984, p. 85-97.

YARSHELL, Flávio Luiz. Ação rescisória: juízos rescindente e rescisório. São Paulo: Malheiros, 2005. Antecipação da prova sem o requisito da urgência e direito autônomo à prova. São Paulo: Malheiros, 2009. Tutela jurisdicional. 2. ed. São Paulo: DPJ, 2006. Tutela jurisdicional específica nas obrigações de declaração de vontade. São Paulo: Malheiros, 1993. . Três temas de direito processual no âmbito do direito das obrigações e dos contratos. In: FILOMENO, José Geraldo Brito; WAGNER JUNIOR, Luiz Guilherme da Costa; GONÇALVES, Renato Afonso (coord.). O Código Civil e sua interdisciplinaridade: os reflexos do Código Civil nos demais ramos do direito. Belo Horizonte: Del Rey, 2004, p. 307-316.

ZANI, Gino. Litisconsorzio (verbete). In: Nuovo digesto italiano. Torino: UTET, 1938. vol. VII, p. 986-989.

ZAVASCKI, Teori Albino. Processo coletivo: tutela de direitos coletivos e tutela coletiva de direitos. 3. ed. São Paulo: RT, 2008.

ZOLLINGER, Marcia Brandão. Proteção processual aos direitos fundamentais. Salvador: JusPodivm, 2006. 